Portland State University

PDXScholar

Winter 3-21-2018

\title{
Hydrodynamic and Water Quality Modeling of the Tigris River System in Iraq Using CE-QUAL-W2
}

Muhanned Al Murib

Portland State University

Follow this and additional works at: https://pdxscholar.library.pdx.edu/open_access_etds

Part of the Civil and Environmental Engineering Commons, and the Water Resource Management Commons

Let us know how access to this document benefits you.

\section{Recommended Citation}

Al Murib, Muhanned, "Hydrodynamic and Water Quality Modeling of the Tigris River System in Iraq Using CE-QUAL-W2" (2018). Dissertations and Theses. Paper 4230.

https://doi.org/10.15760/etd.6114

This Dissertation is brought to you for free and open access. It has been accepted for inclusion in Dissertations and Theses by an authorized administrator of PDXScholar. Please contact us if we can make this document more accessible: pdxscholar@pdx.edu. 
Hydrodynamic and Water Quality Modeling of the Tigris River System in Iraq Using

\title{
CE-QUAL-W2
}

\author{
by \\ Muhanned Al Murib
}

A dissertation submitted in partial fulfillment of the requirements for the degree of

Doctor of Philosophy

in

Civil and Environmental Engineering

Dissertation Committee:

Scott Wells, Chair

Chris Berger

Mark Sytsma

Stefan Talke

Portland State University

2018 
(C) 2018 Muhanned Al Murib 


\begin{abstract}
The Tigris River is one of two primary rivers in Iraq and is, along with the Euphrates, the main source for drinking and irrigation water in the country. The Tigris River originates in the Taurus Mountains in Turkey, and is $1850 \mathrm{~km}$ long. The majority of the river, $1418 \mathrm{~km}$ lie within Iraq. The river passes through, and is the primary drinking water source for, major cities such as Mosul, Baeji, Samarra, Baghdad (the capital), and Kut. The Tigris River joints the Euphrates River in Qurna city within Basra province to form the Shatt AlArab River which eventually discharges into the Persian Gulf.

As a result of fluctuations in flow rate along the Tigris River that cause both potential flooding and drought, Mosul Dam was built on the mainstem of the Tigris River upstream of the city of Mosul and was operated starting in July1986 to control the river flow and to generate hydroelectricity. Some canals were also constructed to divert excess fresh water from the mainstem of the river at Samarra Barrage located $125 \mathrm{~km}$ north (upstream) of Baghdad to Tharthar Lake, an artificial lake located $100 \mathrm{~km}$ northwest Baghdad city. The Tigris-Tharthar canal, $75 \mathrm{~km}$ long, was constructed in 1956 to divert excess water from Samarra Barrage to Tharthar Lake and to prevent potential flooding in Baghdad. During dry seasons, high total dissolved solids (TDS) water is diverted from Tharthar Lake into the mainstem of the Tigris River through the $65 \mathrm{~km}$ long Tharthar-Tigris canal, which is located $25 \mathrm{~km}$ upstream Baghdad.
\end{abstract}


Due to rapid population growth and increasing industrial activates, the Tigris River is also facing many water quality challenges from inflows of contaminated wastewater from treatment plant stations. A water quality model that simulates the Tigris River system is therefore needed to study the effects of these discharges and how water quality of the Tigris River could be managed. To address this issue, I used CE-QUAL-W2 to develop a 2-D (longitudinal and vertical) hydrodynamic and water quality model of the mainstem Tigris River from Mosul Dam (Rkm 0) to Kut Barrage (Rkm 880). In addition, Tharthar Lake and its canals were modeled.

A full suite of hydrodynamic and water quality variables were simulated for the year 2009, including flowrates, water level, and water temperature. Additionally, water quality constituents such as total dissolved solids (TDS), phosphate (PO4), ammonium (NH4), nitrate (NO3), biochemical oxygen demand (BOD), chlorophyll-a (Chl-a), and dissolved oxygen (DO) were also simulated. Bathymetry of the Tigris River and field data such as flowrate, water level, TDS, NO3 were obtained from the Ministry of Water Resources in Iraq, while surface water temperatures of the Tigris River were estimated remotely using Landsat satellites. These satellites provided a continuous observation record of remote sites. Other water quality field data, such as PO4, NH4, BOD, and DO, were estimated from literature values. 
Meteorological data, including, wind speed, wind direction, air and dew point temperatures, cloud cover, and solar radiation were obtained from the Iraqi Ministry of Transportation, the General Organization for Meteorology and Seismic Monitoring.

Model predictions of flow and water level were compared to field data at three stations along the mainstem of the Tigris River, including Baeji, downstream of Samarra Barrage, and Baghdad. The absolute mean error in the flow varied from 12.6 to $3.4 \mathrm{~m}^{3} / \mathrm{s}$ and the water level absolute mean error varied from 0.036 to $0.018 \mathrm{~m}$. The percentage error of the overall flowrate at Baeji, downstream Samarra Barrage and Baghdad was 1.9\%, 0.8\%, and $0.8 \%$ respectively. Injecting a conservative tracer at Mosul Dam showed that a parcel of water reaches to Baeji, Samarra Barrage, Baghdad, and Kut Barrage after approximately 3 days, 5 days, 10 days, and 19 days, respectively.

Water temperature field data in Iraq are limited and there was no archive of existing field data. Therefore, I obtained estimates of surface water temperature on the Tigris River using the thermal band of the Landsat satellite, one of a series of satellites launched by the National Aeronautics and Space Administration (NASA). The calibration between satellite data and water temperature was validated using sparse field data from 2004, and the calibration then applied to 82 Landsat images from the year 2009. Landsat estimates showed a bias of $-2{ }^{\circ} \mathrm{C}$ compared to model results in winter months, possibly due to uncertainty in Landsat estimations. The absolute mean errors of the CE-QUAL-W2 model predictions of water temperature compared to Landsat estimated temperatures were 0.9 and $1.0^{\circ} \mathrm{C}$ at Baeji and Baghdad respectively. Temperature calibration in the Tigris River system was highly sensitive to meteorological input data. Landsat Images were also used to estimate longitudinal variation in surface water temperature of Tharthar Lake. It was 
found that surface water temperature in Tharthar Lake varied longitudinally along the North-South axis with warmer temperatures in the lower part compared with the upper part of the lake.

Total dissolved solids concentrations in the Tigris River significantly increased from Mosul Dam to Kut Barrage with peak concentrations of $900 \mathrm{mg} / \mathrm{l}$ and $1050 \mathrm{mg} / \mathrm{l}$ at Baghdad and Kut, respectively, due to high TDS water diverted from Tharthar Lake, irrigation return flow, urban runoff, and uncontrolled discharge of wastewater effluents. NO3 concentrations did not significantly increase between Samarra Barrage and Baghdad city. BOD concentrations within Baghdad were extremely high due to direct discharge of industrial wastewater into the mainstem of the Tigris River from outlets located within the city.

Management scenarios were simulated with the model of the Tigris River system and were compared with the base model. The main scenarios implemented on the Tigris River system were altering upstream hydrology, increasing air temperature due to the effect of climate change, disconnecting Tharthar Lake from the Tigris River system, and simulating long-term effects on Tharthar Lake. Increasing upstream inflows caused a decrease in TDS concentrations from $495 \mathrm{mg} / \mathrm{l}$ to $470 \mathrm{mg} / \mathrm{l}$ over all the mainstem of the river. In addition, CBOD concentrations decreased somewhat from $5.9 \mathrm{mg} / \mathrm{l}$ to $5.74 \mathrm{mg} / \mathrm{l}$. On the other hand, decreasing upstream flows caused a significant increase in average TDS concentrations over the entire Tigris mainstem from $495 \mathrm{mg} / \mathrm{l}$ to $527 \mathrm{mg} / \mathrm{l}$. Also, an increase in CBOD concentrations from $5.9 \mathrm{mg} / \mathrm{l}$ to $6.2 \mathrm{mg} / \mathrm{l}$ was predicted over all the mainstem of the river. Implementing the climate change scenario on the base model of the Tigris River system showed a $5 \%$ increase in annually averaged water temperature from $20.7{ }^{\circ} \mathrm{C}$ to $21.68{ }^{\circ} \mathrm{C}$ 
over the mainstem river. Climate change scenarios produced no significant impacts on TDS and CBOD concentrations in the mainstem, while DO concentrations decreased from 8.15 $\mathrm{mg} / \mathrm{l}$ to $7.98 \mathrm{mg} / \mathrm{l}$ with a slight increase in Chl-a concentration from $1.97 \mu \mathrm{g} / \mathrm{l}$ to $2 \mu \mathrm{g} / \mathrm{l}$ in the mainstem. Disconnecting Tharthar Lake from the system showed a remarkable 25\% decrease in TDS concentrations, with an average concentration changed from $495 \mathrm{mg} / \mathrm{l}$ to $397 \mathrm{mg} / \mathrm{l}$ in the mainstem due to an extra $36 \%$ increase in flow discharged downstream of Samarra Barrage. Also, Chl-a concentration significantly decreased by $40 \%$ with an average concentration changed from $2 \mu \mathrm{g} / 1$ to $1.2 \mu \mathrm{g} / \mathrm{l}$.

Additionally, a 6-year model simulation of the Tigris River system was performed to evaluate the long-term effects on Tharthar Lake. No significant impact was observed in the average temperature of the lake. TDS concentrations in the lake decreased from $1239 \mathrm{mg} / \mathrm{l}$ to $1041 \mathrm{mg} / \mathrm{l}$. PO4, NH4 and NO3 concentrations decreased by $2 \%, 66 \%$ and $26 \%$, respectively. Chl-a concentration in Tharthar Lake decreased from $2.0 \mu \mathrm{g} / \mathrm{l}$ to $1.61 \mu \mathrm{g} / \mathrm{l}$. After decreasing BOD concentrations of the Tigris River by 50\%, BOD concentrations in the mainstem decreased by $24 \%$, while DO concentrations increased by $2.8 \%$. There were no significant impacts on Chl-a concentrations in the mainstem of the river. Finally, for a scenario where extremely low dissolved oxygen release from Mosul Dam in the summer, it was found that approximately $50 \mathrm{~km}$ below Mosul Dam was affected before DO concentrations reached an equilibrium concentration. 
For further work on the Tigris River system, it is recommended to model the Tigris River from Kut Barrage to the confluence with the Euphrates River, about $400 \mathrm{~km}$ long, and connect it with the current model to have a complete model of the Tigris River system from Mosul Dam to the confluence with the Euphrates River. This is necessary to manage water the entire system of the Tigris River and also to provide enough water with good quality in Basra. 


\section{Acknowledgments}

A huge thank you to Dr. Scott Wells for his continued teaching, assistance, kindness, and availability throughout my $\mathrm{PhD}$ program. Without him, this work wouldn't be possible.

Thanks and appreciation to Dr. Stefan Talke for his assistance with remote sensing techniques.

Thanks to Dr. Chris Berger and Dr. Mark Sytsma for serving in my PhD committee.

Thanks and appreciations to the Civil and Environmental Department of Portland State University for having me succeed through this journey.

Thanks and appreciations to my parents, my wife (Mawj) and kids (Abdullah and Taim), and my friends for their continuous support and encouragement.

Thanks to the Iraqi Ministry of Water Resources and the Iraqi Ministry of Communication for providing field data of the Tigris River system. 


\section{Table of Contents}

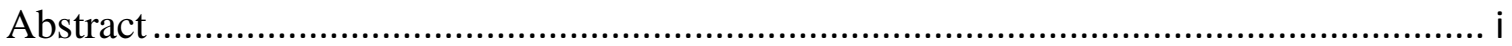

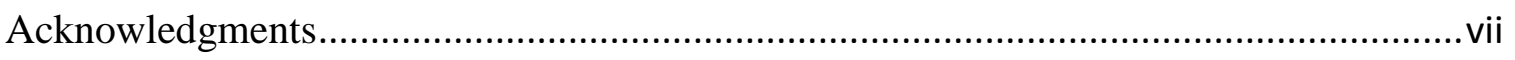

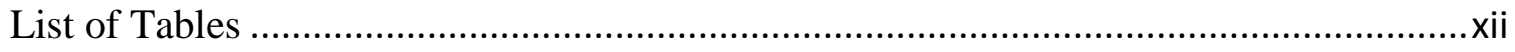

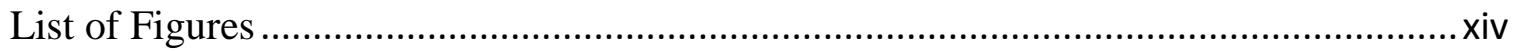

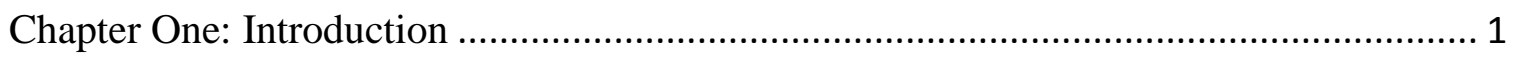

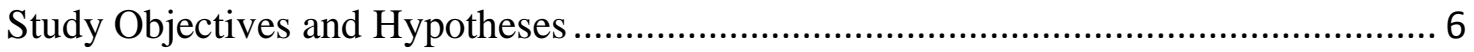

Chapter Two: The Tigris River and Tharthar Lake Study Area ................................... 8

Point Sources in the Study area within Baghdad City ............................................ 13

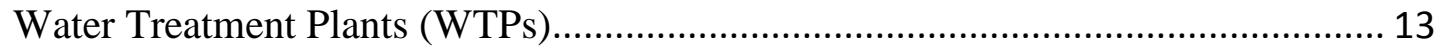

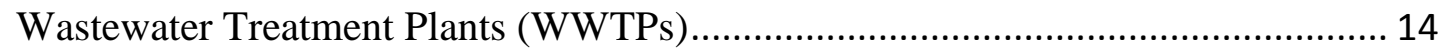

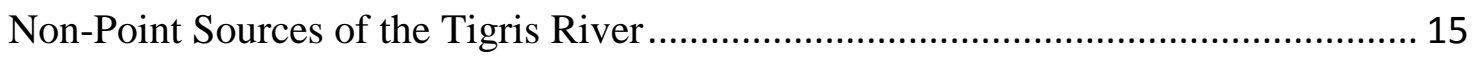

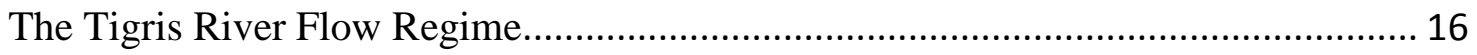

Hydraulic Structures on The Tigris River in Iraq ................................................. 20

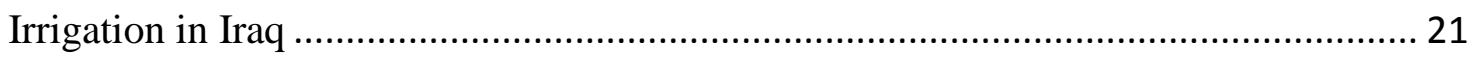

Water Quality in The Tigris River System....................................................... 22

Chapter Three: Surface Water Temperature Estimation from Remote Sensing .............. 34

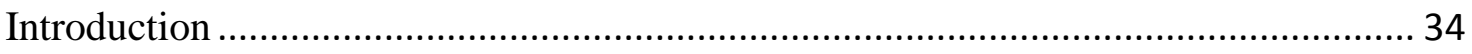

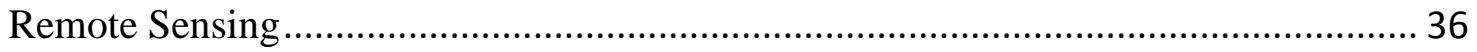

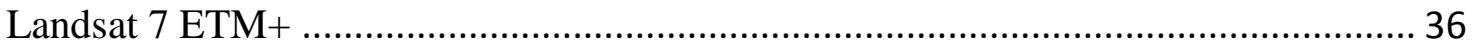

Previous Research Studies Using Remote Sensing Data ........................................ 37

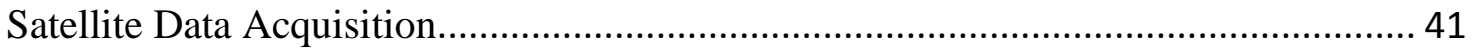

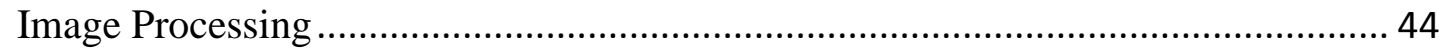

Converting Landsat Thermal Bands to Surface Temperature ............................... 46

Estimation of Surface Water Temperature of the Tigris River .................................. 48

Validation of Surface Water Temperature ........................................................ 50

Surface Water Temperature Statistical Model................................................... 51

Estimation of Surface water Temperature in Tharthar Lake .................................... 57

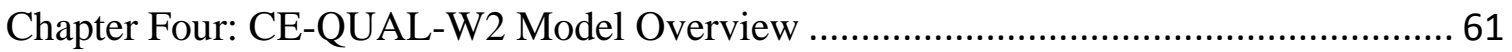

Hydraulic Model Selection for the Tigris River System ....................................... 61 


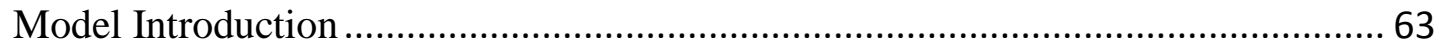

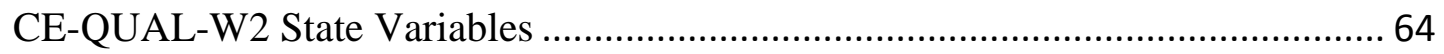

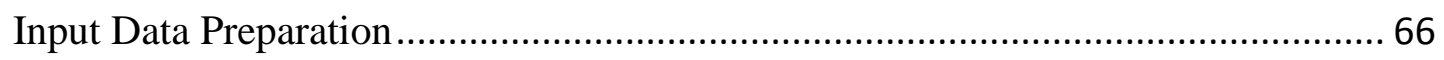

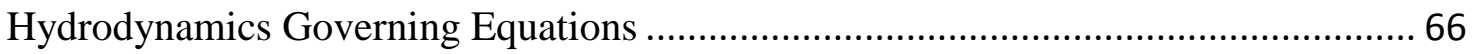

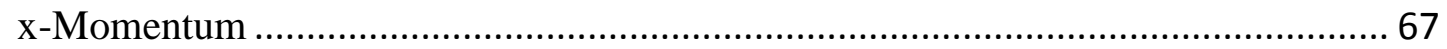

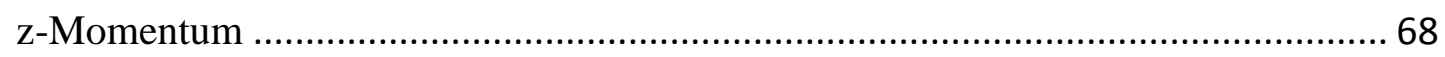

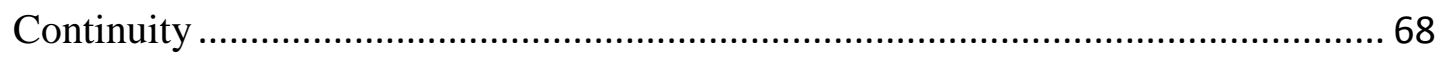

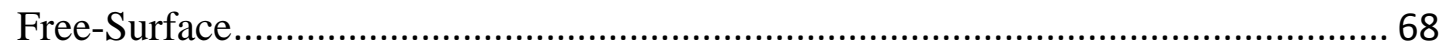

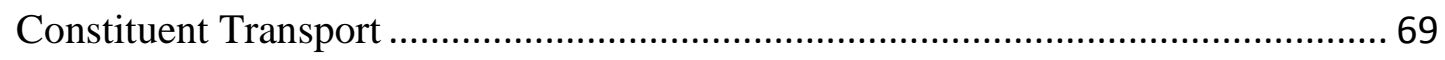

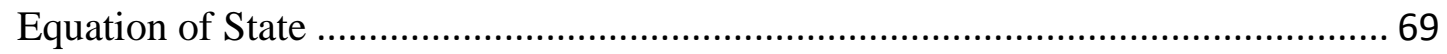

Chapter Five: The Tigris River Model Set Up......................................................... 70

Bathymetry and Grid Development of the Tigris River System .................................. 71

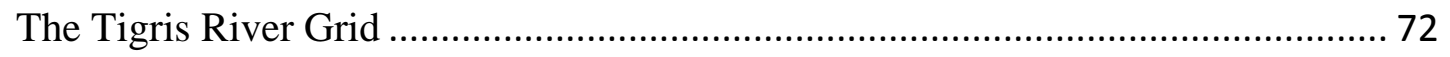

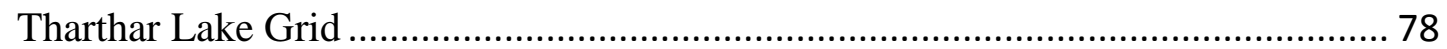

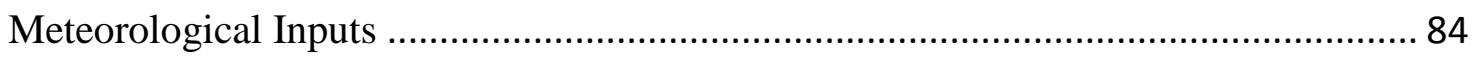

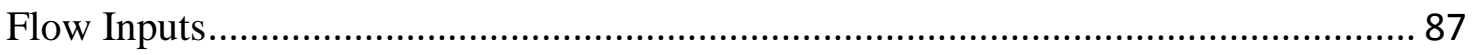

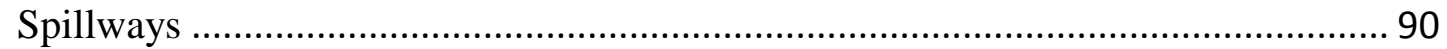

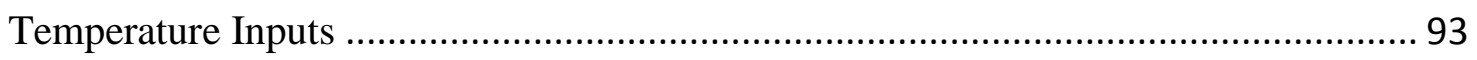

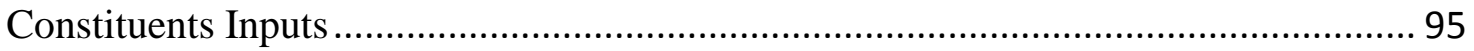

Chapter Six: The Tigris River Model Calibration ....................................................... 101

Model Calibration: Flow-Tharthar Lake …………….......................................... 101

Evaporation in Tharthar Lake ............................................................................. 103

Model Calibration: Flow in the Tigris River.......................................................... 104

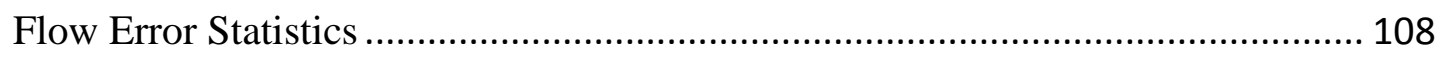

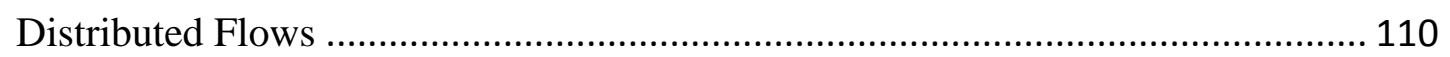

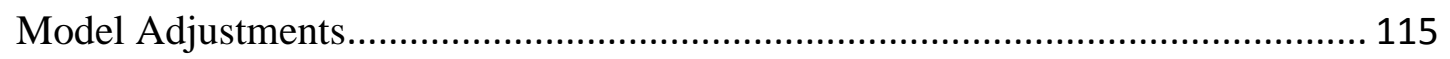

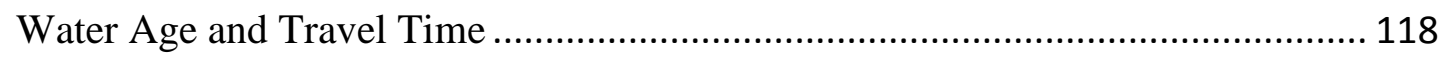

Model Calibration: Temperature …………………................................................ 122

Water Temperature of Tharthar Lake ……………………………….............. 122

Water Temperature of the Tigris River ............................................................ 125 
Model Calibration: Water Quality Constituents................................................... 132

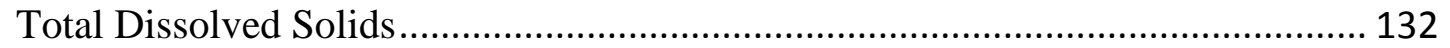

Other Water Quality State Variables ............................................................... 139

Chapter Seven: The Tigris River Management Scenarios .......................................... 151

Historical Hydrology of the Tigris River System ................................................. 153

Management Scenario 1: Increasing Upstream Flow .......................................... 154

Management Scenario 2: Decreasing Upstream Flow ........................................ 157

Management Scenario 3: Decreasing Upstream Flow and Increasing Nutrients ........ 163

Management Scenario 4: Increasing Tharthar Lake's Flow ................................... 169

Management Scenario 5: The Effect of Climate Change....................................... 171

Management Scenario 6: The Effect of Climate Change with Decreasing Upstream

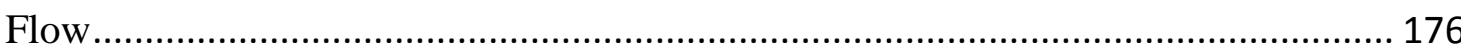

Management Scenario 7: Disconnecting Tharthar Lake ........................................ 182

Management Scenario 8: Long Term Model ............................................................. 188

Management Scenario 9: Decreasing BOD in the Tigris River within Baghdad City 193

Management Scenario 10: Dissolved Oxygen Release from Mosul Dam .................. 197

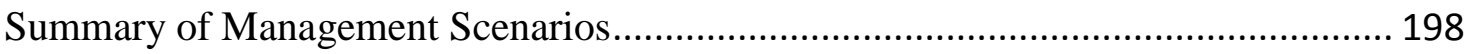

Chapter Eight: Conclusions and Recommendations ................................................ 200

The Tigris River Model Improvements and Recommendations ................................ 208

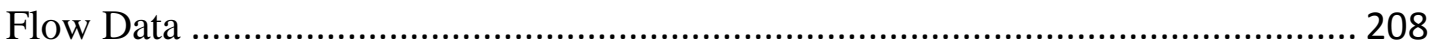

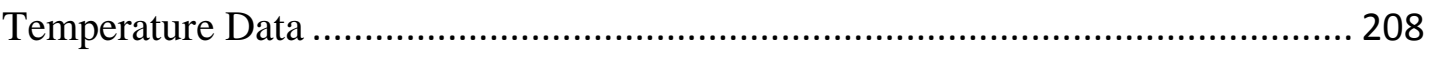

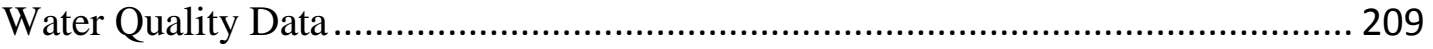

Model Grid and Bathymetry Data ..................................................................... 210

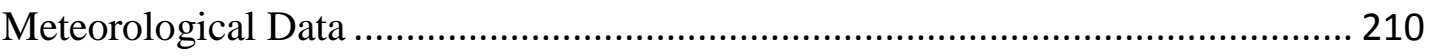

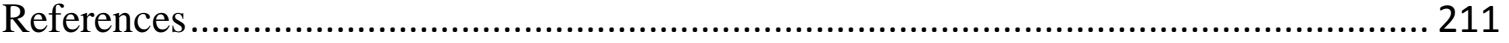

Appendix A: Management Scenarios of the Tigris River Model ................................ 219

Management Scenario 1: Increasing Upstream Flow .......................................... 219

Management Scenario 2: Decreasing Upstream Flow …....................................... 225

Management Scenario 3: Decreasing Upstream Flow and Increasing Nutrients....... 228

Management Scenario 4: Increasing Tharthar Lake's Flow ................................... 231

Management Scenario 5: The Effect of Climate Change........................................ 238 
Management Scenario 6: The Effect of Climate Change with Decreasing Upstream

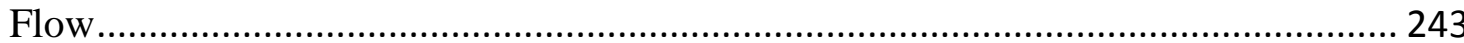

Management Scenario 7: Disconnecting Tharthar Lake ............................................ 246

Appendix B: Histograms of Water Quality Constituents in the Tigris River System .... 250

Appendix C: The Tigris River Model Control File ...................................................... 258 


\section{List of Tables}

Table 1: Lower tributaries of the Tigris River (ESCWA-BGR, 2013) ........................... 11

Table 2: Designed and Produced capacity of WTPs in Baghdad city in 2009 (CSO, 2010).

Table 3: Designed and Produced capacity of WWTPs in Mosul, Tikrit, and Baghdad

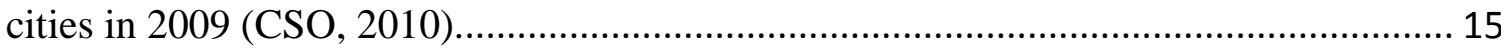

Table 4: Drainage area of the Tigris River basin (Al-Ansari and Knutsson, 2011)......... 18

Table 5: Dams in the Tigris River Basin, Iraq; BCM: billion cubic meters; I: Irrigation; F:

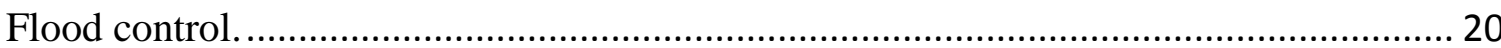

Table 6: Water characteristics of the Tigris River within Baghdad City (Mutlak et al.,

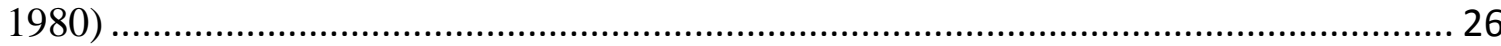

Table 7: USDA Salinity Laboratory's classification of saline irrigation water based on salinity level, potential injury to plants, and management necessary for satisfactory utilization (Camberato, 2001).

Table 8: Water quality correlations of some research studies. B1, B2, B3, B4, B5, B6, B61, and B62 are blue, green, red, near infrared, shortwave infrared, thermal, thermal Low Gain, and thermal High Gain bands respectively..................................................... 40

Table 9: Landsat 5 (LT5) and Landsat 7 (LE7) images used in this study...................... 43

Table 10: Statistical values of the surface water models............................................... 54

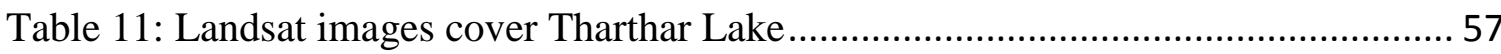

Table 12: Comparison of 1-D, 2-D, and 3-D hydraulic models ...................................... 62

Table 13: Dimensions of all waterbodies and branches of the Tigris River System, DS:

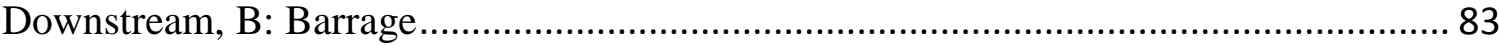

Table 14: Spillway specifications in the Tigris River System........................................ 92

Table 15: Water Quality field data extracted from literatures and used for boundary conditions at Mosul Dam and downstream model calibration at Baghdad City; WWTPs:

Wastewater treatment plants...................................................................................... 96

Table 16: Error statistics for model comparisons to field data for flow and water level (W.L.)

Table 17: Model and theoretical estimation of irrigation water in Baghdad, Diyala, and

Kut. 114

Table 18: Manning's coefficients and slopes used in the Tigris River model................ 117

Table 19: Travel time of upstream pulse inputs every 2 months 121

Table 20: Error statistics for model comparisons to satellite data for longitudinal water temperature in Tharthar Lake. 124

Table 21: Error statistics for model comparisons to satellite data for water temperature from January to December 2009. 130

Table 22: Error statistics for model comparisons to satellite data for water temperature from April to October 2009. 131 
Table 23: Error statistics for model predictions of TDS in the middle of the month compared with field data...

Table 24: The Tigris River management scenarios

Table 25: Average of water quality constituents in the mainstem of the Tigris River for the base model and management scenarios.

Table 26: Average of water quality constituents in Tharthar Lake for the base model and management scenarios. 


\section{List of Figures}

Figure 1: The official map of Iraq showing the Tigris and the Euphrates Rivers (Arc GIS)

Figure 2: Sources of water for the Tigris and the Euphrates Rivers in Iraq (MWR 2005). 3

Figure 3: Water uses in Iraq in 2009 (CSO, 2010). ................................................... 4

Figure 4: Land characteristics in Iraq in 2009 (CSO, 2010)........................................ 4

Figure 5: The Tigris River and Tharthar Lake study area from Mosul Dam to Kut

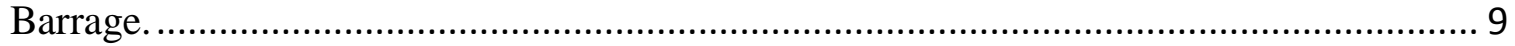

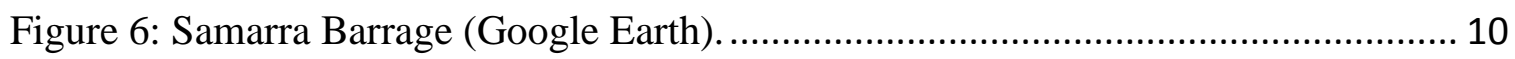

Figure 7: Kut Barrage (Google Earth). .................................................................. 10

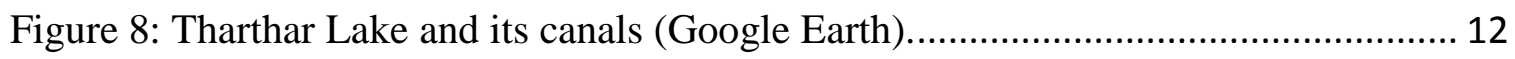

Figure 9: Point and non-point sources in Baghdad city............................................. 14

Figure 10: A famous Iraqi street in Bagdad City under flooding in 1950 (Mix Max,

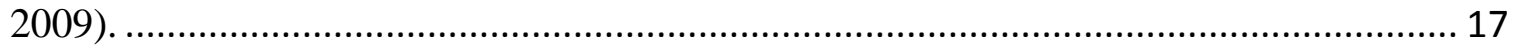

Figure 11: Schematic of Landsat 7 ETM+ satellite (NASA, 2014) ............................... 37

Figure 12: Landsat TM5 covers the Tigris River at Mosul Dam.................................. 42

Figure 13: Landsat TM5 covers the Tigris River at Samarra Barrage and Tharthar Lake.

Figure 14: Landsat TM5 covers the Tigris River at Baghdad and Kut.......................... 42

Figure 15: Land-water mask of the Tigris River at Mosul Dam and Mosul City............ 46

Figure 16: Surface water temperature of the Tigris River at Mosul Dam Lake. ............. 49

Figure 17: Surface water temperature of the Tigris River at Samarra Barrage. ............... 49

Figure 18: Surface water temperature of the Tigris River within Baghdad City............. 50

Figure 19: Validation of satellite water temperature. ............................................... 51

Figure 20: Daily air temperature at Mosul, Baeji, and Baghdad cities (2009)................ 52

Figure 21: Satellite data (Landsat 5 and Landsat 7) and daily surface water temperature of the Tigris River estimated by regression models at Mosul Dam, Baeji city, and Baghdad

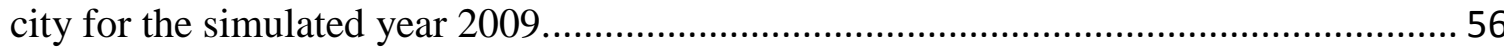

Figure 22: Surface water temperature in the upper and the lower parts of Tharthar Lake (part 1); the top row represents the upper part of the lake, while the bottom row represents the lower part of the lake. ........................................................................ 58

Figure 23: Surface water temperature in the upper and the lower parts of Tharthar Lake (part 2); the top row represents the upper part of the lake, while the bottom row

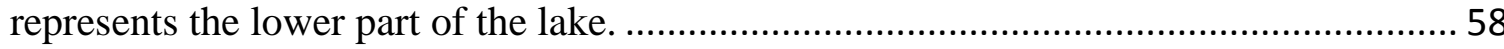
Figure 24: Seasonal variation in longitudinal surface water temperature in Tharthar Lake in 2009. 59

Figure 25: Longitudinal surface water temperature in Tharthar Lake in winter and

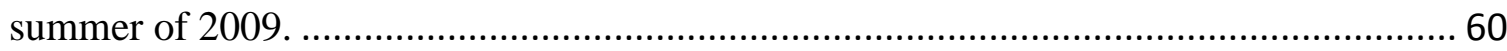

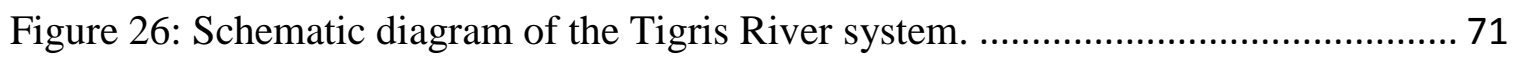


Figure 27: Cross sections of the Tigris River from Mosul Dam to Kut Barrage with the river cross-sections as provided from the Iraqi Water Resources Ministry (WRM), colors represent river cross-section files as received from WRM............................................ 73

Figure 28: The Tigris River cross-section at river km $490 \mathrm{~km}$.................................... 74

Figure 29: Bottom elevation of the mainstem of the Tigris River study area from Mosul Dam to Kut Barrage. ................................................................................................. 75

Figure 30: Segment section \# 123 (Baghdad city) with 82 active layers (1 m each) constructed by the W2 model. ................................................................................. 75

Figure 31: Longitudinal profile for waterbody 1 , branch 1 of the Tigris River model constructed by the W2 model, Upper Zab and lower Zab at model segment 27 and 50 respectively with purple colors. 76

Figure 32: Longitudinal profile for waterbody 2, branch 2 of the Tigris River model constructed by the W2 model, Samarra Barrage at model segment 80 with a brown color.

Figure 33: Longitudinal profile for waterbody 3, branch 3 of the Tigris River model constructed by the W2 model. Extra tributary at model segment 84 . Audaim and Diyala Rivers at model segments 97 and 130 respectively with purple colors. Withdrawals represented in red colors.

Figure 34: Longitudinal profile for waterbody 4, branch 4 of the Tigris River model constructed by the W2 model, an extra tributary at model segment 140 with a purple color. 77

Figure 35: Topographic map of Tharthar Lake (Sissakian 2011) …………………....... 79

Figure 36: Tharthar Lake digitized contour lines. ....................................................... 79

Figure 37: Constructing of contour lines in meters of Tharthar Lake constructed by

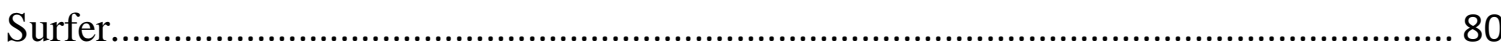

Figure 38: Model segments of Tharthar Lake created by Surfer.................................... 80 Figure 39: Longitudinal profile for waterbody 5, branch 5 (Tigris-Tharthar Canal) of the Tigris River model constructed by the W2 model (Cole and Wells, 2017)..................... 81 Figure 40: Model longitudinal profile of water body 6, branch 6 Tharthar Lake, including all segments and layers constructed by W2 model (Cole and Wells, 2017), the outlet of the lake at segment 297 with a brown color. 81

Figure 41: Model segment \#270 section (Tharthar Lake) with 82 active layers (1 m each) constructed by the W2 model (Cole and Wells, 2017). 82

Figure 42: Longitudinal profile for waterbody 7, branch 7 (Tharthar Canal) of the Tigris River model constructed by the W2 model (Cole and Wells, 2017)............................. 82 Figure 43: Longitudinal profile for waterbody 8 , branch 8 (Tharthar-Tigris Canal) of the Tigris River model constructed by the W2 model (Cole and Wells, 2017)..................... 83 Figure 44: Daily dew-point temperature at Mosul, Baeji, and Baghdad cities (2009)..... 85 Figure 45: Daily wind speed at Mosul, Baeji, and Baghdad cities (2009). .................... 85

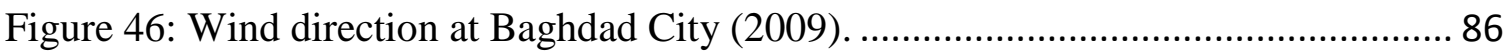

Figure 47: Daily cloud cover at Mosul, Baeji, and Baghdad cities (2009)..................... 87 
Figure 48: Daily flowrates of the Tigris River in 2009 at Mosul Dam, Baeji city, Samarra

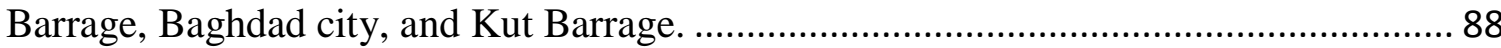

Figure 49: Daily flowrates of the Upper and Lower Zab Rivers in 2009..................... 89

Figure 50: Water sources of the Tigris River in Iraq for the year 2009 (CSO, 2010)..... 90

Figure 51: Schematic diagram of water and spillway elevations for free flowing and submerged weir used in spillway analysis (Cole and Wells, 2017)............................. 92

Figure 52: Daily surface water temperature of the Tigris River at Baeji City with $95 \%$ CI.

Figure 53: Daily surface water temperature of the Tigris River at Baghdad City with 95\% CI

Figure 54: Input field data of TDS concentration for boundary conditions at Mosul Dam. 99

Figure 55: Estimated concentrations of PO4, NH4, and NO3 for boundary conditions at Mosul Dam. 100

Figure 56: Estimated BODu and DO concentrations for boundary conditions at Mosul

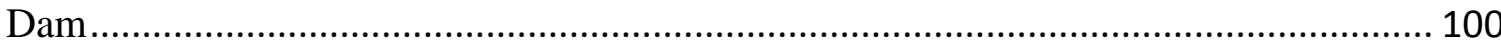

Figure 57: Model and data of the water level of Tharthar Lake in 2009...................... 102

Figure 58: Model flowrate in Tharthar Lake canals in 2009. ..................................... 102

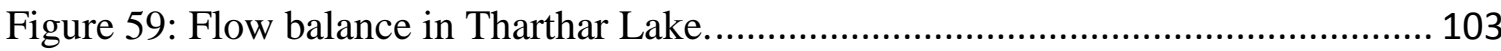

Figure 60: Model flowrate predictions compared to the Tigris River field data at Baeji

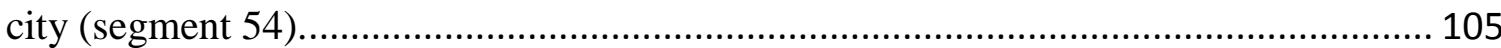

Figure 61: Model water level predictions compared to the Tigris River field data at Baeji city (segment 54) 105

Figure 62: Model flowrate predictions compared to the Tigris River field data at Samarra Barrage (segment 83). 106

Figure 63: Model water level predictions compared to the Tigris River field data at

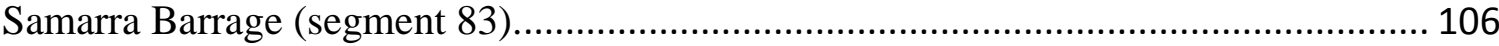
Figure 64: Model flowrate predictions compared to the Tigris River field data at Baghdad City (segment 123) 107

Figure 65: Model water level predictions compared to the Tigris River field data at

Baghdad City (segment 123). 107

Figure 66: Inflow and distributed flow and the ratio of the flow in branch 2 of the Tigris River model. 111

Figure 67: Inflow and distributed flow and the ratio of the flow in branch 2 of the Tigris River model. 112 Figure 68: Inflow and distributed flow and the ratio of the flow in branch 2 of the Tigris River model..... 113

Figure 69: Bridges and meandering on the Tigris River within Mosul city. 116

Figure 70: Bridges and meandering on the Tigris River within Baghdad city. 116 Figure 71: Model predictions of water age throughout the mainstem of the Tigris River

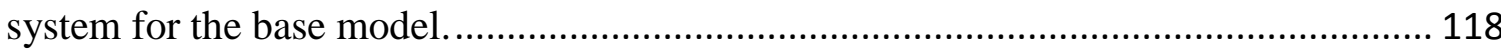


Figure 72: Model predictions of water age in Tharthar Lake.

Figure 73: A tracer pulse input at upstream boundary condition and travel time of that pulse along the main stream of the Tigris River at Baeji city, Samarra Barrage, Baghdad city, and Kut Barrage. 120

Figure 74: A tracer pulse input at JDAY 1.5 condition and travel time of that pulse along the main stream of the Tigris River at Baeji city, Samarra Barrage, Baghdad city, and Kut Barrage. 120

Figure 75: A tracer pulse input at JDAY 1.0 condition and travel time of that pulse in Tharthar Lake.

Figure 76: Model predictions of longitudinal surface water temperature in Tharthar Lake on February $4^{\text {th }}$, March8th, and May $27^{\text {th }}$.... 123

Figure 77: Model predictions of longitudinal surface water temperature in Tharthar Lake on July $30^{\text {th }}$ and August $15^{\text {th }}$. 124

Figure 78: Model surface water temperature predictions compared to the Tigris River remote sensing data at Baeji City (segment 54).....

Figure 79: Model surface water temperature predictions compared to the Tigris River remote sensing data at Baghdad City (segment 123)...

Figure 80: Model temperature contour lines of Tharthar Lake at JDAY 5.5, 55.5, and 105.5 of 2009 (Part 1).

Figure 81: Model temperature contour lines of Tharthar Lake at JDAY 170.5, 260.5, and 350.5 of 2009 (Part 2).

Figure 82: Model temperature contour lines of Samarra Barrage (model segment 80) . 129 Figure 83: Model temperature contour lines of Kut Barrage (model segment 189)...... 129 Figure 84: Model TDS predictions compared to the Tigris River field data at Mosul Dam (segment 2) the upstream boundary condition.

Figure 85: Model TDS predictions compared to the Tigris River field data at Samarra Barrage (segment 83).....

Figure 86: Model TDS predictions compared to the Tigris River field data at Baghdad City (segment 123).

Figure 87: Model TDS predictions compared to the Tigris River field data at Kut Barrage (segment 189). 135

Figure 88: Model TDS predictions at the outlet of Tharthar Lake in 2009 (segment 297).

Figure 89: Model contours of TDS in Tharthar Lake at JDAY 55.5, and 105.5 of 2009 (Part 1).

Figure 90: Model contours of TDS in Tharthar Lake at JDAY 170.5, 260.5, and 360.5 of 2009 (Part 2). 138

Figure 91: Model PO4 predictions at Mosul Dam, at Samarra Barrage, at Tharthar Lake, at Baghdad City, and at Kut City. 141 Figure 92: Model Ammonium predictions at Mosul Dam, at Samarra Barrage, at Tharthar Lake, at Baghdad City, and at Kut Barrage. 142 
Figure 93: Model Nitrate predictions at Mosul Dam, at Samarra Barrage (model Vs. field data), at Tharthar Lake, at Baghdad City (model Vs. field data), and at Kut City........ 143 Figure 94: Model Dissolved Oxygen predictions at Mosul Dam, at Samarra Barrage, at Tharthar Lake, at Baghdad City, and at Kut Barrage. ................................................ 144

Figure 95: Model CBOD predictions at Mosul Dam, at Samarra Barrage, at Baghdad City (model Vs. field data), and at Kut Barrage. 145 Figure 96: Model Chlorophyll-a predictions at Mosul Dam, at Samarra Barrage, at Tharthar Lake, at Baghdad City, and at Kut Barrage using algae growth rate of $1.5 \mathrm{~d}^{-1}$.

Figure 97: Model predictions of Chl-a in Tharthar Lake using [AG] $1.5 \mathrm{~d}^{-1}$ compared with Satellite data. 148

Figure 98: Model predictions of Chl-a in Tharthar Lake using [AG] $0.98 \mathrm{~d}^{-1}$ compared with Satellite data 148

Figure 99: Model predictions of Chl-a in the Tigris River system using [AG] $0.98 \mathrm{~d}^{-1} .149$ Figure 100: Model predictions of NH4 in Kut Barrage and Tharthar Lake. 150 Figure 101: Model predictions of NO3 in Kut Barrage and Tharthar Lake. ................. 150 Figure 102: Historical flow regime in Mosul city before and after Mosul Dam Operation.

Figure 103: Model total dissolved solids (TDS) predictions for base model and management scenario 1 (increasing upstream flow) at Samarra Barrage, Baghdad City, Kut Barrage, and Tharthar Lake. 155 Figure 104: Model carbonaceous biological oxygen demand (CBOD) predictions for base model and management scenario 1 (increasing upstream flow) at Samarra Barrage, Baghdad City, Kut Barrage, and Tharthar Lake. 156

Figure 105: Model total dissolved solids (TDS) predictions for base model and management scenario 2 (decreasing upstream flow) at Samarra Barrage, Baghdad City, Kut Barrage, and Tharthar Lake. 158 Figure 106: Model phosphate (PO4) predictions for base model and management scenario 2 (decreasing upstream flow) at Samarra Barrage, Baghdad City, Kut Barrage, and Tharthar Lake. 159 Figure 107: Model ammonia (NH4) predictions for base model and management scenario 2 (decreasing upstream flow) at Samarra Barrage, Baghdad City, Kut Barrage, and Tharthar Lake. 160

Figure 108: Model nitrate (NO3) predictions for base model and management scenario 2 (decreasing upstream flow) at Samarra Barrage, Baghdad City, Kut Barrage, and Tharthar Lake 161

Figure 109: Model carbonaceous biological oxygen demand (CBOD) predictions for base model and management scenario 2 (decreasing upstream flow) at Samarra Barrage, Baghdad City, Kut Barrage, and Tharthar Lake. 162 
Figure 110: Model total dissolved solids (TDS) predictions for base model and management scenario 3 (decreasing upstream flow with increasing nutrients) at Samarra Barrage, Baghdad City, Kut Barrage, and Tharthar Lake. 164

Figure 111: Model phosphate (PO4) predictions for base model and management scenario 3 (decreasing upstream flow with increasing nutrients) at Samarra Barrage, Baghdad City, Kut Barrage, and Tharthar Lake. 165 Figure 112: Model ammonia (NH4) predictions for base model and management scenario 3 (decreasing upstream flow with increasing nutrients) at Samarra Barrage, Baghdad City, Kut Barrage, and Tharthar Lake. 166

Figure 113: Model nitrate (NO3) predictions for base model and management 3 (decreasing upstream flow with increasing nutrients) at Samarra Barrage, Baghdad City, Kut Barrage, and Tharthar Lake. 167

Figure 114: Model carbonaceous biological oxygen demand (CBOD) predictions for base model and management scenario 3 (decreasing upstream flow with increasing nutrients) at Samarra Barrage, Baghdad City, Kut Barrage, and Tharthar Lake. 168 Figure 115: Model total dissolved solids (TDS) predictions for base model and management scenario 4 (increasing Tharthar Lake's inflow) at Samarra Barrage, Baghdad City, Kut Barrage, and Tharthar Lake. 170

Figure 116: Dew point temperature of the base model and management scenario 5 (Climate Change) at Mosul, Baeji, and Baghdad cities in 2009. 172

Figure 117: Model water temperature (T) predictions for base model and management scenario 5 (climate change) at Samarra Barrage, Baghdad City, Kut Barrage, and Tharthar Lake 173

Figure 118: Model dissolved oxygen (DO) predictions for base model and management scenario 5 (climate change) at Samarra Barrage, Baghdad City, Kut Barrage, and Tharthar Lake. 174

Figure 119: Model chlorophyll-a (Chl-a) predictions for base model and management scenario 5 (climate change) at Samarra Barrage, Baghdad City, Kut Barrage, and Tharthar Lake.

Figure 120: Model water temperature $\left(\mathrm{T}_{\mathrm{w}}\right)$ predictions for base model and management scenario 6 (climate change with decreasing hydrology) at Samarra Barrage, Baghdad City, Kut Barrage and Tharthar Lake.

Figure 121 Model total dissolved solids (TDS) predictions for base model and management scenario 6 (climate change with decreasing hydrology) at Samarra Barrage, Baghdad City, Kut Barrage and Tharthar Lake. 178

Figure 122: Model carbonaceous biological oxygen demand (CBOD) predictions for base model and management scenario 6 (climate change with decreasing hydrology) at Samarra Barrage, Baghdad City, Kut Barrage and Tharthar Lake. 179 Figure 123: Model dissolved oxygen (DO) predictions for base model and management scenario 6 (climate change with decreasing hydrology) at Samarra Barrage, Baghdad City, Kut Barrage and Tharthar Lake. 180 
Figure 124 Model chlorophyll-a (Chl-a) predictions for base model and management scenario 6 (climate change with decreasing hydrology) at Samarra Barrage, Baghdad City, Kut Barrage and Tharthar Lake.

Figure 125 Model total dissolved solids (TDS) predictions for base model and management scenario 7 (disconnecting Tharthar Lake) at Samarra Barrage, Baghdad City, Kut Barrage.

Figure 126: Model carbonaceous biological oxygen demand (CBOD) predictions for base model and management scenario 7 (disconnecting Tharthar Lake) at Samarra Barrage, Baghdad City, Kut Barrage.

Figure 127: Model dissolved oxygen (DO) predictions for base model and management scenario 7 (disconnecting Tharthar Lake) at Samarra Barrage, Baghdad City, Kut Barrage. 185

Figure 128: Model chlorophyll-a (Chl-a) predictions for base model and management scenario 7 (disconnecting Tharthar Lake) at Samarra Barrage, Baghdad City, Kut Barrage. 186

Figure 129: Model flowrate (Q) predictions for base model and management scenario 7 (disconnecting Tharthar Lake) at Samarra Barrage and Baghdad City. 187 Figure 130: Model water temperature $\left(\mathrm{T}_{\mathrm{w}}\right)$ predictions for management scenario 8 (Long Term simulation) in Tharthar Lake. 189 Figure 131: Model total dissolved solids (TDS) predictions for management scenario 8 (Long Term simulation) in Tharthar Lake. 189

Figure 132: Model phosphate (PO4) predictions for management scenario 8 (Long Term simulation) in Tharthar Lake. 190 Figure 133: Model ammonia (NH4) predictions for management scenario 8 (Long Term simulation) in Tharthar Lake. 190

Figure 134: Model nitrate (NO3) predictions for management scenario 8 (Long Term simulation) in Tharthar Lake. 191

Figure 135: Model carbonaceous biological oxygen demand (CBOD) predictions for management scenario 8 (Long Term simulation) in Tharthar Lake. 191

Figure 136: Model dissolved oxygen (DO) predictions for management scenario 8 (Long Term simulation) in Tharthar Lake. 192

Figure 137: Model chlorophyll-a (Chl-a) predictions for management scenario 8 (Long Term simulation) in Tharthar Lake. 192

Figure 138: Model carbonaceous biological oxygen demand (CBOD) predictions for base model and management scenario 9 (50\% BOD Reduction) at Baghdad City and Kut Barragel. 194

Figure 139: Model dissolved oxygen (DO) predictions for base model and management scenario 9 (50\% BOD Reduction) at Baghdad City and Kut Barrage. 195 Figure 140: Model chlorophyll-a (Chl-a) predictions for base model and management scenario 9 (50\% BOD Reduction) at Baghdad City and Kut Barrage. 196 
Figure 141: Model predictions of DO in the Mainstem of the Tigris River at model

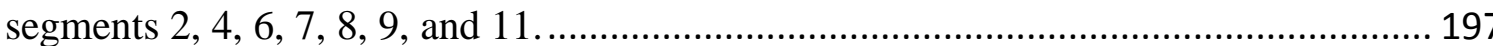




\section{Chapter One: Introduction}

The Tigris River is one of the largest rivers in the Middle East and is one of two primary rivers in Iraq (Figure 1). The Tigris River is the main source for drinking and irrigation water for Baghdad which is the largest city in the country and the second largest city in the Arab world with a population estimated to be 7.5 million (Burnham et al., 2006). The Tigris is $1850 \mathrm{~km}$ long of which $1418 \mathrm{~km}$ are within Iraq. It rises in the Taurus Mountains of eastern Turkey about $25 \mathrm{~km}$ southeast of the city of Elazig and about $30 \mathrm{~km}$ from the headwaters of the Euphrates. The Tigris River then flows for about $400 \mathrm{~km}$ through Turkey before entering Iraq, and then passes through major cities in Iraq such as Mosul city, Samarra city, Baghdad city and Kut city. Hence, Iraq, with a population of about 31.5 million according to 2009 estimates (CSO, 2010), depends heavily on the Tigris River to supply water for drinking, municipal use, irrigation, industries, power generation, navigation, and recreation. However, the seasonal pattern of flow and the river discharge has decreased over time, primarily due to the many storage reservoirs have been built along the Tigris in both Turkey and Iraq. Altered flow has led to changes in the elevation of the river, with implications for water resource management. As an example, intakes for water treatment plants and power generation plants have been affected (Al-Obaidy, 1996; AlJubori, 1998). Figure 1 shows the two main rivers, the Tigris and the Euphrates, from their headwaters in Turkey to the confluence in Iraq, where they form Shatt Al-Arab River. The continued Shatt Al-Arab River, which is 200 km long, discharges into the Persian Gulf. 


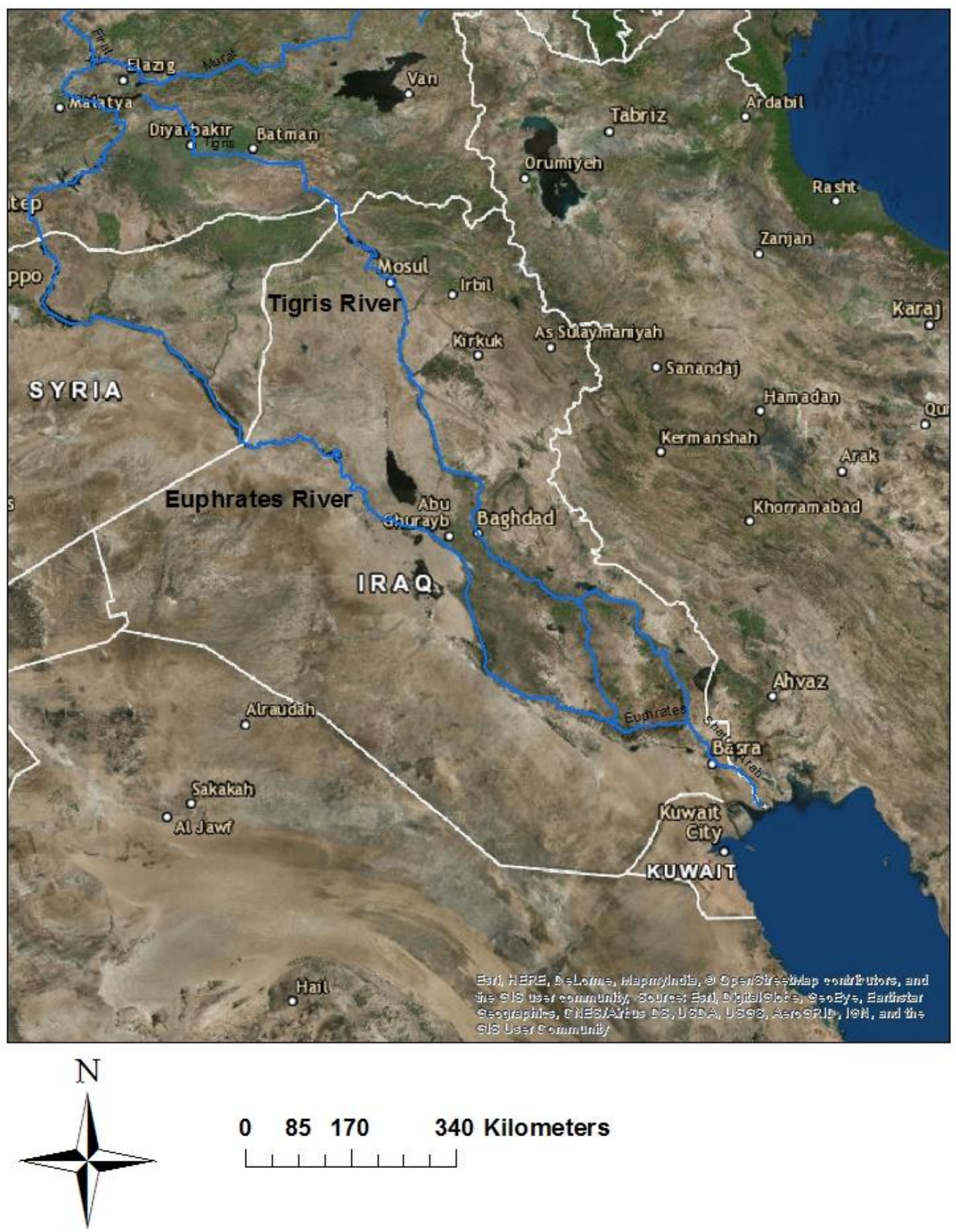

Figure 1: The official map of Iraq showing the Tigris and the Euphrates Rivers (Arc GIS). 
The Tigris and Euphrates Rivers form the main water sources in Iraq and represent together $98 \%$ of the water resources in the country. Both these rivers originate in the highlands of Turkey and share similar physical, climatic, hydrologic and geomorphologic characteristics. The Ministry of Water Resources (MWR) in Iraq estimated that the annual flow from both rivers dropped from 30 billion cubic meter (BCM) to only $11 \mathrm{BCM}$ over the last seven years (USAID 2007). Figure 2 shows the origin of water sources for both the Tigris and the Euphrates Rivers.

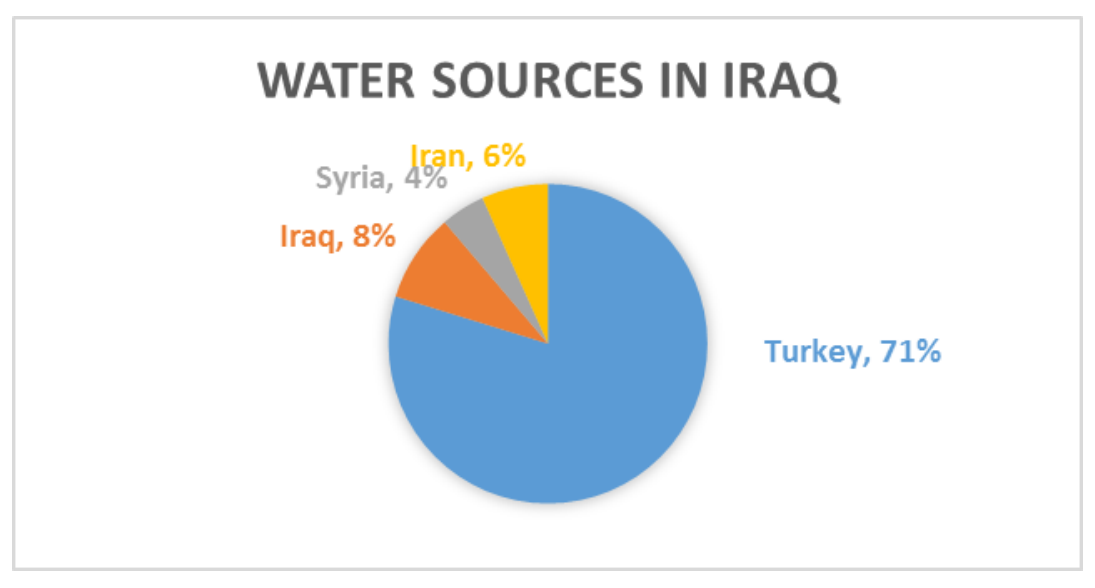

Figure 2: Sources of water for the Tigris and the Euphrates Rivers in Iraq (MWR 2005).

Figure 3 shows water uses in Iraq in 2009. More than $85 \%$ of all water resources in Iraq are allocated for irrigation, while only $3 \%$ of the water is allocated for domestic uses. Since agriculture in Iraq plays a crucial role for increasing Iraq's revenue, water quality of the Tigris River such as total dissolved solids (TDS) and nutrients is critical for meeting irrigation standards. Central Statistical Organization (CSO) (2010) reported the Iraqi land characteristics for the year 2009 as shown in Figure 4. About 27\% of the land is classified as agricultural areas. 


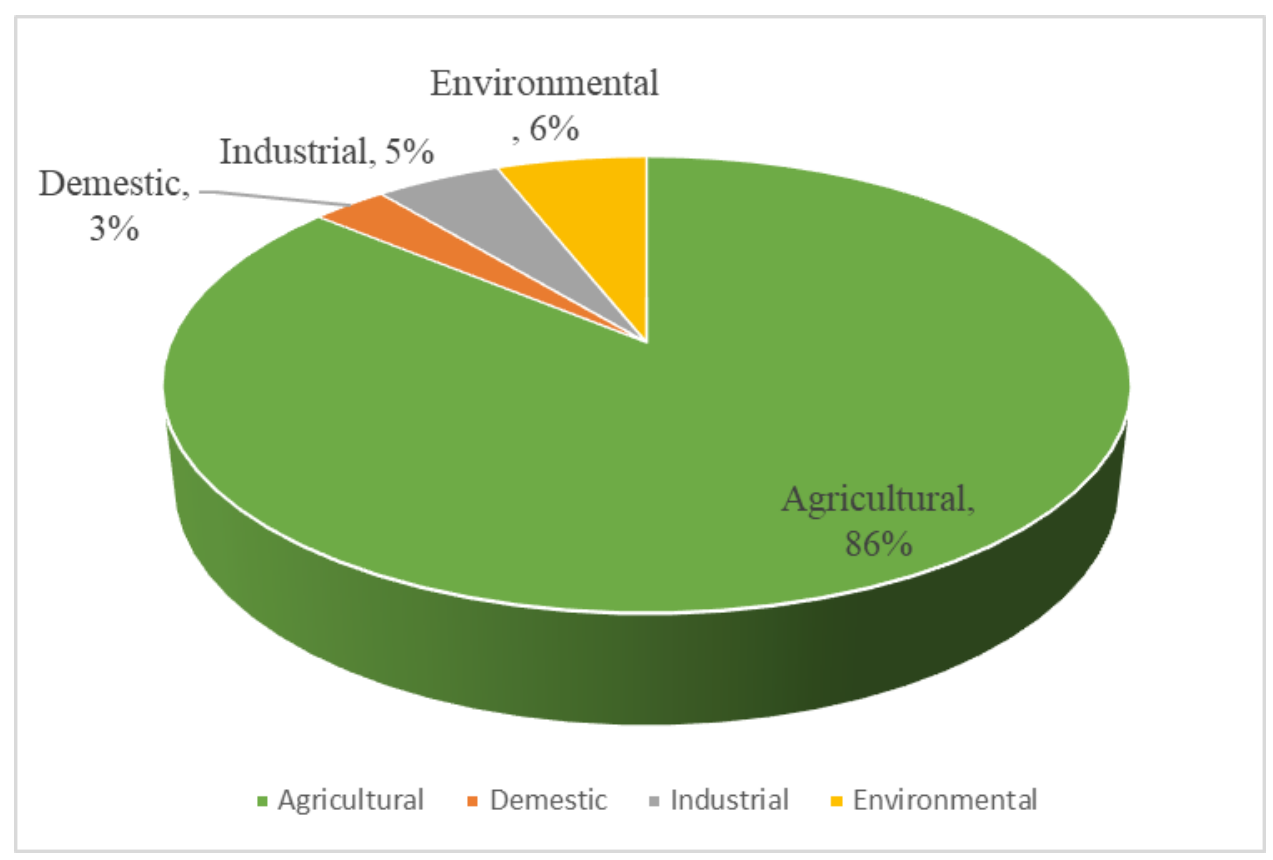

Figure 3: Water uses in Iraq in 2009 (CSO, 2010).

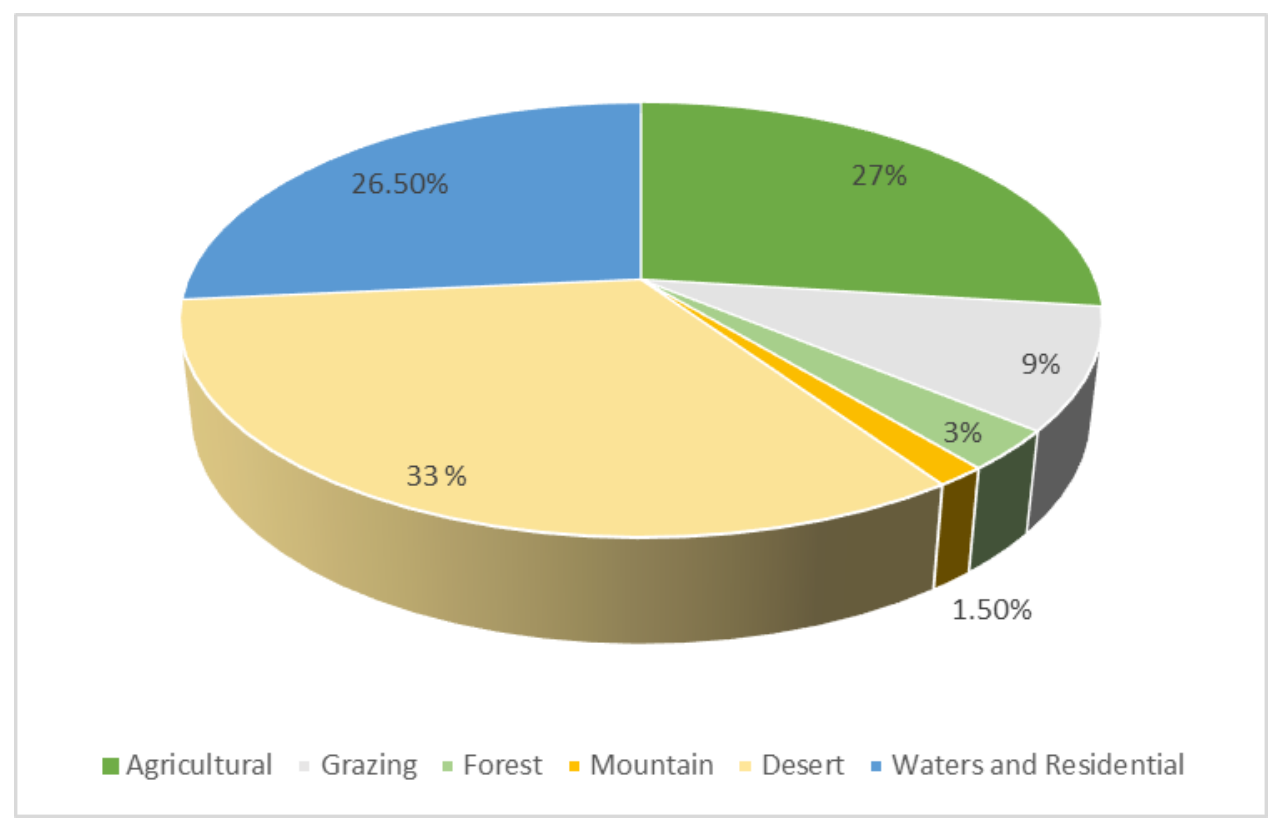

Figure 4: Land characteristics in Iraq in 2009 (CSO, 2010).

A water quality model that simulates the Tigris River system is needed to study the effects of how changes in water quality affect the Tigris River. Besides modeling changes in water 
level and flow and velocity, important water quality state variables include temperature, total dissolved solids (TDS), organic matter, nutrients, dissolved oxygen, and algae. TDS is an important variable for the Tigris River since agricultural areas downstream of Baghdad city are heavily dependent on the Tigris River for irrigation.

Field data required to set-up and evaluate a water quality model are very limited in Iraq. Using conventional monitoring techniques are often prohibitive because of the current social and political upheavals in the country. Since there is a lack of water quality data, satellite imagery is potentially a useful source for obtaining the field data required for developing a water quality model. 


\section{Study Objectives and Hypotheses}

The primary objective of this research is to develop a systematic hydrodynamic and water quality model of the Tigris River and use it to evaluate changes in water quality as a result of changes in flow management in the Tigris basin. Specifically, this objective will be met by

- Developing a 2-D water quality model of the Tigris River system and Tharthar Lake using the water quality and hydrodynamics model CE-QUAL-W2 (Cole and Wells, 2017). This includes compiling historical water quality, meteorological, and stream channel morphology data for the Tigris River System.

- Estimating surface water temperature of the Tigris River from remotely sensed data using thermal bands of both Landsat 5 TM and Landsat 7 ETM+ to obtain upstream boundary conditions and downstream water temperatures for the model calibration.

- Estimating water quality constituents such as total dissolved solids (TDS), biological oxygen demand (BOD), nutrients $\left(\mathrm{NO}_{3}\right)$ and $\left(\mathrm{PO}_{4}\right)$, and algae of the Tigris River using limited field data obtained from Water Resources Ministry in Iraq (WRM) and other field data extracted from previous studies of the Tigris River.

- Using the Tigris model system to evaluate some management scenarios for improving water quality in the Tigris River such as altering river flow due to upstream flow control by Turkey and disconnecting Tharthar Lake from the Tigris River system to enhance the river quality in Baghdad and downstream cities.

- Estimating the potential impact of climate change on the river system. 
The hypotheses to be investigated by this dissertation are:

- Increasing upstream river flow at Mosul Dam will decrease total dissolved solids (TDS) concentrations in both Tharthar Lake and the Tigris River through dilution and reduction in both residence time and evaporation rates.

- Estimating surface water temperature from remote sensing is a feasible method for defining the model's upstream boundary conditions and calibrating downstream areas.

- Disconnecting Tharthar Lake from the Tigris River system will enhance water quality in Baghdad and downstream cities by passing more waters from Samarra Barrage.

- Increasing air temperature due to the impact of climate change will increase water temperature in the Tigris River system and negatively impact DO concentrations. 


\section{Chapter Two: The Tigris River and Tharthar Lake Study Area}

The study area in this dissertation includes the mainstem of the Tigris River, from Mosul Dam (Rkm 0) and ending at Kut Barrage (Rkm 880) (Figure 5). Mosul Dam, which began operations in 1986, is the largest dam in Iraq with a total length of $3.65 \mathrm{~km}$ and crest elevation of $341 \mathrm{~m}$ above sea level; the storage capacity at normal operation level (330 m above sea level) is $11.11 \mathrm{~km}^{3}$ (Al-Ansari, 2015). Samarra Barrage and Kut Barrage are crucial flow control structures located on the mainstem of the Tigris River and regulate the river flow upstream and downstream Baghdad city, respectively, as shown in Figure 6 and Figure 7. Four major tributaries join the eastern bank of the Tigris River. These tributaries are (upstream to downstream): (a) the Upper Zab, located about $50 \mathrm{~km}$ downstream of Mosul, (b) the Lower Zab, located about $220 \mathrm{~km}$ upstream of Baghdad, (c) the Adhaim River, located $50 \mathrm{~km}$ upstream of Baghdad, and (d) the Diyala River, located $10 \mathrm{~km}$ downstream of Baghdad city (Al-Samak et al., 1985). Table 1 lists a description of the main tributaries of the Tigris River in Iraq. 


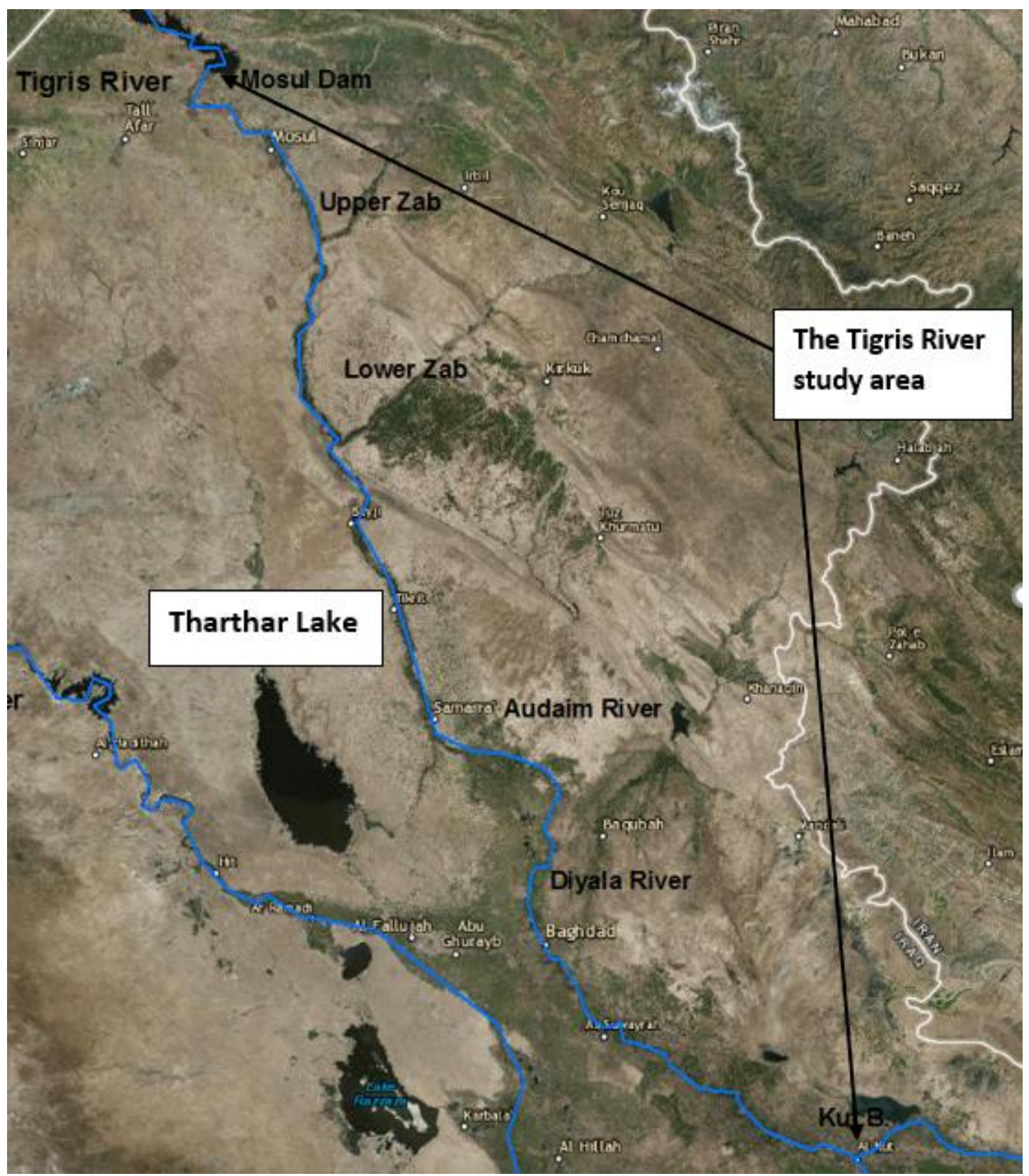

Figure 5: The Tigris River and Tharthar Lake study area from Mosul Dam to Kut Barrage. 


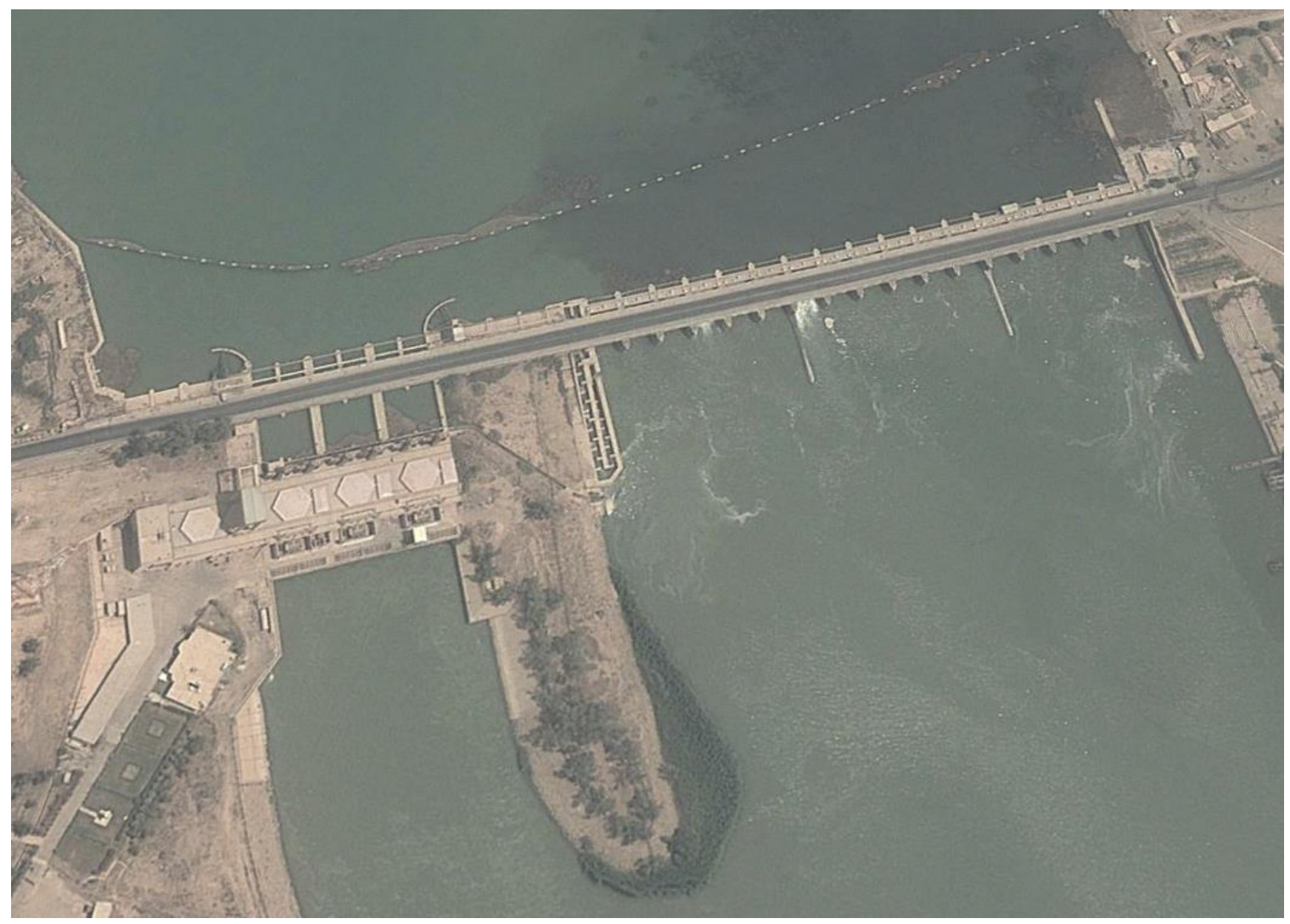

Figure 6: Samarra Barrage (Google Earth).

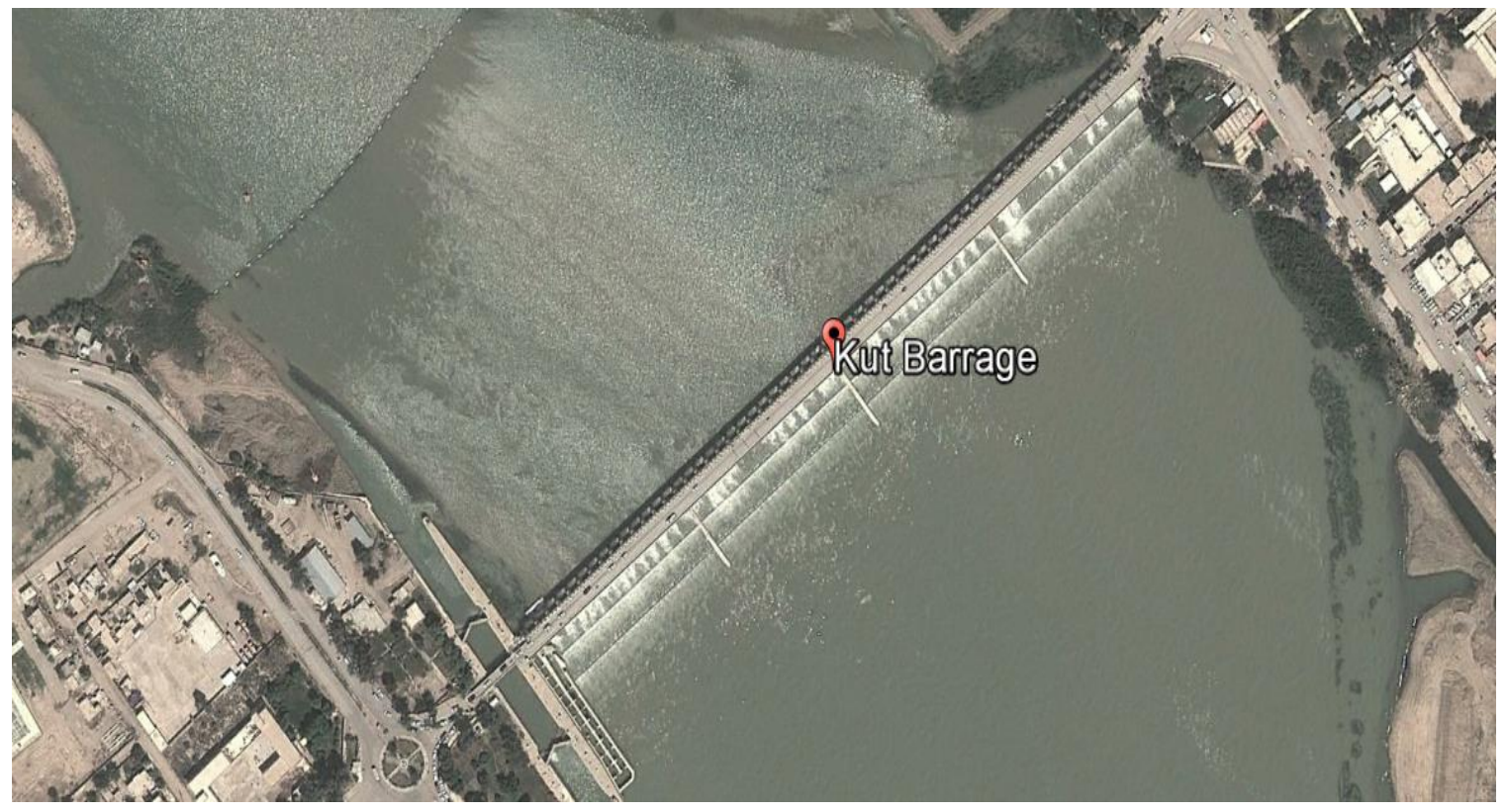

Figure 7: Kut Barrage (Google Earth). 
Table 1: Lower tributaries of the Tigris River (ESCWA-BGR, 2013)

\begin{tabular}{|c|c|}
\hline Tributary & Description \\
\hline $\begin{array}{l}\text { Feesh } \\
\text { Khabour }\end{array}$ & $\begin{array}{l}\text { This tributary is shared between Iraq and Turkey. It originates in } \\
\text { Sirnak, Turkey, and flows through Zakho, Iraq, before its confluence } \\
\text { with the Tigris at the Iraqi-Turkish border. The Feesh Khabour } \\
\text { delineates the international border between Iraq and Turkey. Its mean } \\
\text { annual flow volume at the confluence with the Tigris is approximately } \\
2 \text { BCM. }\end{array}$ \\
\hline Greater Zab & $\begin{array}{l}\text { This river, which is shared by Iraq and Turkey, originates in Turkey } \\
\text { and is the largest Tigris tributary. It supplies the Tigris River with an } \\
\text { average annual flow volume of } 12.7 \text { BCM. } 62 \% \text { of the total area of } \\
\text { the river's basin of } 25810 \mathrm{~km}^{2} \text { is in Iraq }\end{array}$ \\
\hline Lesser Zab & $\begin{array}{l}\text { The Lesser Zab is shared by Iran and Iraq. It originates in Iran, not far } \\
\text { from the Iraqi border. The total river basin is } 21475 \mathrm{~km}^{2} \text {, of which } \\
74 \% \text { is in Iraq. } \\
\text { The average annual flow volume of the Lesser Zab is about } 7.8 \mathrm{BCM} \text {, } \\
\text { contributing an average of } 249 \mathrm{~m} 3 / \mathrm{s} \text { to the Tigris. }\end{array}$ \\
\hline Adhaim & $\begin{array}{l}\text { While not a shared tributary, Adhaim is an intermittent stream that } \\
\text { drains an area of about } 13,000 \mathrm{~km}^{2} \text { in Iraq. The river generates about } \\
0.79 \mathrm{KCM} \text { annually at its confluence with the Tigris and is subject to } \\
\text { flash flooding. }\end{array}$ \\
\hline Diyala & $\begin{array}{l}\text { Shared by Iran and Iraq, this tributary forms the border between the } \\
\text { two countries. It drains about } 31896 \mathrm{~km}^{2} \text {, of which } 75 \% \text { in Iraqi } \\
\text { territory. The Diyala has a mean annual flow volume of } 5.74 \mathrm{KCM} \text {. }\end{array}$ \\
\hline
\end{tabular}

In addition, Tharthar Lake and its canals are also included in the study area (Figure 8). The Tharthar reservoir was originally a natural depression with a floor at $-3 \mathrm{~m}$ below sea level. It serves as a discharge area for the ground water in the vicinity of the depression and as storage for the runoff of wadi Tharthar. After the diversion channel from the Tigris River was constructed in 1956, Tharthar Lake became a large flood storage reservoir to protect Baghdad from flooding and a potential source of water for irrigation. The lake has a maximum length of $120 \mathrm{~km}$, a width of $48 \mathrm{~km}$, and an average depth of 40-65 $\mathrm{m}$. The main purpose of Tharthar Lake is to collect the excess or flood waters from the Tigris River during flood seasons and to recharge the waters of both the Tigris and Euphrates Rivers 
during dry seasons. Evaporation and leakage through soil beds are the main causes of water losses in the lake.

In 1969, the water level in the lake reached its maximum permissible level of $60 \mathrm{~m}$, and the ministry of irrigation investigated other options to store the excess water from Tigris River. As result was the construction of the Tharthar-Euphrates canal, with a total length of $37.5 \mathrm{~km}$. Additionally, the Tharthar-Tigris canal with a total length of $65 \mathrm{~km}$ was constructed and began to operate in 1988. Water from this canal is being diverted to the Tigris River, upstream of Baghdad, to compensate for the water deficit in Baghdad and downstream cities (Jasim, 1988).

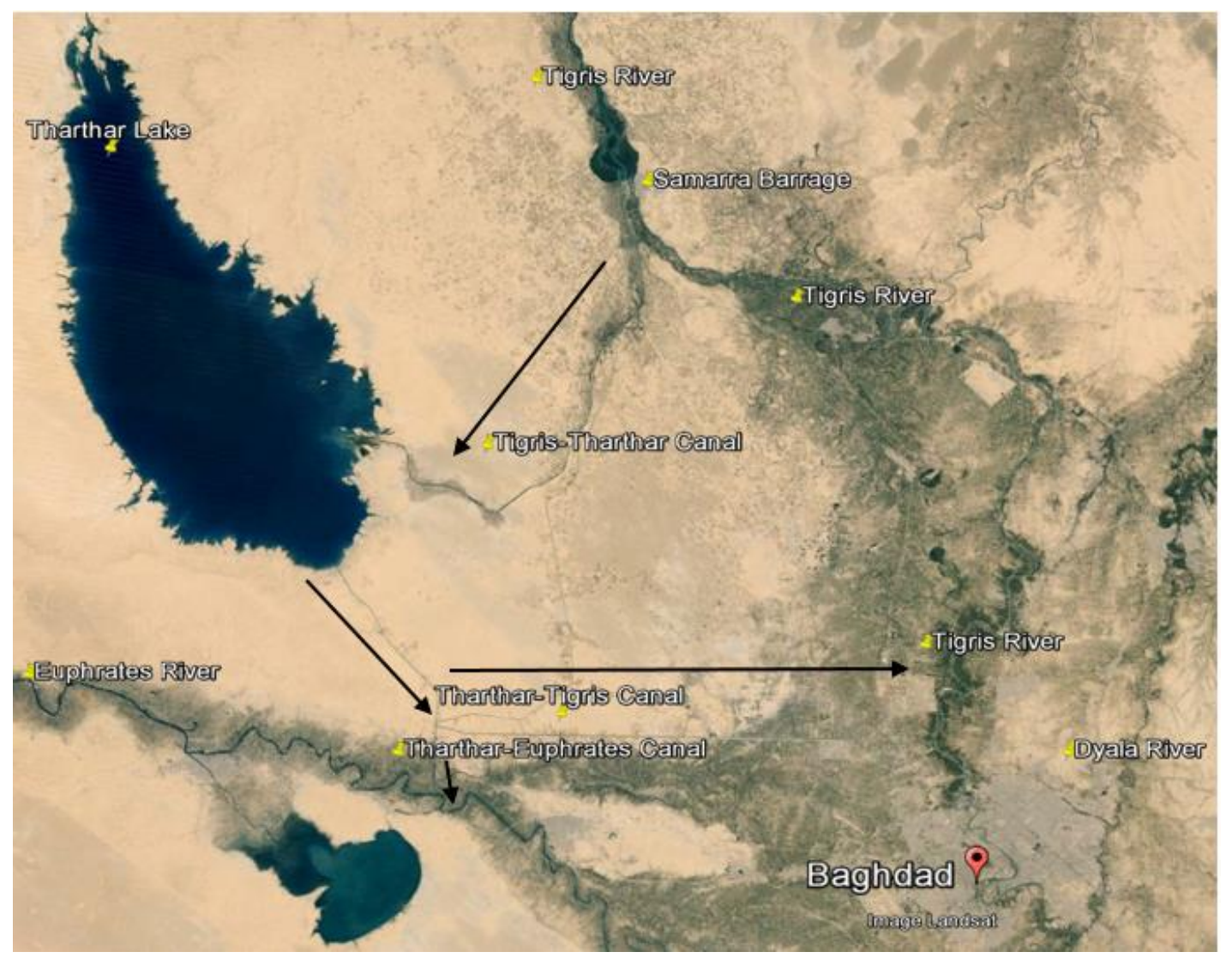

Figure 8: Tharthar Lake and its canals (Google Earth). 


\section{Point Sources in the Study area within Baghdad City}

Water Treatment Plants (WTPs)

Eight water treatment plants (WTPs) are located along the main stream of the Tigris River within Baghdad city that draw water from the river. These water treatment plants (see Figure 9) from upstream to downstream area: Karkh, Sharq Dijlah (or East Tigris), Karama, Wathba, Qadisiya, Dora, and Rasheed water treatment plants. The annual amount of treated water produced by these plants in the year 2009 was about 797.5E6 m³. Relative to the average flow of the Tigris River within Baghdad city, the water treatment plants mentioned above withdrew about $6 \%$ of the average water flow in the Tigris River.

Table 2: Designed and Produced capacity of WTPs in Baghdad city in 2009 (CSO, 2010).

\begin{tabular}{|c|c|c|}
\hline $\begin{array}{c}\text { Water } \\
\text { TreatmentPlant }\end{array}$ & $\begin{array}{c}\text { Designed Capacity } \\
\left(\mathbf{1 0 0 0} \mathbf{~ m}^{\mathbf{3}} / \mathbf{y e a r}\right)\end{array}$ & $\begin{array}{c}\text { Produced Capacity } \\
\left(\mathbf{1 0 0 0} \mathbf{~ m}^{\mathbf{3}} \mathbf{\text { year}}\right)\end{array}$ \\
\hline Kharkh & 491400 & 415160 \\
\hline East Dijla & 269700 & 225387 \\
\hline Karama & 79200 & 54837 \\
\hline Wathba & 48900 & 28250 \\
\hline Qadisiya & 74640 & 31721 \\
\hline Dora & 41400 & 26328 \\
\hline Wihda & 5920 & 19480 \\
\hline Rasheed & 24480 & 15780 \\
\hline Total & 1055640 & 816943 \\
\hline
\end{tabular}




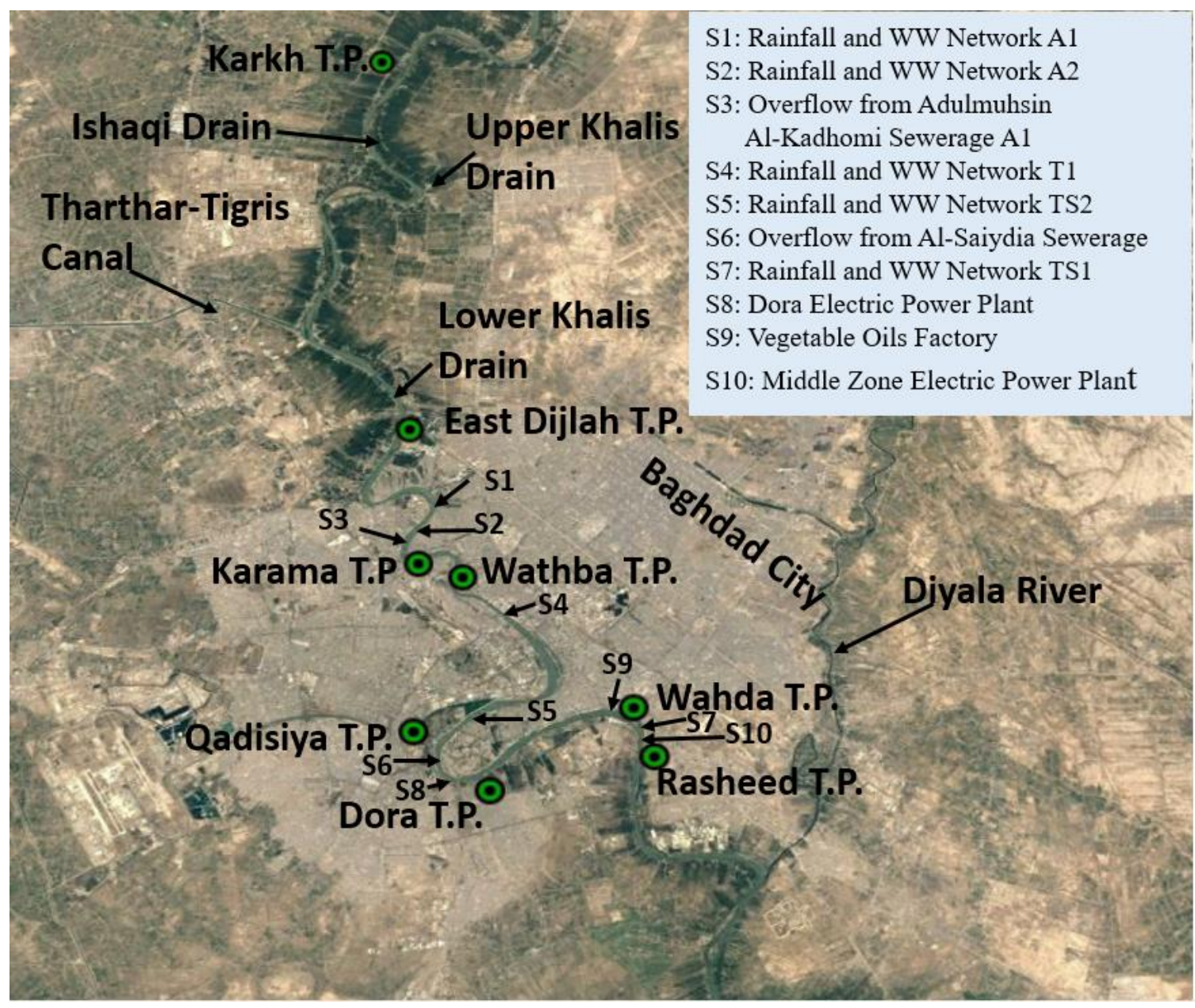

Figure 9: Point and non-point sources in Baghdad city.

\section{Wastewater Treatment Plants (WWTPs)}

Baghdad city has only three sewage treatment plants (WWTPs) that serve Baghdad's residents. These three plants together contribute three-quarters of the entire nation's sewage treatment capacity. Currently, some raw waste from residential areas in Baghdad city flows untreated directly into the Tigris River (USAID 2003). WWTPs face many problems related to improper design, population growth, power shortages, lack of maintenance, and lack of experienced operators. In Iraq, 13 municipal sewage treatment plants are located across the country, however, several are not in service, three of which are in Baghdad city (USAID 2003). The amount of generated and treated wastewater 
through central and small wastewater plants (WWTPs) in Mosul, Tikrit, and Baghdad cities in the year 2009 is listed in Table 3. According to CSO (2010), 100\% of treated wastewater in Mosul city was discharged into natural Wadies (Valleys), while 25\% and $75 \%$ of treated wastewater in Tikrit city was discharged into the mainstem of the Tigris River and irrigational canals, respectively. In Baghdad city, $100 \%$ of treated sewage in Baghdad is directed from treatment plants to the Diyala River, a tributary of the Tigris River, and eventually to the Tigris River through additional treatment (Aziz and Aws, 2012).

Table 3: Designed and Produced capacity of WWTPs in Mosul, Tikrit, and Baghdad cities in 2009 (CSO, 2010).

\begin{tabular}{|c|c|c|c|c|c|c|c|c|}
\hline Province & Population & $\begin{array}{l}\text { Population } \\
\text { served by } \\
\text { WWTPs }\end{array}$ & $\begin{array}{l}\% \\
\text { Population } \\
\text { served by } \\
\text { WWTPs }\end{array}$ & $\begin{array}{l}\text { Number } \\
\text { of } \\
\text { Central } \\
\text { WWTPs }\end{array}$ & $\begin{array}{l}\text { Number } \\
\text { of Small } \\
\text { WWTPs }\end{array}$ & $\begin{array}{l}\text { WW } \\
\text { generated } \\
\text { (m3/d) }\end{array}$ & $\begin{array}{l}\text { WW } \\
\text { treated } \\
\text { (m3/d) }\end{array}$ & $\begin{array}{l}\text { Type of } \\
\text { treatment }\end{array}$ \\
\hline Mosul & 2994979 & 263558 & 8.8 & 0 & 2 & 8400 & 8400 & Biological \\
\hline Tikrit & 1351150 & 337788 & 25 & 4 & 0 & 35000 & 34900 & Biological \\
\hline Baghdad & 7455849 & 4337991 & 58 & 3 & 0 & 1225000 & 540000 & $\begin{array}{l}\text { Physical/ } \\
\text { Biological }\end{array}$ \\
\hline
\end{tabular}

\section{Non-Point Sources of the Tigris River}

Non-point source pollution generally results from land runoff, precipitation, atmospheric deposition, drainage, seepage or hydrologic modification. Non-point source pollution could include excess fertilizer such as herbicides and insecticides from agricultural lands and residential areas, oil, grease and toxic chemicals from urban runoff and energy production, salt from irrigation practices and acid drainage from abandoned mines, bacteria and nutrients from livestock, pet wastes and faulty septic systems. Unfortunately, no information was available about these non-point sources. 


\section{The Tigris River Flow Regime}

Due to large annual and interannual fluctuations in both the Tigris and the Euphrates Rivers, the average annual flow in both rivers is difficult to estimate (FAO, 2008). Baghdad city is occasionally exposed to flooding due to high flows in the Tigris River. The last big flood happened in 1950 as shown in Figure 10 with minor ones occurred later. Therefore, the Iraqi Government started to construct a series of dams and projects to control the flow and to prevent major cities from flooding. According to Al-Shahrabaly (2008), monthly average discharge of the Tigris River within Baghdad city at Sarai Baghdad station has fallen sharply from $927 \mathrm{~m}^{3} / \mathrm{s}$ during the $1960-1999$ period to $531 \mathrm{~m}^{3} / \mathrm{s}$ during the 2000 2010 period. Since water is highly regulated by Turkey and there has been a huge increase of water demand, the Iraqi Government realized that a plan of building dams along both rivers and all tributaries should be investigated and considered seriously. 


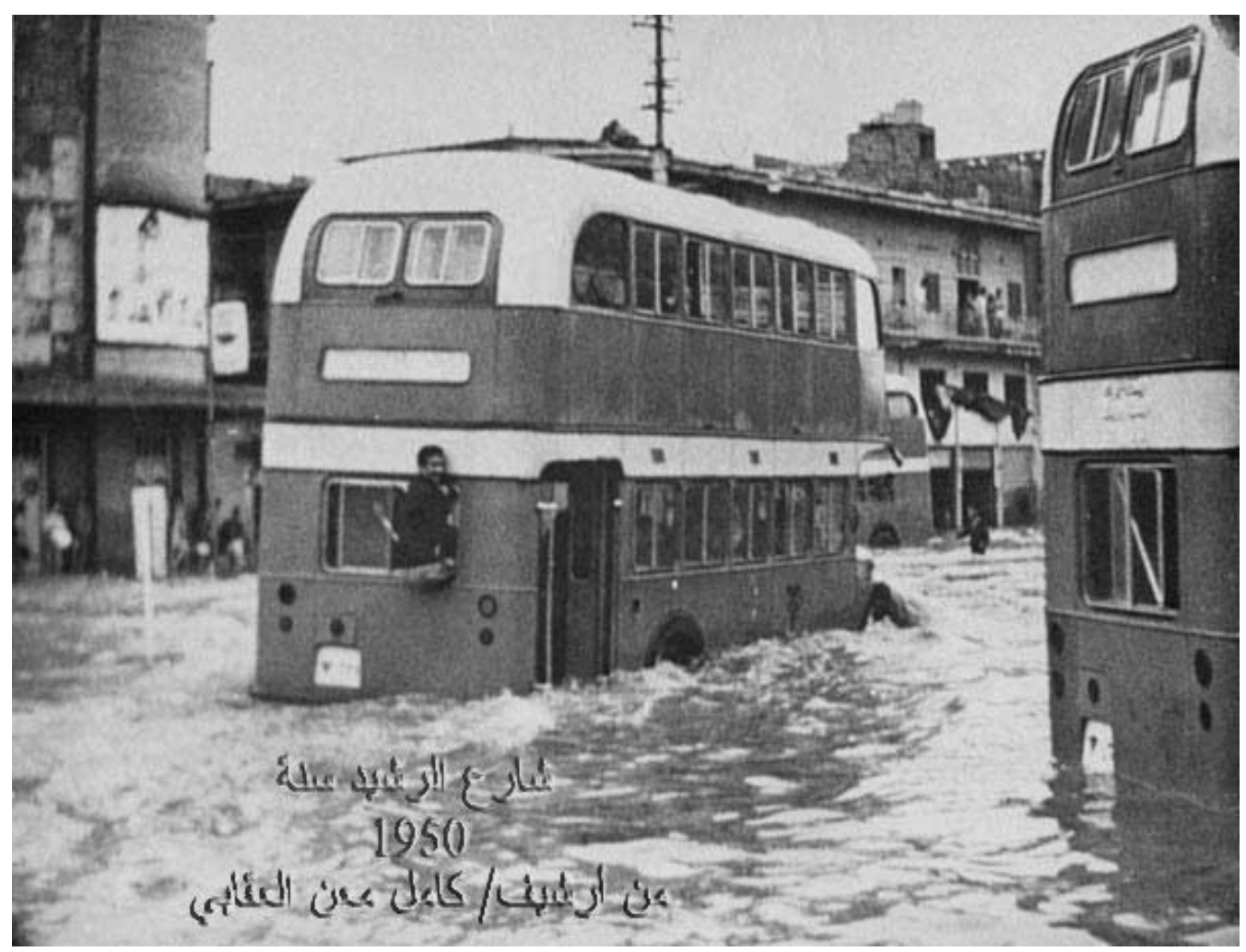

Figure 10: A famous Iraqi street in Bagdad City under flooding in 1950 (Mix Max, 2009).

Issa et al. (2014) studied the expected future of water resources within Tigris-Euphrates Rivers Basins in Iraq. In this study, 15 flow gage stations within both basins were used to evaluate and compare current and future challenges of water availability and demand in Iraq. The results showed that Iraq receives annually $70.92 \mathrm{~km}^{3}$ of water with 45.4 and 25.52 $\mathrm{km}^{3}$ coming from Tigris and Euphrates Rivers, respectively. Table 4 lists the drainage area of the Tigris River basin, divided between countries. An amount of $18.04 \mathrm{~km}^{3}$ of the Tigris water comes from Turkey while its tributaries inside Iraq supply $27.36 \mathrm{~km}^{3}$. It was found that the annual decrease in the Tigris water inflow is $0.1335 \mathrm{~km}^{3} / \mathrm{yr}$ due to upstream decrease in water sources, while water demand increases annually by $1.002 \mathrm{~km}^{3}$. 
Table 4: Drainage area of the Tigris River basin (Al-Ansari and Knutsson, 2011).

\begin{tabular}{|c|c|c|}
\hline Country & Catchment Area $\left(\mathbf{k m}^{2}\right)$ & $\begin{array}{c}\text { Catchment } \\
\text { Area (\%) }\end{array}$ \\
\hline Iraq & 253,000 & 58 \\
\hline Turkey & 57,614 & 12.2 \\
\hline Syria & 834 & 0.2 \\
\hline Iran & 140180 & 29.6 \\
\hline Total & 473103 & 100 \\
\hline
\end{tabular}

Al-Anbari et al. (2006) studied the hydraulic geometry for a stretch of $202.5 \mathrm{~km}$ on the Tigris River from Mosul at km 177.5 in the north, downstream to $\mathrm{km} 380$ near Baeji at the Al-Fathaa Bridge using Leopold's method of maximum, minimum, and average discharges. They defined and estimated Manning friction values for the entire $202.5 \mathrm{~km}$ study area. The results show that there are different hydraulic geometry characteristics along the river reach with high width to depth ratio. At Al-Fathaa gauging station, the width (W) and depth (D) of Tigris River was correlated to its flowrate (Q) according to the following equations:

$\mathrm{W}=136 \mathrm{Q}^{0.05}$

$\mathrm{D}=0.0748 \mathrm{Q}^{0.61}$ 
Ali et al. (2012) used surveyed data of the bed of Tigris River to predict the maximum flood capacity for the river using the HEC-RAS (U.S. army Corps of Engineers, 2010) onedimensional hydraulic model for steady flow. This study used bathymetry data from MWR (2008) and extended from north of Baghdad to the confluence with the Diyala River south of Baghdad. Calibration of the model was carried out using field measurements for water level. The model showed a significant predicted reduction in the current river capacity below that which the river had carried during the floods of 1971 and 1988. 


\section{Hydraulic Structures on The Tigris River in Iraq}

The Ministry of Water Resources in Iraq has undertaken the task of dam construction in Iraq (Table 5) since 1962 when the first concrete dam, Dokan Dam, was constructed on the Lower Zab tributary of the Tigris River. Water shortage and drought are fundamental motivations for the construction of dams. Therefore, the Ministry of Water Resources in Iraq planned a strategy to construct numerous dams across the country to save and control water.

Table 5: Dams in the Tigris River Basin, Iraq; BCM: billion cubic meters; I: Irrigation; F: Flood control.

\begin{tabular}{|l|l|l|l|l|l|l|}
\hline Dam & River & Year & $\begin{array}{l}\text { Height } \\
(\mathrm{m})\end{array}$ & $\begin{array}{l}\text { Length } \\
(\mathrm{m})\end{array}$ & $\begin{array}{l}\text { Capacity } \\
(\mathrm{BCM})\end{array}$ & $\begin{array}{l}\text { Main } \\
\text { Use }\end{array}$ \\
\hline Dokan & Lower Zab & 1962 & 116 & 360 & 6.8 & I \\
\hline Mosul & Tigris & 1983 & 131 & 3650 & 12.5 & I \\
\hline Dibis & Lower Zab & 1965 & 15 & & 3 & I \\
\hline Samarra & Tigris & 1954 & - & & 72.8 & F \\
\hline Adhaim & $\begin{array}{l}\text { Adhaim } \\
\text { River }\end{array}$ & 1999 & - & 3800 & - & - \\
\hline Himrin & $\begin{array}{l}\text { Diyalah } \\
\text { River }\end{array}$ & 1980 & 40 & 3500 & 4 & I \\
\hline Derbendi Khan & $\begin{array}{l}\text { Diyalah } \\
\text { River }\end{array}$ & 1962 & 128 & 445 & 3 & I \\
\hline
\end{tabular}




\section{Irrigation in Iraq}

Although treated wastewater, rich in nutrients, has been used for irrigation of grasslands and pastures and some vegetables, some raw wastewater has also been used by some farmers. This has caused serious problems such as crop contamination with pathogens and heavy metals, and salinity accumulation in soils (Aziz and Aws, 2012). The reuse of drainage irrigation flow can lead to salt accumulation in soils. Irrigation return flows are large and are approximately $20-25 \%$ of the original supplied water, or about 7 billion cubic meters (BCM) (Aziz and Aws, 2012). This implies that about 14\% of the water contribution to the Tigris and the Euphrates Rivers is from irrigation return flows.

Due to numerous wars during the 1980s, 1991, and 2003, lack of maintenance and irrigation development plans have adversely affected agriculture and consequently reduced the percentage of irrigable lands. To a substantial extent, the irrigation infrastructure has broken down in Iraq (The World Bank, 2006). On the other hand, the combination of overirrigation, poor drainage, and high evaporation rates are the main factors that significantly affect the quality of irrigation water. Currently, unregulated water has been withdrawn from the main stream of the Tigris River through pumps, while saline return flow is being directly discharged into the river causing a significant degradation in its quality. 


\section{Water Quality in The Tigris River System}

Due to the rapid population growth from about 11.5 million in 1975 to 31 million in 2010 (Worldometers, 2017) and increasing industrial development, the Tigris River is facing many water quality challenges such as inflows of contaminated water from wastewater treatment plants and saline irrigation return flows (Baban, 1977). Several provinces including Baghdad have suffered from fatal outbreaks of cholera due to poor drinking water quality (Aenab and Singh 2012). Also, sewage is often discharged directly into the river because some areas do not have sewage treatment plants. In central Baghdad, the water supply and sewerage network system are broken in many places and therefore there is cross-contamination of the drinking water supply (Aenab and Singh 2012). According to the UN factsheet (2013), water quality of the water used for drinking and irrigation is poor and violates both Iraqi National Standards and World Health Organization guidelines. As reported by IOM (2012), high pollution and salinity had devastating effects on livestock, agriculture, and fishing in the southern part of Iraq.

Many researchers have studied water quality of the Tigris River. A summary of several of these studies is listed below.

Ismail and Abed (2013) conducted a BOD and DO modeling study of the Tigris River within Baghdad city using the QUAL2K model. The study area was $50 \mathrm{~km}$ long and extended from Fahama region at which the river enters Baghdad city into the south of Baghdad at Zuforaniyah where the river exits Baghdad city. Field DO concentrations at multiple locations within the study area were $5,7.2,1,5.5,7.6$, and $0 \mathrm{mg} / \mathrm{l}$ at river $\mathrm{km} 0$, 17.7, 20,38, 43.4, and 48.5 respectively, while field BOD concentrations at these river kms were $2,2,120,5.2,220$, and $160 \mathrm{mg} / \mathrm{l}$ respectively. The high concentrations of BOD were 
found at locations where industrial and oil effluents were discharged directly to the Tigris River. Remote sensing and GIS applications were used in this study to provide input data for the QUAL2K model. It was found that the simulation results agreed with the measured concentrations. DO concentrations in the entire study area were found above $4 \mathrm{mg} / \mathrm{l}$. CBOD in the Tigris River within Baghdad city from Fahama region to Al-Dora district was between $2-4 \mathrm{mg} / \mathrm{l}$. Due to the industrial discharge of pollutants to the river, the most polluted zone in the Tigris River study area was located downstream of Al-Dora refinery and extended to the end of the study area. To control the level of CBOD in the river, it was suggested that CBOD of the discharged effluents from industries should not exceed 50 $\mathrm{mg} / \mathrm{l}$ to keep the CBOD in the study area no more than $4 \mathrm{mg} / \mathrm{l}$.

Al-Jebouri and Edham (2012) conducted a study in 2004 utilizing selected sectors of the Tigris River and the Lower Zab tributary in Kirkuk and Salahaldeen cities. The study area was divided into eight stations starting at the confluence of the Lower Zab and the Tigris River passing through downstream of the river at Samarra. Water quality analyzed in this study were BOD, turbidity, electrical conductivity (EC), and water temperature. It was found that BOD concentrations at the end of the Lower Zab before the confluence with the Tigris River were in the range of 1.4-3.8 mg/l in August and January, the mean water turbidity was $35 \mathrm{NTU}$, while EC was about $354 \mu \mathrm{S} / \mathrm{cm}$. A wide variation in the water quality was found in this study. BOD data provided in this study were used in our study for boundary conditions of the Upper Zab and the Lower Zab Rivers in the Tigris River model. 
Alobaidy et al. (2010) evaluated both raw and treated water quality of the Tigris River within Baghdad city by means of a water quality index (WQI). WQI was a single value indicator of the water quality determined through summarizing multiple parameters of water test results into simple terms for management and decision makers. In this study, 7 sampling stations and 13 water quality parameters were considered. These parameters were pH (7.63), alkalinity (139.88 mg/l), turbidity (5.5 NTU), total dissolved solids, hardness, calcium, magnesium, chloride, sulphate, ammonia, fluoride, iron, and aluminum. The data used in this study were provided from Baghdad Mayoralty and covered the period from February 2002 to December 2008. According to the WQI, it was concluded that the Tigris water never reached an excellent nor an unsuitable condition.

Abdul Razzak et al. (2009) developed a model to simulate the distribution of total dissolved solids (TDS) and biochemical oxygen demand (BODs) in a stretch of $9 \mathrm{~km}$ of the Tigris River extended from Al-A'imma Bridge to Al-Jumhuria Bridge within Baghdad city. Field data were collected from twelve stations along the river twice a month from November 2005 to April 2006. It was found that the concentration of $\mathrm{BOD}_{5}$ varied in the range of 140$170 \mathrm{mg} / \mathrm{l}$, while TDS concentrations were at the acceptable range $500 \mathrm{mg} / \mathrm{l}$ with exception of a high value of $1100 \mathrm{mg} / \mathrm{l}$ was measured $1 \mathrm{~km}$ downstream Al-Sarafiya Bridge. During the days of field sampling, the water level (Z) $\mathrm{m}$ and flowrate $(\mathrm{Q}) \mathrm{m}^{3} / \mathrm{s}$ of the Tigris River were measured at Sarai gauging station (6.8 $\mathrm{km}$ from Al'Aimma Bridge). The rating curve was estimated using the following correlation

$\mathrm{Q}=32.014(\mathrm{Z}-24.01)^{1.89}$ 
Odemis et al. (2010) studied the quantifying long-term changes in water quality and quantity of the Euphrates and the Tigris Rivers in Turkey. Both watersheds originate in Turkey and are "one of the most import transboundary watersheds in the Middle East." In this study, data from 1971 to 2002 from 14 stations on the Euphrates River and seven stations on the Tigris River were analyzed. It was found that the upper west part of the Tigris River had higher electrical conductivity (EC), $\mathrm{Ca}, \mathrm{Mg}$, and $\mathrm{SO}_{4}$ and lower flow rate, $\mathrm{Na}$, and sodium adsorption ratio (SAR) than the lower parts of the Tigris River. The upper east parts of the river had higher $\mathrm{HCO}_{3}$ and Boron (B) and lower flowrate and water temperature than the lower Tigris River.

Mutlak et al. (1980), studied the effect of Baghdad on the water quality of the Tigris River from April 1977 to March 1978. Typical chemical and physical characteristics of the water that were necessary in judging the quality of water for irrigation were studied. The study area was divided into four sampling sites with a total length of $50 \mathrm{~km}$ and extended from Fahama region at which the river enters Baghdad City into the south of Baghdad at Zuforaniyah region at which Baghdad City ends. Water temperature, $\mathrm{pH}$, turbidity, flow rate and the stream level were recorded once a month at each sampling site. Other water quality parameters measured in this study were dissolved oxygen (DO), biochemical oxygen demand (BOD), nitrate $\left(\mathrm{NO}_{3}{ }^{-}\right)$, nitrite $\left(\mathrm{NO}_{2}{ }^{-}\right)$, and ammonium $\left(\mathrm{NH}_{4}^{+}\right)$ions. It was found that Baghdad City was responsible for increasing the water salinity from 390 to 443 $\mathrm{mg} / \mathrm{l}$. On the other hand, total hardness and turbidity were increased in the Tigris River when it passed through Baghdad City. It was concluded that the increase in the total hardness was mostly due to the increase in Mg concentration. Heavy metals have no direct impact on the water used for irrigation. Table 6 shows changes in temperature, water level, 
discharge, and turbidity of the Tigris River passing through Baghdad City from April 1977 to March 1978.

Table 6: Water characteristics of the Tigris River within Baghdad City (Mutlak et al., 1980)

\begin{tabular}{|l|l|l|l|l|}
\hline Month & Temp ${ }^{\circ} \mathrm{C}$ & $\begin{array}{l}\text { Water Level } \\
(\mathrm{m})\end{array}$ & $\begin{array}{l}\text { Discharge } \\
\left(\mathrm{m}^{3} / \mathrm{s}\right)\end{array}$ & $\begin{array}{l}\text { Turbidity } \\
(\mathrm{NTU})\end{array}$ \\
\hline April-1977 & 15 & 31.74 & 1920 & 149.35 \\
\hline May & 18 & 32.72 & 1960 & 256.77 \\
\hline June & 22 & 29.83 & 1060 & 73.35 \\
\hline July & 25.5 & 28.83 & 507 & 54.52 \\
\hline August & 27.5 & 28.68 & 379 & 45.82 \\
\hline September & 25.2 & 28.40 & 321 & 35.60 \\
\hline October & 19.7 & 28.35 & 384 & 32.50 \\
\hline November & 14.3 & 28.66 & 470 & 34.90 \\
\hline December & 12 & - & 898 & 37.91 \\
\hline January-1978 & 9.8 & 30.83 & 989 & 81.92 \\
\hline February & 10 & 30.52 & 1370 & 312.5 \\
\hline March & 18 & 32.43 & 1960 & 408 \\
\hline
\end{tabular}

Al-Rawi (2005) studied the contribution of man-made activities to the pollution of the Tigris River within Mosul city. In his study, Al-Rawi presented an overall view of major sources that may lead to the pollution of the Tigris River within Mosul city. The study area was a river stretch of about $20 \mathrm{~km}$ in length. Samples from 40 sources sites were taken for quality analyses. It was found that domestic discharges were among the most important sources of pollution. In addition, untreated sanitary wastes were often discharged directly into the Tigris River. Other illegal practices such as in-house slaughtering add to the 
pollution as well. Industrial wastewater was discharged to the Tigris River with low treatment efficiency. These wastes contain lead, chrome, and other heavy metals that may pose health risks. On the other hand, eutrophication which is a characteristic problem of lakes was found to occur in the Tigris River because of the intensive use of detergents rich in nutrients (P\&N compounds). Textile industries discharged effluents with $\mathrm{pH}$ (7.7), PO4 (1.01 mg/l), NO3 (1.22 mg/l), and BOD (135 mg/l).

The Tigris River system has suffered from high water salinity for decades. Total dissolved solids (TDS) refer to any minerals, salts, metals, cations (positive ions) or anions (negative ions) dissolved in water. TDS represent the total amount of mobile charged ions and expressed in units of $\mathrm{mg} / \mathrm{unit}$ volume of water $\mathrm{mg} / \mathrm{l}$ or sometimes referred to as parts per million (ppm). In general, TDS concentration is the sum of both cations and anions. Some principal constituents of TDS in water are calcium, carbonate, nitrate, phosphate, sodium, potassium, chloride, iron, manganese, magnesium, and aluminum. Potential sources of TDS are leaves, industrial waste, wastewater or sewage, silt, fertilizers, pesticides, mining, and runoff from urban areas. The current EPA secondary maximum contaminant level (MCL) for TDS in drinking water is $500 \mathrm{mg} / \mathrm{l}$ (Water research foundation, 2015).

The Iraqi standards of TDS concentrations in drinking water is $500 \mathrm{mg} / \mathrm{l}$ (Ministry of Environment, 1998). Many researchers have studied the effect of salinity on the water quality of both the Tigris River and Tharthar Lake. It was found that the salinity in the Tigris river increased from 390 to $443 \mathrm{mg} / \mathrm{l}$ in Baghdad city as the river passes through the city from April 1977 to March 1978 (Mutlak et al., 1980). The main cations causing hardness in the water of the Tigris River are calcium and magnesium, while the predominant anions are bicarbonates, sulphate, chlorides, and carbonate of calcium and 
magnesium. It was also found that hardness in the Tigris River increases in the middle and southern regions of Iraq due to existing irrigation return flow drainage canals (Baban, 1977). In general, the concentration of total dissolved solids in the Tigris River is governed by urban runoff, irrigation return flow through multiple canals along both banks of the Tigris River, wastewater flow into the river through Diyala River, and high salinity intrusion through both Tharthar-Tigris canal and Audaim River tributary. On the other hand, salinity in Tharthar Lake is of high concern in Iraq since the lake is the largest reservoir in the country and the main water supply to Baghdad city and downstream areas during dry seasons. The water in Tharthar Lake is unsuitable for both drinking and irrigation purposes due to high concentrations of sulphate and salinity (Albadry, 1972). Tharthar Lake's water is classified as C4S1 (C4: waters with electrical conductivity $>2.25$ $\mathrm{dS} / \mathrm{m} ; \mathrm{S} 1$ : very high sodium adsorption ratio) class according to the U.S. salinity laboratory classificatory (Jehad, 1983). According to Swiss consultants (1979), salinity in Wadi AlTharthar was estimated as $5000 \mathrm{mg} / \mathrm{l}$. It was found that there was only a 1-3\% change in the vertical gradient in salinity from the surface of the lake to the bottom (Al-Badry and Artin, 1972), while the horizontal gradient in salinity along the North-South axis of the lake was in the range of $4500-2500 \mathrm{mg} / \mathrm{l}$ (Swiss consultants, 1979). This indicates that water salinity highly corresponds to the inflow from local catchment areas in the northern parts of the lake. According to the salinity classifications listed in Table 7, irrigation water in the Tigris River at Baghdad and downstream areas is classified as high salinity water. 
Table 7: USDA Salinity Laboratory's classification of saline irrigation water based on salinity level, potential injury to plants, and management necessary for satisfactory utilization (Camberato, 2001).

\begin{tabular}{|l|l|l|}
\hline Salinity Class & TDS mg/l & $\begin{array}{l}\text { Potential injury and necessary management for use } \\
\text { as irrigation water }\end{array}$ \\
\hline Low & $<150$ & $\begin{array}{l}\text { Low salinity hazard; generally, not a problem; } \\
\text { additional management is not needed }\end{array}$ \\
\hline Medium & $150-500$ & $\begin{array}{l}\text { Damage to salt sensitive plants may occur. } \\
\text { Occasional flushing with low salinity water may } \\
\text { be necessary. }\end{array}$ \\
\hline High & $500-1500$ & $\begin{array}{l}\text { Damage to plants with low tolerance to salinity } \\
\text { will likely occur. Plant growth and quality will be } \\
\text { improved with excess irrigation for leaching, } \\
\text { and/or periodic use of low salinity water and good } \\
\text { drainage provided. }\end{array}$ \\
\hline Very High & $>1500$ & $\begin{array}{l}\text { Damage to plants with high tolerance to salinity } \\
\text { may occur. Successful use as an irrigation source } \\
\text { requires salt tolerant plants, good soil drainage, } \\
\text { excess irrigation for leaching, and/or periodic } \\
\text { utilization of low salinity water }\end{array}$ \\
\hline
\end{tabular}

Rahi and Halihan (2010) studied water salinity in the Euphrates River as it enters Iraq. It was found that the concentration of total dissolved solids (TDS) in the river was more than doubled compared with that in 1973. Also, it was showed that TDS concentration in Tharthar Lake was $1500 \mathrm{mg} / \mathrm{l}$ in 2003 causing high TDS concentration in the mainstem of the Euphrates River as water diverted from the lake to the river through Tharthar-Euphrates canal. Other causes of high TDS in the river were attributed to irrigation back flow and a decrease in upstream river flow. 
Kadhem (2013) compared water quality data of the Tigris River using a geographic information system (GIS). In his study, 96 water samples were collected from eight locations along the Tigris River. The locations were chosen to cover all the distance of the Tigris River within Baghdad city during Jun-Dec 2008. The chemical analysis shows the mean concentration of $700 \mathrm{mg} / \mathrm{l}$ for total dissolved solid (TDS), $28 \mathrm{NTU}$ for turbidity, and $0.77 \mathrm{mg} / \mathrm{l}$ for Iron $(\mathrm{Fe})$. Field data compiled by Kadhem (2013) were compared to the World Health Organization (WHO) and Iraqi drinking water quality standards. These standards were $500 \mathrm{mg} / \mathrm{l}$ for TDS, $5 \mathrm{NTU}$ for turbidity, and $0.3 \mathrm{mg} / \mathrm{l}$ for Fe. Other water quality variables included in this study that were compared with the Iraqi drinking water quality standards were $\mathrm{pH}$, total hardness $(\mathrm{TH})$, Magnesium $(\mathrm{Mg})$, Chlorine $(\mathrm{Cl})$, Nitrate $\left(\mathrm{NO}_{2}\right)$, Nitrate $\left(\mathrm{NO}_{3}\right)$, and Phosphate $\left(\mathrm{PO}_{4}\right)$. The average values for $\mathrm{pH}, \mathrm{NO}_{3}, \mathrm{PO}_{4}$ were $8.02,0.53$, and $0.07 \mathrm{mg} / \mathrm{l}$, respectively.

Al-Marsoumi et al. (2006) investigated the ionic concentrations of the Tigris and Euphrates Rivers. A significant increase in the total dissolved solids (TDS) concentrations was found downstream of Baghdad city $(557 \mathrm{mg} / \mathrm{l})$ at Amara city compared to $260 \mathrm{mg} / \mathrm{l}$ at Mosul city which is located about $560 \mathrm{~km}$ north of Baghdad. As total hardness was measured in the study, the Euphrates could be divided into two groups from upstream to downstream as hard to very hard, respectively, while Tigris water is considered hard.

Al-Layla and Al-Rizzo (1989) developed and calibrated a mathematical model that numerically solved a 1-D advection-dispersion equation for water quality parameters of interest in the Tigris River downstream of Sadam Dam. The studied study area was $75 \mathrm{~km}$ long extending from Sadam Dam to Mosul city. Fieldwork was conducted in the period 
from July to September 1986. Water samples were collected twice a month. Water quality parameters of interest were DO with a range of 7.0-9.0 mg/l, BOD with a range of 0.7-1.0 $\mathrm{mg} / \mathrm{l}$, ammonia-N with a range of $0.02-0.24$, nitrate- $\mathrm{N}$ with a range of $1.0-0.7$, nitrite- $\mathrm{N}$ with a range of 0.01-0.06, phosphate with a range of $0.4-0.55$, chloride with a range of 3548 , sulphate with a range of $0.02-0.24$, hardness with a range of $210-260$, and TDS with a range of 234-260. Good agreement was found between modeled and in-situ measurements. It was found that DO concentrations increased downstream of the dam due to re-aeration by turbulence.

Jehad (1983) conducted a study to develop a mathematical model to decrease sulphate (SO4) concentrations in Tharthar Lake. He tested the scenario of diverting different quantities of fresh water through Tigris- Tharthar canal and releasing the same quantities through Tharthar canal to the Euphrates River. SO4 concentration could be reduced to the maximum allowable concentration of $400 \mathrm{mg} / \mathrm{l}$ after 11 years if 10 cubic $\mathrm{km}$ water diverted through the Tigris River and released through the lake.

Al-Dabbas and Al-Juburi (1985) evaluated the hydrochemical and sediment transport in Tharthar Lake and its canals. They confirmed that salinity in the lake was mostly increasing in the northern parts of the lake and the lake's water contains $\mathrm{Ca}, \mathrm{Mg}, \mathrm{Na}, \mathrm{K}$, and a combination of sulphate and chloride, while very low concentrations of $\mathrm{Br}, \mathrm{Cr}, \mathrm{Cd}, \mathrm{Fe}, \mathrm{Cu}$, $\mathrm{Zn}$, and Mn were determined. 
The following conclusions can be reached:

- Most studies on the Tigris River were conducted for the river reaches within Baghdad, and focused on water quality and river discharge.

- Iraq heavily depends on the Tigris River for its water resources, including irrigation and drinking water.

- High concentrations of BOD were found in Baghdad at locations where industrial and oil effluents were discharged directly to the Tigris River.

- The Tigris River water never reached a quality of excellent nor of unsuitable.

- The increase in the total hardness in the Tigris River within Baghdad was mostly due to the increase in $\mathrm{Mg}$ concentration

- There is an increase in the annual water demand by $1 \mathrm{~km}^{3}$, while there is an annual decrease in the Tigris water by $0.133 \mathrm{~km}^{3}$ due to upstream decrease in water quantity.

- Field data in the Tigris River within Baghdad were compared with the Iraqi and the World Health Organization (WHO) water quality standards and showed that TDS concentrations exceeded both water quality standards.

- TDS in the Tigris River does not meet the Iraqi drinking water standards and does not reach the excellent level according to a water quality index. The Tigris River is considered medium to highly saline.

- Untreated domestic and industrial effluents were directly discharged to the Tigris River and are a main major source of pollution in the river. 
- Eutrophication, which is a characteristic problem of lakes, was found to occur in the Tigris River because of the intensive use of detergents rich in nutrients ( $\mathrm{P}$ and N compounds).

- The average Total dissolved solids (TDS) concentration in Tharthar Lake was 1500 $\mathrm{mg} / \mathrm{l}$ in 2003, and salinity in the lake was mostly increasing in the northern parts of the lake.

- TDS concentrations were significantly increased in the Tigris River between Mosul Dam and Baghdad city as a result of irrigation return flow, saline water diverted through Tharthar-Tigris canal, and urban runoff.

- Typical BOD concentrations in the Lower Zab tributary were in the range of 1.4$3.8 \mathrm{mg} / \mathrm{l}$ in 2004, while seasonal BOD concentrations in the mainstem of the Tigris River within Baghdad city were in the range of 2-4 mg/l in 2009. 


\section{Chapter Three: Surface Water Temperature Estimation from Remote Sensing}

In this chapter, the process of utilizing remote sensing to estimate the surface water temperature of the Tigris River is described. A statistical model of water temperature based on air temperature and flow rate is developed from these surface water temperature estimates, and is used to infill temporal gaps in the satellite record. The resulting daily water temperature data is used to define the upstream boundary conditions for water temperature and to calibrate/validate the model within the domain.

\section{Introduction}

Monitoring the temperature distribution in water is fundamental for modeling and interpreting the water quality of waterbodies. Water temperature is a key factor of chemical and biochemical processes in aquatic ecosystems and controls the thermodynamics of waterbodies. Conventional monitoring of water surface temperature requires in-situ measurements, which can be expensive, time consuming and limited in spatial extent. In Iraq, the evaporation rate during the summer is large and both water temperature and evaporation in off-river storage lakes such as Tharthar Lake (see Figure 8) is significant. Other factors influence water temperature, including effluents from water and wastewater treatment plants, agricultural return flow, and industrial wastewater discharged to the Tigris River. In addition, short wave solar radiation, long wave atmospheric radiation, back radiation, and conduction are significantly influence water temperature.

Unfortunately, surface water temperature field data in Iraq is limited, and there is no publically available archive of in-situ data. Therefore, remote sensing from satellites is 
potentially an effective method of estimating surface water temperature over a range of temporal and spatial scales.

In remote sensing, satellites such as Landsat, TRMM, MODIS, MERIS, SPOT, Quickeye, Worldview, Aqua, Terra, and Quickbird have been continuously acquiring earth observations. Since publically available, Landsat satellite is adequate for estimating water temperature of the Tigris River. Landsat satellites have been continuously acquiring earth observations since 1972. Eight Landsat satellites have been built, and seven have been successfully launched and operated in orbit. The Landsat 5 thematic mapper (TM) was operational from 1984 to 2012, and the Landsat 7 enhanced thematic mapper plus (ETM+) launched on April 15, 1999 and is still operating. The thematic mapper sensor installed on the Landsat satellite has been the most widely used sensor to monitor inland waters (Ritchie et al. 1990). Due to good time coverage and good spatial and temporal resolution, remote sensing is a convenient alternative to estimate water quality variables of water waterbodies. However, weather conditions such as cloud cover might adversely influence quality of satellite images. 


\section{Remote Sensing}

Remote sensing is the science of gathering object information on earth's surface, land and ocean, by sensors installed on aircrafts or on satellites. Satellites observe earth's surface and acquire images at different temporal ( $<24$ hours $->16$ days) and spatial $(0.41 \mathrm{~m}-$ $>1000 \mathrm{~m}$ ) resolutions. Reflective radiance from an object or a phenomenon is detected within a wide range of wavelengths. Reflective radiance can be converted to Top Of Atmosphere (TOA) reflectance where subsequent atmospheric correction is needed. Compared with conventional and traditional methods, data acquired from satellites could be a reliable alternative to provide information on earth's and water's surface such as surface water temperature, land use and cover.

\section{Landsat 7 ETM+}

Landsat is one of a series of satellites launched by the National Aeronautics and Space Administration (NASA) to acquire satellite imageries of earth. Landsat program began in 1972 with Landsat 1. Landsat 5 Thematic Mapper (TM) was launched on March 1, 1984 and decommissioned on January 2013. Landsat 7 enhanced thematic mapper plus (ETM+) was launched on April 15, 1999 and is still operating. Landsat satellites provide continuous earth observation information that are important for monitoring global changes (Fuller at al., 1994; Wulder at al., 2008). Figure 11 shows a schematic of Landsat 7 ETM+. Landsat imageries have been archived and available from the United States and Geological Surveys (USGS). 


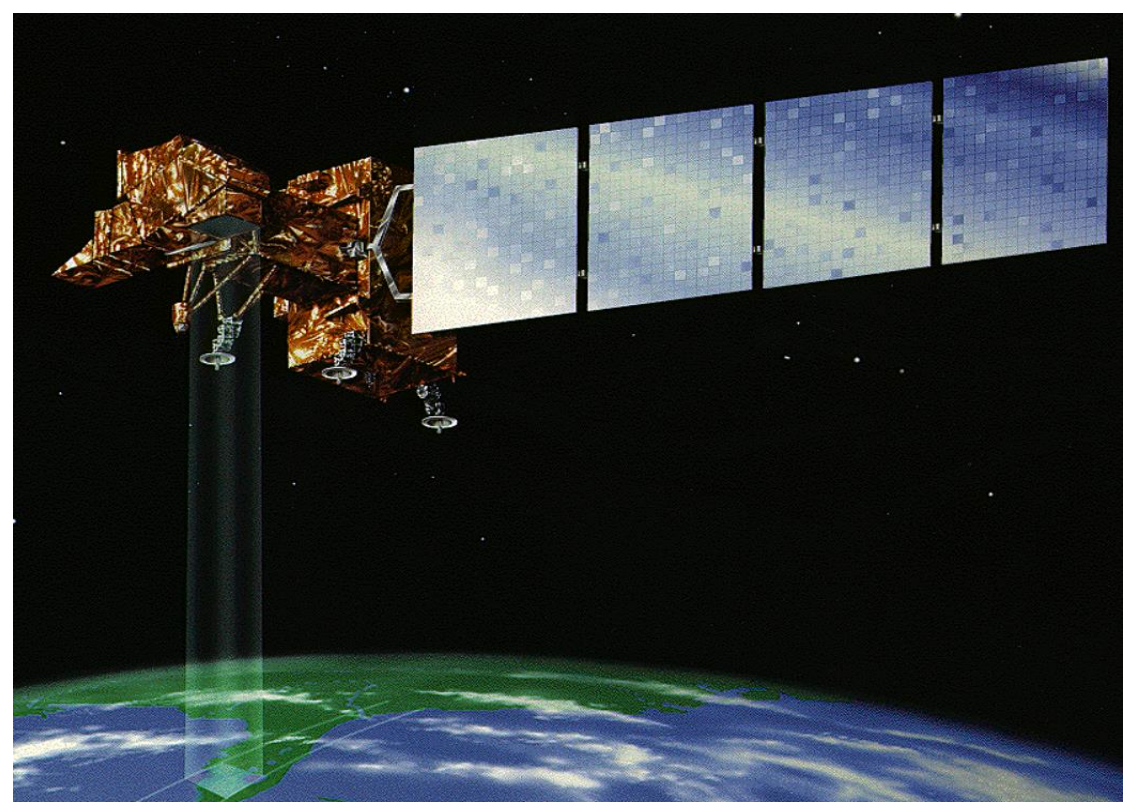

Figure 11: Schematic of Landsat 7 ETM+ satellite (NASA, 2014).

\section{Previous Research Studies Using Remote Sensing Data}

Nas et al. (2010) have investigated spatial patterns in water quality in Lake Beysehir, the largest fresh water reservoir in Turkey, using Landsat 5 Thematic Mapper (TM) data and ground data. Water quality variables of interest were suspended sediments (SS), turbidity, secchi disk depth (SDD), and chlorophyll-a (chl-a). Multiple regression (MR) and bivariate ( 2 band independents) were used to estimate spatial patterns based on both remote sensed and ground data. It was found that band 3 (TM3) provided a significant relationship with SS concentration, while band 1 (TM1), band 2 (TM2), and band 4 (TM4) were strongly correlated with Ch-a concentrations. Turbidity was shown to be significantly correlated with TM1, TM2, and TM3, while SDD was correlated with the ratio TM1/TM3 and TM1.

In Kabbara et al. (2008), Landsat 7 ETM+ was used to assess water quality in the coastal area of Tripoli (Lebanon). Empirical algorithms for chlorophyll-a concentration, secchi disk depth, and turbidity were derived. Maps of the distribution of selected water quality 
parameters were generated for the entire area of interest. Moderate eutrophication conditions were indicated by the water quality in the coastal area.

Wang et al. (2006) investigated water quality in the Reelfoot Lake, Tennessee using Landsat5 TM imagery. Empirical algorithms were developed for water quality parameters such as turbidity, chlorophyll-a (Chl-a), and Secchi disk depth as listed in Table 8. They concluded that remote sensing was a useful tool to map Chl-a distribution in Reelfoot Lake.

Khattab and Merkel (2014) derived simple and accurate algorithms for the retrieval of water quality variables for Mosul Dam Lake, Iraq. Landsat 5 TM and Landsat 7 ETM+ were used in this study. Water quality variables of interest included temperature, turbidity, Secchi disk, chlorophyll-a, nitrate, nitrite, phosphate, total inorganic carbon, dissolved organic carbon, total dissolved solids, and $\mathrm{pH}$. Image enhancement was used to evaluate the values of reflectance bands properly. A significant correlation between developed models and water quality variables was concluded in this study. Normalized difference water index (NDWI) was used to delineate the surface water of the lake. It was concluded that "ETM+ algorithms were more precise" and that algorithms based on surface reflectance for Landsat7 ETM+ were more quantitative and accurate than those based on Landsat 5TM.

Using Landsat Thematic Mapper (TM), Giardino et al. (2001) modeled and mapped water quality parameters including temperature in the sub-alpine Lake Iseo, Italy. A Landsat imagery-independent procedure was used to derive the surface temperature of the lake from the TM data. A window of 3×3-pixel array was used in the study. The temperature model was not based on a correlation between satellite and in-situ data such as other water quality 
variables used in the study. It was based on an image independent procedure using the inverted Plank's law of temperature.

Lamaro et al. (2013) utilized the thermal bands of Landsat7 ETM+ to estimate surface water temperature in Embalse del Rio Tercero reservoir, Argentina. "The single-channel generalized method (SCGM) developed by Jimenez-Munoz and Sobrino (2003)" was used in this study. A constant water emissivity value of 0.9885 was used. Significant correlation coefficients $\mathrm{R}^{2}$ of 0.9498 for SCGM method and $\mathrm{R}^{2}$ of 0.9584 for RTM method were achieved.

Fan et al. (2014) predicted the chlorophyll a concentration in Xiangxi Bay in the Three Gorges Reservoir using $\mathrm{Hj}-1$ satellite imagery. Several models were established based on a correlation analysis between in situ measurements of the chlorophyll a concentration and the values obtained from satellite images of the study area from January 2010 to December 2011. The results show that the maximum correlation is between the reflectance of the band combination of B4/(B2+B3) and in situ measurements of chlorophyll a concentration (see Table 8). The results provided a reference for water bloom prediction in typical tributaries of the Three Gorges Reservoir and was deemed useful for water quality management. 
Table 8: Water quality correlations of some research studies. B1, B2, B3, B4, B5, B6, B61, and B62 are blue, green, red, near infrared, shortwave infrared, thermal, thermal Low Gain, and thermal High Gain bands respectively.

\begin{tabular}{|c|c|c|c|}
\hline $\begin{array}{l}\text { Water Quality } \\
\text { Variable }\end{array}$ & Correlation & $\mathrm{R}^{2}$ & Reference \\
\hline Ln(Turbidity) & 10.6-5.6Ln(B1) +3.5Ln(B2) & 0.57 & \\
\hline $\operatorname{Ln}(\mathrm{SDD})$ & $-7.27+4.84 \operatorname{Ln}(\mathrm{B} 1)-2.95 \operatorname{Ln}(\mathrm{B} 2)$ & 0.57 & Kabbara et al. \\
\hline $\operatorname{Ln}(\mathrm{Chl}-\mathrm{a})$ & $1.67-3.9 \operatorname{Ln}(\mathrm{B} 1)+3.8 \mathrm{Ln}(\mathrm{B} 2)$ & 0.72 & $(2008)$ \\
\hline Turbidity & $-0.22-.46 \times \mathrm{B} 1+0.72 \times \mathrm{B} 2+0.84 \times \mathrm{B} 3$ & 0.6 & \\
\hline SDD & $-16.89+93.84 \times(\mathrm{B} 1 / \mathrm{B} 3)-2.162 \times \mathrm{B} 1$ & 0.71 & Nas et al. (2010) \\
\hline Chl-a & $7.4-0.38 \times \mathrm{B} 1+0.54 \times \mathrm{B} 2+0.73 \times \mathrm{B} 4$ & 0.6 & \\
\hline Turbidity & $19+144 \times \mathrm{B} 2-118.7 \times \mathrm{B} 3$ & 0.537 & Wang et al. (2006) \\
\hline SDD & $33.6-133 \times \mathrm{B} 2+97.94 \times \mathrm{B} 3$ & 0.588 & \\
\hline Chl-a & $48.4+1142.22 \times \mathrm{B} 2-876.368 \times \mathrm{B} 3$ & 0.705 & \\
\hline Temperature & No Correlation & 0.95 & Lamaro et al. (2013) \\
\hline Turbidity & $35.121-14.489(\mathrm{~B} 2 / \mathrm{B} 3)-0.911 \mathrm{~B} 4$ & 0.99 & \\
\hline SDD & $3119.27 \mathrm{e}-0.233 \mathrm{~B} 3$ & 0.88 & \\
\hline Chl-a & $-15.16+0.449 \mathrm{~B} 1-1.252(\mathrm{~B} 3 / \mathrm{B} 1)$ & 0.88 & \\
\hline TDS & $-0.920-0.002 \mathrm{~B} 2+0.01 \mathrm{~B}_{2}+0.001 \mathrm{~B} 4$ & 0.96 & Khattab et al. (2014) \\
\hline $\mathrm{NO}_{3}$ & $1.782+75.469 \ln \left(\mathrm{B}_{2} / \mathrm{B} 6_{1}\right)$ & 0.6 & \\
\hline $\mathrm{PO}_{4}$ & $-0.081-0.008 \mathrm{~B} 3+0.018 \mathrm{~B} 4$ & 0.96 & \\
\hline Temperature & $-7.4+0.119 \mathrm{~B} 6+0.066 \mathrm{~B} 6_{2}-0.017 \mathrm{~B} 5$ & 0.97 & \\
\hline SDD & $8.01(\mathrm{~B} 1 / \mathrm{B} 2)-8.27$ & 0.99 & Giardino et al. (2001) \\
\hline Chl-a & $11.18 \mathrm{~B} 1-8.96 \mathrm{~B} 2-3.28$ & 0.85 & \\
\hline
\end{tabular}




\section{Satellite Data Acquisition}

Landsat imageries of interest that are used in this study were accessed from the US Geological Survey (USGS) database at http://glovis.usgs.gov/ and http://www.earthexplorer.usgs.gov/. Landsat images can be inquired over any portion in the world by specifying a nominal image center referred as Path/Row numbers. Figure 12, Figure 13, and Figure 14 show three satellite imageries cover the study area and their Path/Row from upstream to downstream are (170/35) at Mosul Dam, (169/36) at Samarra City, and (168/37) at Baghdad City respectively. All imageries of interest are available in both the Landsat 7 ETM+ and Landsat 5 TM archive. Level 1-T and atmosphericallycorrected level 2 surface reflectance have been used in this study. All remotely sensed imageries used in this study are a combination of both Landsat7 ETM+ and Landsat 5 TM. The dimensions of each imagery are about $7000 \times 8000$ pixels which is equivalent to $210 \times 240 \mathrm{~km}$. All Landsat scenes were acquired at 10:30 AM local time. Table 9 lists Landsat 5 (LT5) and Landsat 7 (LE7) images used in this study.

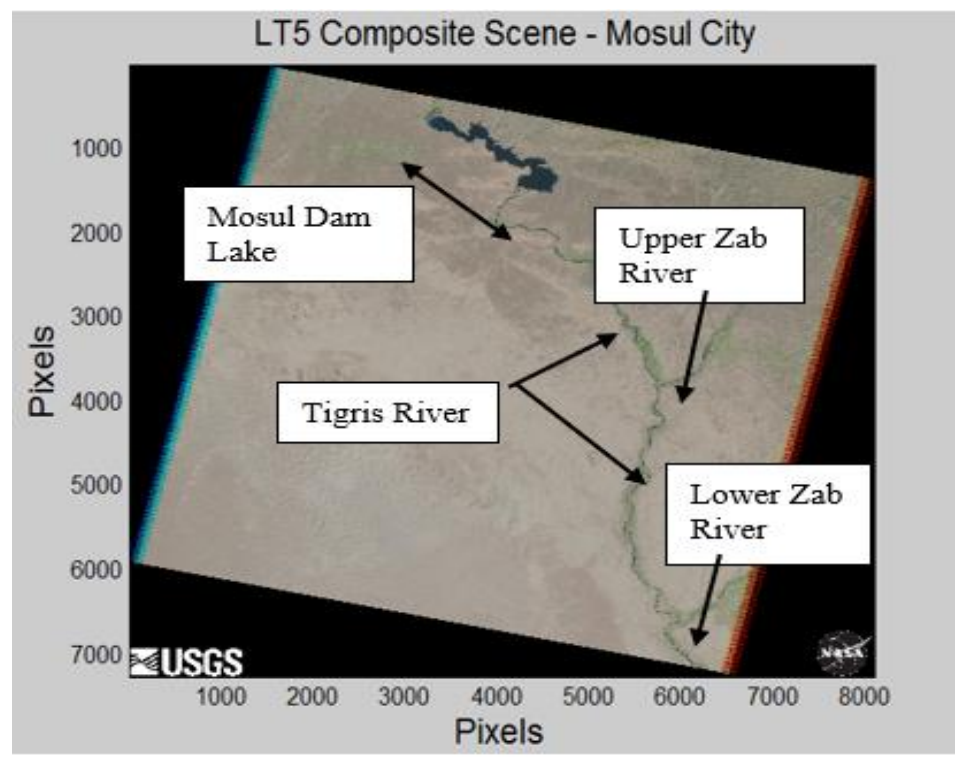


Figure 12: Landsat TM5 covers the Tigris River at Mosul Dam.

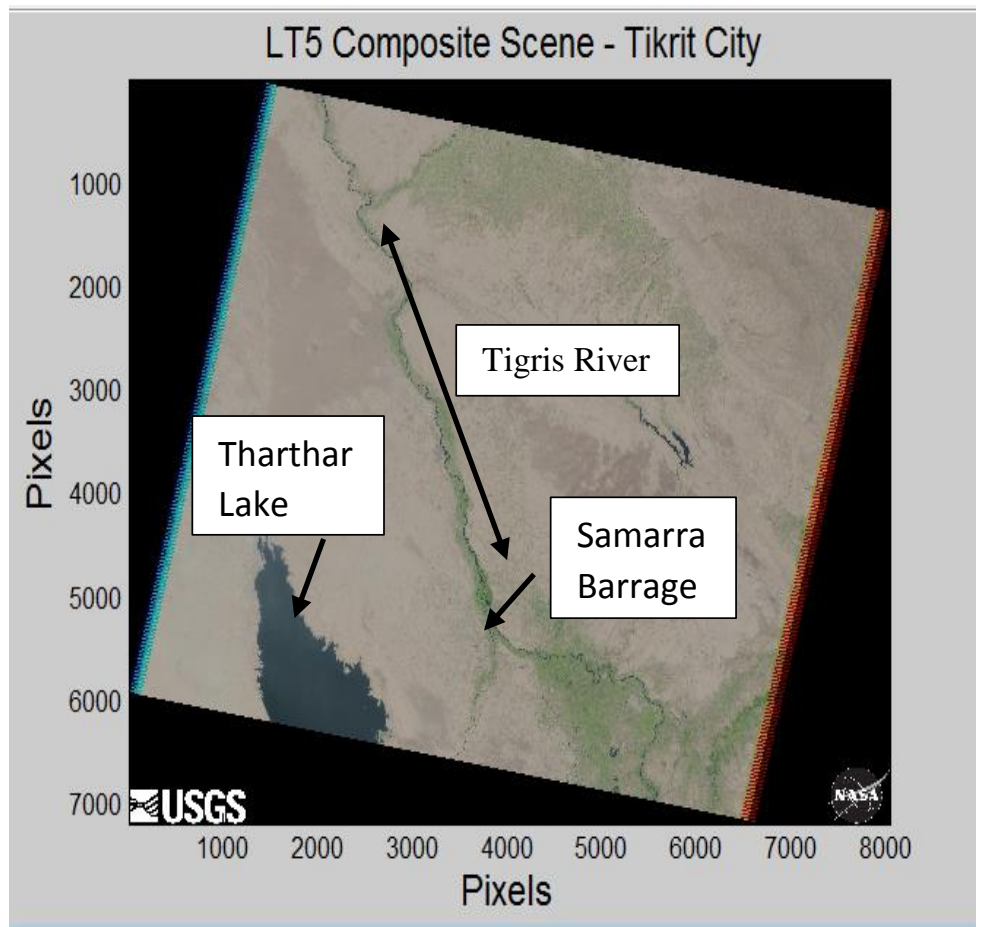

Figure 13: Landsat TM5 covers the Tigris River at Samarra Barrage and Tharthar Lake.

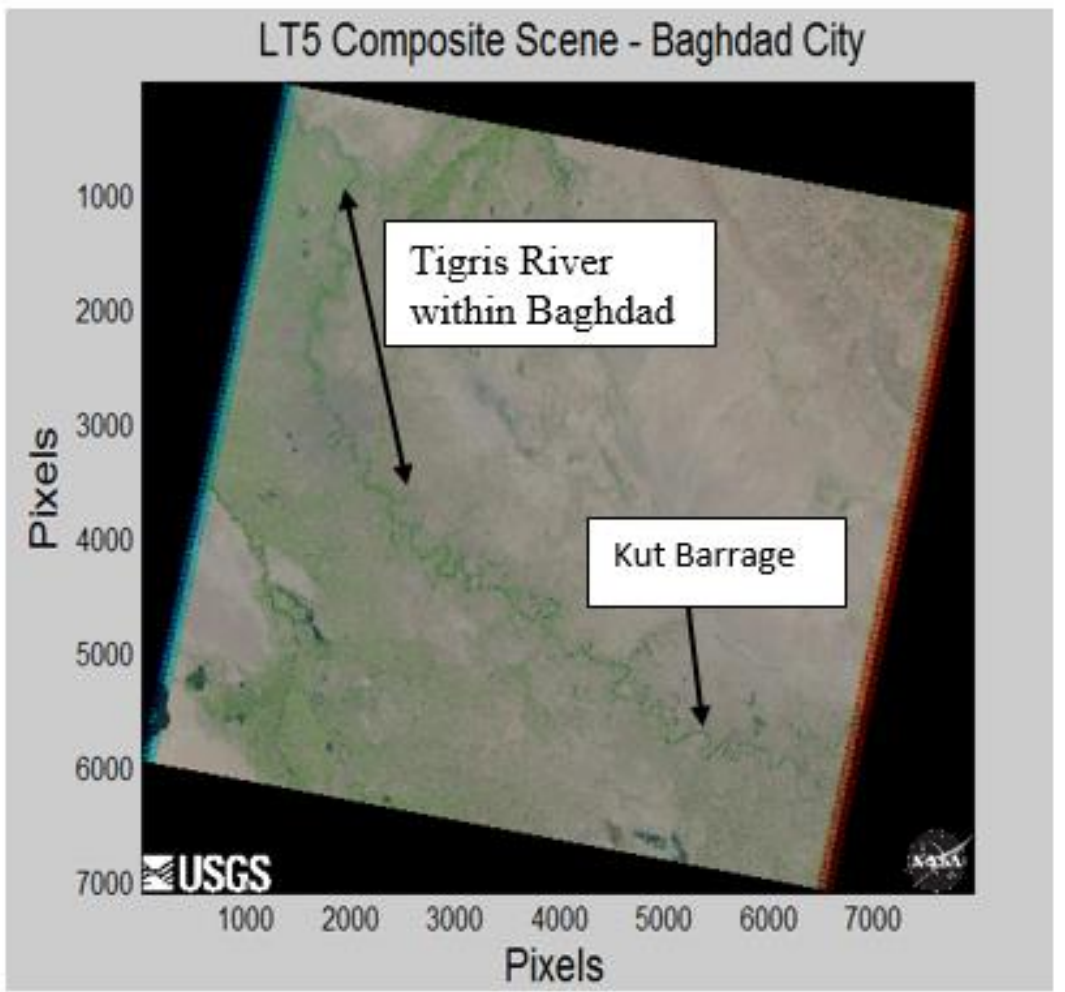

Figure 14: Landsat TM5 covers the Tigris River at Baghdad and Kut. 
Table 9: Landsat 5 (LT5) and Landsat 7 (LE7) images used in this study.

\begin{tabular}{|c|c|c|c|c|c|c|c|c|c|c|c|}
\hline \multicolumn{4}{|c|}{ Mosul City } & \multicolumn{4}{|c|}{ Baeji City } & \multicolumn{4}{|c|}{ Baghdad City } \\
\hline $\begin{array}{c}\text { Path/Row } \\
170 / 35\end{array}$ & Date & $\begin{array}{l}\text { JDAY } \\
2009\end{array}$ & $\begin{array}{c}\text { Cloud } \\
\text { Cover \% }\end{array}$ & $\begin{array}{c}\text { Path/Row } \\
169 / 36\end{array}$ & Date & $\begin{array}{l}\text { JDAY } \\
2009\end{array}$ & $\begin{array}{c}\text { Cloud } \\
\text { Cover \% }\end{array}$ & $\begin{array}{c}\text { Path/Row } \\
168 / 37\end{array}$ & Date & $\begin{array}{l}\text { JDAY } \\
2009\end{array}$ & $\begin{array}{c}\text { Cloud } \\
\text { Cover \% }\end{array}$ \\
\hline \multirow{6}{*}{ LE7 } & $2 / 11 / 2009$ & 42 & 8 & \multirow{8}{*}{ LE7 } & $2 / 4 / 2009$ & 35 & 3 & \multirow{15}{*}{ LE7 } & \begin{tabular}{|l|}
$1 / 12 / 2009$ \\
\end{tabular} & 12 & 14 \\
\hline & $5 / 2 / 2009$ & 122 & 0 & & $3 / 8 / 2009$ & 67 & 4 & & $1 / 28 / 2009$ & 28 & 2 \\
\hline & $5 / 18 / 2009$ & 138 & 0 & & $5 / 27 / 2009$ & 147 & 0 & & \begin{tabular}{|l|}
$2 / 13 / 2009$ \\
\end{tabular} & 44 & 7 \\
\hline & $6 / 3 / 2009$ & 154 & 0 & & $7 / 30 / 2009$ & 211 & 2 & & \begin{tabular}{|l|}
$3 / 17 / 2009$ \\
\end{tabular} & 76 & 0 \\
\hline & $7 / 5 / 2009$ & 186 & 0 & & $8 / 15 / 2009$ & 227 & 0 & & \begin{tabular}{|l|}
$4 / 18 / 2009$ \\
\end{tabular} & 108 & 1 \\
\hline & $12 / 28 / 2009$ & 362 & 12 & & $9 / 16 / 2009$ & 259 & 4 & & $5 / 20 / 2009$ & 140 & 6 \\
\hline \multirow{7}{*}{ LT5 } & $5 / 26 / 2009$ & 146 & 1 & & \begin{tabular}{|l|}
$10 / 2 / 2009$ \\
\end{tabular} & 275 & 0 & & $6 / 5 / 2009$ & 156 & 0 \\
\hline & \begin{tabular}{|l|}
$7 / 13 / 2009$ \\
\end{tabular} & 194 & 0 & & $10 / 18 / 2009$ & 291 & 0 & & \begin{tabular}{|l|}
$6 / 21 / 2009$ \\
\end{tabular} & 172 & 0 \\
\hline & \begin{tabular}{|l|}
$7 / 29 / 2009$ \\
\end{tabular} & 210 & 0 & \multirow{12}{*}{ LT5 } & $5 / 3 / 2009$ & 123 & 16 & & $7 / 7 / 2009$ & 188 & 0 \\
\hline & $8 / 30 / 2009$ & 242 & 0 & & $5 / 19 / 2009$ & 139 & 0 & & \begin{tabular}{|l|}
$7 / 23 / 2009$ \\
\end{tabular} & 204 & 0 \\
\hline & 9/15/2009 & 258 & 0 & & $6 / 4 / 2009$ & 155 & 0 & & \begin{tabular}{|l|}
$9 / 25 / 2009$ \\
\end{tabular} & 268 & 0 \\
\hline & \begin{tabular}{|l|}
$10 / 1 / 2009$ \\
\end{tabular} & 274 & 0 & & $6 / 20 / 2009$ & 171 & 0 & & $10 / 11 / 2009$ & 284 & 2 \\
\hline & $10 / 17 / 2009$ & 290 & 0 & & $7 / 22 / 2009$ & 203 & 3 & & $10 / 27 / 2009$ & 300 & 4 \\
\hline $\begin{array}{c}\text { Path/Row } \\
169 / 35\end{array}$ & & & & & $8 / 7 / 2009$ & 219 & 1 & & $11 / 12 / 2009$ & 316 & 0 \\
\hline \multirow{10}{*}{ LE7 } & $2 / 4 / 2009$ & 35 & 3 & & $8 / 23 / 2009$ & 235 & 0 & & $12 / 14 / 2009$ & 348 & 14 \\
\hline & $5 / 27 / 2009$ & 147 & 6 & & $9 / 8 / 2009$ & 251 & 0 & $\begin{array}{c}\text { Path/Row } \\
169 / 37 \\
\end{array}$ & & & \\
\hline & $6 / 28 / 2009$ & 179 & 0 & & $9 / 24 / 2009$ & 267 & 0 & \multirow{11}{*}{ LE7 } & $1 / 19 / 2009$ & 19 & 14 \\
\hline & $7 / 14 / 2009$ & 195 & 0 & & $10 / 10 / 2009$ & 283 & 2 & & $2 / 4 / 2009$ & 35 & 1 \\
\hline & $7 / 30 / 2009$ & 211 & 0 & & $10 / 26 / 2009$ & 299 & 3 & & \begin{tabular}{|l|}
$2 / 20 / 2009$ \\
\end{tabular} & 51 & 9 \\
\hline & \begin{tabular}{|l|}
$8 / 15 / 2009$ \\
\end{tabular} & 227 & 0 & & $11 / 11 / 2009$ & 315 & 0 & & $3 / 8 / 2009$ & 67 & 11 \\
\hline & $8 / 31 / 2009$ & 243 & 0 & & & & & & $5 / 27 / 2009$ & 147 & 8 \\
\hline & \begin{tabular}{|l|}
$9 / 16 / 2009$ \\
\end{tabular} & 259 & 14 & & & & & & $7 / 14 / 2009$ & 195 & 3 \\
\hline & \begin{tabular}{|l|}
$10 / 2 / 2009$ \\
\end{tabular} & 275 & 0 & & & & & & \begin{tabular}{|l|}
$7 / 30 / 2009$ \\
\end{tabular} & 211 & 1 \\
\hline & $10 / 18 / 2009$ & 291 & 0 & & & & & & $8 / 15 / 2009$ & 227 & 0 \\
\hline \multirow{13}{*}{ LT5 } & $5 / 3 / 2009$ & 123 & 1 & & & & & & 9/16/2009 & 259 & 3 \\
\hline & $5 / 19 / 2009$ & 139 & 2 & & & & & & \begin{tabular}{|l|}
$10 / 2 / 2009$ \\
\end{tabular} & 275 & 0 \\
\hline & $6 / 4 / 2009$ & 155 & 0 & & & & & & $10 / 18 / 2009$ & 291 & 1 \\
\hline & $6 / 20 / 2009$ & 171 & 5 & & & & & & & & \\
\hline & $7 / 6 / 2009$ & 187 & 5 & & & & & & & & \\
\hline & \begin{tabular}{|l|}
$7 / 22 / 2009$ \\
\end{tabular} & 203 & 1 & & & & & & & & \\
\hline & $8 / 7 / 2009$ & 219 & 1 & & & & & & & & \\
\hline & $8 / 23 / 2009$ & 235 & 0 & & & & & & & & \\
\hline & $9 / 8 / 2009$ & 251 & 0 & & & & & & & & \\
\hline & \begin{tabular}{|c|}
$9 / 24 / 2009$ \\
\end{tabular} & 267 & 5 & & & & & & & & \\
\hline & $10 / 10 / 2009$ & 283 & 0 & & & & & & & & \\
\hline & $10 / 26 / 2009$ & 299 & 1 & & & & & & & & \\
\hline & $11 / 11 / 2009$ & 315 & 0 & & & & & & & & \\
\hline $\begin{array}{c}\text { Total } \\
\text { Images }\end{array}$ & 36 & & & $\begin{array}{c}\text { Total } \\
\text { Images }\end{array}$ & 20 & & & $\begin{array}{c}\text { Total } \\
\text { Images }\end{array}$ & 26 & & \\
\hline
\end{tabular}




\section{Image Processing}

Remotely sensed data acquired from Landsat7 ETM+ is processed to convert the digital numbers (DNs) to reflectance and to minimize atmospheric effects (Lu et al. 2002). Image processing includes:

- Geometric Correction using ground control points (GCPs)

- Radiometric correction (Conversion of DNs to spectral radiance) using Equation 1 proposed by Chander and Markham (2003).

Equation 1. Radiometric correction equation

\section{$L=($ Gain $* \mathrm{DN})+$ Bias}

where:

L: Radiance at satellite level of a specific band $\left(\mathrm{W} \mathrm{m}^{-2} \mathrm{sr}^{-1} \mathrm{u}^{-1}\right)$.

DN: Value of the digital number.

Gain: Gain value for a specific band.

Bias: Bias value for a specific band.

- Conversion from spectral radiance to TOA planetary reflectance. This step is used to make the satellite data comparable with the spectral in-situ measurements. Equation 2 is used for this purpose.

Equation 2. Conversion from spectral radiance to TOA planetary reflectance

$$
\mathrm{R}=\frac{\pi \mathrm{Ld} 2}{\operatorname{Esun} \operatorname{Cos} \theta}
$$

where:

$\mathrm{R}=$ Planetary TOA reflectance [unit less]

$\pi=$ Mathematical constant equal to $\sim 3.14159$ [unit less]

$\mathrm{L}=$ Spectral radiance at the sensor's aperture $\left[\mathrm{W} /\left(\mathrm{m}^{2} \mathrm{sr} \mu \mathrm{m}\right)\right]$

$\mathrm{d}=$ Earth - Sun distance [astronomical units]

ESUN= Mean exoatmospheric solar irradiance $\left[\mathrm{W} /\left(\mathrm{m}^{2} \mu \mathrm{m}\right)\right]$

$\theta=$ Solar zenith angle [degrees] 
Atmospheric correction is needed because electromagnetic radiation travels through the atmosphere along its two paths from the sun to the earth surface and from there to the sensor, undergoing alterations to the radiometric signal.

- Waterline Extraction

According to Liu et al., (2011) and Ryu et al., (2002), the waterline is defined as a spatially continuous boundary between water and an exposed land mass. It is important to extract the water line for all Landsat imageries used to estimate surface water temperature of the Tigris River. For each individual scene, surface temperatures were estimated for the water pixels only, and land pixels were ignored. In this research, the surface reflectance landwater mask which is processed and provided by USGS as level 2 processed data, is used to extract the water line of the main stream of the Tigris River over the study area. The landwater mask is one of the successful methods used to extract the waterline from satellite images. Figure 15 shows an example of land-water mask of Landsat TM5 image that covered the Tigris River at Mosul Dam lake and the main stream of the Tigris river. 


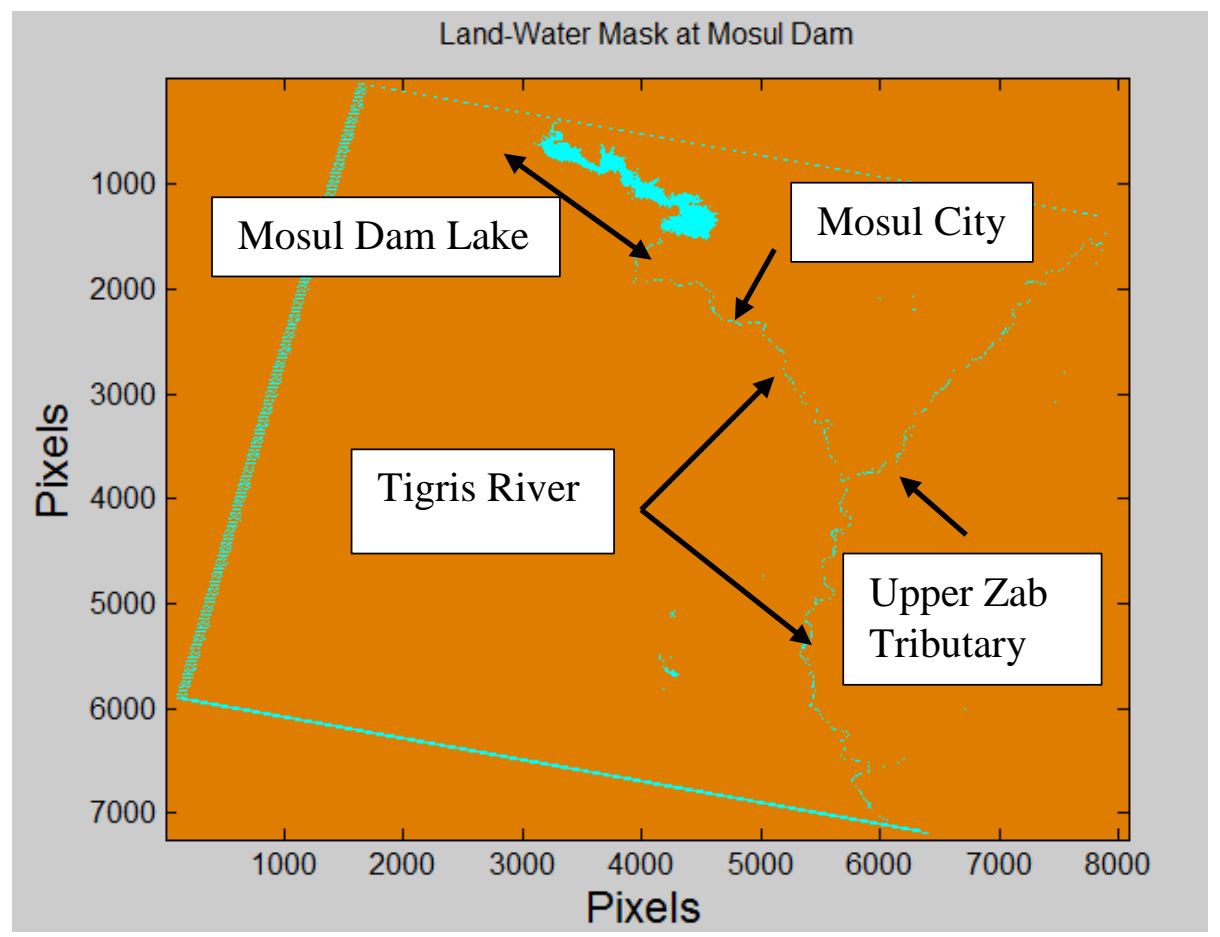

Figure 15: Land-water mask of the Tigris River at Mosul Dam and Mosul City.

\section{Converting Landsat Thermal Bands to Surface Temperature}

Landsat 5TM and Landsat 7 ETM+ sensors provide the spectral radiance that is stored at the sensor as digital numbers (DNs). It is possible to convert DNs to temperature values in degrees Kelvin using a two-step processes utilizing MATLAB for image processing, as described below (Coll et al. 2010):

- Conversion of DNs to Radiance, using Equation 1 "Gain and Bias Method"

- Conversion of Radiance to Kelvin, using the inverse of the Planck function as described in Equation 3 which determines at sensor temperature (this equation should be applied if no atmospheric correction is done on the band). Planck function is described in Equation 4.

Equation 3. Estimation of Pixel's temperature 


$$
T_{w}=\frac{K 2}{\ln \left(\left(K 1 * \frac{\varepsilon}{L}\right)+1\right)}
$$

where:

$\mathrm{T}_{\mathrm{w}}$ : At sensor brightness temperature in Degrees Kelvin

L: Radiance, estimated from Equation 1

$\varepsilon$ : Emissivity (0.975)

K1: Constant (666.09 for ETM+), (607.76 for TM)

K2: Constant (1282.71 for ETM+), (1260.56 for TM)

Equation 4: Planck function

$$
L=\frac{a}{\lambda^{5}\left(e^{b / \lambda t}-1\right)}
$$

where:

L: Radiance

a: $1.191042 \mathrm{E} 8\left(\mathrm{w} / \mathrm{m}^{2} \mathrm{sr} \mu \mathrm{m}^{-4}\right)$

b: 1.4387752E4 $(\mathrm{k} \mu \mathrm{m})$

$\lambda$ : Wavelength $(\mu \mathrm{m})$

$\mathrm{t}$ : Blackbody temperature $(\mathrm{k})$

Emissivity is the ratio of the thermal radiation from a surface to the radiation from an ideal black surface. This ratio varies between 0 (gray bodies) and 1 (ideal blackbodies). Some factors affect emissivity such as temperature, emission angle, and wavelength. In this study, emissivity in Equation 3 was assumed constant with a value of 0.975 during the year 2009. This could introduce uncertainty in estimating of surface water temperature. 


\section{Estimation of Surface Water Temperature of the Tigris River}

Thermal bands of Landsat images were utilized to estimate surface water temperature at Mosul Dam, Baeji city, and Baghdad city. For the year 2009, a total of 82 Landsat 5 TM and Landsat 7 ETM+ images with $20 \%$ or less image cloud cover condition were used to estimate surface water temperature in the mainstem the Tigris River. Unfortunately, most of Landsat images were unavailable in USGS archive for March and April of 2009. Figure 16 shows an example of surface water temperature at Mosul Dam and the main stream of the Tigris River downstream of Mosul City estimated in January 2009. A box filter of $2 \times 2$ $\mathrm{km}$ was used to estimate $T_{w}$. After defining the box filter, the median value was used to estimate $T_{w}$ in that box. Although a land-water mask was used to differentiate between land and water pixels, some errors could be introduced by any remaining land pixels that have larger surface temperature than water pixels. Similarly, surface water temperatures at both Baeji and Baghdad cities were estimated from a combination of Landsat 5 TM and Landsat 7ETM+. Figure 17 and Figure 18 show surface water temperatures of the Tigris River at Baeji, Baghdad cities, and downstream areas along the main stream of the Tigris River estimated in January 2009. It can be seen that $T_{w}$ at the northern ends of both Mosul Dam Lake and Tharthar Lake is very low (potentially spurious). 


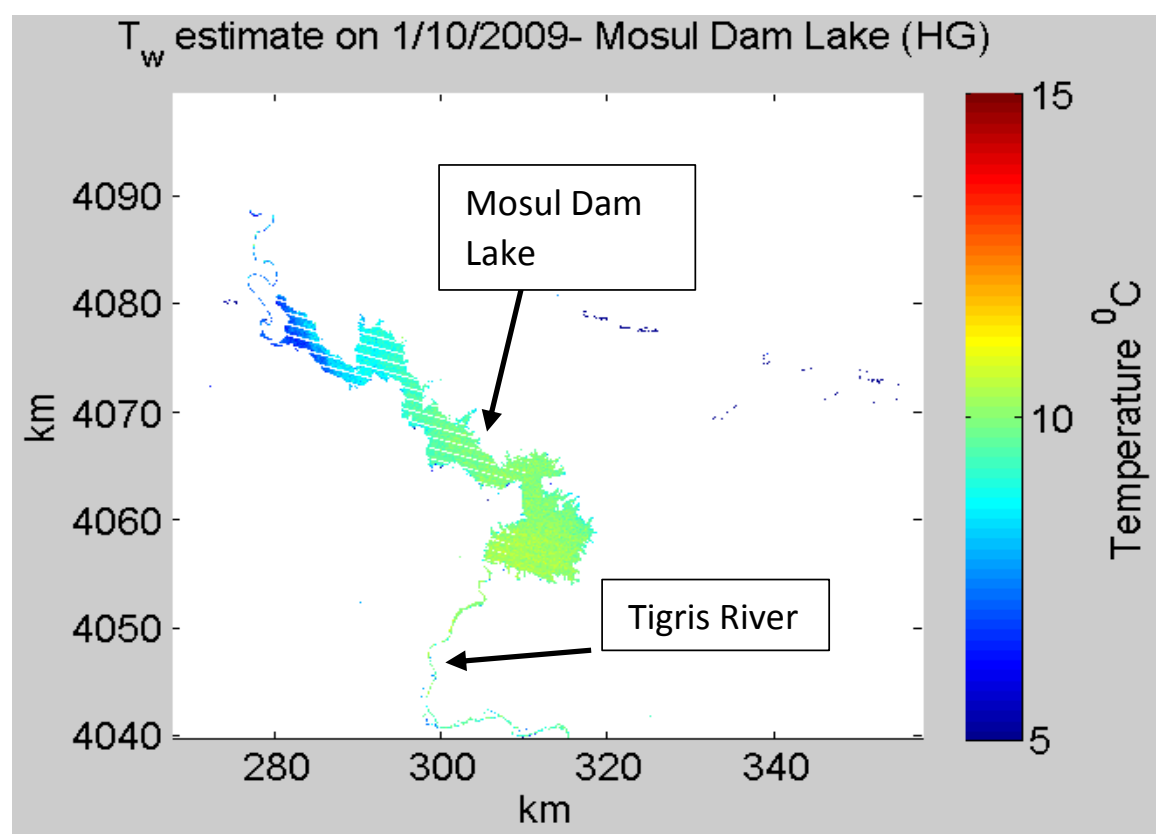

Figure 16: Surface water temperature of the Tigris River at Mosul Dam Lake.

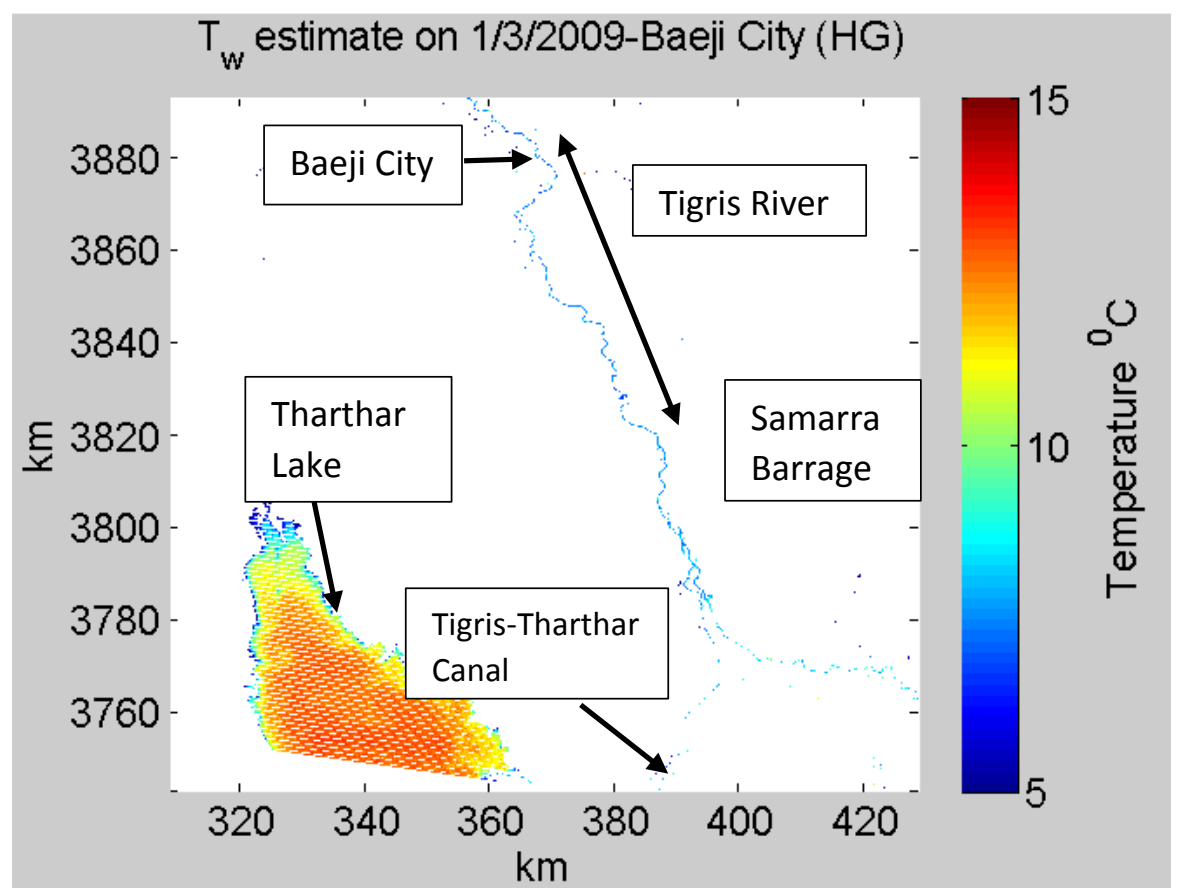

Figure 17: Surface water temperature of the Tigris River at Samarra Barrage. 


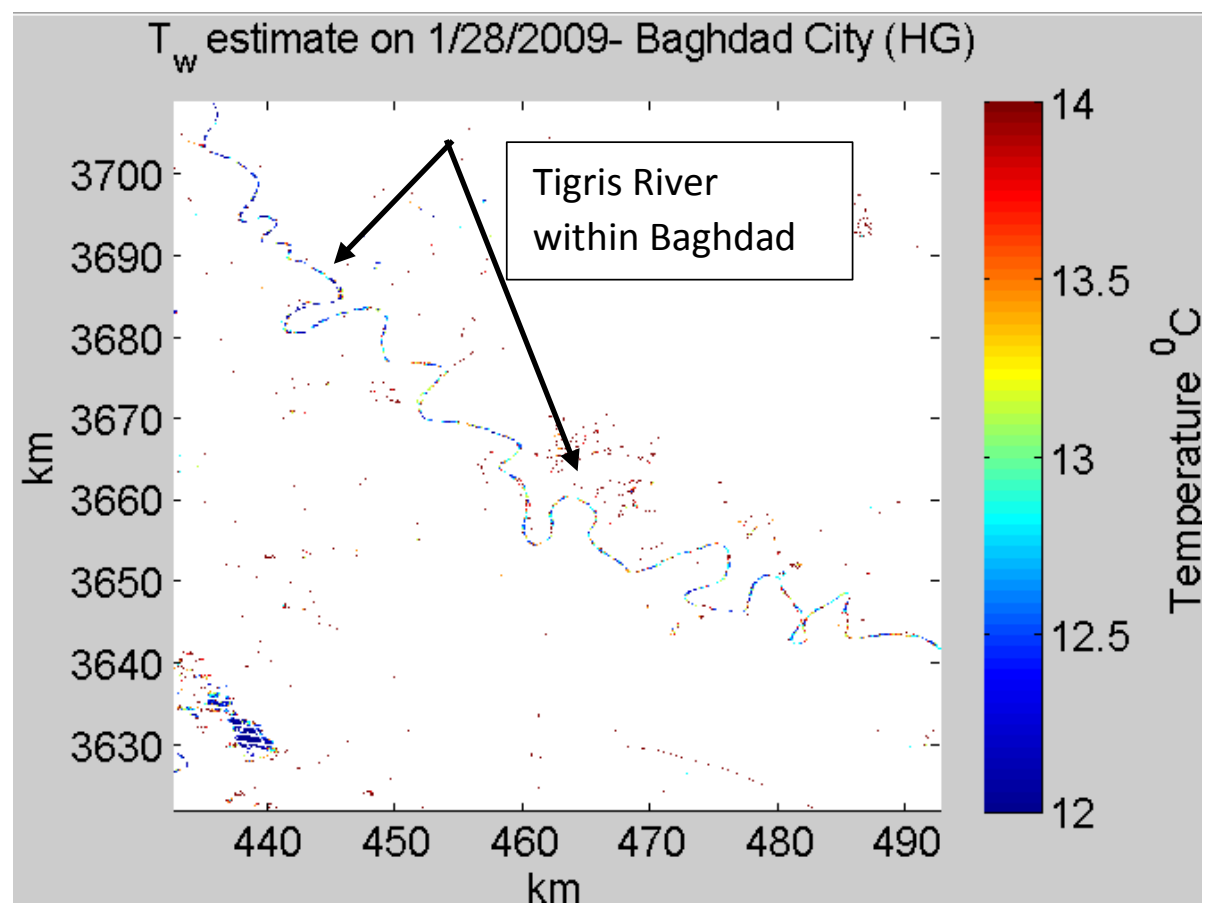

Figure 18: Surface water temperature of the Tigris River within Baghdad City.

\section{Validation of Surface Water Temperature}

Limited surface water temperature data of the Tigris River in Baghdad were obtained from a Master's thesis by Hikmat (2005). In 2004, Hikmat measured surface water temperature of the main stream of the Tigris River at a station located $3 \mathrm{~km}$ upstream of the confluence of the Tharthar-Tigris canal. Eleven point measurements of temperature were obtained that were used for validation. Landsat 7 ETM+ images were obtained within an acceptable range of \pm 5 days to the actual measured date. The median temperature of a $2 \times 2 \mathrm{~km}$ box around the measurement site was estimated and regressed against in-situ data. Figure 19 shows the regression line, which shows a correlation coefficient of 0.915 and a root mean square error (RMSE) of $2.45^{\circ} \mathrm{C}$. 


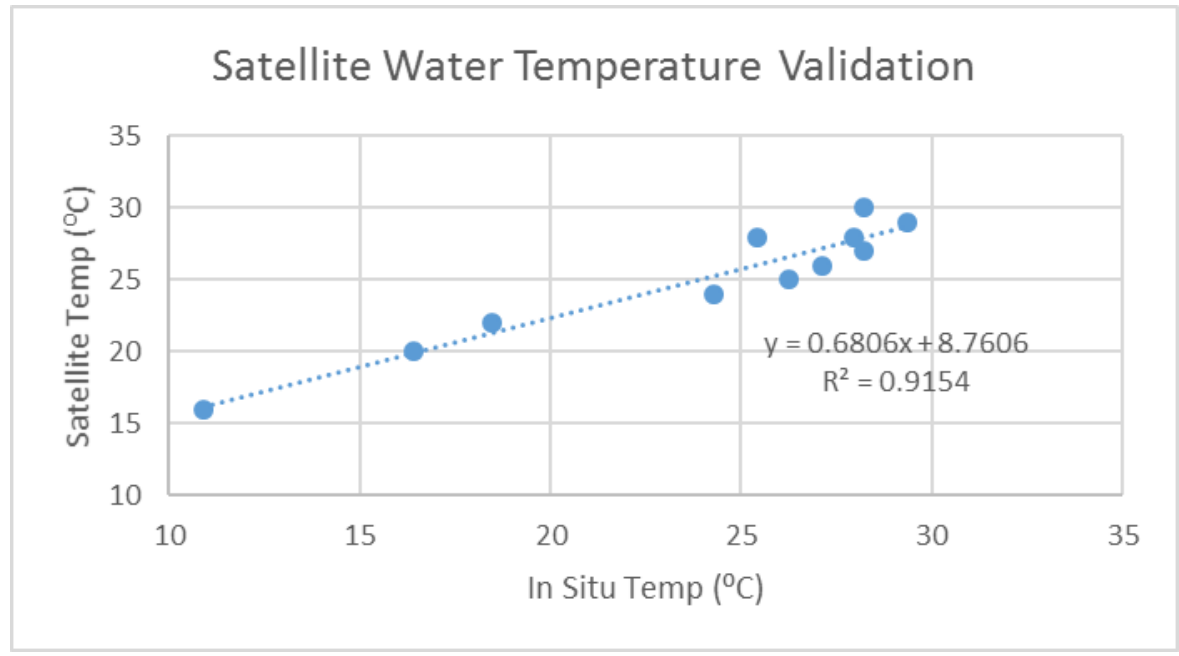

Figure 19: Validation of satellite water temperature.

\section{Surface Water Temperature Statistical Model}

A statistical model for surface water temperature of the Tigris River at Mosul, Baeiji, and Baghdad was next developed by correlating $T_{w}$ estimated from Landsat against air temperature and river flow. Air temperature data (Figure 20) at Mosul, Baeji, and Baghdad cities were provided from the Iraqi Ministry of Transportation, the General Organization for Meteorology and Seismic Monitoring (MOT-IMOAS 2014) with a frequency of four hours for the year 2009. A weighted air temperature, with a five day response time was developed using an exponential filter to Equation 5 as below (Adams and Wells, 1984): 


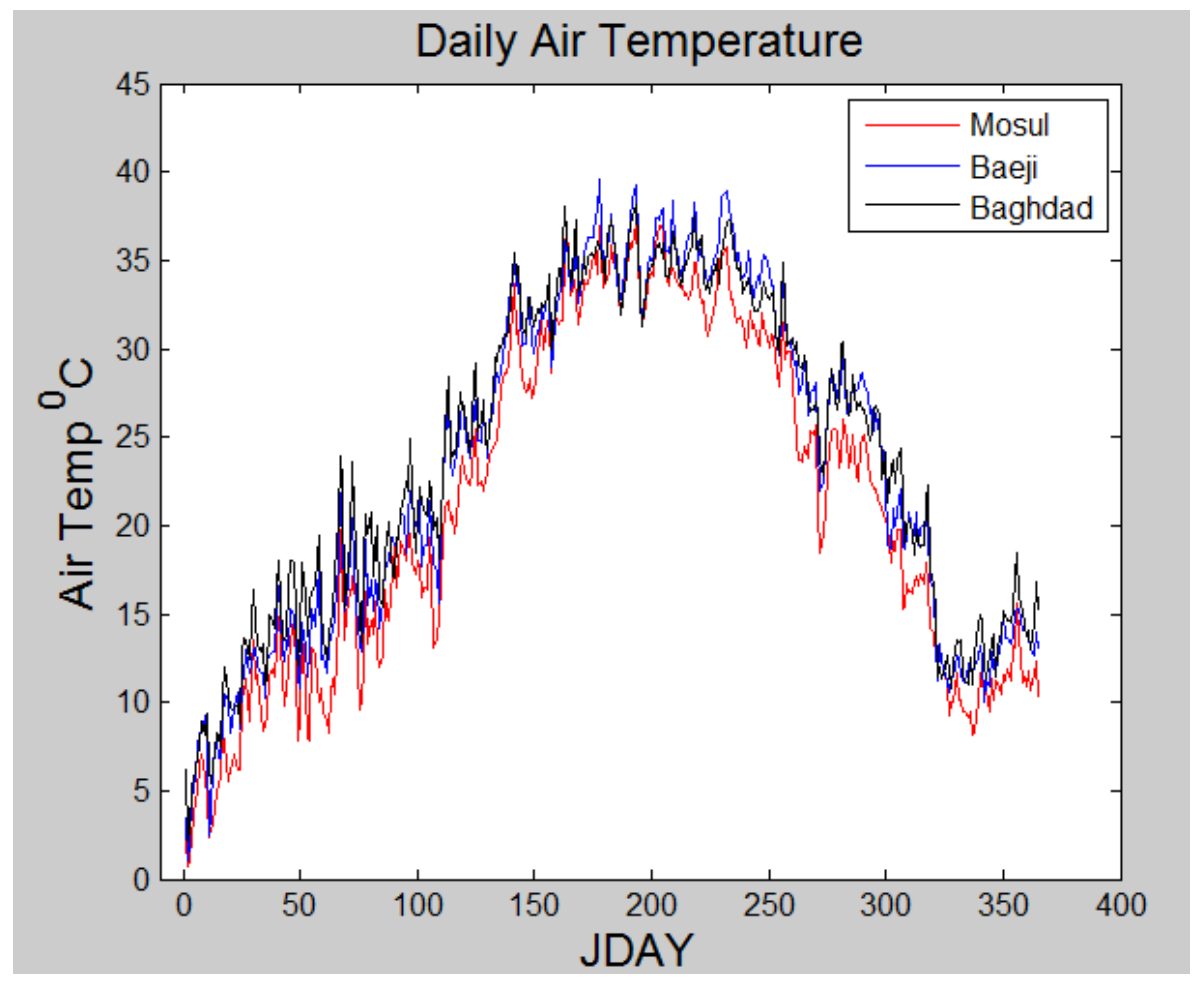

Figure 20: Daily air temperature at Mosul, Baeji, and Baghdad cities (2009).

Equation 5: Five days weighted air temperature

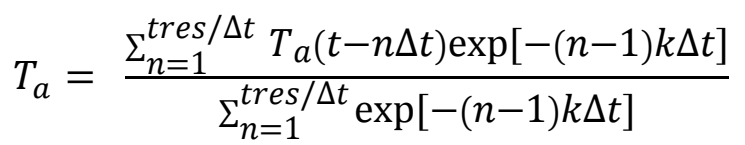

where:

$\mathrm{T}_{\mathrm{a}}: 5$ days averaged air temperature in ${ }^{\circ} \mathrm{C}$

$t_{\text {res: }}$ Response time (5 days)

$\Delta \mathrm{t}$ : time step (1 day)

$\mathrm{k}: \frac{\text { Average depth }(\mathrm{m})}{\text { Response Time }(\mathrm{s})}\left(\right.$ Generally $\left.\mathrm{k}=10^{-5} \mathrm{~m} / \mathrm{s}\right)$

The time frame and the constants were selected based on the average river's depth of 4.5-

$5 \mathrm{~m}$. Together, the weighted average in Equation 5 can be written more specifically as below:

$$
T_{a}=\frac{T_{a}(n-1) * w 1+T_{a}(n-2) * w 2+T_{a}(n-3) * w 3+T_{a}(n-4) * w 4+T_{a}(n-5) * w 5}{\sum_{n=1}^{5} w_{n}}
$$


where:

W: Weight assigned to each day (the closer day to $T_{n}$ the higher weight value assigned)

The last step after developing a weighted air temperature was to regress it, along with daily average flowrate, to the entire year of surface water temperatures estimated from Landsat images. The following statistical correlation (Equation 6) was solved using least-squares regression.

Equation 6: The statistical equation

$T_{w}=a+b T_{a}+c Q$

Flowrate was found to be a statistically insignificant predictor of surface water temperature, and was subsequently eliminated from all regression models (Equation 7, Equation 8, and Equation 9). Table 10 shows regression statistics. It can be seen that all coefficients (a1 and a2) are significant with a P-value much less than 0.05 for a confidence interval of $95 \%$.

Equation 7: Statistical Model of water temperature at Mosul Dam

$T_{w(\text { Mosul })}=4.3022+0.7294 * T_{a}$

Equation 8: Statistical Model of water temperature at Baeji city

$T_{w(\text { Baeji })}=4.7764+0.7010 * T_{a}$

Equation 9: Statistical Model of water temperature at Baghdad city

$T_{w(\text { Baghdad })}=3.4249+0.7594 * T_{a}$ 
Table 10: Statistical values of the surface water models.

\begin{tabular}{|l|l|l|l|}
\hline Parameter & $\begin{array}{l}\text { Mosul Dam } \\
\text { Model }\end{array}$ & $\begin{array}{l}\text { Baeji } \\
\text { City Model }\end{array}$ & $\begin{array}{l}\text { Baghdad City } \\
\text { Model }\end{array}$ \\
\hline Intercept (a1) & 4.3022 & 4.7764 & 3.4249 \\
\hline Slope (a2) & 0.7294 & 0.7010 & 0.7594 \\
\hline P-value (a1) & 0.0035 & 0.0046 & $1.725 \mathrm{E}-5$ \\
\hline P-value (a2) & $9.4 \mathrm{E}-17$ & $3.33 \mathrm{E}-11$ & $8.411 \mathrm{E}-21$ \\
\hline $\mathbf{R}^{2}$ & 0.864 & 0.9177 & 0.9753 \\
\hline Standard Error & 2.160 & 1.537 & 1.148 \\
\hline Observations & 36 & 20 & 26 \\
\hline
\end{tabular}

Figure 21 shows estimated daily surface water temperature at Mosul Dam, Baeji, and Baghdad cities. The data show that water temperature typically increases by $25^{\circ} \mathrm{C}$ (range 6-31 ${ }^{\circ} \mathrm{C}$ ) over a year, with the largest along-channel gradients observed in spring/autumn and the smallest gradients observed in the summer. Also, the statistical model used to estimate $T_{w}$ based on Landsat well captures the seasonal cycle of $T_{w}$. The standard error of statistical models was in the range of $1-2^{\circ} \mathrm{C}$ and was small relative to the amount of seasonal variation. Contamination of river pixels by land reflection could affect estimated water temperatures and causes uncertainty in the measurements. Temporal variation in water temperature of the Tigris River might be affected by the seasonal variations of both flow and solar radiation and other meteorological forcing data such as wind speed and direction, cloud cover, precipitation air temperature, and dew point temperature or relative humidity. These factors may not be captured by a regression model. On the other hand, spatial variation in water temperature of the Tigris River is mostly affected by the physical structure of the stream itself such as channel bathymetry (slope, width, and depth) and channel substrate (flow regime and sediment sources). Daily surface water temperatures 
obtaining using Equation 7 were used to develop flow temperature input files as boundary conditions of the Tigris River model at Mosul Dam, while daily surface water temperatures at both Baeji and Baghdad (Equation 8 and Equation 9) were used for the model calibration. 


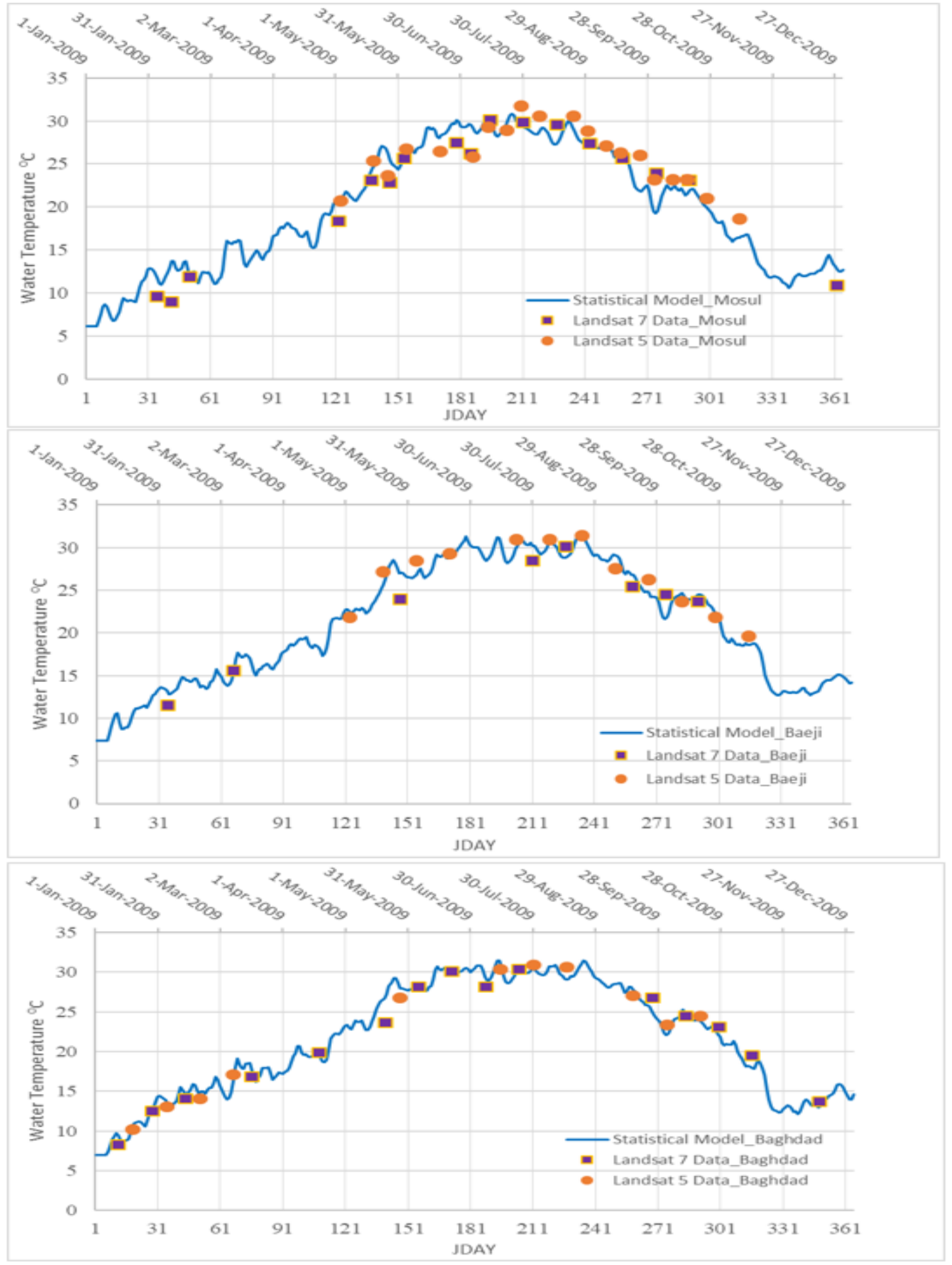

Figure 21: Satellite data (Landsat 5 and Landsat 7) and daily surface water temperature of the Tigris River estimated by regression models at Mosul Dam, Baeji city, and Baghdad city for the simulated year 2009. 


\section{Estimation of Surface water Temperature in Tharthar Lake}

Thermal bands of Landsat 5TM and Landsat 7ETM+ images were utilized to estimate surface water temperature in Tharthar Lake. Two Landsat images cover the entire lake; Landsat image with path/row of 169/36 covers the upper part of the lake, while Landsat image with path/row of 169/37 cover the lower part of the lake. The Landsat images used to estimate surface water temperature in Tharthar Lake are listed in Table 11. Figure 22 and Figure 23 show surface water temperature in Tharthar Lake extracted from Landsat images taken at the same day during different months of 2009 . A box filter $5 \times 5 \mathrm{~km}$ was used to estimate $T_{w}$ in the lake. After defining the box filter, the median value was used to estimate $T_{w}$ in that box.

Table 11: Landsat images cover Tharthar Lake

\begin{tabular}{|l|l|l|}
\hline Landsat & Date & Julian Day \\
\hline LE7 & $1 / 3 / 2009$ & 3 \\
$\mathbf{1 6 9 / 3 6}$ & $2 / 4 / 2009$ & 35 \\
\cline { 2 - 3 } $\boldsymbol{\&}$ & $3 / 8 / 2009$ & 67 \\
\cline { 2 - 3 } $\mathbf{4} 5$ & $5 / 27 / 2009$ & 147 \\
\cline { 2 - 3 } $\mathbf{1 6 9 / 3 7}$ & $7 / 30 / 2009$ & 211 \\
\cline { 2 - 3 } & $8 / 15 / 2009$ & 227 \\
\cline { 2 - 3 } & $9 / 16 / 2009$ & 259 \\
\cline { 2 - 3 } & & \\
\cline { 2 - 3 } & $10 / 18 / 2009$ & 291 \\
\hline
\end{tabular}



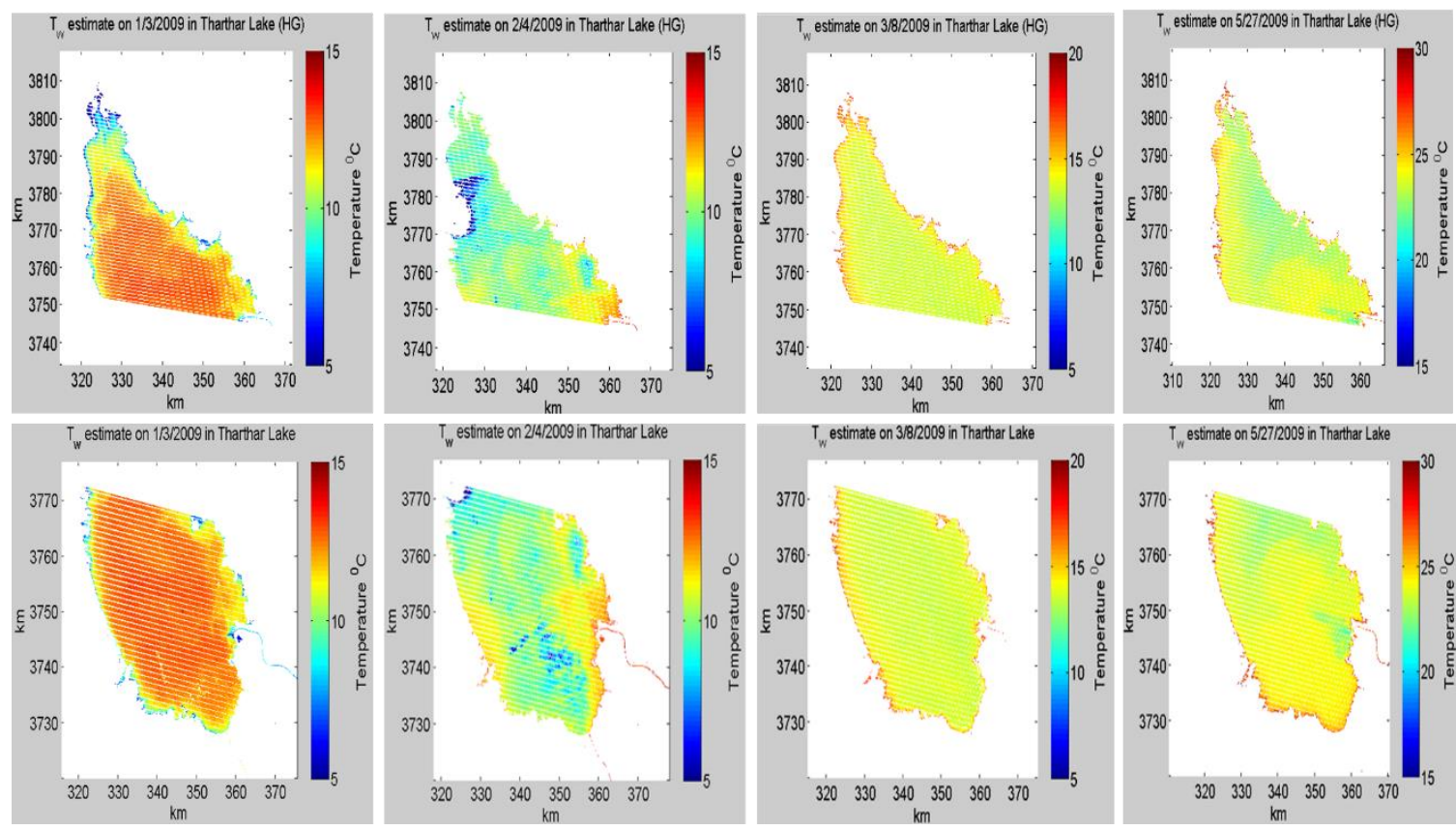

Figure 22: Surface water temperature in the upper and the lower parts of Tharthar Lake (part 1); the top row represents the upper part of the lake, while the bottom row represents the lower part of the lake.
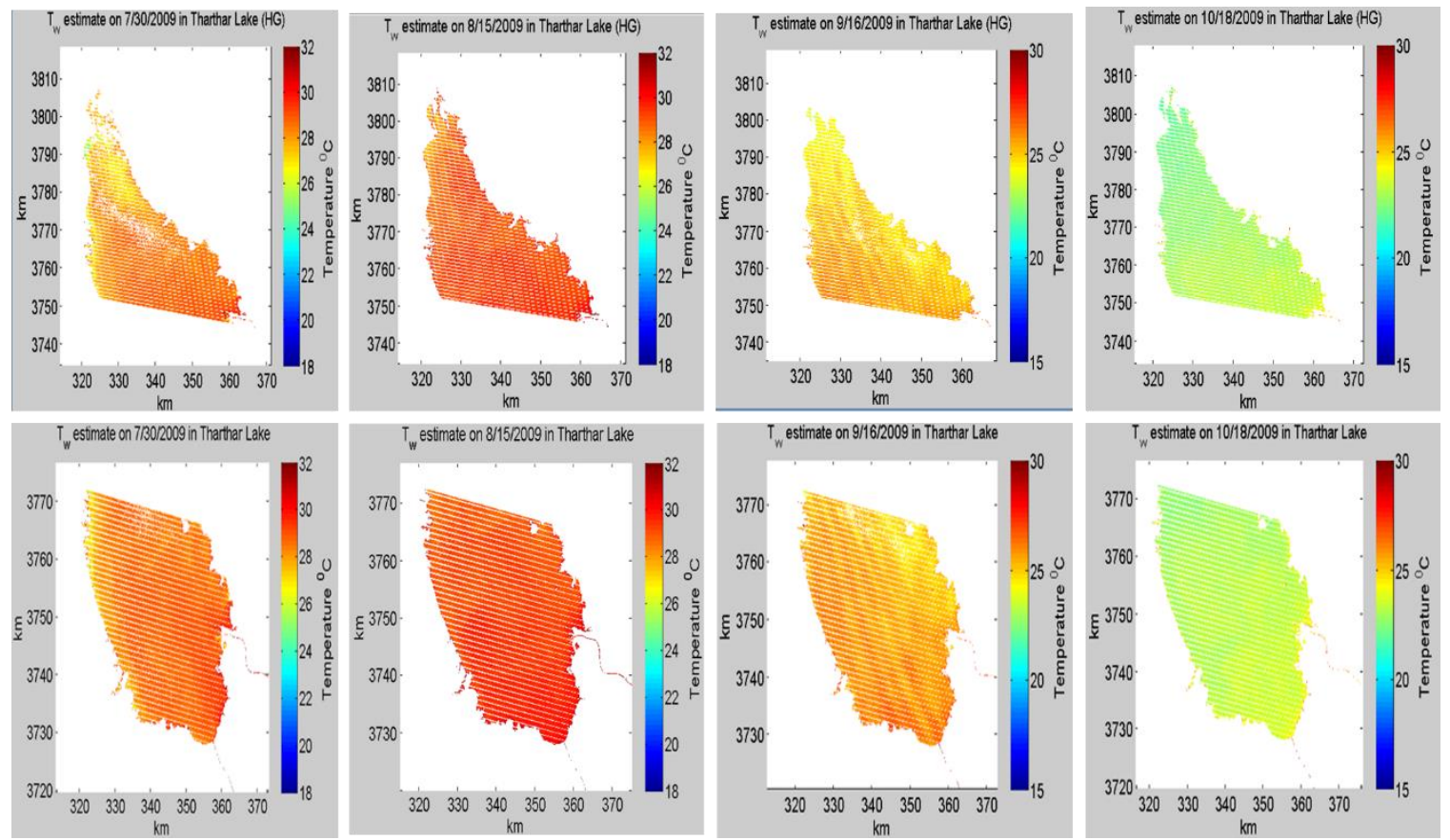

Figure 23: Surface water temperature in the upper and the lower parts of Tharthar Lake (part 2); the top row represents the upper part of the lake, while the bottom row represents the lower part of the lake. 
Figure 24 shows longitudinal profile of seasonal variation in surface water temperature in Tharthar Lake, while Figure 25 shows longitudinal profile of surface water temperature in Tharthar Lake during winter and summer of 2009. The spatial gradient of surface water temperatures along the North-South axis of Tharthar Lake varied throughout the year. A larger gradient over a distance of $90 \mathrm{~km}$ can be observed in winter months with a temperature difference of $2.56{ }^{\circ} \mathrm{C}$ in January and $2.27{ }^{\circ} \mathrm{C}$ in February compared with summer months with a temperature difference of $1.40{ }^{\circ} \mathrm{C}$ in July and $1.92{ }^{\circ} \mathrm{C}$ in August. Longitudinal gradient in water temperature of Tharthar Lake is highly attributed to the lake's bathymetry and to meteorological forcing data that control evaporation in the lake. Some errors in estimation of surface water temperature in Tharthar Lake in winter could be attributed to cloud cover percentage on the day Landsat images were taken.

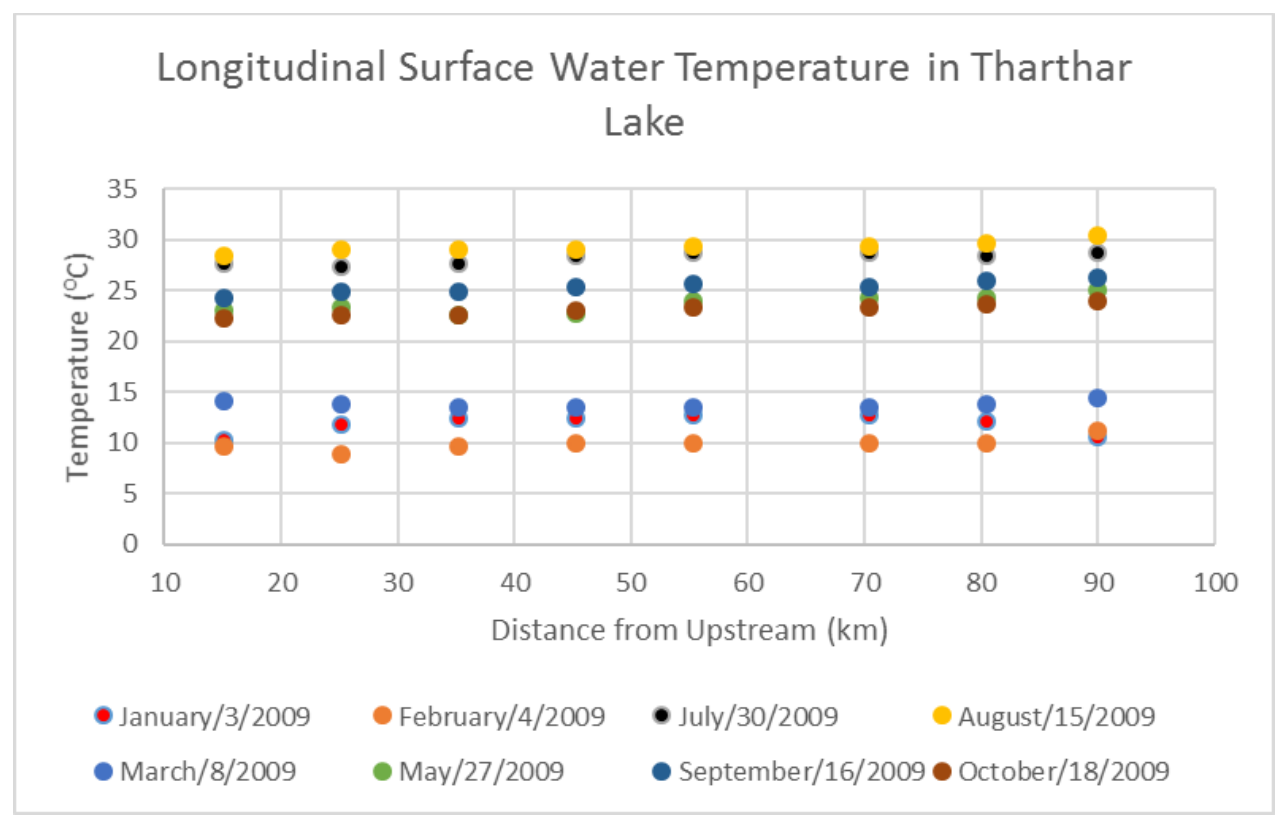

Figure 24: Seasonal variation in longitudinal surface water temperature in Tharthar Lake in 2009. 

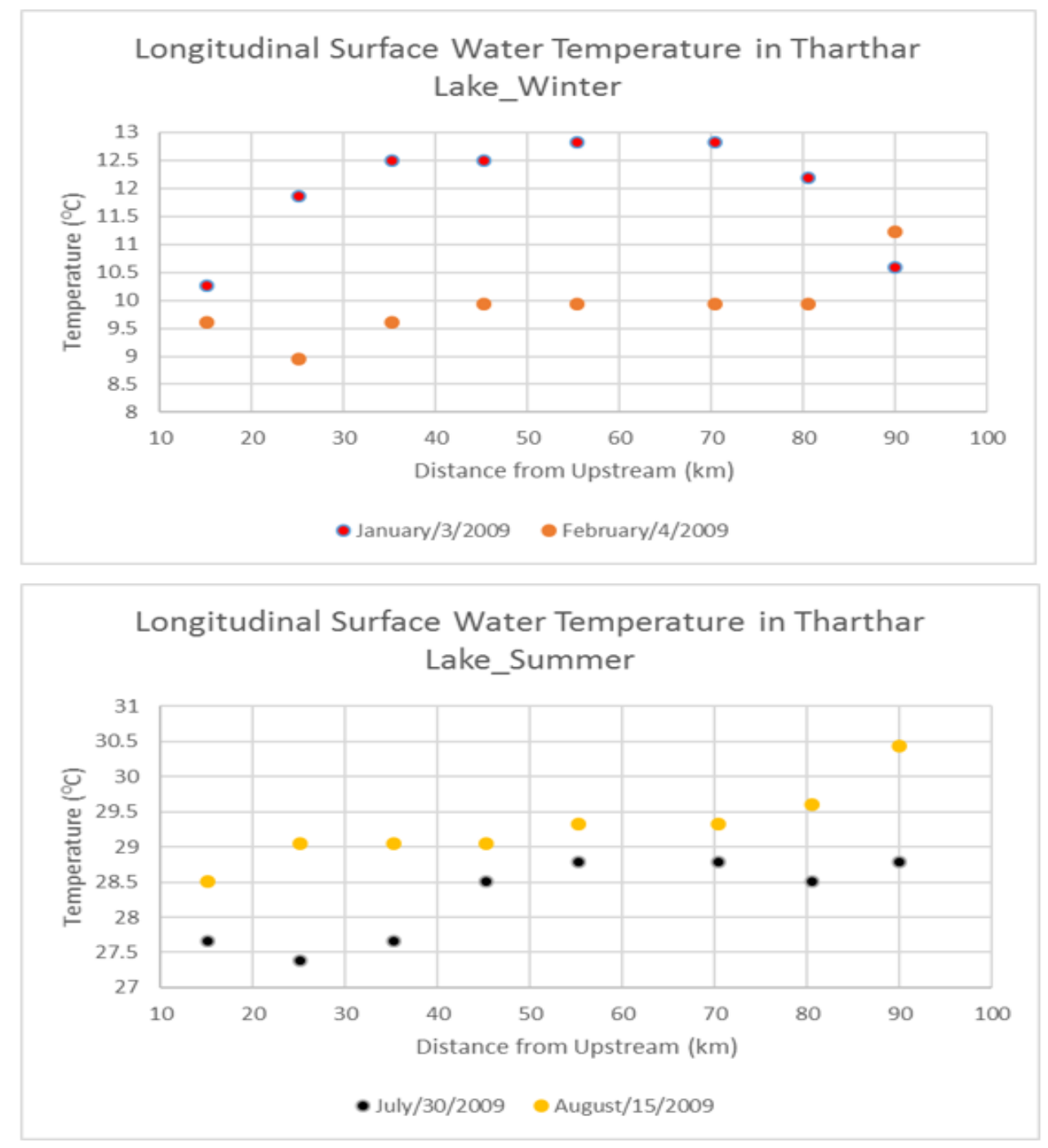

Figure 25: Longitudinal surface water temperature in Tharthar Lake in winter and summer of 2009. 


\section{Chapter Four: CE-QUAL-W2 Model Overview}

This chapter reviews the governing equations of the hydrodynamic and water quality model, CE-QUAL-W2, Version 4. For more detailed discussion, refer to the user manual by Cole and Wells (2017).

\section{Hydraulic Model Selection for the Tigris River System}

1-D, 2-D, and 3-D models are general applications to simulate hydrodynamics and water quality of surface waterbodies. The choice of the proper model is based on the application of the model to evaluate management strategies, model calibration, model sensitivity analysis, computational representation, and the physical characteristics of each system component such as river, reservoir. Table 12 lists the main advantages and disadvantages of 1-D, 2-D, and 3-D hydraulic models. 
Table 12: Comparison of 1-D, 2-D, and 3-D hydraulic models

\begin{tabular}{|c|l|l|}
\hline $\begin{array}{c}\text { Hydraulic } \\
\text { Model }\end{array}$ & \multicolumn{1}{|c|}{ Advantage } & \multicolumn{1}{|c|}{ Disadvantage } \\
\hline $1-\mathrm{D}$ & $\begin{array}{l}\text { Fast to run } \\
\text { Easy to set up }\end{array}$ & $\begin{array}{l}\text { Need to identify major flow } \\
\text { routes to set up the model } \\
\text { No stratification } \\
\text { Cross-sectionally averaged }\end{array}$ \\
\hline 2-D (x-z) & $\begin{array}{l}\text { Solves 2-D flow equations } \\
\text { Utilizes channel shape } \\
\text { Easy to set up } \\
\text { Velocity distribution can be } \\
\text { calculated in 2-D vertical } \\
\text { Applies to stratified flows }\end{array}$ & $\begin{array}{l}\text { Relatively slow to run } \\
\text { compared to 1D }\end{array}$ \\
\hline 2-D (x-y) & $\begin{array}{l}\text { Solves 2-D flow equations } \\
\text { Utilizes channel shape } \\
\text { Easy to set up } \\
\text { Velocity distribution can be } \\
\text { calculated in 2-D horizontal }\end{array}$ & $\begin{array}{l}\text { Relatively slow to run } \\
\text { compared to 1D } \\
\text { No stratification }\end{array}$ \\
\hline 3-D & $\begin{array}{l}\text { Solves 3-D flow equations } \\
\text { Good representation of complex } \\
\text { riverine systems } \\
\text { Good for systems with depth varied } \\
\text { velocity } \\
\text { Good representation of flow around } \\
\text { structures }\end{array}$ & $\begin{array}{l}\text { Complexity of model } \\
\text { formulations and application } \\
\text { Long model run times }\end{array}$ \\
\hline
\end{tabular}

Most studies on the Tigris River assumed one dimensional, steady state, and well-mixed in

the cross-section conditions. These 1-D models are not adequate to compute stratification dynamics in deeper pools. Based on the depth of Tharthar Lake, a one-dimensional model would not be adequate because of possible vertical, as well as longitudinal gradients in water quality. Therefore, the model chosen for the Tigris River system is the 2-D Corps of Engineers model CE-QUAL-W2 (W2) (Cole and Wells, 2017). W2 is a dynamic 2-D (xz) model that can simulate stratification in Tharthar Lake. W2 can handle a branched and/or looped system with flow and/or head boundary conditions. W2 model is efficient and 
allows the user to use the ultimate quickest numerical scheme for improved numerical accuracy.

\section{Model Introduction}

CE-QUAL-W2 is a physically based, two-dimensional (longitudinal and vertical), laterally averaged, finite difference hydrodynamic and water quality model. The Version 3 model to Version 3.5 model was developed by a collaboration between the U.S. Army Corps of Engineers and the Water Quality Research Group at Portland State University. After Version 3.5, the model has been maintained by the water quality research group at Portland State University. The model applies spatial and temporal averaging to the Navier-Stokes and continuity equations to model surface water hydrodynamics. In addition, the advection diffusion equation is used for the transport of heat and water quality constituents. Because the model assumes lateral homogeneity, it is best suited for relatively long and narrow waterbodies exhibiting longitudinal and vertical water quality gradients. W2 simulates river/reservoir, lake stage, vertical and horizontal velocities, water temperature, and a userdefined number of water quality constituents including nutrients, algae, dissolved oxygen, and suspended sediment. W2 has been applied to hundreds of reservoirs, lakes, estuaries, and river systems all over the world (Cole and Wells 2017). W2 model has been used in many countries outside the United States such as Columbia, Brazil, Venezuela, Panama, United Kingdom, Spain, Thailand, Italy, New Zealand, China, South Korea, Taiwan, South Africa, Iran, Peru, Costa Rica, Israel, Canada, and Norway. 


\section{CE-QUAL-W2 State Variables}

The hydrodynamic capabilities of the model include predictions of flow, water surface elevation, velocities, and temperature. The water quality state variables include (Cole and Wells, 2017):

1. any number of generic constituents defined by a 0 and/or a 1st order decay rate and/or a settling velocity and/or an Arrhenius temperature rate multiplier that can be used to define any number of the following:

a. conservative tracer(s)

b. water age or hydraulic residence time

c. N2 gas and \%Total Dissolved Gas

d. coliform bacteria(s)

e. contaminant(s)

2. any number of inorganic suspended solids groups

3. any number of phytoplankton groups

4. any number of periphyton/epiphyton groups

5. any number of CBOD groups

6. any number of submerged macrophyte groups

7. ammonium

8. nitrate and nitrite

9. bioavailable phosphorus (commonly represented by orthophosphate or soluble reactive phosphorus)

10. silica (dissolved and particulate)

11. labile dissolved organic matter

12. refractory dissolved organic matter

13. labile particulate organic matter

14. refractory particulate organic matter

15. total inorganic carbon

16. alkalinity 
17. iron and manganese

18. dissolved oxygen

19. organic sediments

20. gas entrainment

21. any number of macrophyte groups

22. any number of zooplankton groups

23. labile dissolved organic matter-P

24. refractory dissolved organic matter-P

25. labile particulate organic matter-P

26. refractory particulate organic matter-P

27. labile dissolved organic matter-N

28. refractory dissolved organic matter-N

29. labile particulate organic matter-N

30. refractory particulate organic matter-N

31. Sediment and water column $\mathrm{CH} 4$

32. Sediment and water column $\mathrm{H} 2 \mathrm{~S}$

33. Sediment and water column SO4

34. Sediment and water column Sulfide

35. Sediment and water column $\mathrm{FeOOH}(\mathrm{s})$

36. Sediment and water column $\mathrm{Fe}+2$

37. Sediment and water column $\mathrm{MnO} 2(\mathrm{~s})$

38. Sediment and water column $\mathrm{Mn}+2$

39. Sediment organic P, sediment PO4

40. Sediment organic N, sediment NO3, sediment NH4

41. Sediment Temperature

42. Sediment $\mathrm{pH}$

43. Sediment alkalinity

44. Sediment Total Inorganic C

45. Sediment organic C 
46. Turbidity correlation to Suspended solids

\section{Input Data Preparation}

The follow input files were developed to run W2 model. Detailes about input data preparations are discussed in chapter five "The Tigris River Model Set Up"

- Bathymetry

- Meteorological data

- Shade file

- Wind Sheltering

- Initial conditions

- Boundary conditions, such as inputs from point or non-point sources, outflows or withdrawals from the system

- In-river water quality, water level, flow for calibration

\section{Hydrodynamics Governing Equations}

Governing equations for hydrodynamics are listed below. The assumptions made are (Cole and Wells, 2017):

- Incompressible fluid.

- Centripetal acceleration correction to the gravity term is negligible

- Boussinesq approximation

- Coriolis forces are not important in an X-Z model

- Within a grid cell, density variation can be taken to be negligible for purposes of temporal averaging

- Each cell or control volume is vertically and laterally averaged

- The coordinate system is transformed so that the $+\mathrm{z}$ direction is vertical downward and perpendicular to the channel slope (thus, for a slope channel, there is a small difference in the $+z$ direction and vertically downward). 
- Scaling analysis showed that horizontal velocities are much larger than vertical velocities and was used to simplify the vertical momentum equation which becomes the hydrostatic condition.

- The state equation can be selected to represent freshwater (low salinity) or marine conditions.

In addition, the model allows the user to include the following physical processes:

- Channel bottom shear

- Wind driven surface shear

- Flow control structures such as weirs, gates, intakes, and pumps as well as selective withdrawal.

- Surface heat exchange

- Sediment-water heat exchange

- Vegetative and topographic shading

- Ice cover formation

- Light attenuation with depth

- Oxygen exchange at the air-water interface (reaeration, degassing)

Below are descriptions of $\mathrm{x}$-momentum equation, $\mathrm{z}$-momentum equation, continuity equation, and the equation of state:

\section{x-Momentum}

$$
\frac{\partial U B}{\partial t}+\frac{\partial U U B}{\partial x}+\frac{\partial W U B}{\partial z}=-\frac{1}{\rho} \frac{\partial B P}{\partial x}+\frac{\partial\left(B A_{x} \frac{\partial U}{\partial x}\right)}{\partial x}+\frac{\partial B \tau_{x}}{\partial z}
$$

Where

$$
\begin{aligned}
& \mathrm{U}=\text { longitudinal, laterally averaged velocity, } \mathrm{m} / \mathrm{s} \\
& \mathrm{B}=\text { water body width, } \mathrm{m} \\
& \mathrm{t}=\text { time, } \mathrm{s} \\
& \mathrm{x}=\text { longitudinal Cartesian coordinate } \\
& \mathrm{z}=\text { vertical Cartesian coordinate }
\end{aligned}
$$


$\mathrm{W}=$ vertical, laterally averaged velocity, $\mathrm{m} / \mathrm{s}$

$\rho=$ density, $\mathrm{kg} / \mathrm{m}^{3}$

$\mathrm{P}=$ pressure, $\mathrm{N} / \mathrm{m}^{2}$

$\mathrm{A}_{\mathrm{x}}=$ longitudinal momentum dispersion coefficient, $\mathrm{m}^{2} / \mathrm{s}^{2}$

$\tau_{\mathrm{x}}=$ shear stress per unit mass, $\mathrm{m}^{2} / \mathrm{s}^{2}$

\section{z-Momentum}

$$
0=g-\frac{1}{\rho} \frac{\partial P}{\partial z}
$$

Where

$$
\mathrm{g}=\text { acceleration due to gravity, } \mathrm{m} / \mathrm{s}^{2}
$$

\section{Continuity}

$$
\frac{\partial U B}{\partial x}+\frac{\partial W B}{\partial z}=q B
$$

Where

$\mathrm{q}=$ lateral boundary inflow or outflow, $\mathrm{m}^{3} / \mathrm{s}$

\section{Free-Surface}

$$
\frac{\partial B_{\eta} \eta}{\partial t}=\frac{\partial}{\partial x} \int_{\eta}^{h} U B d z-\int_{\eta}^{h} q B d z
$$

Where

$\mathrm{B}_{\eta}=$ spatially and temporally varying surface width, $\mathrm{m}$

$\eta=$ free water surface location, $m$

$\mathrm{h}=$ total depth, $\mathrm{m}$ 


\section{Constituent Transport}

"The constituent transport relationships compute the transport of constituents with their kinetic reaction rates expressed in source and sink terms" (Cole and Wells, 2017).

$$
\frac{\partial B \varphi}{\partial t}+\frac{\partial U B \varphi}{\partial x}+\frac{\partial W B \varphi}{\partial z}-\frac{\partial\left(B D_{x} \frac{\partial \varphi}{\partial x}\right)}{\partial x}-\frac{\partial\left(B D_{z} \frac{\partial \varphi}{\partial z}\right)}{\partial z}=q_{\varphi} B+S_{k} B
$$

Where

$\varphi=$ laterally averaged constituent concentration, $\mathrm{mg} / \mathrm{L}$

$\mathrm{D}_{\mathrm{x}}=$ longitudinal temperature and constituent dispersion coefficient, $\mathrm{m}^{2} / \mathrm{s}$

$D_{z}=$ vertical temperature and constituent dispersion coefficient, $\mathrm{m}^{2} / \mathrm{s}$

$\mathrm{q}_{\varphi}=$ lateral inflow or outflow mass flow rate of constituent per unit volume, $\mathrm{mg} / \mathrm{L} / \mathrm{s}$

$\mathrm{S}_{\mathrm{k}}=\mathrm{kinetics}$ source/sink term for constituent

\section{Equation of State}

$$
\rho=f\left(T, \varphi_{T D S}, \varphi_{S S}\right)
$$

Where

$$
\begin{aligned}
& \mathrm{T}=\text { temperature, }{ }^{\circ} \mathrm{C} \\
& \varphi_{\mathrm{TDS}}=\text { total dissolved solids concentration, } \mathrm{mg} / \mathrm{L} \\
& \varphi_{\mathrm{SS}}=\text { suspended solids concentration, } \mathrm{mg} / \mathrm{L}
\end{aligned}
$$

For a detailed description of the assumptions and processes in the derivation of these equations, and for other equations used in CE-QUAL-W2, see the user manual (Cole and Wells, 2017). 


\section{Chapter Five: The Tigris River Model Set Up}

The mainstem of the Tigris River was modeled from Mosul Dam (river km 0) to Kut Barrage (river $\mathrm{km} \mathrm{880)}$ ). The mainstem of the Tigris River was discretized into four waterbodies. A waterbody is defined in the model by specifying the waterbody latitude and longitude, bottom elevation of the grid, starting and ending branches of the waterbody. Due to varying channel slope, the mainstem of the river was divided into four branches, a branch is a collection of model segments with variable model slope. The physical characteristics of the river varied widely, and multiple branches allowed for separate characteristics such as branch slope to be implemented in the model. In addition, Tigris-Tharthar Canal, Tharthar Arm, Tharthar-Tigris Canal, Tharthar Lake, and Erwaeiya canal were discretized into five waterbodies and were also modeled in this study. All model branches were connected based on specified upstream and downstream external/internal flow, internal head, or dam flow boundary condition. a schematic diagram of the Tigris River system is shown in Figure 26. Gates, spillways, and hydraulic structures were defined to convey water through the system. 


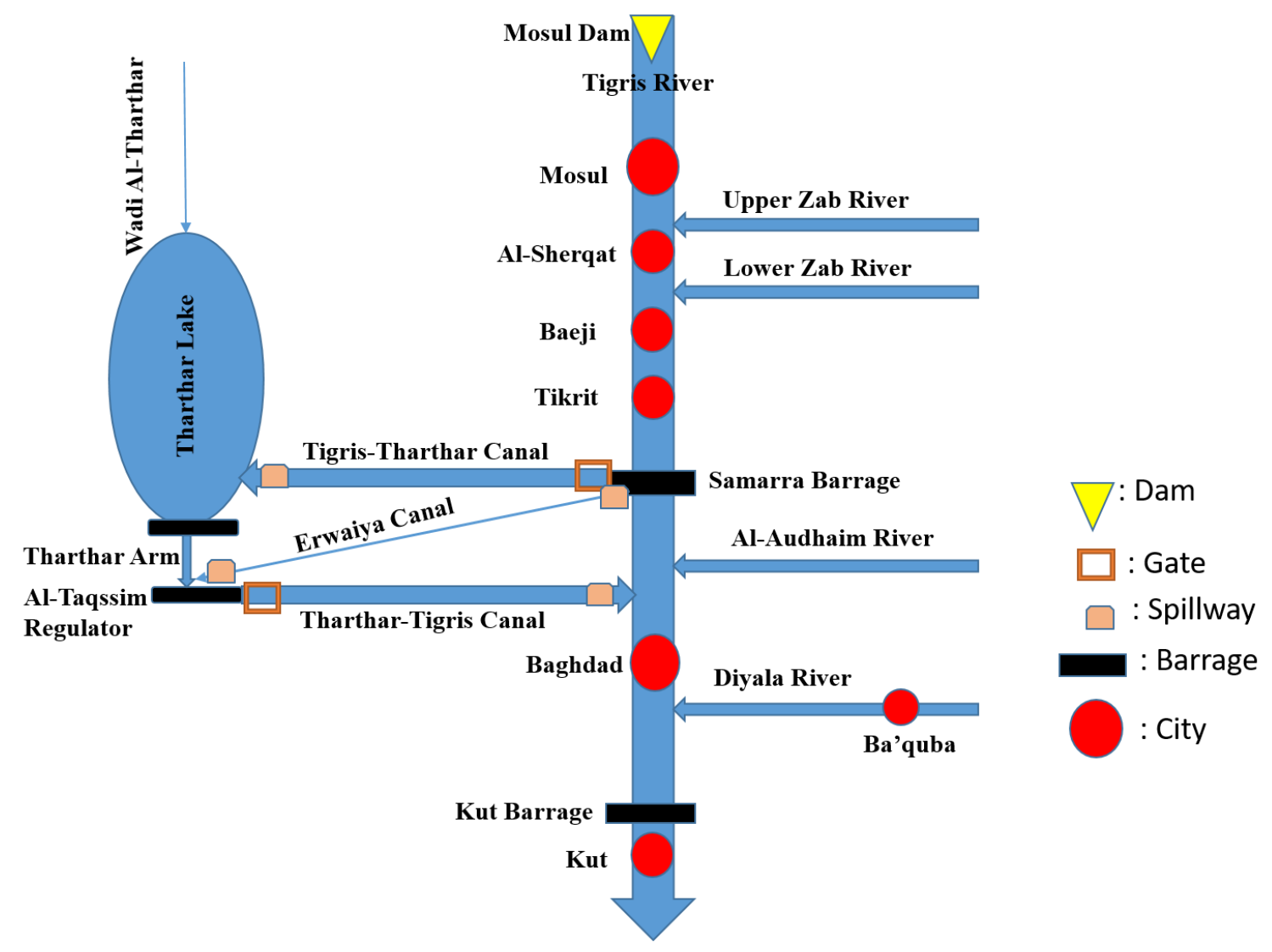

Figure 26: Schematic diagram of the Tigris River system.

\section{Bathymetry and Grid Development of the Tigris River System}

The Tigris River, Tharthar Lake, and canal system is divided into Waterbodies (a collection of model branches that have similar turbulence closure and water quality parameter values and meteorological forcing for a river or a reservoir), branches (a collection of model segments with variable model slope; a river with different slopes or a reservoir with multiple side arms), segments (a longitudinal segment of length DX), and layers (a vertical layer of height DZ). 


\section{The Tigris River Grid}

The model grid of the mainstem of the Tigris River was developed based on the river cross section data provided by the Iraqi Ministry of Water Resources for $880 \mathrm{~km}$ along the main stream of the Tigris River from Mosul Dam to Kut Barrage. Data were provided in the form of $\mathrm{x}, \mathrm{y}, \mathrm{z}$ cross-sections with $5 \mathrm{~km}$ increments as shown in Figure 27 and were used to develop the river grid for the CE-QUAL-W2 model (Al-Murib, 2014). Geographical Information system (GIS) was implemented to visualize river morphology and project all cross sections with a projection UTM 1984 Zone 38N (North) and a datum GCS WGS 1984. Linear regression was used to fill gaps of some missing cross sections.

The first waterbody in the mainstem of the Tigris River (350 km in length) starts at Mosul Dam (River km 0) and ends $15 \mathrm{~km}$ downstream of Tikrit city (River km 350). The second waterbody starts from there to Samarra Barrage (a length of $40 \mathrm{~km}$ ). The third waterbody (a length of $256.5 \mathrm{~km}$ ) starts at Samarra Barrage and ends at $70 \mathrm{~km}$ downstream of Baghdad city, while the fourth waterbody (a length of $233.5 \mathrm{~km}$ ) starts from there to Kut Barrage (at River $\mathrm{km} \mathrm{880).} \mathrm{Four} \mathrm{main} \mathrm{tributaries} \mathrm{flow} \mathrm{from} \mathrm{the} \mathrm{right} \mathrm{bank} \mathrm{of} \mathrm{the} \mathrm{main} \mathrm{stream} \mathrm{of} \mathrm{the}$ Tigris River between Mosul Dam to Kut Barrage. 


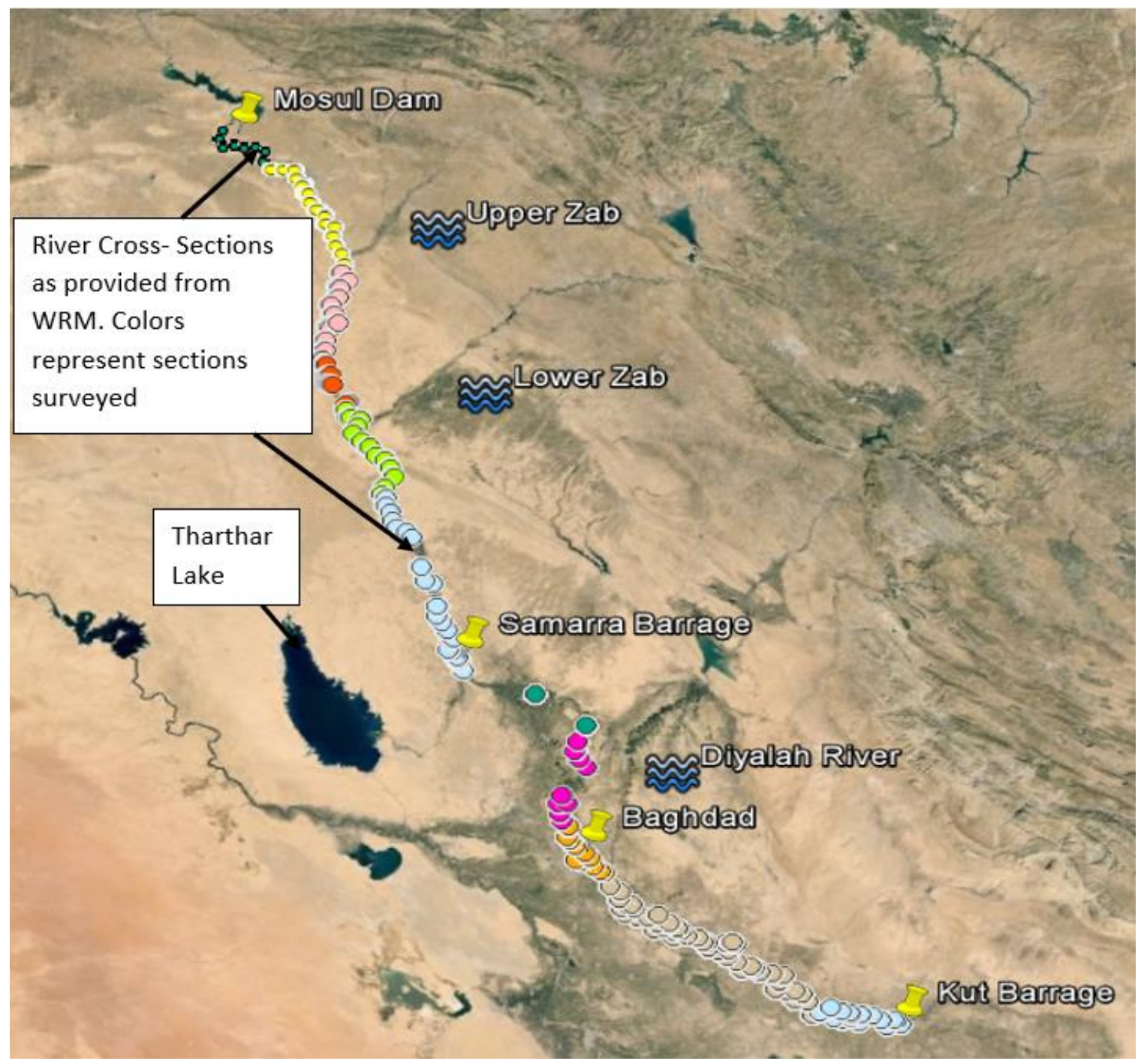

Figure 27: Cross sections of the Tigris River from Mosul Dam to Kut Barrage with the river crosssections as provided from the Iraqi Water Resources Ministry (WRM), colors represent river crosssection files as received from WRM.

The model grid of the Tigris River system consisted of 343 longitudinal segments. Each of the model segments had $1 \mathrm{~m}$ thickness. 84 vertical layers (82 active layers and 2 inactive layers) were used in the model to represent the vertical elevation of the deepest point in Tharthar Lake. Field cross section data were interpolated to determine layer widths in each model segment. As an example, Figure 28 shows the river cross section at river km 490, while Figure 29 shows the bottom elevation of the mainstem of the Tigris River from Mosul 
Dam to Kut Barrage estimated from bathymetric data. Figure 30 shows segment 123 section with 82 active vertical layers as constructed by the W2 model. Although the average water depth in the model segment is $6.3 \mathrm{~m}, 82$ active layers were used in order to have the same number of layers as in Tharthar Lake. Figure 31 through Figure 34 show the longitudinal profile of the mainstem of the Tigris River for waterbody 1 (branch 1), waterbody 2 (branch 2), waterbody 3 (branch 3), and waterbody 4 (branch 4), respectively. The $\mathrm{x}$-axis and $\mathrm{y}$-axis represent segments and layers, respectively.

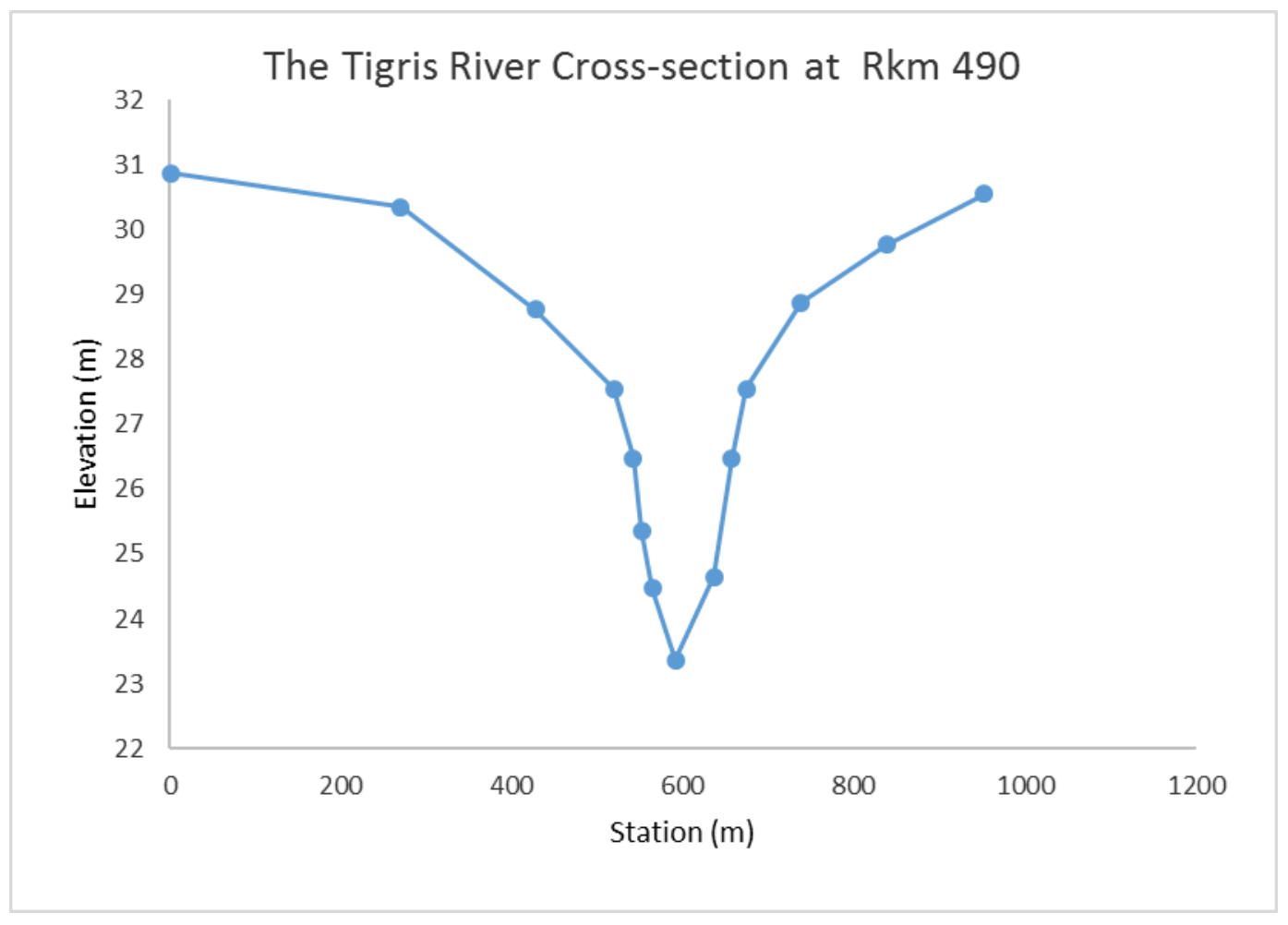

Figure 28: The Tigris River cross-section at river km 490 km. 


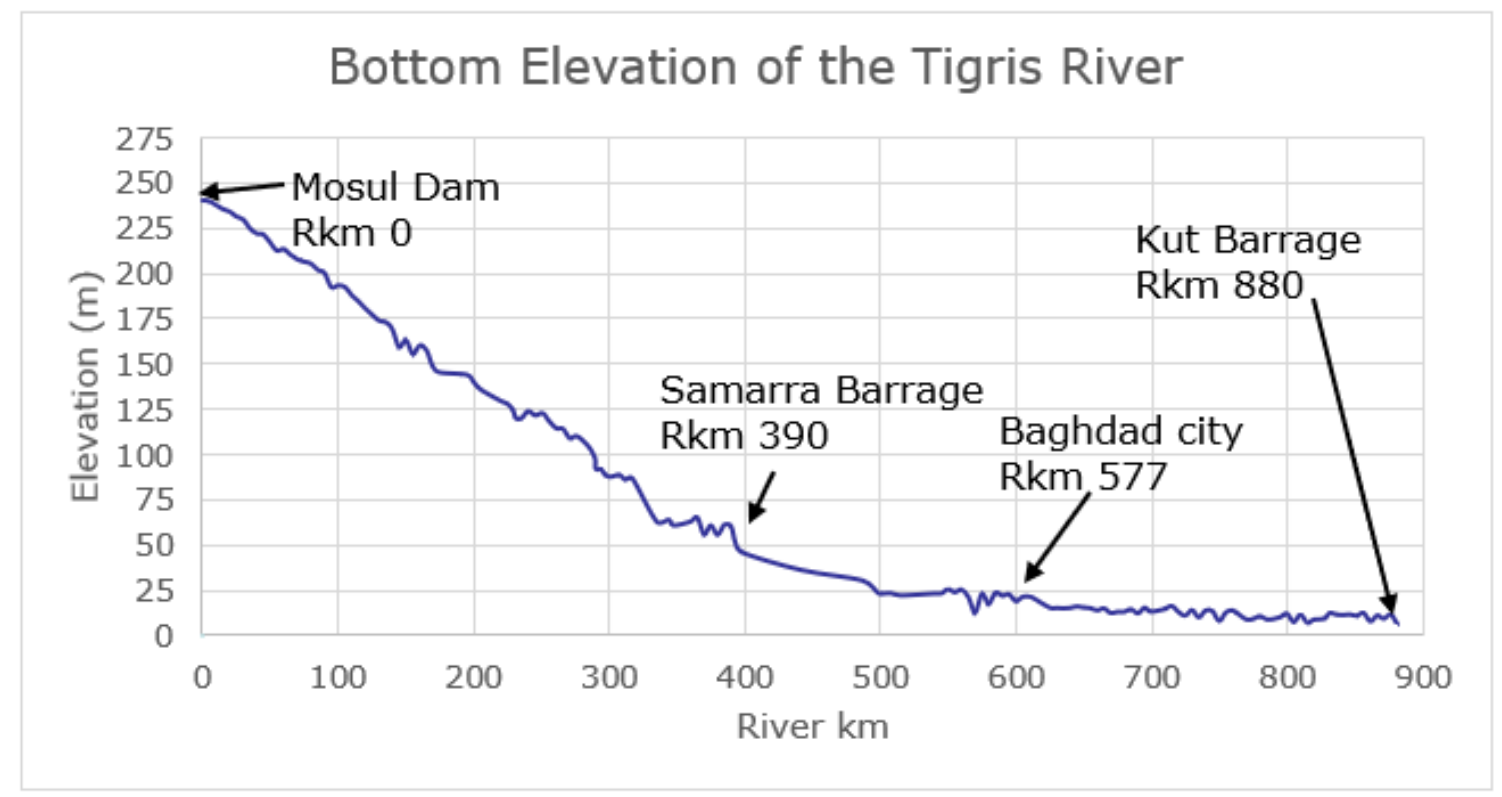

Figure 29: Bottom elevation of the mainstem of the Tigris River study area from Mosul Dam to Kut Barrage.

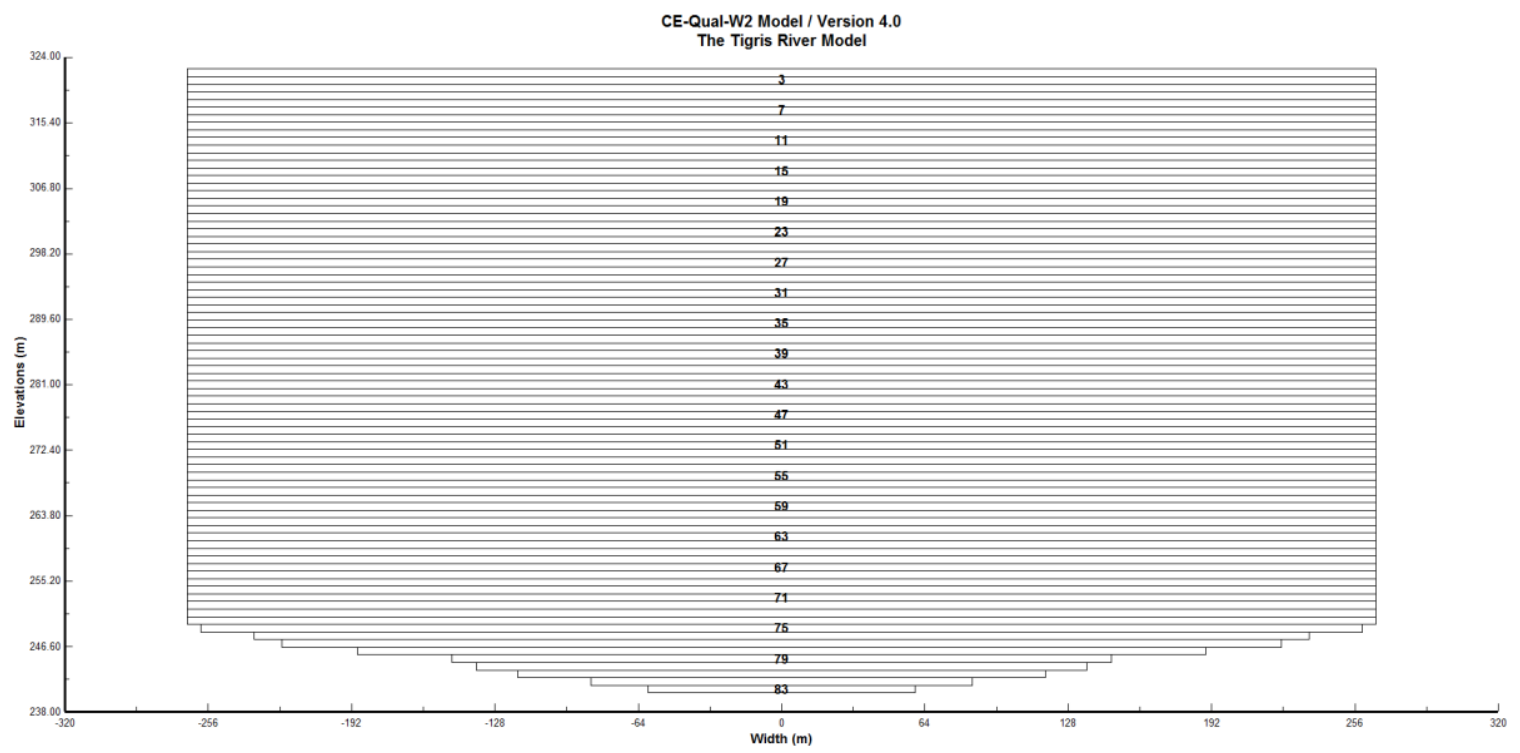

Figure 30: Segment section \# 123 (Baghdad city) with 82 active layers (1 m each) constructed by the W2 model. 


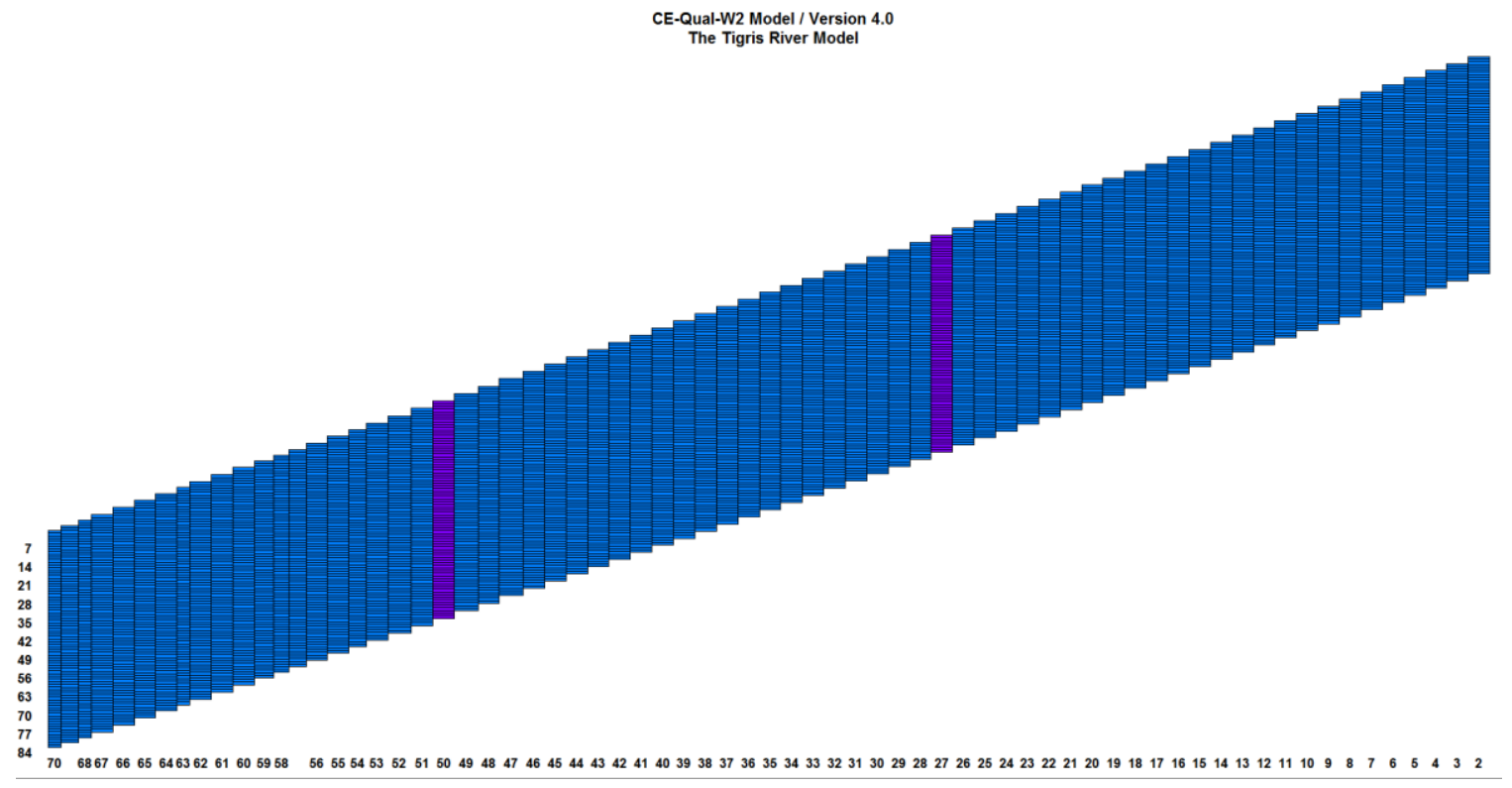

Figure 31: Longitudinal profile for waterbody 1, branch 1 of the Tigris River model constructed by the W2 model, Upper Zab and lower Zab at model segment 27 and 50 respectively with purple colors.

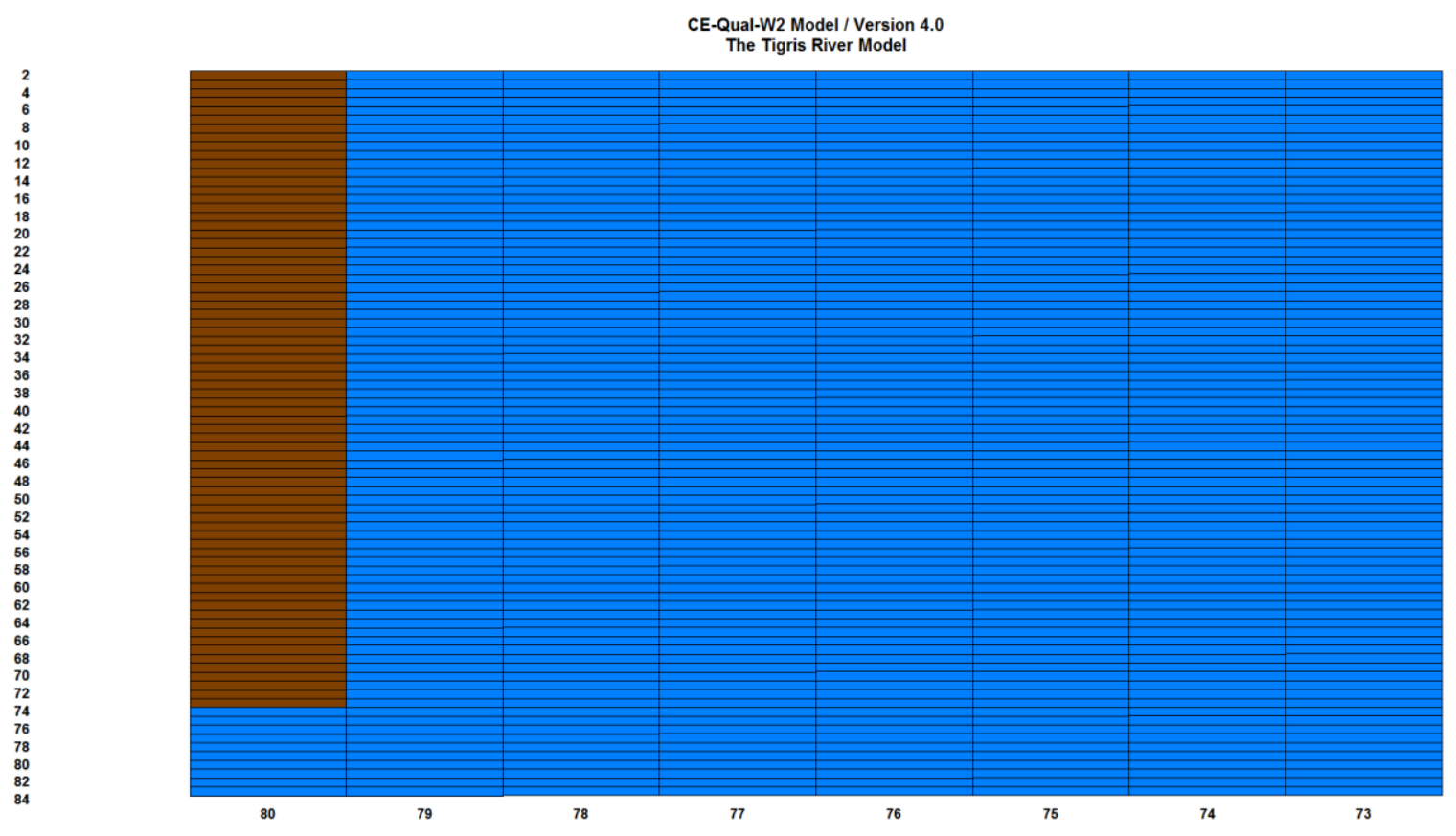

Figure 32: Longitudinal profile for waterbody 2, branch 2 of the Tigris River model constructed by the W2 model, Samarra Barrage at model segment 80 with a brown color. 


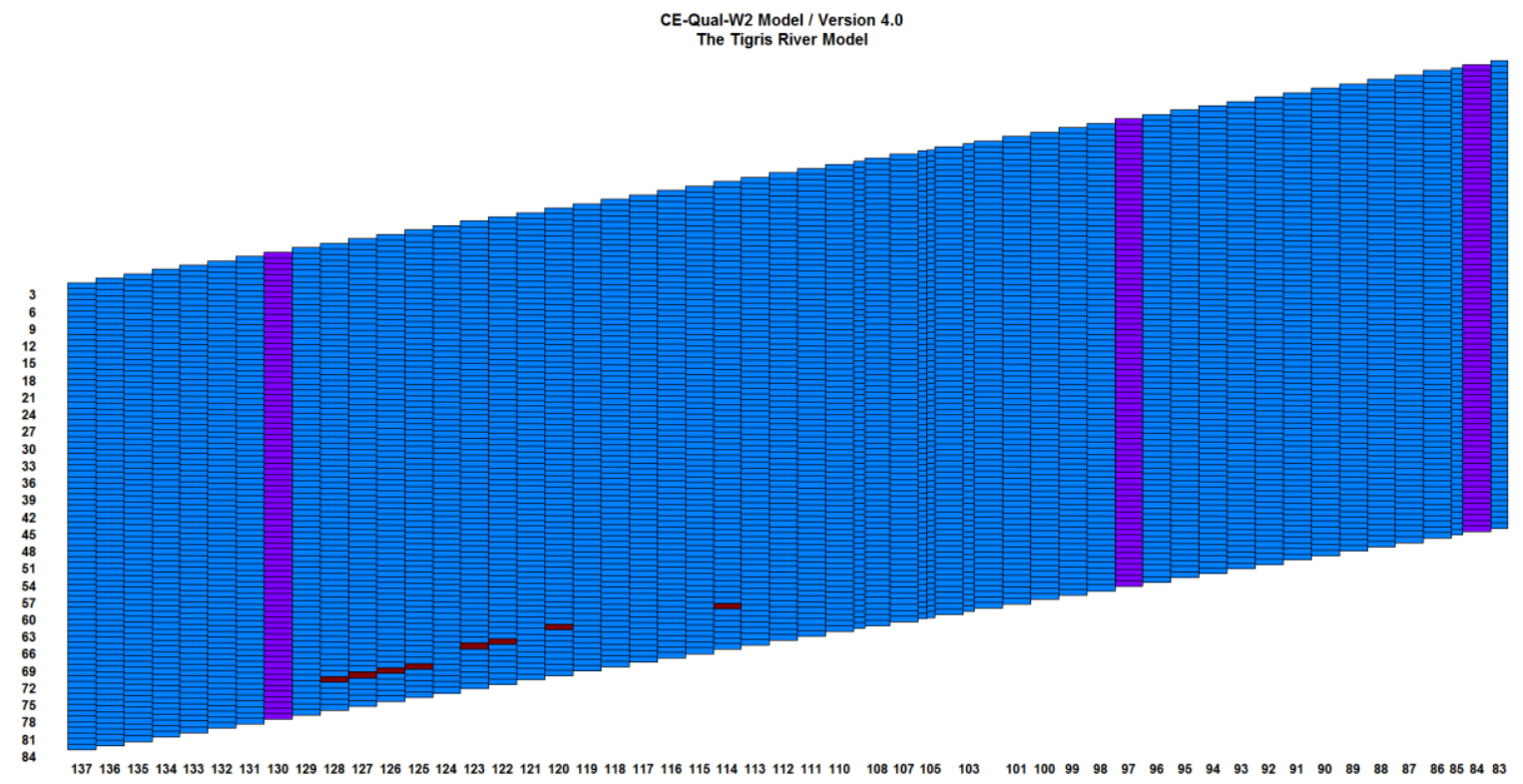

Figure 33: Longitudinal profile for waterbody 3, branch 3 of the Tigris River model constructed by the W2 model. Extra tributary at model segment 84 . Audaim and Diyala Rivers at model segments 97 and 130 respectively with purple colors. Withdrawals represented in red colors.

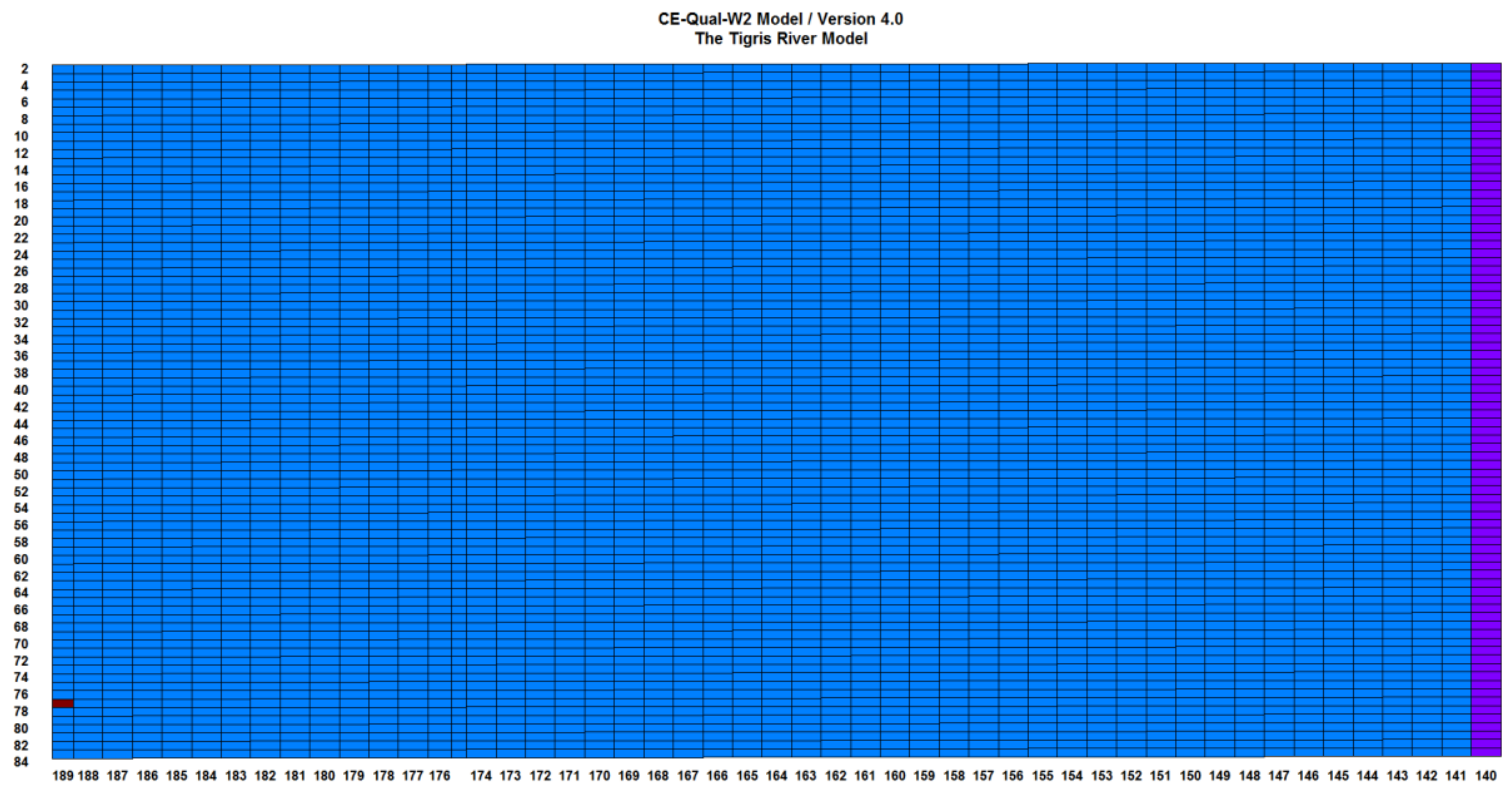

Figure 34: Longitudinal profile for waterbody 4, branch 4 of the Tigris River model constructed by the W2 model, an extra tributary at model segment 140 with a purple color. 


\section{Tharthar Lake Grid}

The topographic map of Tharthar Lake showing the floor morphology was provided from Sissakian (2011) and shown in Figure 35. Arc map (GIS) was used to georeference this photo map with a base map and utilized to digitize and extract $\mathrm{x}$ and $\mathrm{y}$ coordinates of all contour lines at elevations $10 \mathrm{~m}, 25 \mathrm{~m}$, and $50 \mathrm{~m}$. UTM 1984 Zone and datum GCS WGS 1984 was used to project Tharthar Lake's map in GIS. Digitized contour lines, shown in Figure 36, were used to develop the grid for Tharthar Lake. Surfer Version 8 (Golden Software) was used construct the lake's contour lines with minimum and maximum elevations of $-5 \mathrm{~m}$ and $80 \mathrm{~m}$, respectively, as shown in Figure 37. In addition, Surfer was used to create a set of polygons (Figure 38) to produce volume/area elevation curves. All polygons were adjusted to cover the entire lake's boundary. Figure 40 shows the side view of Tharthar Lake grid with its segments and layers constructed by the W2 model. 


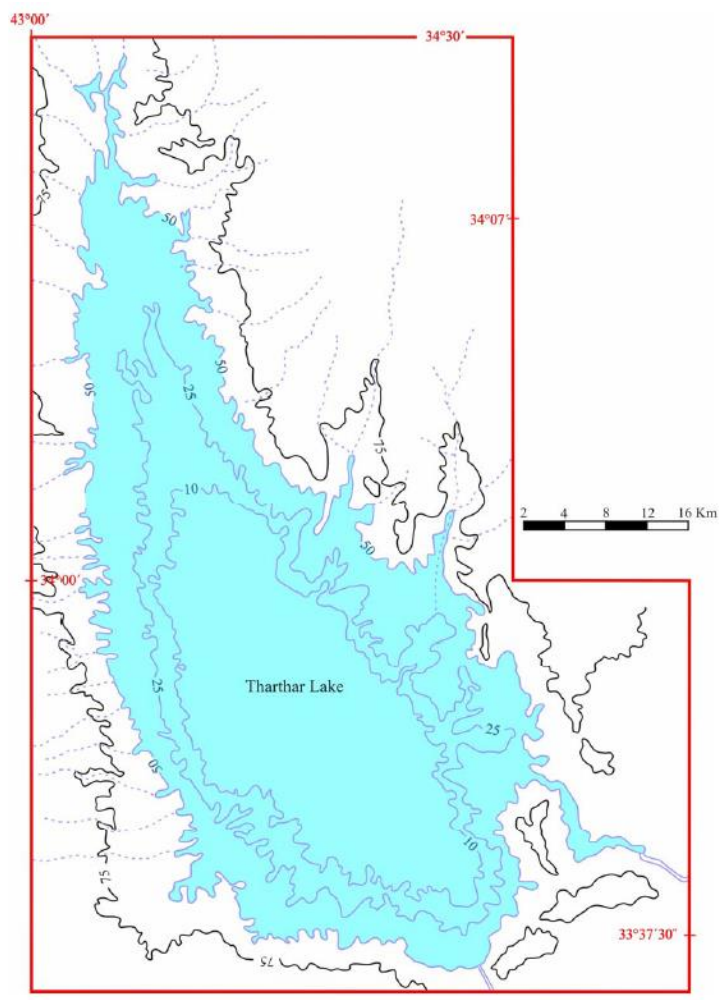

Figure 35: Topographic map of Tharthar Lake (Sissakian 2011).

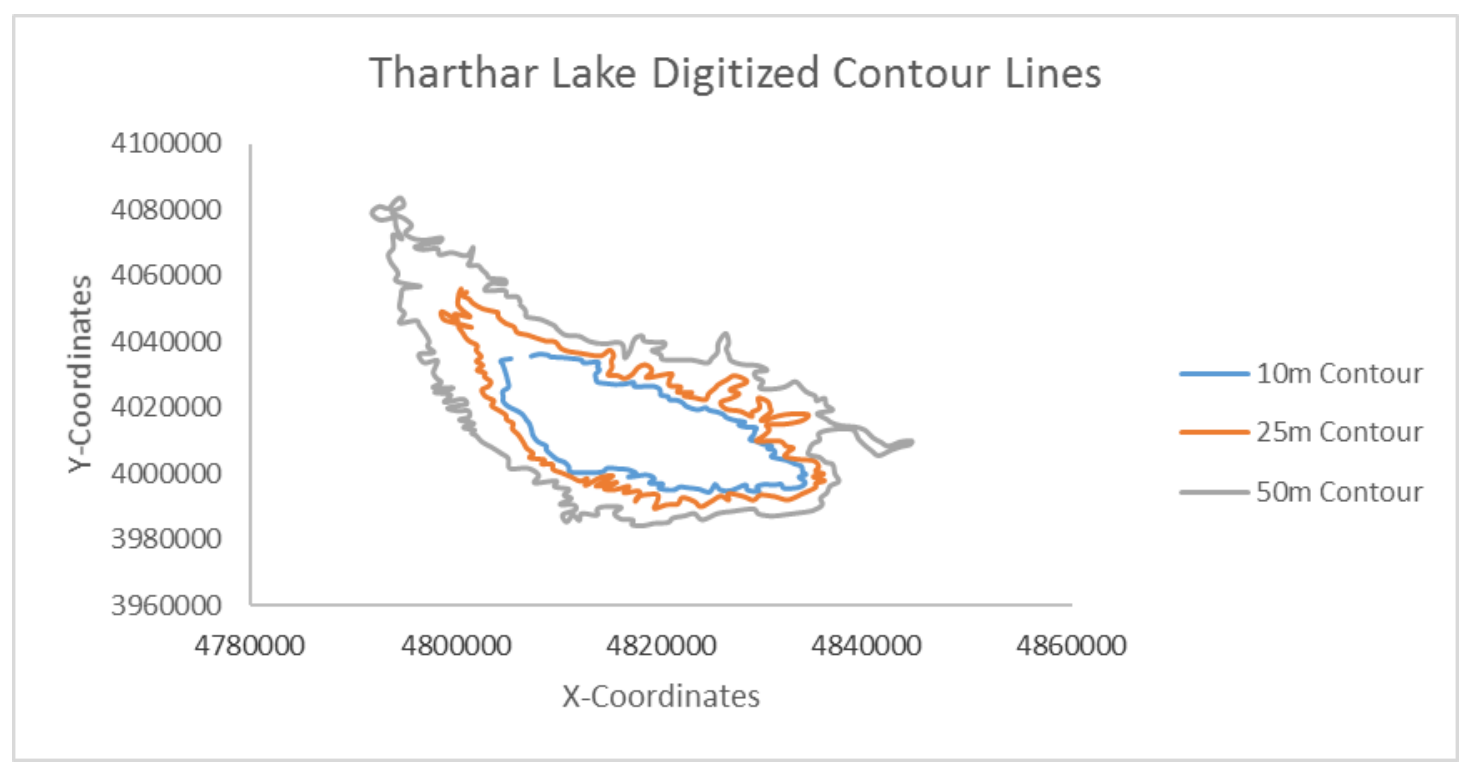

Figure 36: Tharthar Lake digitized contour lines. 


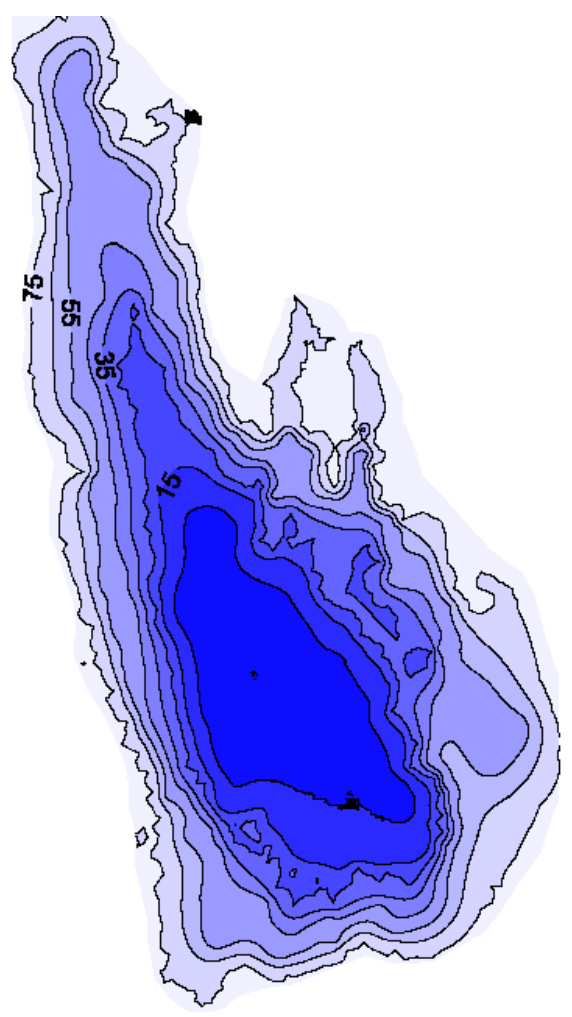

Figure 37: Constructing of contour lines in meters of Tharthar Lake constructed by Surfer.

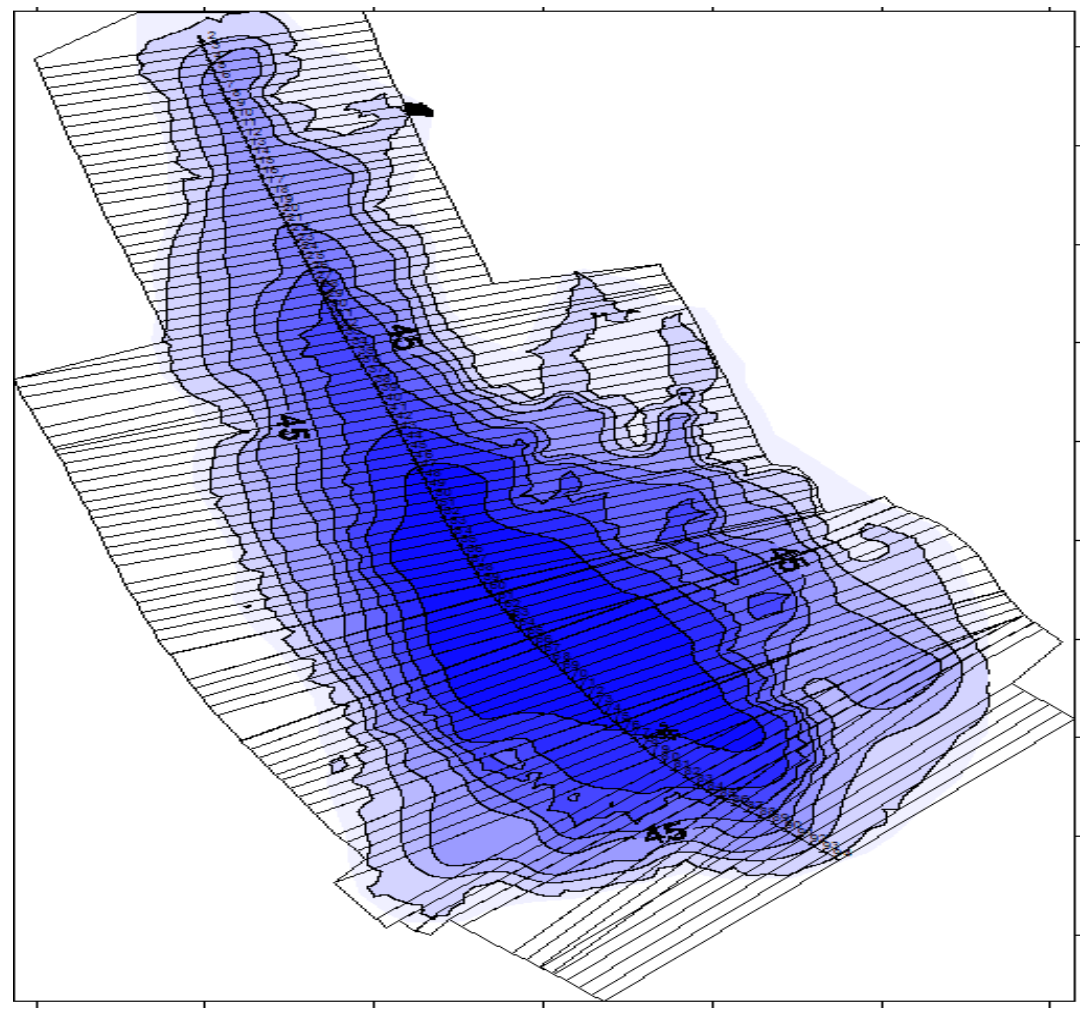

Figure 38: Model segments of Tharthar Lake created by Surfer. 


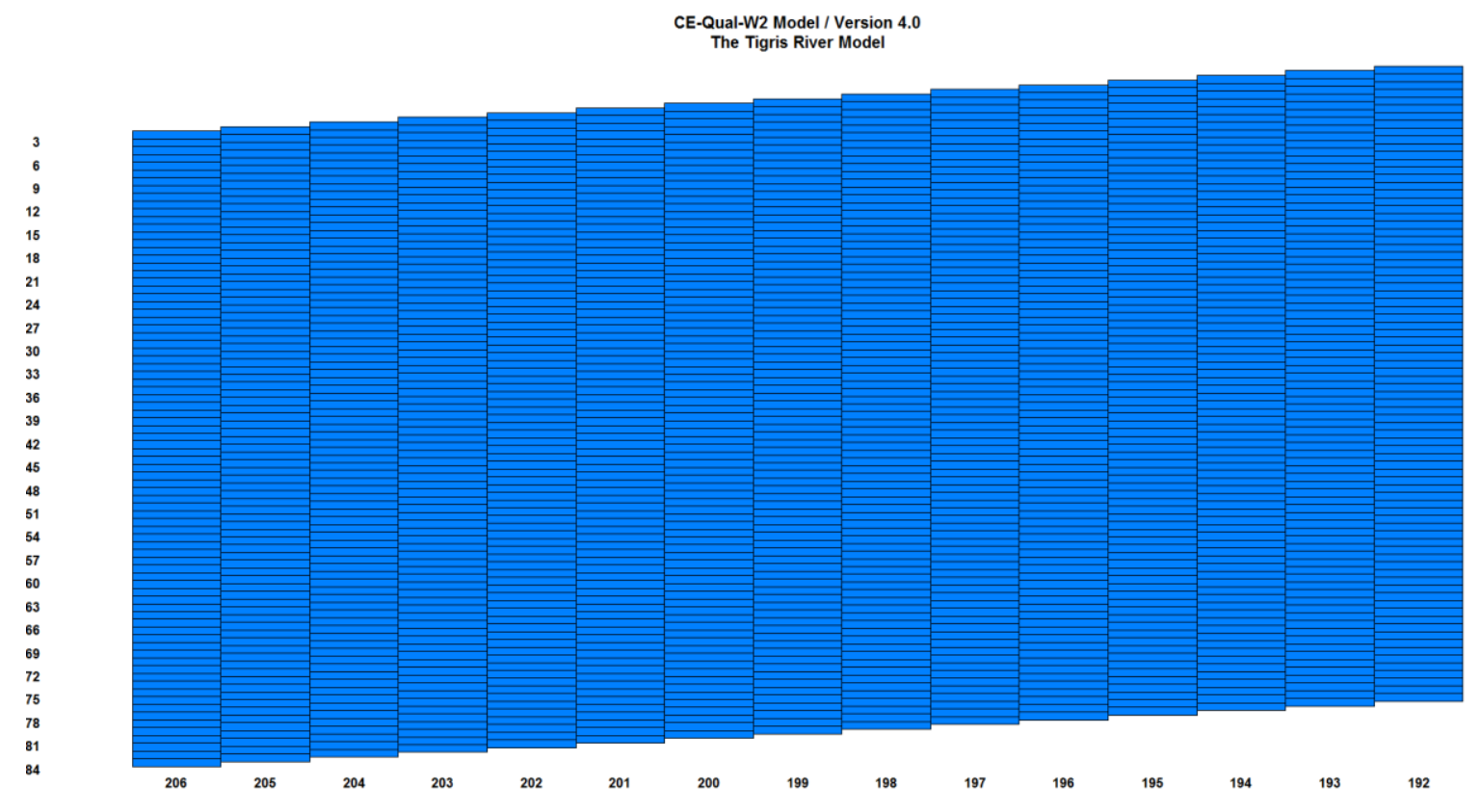

Figure 39: Longitudinal profile for waterbody 5, branch 5 (Tigris-Tharthar Canal) of the Tigris River model constructed by the W2 model (Cole and Wells, 2017).

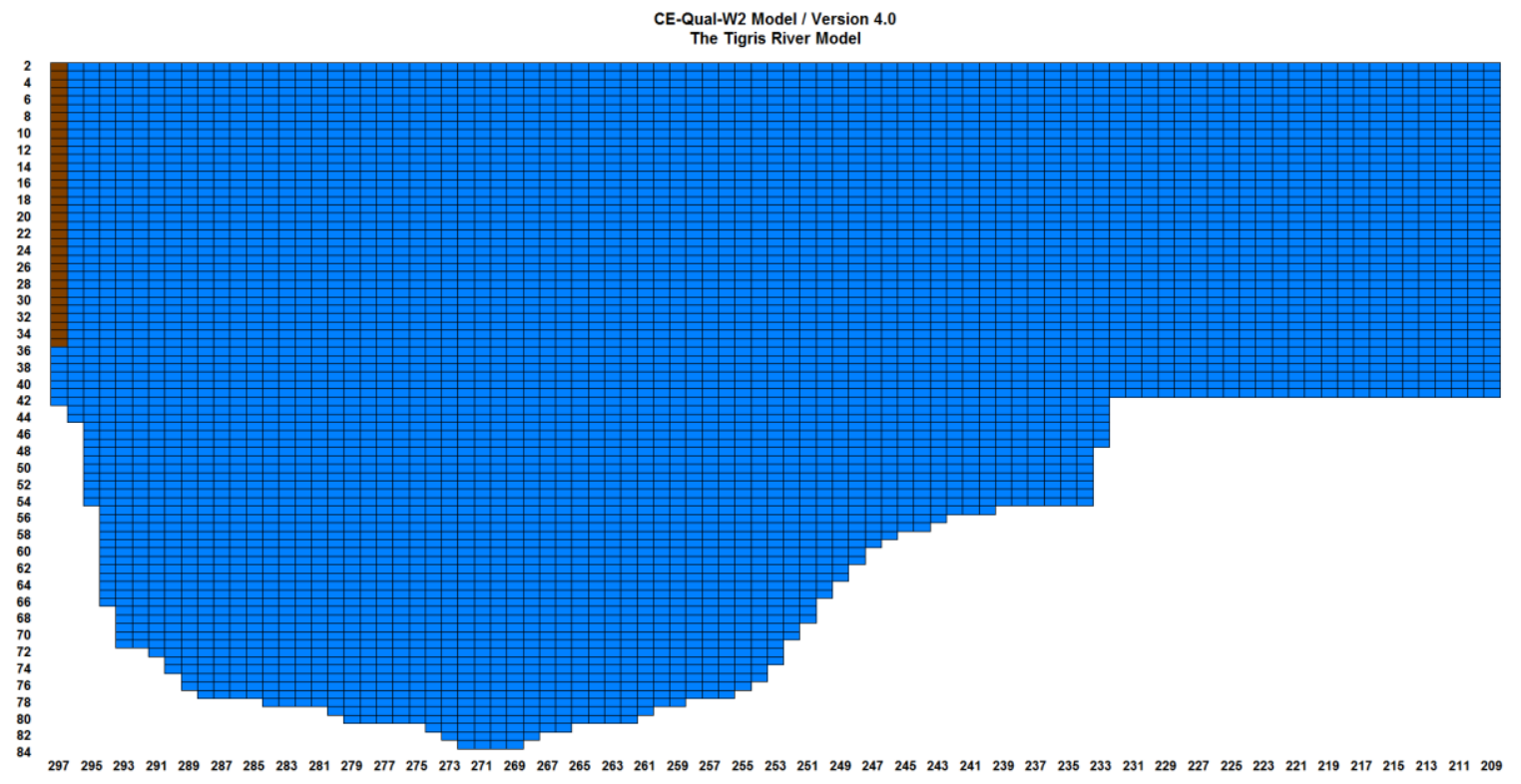

Figure 40: Model longitudinal profile of water body 6, branch 6 Tharthar Lake, including all segments and layers constructed by W2 model (Cole and Wells, 2017), the outlet of the lake at segment 297 with a brown color. 


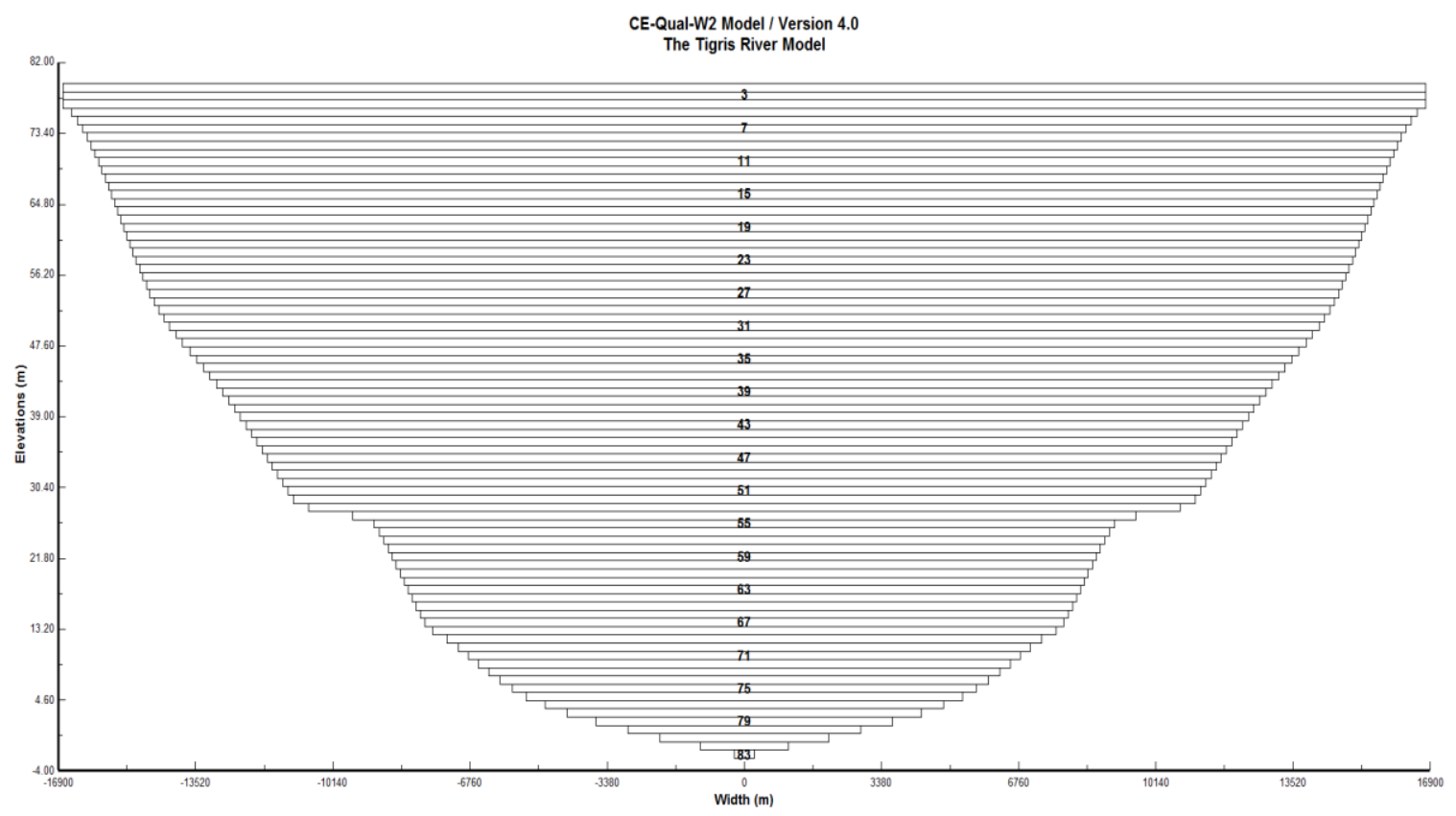

Figure 41: Model segment \#270 section (Tharthar Lake) with 82 active layers (1 m each) constructed by the W2 model (Cole and Wells, 2017).

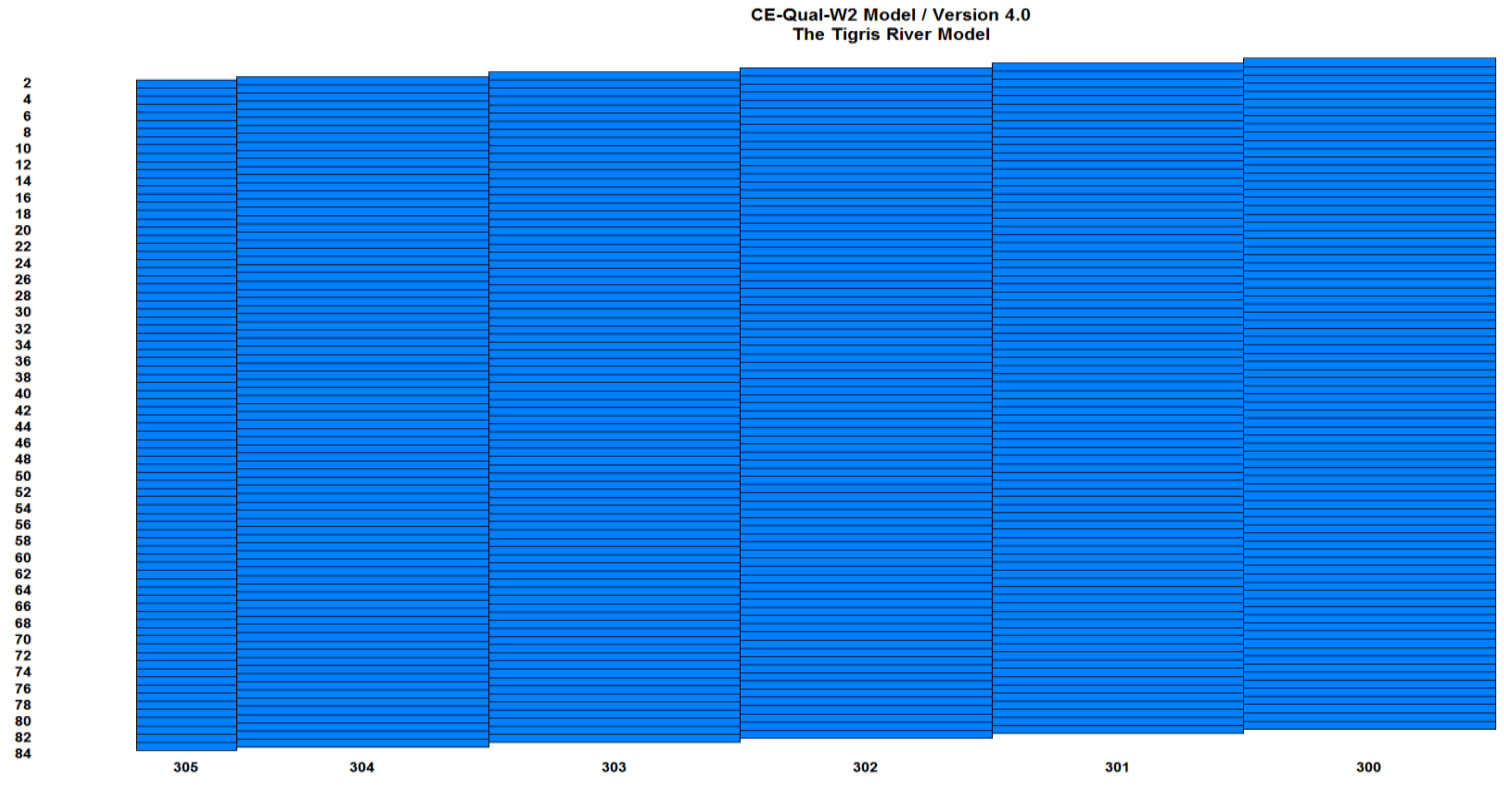

Figure 42: Longitudinal profile for waterbody 7, branch 7 (Tharthar Canal) of the Tigris River model constructed by the W2 model (Cole and Wells, 2017). 


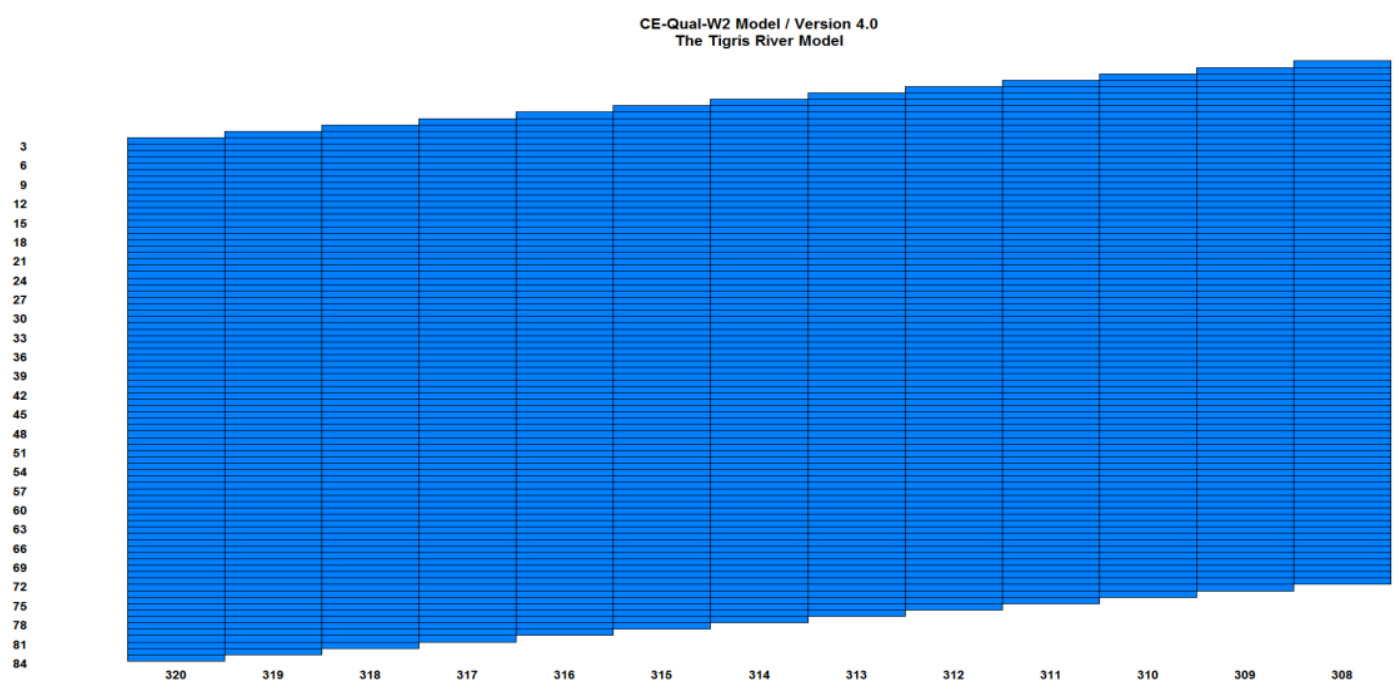

Figure 43: Longitudinal profile for waterbody 8, branch 8 (Tharthar-Tigris Canal) of the Tigris River model constructed by the W2 model (Cole and Wells, 2017).

In summary, Table 13 summarizes the model dimensions of all waterbodies and branches within the study area.

Table 13: Dimensions of all waterbodies and branches of the Tigris River System, DS: Downstream, B: Barrage

\begin{tabular}{|c|c|c|c|c|c|c|c|}
\hline $\begin{array}{c}\text { Water } \\
\text { Body } \\
(\mathrm{Wb})\end{array}$ & $\begin{array}{c}\text { Branch } \\
(\mathrm{Br})\end{array}$ & $\begin{array}{c}\text { Starting } \\
\text { Active } \\
\text { Segment }\end{array}$ & $\begin{array}{c}\text { Ending } \\
\text { Active } \\
\text { Segment }\end{array}$ & $\begin{array}{c}\text { Branch } \\
\text { Length } \\
(\mathrm{km})\end{array}$ & $\begin{array}{c}\text { Number of } \\
\text { Segments }\end{array}$ & $\begin{array}{c}\text { Number } \\
\text { of Vertical } \\
\text { layers }\end{array}$ & Details \\
\hline $\mathrm{Wb} 1$ & $\mathrm{Br} 1$ & 2 & 70 & 350 & 69 & 82 & From Mosul Dam to 15 km DS Tikrit city \\
\hline $\mathrm{Wb} 2$ & $\mathrm{Br} 2$ & 73 & 80 & 40 & 8 & 82 & From 15 km DS Tikrit city to Samarra B. \\
\hline $\mathrm{Wb} 3$ & $\mathrm{Br} 3$ & 83 & 137 & 256.5 & 55 & 82 & From Samarra B. to 70 km DS Baghdad city \\
\hline $\mathrm{Wb} 4$ & $\mathrm{Br} 4$ & 140 & 189 & 233.5 & 50 & 82 & From 70 km DS Baghdad city to Kut B. \\
\hline $\mathrm{Wb} 5$ & $\mathrm{Br} 5$ & 192 & 206 & 75 & 15 & 82 & Tigris-Tharthar Canal \\
\hline $\mathrm{Wb} 6$ & $\mathrm{Br} 6$ & 209 & 297 & 90 & 89 & 82 & Tharthar Lake \\
\hline $\mathrm{Wb} 7$ & $\mathrm{Br} 7$ & 300 & 305 & 27 & 6 & 82 & Tharthar Arm \\
\hline $\mathrm{Wb} 8$ & $\mathrm{Br} 8$ & 308 & 320 & 65 & 13 & 82 & Tharthar-Tigris Canal \\
\hline $\mathrm{Wb} 9$ & $\mathrm{Br} 9$ & 323 & 342 & 97 & 20 & 82 & From Samarra B. to Tharthar Regulator \\
\hline
\end{tabular}




\section{Meteorological Inputs}

Meteorological data for the CE-QUAL-W2 model were obtained from the Iraqi Ministry of Transportation, the General Organization for Meteorology and Seismic Monitoring (MOT-IMOAS 2014). Data were provided in a frequency of four hours for the year 2009 at three main cities along the main stream of the Tigris River, more specifically at Mosul, Baeji, and Baghdad cities. The W2 model utilizes air and dew point temperature, wind speed and direction, and cloud cover or solar radiation. CE-QUAL-W2 has the capability to internally calculate solar radiation based on cloud cover data and latitude and longitude. Daily air temperature collected at Mosul, Samarra, and Baghdad cities was shown earlier in Figure 20 in chapter three. Daily dew-point temperature collected at Mosul, Samarra, and Baghdad cities is shown in Figure 44. Wind speed and direction data are also provided for the year 2009. Figure 45 shows daily wind speed, while Figure 46 show wind rose representations of wind direction at Baghdad city. Wind is mostly blowing from the NorthWest direction. Daily averaged cloud cover is plotted in Figure 47. Cloud cover is measured from zero (no cloud cover) to 10 (maximum cloud cover). 


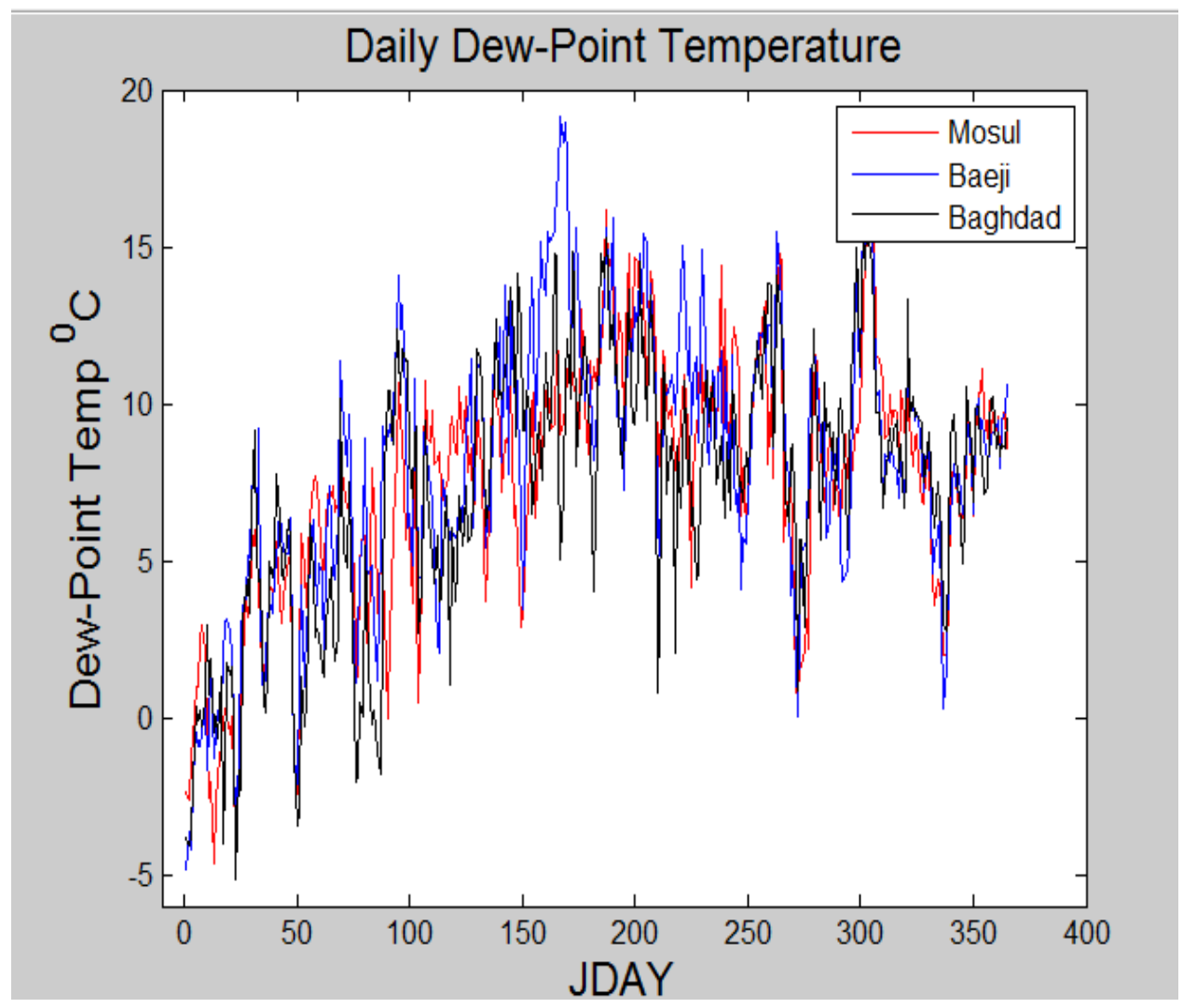

Figure 44: Daily dew-point temperature at Mosul, Baeji, and Baghdad cities (2009).

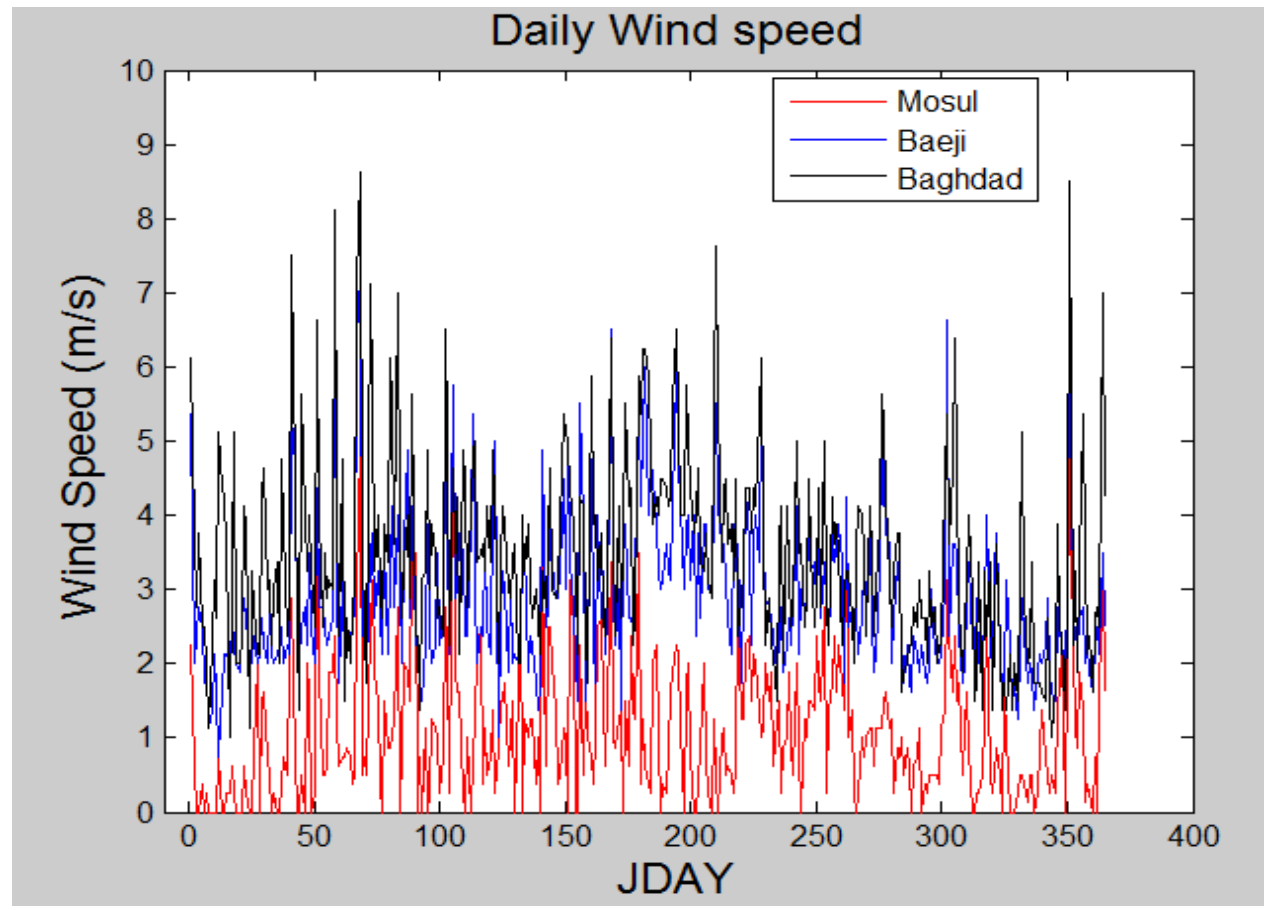

Figure 45: Daily wind speed at Mosul, Baeji, and Baghdad cities (2009). 


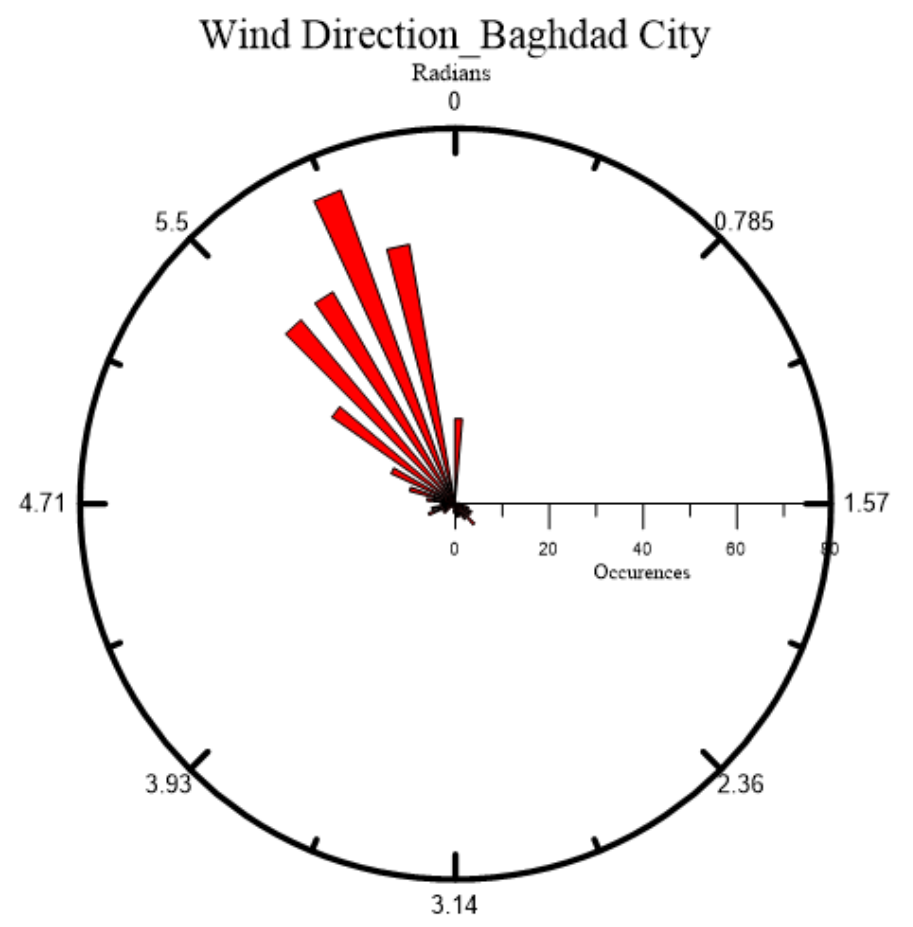

Figure 46: Wind direction at Baghdad City (2009). 


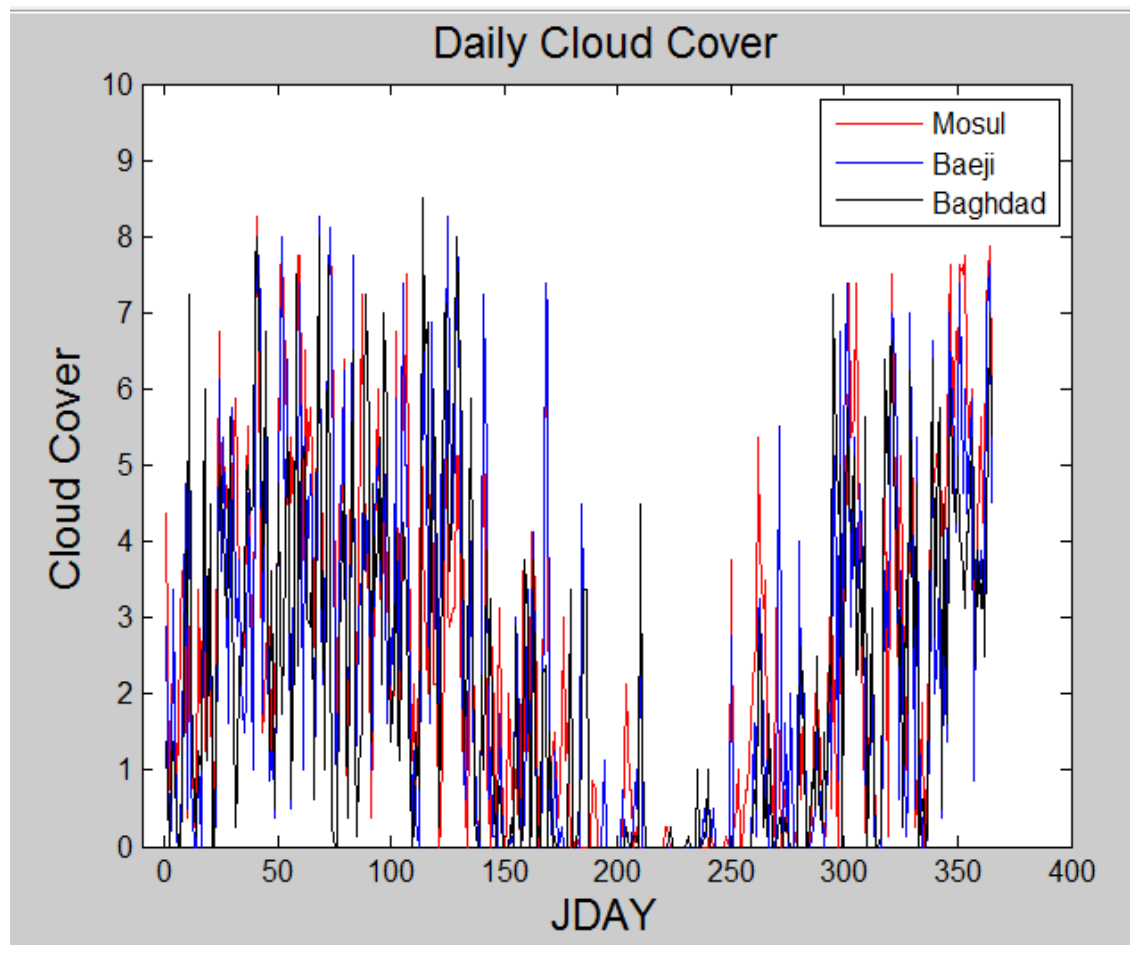

Figure 47: Daily cloud cover at Mosul, Baeji, and Baghdad cities (2009).

\section{Flow Inputs}

Daily flowrate and water level data were required for the entire model time period from January 1, 2009 to December 31, 2009 for upstream boundary conditions and calibration of the mainstem of the Tigris River model. These data were obtained at multiple monitoring stations from the Ministry of Water Resources (MWR) in Iraq for the year of 2009. Flowrate data were provided at Mosul Dam (Rkm 0), Beije city (Rkm 290), outflow from Samarra Barrage (Rkm 390), Baghdad City (Rkm 576.5), outflow from Kut Barrage (Rkm 880), and Tharthar-Euphrates canal. Water level data were provided at Baeji city, Samarra Barrage, and Baghdad city. Figure 48 shows daily flowrates of the mainstem of the Tigris River in 2009 at Mosul Dam, Baeji city, Samarra Barrage, Baghdad city, and Kut Barrage. Unfortunately, flowrate data for the Tigris River main tributaries, Upper Zab and Lower Zab Rivers, were unavailable at the Ministry of Water Resources (MWR) in Iraq for the 
modeled year. However, flowrates at theses tributaries were estimated by computing the flow difference between Mosul Dam station and Baeji city station since these tributaries are located between these two stations. $80 \%$ of this flow difference was from the Upper Zab River and 20\% from the Lower Zab River according to CSO (2010) as shown in Figure 49. Monthly average flowrates of Diyala River were constructed from the Environment statistical report (CSO, 2010). In addition, daily flowrate of Audaim River, located $68 \mathrm{~km}$ downstream Samarra Barrage, was also obtained from the Ministry of Water Resources (MWR) in Iraq for the year of 2009.

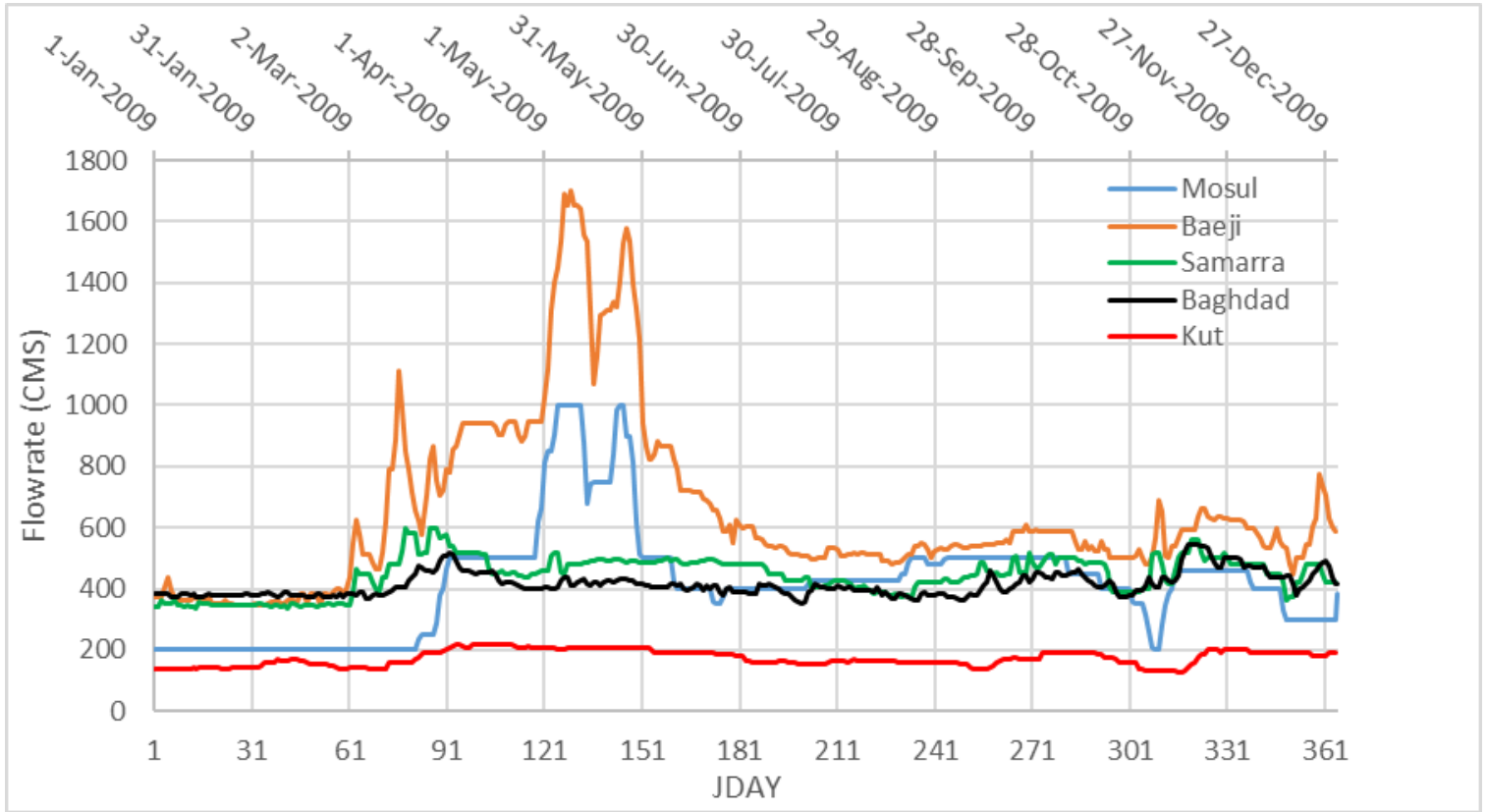

Figure 48: Daily flowrates of the Tigris River in 2009 at Mosul Dam, Baeji city, Samarra Barrage, Baghdad city, and Kut Barrage. 


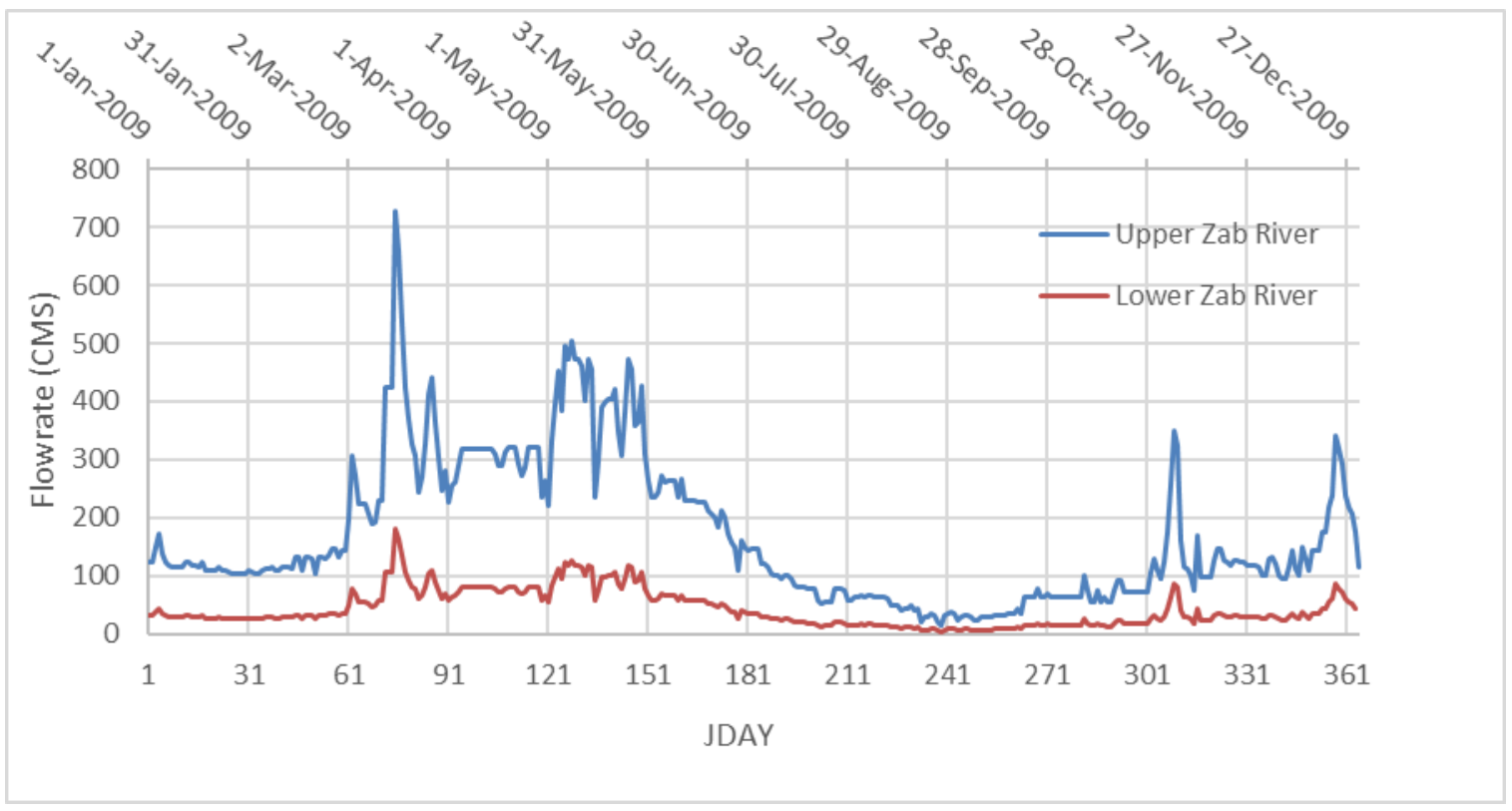

Figure 49: Daily flowrates of the Upper and Lower Zab Rivers in 2009.

Figure 50 shows the main sources of waters that feed the Tigris River in Iraq for the year 2009 (CSO, 2010). The Upper Zab River is the biggest contributor compared with all tributaries of the Tigris River, while Audaim River has no significant impact on the Tigris River flow. With no dams, the Upper Zab River is an uncontrolled tributary. The Ministry of Water Resources had planned to build Bekhme Dam on the Upper Zab tributary, but this project has not been implemented due to wars.

Water is withdrawn from the mainstem of the Tigris River to supply eight water treatment plants located on both banks along the mainstem of the Tigris River within Baghdad city. These withdrawals were specified in the model according to the produced capacity of each treatment plant in the year 2009 as listed previously in Table 2. Other inflows, such as precipitation, flowrate from wastewater treatment plants (WWTPs), agricultural return 
flows, and flowrate of groundwater, were unavailable but were accounted for within the distributed tributary for each waterbody in the Tigris River model.

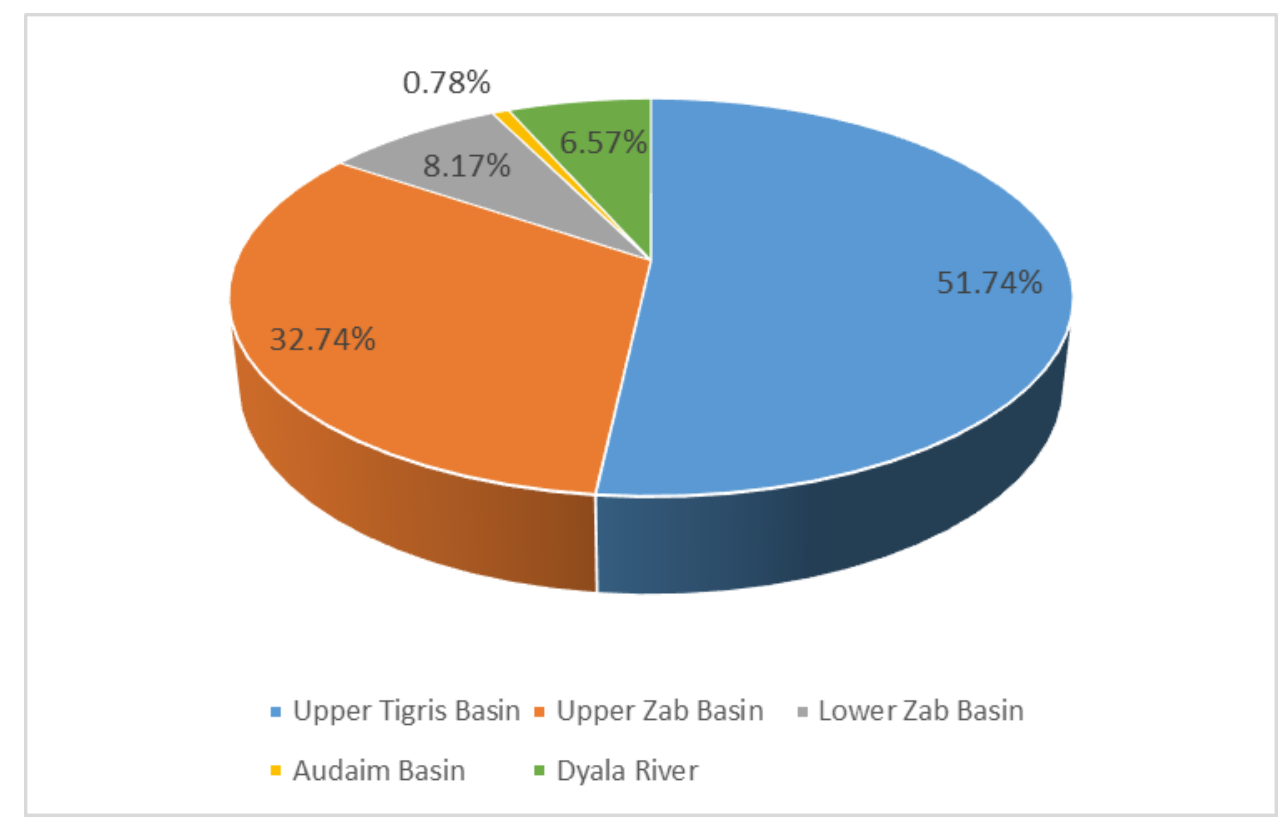

Figure 50: Water sources of the Tigris River in Iraq for the year 2009 (CSO, 2010).

\section{Spillways}

Spillways were added at the end of some branches in the Tigris River model to ensure smooth transition of water between branches. Crest elevations and other used-defined parameters affected the way water moved over the spillway. Generally, most spillways were set so that a spillway's crest was located on the bottom elevation of the channel. Spillways follow power functions for both free flowing and submerged conditions as described in Equation 10 and Equation 11, respectively (Cole and Wells, 2017):

Equation 10: Free flow conditions

$Q=\alpha_{1} \Delta h^{\beta_{1}}$

Equation 11: submerged conditions

$Q=\alpha_{2} \Delta h^{\beta_{2}}$ 
where:

$\alpha 1$ and $\beta 1$ are empirical coefficients

$\alpha 2$ and $\beta 2$ are empirical coefficients

$\Delta \mathrm{h}$ is the difference between the upstream head and spillway crest elevation (Free flow).

$\Delta \mathrm{h}$ is the difference between the upstream head and downstream head (Submerged flow).

$\alpha_{1}$ was calculated by using the equation for a broad crested weir as described in Equation

12 (Cole and Wells, 2017):

Equation 12: Broad crested weir

$\alpha_{1}=C_{D} C_{v} \frac{2}{3} \sqrt{2 g} W$

where:

$\mathrm{C}_{\mathrm{D}}$ : A discharge coefficient (0.84 to 1.06$)$

$\mathrm{C}_{\mathrm{v}}$ : A velocity coefficient (1.0 to 1.2 )

g: gravitational acceleration

W: channel width

$\alpha_{2}$ could be calculated from $\alpha_{1}$ and following the mathematics outlined in the CE-QUAL-

W2 user manual (Cole and Wells, 2017), at a given flow value Q, Equation 10 and

Equation 11 can be combined to solve for $\alpha_{2}$ as described in Equation 13:

Equation 13:

$\alpha_{2}=\frac{\alpha_{1}\left(H_{1}-H_{\text {weir }}\right)^{\beta_{1}-\beta_{2}}}{0.33^{\beta_{2}}}$

Assuming an equal value for both $\beta 1$ and $\beta 2, \alpha_{2}$ could be rewritten as:

$$
\alpha_{2}=\frac{\alpha_{1}}{0.33^{\beta_{2}}}
$$


All spillway coefficients were defined based on above detailed analysis. Figure 51 shows a schematic diagram for water and spillway elevations used in spillway equations. Both $C_{D}$ and $\mathrm{C}_{\mathrm{v}}$ coefficients were assumed 1 , while $\mathrm{W}$, channel width, was estimated based on the average width of the bottom three layers of the segment where spillways were located. Table 14 lists the location of all spillways in the Tigris River system with weir coefficients.

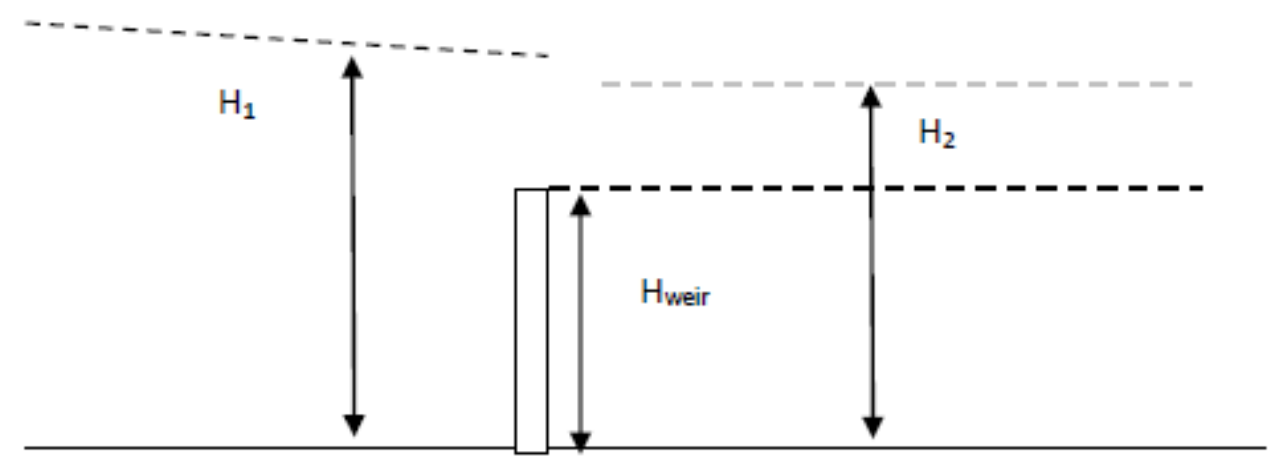

Figure 51: Schematic diagram of water and spillway elevations for free flowing and submerged weir used in spillway analysis (Cole and Wells, 2017).

Table 14: Spillway specifications in the Tigris River System.

\begin{tabular}{|c|c|c|c|c|c|c|c|c|}
\hline $\begin{array}{c}\text { Spillway } \\
\#\end{array}$ & $\begin{array}{c}\text { Branch } \\
(\mathbf{B r})\end{array}$ & $\begin{array}{c}\text { US } \\
\text { Segment }\end{array}$ & $\begin{array}{c}\text { DS } \\
\text { Segment }\end{array}$ & $\begin{array}{c}\text { Spill } \\
\text { Elevation } \\
(\mathbf{m})\end{array}$ & $\mathbf{\alpha l}$ & $\mathbf{\beta 1}=\mathbf{\beta 2}$ & $\mathbf{\alpha 2}$ & Description \\
\hline 1 & 5 & 206 & 278 & 46 & 81 & 1.5 & 427.18 & $\begin{array}{c}\text { From Tigris-Tharthar } \\
\text { canal to Tharthar lake }\end{array}$ \\
\hline 2 & 9 & 342 & 0 & 45.5 & 68.2 & 1.5 & 359.7 & $\begin{array}{c}\text { From Erwaeiya canal to } \\
\text { the Euphrates River }\end{array}$ \\
\hline 3 & 8 & 320 & 119 & 31 & 36.14 & 1.5 & 190.65 & $\begin{array}{c}\text { From Tharthar-Tigris } \\
\text { canal to the Tigris River } \\
\text { upstream Baghdad city }\end{array}$ \\
\hline 4 & 7 & 305 & 0 & 42 & 68.2 & 1.5 & 359.7 & $\begin{array}{c}\text { From Tharthar Arm to the } \\
\text { Euphrates River }\end{array}$ \\
\hline 5 & 4 & 189 & 0 & 17 & 627.4 & 1.5 & 3309.54 & $\begin{array}{c}\text { From Kut Barrage to } \\
\text { downstream of the Tigris } \\
\text { River below Kut city }\end{array}$ \\
\hline 6 & 2 & 80 & 323 & 68.5 & 2045.78 & 1.5 & 10791.9 & $\begin{array}{c}\text { From Samarra Barrage to } \\
\text { Erwaeiva canal }\end{array}$ \\
\hline
\end{tabular}




\section{Temperature Inputs}

Temperature data were required for the entire model time period for all input flows. Daily water temperature data were estimated remotely from Landsat for the boundary conditions at Mosul Dam (Rkm 0). The Landsat data were used to provide in-river temperatures that were used for calibration at both Baeji city and Baghdad city. For Upper and Lower Zab tributaries where no data were available, the input temperature files were developed based on the statistical model developed to estimate water temperatures at Baeji city, while water temperatures for both Audaim and Diyala tributaries were estimated based on the statistical model developed to estimate water temperature at Baghdad city.

A $95 \%$ confidence interval, Equation 14, was estimated for remotely sensed water temperatures at both Baeji and Baghdad cities as shown in Figure 52 and Figure 53, respectively. Since there were no field data of water temperature for the year 2009 to compare with the modeled temperature data, the goal of model calibration will be to ensure that the model predictions of water temperature lie within the upper and lower limits of the confidence interval.

Equation 14: Estimation of $95 \%$ confidence interval

$95 \% C I=T_{w} \pm t_{n-2} * S_{y} \sqrt{\frac{1}{n}+\frac{\left(T_{a}-\mu\right)^{2}}{(n-1) S_{x}{ }^{2}}}$

where:

$\mathrm{T}_{\mathrm{w}}$ : Water temperature estimated from statistical models

$\mathrm{T}_{\mathrm{a}}: 5$ days weighed air temperature

$\mathrm{S}_{\mathrm{y}}:$ Standard error

$\mathrm{S}_{\mathrm{x}}$ : Variance (square of standard deviation)

$\mathrm{n}$ : Sample's number

$\mu$ : Average air temperature of the sample

t: tabulated values based on degree of freedom ( $n-2)$ 


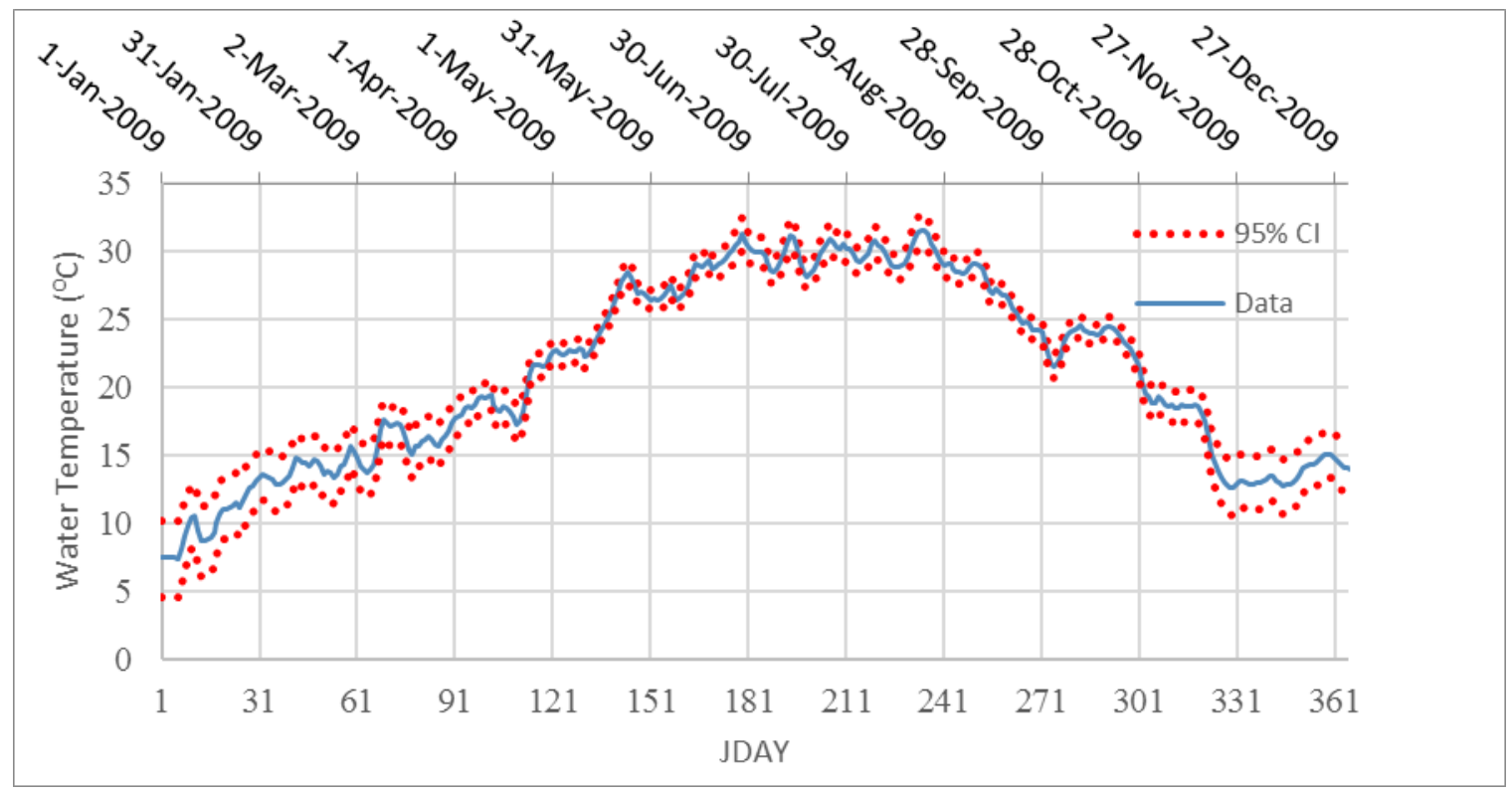

Figure 52: Daily surface water temperature of the Tigris River at Baeji City with 95\% CI.

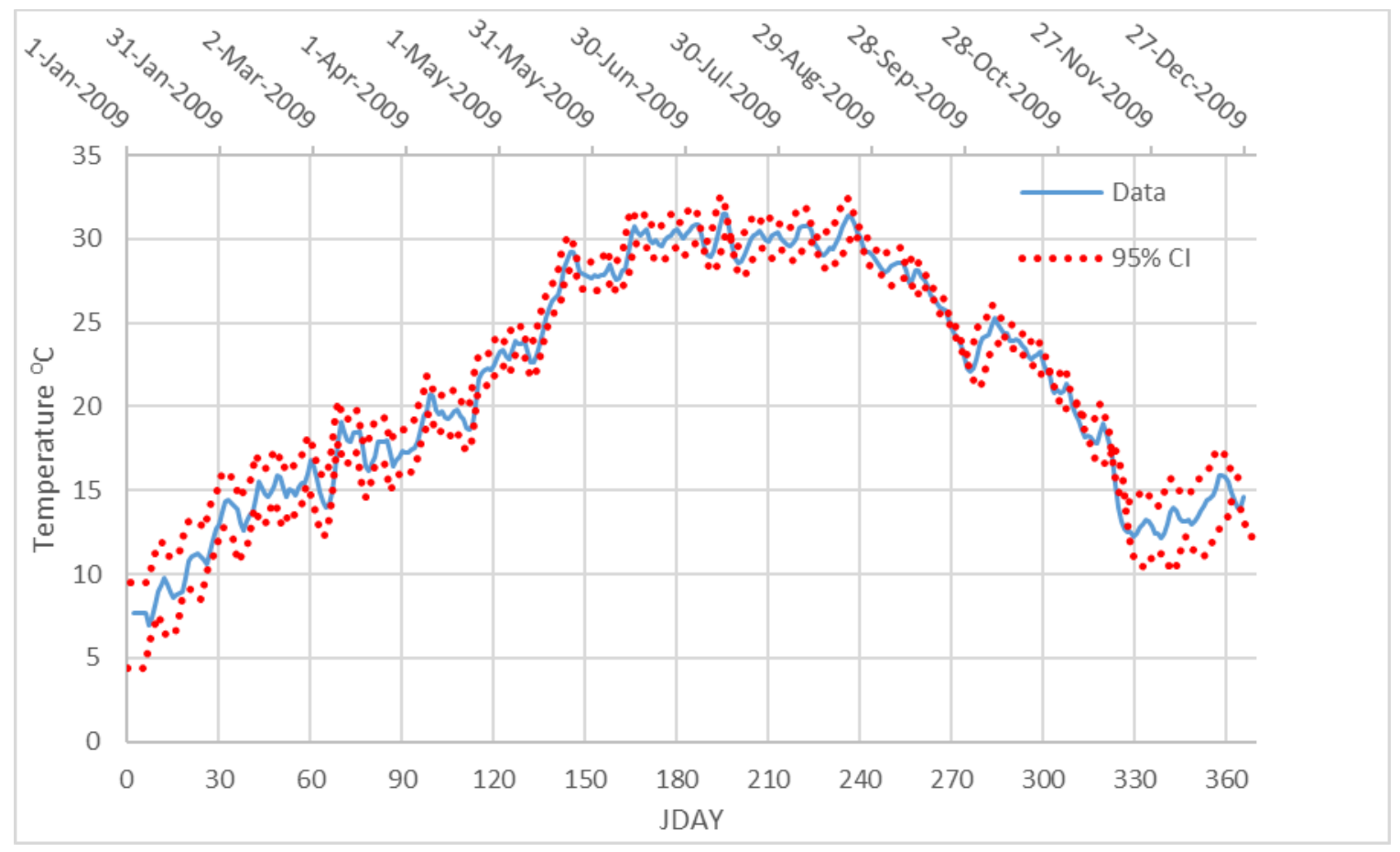

Figure 53: Daily surface water temperature of the Tigris River at Baghdad City with $95 \%$ CI. 


\section{Constituents Inputs}

Water quality state variables modeled were:

- Total dissolved solids (TDS)

- Phosphate (PO4)

- Ammonia (NH3)

- $\quad$ Nitrates (NO3)

- Labile dissolved organic matter (LDOM)

- Refractory dissolved organic matter (RDOM)

- Labile particulate organic matter (LPOM)

- Refractory particulate organic matter (RPOM)

- Biochemical oxygen demand (BOD)

- Biochemical oxygen demand as phosphorus (BOD-P)

- Biochemical oxygen demand as nitrogen (BOD-N)

- Algae

- Dissolved oxygen (DO)

Data were needed for the entire simulation time for all input concentrations, but unfortunately only monthly averaged data of total dissolved solids (TDS) and nitrate (NO3) were available from the Iraqi Water Resources Ministry for the mainstem of the Tigris River. Monthly averaged field data of TDS were provided for Audaim and Diyala tributaries and for four stations along the mainstem of the Tigris River at Mosul Dam, Samarra Barrage, Baghdad City, and Kut Barrage. TDS concentrations for the Upper Zab and the Lower Zab tributaries were assumed as the same TDS concentrations as in Samarra city. Rahi \& Halihan (2010), showed that TDS concentration in Tharthar Lake was 1500 $\mathrm{mg} / \mathrm{l}$ in the year 2003. The initial condition of TDS in Tharthar Lake was assumed 1300 $\mathrm{mg} / \mathrm{l}$. 
Field data of NO3 were provided at two stations along the mainstem of the Tigris River at Samarra Barrage and Baghdad City. Field data for NO3 at Mosul Dam were estimated from literature values measured in previous years.

Other modeled water quality constituents were phosphate (PO4), ammonia (NH3), biochemical oxygen demand (BOD), algae, and dissolved oxygen (DO). Field data of these constituents were estimated from literature values. Table 15 lists field data of water quality constituents extracted from literature studies.

Table 15: Water Quality field data extracted from literatures and used for boundary conditions at Mosul Dam and downstream model calibration at Baghdad City; WWTPs: Wastewater treatment plants.

\begin{tabular}{|c|c|c|c|}
\hline Location & $\begin{array}{c}\text { Data } \\
\text { Available }\end{array}$ & Data year & Reference \\
\hline Mosul Dam & $\begin{array}{l}\text { DO, PO4, } \\
\text { NO3 }\end{array}$ & Aug 1986-Aug1987 & Al-Layla et al., 1990 \\
\hline $\begin{array}{l}\text { Lower Zab / } \\
\text { Tikrit City }\end{array}$ & BOD & Jan-Sep 2004 & $\begin{array}{l}\text { Al-Jebouri and } \\
\text { Edham (2012) }\end{array}$ \\
\hline Lower Zab & $\begin{array}{l}\mathrm{DO}, \mathrm{PO} 4 \\
\mathrm{NO} 3\end{array}$ & Nov2001-Oct2002 & $\begin{array}{l}\text { Abdul Jabar et al., } \\
\text { (2008) }\end{array}$ \\
\hline Diyal River & $\mathrm{BOD}$ & Oct (2002)-March (2003) & Husain Amal (2009) \\
\hline Baghdad City & $\mathrm{BOD}$ & Feb, May, Aug, Oct (2009) & Rabee et al., (2011) \\
\hline Baghdad City & PO4 & Feb, May, Aug, Oct (2009) & Rabee et al., (2011) \\
\hline $\begin{array}{l}\text { WWTPs in Tikrit } \\
\text { and Baghdad cities }\end{array}$ & PO4, NH4 & $\begin{array}{c}\text { Iraqi wastewater standards } \\
\text { for effluents }\end{array}$ & $\begin{array}{l}\text { Aziz and Aws, } \\
(2012)\end{array}$ \\
\hline
\end{tabular}


Water quality conversions were made for field data in order to estimate the state variables modeled with CE-QUAL-W2 model. Due to limitations in water quality field data of the Tigris River, estimates were made for missing data of a given state variable as indicated below:

- TDS concentrations for the Upper Zap and the Lower Zab tributaries were assumed as the same TDS concentrations at Mosul and Samarra cities, respectively, while TDS concentrations for Audaim and Diyala tributaries were provided from the Ministry of Water Resources in Iraq.

- PO4 for input flows at Mosul Dam were assumed from PO4 field data provided by Al-Layla et al., 1990.

- $\mathrm{NH} 3$ concentrations for all input flows were assumed $0.1 \mathrm{mg} / \mathrm{l}$ with exception to $\mathrm{NH} 3$ concentration of the discharged wastewater at Tikirt city that were assumed 1 $\mathrm{mg} / \mathrm{l}$.

- NO3 for input flows at Mosul Dam were assumed $1.5 \mathrm{mg} / \mathrm{l}$ from January $1^{\text {st }}$ to June $30^{\text {th }}$ (due to high downstream NO3 concentration at Samarra Barrage and Baghdad city). NO3 data from July $1^{\text {st }}$ to December $31^{\text {st }}$ were assumed from field data provided by Al-Layla et al., 1990.

- LDOM, RDOM, LPOM, and RPOM were assumed zero for all input flows.

- BOD5 field data were converted to ultimate BOD (BODU), the following typical relationship was used (Cole and Wells, 2017) assuming a BOD decay rate of 0.1 day $^{-1}$ :

$$
B O D_{u}=2.54 \times B O D_{5}
$$


- BOD concentrations in the Lower Zab tributaries were assumed from BOD field data provided by Al-Jebouri and Edham (2012). Same BOD data were used for BOD of the Upper Zab. BOD concentrations in Audaim tributary were assumed as BOD field data in Baghdad city provided by Rabee et al., (2011), while BOD concentrations in Diyala River were assumed from BOD field data provided by Husain Amal (2009).

- BOD-P for all input flows were assumed 0.01 of $\mathrm{BOD}_{\mathrm{u}}$

- BOD-N for all input flows were assumed 0.08 of $\mathrm{BOD}_{\mathrm{u}}$

- Algae concentration was assumed $0.05 \mathrm{mg} / \mathrm{l}$ for all input flows.

- DO concentration for upstream boundary conditions was assumed as $90 \%$ of the saturation oxygen $\mathrm{O}_{\mathrm{s}}$ which was determined from the following equation (APHA 1992):

$\ln O_{s}=-139.34411+\frac{1.575701 \times 10^{5}}{T_{a}}-\frac{6.642308 \times 10^{7}}{T_{a}^{2}}+\frac{1.2438 \times 10^{10}}{T_{a}^{3}}-$ $\frac{8.621949 \times 10^{11}}{T_{a}^{4}}$

where:

$\mathrm{O}_{\mathrm{s}}$ : Saturation concentration of dissolved oxygen in fresh water at $1 \mathrm{~atm} \mathrm{mg} / \mathrm{l}$ $\mathrm{T}_{\mathrm{a}}$ : absolute temperature $(\mathrm{K}), T_{a}=T+273.15$

T: water temperature $\left({ }^{\circ} \mathrm{C}\right)$

- DO Concentrations for Upper Zap, Lower Zab, and Diyala River were assumed as the same DO concentration at Mosul city, Baeji city, and Baghdad city, respectively. 
Figure 54, Figure 55, and Figure 56 show field data used for boundary conditions of the Tigris River model at Mosul Dam for TDS, PO4, NH4, NO3, BODu, and DO. Except for TDS, other input constituent field data for both Upper Zab and Lower Zab Rivers were assumed the same, while other input constituent field data for both Audaim and Diyala Rivers were assumed the same as well.

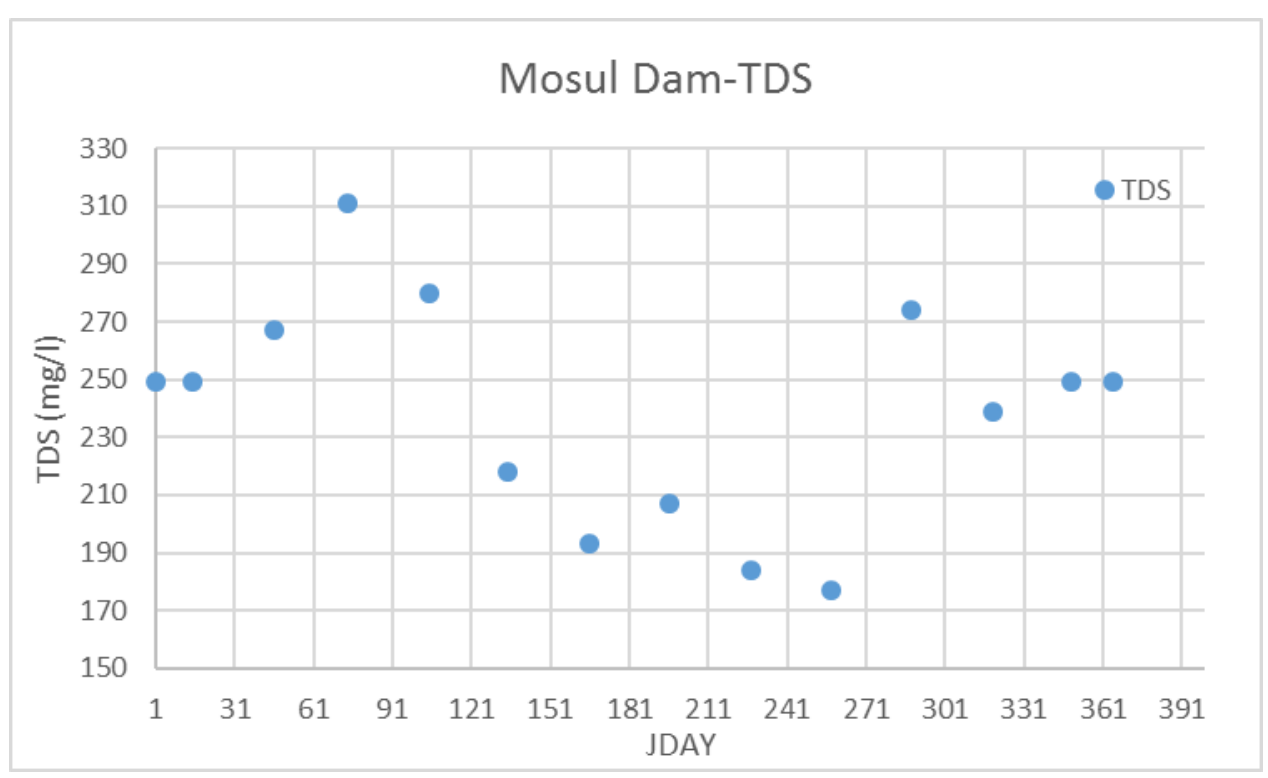

Figure 54: Input field data of TDS concentration for boundary conditions at Mosul Dam. 


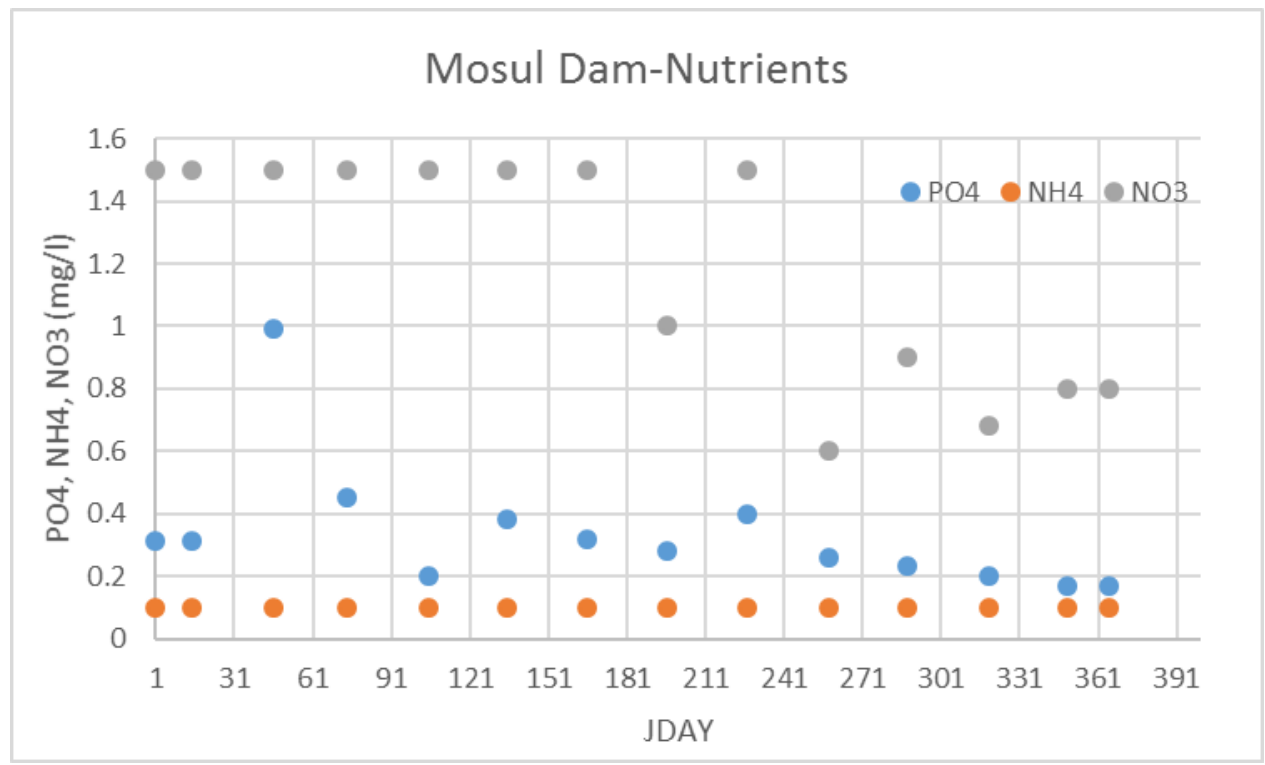

Figure 55: Estimated concentrations of PO4, NH4, and NO3 for boundary conditions at Mosul Dam.

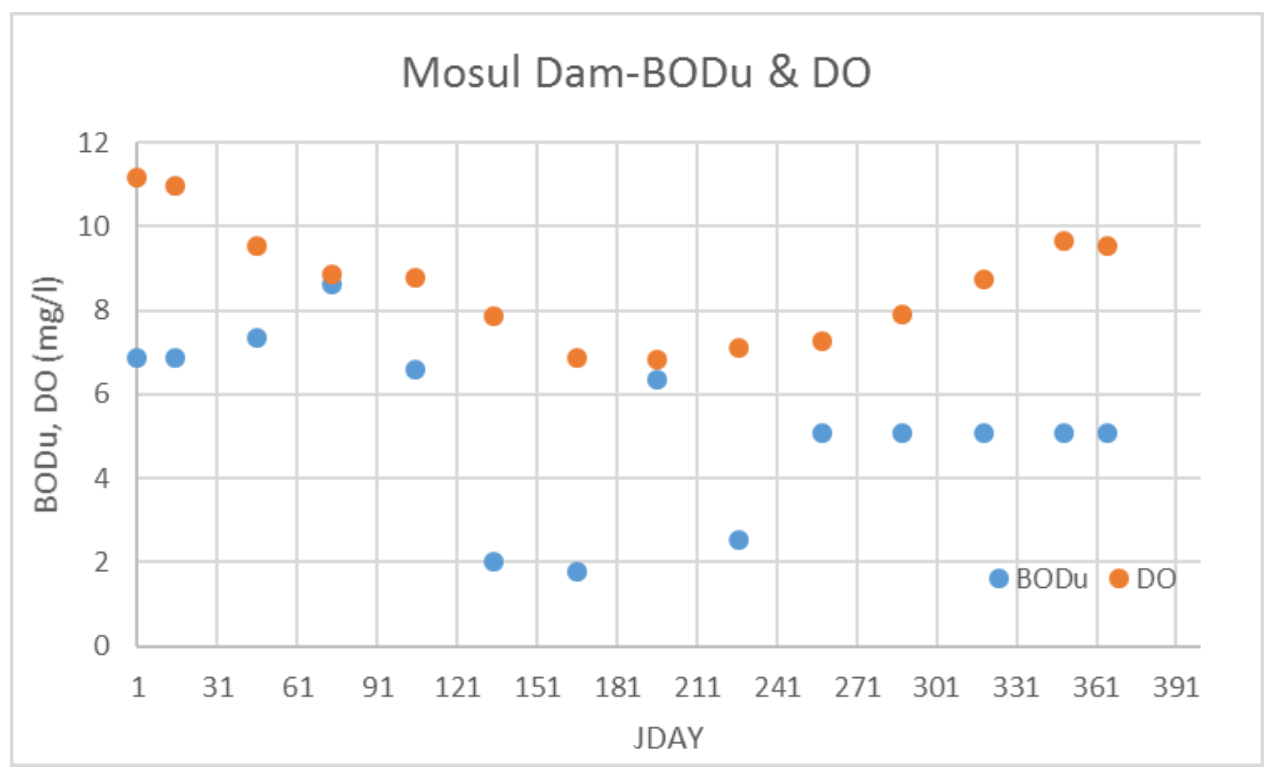

Figure 56: Estimated BODu and DO concentrations for boundary conditions at Mosul Dam 


\section{Chapter Six: The Tigris River Model Calibration}

In this chapter, the calibration of the Tigris River model is described. Model predictions compared to field data included flow and water level at both Tharthar Lake and the mainstem of the Tigris River, water temperature, and water quality constituents such as total dissolved solids (TDS), phosphate (PO4), ammonia (NH4), nitrate (NO3), carbonaceous oxygen demand (CBOD), dissolve oxygen (DO), and chlorophyll-a (Chl-a).

\section{Model Calibration: Flow-Tharthar Lake}

According to the report of environmental statistics in Iraq (CSO, 2010), the water level of Tharthar Lake dropped from $45.75 \mathrm{~m}$ in October 2008 to $44 \mathrm{~m}$ in October 2009. Therefore, the initial condition of the lake's water level was assumed to be $45.5 \mathrm{~m}$ at the beginning of the model simulation in January $1^{\text {st }}, 2009$.

Figure 57 shows the model simulation of the water level at Tharthar Lake comparing it to the only 1 data point on October 2009. Figure 58 shows flowrates in both Tigris-Tharthar canal and Tharthar-Tigris canal for the model year 2009. The water level significantly increased in May due to a large volume of fresh water diverted through Tigris-Tharthar canal. The outflow from Tharthar Lake was diverted to both the Euphrates River through Tharthar-Euphrates canal and to the Tigris River through Tharthar-Tigris canal. Flowrates through the Tharthar-Tigris canal were assumed, while the excess lake's water was diverted to the Euphrates River. 


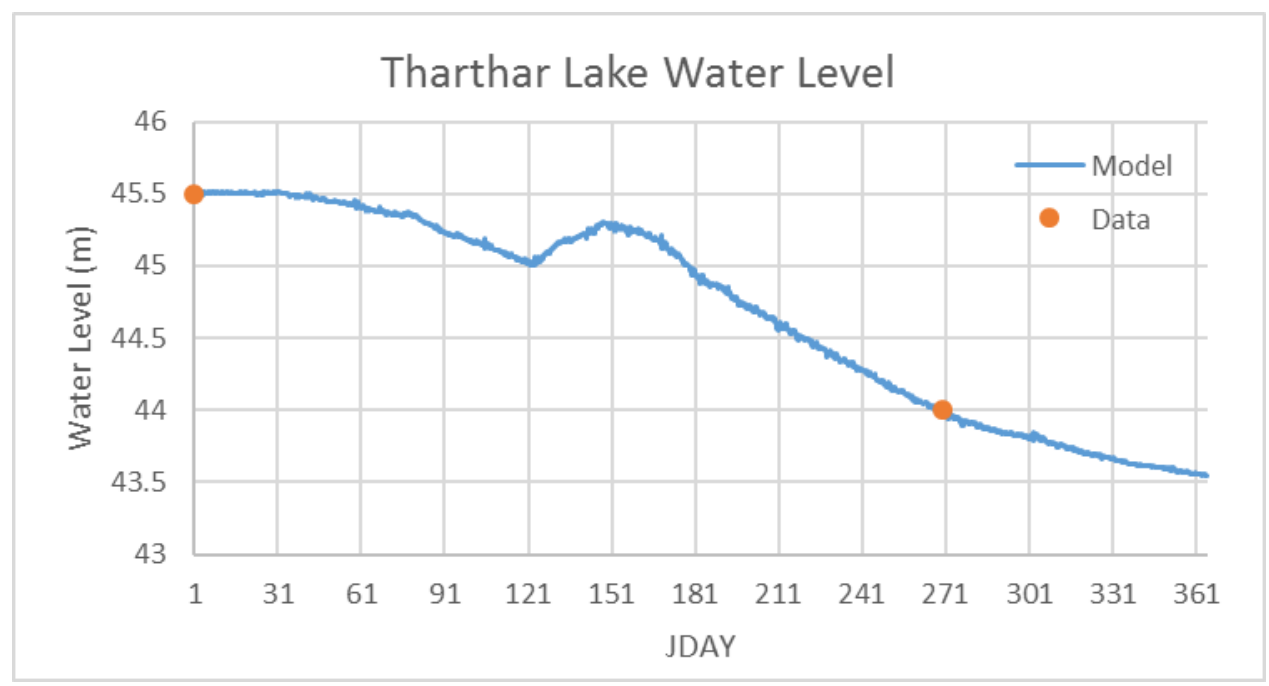

Figure 57: Model and data of the water level of Tharthar Lake in 2009.

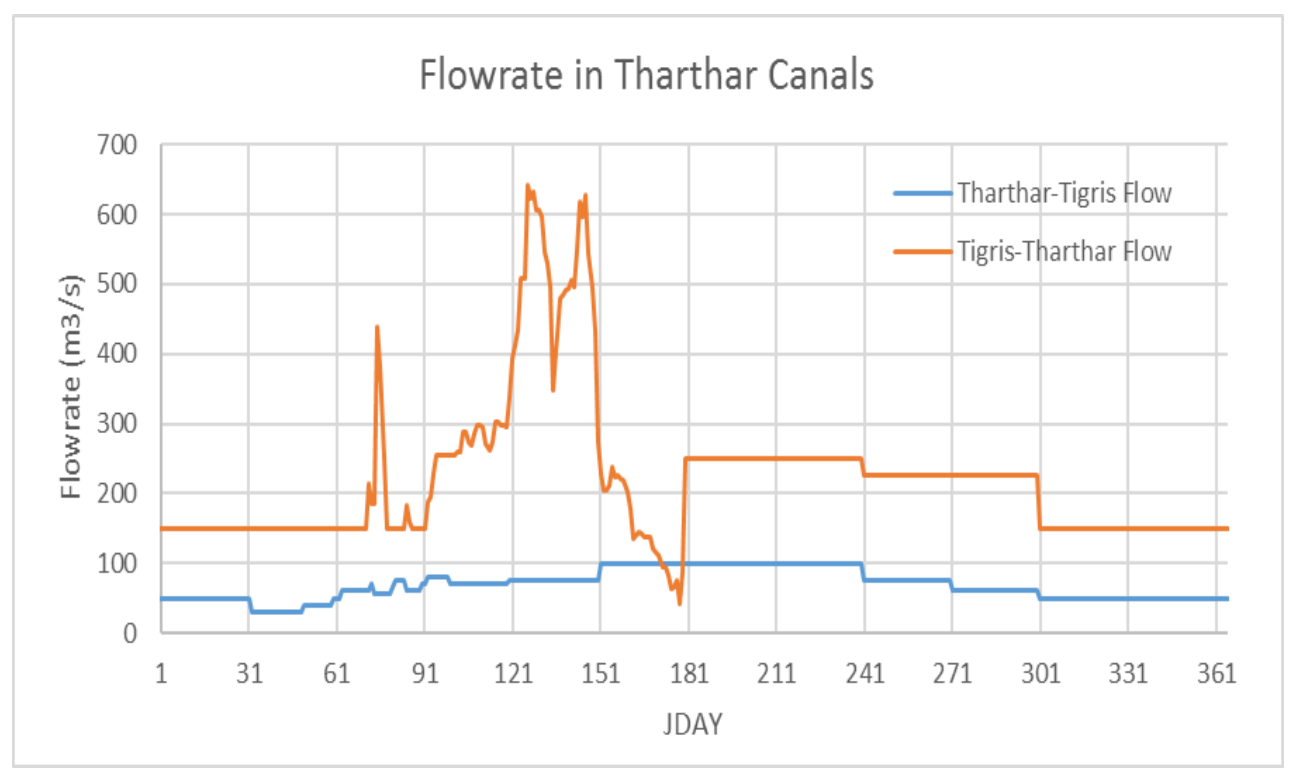

Figure 58: Model flowrate in Tharthar Lake canals in 2009. 


\section{Evaporation in Tharthar Lake}

According to CSO (2010), the annual evaporation in Haditha Dam, $60 \mathrm{~km}$ northwest Tharthar Lake, was $2.27 \mathrm{~m}$ during the water year 2008-2009. Using default values for $[\mathrm{AFW}]$ and $[\mathrm{BFW}]$ evaporation coefficients in the wind speed formulation in the control file of the Tigris River model, model predictions of evaporation in Tharthar Lake was 2.2 $\mathrm{m}$ for the simulated year 2009. Figure 59 shows model flow balance in Tharthar Lake. As evaporation rates increase in the Tharthar Lake, the lake becomes more concentrated with high TDS concentrations causing more water quality issues as water diverts from the lake to both the Tigris and the Euphrates Rivers.

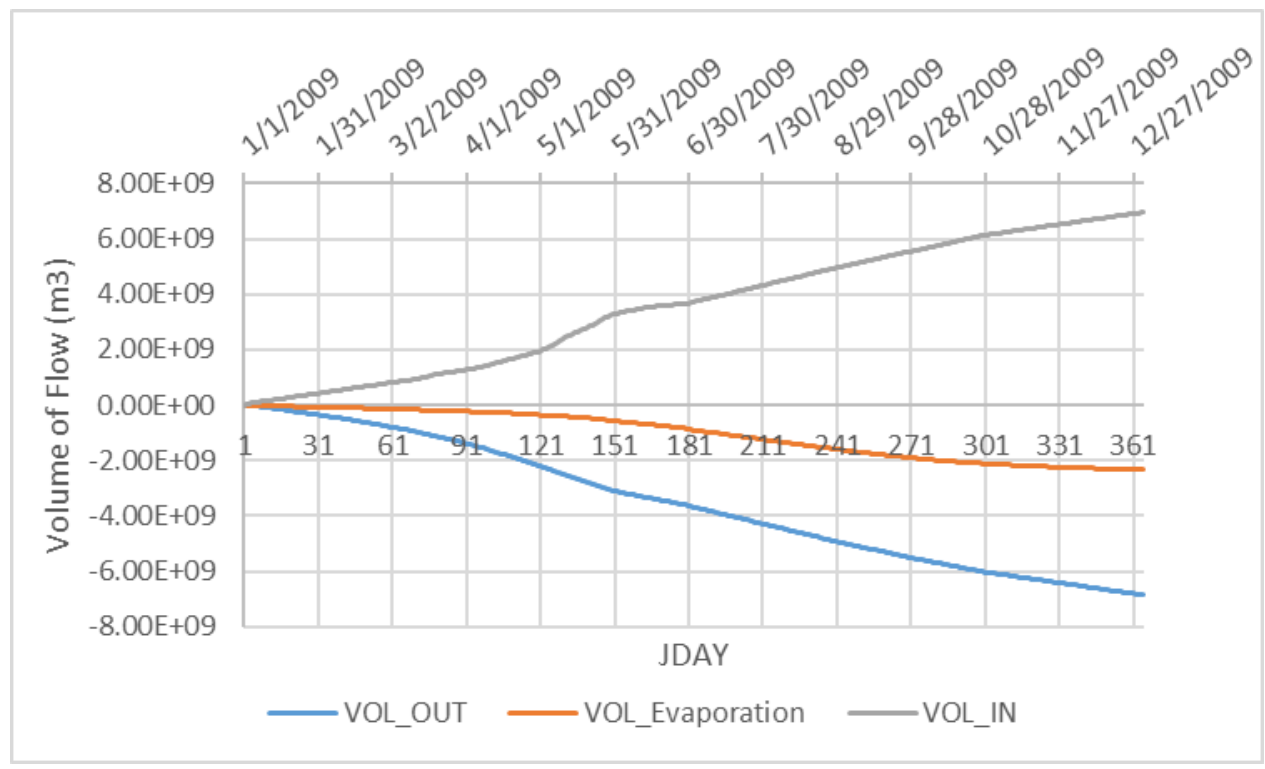

Figure 59: Flow balance in Tharthar Lake. 


\section{Model Calibration: Flow in the Tigris River}

The model calibration of flowrate started at the upstream portions of the model and moved downstream comparing model predictions of flow and water level to field data of flow and water level along the mainstem of the Tigris River. Field data were provided by the Iraqi Ministry of Water Resources and were used for model-data comparisons during the model simulation year 2009. Calibration of flow and water level were done at Baeji city, Samarra Barrage, and Baghdad city. Flow calibration process is based on adding or subtracting flow through a distributed tributary. A distributed tributary accounts for ungaged inflows during storm events or outflow from the system such as numerous ungaged irrigation withdrawals along the river banks. This is done through multiple iterations until model predicted flows agree with field data. Figure 60 through Figure 65 show comparisons of model predictions

and field data for flowrate and water level at Baeji city, Samarra Barrage, and Baghdad city, respectively. 


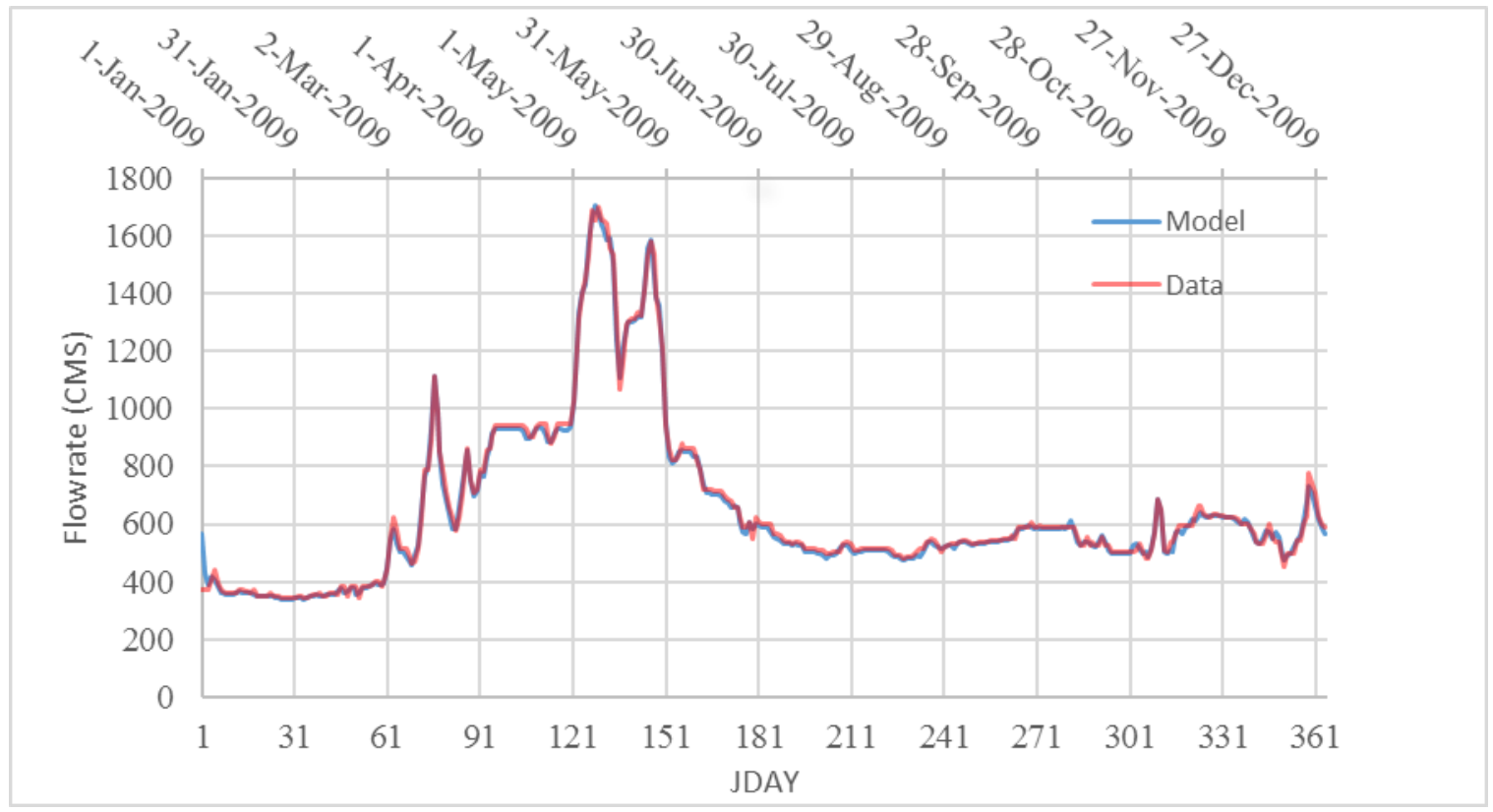

Figure 60: Model flowrate predictions compared to the Tigris River field data at Baeji city (segment $54)$.

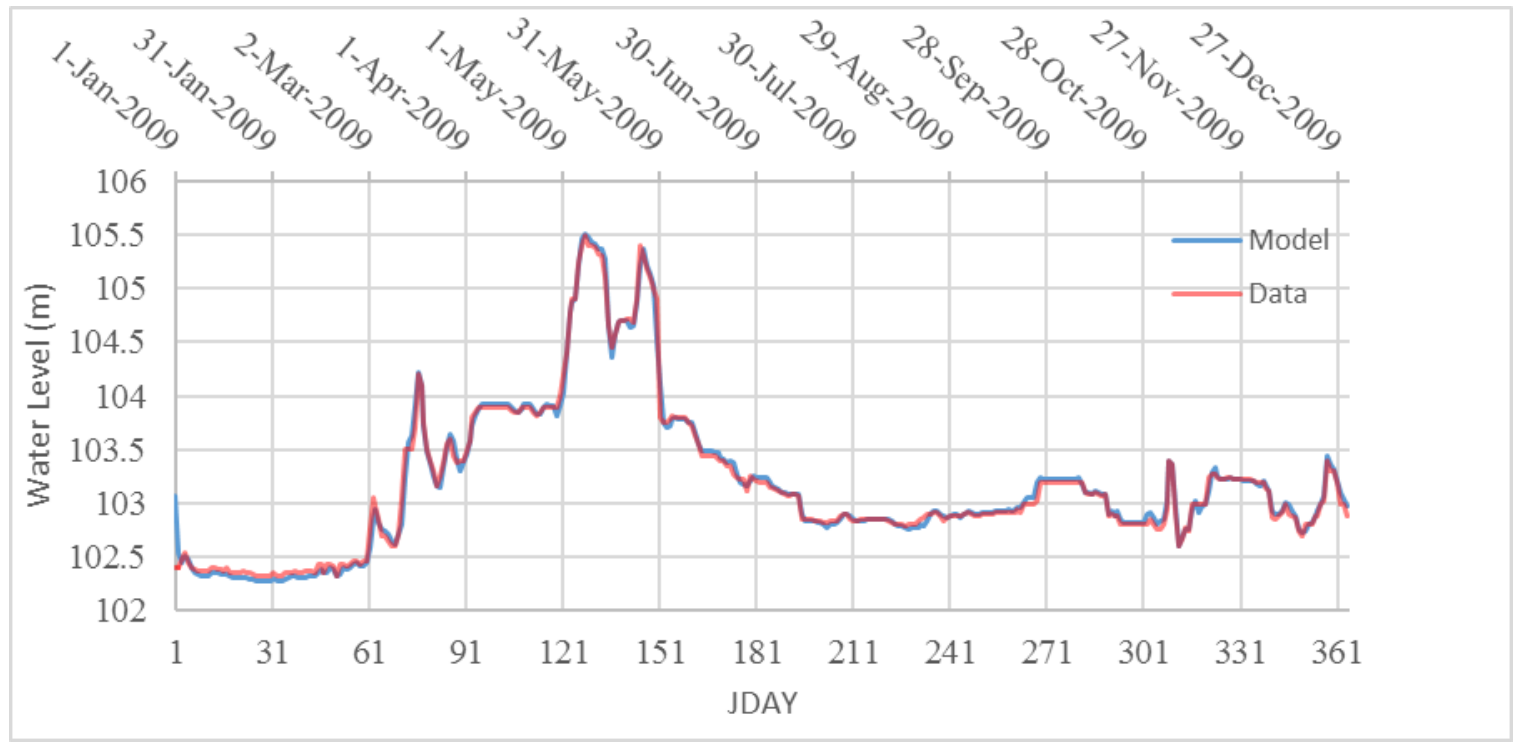

Figure 61: Model water level predictions compared to the Tigris River field data at Baeji city (segment 54). 


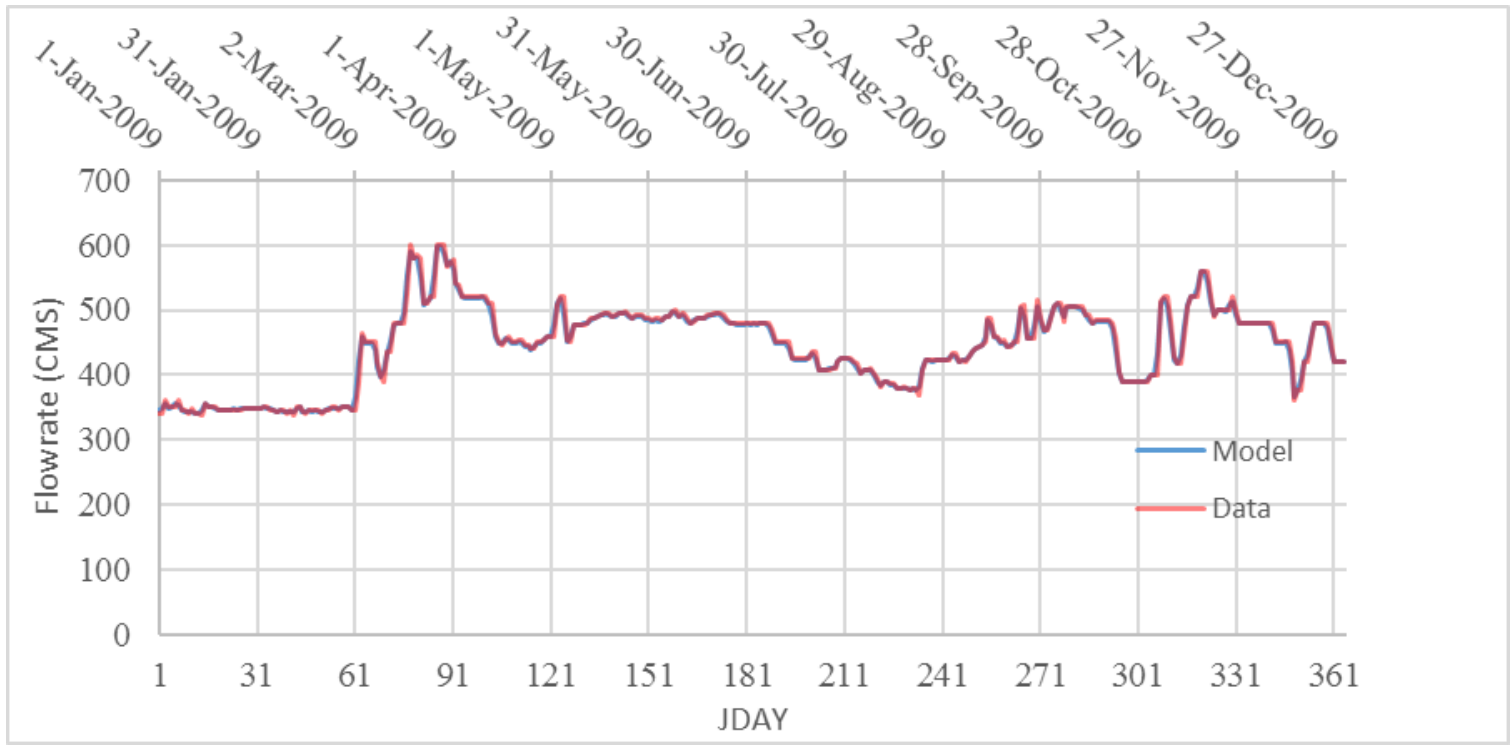

Figure 62: Model flowrate predictions compared to the Tigris River field data at Samarra Barrage (segment 83).
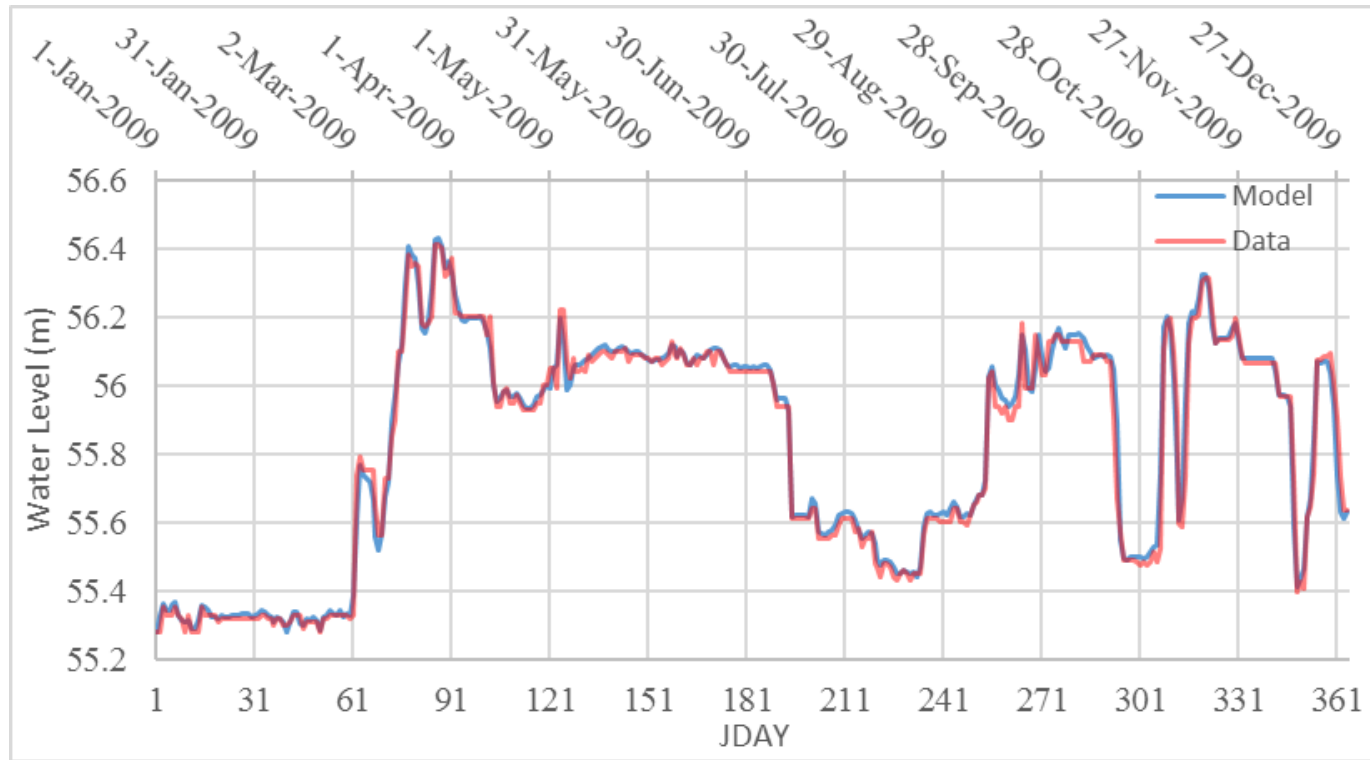

Figure 63: Model water level predictions compared to the Tigris River field data at Samarra Barrage (segment 83). 


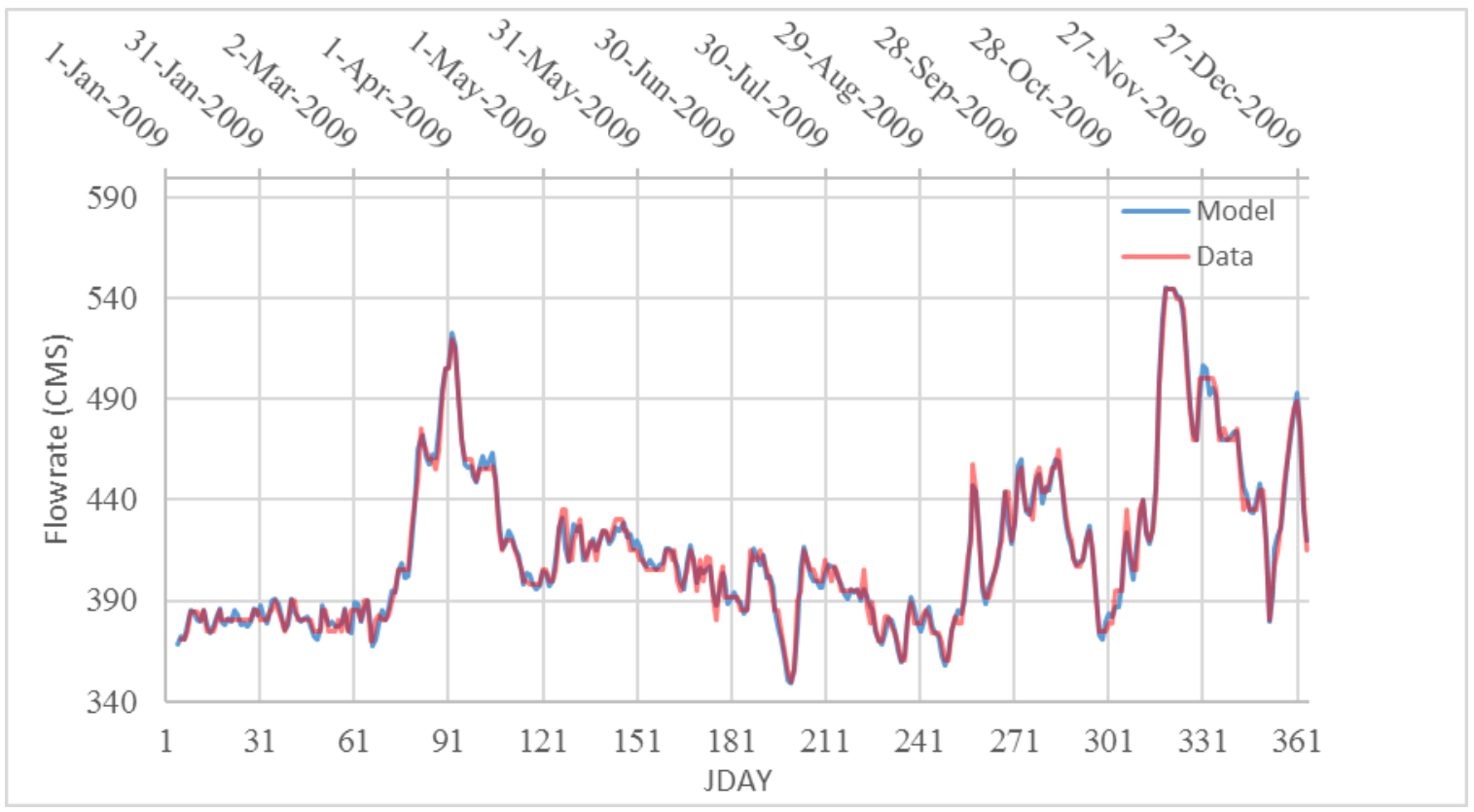

Figure 64: Model flowrate predictions compared to the Tigris River field data at Baghdad City (segment 123).

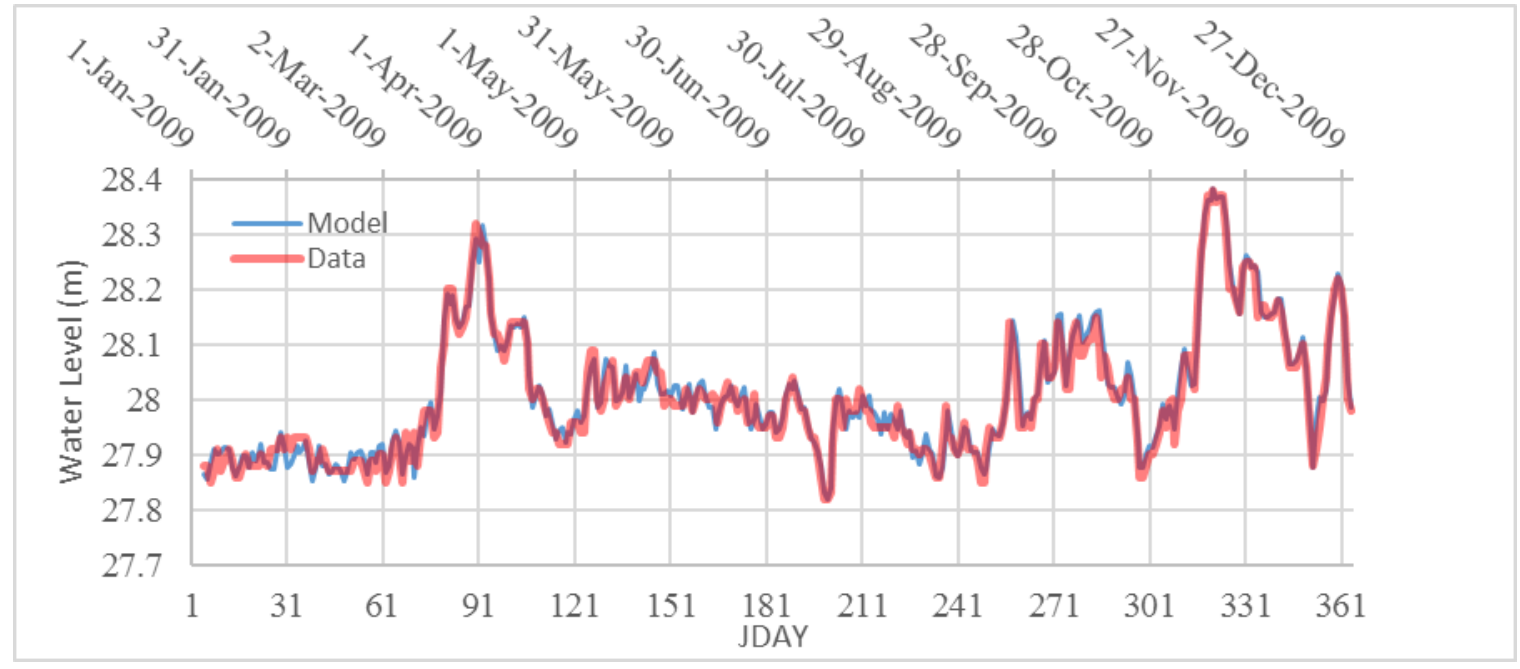

Figure 65: Model water level predictions compared to the Tigris River field data at Baghdad City (segment 123). 


\section{Flow Error Statistics}

The model predicted flow and water level were compared to field data and error statistics using the mean error (ME) (Equation 15), absolute mean error (AME) (Equation 16), and root mean square error (RMSE) (Equation 17) were computed using the following equations:

Equation 15: Mean error.

$M E=\frac{1}{N} \Sigma\left(Q_{\text {model }}-Q_{\text {field data }}\right)$

where

$\mathrm{N}$ is the number of model-field data comparisons

Qmodel is the model flow output value

$\mathrm{Q}_{\text {field data }}$ is the field flow data value

Equation 16: Absolute mean error.

$A M E=\frac{1}{N} \Sigma\left|\left(Q_{\text {model }}-Q_{\text {field data }}\right)\right|$

Equation 17: Root mean square error.

$R M S E=\sqrt{\frac{1}{N} \Sigma\left(Q_{\text {model }}-Q_{\text {field data }}\right)^{2}}$

Error statistics for model comparisons with the field data are listed in Table 16. The goal was to have as minimum flow error as possible. Comparing the average error to the mean 
flow at Baeji, Samarra, and Baghdad cities, the percentage error of flowrate at these cities are $1.93 \%, 0.83 \%$, and $0.81 \%$, respectively.

Table 16: Error statistics for model comparisons to field data for flow and water level (W.L.).

\begin{tabular}{|l|l|l|l|l|l|l|}
\hline \multicolumn{3}{|l|}{ Baeji City } & \multicolumn{2}{l|}{ Samarra City } & \multicolumn{2}{l|}{ Baghdad City } \\
\hline & W.L.(m) & Flow(cms) & W.L.(m) & Flow(cms) & W.L.(m) & Flow(cms) \\
\hline ME & 0.001 & -5.989 & 0.008 & -0.731 & 0.003 & 0.031 \\
\hline AME & 0.037 & 12.574 & 0.023 & 3.673 & 0.019 & 3.388 \\
\hline RMSE & 0.057 & 17.036 & 0.038 & 6.921 & 0.025 & 4.475 \\
\hline N & 360 & 360 & 360 & 360 & 360 & 360 \\
\hline
\end{tabular}




\section{Distributed Flows}

Flow data were likely to contain uncertainty due to errors in gaged stream flow. Uncertainties of river flow data are mainly due to errors in measurements of a river rating curve (Di Baldassarre and Montanari, 2009). Other errors in flow measurements are due to errors in cross section areas, errors in mean stream velocity, or errors from the computed method (Sauer and Meyer 1992). To account for all inflows and outflow sources and sinks of water through precipitation, ground water, irrigation return flows, or seepage, additional flows were added or subtracted from the Tigris River system as distributed flows. Positive flows meant that water was added to the system, while negative flows meant that water was withdrawn from the system. Distributed tributaries were specified only for the mainstem of the Tigris River.

As soon as calibration was done at the first gage station (Baeji City), the same approach was followed with other downstream gage stations at Samarra and Baghdad Cities. Distributed tributaries at Baghdad city (branch 3) and Kut city (branch 4) mostly had negative flows indicating water was being withdrawn from the system because of irrigation. Figure 66 through Figure 68 show inflow and distributed flow with the ratio between flows in model branch 2 , branch 3 , and branch 4 , respectively. 

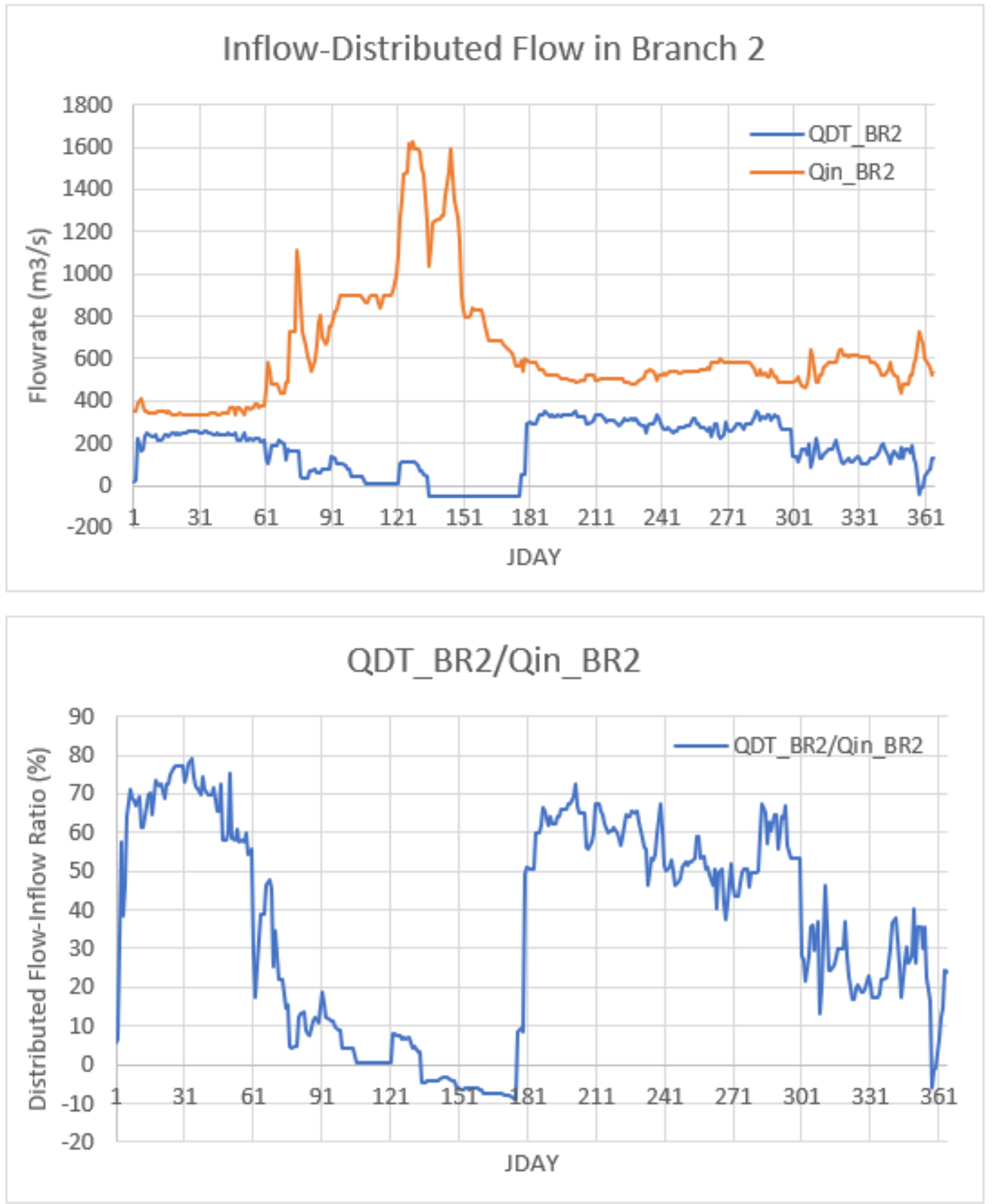

Figure 66: Inflow and distributed flow and the ratio of the flow in branch 2 of the Tigris River model. 

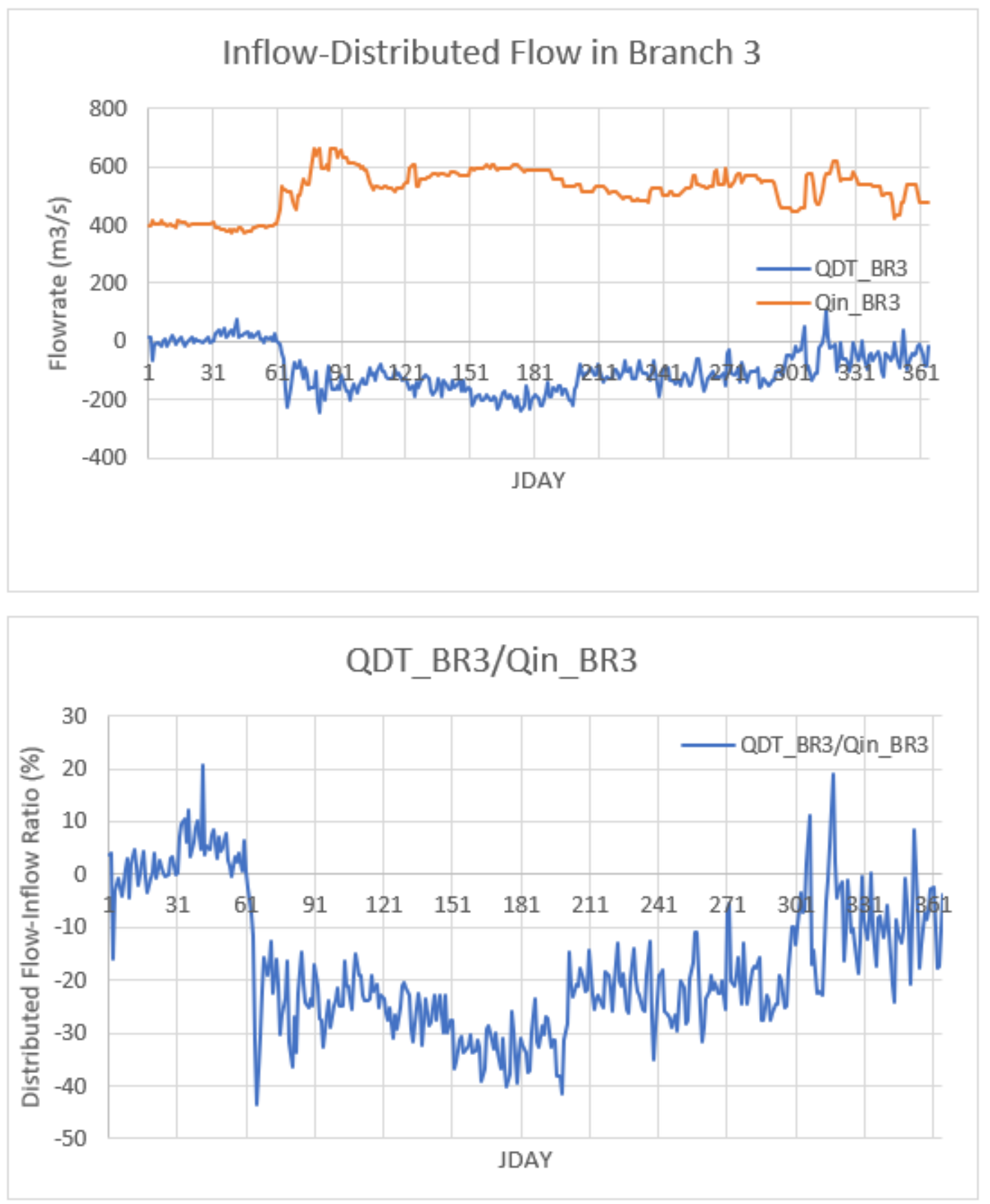

Figure 67: Inflow and distributed flow and the ratio of the flow in branch 2 of the Tigris River model. 

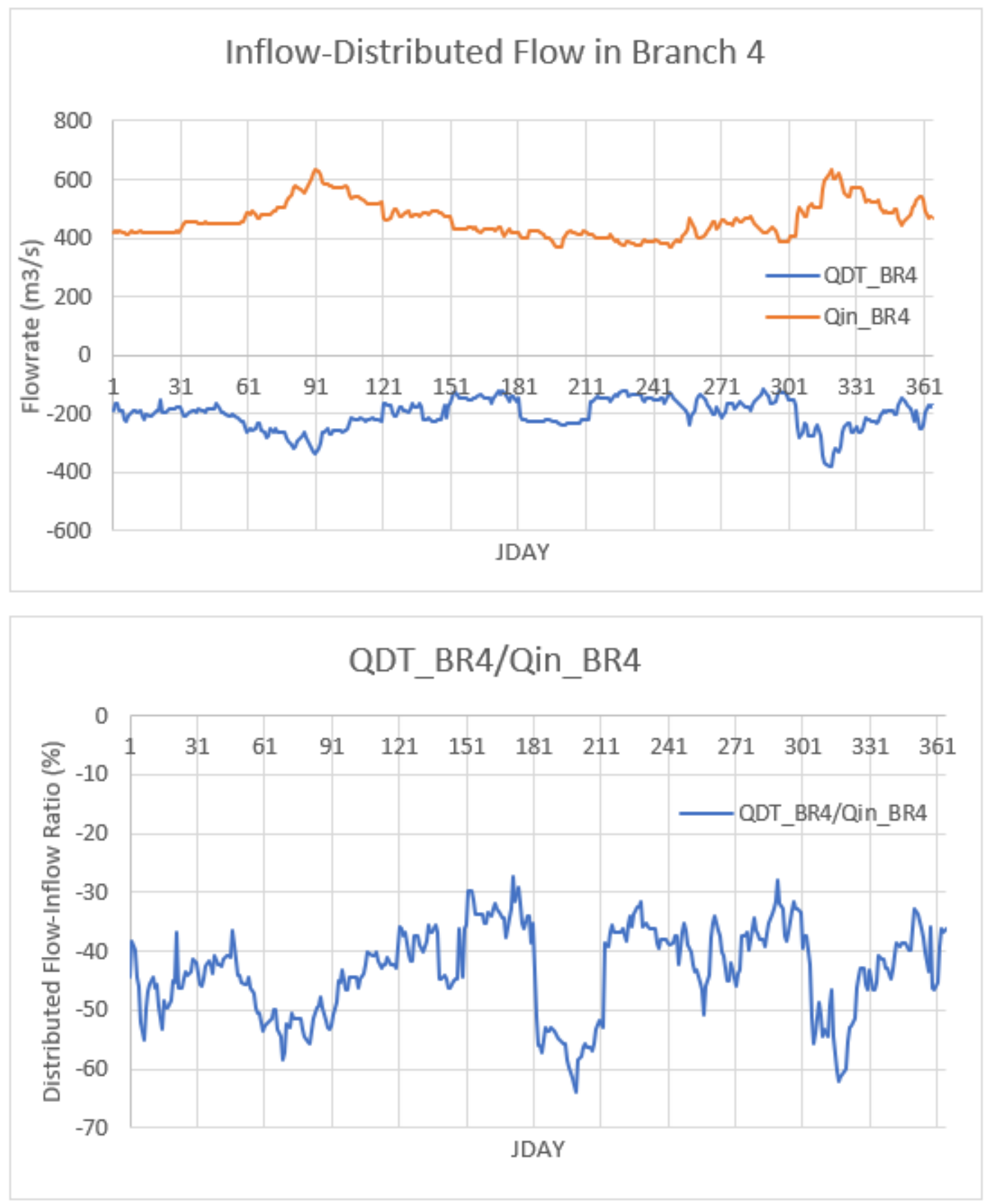

Figure 68: Inflow and distributed flow and the ratio of the flow in branch 2 of the Tigris River model. 
In order to explore whether these distributed flows were reasonable, an estimate was made for typical irrigation demand along the Tigris River. The amount of irrigation water requirement is affected by many factors such as soil types, climate conditions, crop types, and loses through evaporation. Generally, an amount of 27154 gallons of water cover an area of one acre with one-inch depth (Hanson et al., 2004). Assuming 5 inches depth of water required for irrigated crops over a year, the estimated amounts of irrigation in Baghdad, Diyala, and Kut are listed in Table 17. Irrigation land measured in dunam, equivalent to 0.25 acre, in Baghdad, Diyala, and Kut cities is provided by CSO (2010). Theoretically, the average annual irrigation flow is $250 \mathrm{~m}^{3} / \mathrm{s}$ in Kut city compared with 200 $\mathrm{m}^{3} / \mathrm{s}$ average annual withdraw used in the model. The typical irrigation return flow is 20 $25 \%$ of the original supplied volume (Aziz and Aws, 2012). Therefore, model estimations of irrigation flows as distributed tributaries were reasonable.

Table 17: Model and theoretical estimation of irrigation water in Baghdad, Diyala, and Kut.

\begin{tabular}{|c|c|c|c|c|}
\hline City & Total & Total & Model Estimation of & Theoretical \\
& Irrigated & Irrigated & Irrigation as Distributed & Estimation of \\
& Area & Area & Tributary (m3) & Irrigation (m3) \\
$($ Dunam) & (Acre) & & \\
\hline $\begin{array}{c}\text { Baghdad } \\
\text { and }\end{array}$ & 18935718 & 4679118 & $3.00 \mathrm{E}+09$ & $2.40 \mathrm{E}+09$ \\
Diyala & & & & \\
\hline Kut & 62210000 & 15372426 & $6.35 \mathrm{E}+09$ & $8.00 \mathrm{E}+09$ \\
\hline
\end{tabular}




\section{Model Adjustments}

Bathymetry was a crucial factor in flow calibration. Specifying the model grid properly includes describing the channel friction and slope, segment widths and depths.

Channel Friction and Slope

Water depths could be adjusted by altering Manning's coefficient. Decreasing Manning's coefficients cause the water to move more quickly in the system, while increasing Manning's coefficients slow the water in the system. Altering Manning's friction helped in matching water level to field data. According to Othman and Deguan (2004), 74\% of the Tigris River bed within Mosul city was very coarse gravel. The bed of the Tigris River within Baghdad city is mainly covered by sand (Al-Ansari et al., 2015; Ali et al., 2012). Chow (1959) reported a minimum Manning's coefficient of 0.025 for natural streams that are clean with no deep pools and maximum Manning's coefficient of 0.05 for natural streams with sluggish reaches, while a maximum Manning's coefficient of 0.011 for constructed channels with concrete. Small concrete fragments remained in the Tigris River bed within Baghdad city after falling fom three major bridges, Al-Mu'alaq Bridge, Sarafia Bridge, and Jumhuriya Bridge, due to a considerable damage during the wars of 1991 and 2003. Bridge piers are obstacles to stream flows and cause backwater and consequently cause an effective increase in Manning's coefficient (Charbeneau and Holley 2001). Five bridges were constructed on the Tigris River within Mosul city, Figure 69, while 13 bridges were constructed on the Tigris River within Baghdad city, Figure 70. These can cause an increase in the channel friction. In this study, Manning's coefficient of the river within Mosul city to Samarra Barrage was 0.025, while Manning's coefficient of the river within Bagdad city was increased to 0.05 . High Manning's friction in the Tigris River within 
Baghdad city is due to the effect of channel irregularity (scoured banks), channel obstruction (debris deposits and bridge piers), the degree of meandering, and imperfections in the given cross-sectional geometry.

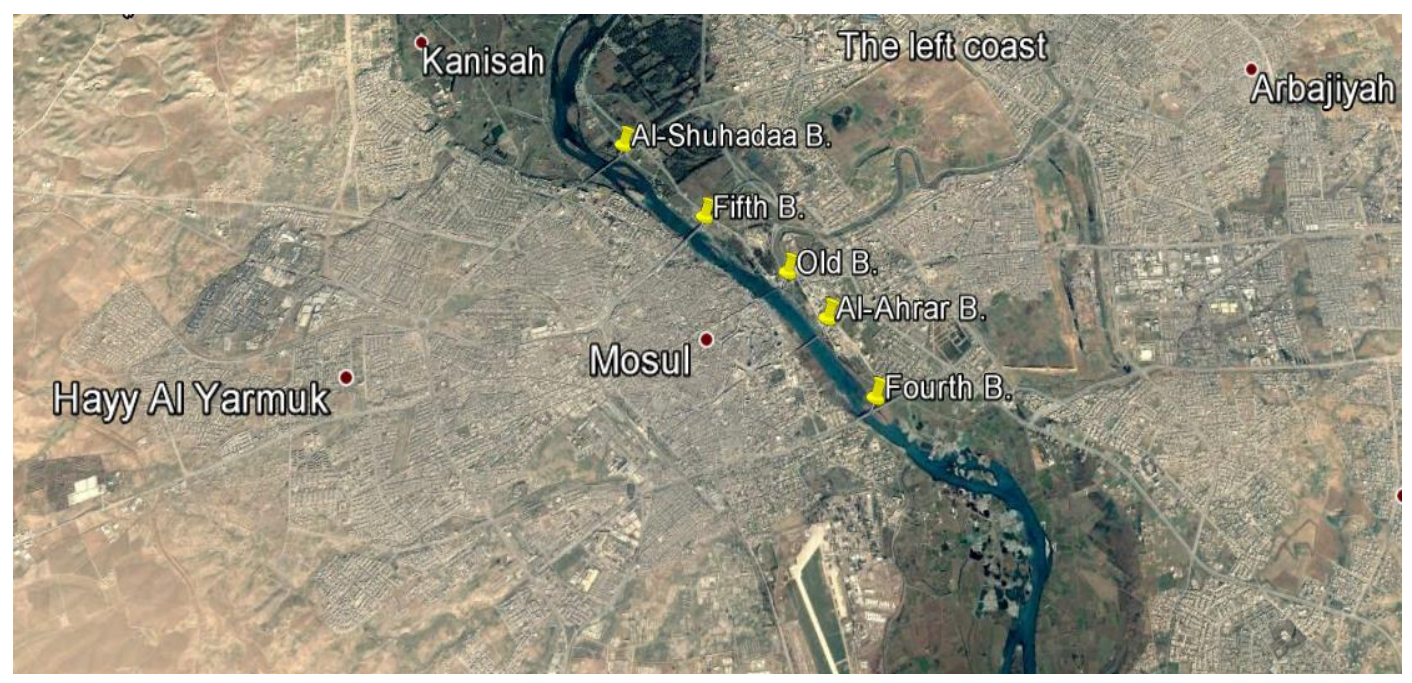

Figure 69: Bridges and meandering on the Tigris River within Mosul city.

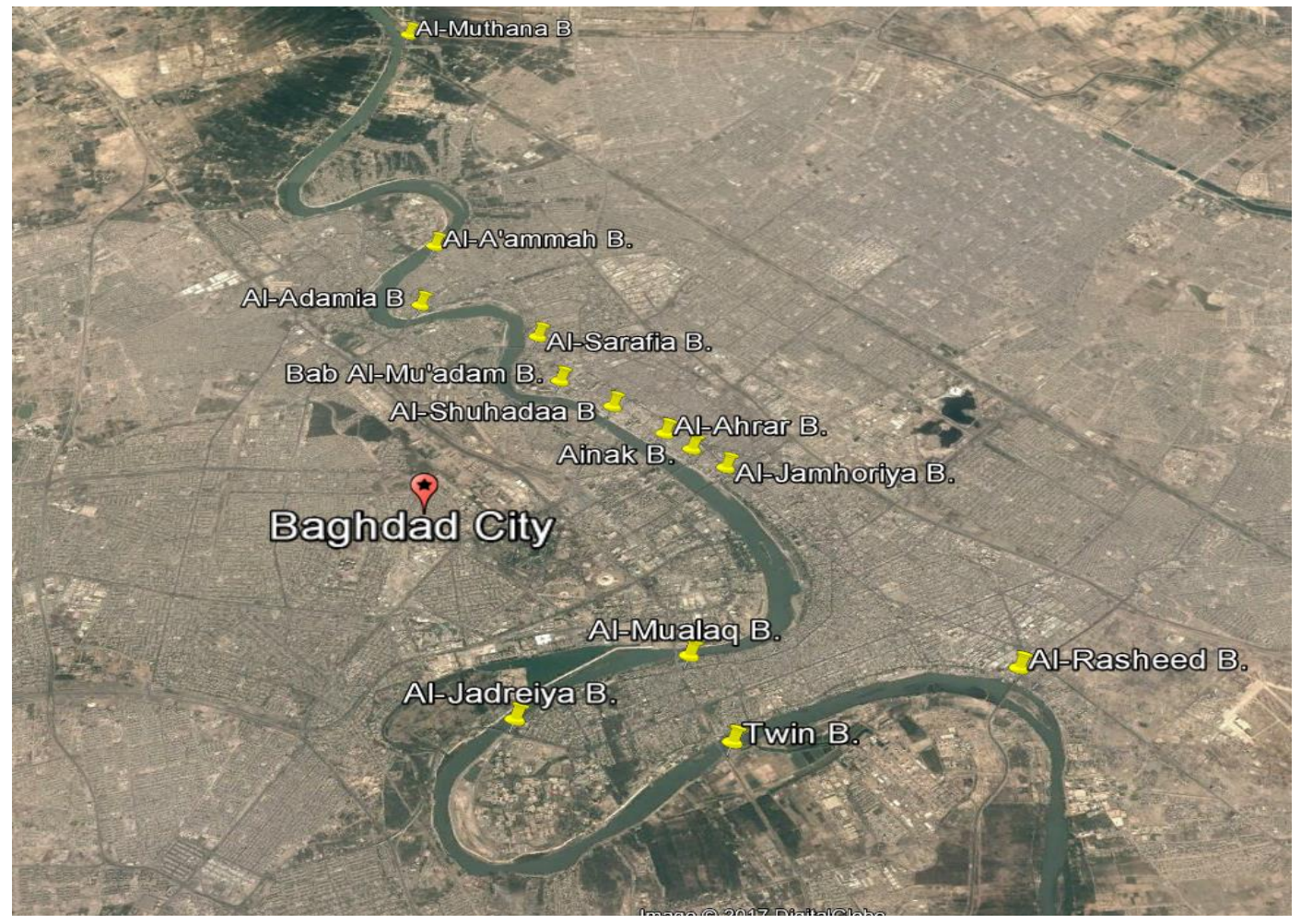

Figure 70: Bridges and meandering on the Tigris River within Baghdad city. 
In the W2 model, each branch had a channel slope. This was the general slope of each branch and the included segments. However, the channel slope may not accurately capture the hydraulic gradient slope due to real channel characteristics, such as falls, riffles, or other features (Cole and Wells, 2017). Due to this reason, a separate variable, SLOPEC in the model control file, was specified for each branch and represented the hydraulic equivalent slope. This variable was used to calculate fluid acceleration in the momentum equations (Cole and Wells, 2017). In the Tigris River model, SLOPEC was assumed as the same as the actual channel slope. According to Al-Obaidy (1996), the slope of the Tigris River below Mosul city in the region between the Upper and the Lower Zabs is 0.000544 . Table 18 lists Manning's coefficients and slopes used in the model.

Table 18: Manning's coefficients and slopes used in the Tigris River model

\begin{tabular}{|c|c|c|c|}
\hline $\begin{array}{c}\text { Model } \\
\text { Branch }\end{array}$ & $\begin{array}{c}\text { Manning's } \\
\text { Coefficients }\end{array}$ & Slope & Details \\
\hline $\mathbf{1}$ & 0.025 & 0.00054 & $\begin{array}{c}\text { From Mosul Dam to 15 km DS Tikrit } \\
\text { city }\end{array}$ \\
\hline $\mathbf{2}$ & 0.025 & 0 & Samarra Barrage \\
\hline $\mathbf{3}$ & 0.05 & 0.000154 & $\begin{array}{c}\text { From Samarra B. to 70 km DS } \\
\text { Baghdad city }\end{array}$ \\
\hline $\mathbf{4}$ & 0.05 & 0 & Kut Barrage \\
\hline $\mathbf{5}$ & 0.011 & 0.00012 & Tigris-Tharthar Canal \\
\hline $\mathbf{6}$ & 0.011 & 0 & Tharthar Lake \\
\hline $\mathbf{7}$ & 0.011 & 0.00011 & Tharthar Arm \\
\hline $\mathbf{8}$ & 0.011 & 0.0002 & Tharthar-Tigris Canal \\
\hline $\mathbf{9}$ & 0.011 & 0.0001 & Erwaeiya Canal \\
\hline
\end{tabular}




\section{Water Age and Travel Time}

Water age measures how long water has been in a waterbody. Water age of the Tigris River system was defined as a state variable and was set to zero in all flow inputs to the system, upstream boundary conditions and side tributaries. Figure 71 and Figure 72 show water age in the mainstem of the Tigris River and Tharthar Lake, respectively. Generally, water age increases as water moves downstream of the system. The water age started to significantly increase downstream of Samarra Barrage due to the fact that inflow from Tharthar-Tigris canal had relatively older water age and mixed with mainstem flow that was relatively newer.

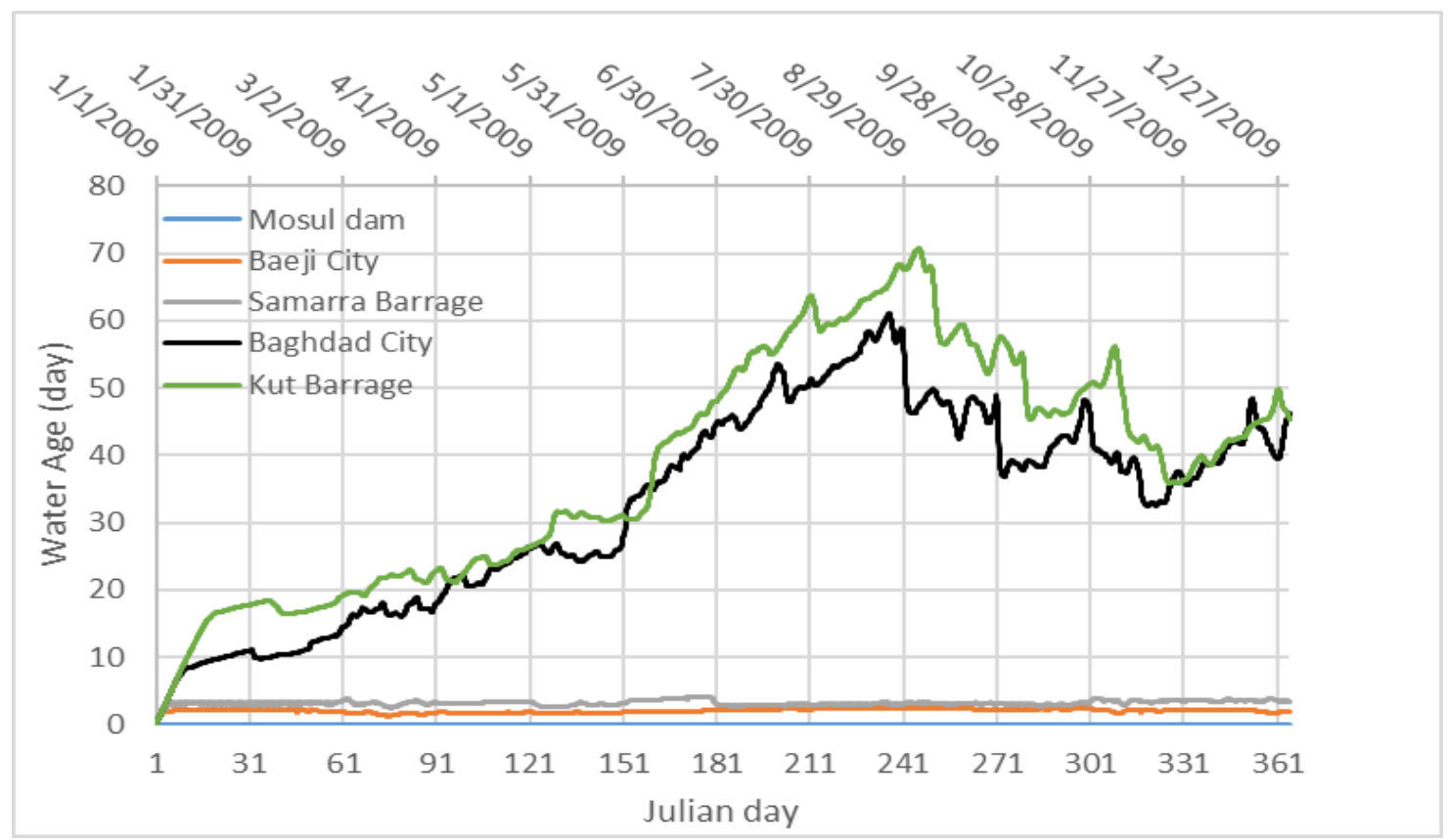

Figure 71: Model predictions of water age throughout the mainstem of the Tigris River system for the base model. 


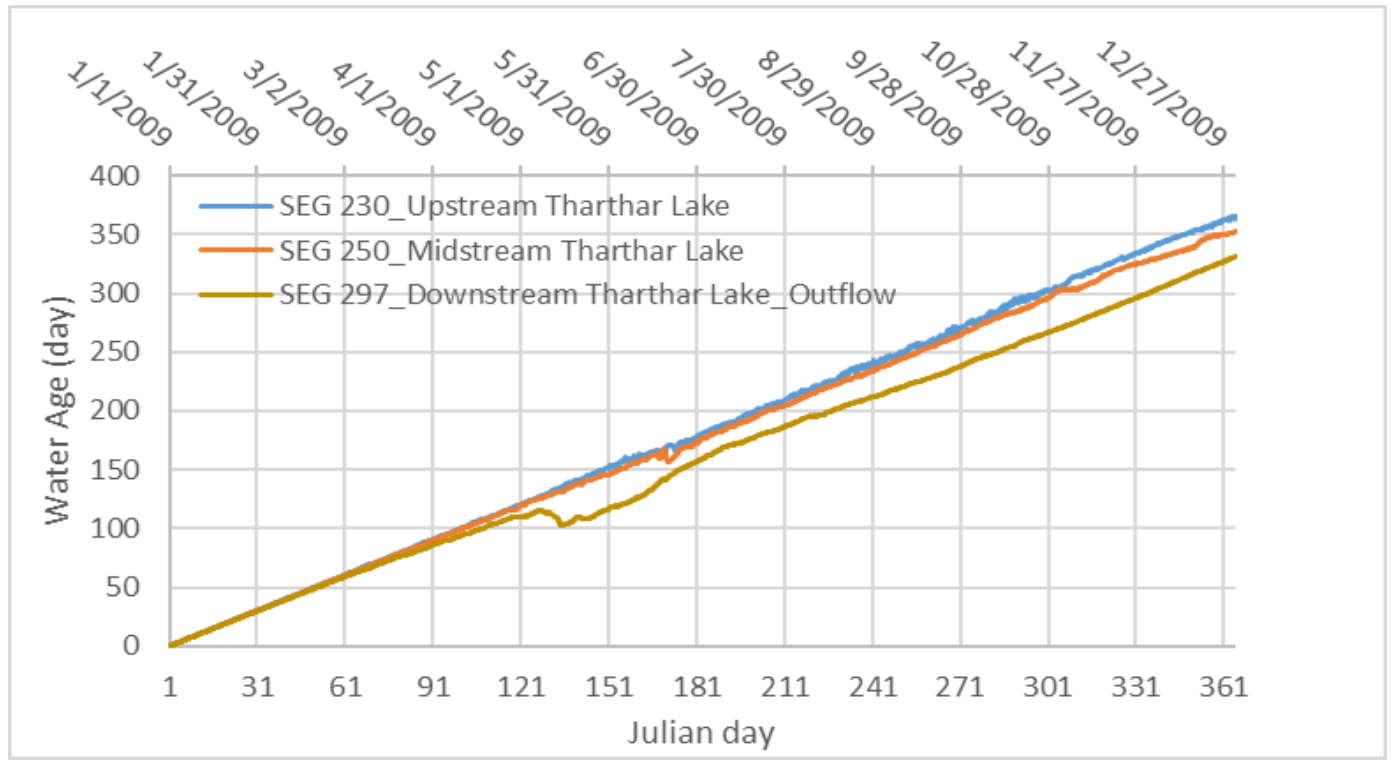

Figure 72: Model predictions of water age in Tharthar Lake.

The travel time of a parcel of water was estimated using a conservative tracer with an arbitrary concentration of $10,000 \mathrm{mg} / \mathrm{l}$ added at the upstream boundary (Mosul Dam) for 1 day and repeated every two months for the entire simulation period. As the pulse moved downstream, the time to peak at Baji city, Samarra Barrage, Baghdad city, and Kut Barrage was recorded. The difference between peak times downstream and the original pulse time injected upstream at the boundary reflected the travel time of the center of mass of the plume. Figure 73 shows the tracer concentration as the plume moved downstream. Tracer concentrations decreased, and associated travel times increased as the peak moved to different stations along the mainstem of the Tigris River. Figure 74 shows an example of a pulse injected at Julian day 1.0 at Mosul Dam and the travel time of the peak at Baeji city, Samarra Barrage, Baghdad city, and Kut Barrage. Figure 75 shows the travel time of the tracer at the output segment of Tharthar Lake. Table 19 lists downstream travel time in days of an upstream pulse injected every 60 days. 


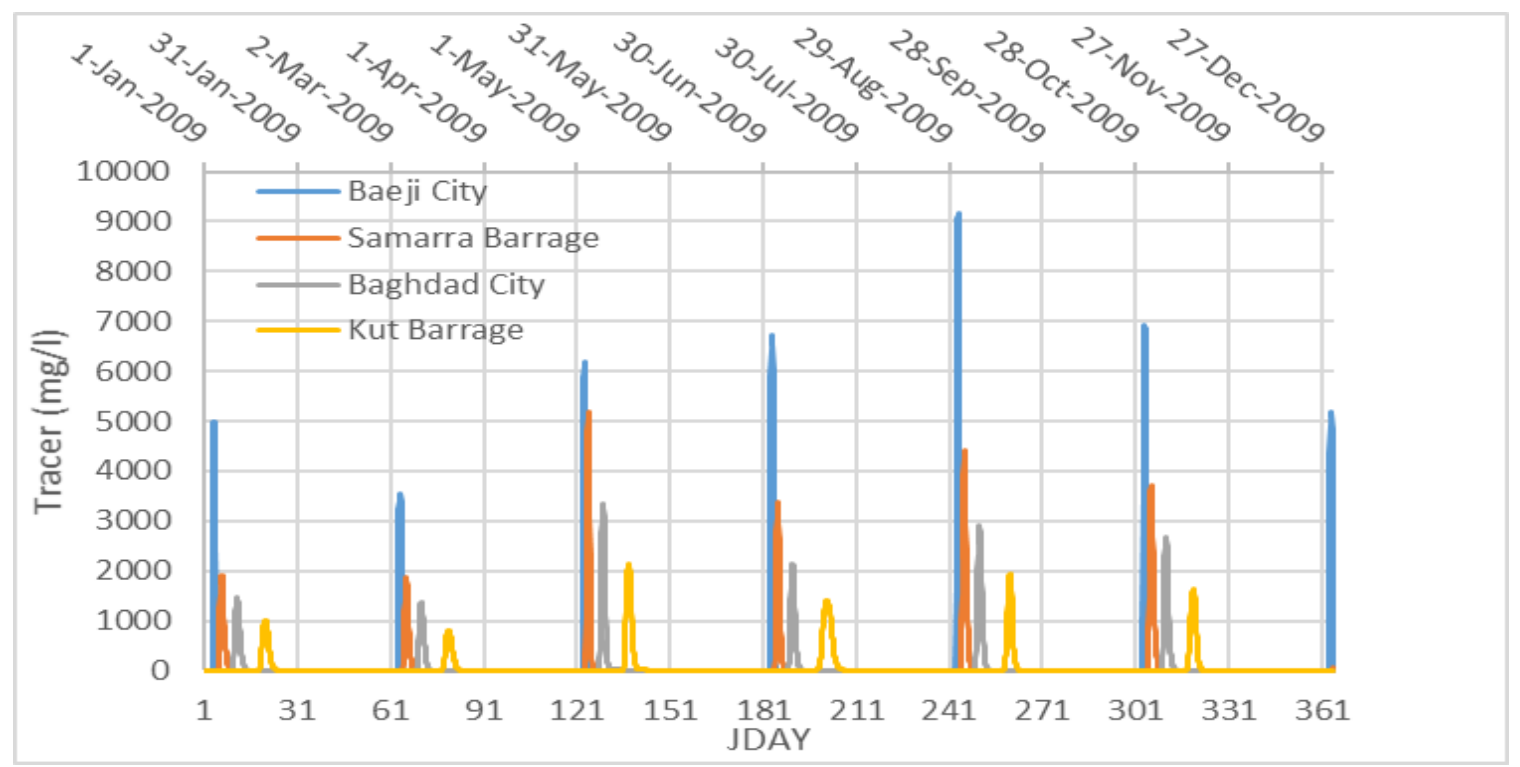

Figure 73: A tracer pulse input at upstream boundary condition and travel time of that pulse along the main stream of the Tigris River at Baeji city, Samarra Barrage, Baghdad city, and Kut Barrage.

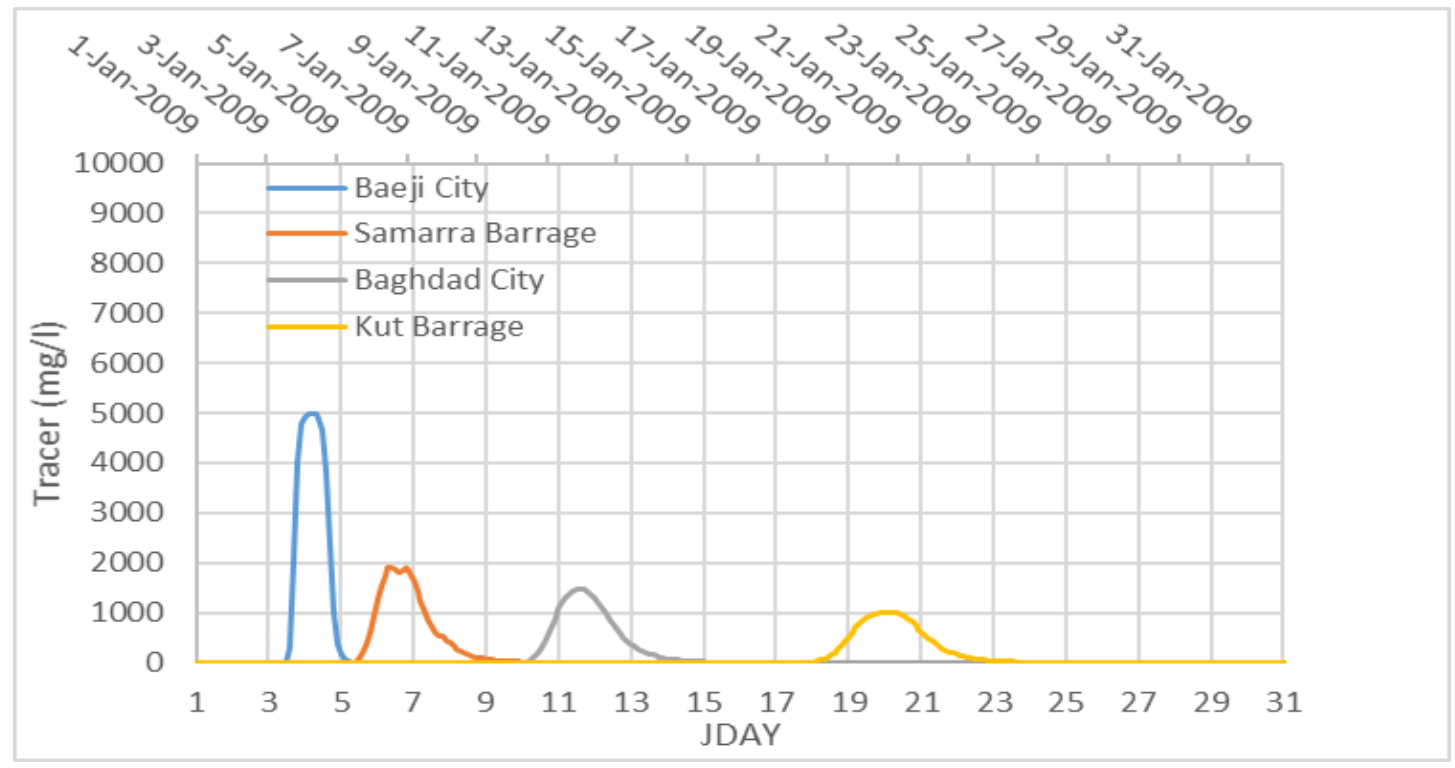

Figure 74: A tracer pulse input at JDAY 1.5 condition and travel time of that pulse along the main stream of the Tigris River at Baeji city, Samarra Barrage, Baghdad city, and Kut Barrage. 


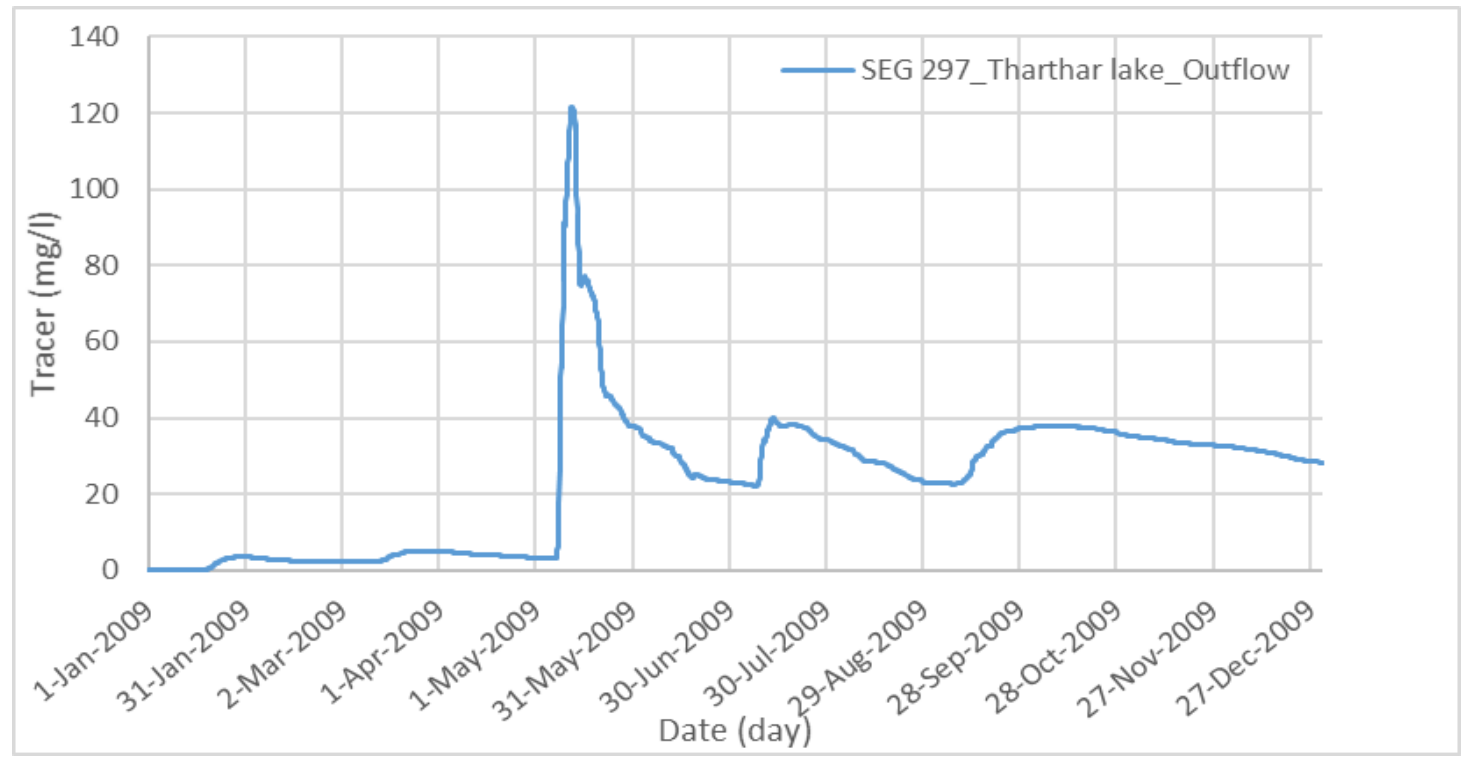

Figure 75: A tracer pulse input at JDAY 1.0 condition and travel time of that pulse in Tharthar Lake.

Table 19: Travel time of upstream pulse inputs every 2 months

\begin{tabular}{|l|l|l|l|l|l|}
\hline & & \multicolumn{4}{|c|}{ Travel Time (day) } \\
\hline $\begin{array}{l}\text { Initial } \\
\text { Upstream Pulse } \\
\text { JDAY }\end{array}$ & $\begin{array}{l}\text { Upstream } \\
\text { Flow at } \\
\text { Mosul Dam } \\
\left(\mathrm{m}^{3} / \mathrm{s}\right)\end{array}$ & Baeji City & $\begin{array}{l}\text { Samarra } \\
\text { Barrage }\end{array}$ & $\begin{array}{l}\text { Baghdad } \\
\text { City }\end{array}$ & Kut Barrage \\
\hline 1.5 & 200 & 3 & 5.5 & 10.5 & 18.5 \\
\hline 61.5 & 200 & 2.8 & 4.8 & 9.5 & 18.5 \\
\hline 121.5 & 810 & 2.3 & 3.5 & 8.2 & 16.5 \\
\hline 181.5 & 400 & 2.7 & 4.5 & 9 & 20.5 \\
\hline 241.5 & 480 & 2.5 & 4.5 & 9.5 & 19.3 \\
\hline 301.5 & 400 & 2.7 & 4.8 & 9.5 & 18.1 \\
\hline 361.5 & 300 & 2.9 & - & - & - \\
\hline
\end{tabular}




\section{Model Calibration: Temperature}

\section{Water Temperature of Tharthar Lake}

Longitudinal water temperature of Tharthar Lake was estimated remotely using Landsat images and was compared to model predictions of water temperature at different segments along the North-South axis of the lake. Figure 76 and Figure 77 show model predictions of longitudinal surface water temperature in Tharthar Lake compared with satellite data estimated for Tharthar Lake at a distance from the North to the South: $15 \mathrm{~km}, 25 \mathrm{~km}, 35$ km, $45 \mathrm{~km}, 55 \mathrm{~km}, 70.5 \mathrm{~km}$ (input of the lake), $80.5 \mathrm{~km}$, and $90 \mathrm{~km}$ (outlet of the lake). Model predictions of surface water temperature of the lake agreed with satellite data in that there was a longitudinal variation in water temperature along the North-South axis of the lake and the southern part was warmer than the northern part. However, the model often estimated a larger surface temperature variation than the satellite-based estimates. Table 20 lists error statistics of model comparisons to satellite data in Tharthar Lake. 


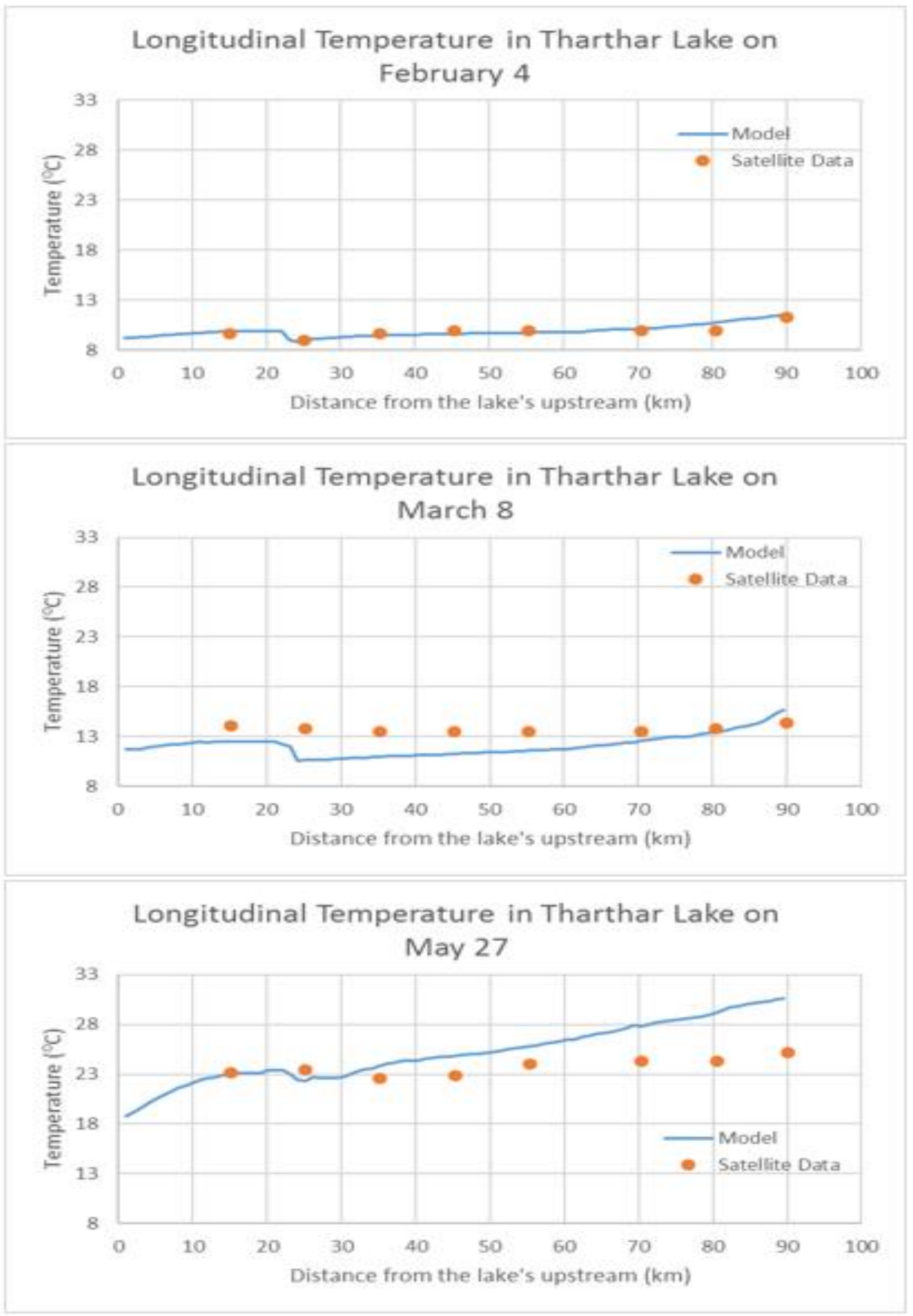

Figure 76: Model predictions of longitudinal surface water temperature in Tharthar Lake on February $4^{\text {th }}$, March8th, and May $27^{\text {th }}$. 


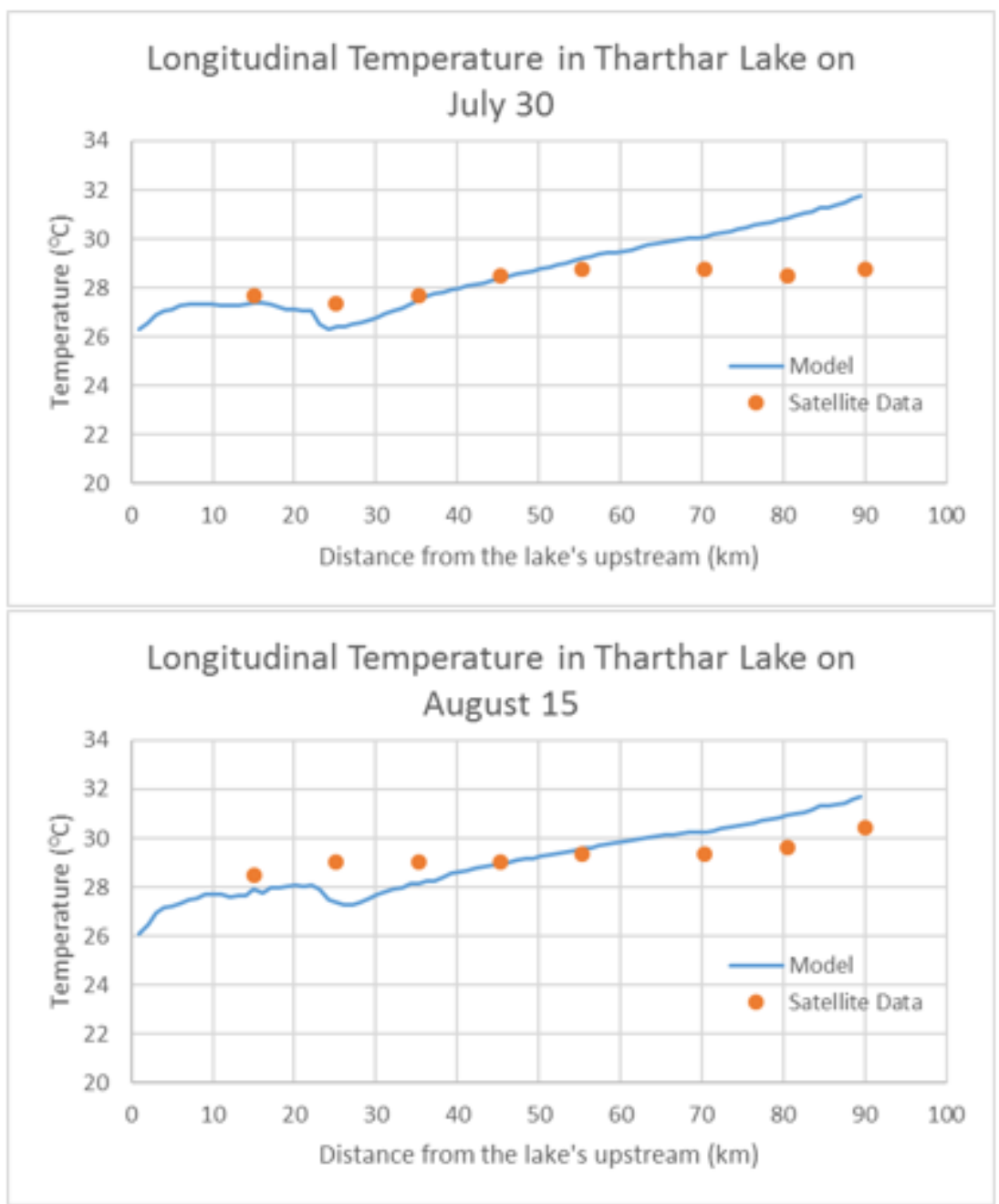

Figure 77: Model predictions of longitudinal surface water temperature in Tharthar Lake on July $30^{\text {th }}$ and August $15^{\text {th }}$.

Table 20: Error statistics for model comparisons to satellite data for longitudinal water temperature in Tharthar Lake.

\begin{tabular}{|l|l|l|l|l|l|}
\hline & $\begin{array}{l}\text { February 4, } \\
\mathbf{2 0 0 9}\end{array}$ & $\begin{array}{l}\text { March 8, } \\
\mathbf{2 0 0 9}\end{array}$ & $\begin{array}{l}\text { May 27, } \\
\mathbf{2 0 0 9}\end{array}$ & $\begin{array}{l}\text { July 30, } \\
\mathbf{2 0 0 9}\end{array}$ & $\begin{array}{l}\text { August 15, } \\
\mathbf{2 0 0 9}\end{array}$ \\
\hline ME & 0.13 & -1.39 & 2.24 & 0.69 & 0.06 \\
\hline AME & 0.30 & 1.72 & 2.55 & 1.08 & 0.88 \\
\hline RMSE & 0.37 & 1.90 & 3.11 & 1.48 & 1.01 \\
\hline N & 8 & 8 & 8 & 8 & 8 \\
\hline
\end{tabular}




\section{Water Temperature of the Tigris River}

Water temperature of the Tigris River was calibrated after the flowrate calibration since water temperature is highly dependent on water depth and travel time. Most of water quality constituent state variables were temperature dependent and therefore calibrating temperature was performed before water quality. The model predictions of surface water temperature were compared with remote sensed temperature data estimated from Landsat satellite at both Baeji City and Baghdad City. Figure 78 and Figure 79 show model predictions of water temperature compared with satellite data along the mainstem of the Tigris River at both Baeji and Baghdad cities, respectively. Unfortunately, field data of vertical temperature profiles were not available for model comparisons. Figure 80 and Figure 81 show temperature contour lines of Tharthar Lake, while Figure 82 and Figure 83 show temperature contour lines of Samarra Barrage and Kut Barrage for the simulated year 2009. The temperature profiles show that the lake's water was well mixed at the beginning of the simulation and started to stratify during the summer months, while weak stratification did occur from time to time at Samarra Barrage and Kut Barrage during low flow conditions. 


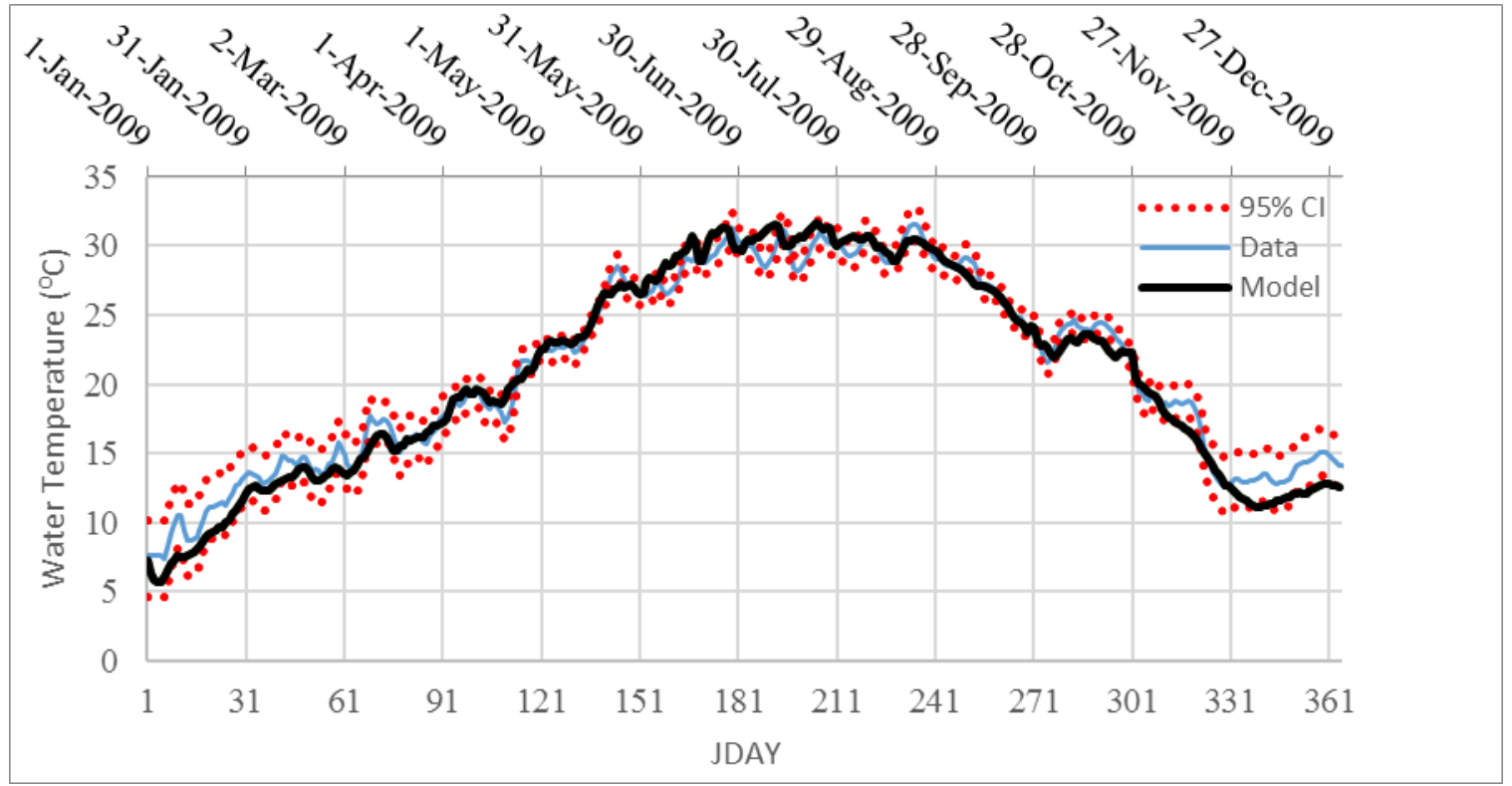

Figure 78: Model surface water temperature predictions compared to the Tigris River remote sensing data at Baeji City (segment 54).

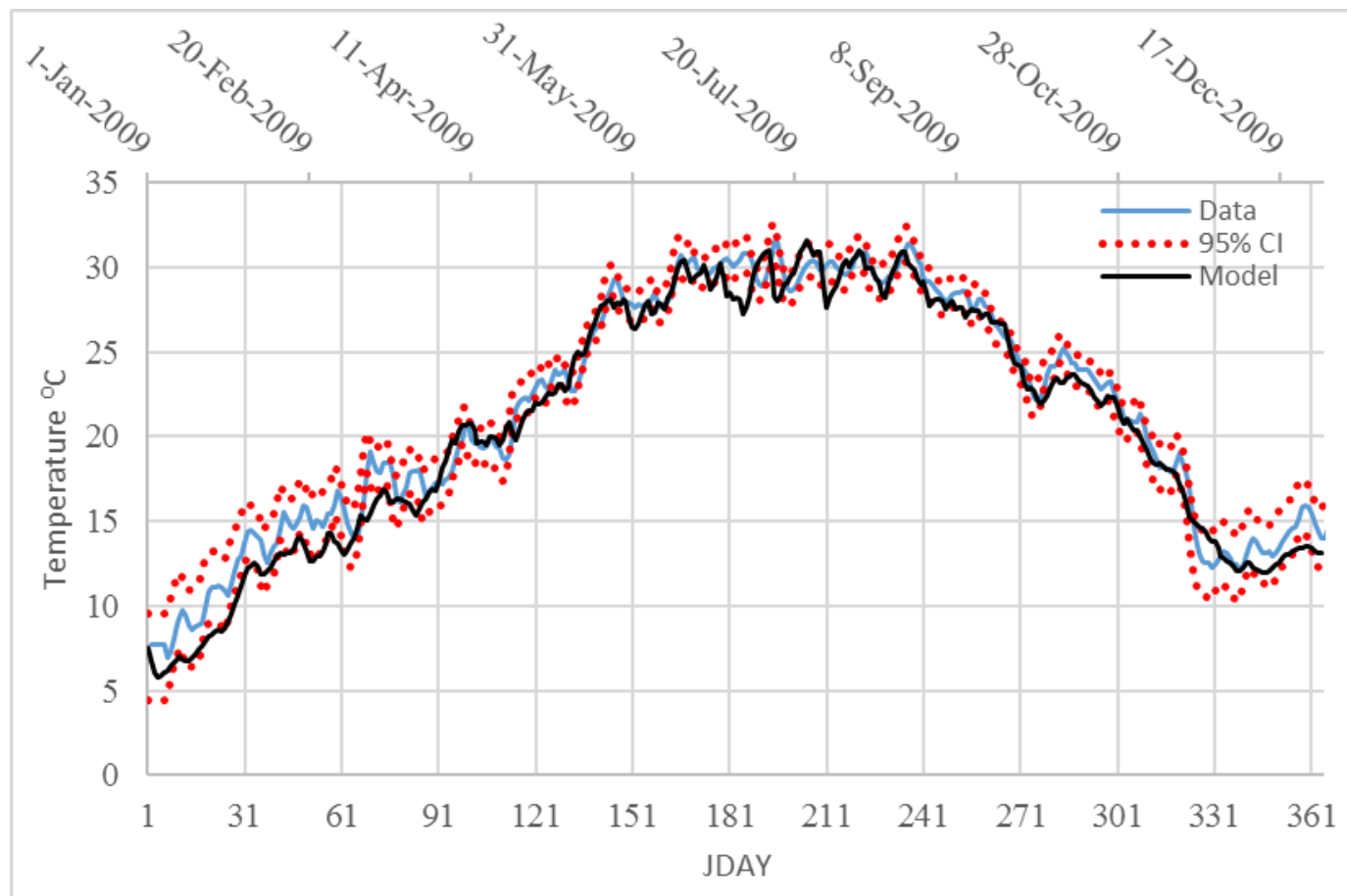

Figure 79: Model surface water temperature predictions compared to the Tigris River remote sensing data at Baghdad City (segment 123). 

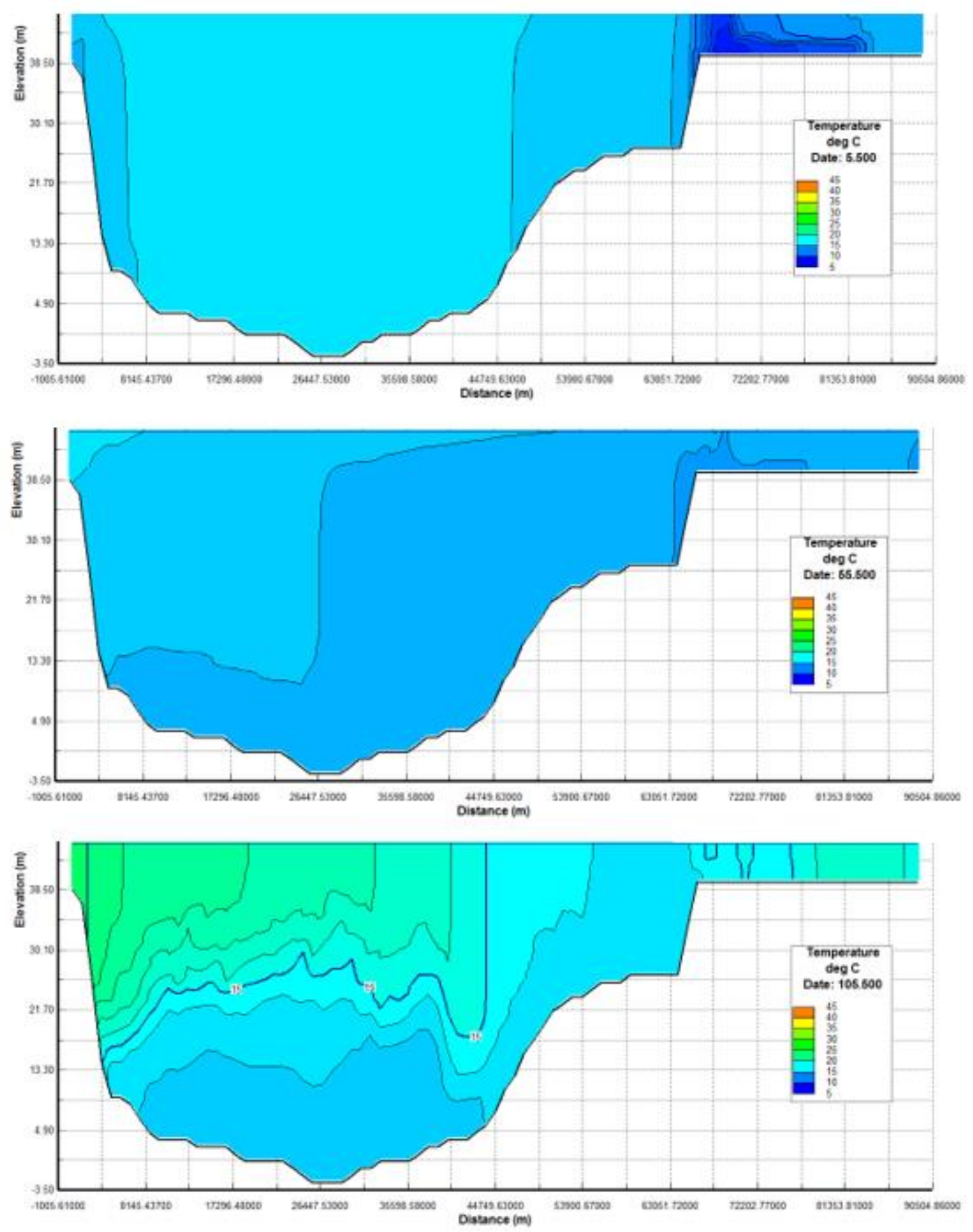

Figure 80: Model temperature contour lines of Tharthar Lake at JDAY 5.5, 55.5, and 105.5 of 2009 (Part 1). 

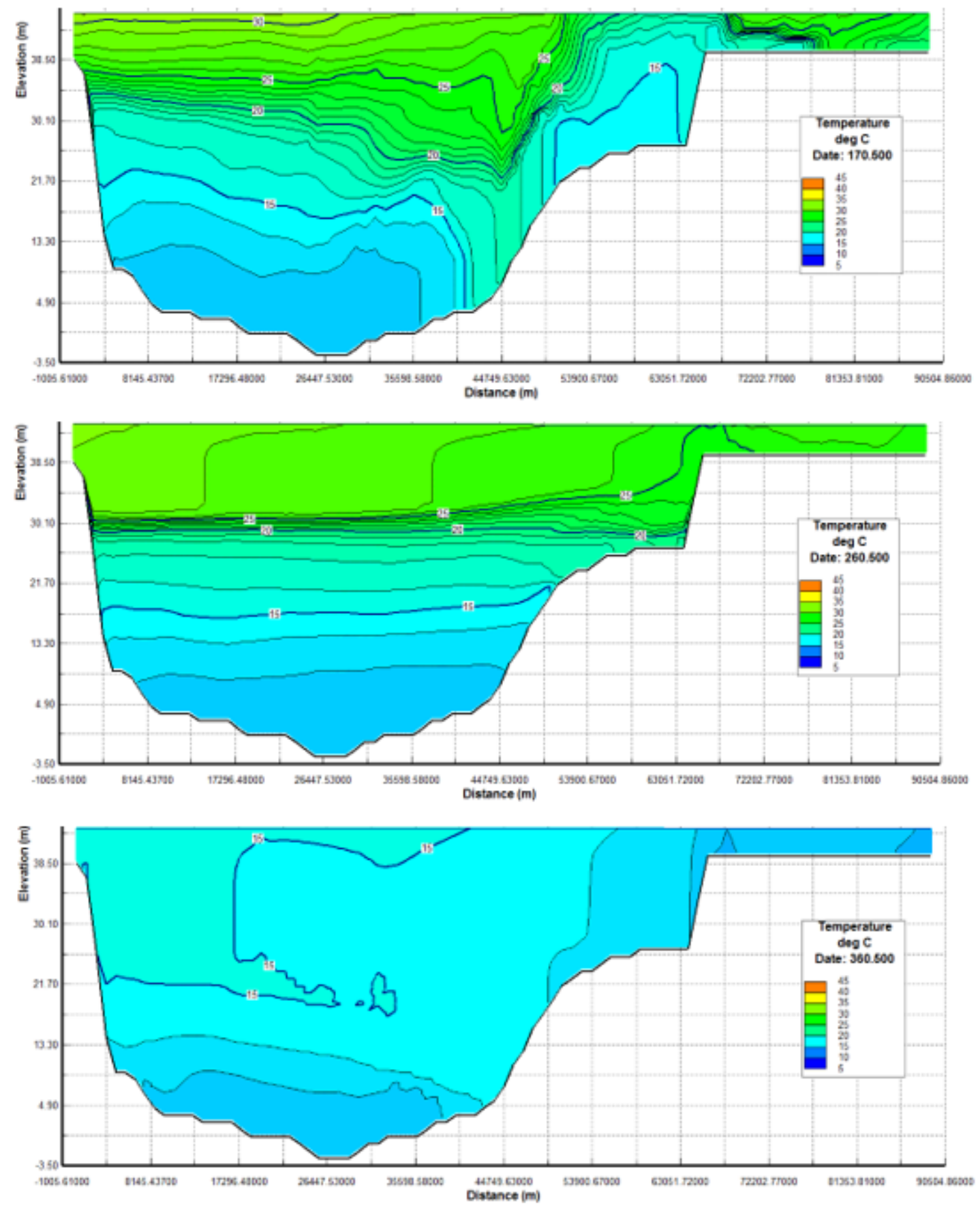

Figure 81: Model temperature contour lines of Tharthar Lake at JDAY 170.5, 260.5, and 350.5 of 2009 (Part 2). 

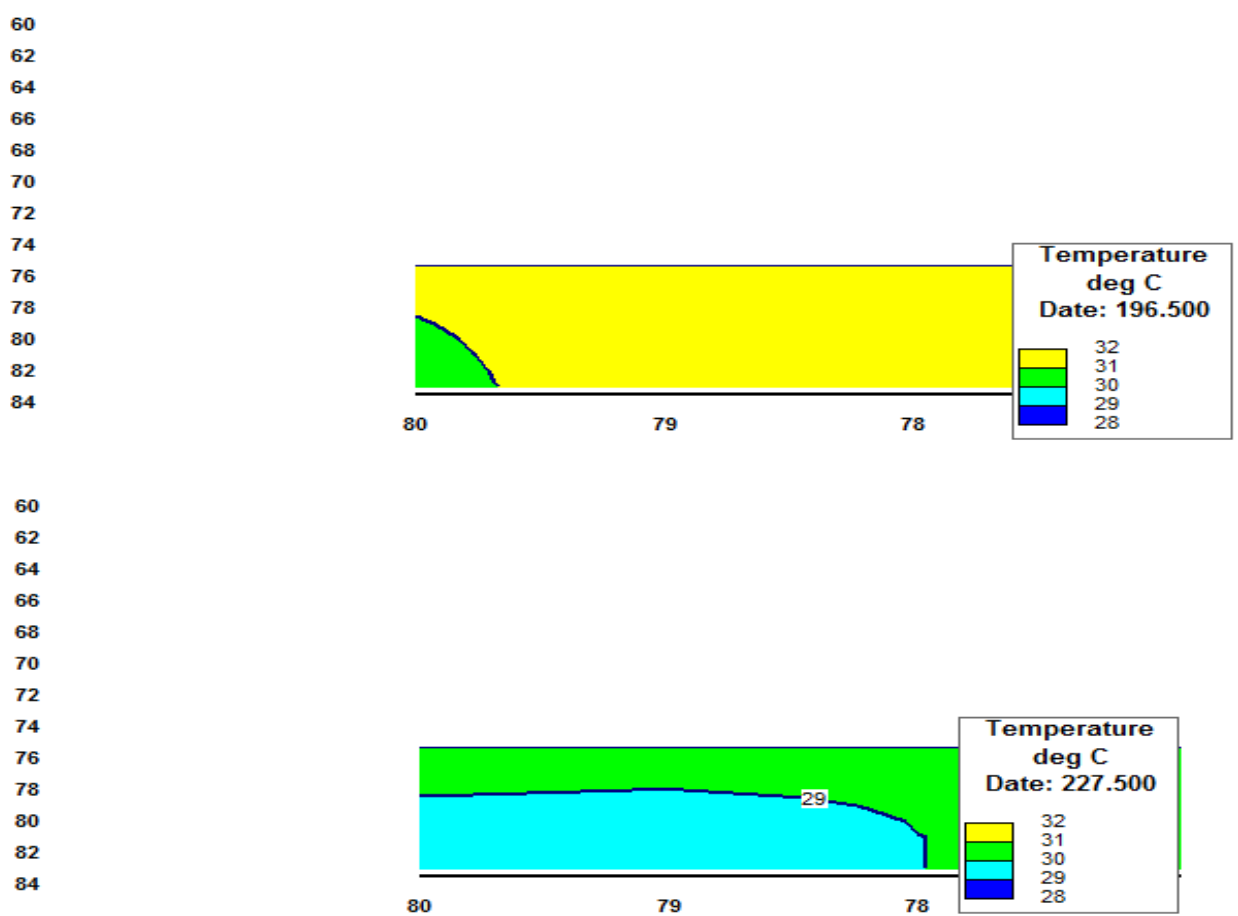

Figure 82: Model temperature contour lines of Samarra Barrage (model segment 80) at JDAY 196.5 and 227.5 of 2009.

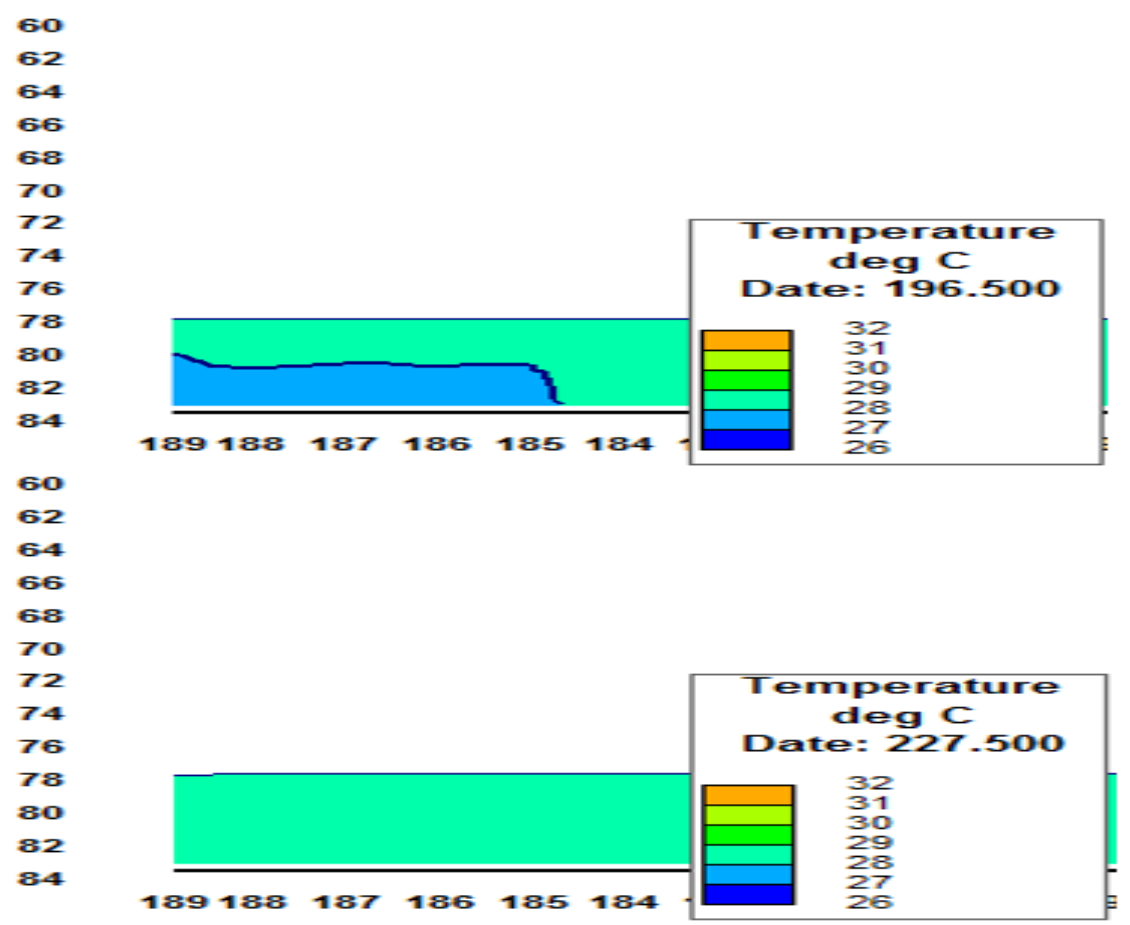

Figure 83: Model temperature contour lines of Kut Barrage (model segment 189) at JDAY196.5 and 227.5 of 2009. 


\section{Temperature Error Statistics}

Following the same procedure as with flow, the model predicted temperature was compared to estimated temperatures using satellite data.

Table 21 lists error statistics for model predicted temperature values compared to satellite data at stations along the mainstem of the Tigris River at Baeji city and Baghdad city. Model predictions of temperatures were relatively colder than satellite data during winter months but were within the confidence interval. This could be attributed to a contamination of the satellite water pixels by land pixels. In addition, high image cloud cover and lack of Landsat images, as listed previously in Table 9 in chapter three, likely produced a bias between model predictions and the statistical models of water temperature at Baeji and Baghdad cities in winter months of the simulated year 2009; essentially, summertime conditions were optimized. According to Boer (2014), another possible error contribution could be introduced due to undetected thin clouds. Table 22 lists error statistics for model predicted temperature values from April to October compared to satellite data at stations along the mainstem of the Tigris River at Baeji city and Baghdad city.

Table 21: Error statistics for model comparisons to satellite data for water temperature from January to December 2009.

\begin{tabular}{|l|l|l|}
\hline & Baeji City & Baghdad City \\
\hline & Temp $\left(^{\mathbf{0}} \mathbf{C}\right)$ & Temp $\left.^{(\mathbf{0}} \mathbf{C}\right)$ \\
\hline ME & -0.324 & -0.727 \\
\hline AME & 0.911 & 1.047 \\
\hline RMSE & 1.140 & 1.315 \\
\hline N & 360 & 360 \\
\hline
\end{tabular}


Table 22: Error statistics for model comparisons to satellite data for water temperature from April to October 2009.

\begin{tabular}{|l|l|l|}
\hline & $\begin{array}{l}\text { Baeji City } \\
{[\text { BFW 0.46] }}\end{array}$ & $\begin{array}{l}\text { Baghdad City } \\
{[\text { BFW 0.46] }}\end{array}$ \\
\hline & Temp $\left(^{\mathbf{0}}\right.$ C) & Temp $\left(^{\mathbf{0}} \mathbf{C}\right)$ \\
\hline ME & 0.337 & -0.314 \\
\hline AME & 0.710 & 0.775 \\
\hline RMSE & 0.938 & 1.016 \\
\hline $\mathbf{N}$ & 184 & 184 \\
\hline
\end{tabular}




\section{Model Calibration: Water Quality Constituents}

Like flow and temperature calibration, model predictions of water quality constituents were compared to the measurements in the Tigris River when field data were available. Unfortunately, not all water quality field data were available for either the model boundary conditions or for comparisons to model predictions during model calibration. Monthly average field data of both total dissolved solids (TDS) and nitrates (NO3) were the only two water quality constituents provided by the Iraqi Ministry of Water Resources for the modeled year 2009. Other water quality constituents modeled in this study such as PO4, $\mathrm{NO} 3, \mathrm{BOD}_{\mathrm{u}}$, algae, and $\mathrm{DO}$ were estimated from literature values.

\section{Total Dissolved Solids}

In-situ monthly average data of total dissolved solids were provided by the Iraqi ministry of Water Resources (MOWR 2014). Data were provided at Mosul Dam, Samarra Barrage, Audaim tributary, Baghdad City (Al-Shahada Bridge), Diyala River tributary, and Kut Barrage. No TDS data are available for both Upper Zab and Lower Zab Rivers, and therefore TDS concentrations at these two tributaries were assumed based on the available data. Unfortunately, daily average data of TDS were unavailable and therefore the model calibration for TDS was based on the monthly average data.

Due to relatively low flowrates and high TDS concentrations introduced to the mainstem of the Tigris River upstream Baghdad city through the Tharthar-Tigris canal, TDS in the mainstem of the river at Baghdad city was relatively high during the first two months of the year (winter time). This peak in TDS concentration at Baghdad city and downstream areas (Kut Barrage) could mostly be due to ungaged irrigation return flows that were 
directly discharged into the mainstem of the Tigris River through numerous man-made irrigation channels along both river banks. The effects of these return flows were added to the model as tributaries.

To account for high TDS concentration in Baghdad City during the first two months of the year, an extra tributary was introduced into the mainstem of the Tigris River system and was placed downstream of Samarra Barrage. This extra tributary had low flowrates $\left(1 \mathrm{~m}^{3} / \mathrm{s}\right)$ with high mass of TDS to adjust for the deficit in TDS concentrations during the winter months. This was like adding a mass source of TDS to the river. Another tributary was introduced downstream of Baghdad City to account for high TDS at Kut Barrage in winter months. Figure 84 through Figure 88show the model predictions of TDS compared with field data at Mosul Dam (boundary condition), Samarra Barrage, Baghdad City, Kut Barrage, and Tharthar Lake respectively. Unfortunately, field data of TDS in Tharthar Lake were not available for model comparison. TDS contour lines for the longitudinal and vertical at Tharthar Lake are shown in Figure 90. As water was continuously diverted to Tharthar Lake from Samarra Barrage through Tigris-Tharthar Canal, TDS concentrations in Tharthar Lake decreased during the simulated year due to continuous dilution. According to Ansari et al., (2012), TDS and other water quality constituents decrease with increasing dilution. The initial condition of TDS at Tharthar Lake was $1300 \mathrm{mg} / \mathrm{l}$ and dropped down to about $1150 \mathrm{mg} / \mathrm{l}$ at the end of the simulation. Table 23 lists error statistics of model predictions for TDS compared with the monthly averaged field data at Samarra Barrage, Baghdad city, and Kut Barrage. 


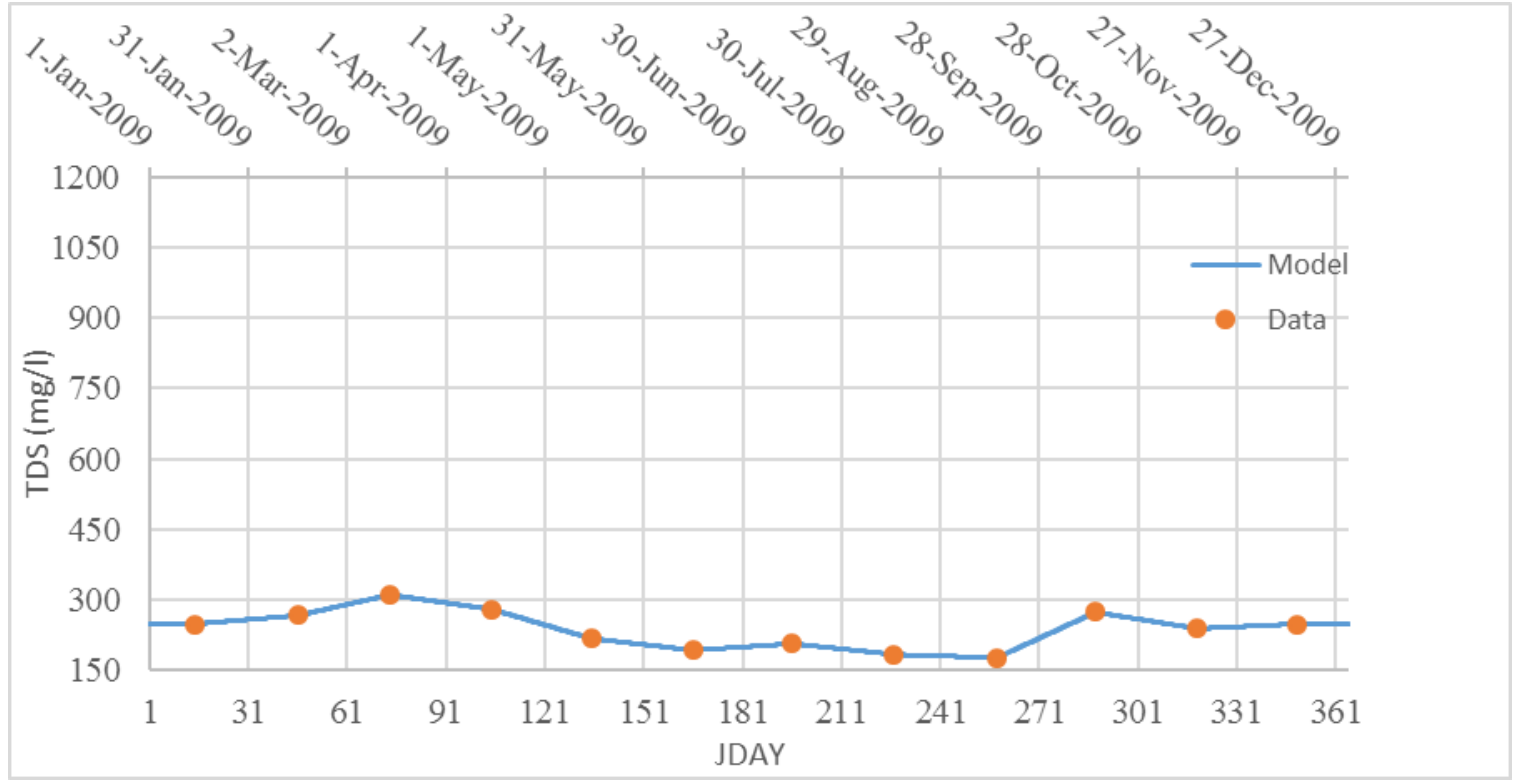

Figure 84: Model TDS predictions compared to the Tigris River field data at Mosul Dam (segment 2) the upstream boundary condition.

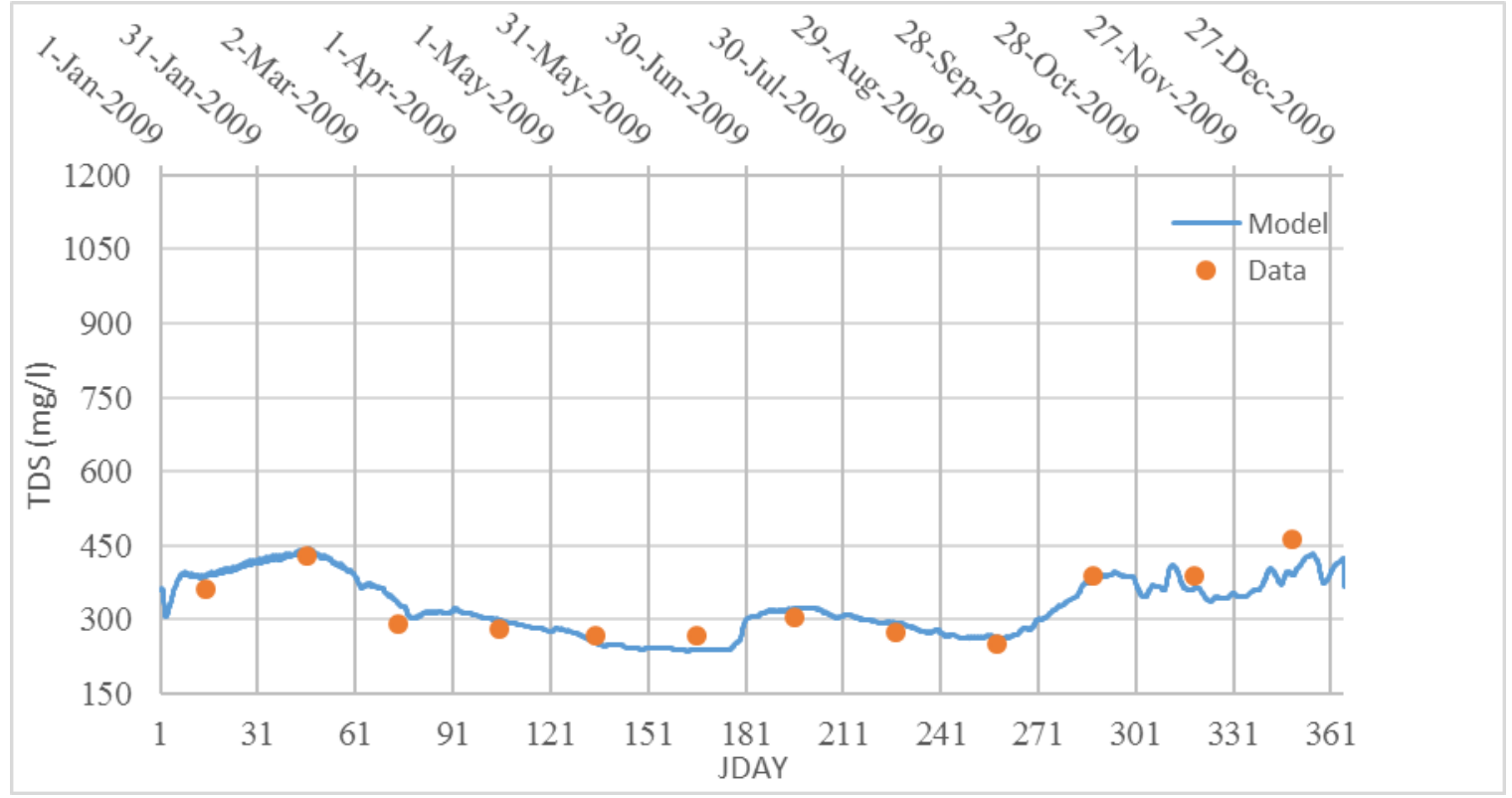

Figure 85: Model TDS predictions compared to the Tigris River field data at Samarra Barrage (segment 83). 


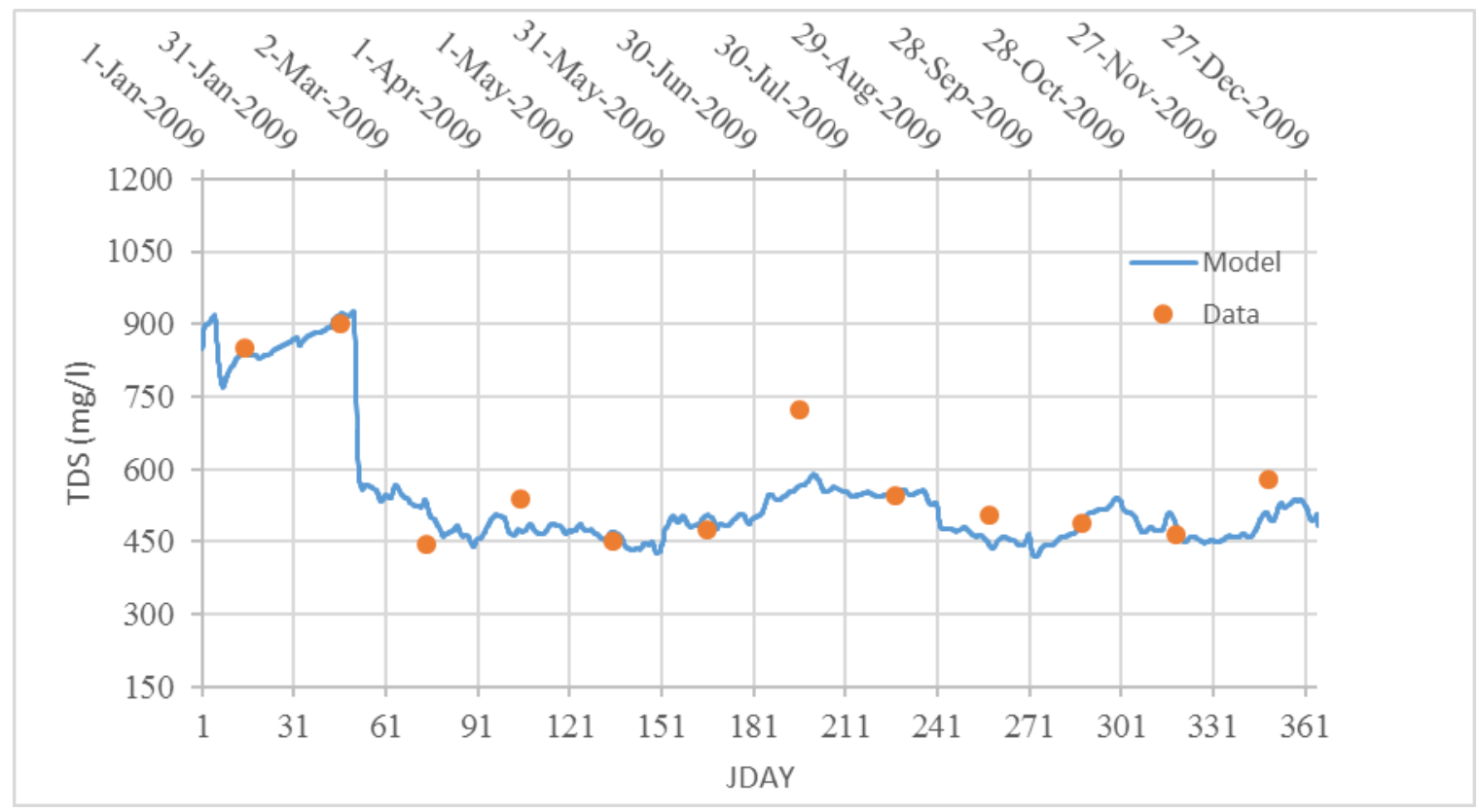

Figure 86: Model TDS predictions compared to the Tigris River field data at Baghdad City (segment 123).

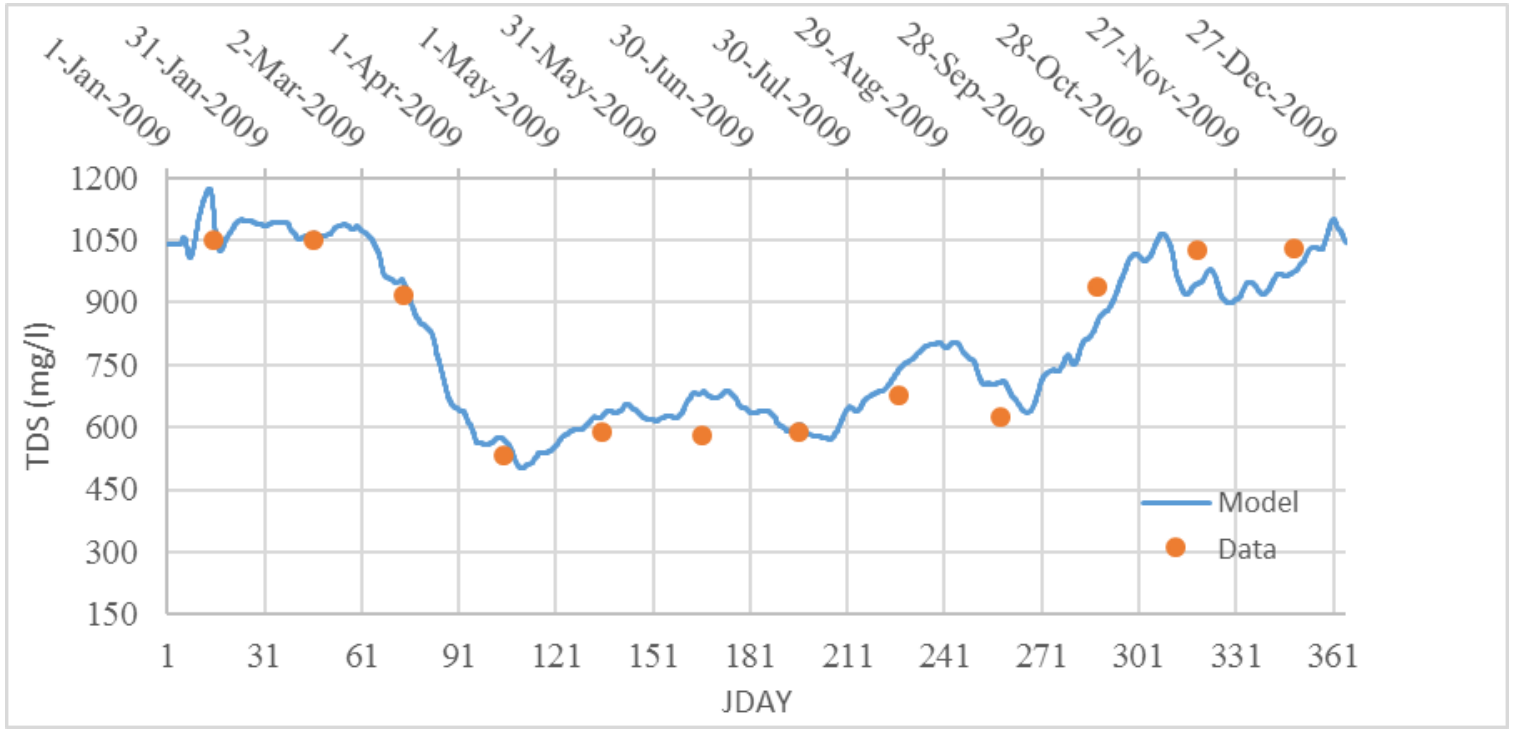

Figure 87: Model TDS predictions compared to the Tigris River field data at Kut Barrage (segment 189). 


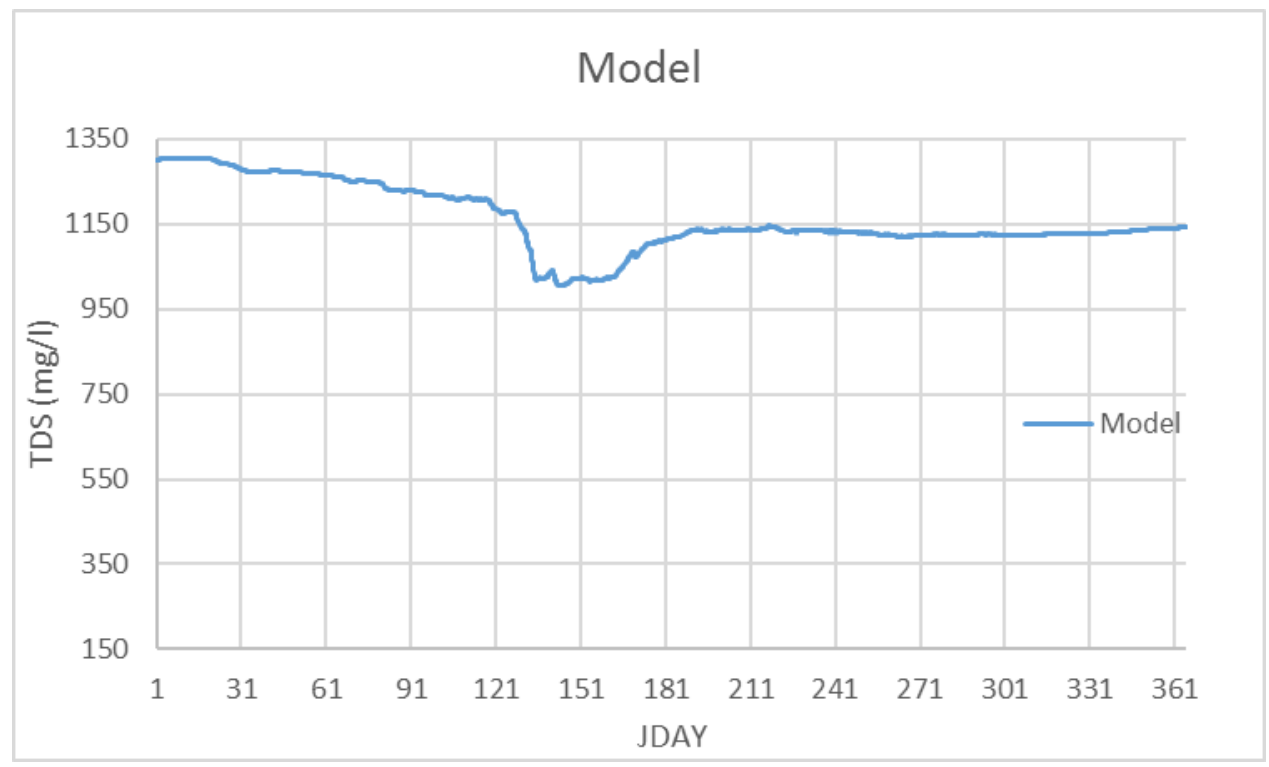

Figure 88: Model TDS predictions at the outlet of Tharthar Lake in 2009 (segment 297).

Table 23: Error statistics for model predictions of TDS in the middle of the month compared with field data.

\begin{tabular}{|c|c|c|c|}
\hline & Samarra & Baghdad & Kut \\
\hline ME (mg/l) & 2.567 & -12.896 & 17.692 \\
\hline AME (mg/l) & 27.083 & 53.163 & 53.175 \\
\hline RMSE (mg/l) & 31.692 & 64.778 & 60.361 \\
\hline $\mathbf{N}$ & 12 & 12 & 12 \\
\hline
\end{tabular}



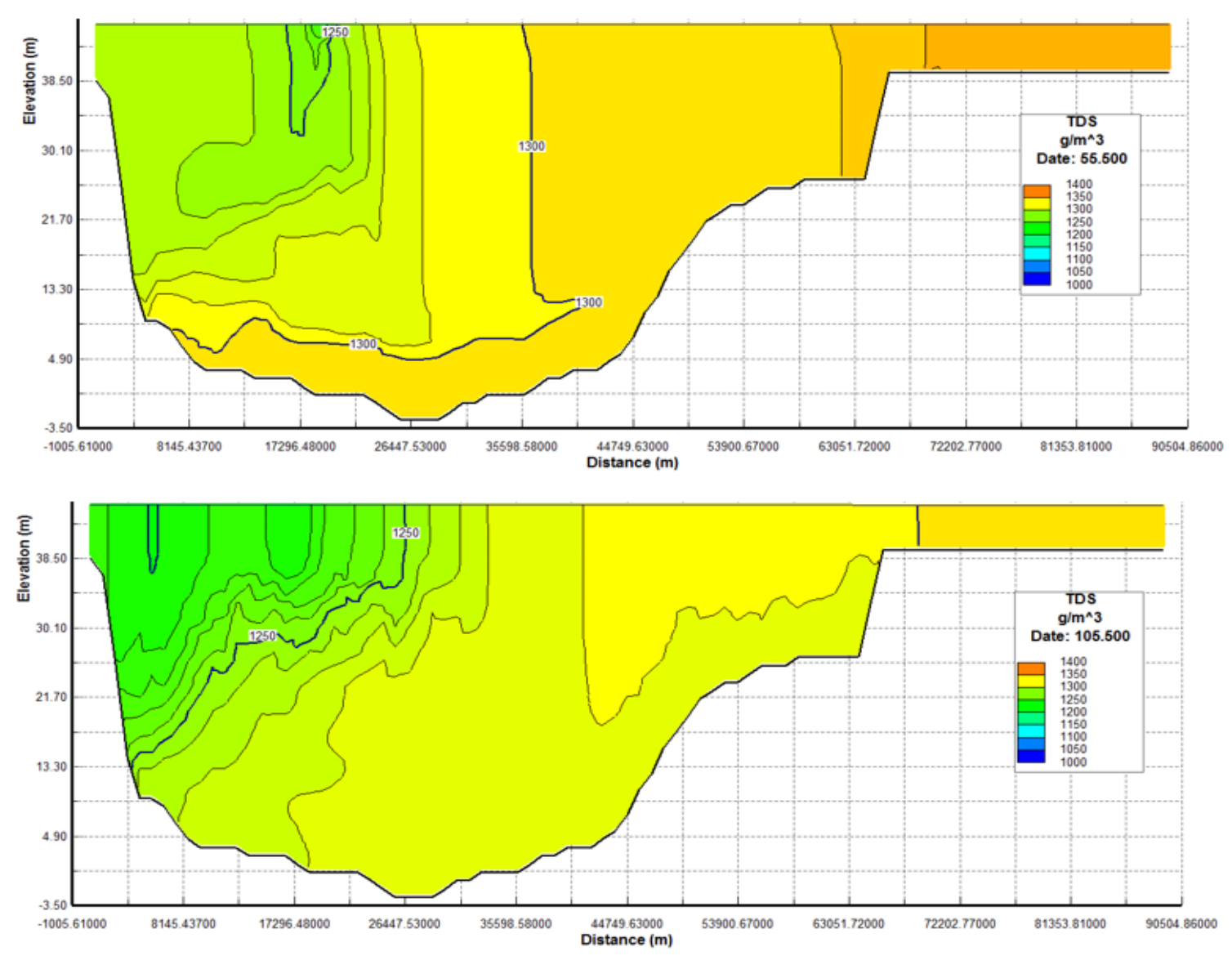

Figure 89: Model contours of TDS in Tharthar Lake at JDAY 55.5, and 105.5 of 2009 (Part 1). 

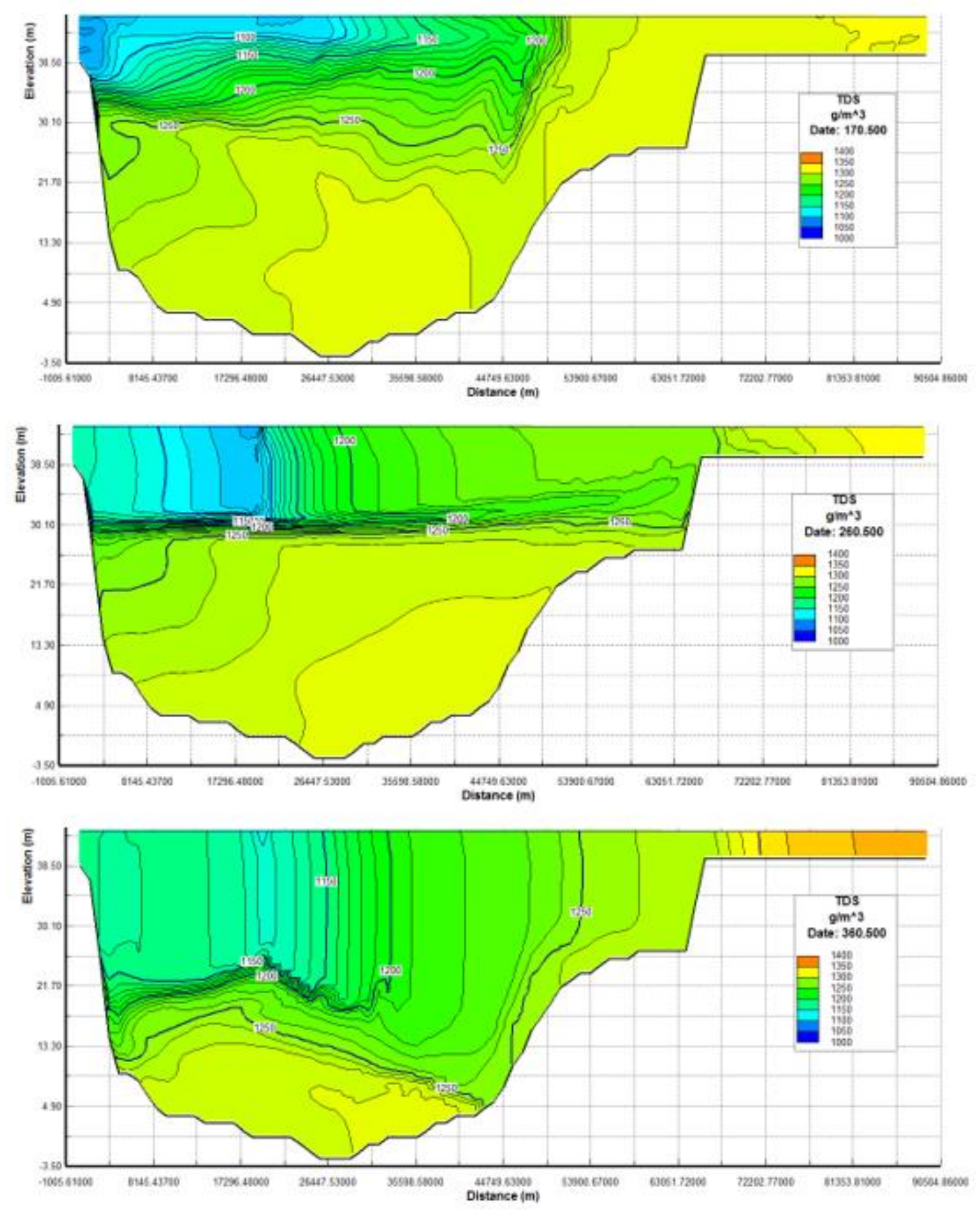

Figure 90: Model contours of TDS in Tharthar Lake at JDAY 170.5, 260.5, and 360.5 of 2009 (Part 2). 


\section{Other Water Quality State Variables}

Other water quality state variables modeled in this study were phosphate (PO4), ammonium (NH4), nitrate (NO3), biochemical oxygen demand (BOD), algae, and dissolved oxygen (DO). Historical data of water quality state variables at Mosul Dam were determined from other field studies. Water quality constituents for tributaries of the Tigris River were assumed based on data availability from the literature as listed in Table 15 in chapter 5. For both Upper Zab and Lower Zab tributaries, PO4 concentrations were assumed the same. The same assumption was used for NO3 and BOD concentrations, while DO concentrations were estimated based on water temperature at Mosul Dam for the Upper Zab and water temperature at Beaji city for the Lower Zab. On the other hand, for both Audaim and Diyala tributaries, PO4 concentrations were assumed the same. The same assumption was used for NO3 and DO, while BOD concentrations were estimated from literature values. Figure 91 through Figure 96 show model results for PO4, NH4, NO3, DO, CBOD, and Chl-a at Mosul Dam, Samarra Barrage, Tharthar Lake, Baghdad city, and Kut Barrage, respectively. Unfortunately, field data of PO4, NH4, DO, and Chl-a were unavailable for model comparisons. Some monthly average of NO3 field data for the Tigris River at Samarra Barrage and Baghdad city were available, while seasonal BOD field data were available only at Baghdad city for the modeled year 2009 and were used for model

comparisons. NO3 concentrations at Mosul Dam were assumed $1.5 \mathrm{mg} / \mathrm{l}$ from January $1^{\text {st }}$ to June $30^{\text {th }}$ for better model predictions at Samarra Barrage and Baghdad city as shown in Figure 93. 
Model predictions of dissolved oxygen in the mainstem of the Tigris River and Tharthar Lake are shown in Figure 94. DO concentrations decreased during the summer with the exception at Kut Barrage where DO concentrations were relatively high in the period from May to August of the simulated year. This was mostly due to a significant high concentration in chlorophyll-a at Kut Barrage as shown in Figure 96.

Like the TDS calibration approach in Baghdad city, a high mass with a low flowrate of ultimate biochemical oxygen demand (BODu) was introduced into the mainstem of the Tigris River at Baghdad city through model branch 5 located downstream of Samarra Barrage to match seasonal field data as shown in Figure 95. This was essentially adding a mass load to the river. High BOD concentrations within Baghdad city were mainly related to the direct discharge of wastewater treatment plants and other industrial discharges. This was especially important during the summer months when flow in the Tigris River was low.

Model predictions of chlorophyll-a were high below Baghdad city and Tharthar Lake as shown in Figure 96. A sensitivity study, in the next section, was conducted to check if satellite images also show high Chl-a concentrations.

In summary, model predictions of phosphate, ammonium, nitrate, carbonaceous biological oxygen demand, dissolved oxygen, and chlorophyll-a for the base model of the Tigris River system will be compared with management scenarios in the next chapter. 

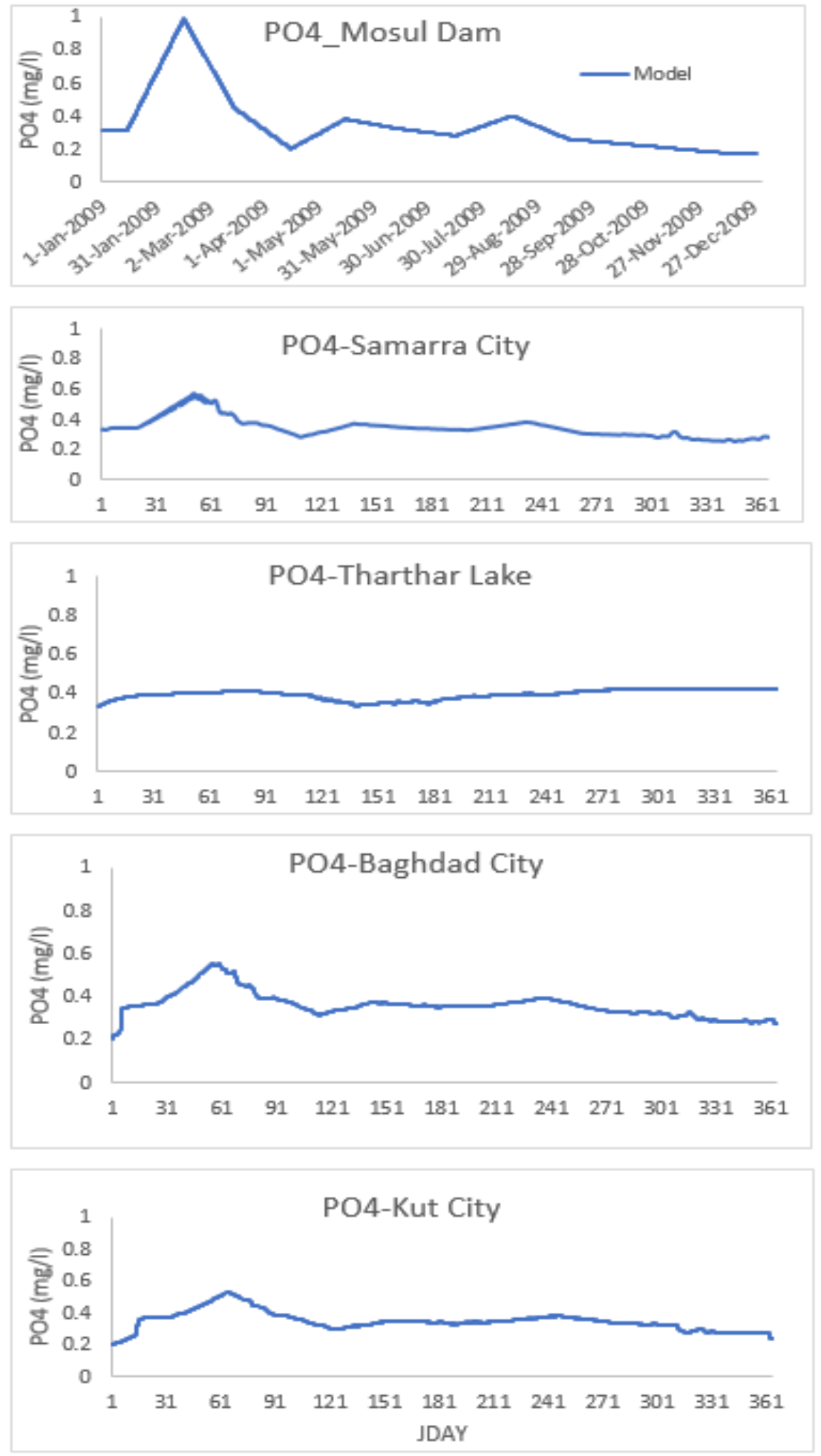

Figure 91: Model PO4 predictions at Mosul Dam, at Samarra Barrage, at Tharthar Lake, at Baghdad City, and at Kut City. 

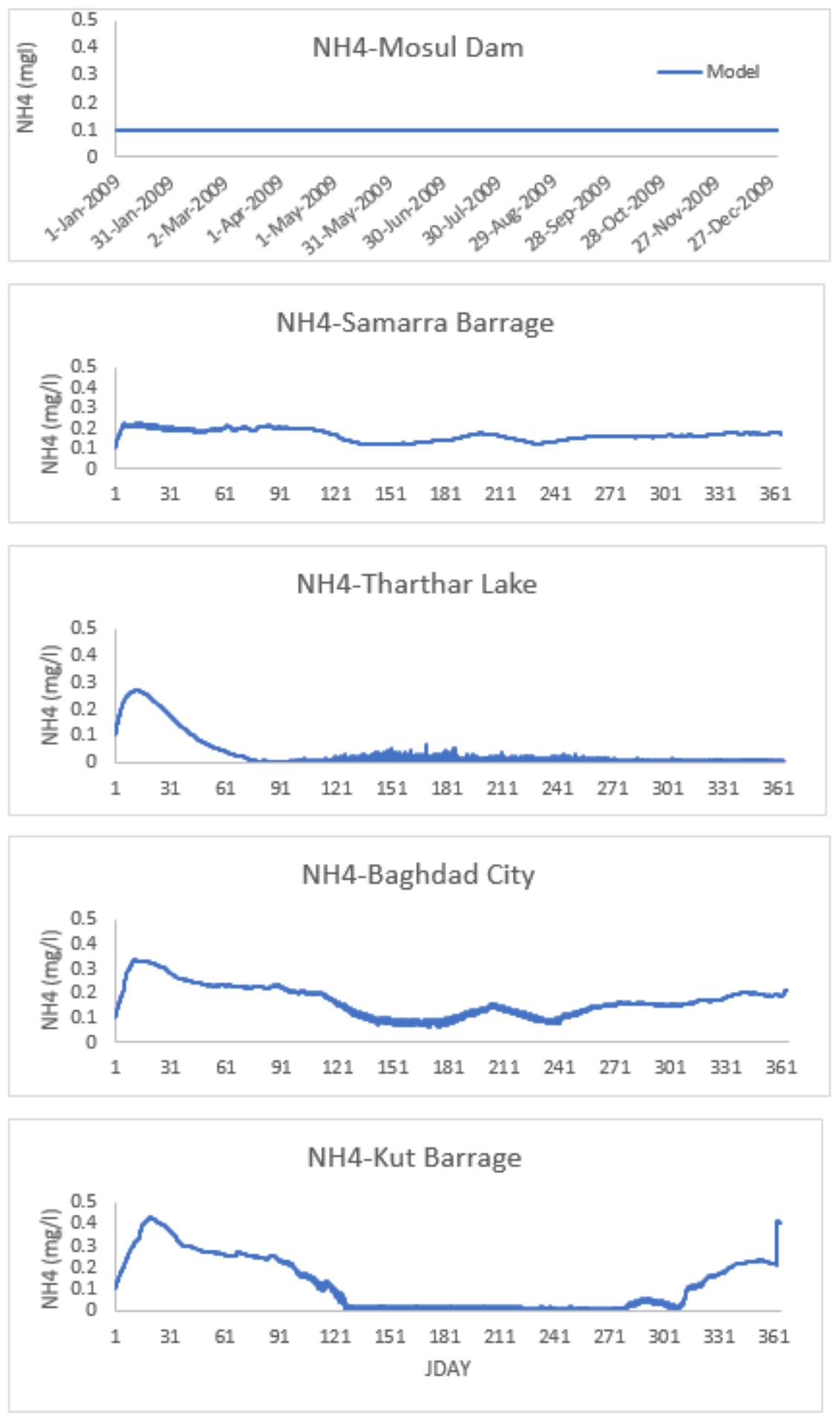

Figure 92: Model Ammonium predictions at Mosul Dam, at Samarra Barrage, at Tharthar Lake, at Baghdad City, and at Kut Barrage. 

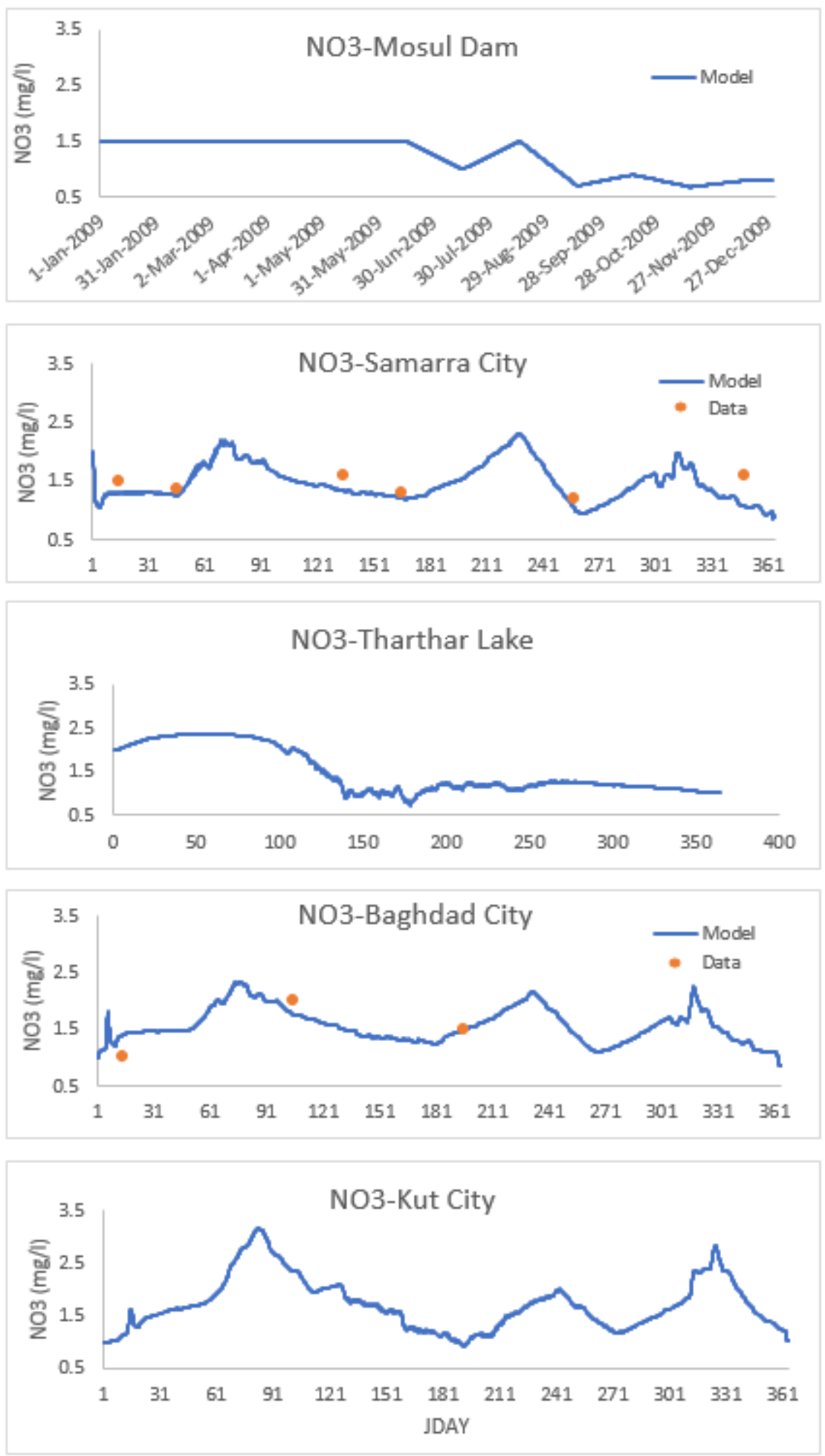

Figure 93: Model Nitrate predictions at Mosul Dam, at Samarra Barrage (model Vs. field data), at Tharthar Lake, at Baghdad City (model Vs. field data), and at Kut City. 

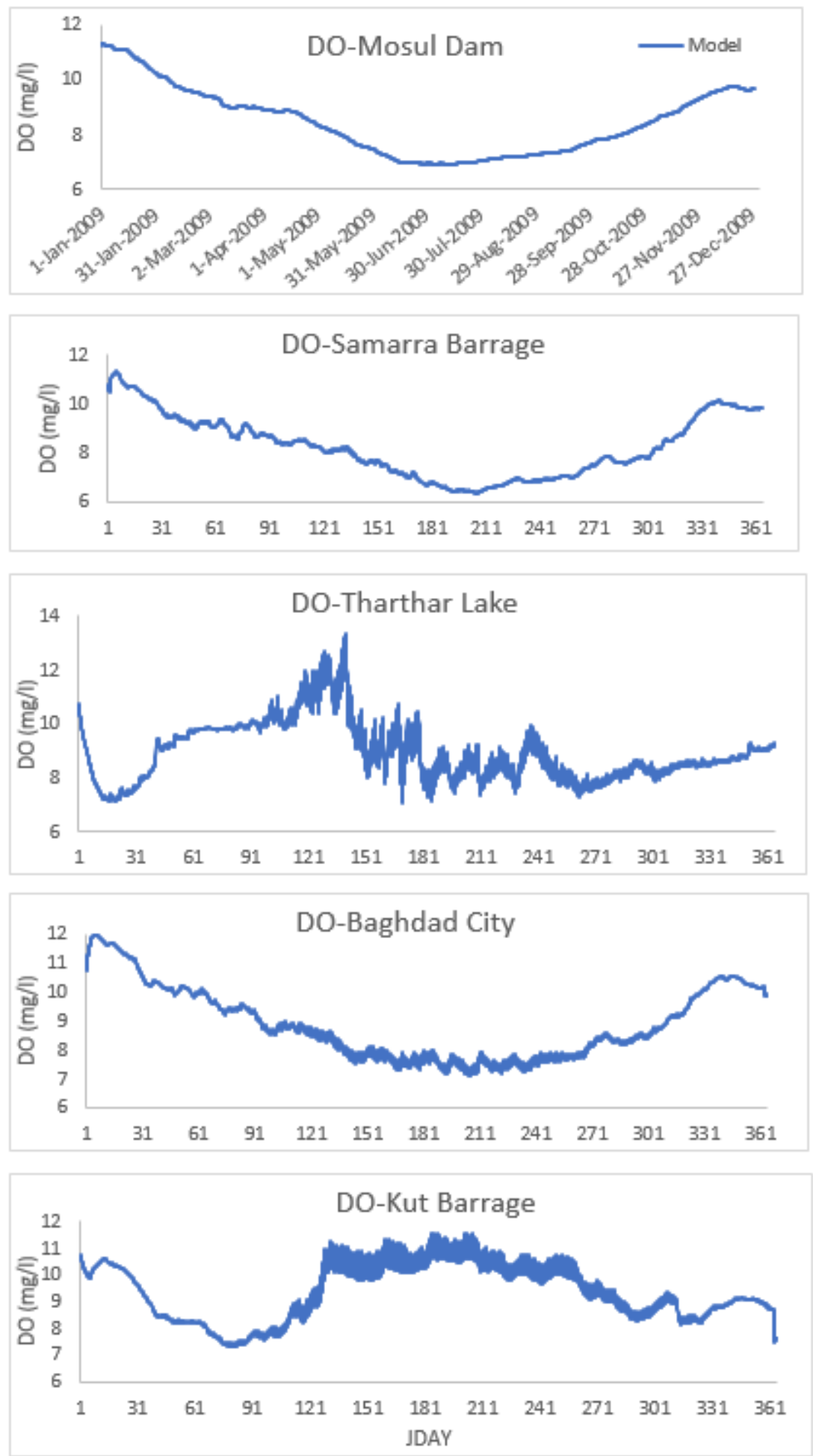

Figure 94: Model Dissolved Oxygen predictions at Mosul Dam, at Samarra Barrage, at Tharthar Lake, at Baghdad City, and at Kut Barrage. 

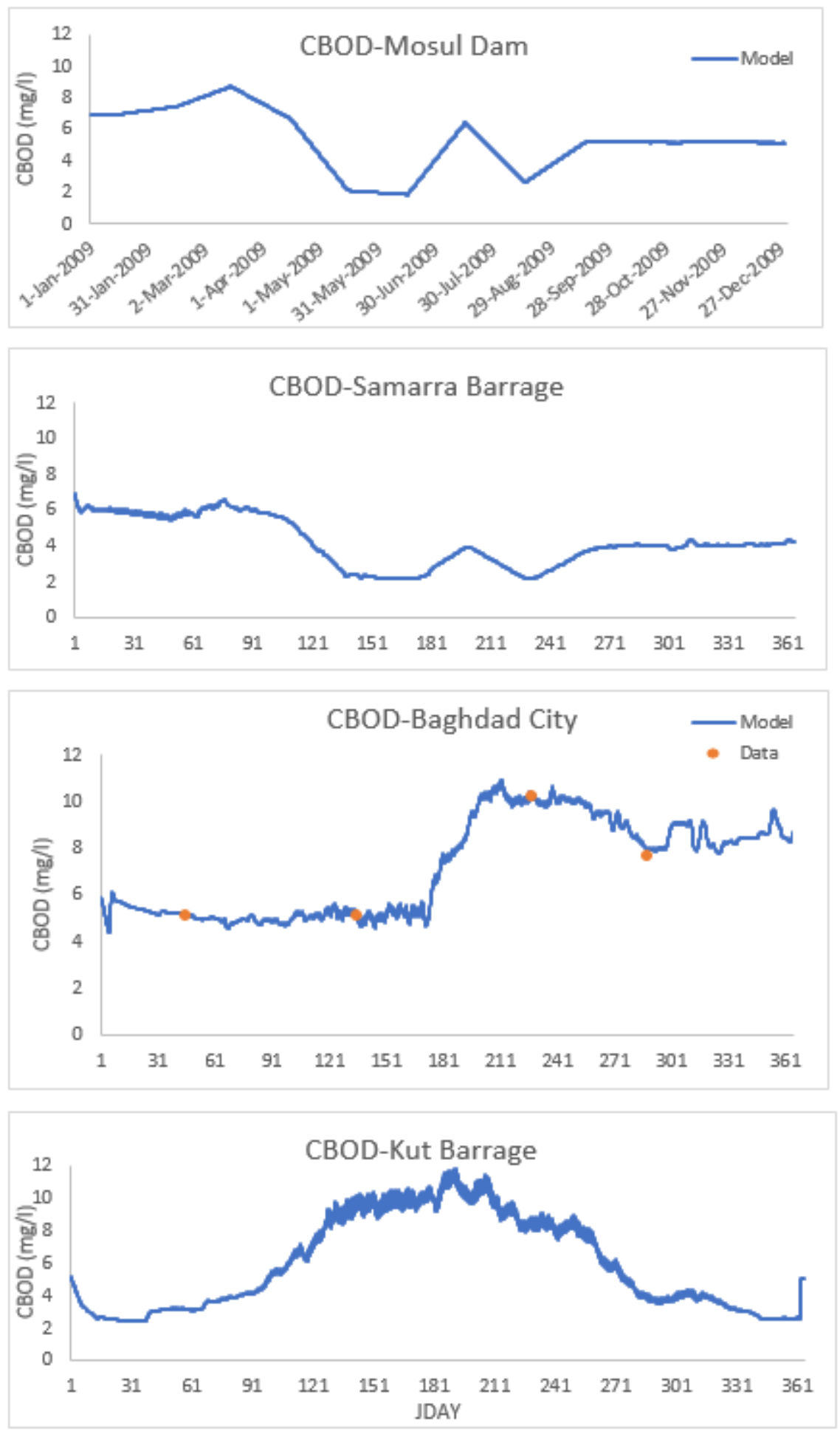

Figure 95: Model CBOD predictions at Mosul Dam, at Samarra Barrage, at Baghdad City (model Vs. field data), and at Kut Barrage. 

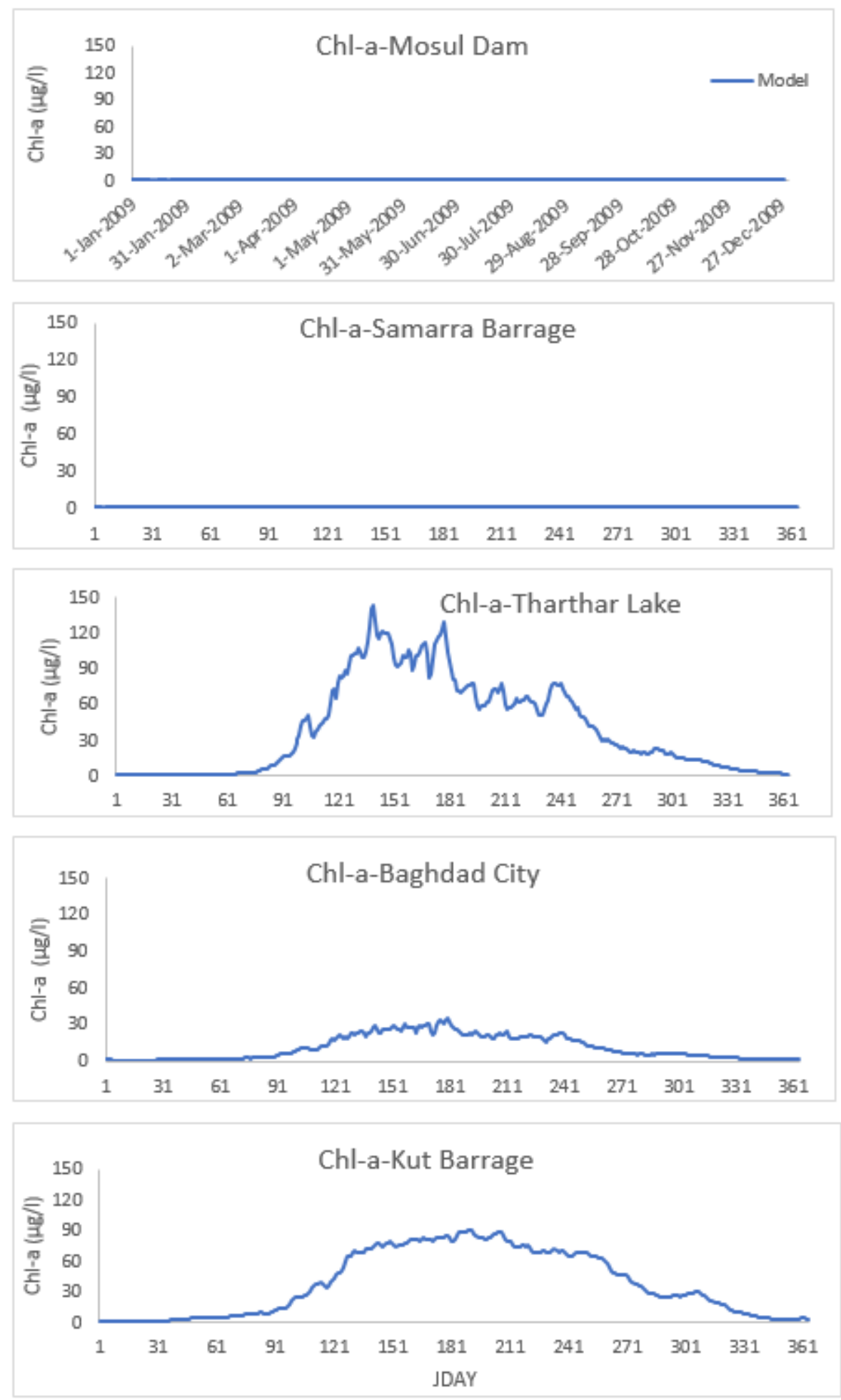

Figure 96: Model Chlorophyll-a predictions at Mosul Dam, at Samarra Barrage, at Tharthar Lake, at Baghdad City, and at Kut Barrage using algae growth rate of $1.5 \mathrm{~d}^{-1}$. 


\section{Chlorophyll-a}

The model predicts a large growth of algae below Baghdad city and Tharthar Lake. For the base model, a value of 1.5 day $^{-1}$ was set as the maximum algal growth rate $[A G]$ in the control file. A sensitivity study was conducted to check if satellite images also show high Chl-a concentrations using a Chl-a correlation provided from previous literature studies. 13 Landsat 5 TM images with path/row 169/36 were used to extract pixel's reflectance for both band 1 (B1) and band 2 (B2) at a point corresponding to model segment 230 in Tharthar Lake. B1 and B2 values were then used to estimate Chl-a concentration using a Chl-a correlation, Equation 18, estimated by Khattab et al. (2014) that was used to estimate Chl-a in Mosul Dam Lake. Figure 97 shows model predictions of Chl-a for model segment 230 in Tharthar Lake using [AG] of $1.5 \mathrm{~d}^{-1}$ compared with satellite data. Model predictions of Chl-a were too high compared with satellite data.

Equation 18: Chl-a correlation estimated by Khattab et al. (2014)

$C h l-a=111.236-27.416 * \frac{B 1}{B 2}-70.17 * \frac{B 2}{B 1}$

Multiple simulations were performed to evaluate model sensitivity to [AG]. The best fit was reached using [AG] $0.98 \mathrm{~d}^{-1}$. Figure 98 shows model predictions of Chl-a for model segment 230 in Tharthar Lake using [AG] of $0.98 \mathrm{~d}^{-1}$ compared with satellite data. Therefore, the model is sensitive to the maximum algal growth rate.

B1 and B2 values were also estimated in the mainstem of the Tigris River at Baghdad city in an attempt to estimate Chl-a concentrations in the river using the same correlation used for Tharthar Lake. Unfortunately, the correlation did not work out to estimate Chl-a concentrations in the river. 


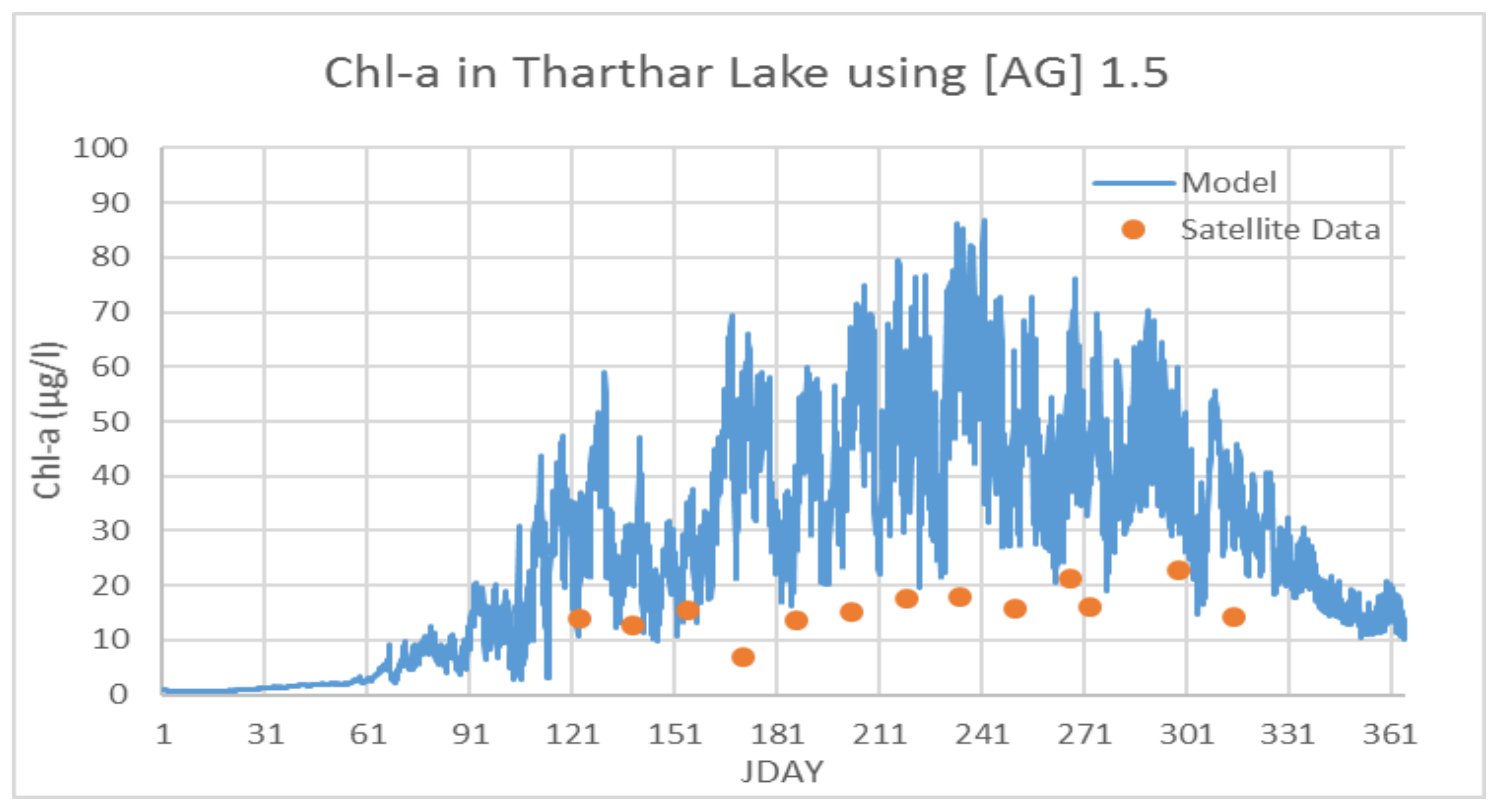

Figure 97: Model predictions of Chl-a in Tharthar Lake using [AG] $1.5 \mathrm{~d}^{-1}$ compared with Satellite data.

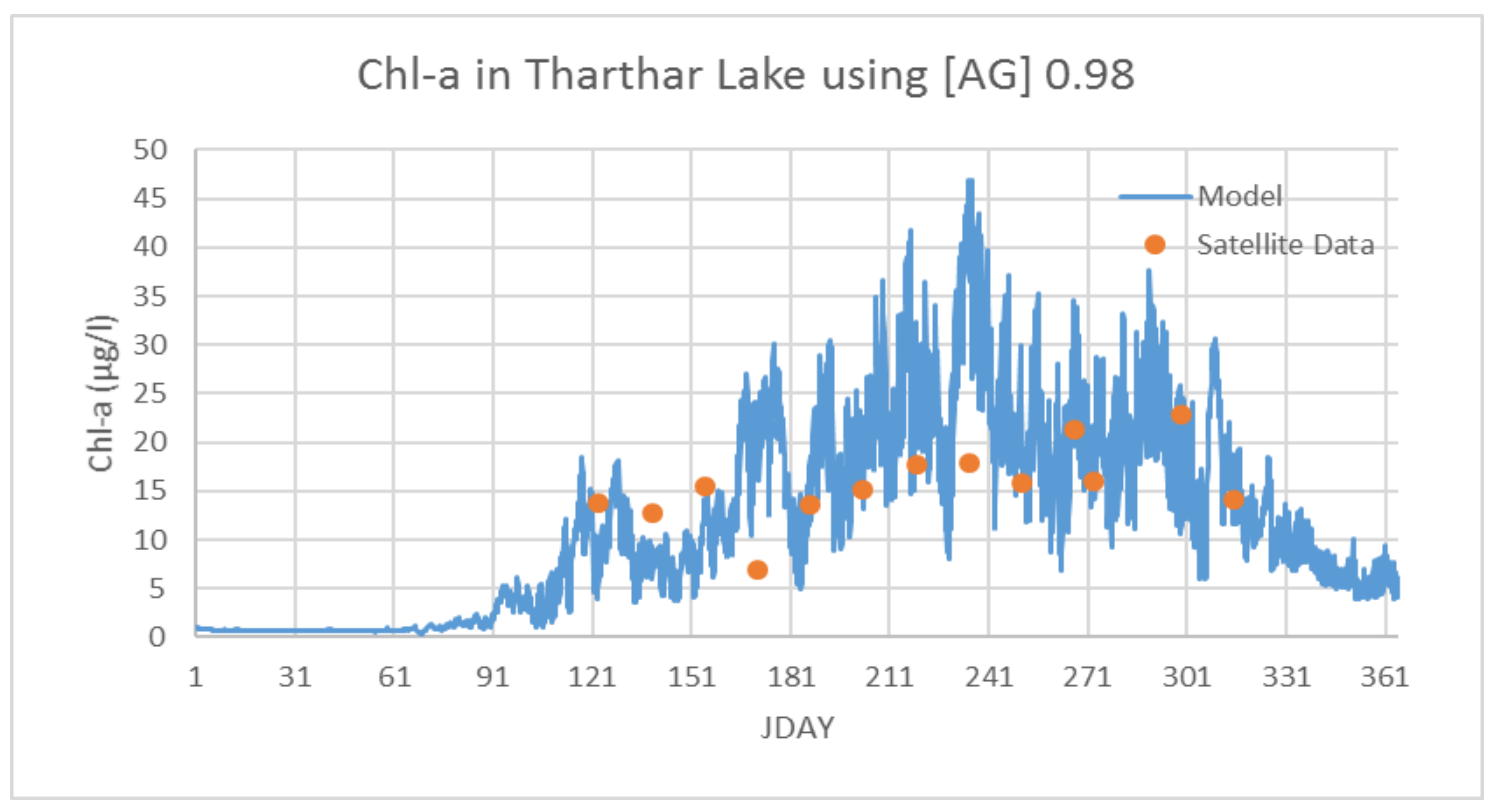

Figure 98: Model predictions of Chl-a in Tharthar Lake using [AG] $0.98 \mathrm{~d}^{-1}$ compared with Satellite data. 


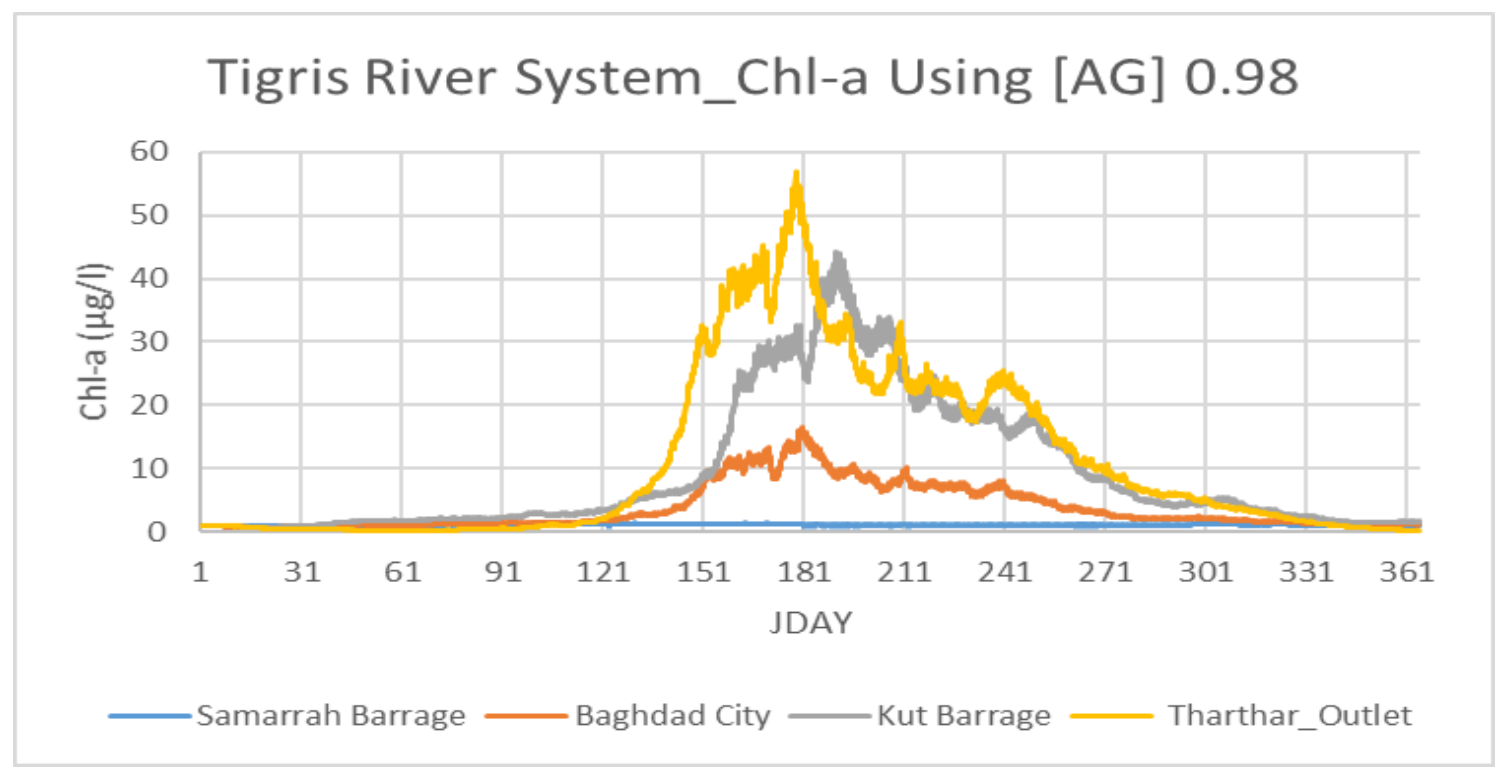

Figure 99: Model predictions of Chl-a in the Tigris River system using [AG] $0.98 \mathrm{~d}^{-1}$ 


\section{Nutrients}

After a sensitivity study was conducted on Chl-a by decreasing algal growth to $0.98 \mathrm{~d}^{-1}$, concentrations of NH4 (Figure 100) and NO3 (Figure 101) in the Tigris River system at Kut Barrage and Tharthar Lake were slightly affected, while no significant change was observed on PO4 concentration over all the Tigris River system.

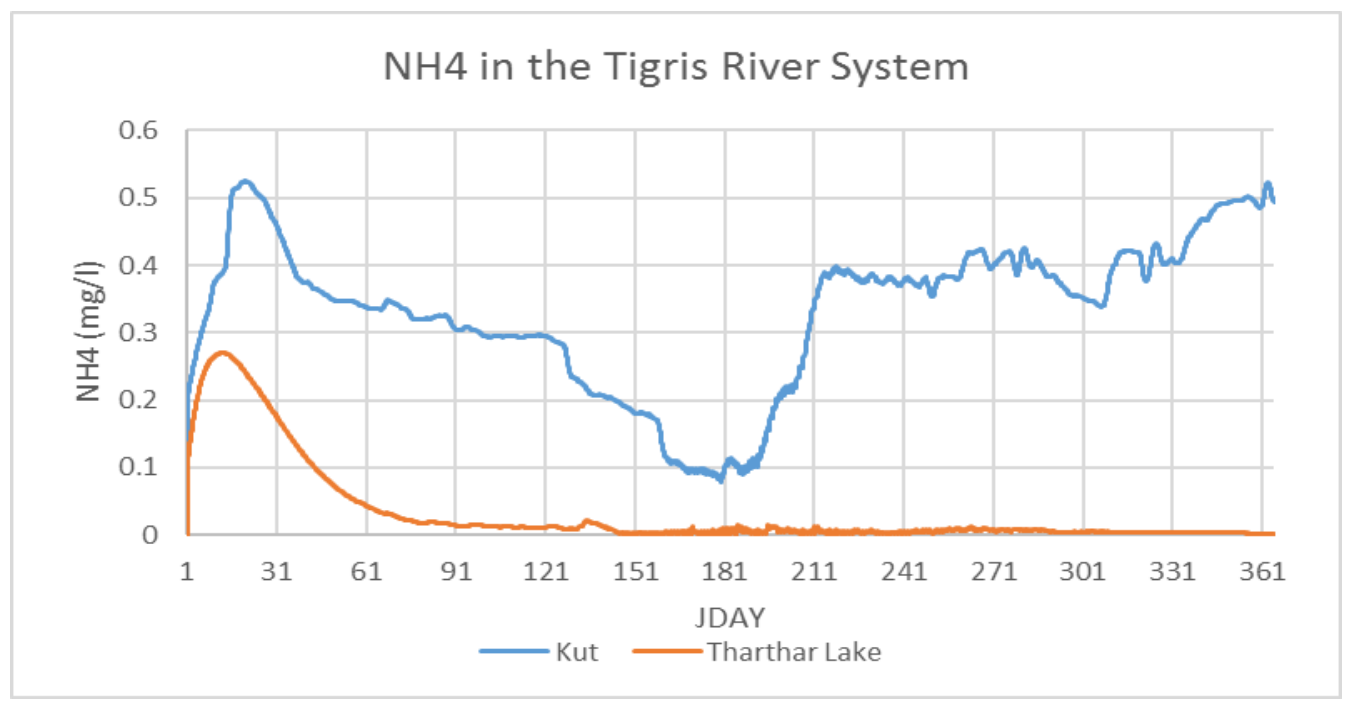

Figure 100: Model predictions of NH4 in Kut Barrage and Tharthar Lake.

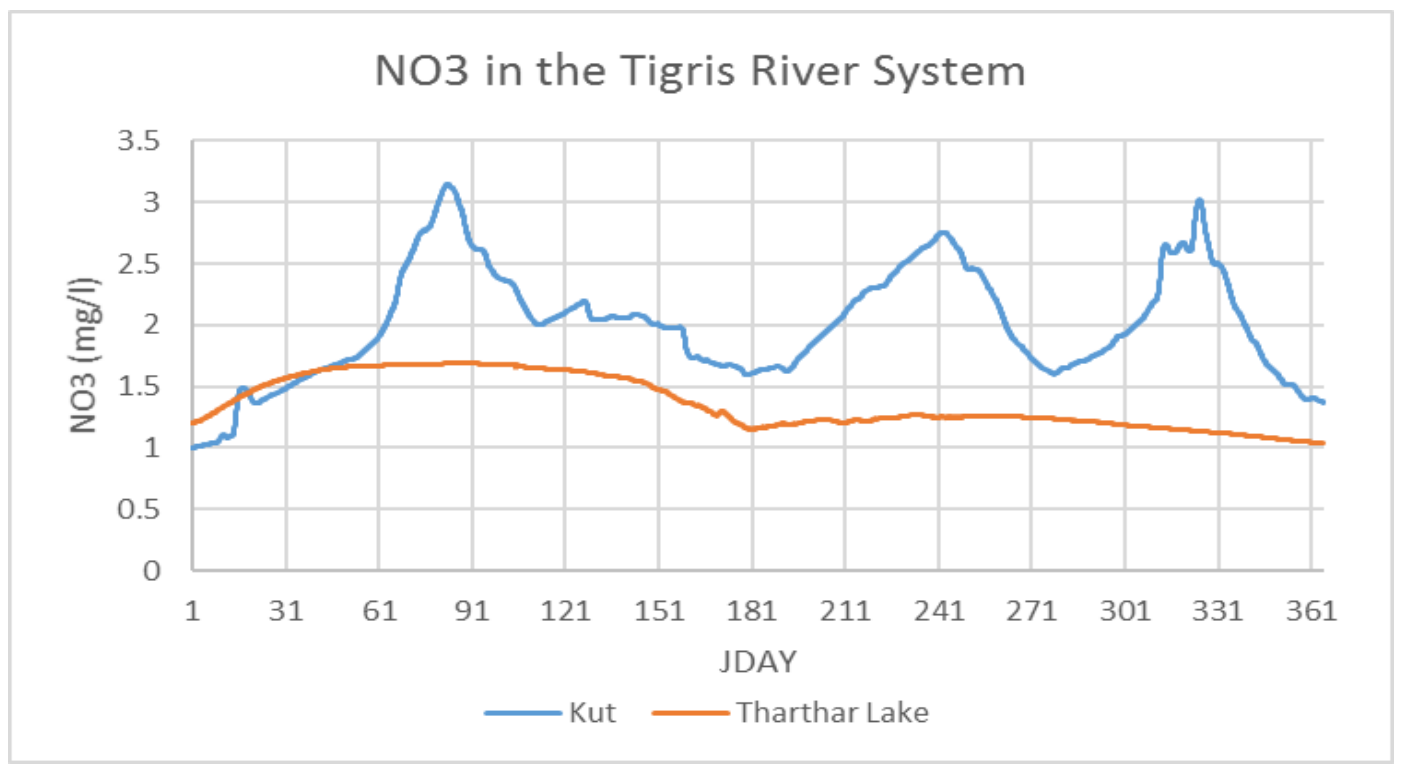

Figure 101: Model predictions of NO3 in Kut Barrage and Tharthar Lake. 


\section{Chapter Seven: The Tigris River Management Scenarios}

Multiple management scenarios were applied to the model inputs to simulate the effect of changing flow regime (hydrology), upstream increase in nutrient concentrations from Turkey, the impact of climate change, disconnection of Tharthar Lake from the Tigris River system, and a 6-year simulation of the Tigris River model evaluating longer-term changes inn Tharthar Lake. Model scenarios were chosen based on potential change in upstream flow and nutrient concentrations from Turkey, future increase in air temperatures, and potential decrease in TDS concentrations in the mainstem of the Tigris River. Management scenarios were then compared with the base model of the simulated year 2009. For each management scenario, only pertinent results are showed and discussed, while the remaining results that caused little change are discussed and placed in appendix A. Table 24 lists all management scenarios applied to the Tigris River system. 
Table 24: The Tigris River management scenarios

\begin{tabular}{|c|c|c|c|c|c|c|c|c|c|c|c|}
\hline Run \# & Description & $\begin{array}{l}\text { Year } \\
2009\end{array}$ & $\begin{array}{l}\text { 6-Year } \\
\text { Model }\end{array}$ & $\begin{array}{l}\text { Existing } \\
\text { Flow } \\
\text { Conditions }\end{array}$ & $\begin{array}{c}\text { Existing } \\
\text { Meteorolo } \\
\text { gical data }\end{array}$ & $\begin{array}{c}\text { Existing } \\
\text { Nutrients }\end{array}$ & $\begin{array}{c}\text { Increasing } \\
\text { Upstream } \\
\text { Flow }\end{array}$ & $\begin{array}{c}\text { Decreasing } \\
\text { Upstream } \\
\text { Flow }\end{array}$ & $\begin{array}{l}\text { Increasing } \\
\text { Nutrients }\end{array}$ & $\begin{array}{l}\text { Climate } \\
\text { Change }\end{array}$ & $\begin{array}{c}\text { Decreasing } \\
\text { BOD by } \\
50 \%\end{array}$ \\
\hline 1 & Base Model & $x$ & & $x$ & $x$ & $x$ & & & & & \\
\hline 2 & $\begin{array}{l}\text { Increasing } \\
\text { Upstream } \\
\text { Flow }\end{array}$ & $\mathbf{x}$ & & & $\mathbf{x}$ & $x$ & $\mathbf{x}$ & & & & \\
\hline 3 & $\begin{array}{l}\text { Decreasing } \\
\text { Upstream } \\
\text { Flow }\end{array}$ & $\mathbf{x}$ & & & $\mathbf{x}$ & $x$ & & $\mathbf{x}$ & & & \\
\hline 4 & $\begin{array}{l}\text { Decreasing } \\
\text { Upstream } \\
\text { Flow with } \\
\text { increasing } \\
\text { nutrients }\end{array}$ & $x$ & & & $x$ & & & $x$ & $x$ & & \\
\hline 5 & $\begin{array}{l}\text { Increasing } \\
\text { Tharthar } \\
\text { Lake's Flow } \\
\text { from Samarra } \\
\text { Barrage }\end{array}$ & $x$ & & & $x$ & $x$ & $x$ & & & & \\
\hline 6 & $\begin{array}{l}\text { Climate } \\
\text { change }\end{array}$ & $\mathbf{x}$ & & $x$ & & $x$ & & & & $x$ & \\
\hline 7 & $\begin{array}{l}\text { Climate } \\
\text { change with } \\
\text { decreasing } \\
\text { upstream } \\
\text { flow }\end{array}$ & $x$ & & & & $x$ & & $x$ & & $x$ & \\
\hline 8 & $\begin{array}{l}\text { Disconnecting } \\
\text { Tharthar Lake }\end{array}$ & $\mathbf{x}$ & & $x$ & $x$ & $x$ & & & & & \\
\hline 9 & $\begin{array}{l}\text { Decreasing } \\
\text { BOD by } 50 \%\end{array}$ & $\mathbf{x}$ & & $x$ & $x$ & $x$ & & & & & $x$ \\
\hline 10 & Base Model & & $x$ & $x$ & $x$ & $x$ & & & & & \\
\hline
\end{tabular}




\section{Historical Hydrology of the Tigris River System}

Hydrology of the Tigris River system has been significantly impacted by flows entering Iraq at the Turkey-Iraq border. Historical flow regime of the Tigris River at Mosul city before and after Mosul Dam operation in July 1986 is shown in Figure 102. Compared with the mean annual flow before Mosul Dam operation, the mean annual flow of the Tigris River system decreased by $12 \%$ after Mosul Dam operation in July 1986. Also, the mean annual discharge at Mosul city before 1984 was $701 \mathrm{~m}^{3} / \mathrm{s}$ and dropped to $596 \mathrm{~m}^{3} / \mathrm{s}$ afterwards. This is a 15\% decrease of the river discharge (Al-Ansari and Knutsson, 2011). This is because of the construction projects that have been built in Turkey after 1984 causing increased upstream utilization.

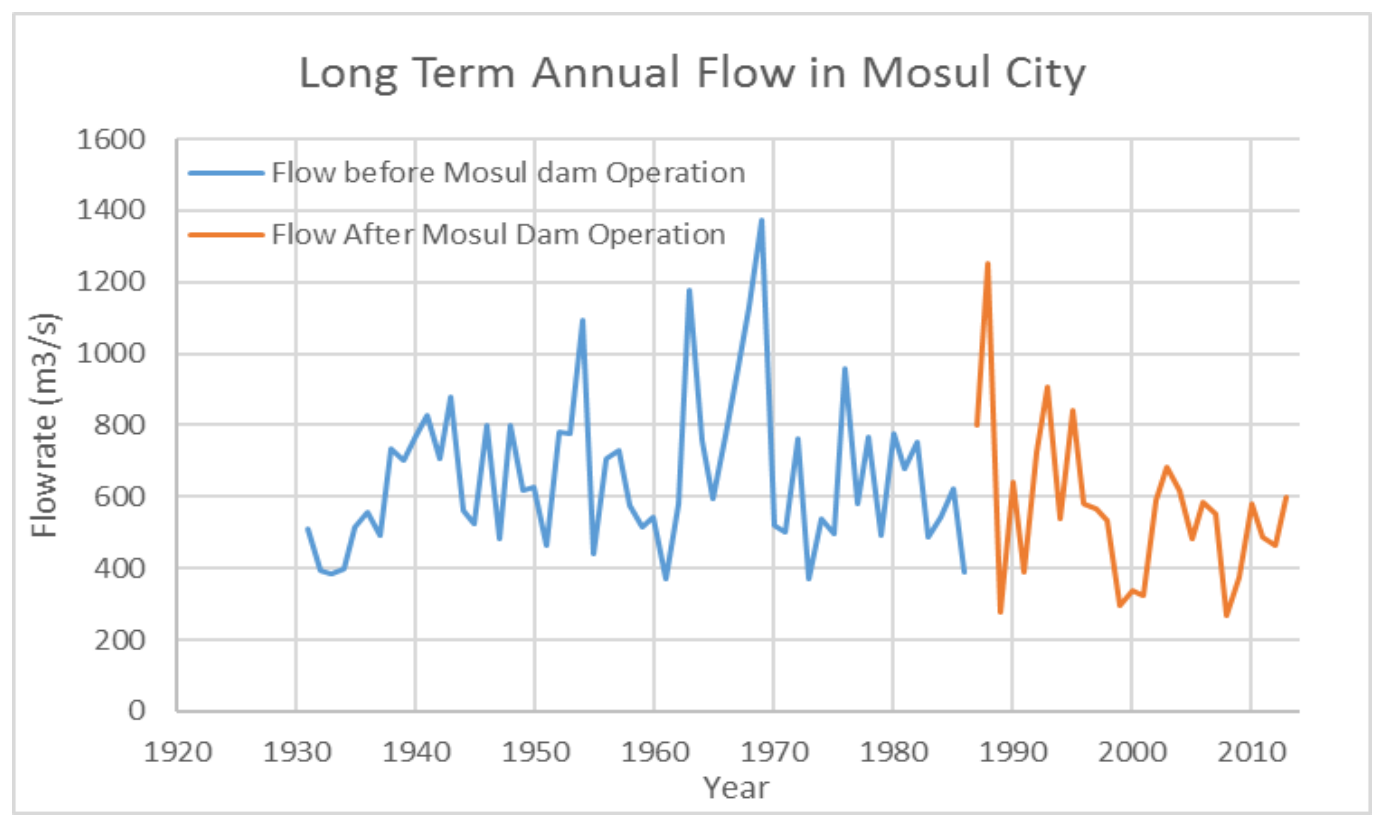

Figure 102: Historical flow regime in Mosul city before and after Mosul Dam Operation. 


\section{Management Scenario 1: Increasing Upstream Flow}

Since the mean annual flow of the Tigris River system has decreased by $15 \%$ after the Mosul Dam was put into operation in July 1986, the first management scenario increased the mainstem flow by $15 \%$ and compared the results with the base. Figure 103 and Figure 104 show model predictions of management scenario 1 for total dissolved solids (TDS) and carbonaceous biological oxygen demand (CBOD) at Samarra Barrage, Baghdad city, Kut Barrage, and Tharthar Lake. Model predictions for water temperature $\left(\mathrm{T}_{\mathrm{w}}\right)$, phosphate (PO4), ammonium (NH4), nitrate (NO3), dissolved oxygen (DO), and chlorophyll-a are shown in appendix A. Predictions of management scenario 1 were compared with the base model of the Tigris River system.

Due to an increase in upstream flowrate, most of water quality constituents were decreased compared with the base model with the exception of water temperature and DO. Since TDS is a conservative state variable and decreased by dilution, TDS concentrations decreased from $495 \mathrm{mg} / \mathrm{l}$ to $470 \mathrm{mg} / \mathrm{l}$ in the mainstem and from $1239 \mathrm{mg} / \mathrm{l}$ to $1226 \mathrm{mg} / \mathrm{l}$ in Tharthar Lake. CBOD concentrations decreased from $5.9 \mathrm{mg} / \mathrm{l}$ to $5.74 \mathrm{mg} / \mathrm{l}$.

No major changes were observed in water temperature predictions in scenario 1 with an average temperature changed from $20.7^{\circ} \mathrm{C}$ to $20.8^{\circ} \mathrm{C}$ over all the mainstem of the river. No major changes were observed in model predictions for nutrients with a negligible decrease in $\mathrm{PO} 4, \mathrm{NH} 4$, and $\mathrm{NO} 3$ by $0.1 \%, 0.1 \%$, and $1.3 \%$, respectively in the mainstem of the Tigris River. Also, DO and Chl-a concentrations increased negligibly over all the mainstem of the river from $8.15 \mathrm{mg} / \mathrm{l}$ to $8.2 \mathrm{mg} / \mathrm{l}$ and from $1.97 \mu \mathrm{g} / \mathrm{l}$ to $2 \mu \mathrm{g} / \mathrm{l}$, respectively. 

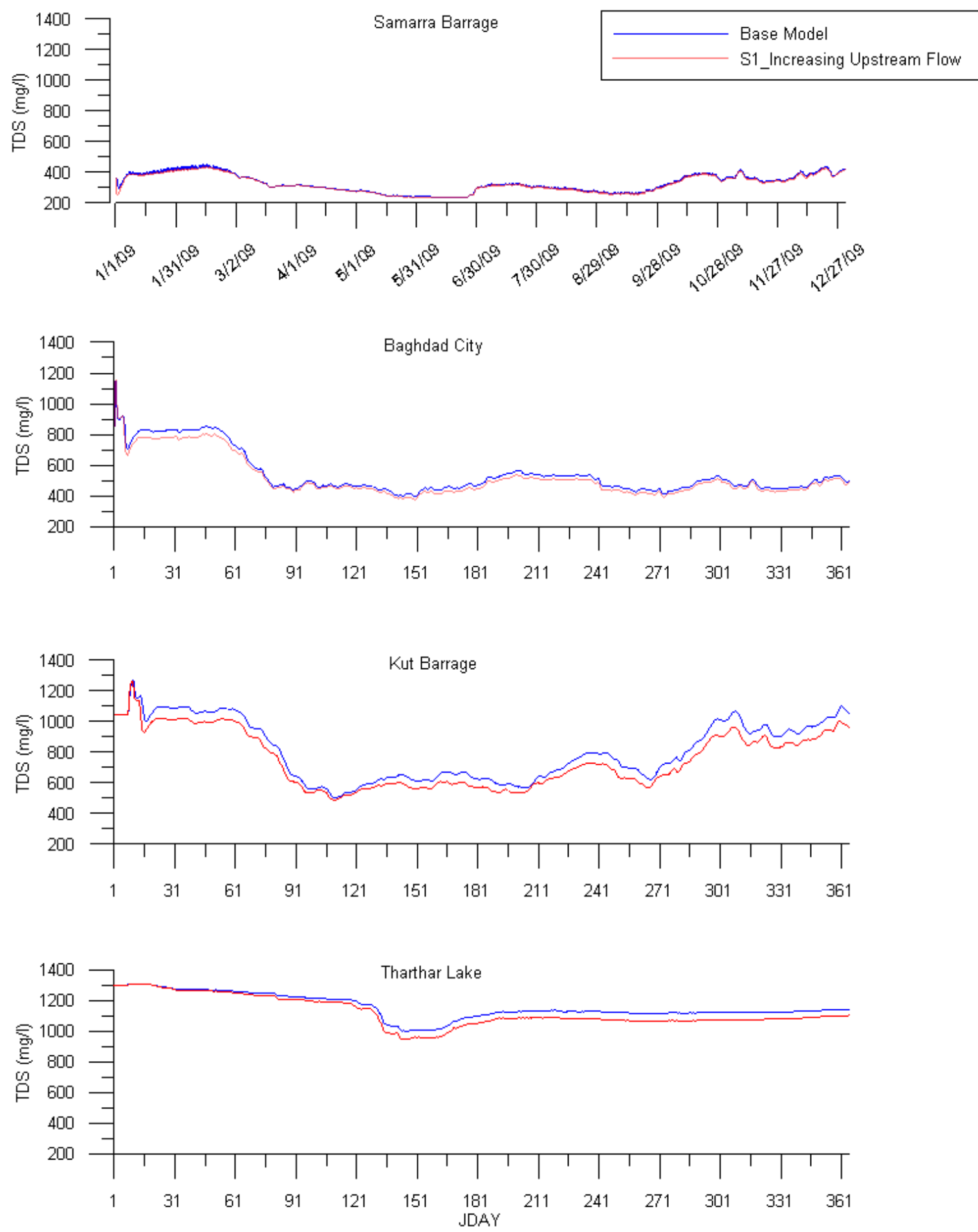

Figure 103: Model total dissolved solids (TDS) predictions for base model and management scenario 1 (increasing upstream flow) at Samarra Barrage, Baghdad City, Kut Barrage, and Tharthar Lake. 

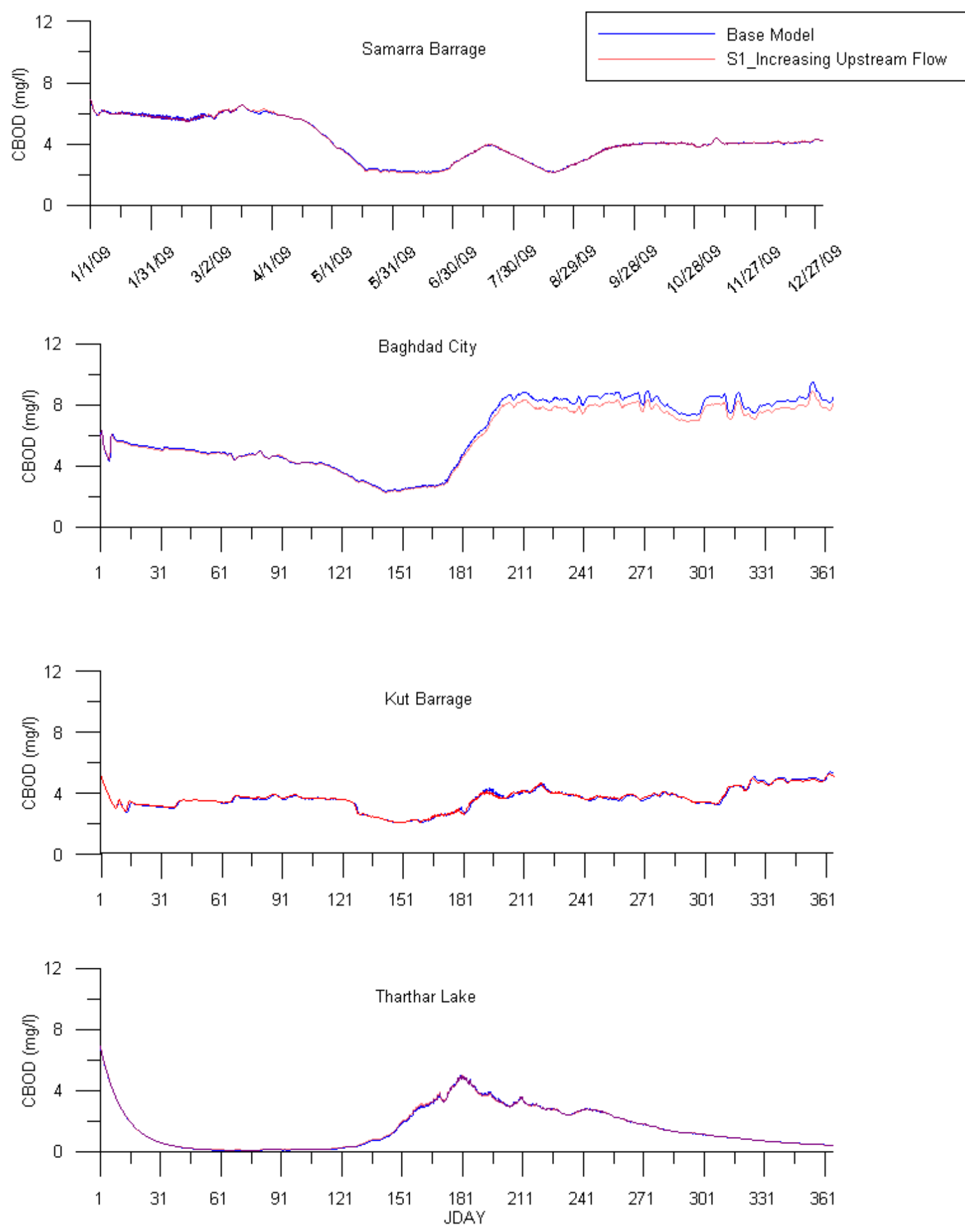

Figure 104: Model carbonaceous biological oxygen demand (CBOD) predictions for base model and management scenario 1 (increasing upstream flow) at Samarra Barrage, Baghdad City, Kut Barrage, and Tharthar Lake. 


\section{Management Scenario 2: Decreasing Upstream Flow}

The upstream flow boundary condition of the Tigris River system at Mosul Dam was decreased by $15 \%$ to study the effect of altering flow on the mainstem of the river and thereby also decreasing the flow to Tharthar Lake. Figure 105 through Figure 109 show model predictions of management scenario 2 for total dissolved solids, phosphate, ammonium, nitrate, and carbonaceous biological oxygen demand, respectively at Samarra Barrage, Baghdad city, Kut Barrage, and Tharthar Lake. Model predictions for water temperature, dissolved oxygen, and chlorophyll-a are shown in appendix A. Predictions of management scenario 2 were compared with the base model of the Tigris River system.

As was expected, concentrations of the most of water quality constituents increased with decreasing upstream flow at Mosul Dam due to decrease in dilution. TDS concentrations were increased from $495 \mathrm{mg} / \mathrm{l}$ to $527 \mathrm{mg} / \mathrm{l}$ in the mainstem and from $1239 \mathrm{mg} / \mathrm{l}$ to 1253 $\mathrm{mg} / \mathrm{l}$ in Tharthar Lake. Concentrations of $\mathrm{PO} 4, \mathrm{NH} 4$, and $\mathrm{NO} 3$ in the mainstem were increased from $0.35 \mathrm{mg} / \mathrm{l}, 0.23 \mathrm{mg} / \mathrm{l}$, and $1.54 \mathrm{mg} / \mathrm{l}$ to $0.36 \mathrm{mg} / \mathrm{l}, 0.25 \mathrm{mg} / \mathrm{l}$, and $1.57 \mathrm{mg} / \mathrm{l}$, respectively. CBOD concentrations increased from $5.9 \mathrm{mg} / \mathrm{l}$ to $6.2 \mathrm{mg} / \mathrm{l}$. There was no significant impact on water temperature, dissolved oxygen, and chlorophyll-a. 

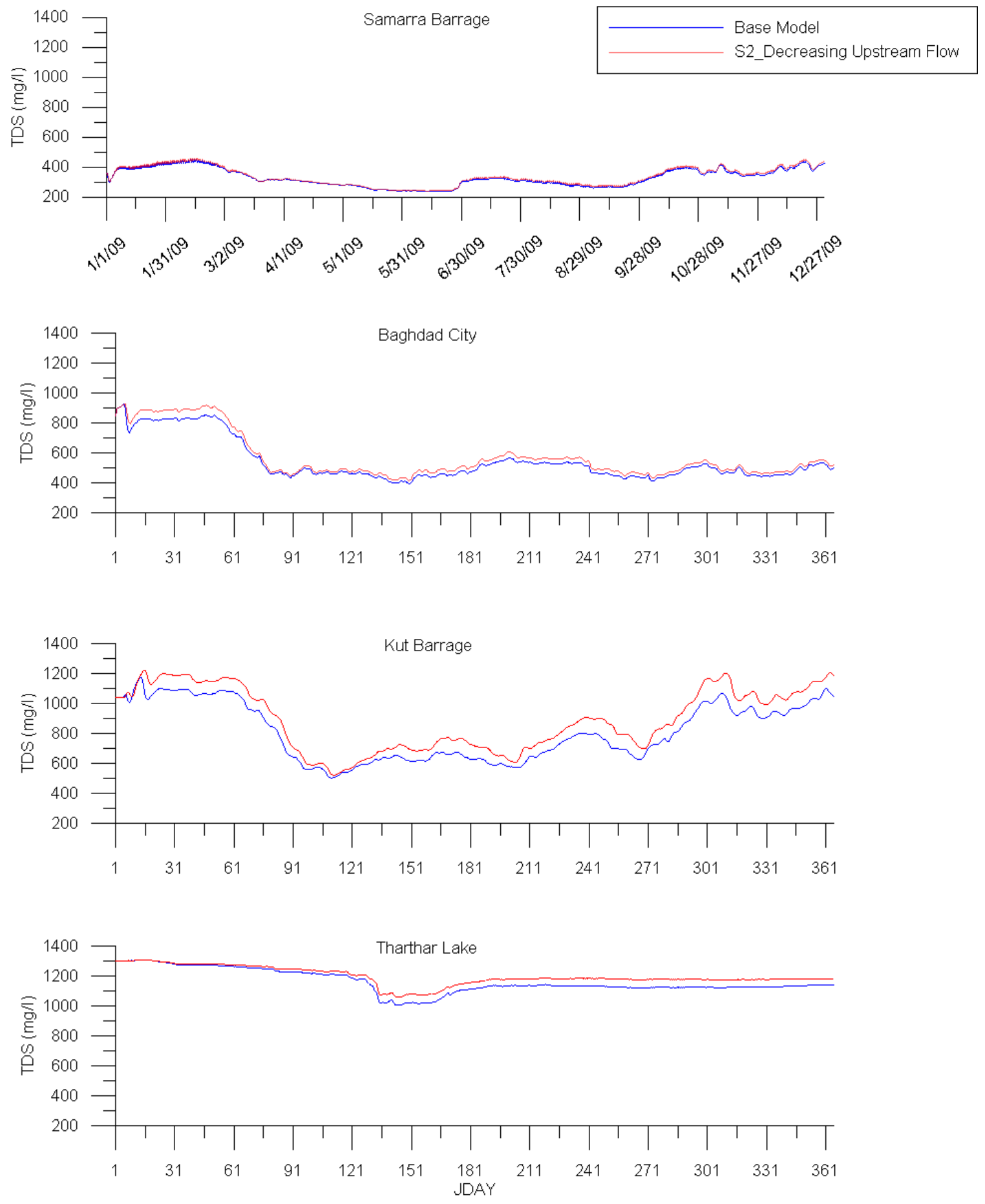

Figure 105: Model total dissolved solids (TDS) predictions for base model and management scenario 2 (decreasing upstream flow) at Samarra Barrage, Baghdad City, Kut Barrage, and Tharthar Lake. 

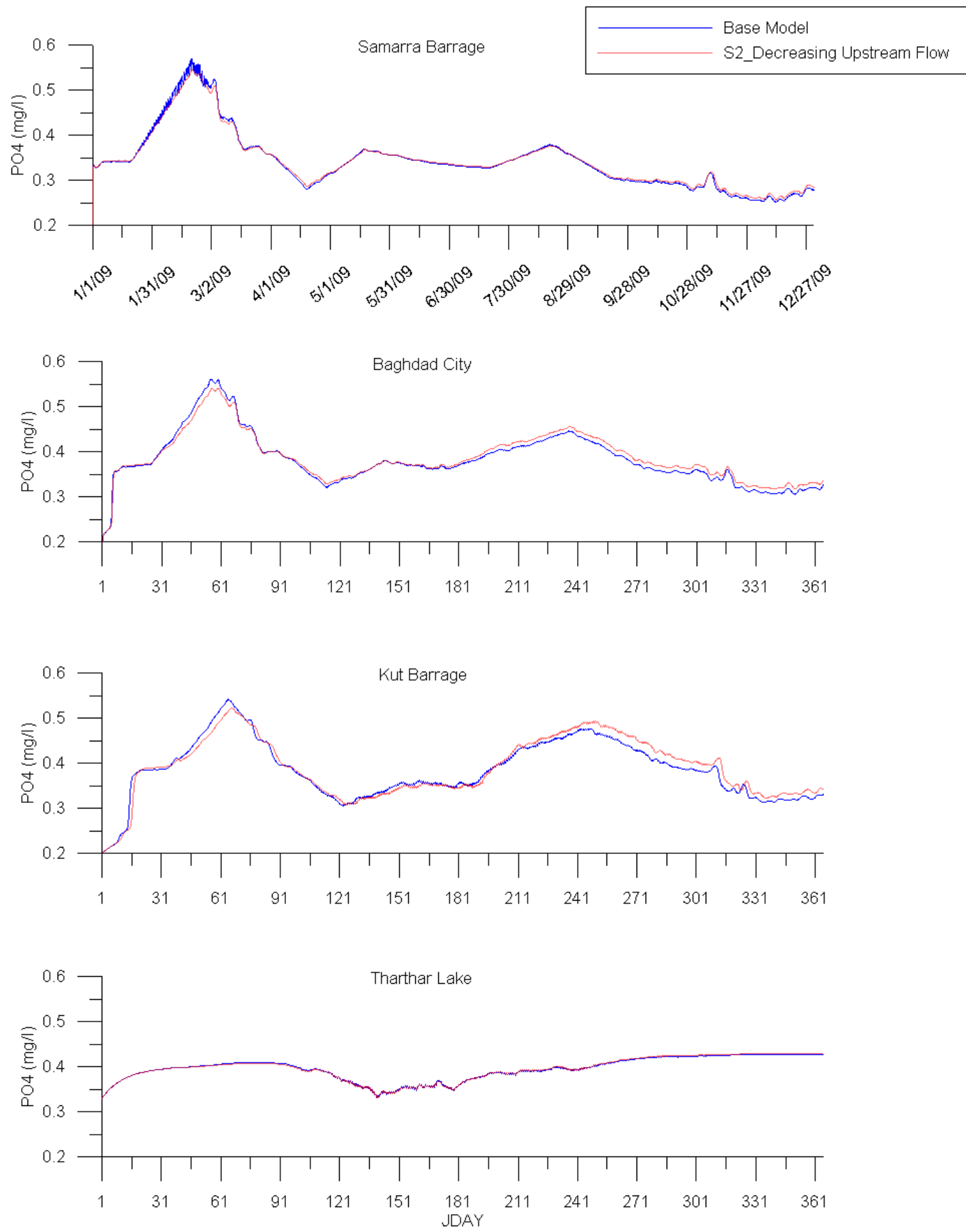

Figure 106: Model phosphate (PO4) predictions for base model and management scenario 2 (decreasing upstream flow) at Samarra Barrage, Baghdad City, Kut Barrage, and Tharthar Lake. 

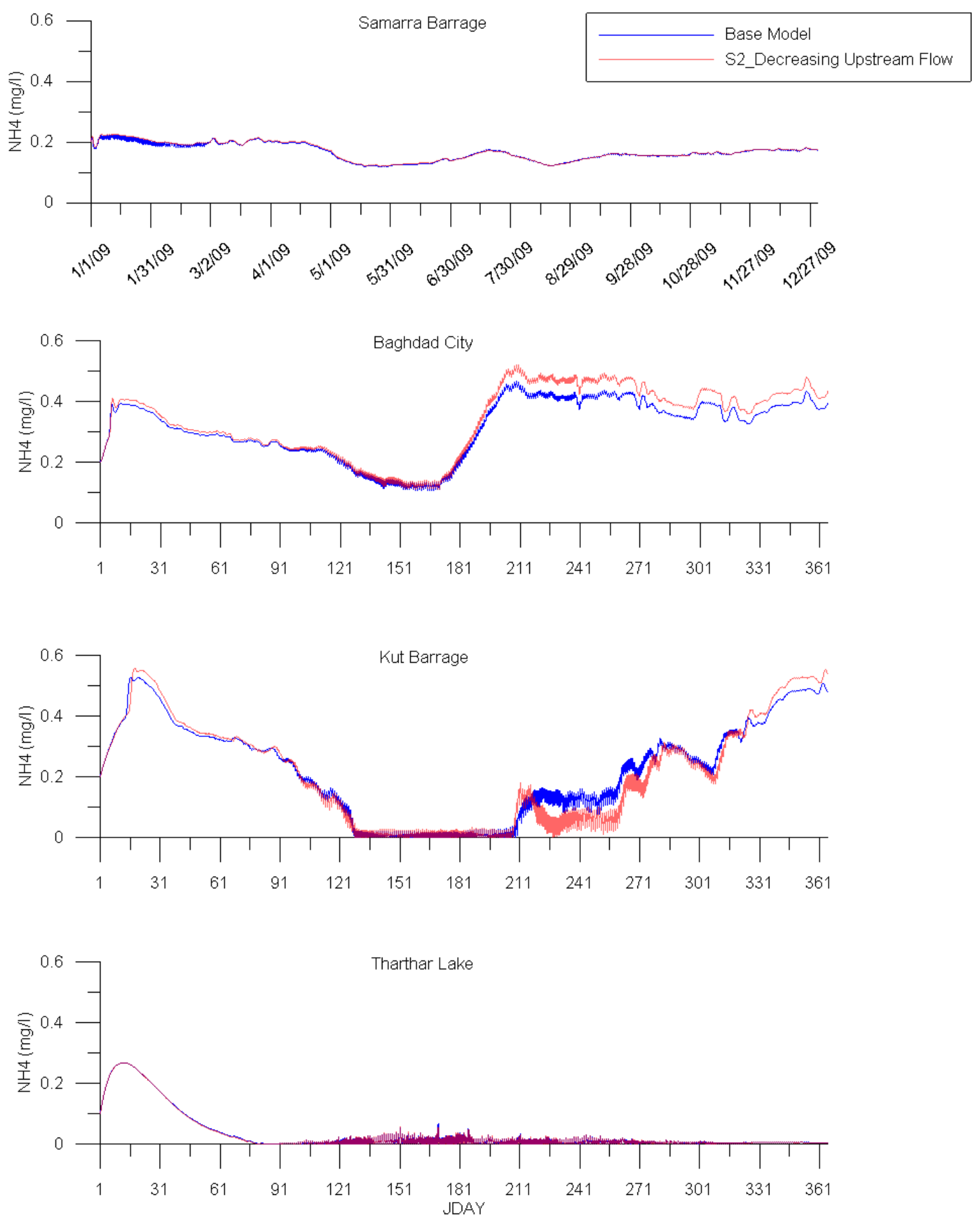

Figure 107: Model ammonia (NH4) predictions for base model and management scenario 2 (decreasing upstream flow) at Samarra Barrage, Baghdad City, Kut Barrage, and Tharthar Lake. 

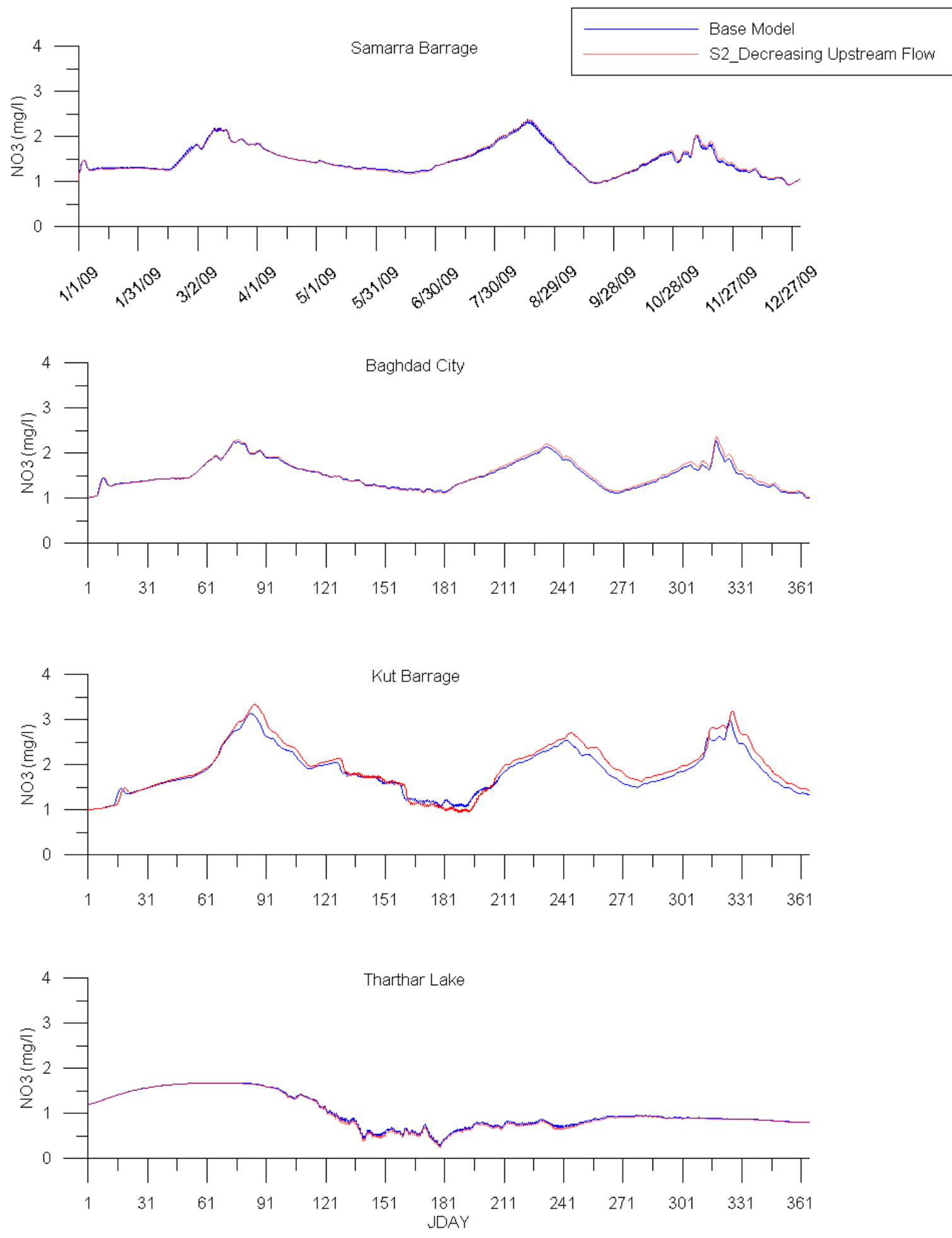

Figure 108: Model nitrate (NO3) predictions for base model and management scenario 2 (decreasing upstream flow) at Samarra Barrage, Baghdad City, Kut Barrage, and Tharthar Lake. 

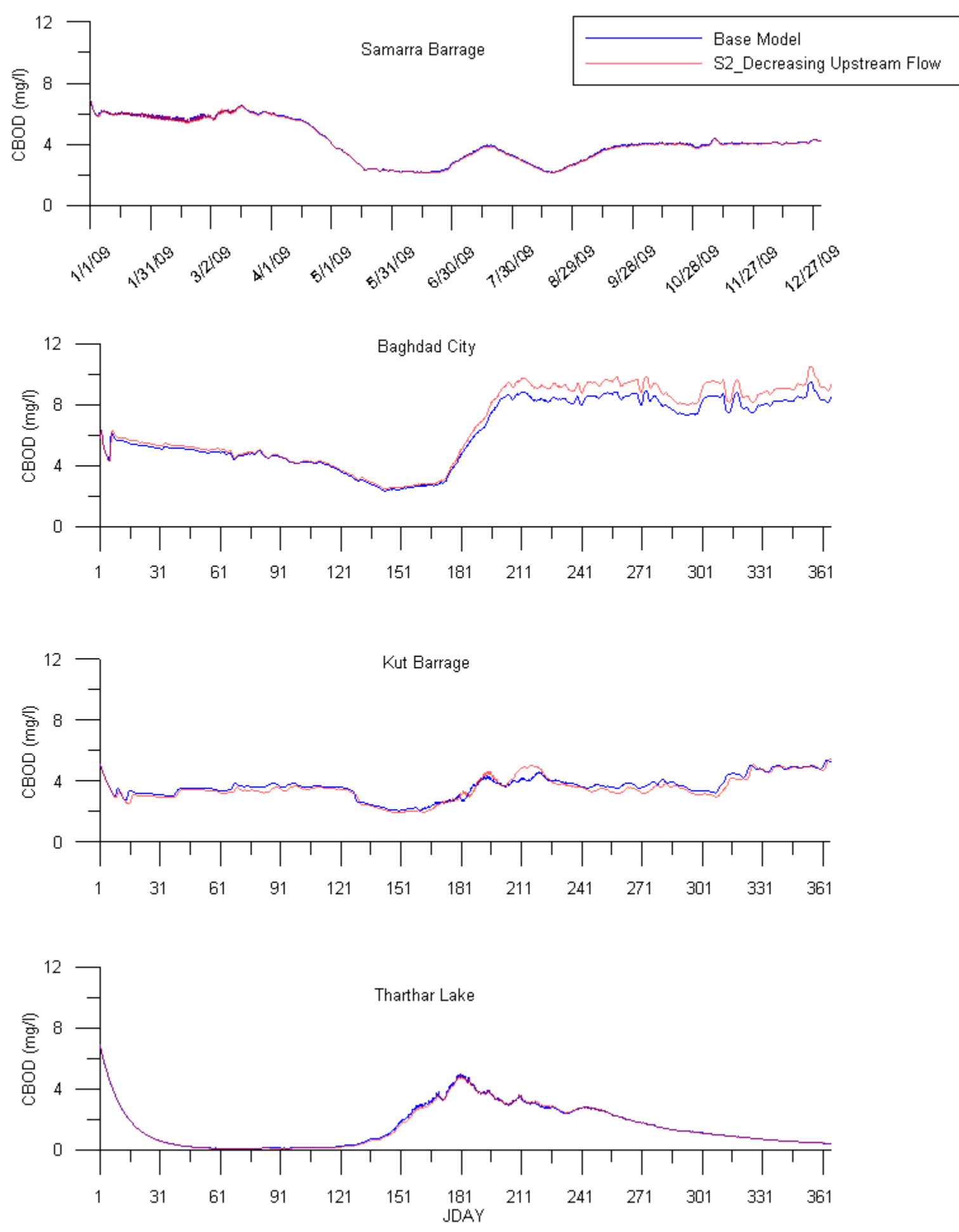

Figure 109: Model carbonaceous biological oxygen demand (CBOD) predictions for base model and management scenario 2 (decreasing upstream flow) at Samarra Barrage, Baghdad City, Kut Barrage, and Tharthar Lake. 


\section{Management Scenario 3: Decreasing Upstream Flow and Increasing Nutrients}

Assuming a future increase in nutrient concentrations at Mosul Dam, a 10\% increase in phosphate, ammonium, and nitrate concentrations was implemented along with a $15 \%$ decrease in upstream flow boundary conditions at Mosul Dam. Figure 110 through Figure 114 show model predictions of management scenario 3 for total dissolved solids, phosphate, ammonium, nitrate, and carbonaceous biological oxygen demand, respectively, at Samarra Barrage, Baghdad city, Kut Barrage, and Tharthar Lake. Model predictions for water temperature, dissolved oxygen, and chlorophyll-a are shown in appendix A. Predictions of management scenario 3 were compared with the base model of the Tigris River system.

In this scenario, a similar trend in water quality concentrations was noticed as in scenario 2 with a slight increase in nutrient concentrations. Compared with the base model, TDS concentrations increased by $9 \%$ in the mainstem and by $1.2 \%$ in Tharthar Lake. Concentrations of $\mathrm{PO} 4, \mathrm{NH} 4$, and $\mathrm{NO} 3$ increased in the mainstem from $0.35 \mathrm{mg} / \mathrm{l}, 0.23$ $\mathrm{mg} / \mathrm{l}$, and $1.54 \mathrm{mg} / \mathrm{l}$ to $0.37 \mathrm{mg} / \mathrm{l}, 0.25 \mathrm{mg} / \mathrm{l}$, and $1.63 \mathrm{mg} / \mathrm{l}$ respectively. CBOD concentrations increased from $5.9 \mathrm{mg} / \mathrm{l}$ to $6.2 \mathrm{mg} / \mathrm{l}$. There were no significant impacts on water temperature and dissolved oxygen. 

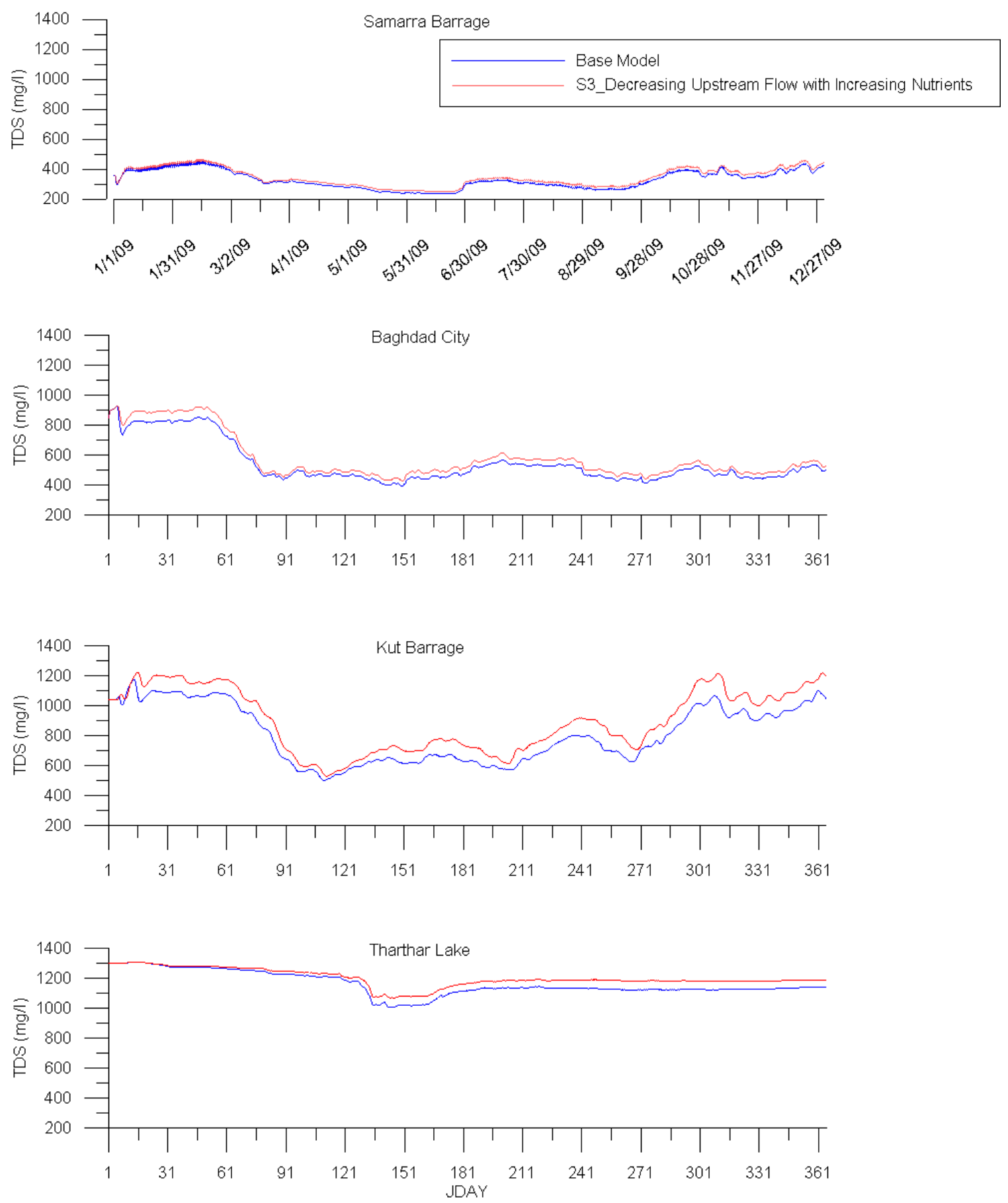

Figure 110: Model total dissolved solids (TDS) predictions for base model and management scenario 3 (decreasing upstream flow with increasing nutrients) at Samarra Barrage, Baghdad City, Kut Barrage, and Tharthar Lake. 

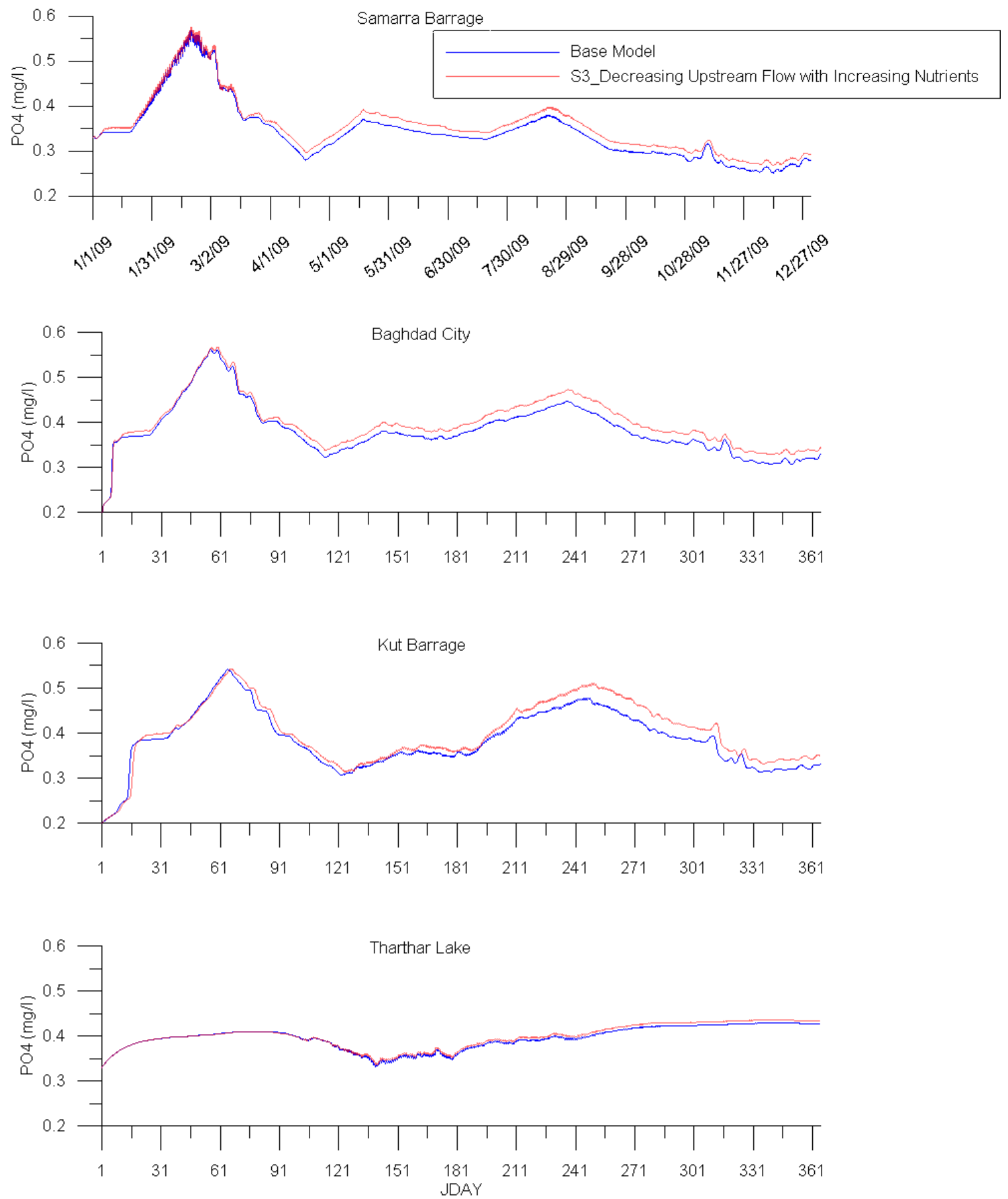

Figure 111: Model phosphate (PO4) predictions for base model and management scenario 3 (decreasing upstream flow with increasing nutrients) at Samarra Barrage, Baghdad City, Kut Barrage, and Tharthar Lake. 

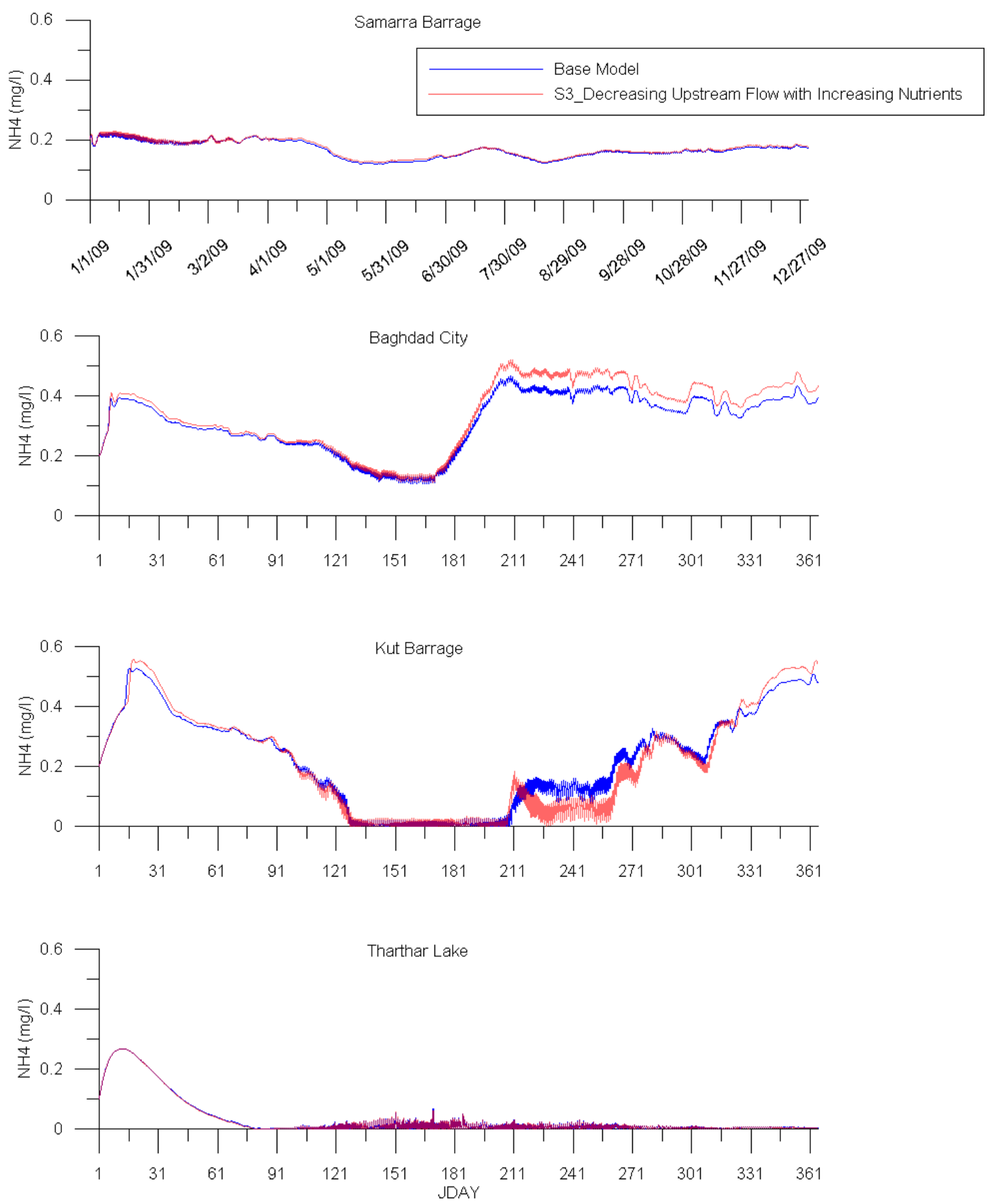

Figure 112: Model ammonia (NH4) predictions for base model and management scenario 3 (decreasing upstream flow with increasing nutrients) at Samarra Barrage, Baghdad City, Kut Barrage, and Tharthar Lake. 

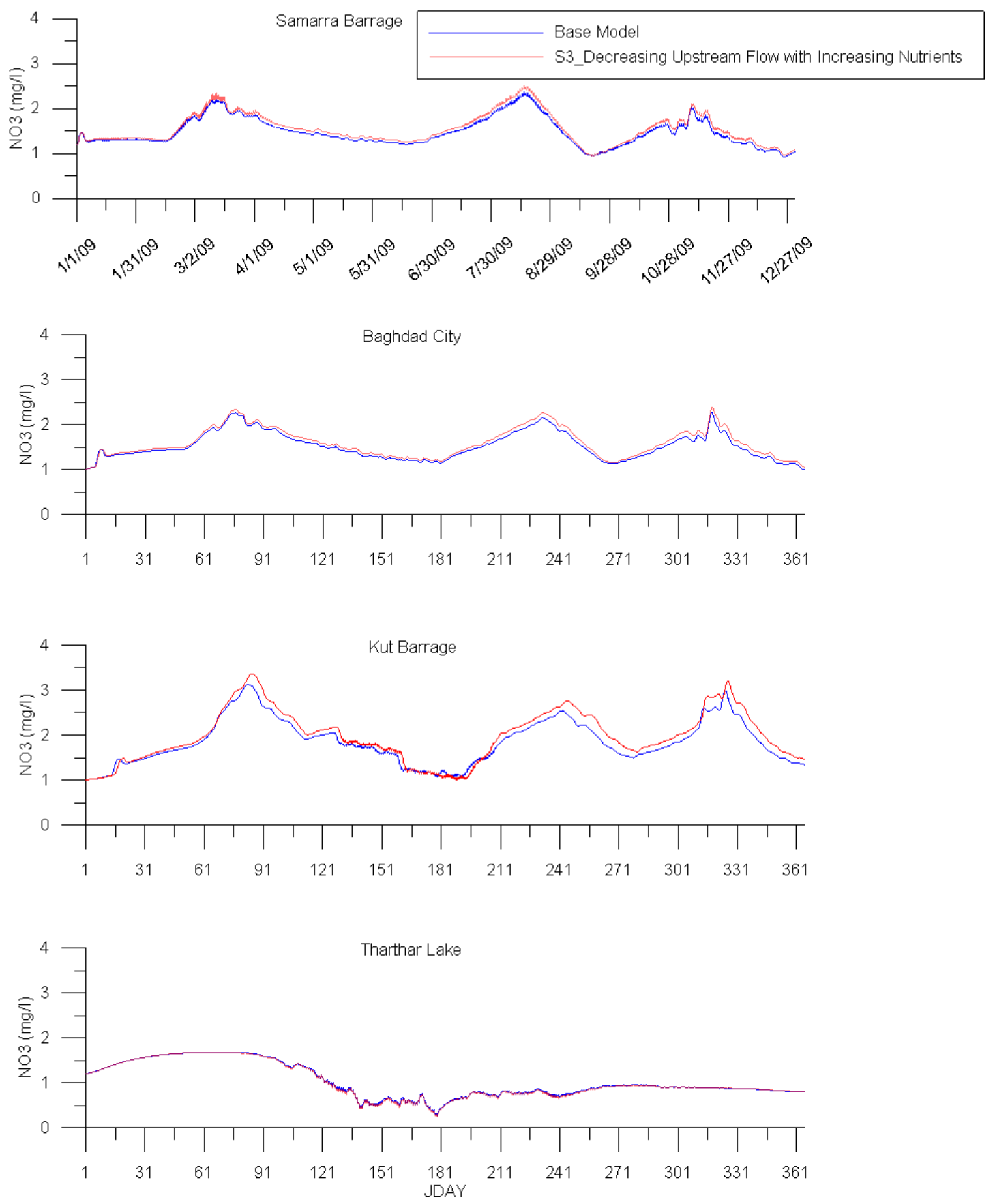

Figure 113: Model nitrate (NO3) predictions for base model and management 3 (decreasing upstream flow with increasing nutrients) at Samarra Barrage, Baghdad City, Kut Barrage, and Tharthar Lake. 

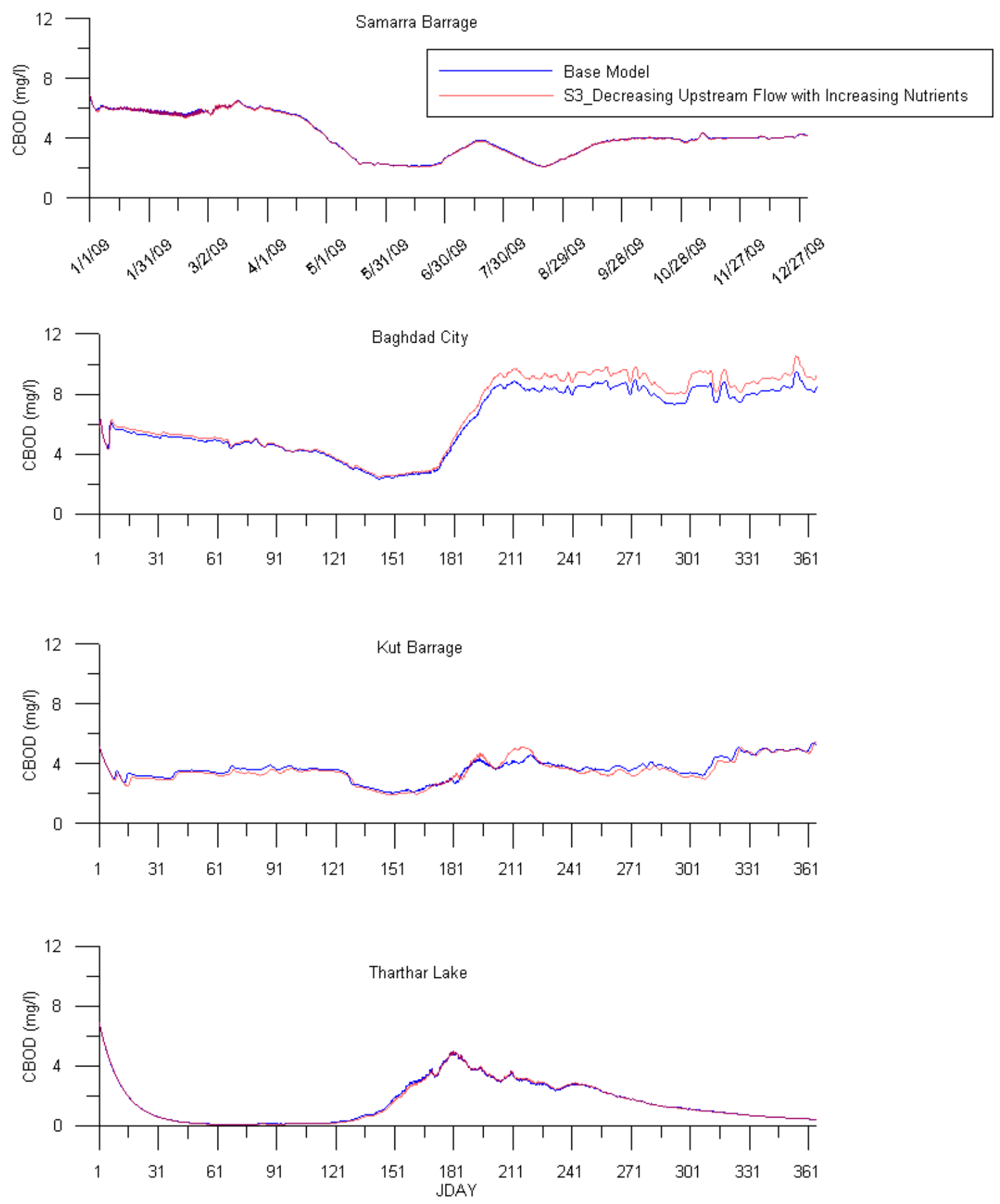

Figure 114: Model carbonaceous biological oxygen demand (CBOD) predictions for base model and management scenario 3 (decreasing upstream flow with increasing nutrients) at Samarra Barrage, Baghdad City, Kut Barrage, and Tharthar Lake. 


\section{Management Scenario 4: Increasing Tharthar Lake's Flow}

In this management scenario, a 10\% increase in flow was diverted from Samarra barrage to Tharthar Lake through Tigris-Tharthar canal to study the effect of increasing the lake's flow on Tharthar Lake and the mainstem of the Tigris River downstream Samarra Barrage. Figure 115 shows model predictions of management scenario 4 for total dissolved solids at Samarra Barrage, Baghdad city, Kut Barrage, and Tharthar Lake. Model predictions of phosphate, ammonium, nitrate, carbonaceous biological oxygen demand, and chlorophylla are shown in appendix A. Predictions of management scenario 4 were compared with the base model of the Tigris River system.

There was no substantial impact on TDS concentrations in the mainstem with an average concentration decreased from $495 \mathrm{mg} / \mathrm{l}$ to $493 \mathrm{mg} / \mathrm{l}$, while a decrease from $1239 \mathrm{mg} / \mathrm{l}$ to $1231 \mathrm{mg} / \mathrm{l}$ was recorded in Tharthar Lake. There were no major changes in water temperature, nutrients, CBOD, DO, and Chl-a. 

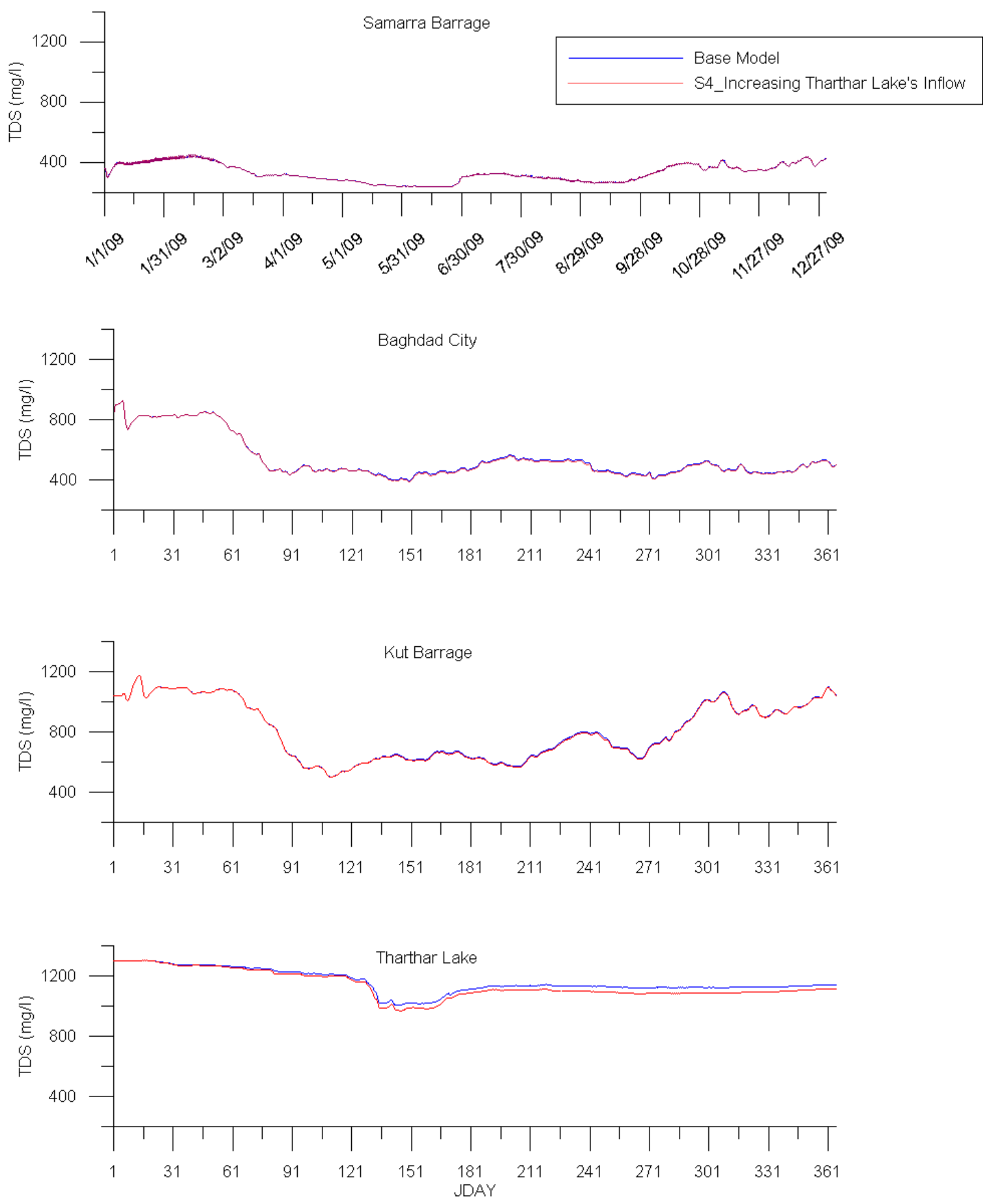

Figure 115: Model total dissolved solids (TDS) predictions for base model and management scenario 4 (increasing Tharthar Lake's inflow) at Samarra Barrage, Baghdad City, Kut Barrage, and Tharthar Lake. 


\section{Management Scenario 5: The Effect of Climate Change}

Climate change was evaluated on the Tigris River system assuming that air temperature was increased by $2^{\circ} \mathrm{C}$. This affected all the meteorological input files for the Tigris River model. Assuming constant relative humidity, dew point temperatures were then estimated based on Equation 19:

Equation 19: Dew point Temperature estimation (Wanielista, 1997)

$T_{\text {dewpoint }}=\left(\frac{R H}{100}\right)^{\frac{1}{8}} *(112+0.9 * T)+0.1 * T-112$

Figure 116 shows the new dewpoint temperatures compared with that of the base model at Mosul, Baeji, and Baghdad cities. The average change in dew point temperature over the simulated year 2009 at Mosul, Baeji, and Baghdad cities are 24\%, 22\%, and 24\%, respectively. The climate change management scenario was implemented and compared to the base model.

Figure 117 through Figure 119 show model predictions of management scenario 5 for water temperature, dissolved oxygen, and chlorophyll-a respectively at Samarra Barrage, Baghdad city, Kut Barrage, and Tharthar Lake. Model predictions of total dissolved solids, phosphate, ammonium, nitrate, and carbonaceous biological oxygen demand are shown in appendix A. Predictions of management scenario 5 were compared with the base model of the Tigris River system.

Water temperature increased by $5 \%$ with an average temperature increased from $20.7^{\circ} \mathrm{C}$ to $21.7^{\circ} \mathrm{C}$ in the mainstem and from $17.44^{\circ} \mathrm{C}$ to $18.35^{\circ} \mathrm{C}$ in Tharthar Lake. On the other hand, DO concentrations decreased from $8.15 \mathrm{mg} / \mathrm{l}$ to $7.98 \mathrm{mg} / \mathrm{l}$ and from $6.98 \mathrm{mg} / \mathrm{l}$ to $6.66 \mathrm{mg} / \mathrm{l}$ in the mainstem and Tharthar Lake, respectively. Chl-a concentrations slightly 
increased in the mainstem due to climate change effect with an average concentration changed from $1.97 \mu \mathrm{g} /$ to $2 \mu \mathrm{g} / \mathrm{l}$. There was no significant change in the average TDS, nutrients, and CBOD concentrations in the mainstem and in the lake.
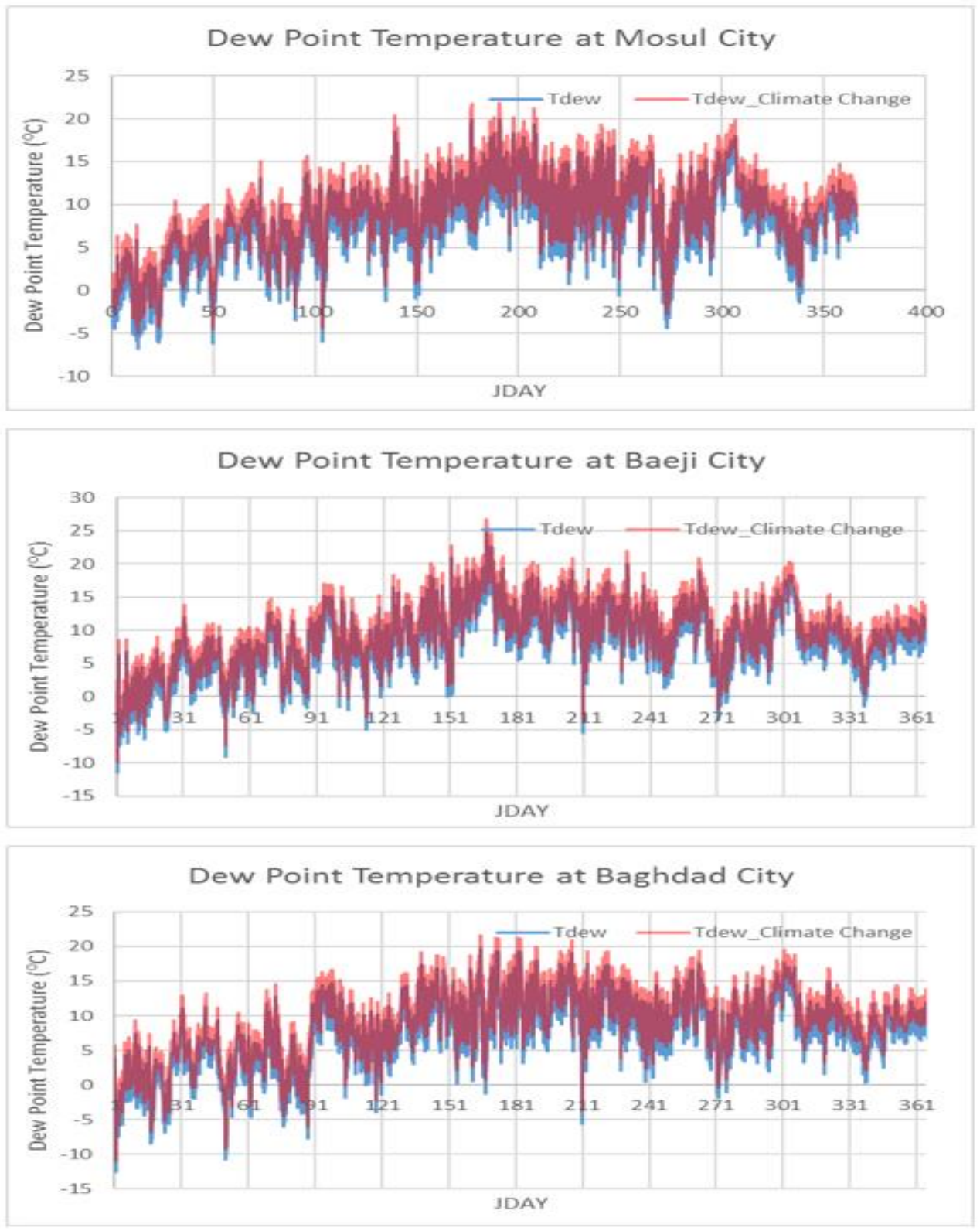

Figure 116: Dew point temperature of the base model and management scenario 5 (Climate Change) at Mosul, Baeji, and Baghdad cities in 2009. 

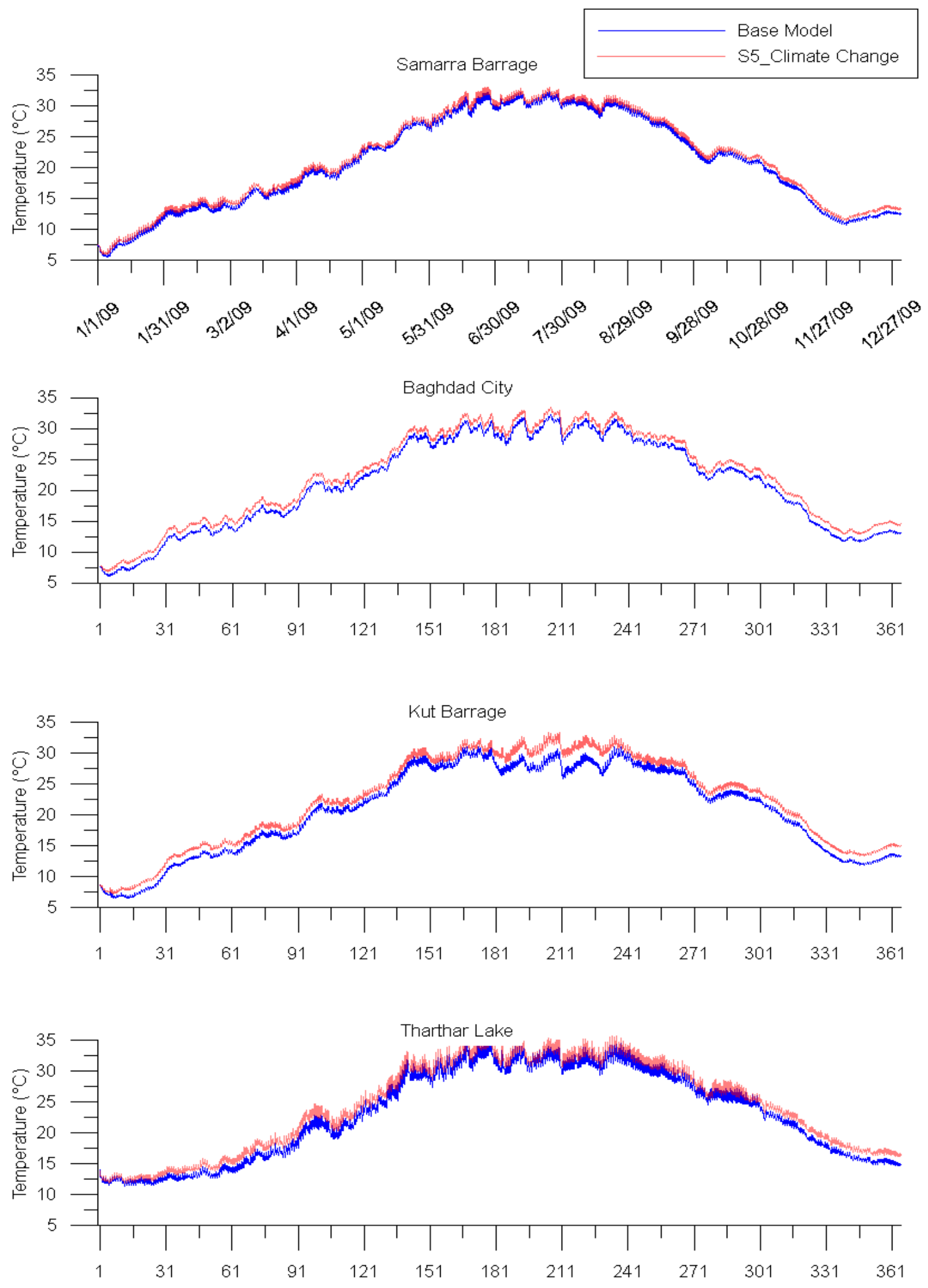

Figure 117: Model water temperature (T) predictions for base model and management scenario 5 (climate change) at Samarra Barrage, Baghdad City, Kut Barrage, and Tharthar Lake. 

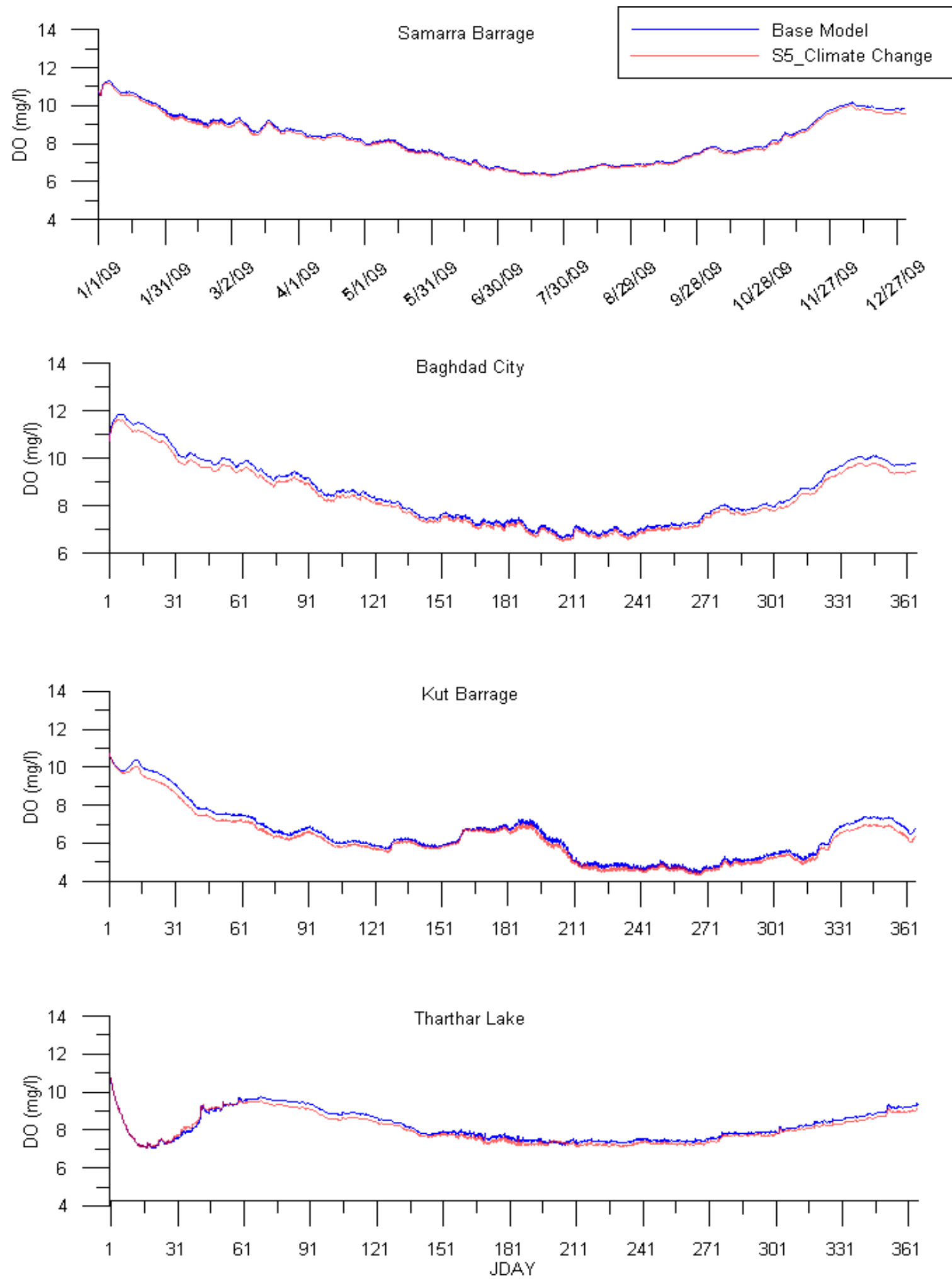

Figure 118: Model dissolved oxygen (DO) predictions for base model and management scenario 5 (climate change) at Samarra Barrage, Baghdad City, Kut Barrage, and Tharthar Lake. 

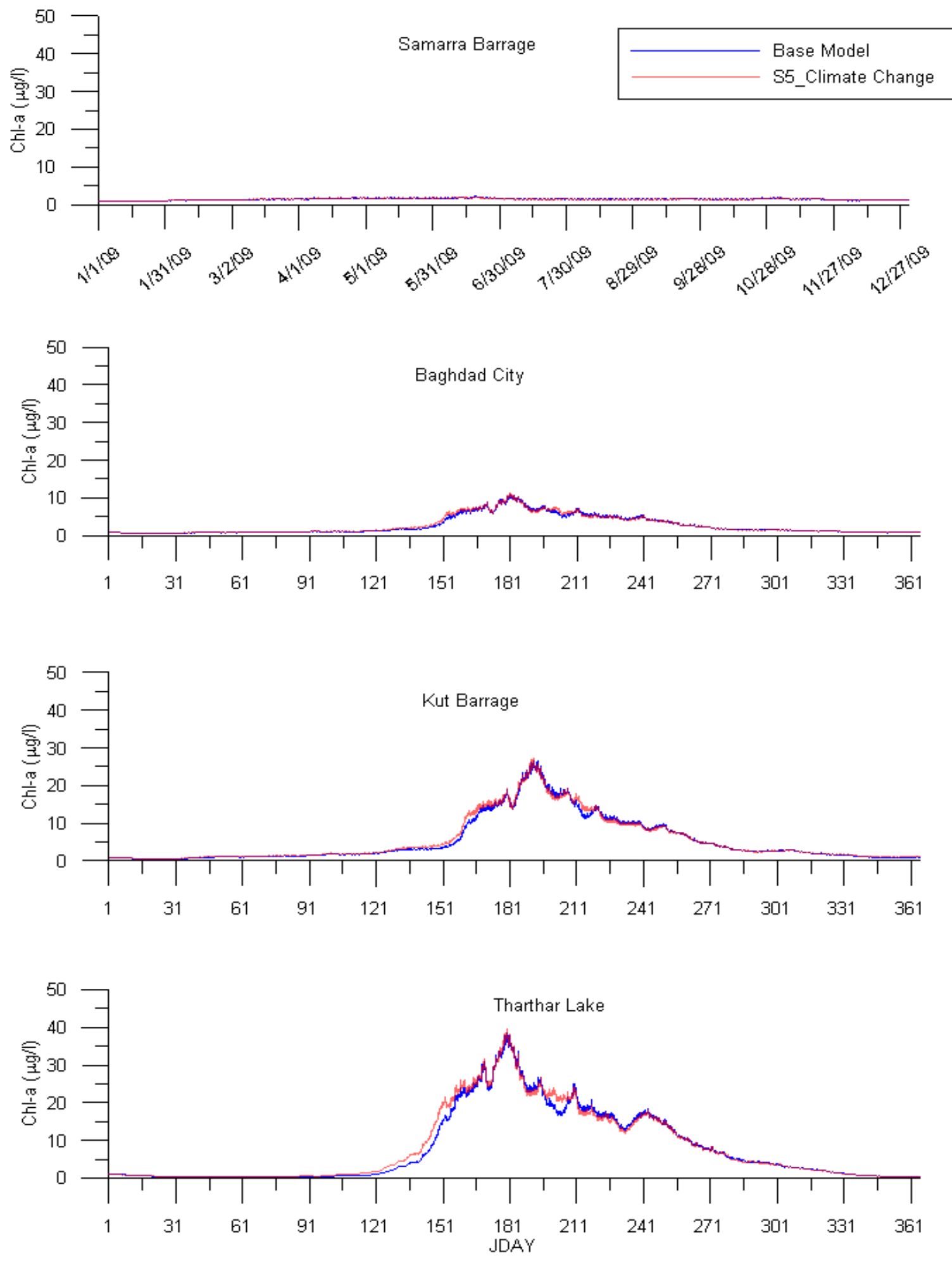

Figure 119: Model chlorophyll-a (Chl-a) predictions for base model and management scenario 5 (climate change) at Samarra Barrage, Baghdad City, Kut Barrage, and Tharthar Lake. 


\section{Management Scenario 6: The Effect of Climate Change with Decreasing Upstream Flow}

In this management scenario, the effect of climate change was implemented along with an expected decrease in the system's hydrology. Upstream flow boundary conditions at Mosul

Dam were decreased by $15 \%$. Like scenario 5 , a $2^{\circ} \mathrm{C}$ increase in air temperature and subsequent increase in dew point temperatures was implemented in this management scenario also. Figure 120 through Figure 124 show model predictions of management scenario 6 for water temperature, total dissolved solids, carbonaceous biological oxygen demand, dissolved oxygen, and chlorophyll-a, respectively, at Samarra Barrage, Baghdad city, Kut Barrage, and Tharthar Lake. Model predictions of phosphate, ammonium, and nitrate are shown in appendix A. Predictions of management scenario 6 were compared with the base model of the Tigris River system.

Like scenario 5, temperature predictions were warmer than the temperature predictions of the base model. There was also a corresponding decrease in DO concentrations in the Tigris River system was at all four stations. The average temperatures in the mainstem and Tharthar Lake were increased from $20.7^{\circ} \mathrm{C}$ and $17.44^{\circ} \mathrm{C}$ to $21.56^{\circ} \mathrm{C}$ and $18.37^{\circ} \mathrm{C}$ respectively. A $6.7 \%$ and $1.3 \%$ increase in TDS concentration were recorded in the mainstem and Tharthar Lake respectively. There was no major impact on $\mathrm{PO} 4, \mathrm{NH} 4$, and NO3 concentrations in the mainstem. On the other hand, CBOD concentrations increased from $6 \mathrm{mg} / \mathrm{l}$ to $6.15 \mathrm{mg} / \mathrm{l}$, while DO concentrations decreased from $8.15 \mathrm{mg} / \mathrm{l}$ to $7.93 \mathrm{mg} / \mathrm{l}$ in the mainstem. Chl-a concentrations decreased in the mainstem with an average concentration decreasing from $1.97 \mu \mathrm{g} / \mathrm{l}$ to $1.91 \mu \mathrm{g} / \mathrm{l}$. 

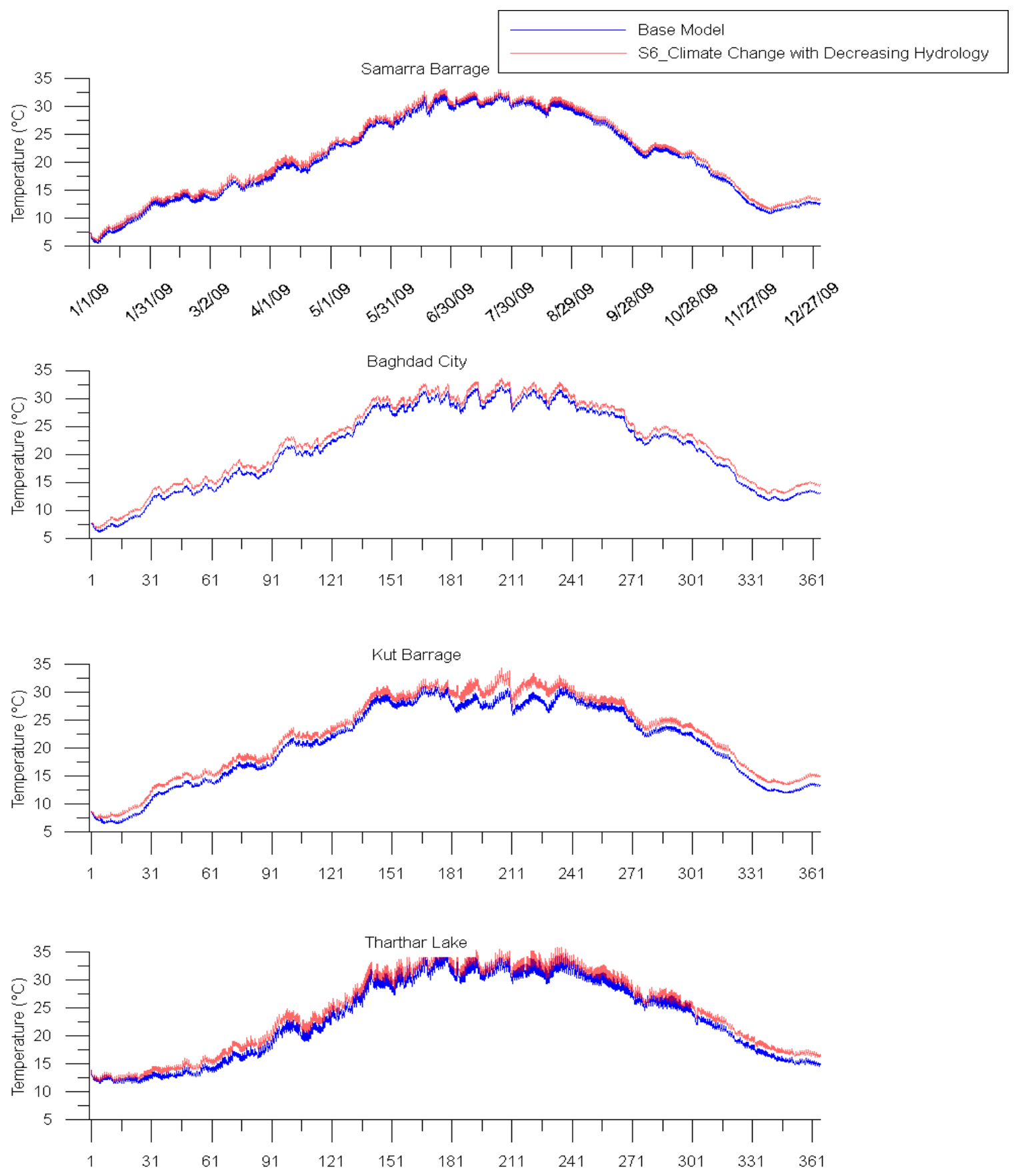

Figure 120: Model water temperature $\left(\mathrm{T}_{\mathrm{w}}\right)$ predictions for base model and management scenario 6 (climate change with decreasing hydrology) at Samarra Barrage, Baghdad City, Kut Barrage and Tharthar Lake. 

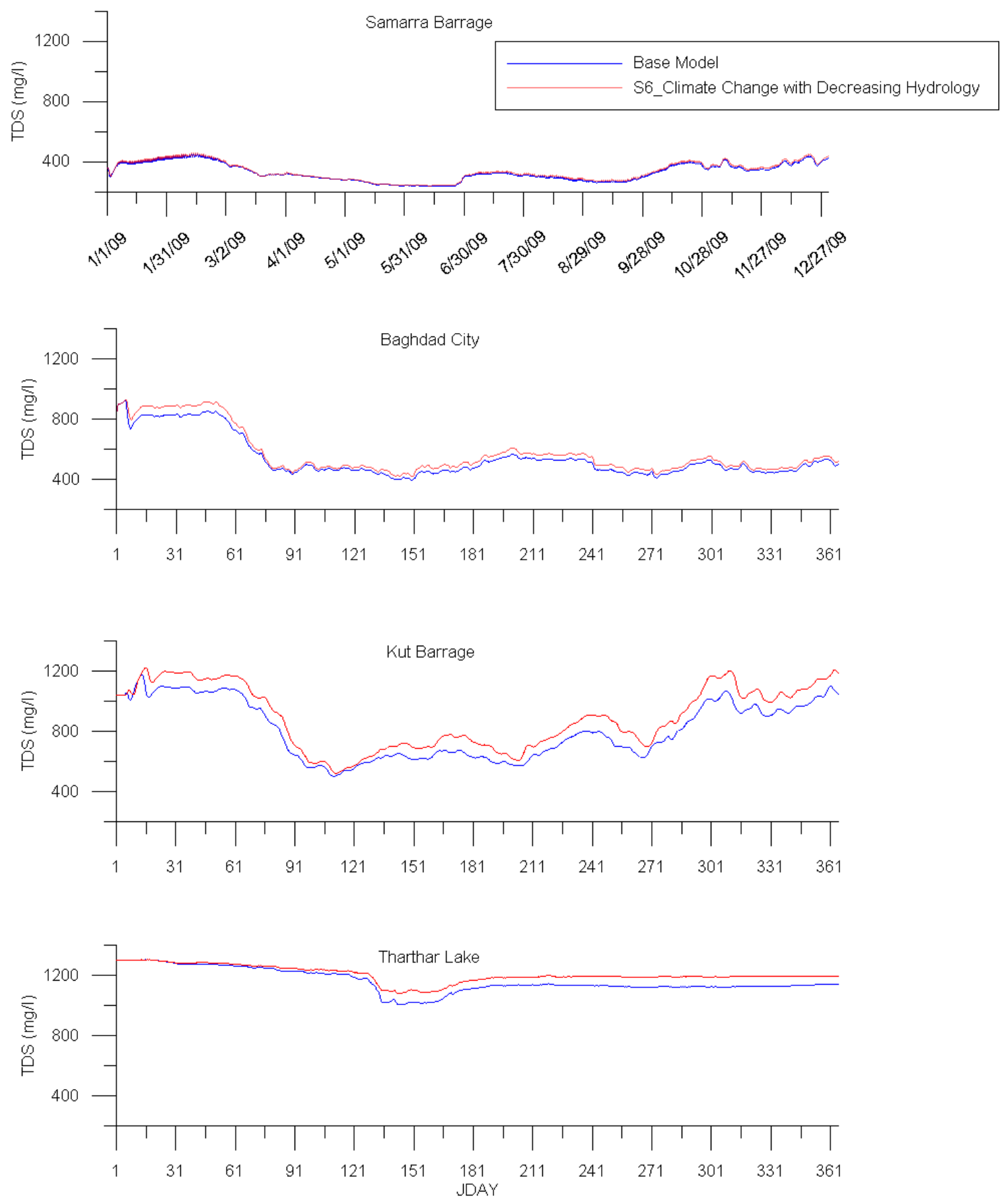

Figure 121 Model total dissolved solids (TDS) predictions for base model and management scenario 6 (climate change with decreasing hydrology) at Samarra Barrage, Baghdad City, Kut Barrage and Tharthar Lake. 

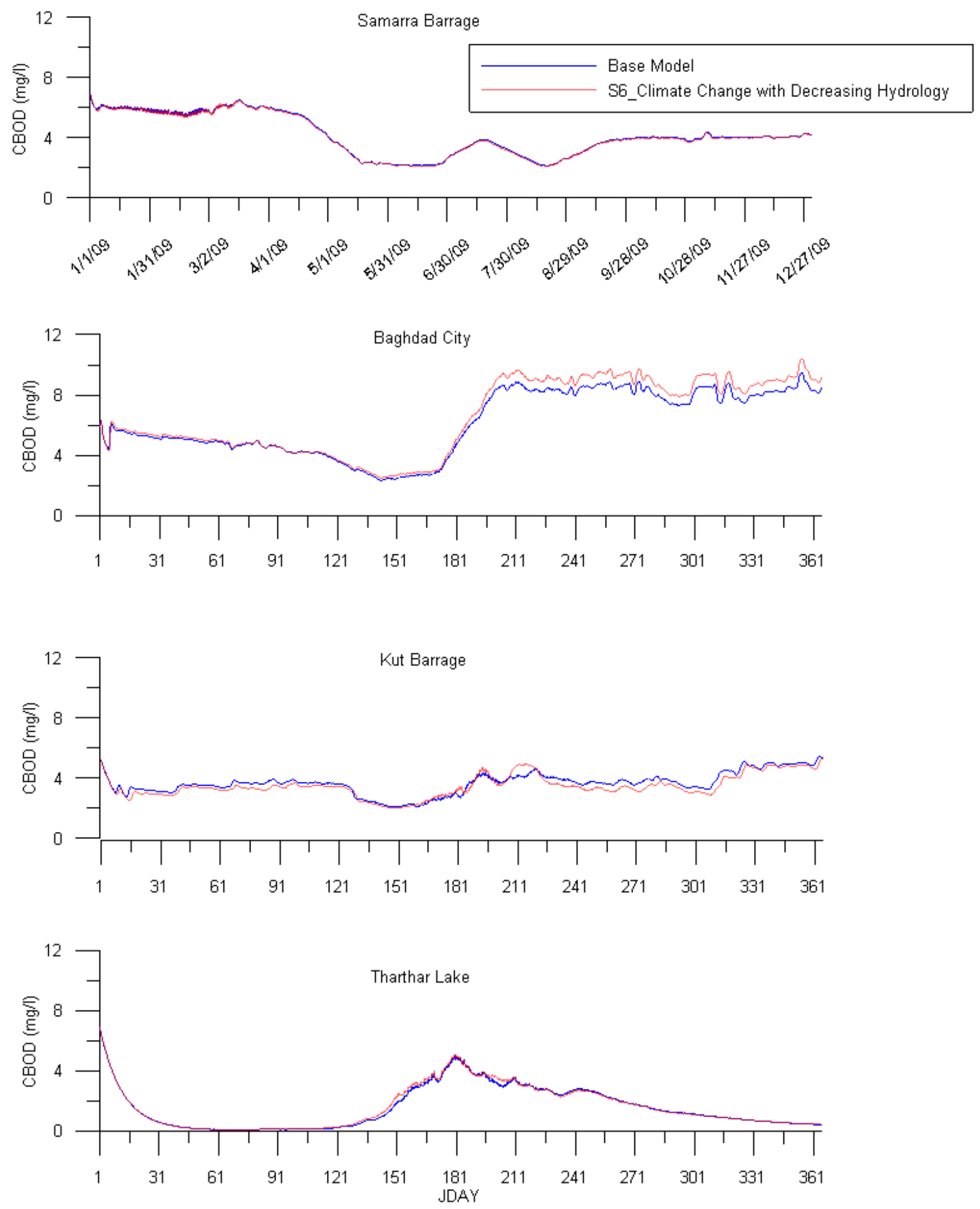

Figure 122: Model carbonaceous biological oxygen demand (CBOD) predictions for base model and management scenario 6 (climate change with decreasing hydrology) at Samarra Barrage, Baghdad City, Kut Barrage and Tharthar Lake. 

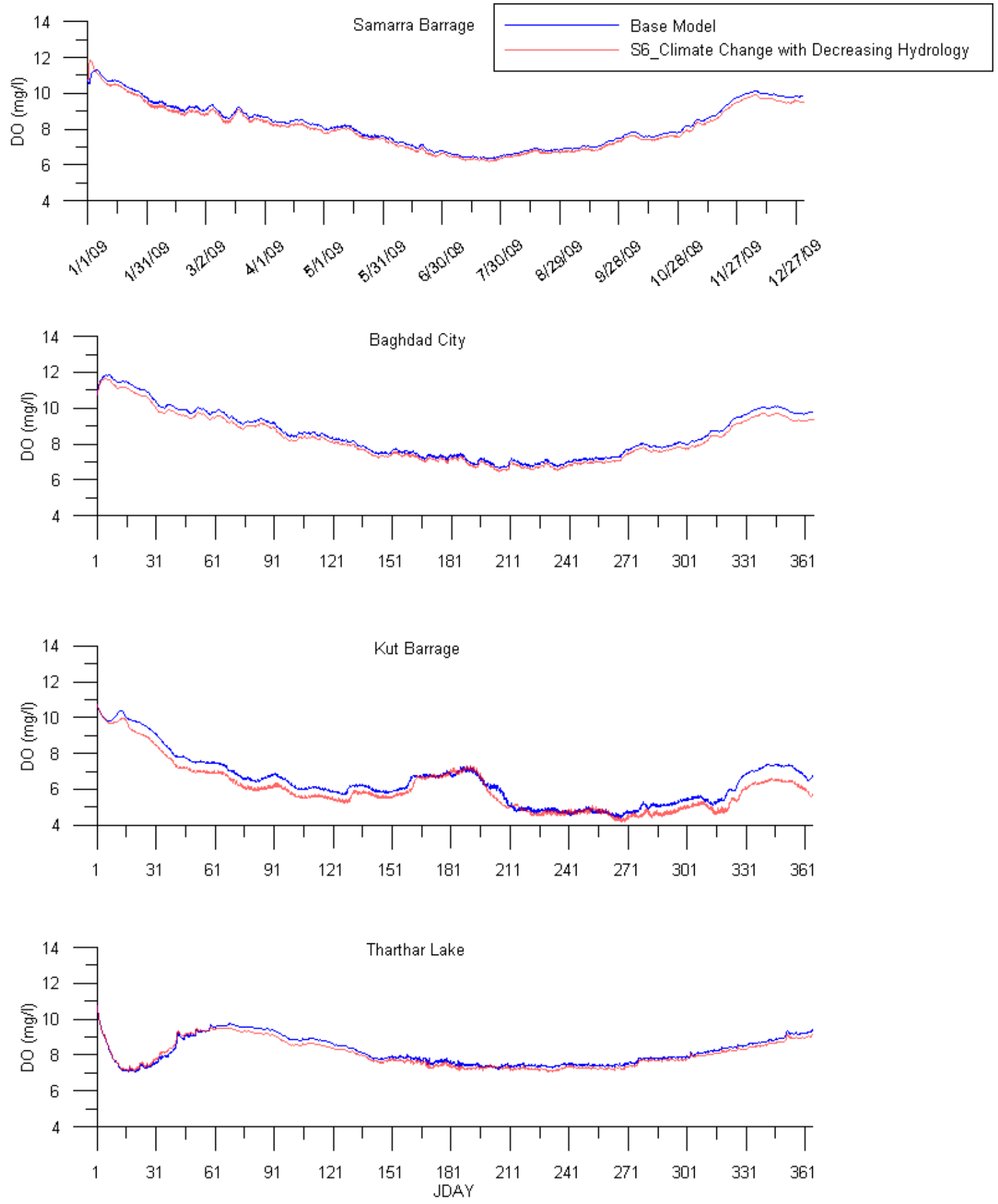

Figure 123: Model dissolved oxygen (DO) predictions for base model and management scenario 6 (climate change with decreasing hydrology) at Samarra Barrage, Baghdad City, Kut Barrage and Tharthar Lake. 

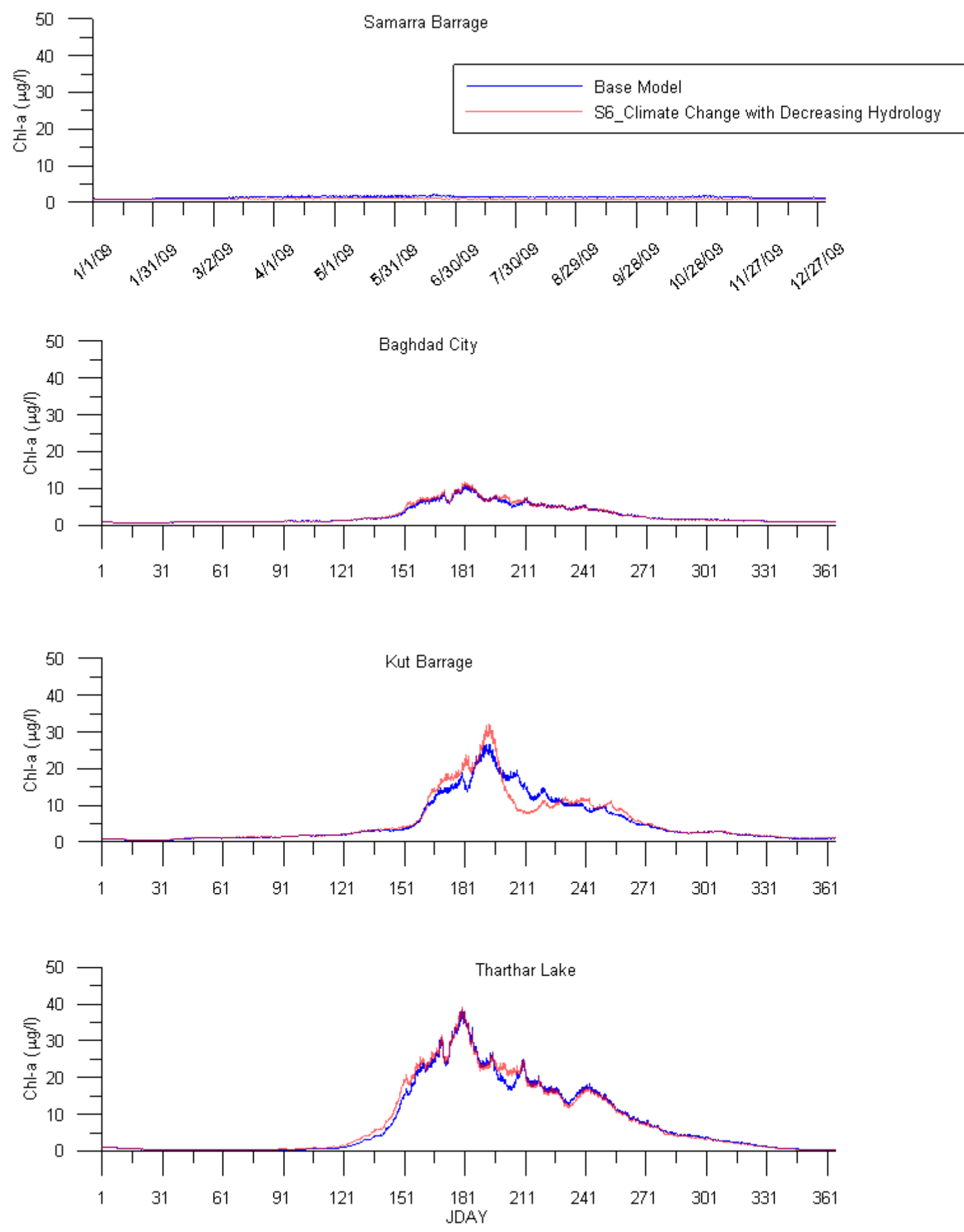

Figure 124 Model chlorophyll-a (Chl-a) predictions for base model and management scenario 6 (climate change with decreasing hydrology) at Samarra Barrage, Baghdad City, Kut Barrage and Tharthar Lake. 


\section{Management Scenario 7: Disconnecting Tharthar Lake}

To study the importance of Tharthar Lake on the Tigris River system and its water quality, Tharthar Lake and its canals (Tigris-Tharthar canal, Tharthar arm, and Tharthar-Tigris canal) were disconnected from the entire system. Figure 125 through Figure 128 show model predictions of management scenario 7 for total dissolved solids, carbonaceous biological oxygen demand, dissolved oxygen, and chlorophyll-a, respectively, at Samarra Barrage, Baghdad city, Kut Barrage. Model predictions of water temperature, phosphate, ammonium, nitrate are shown in appendix A. Predictions of management scenario 7 were compared with the base model of the Tigris River system.

There was a significant 25\% decrease in TDS concentrations in the mainstem due to a $36 \%$ increase in flow from Samarra Barrage to Baghdad city. CBOD concentrations decreased from $6 \mathrm{mg} / \mathrm{l}$ to $5.2 \mathrm{mg} / \mathrm{l}$ in the mainstem. Chl-a concentrations significantly decreased by $40 \%$ with an average concentration decreasing from $2 \mu \mathrm{g} / \mathrm{l}$ to $1.2 \mu \mathrm{g} / \mathrm{l}$. Figure 129 shows flow of the mainstem of the Tigris River at Samarra Barrage and Baghdad city. High volumes of water passed to Baghdad city through Samarra Barrage. There were no major changes noticed in the system's temperature and nutrients. 

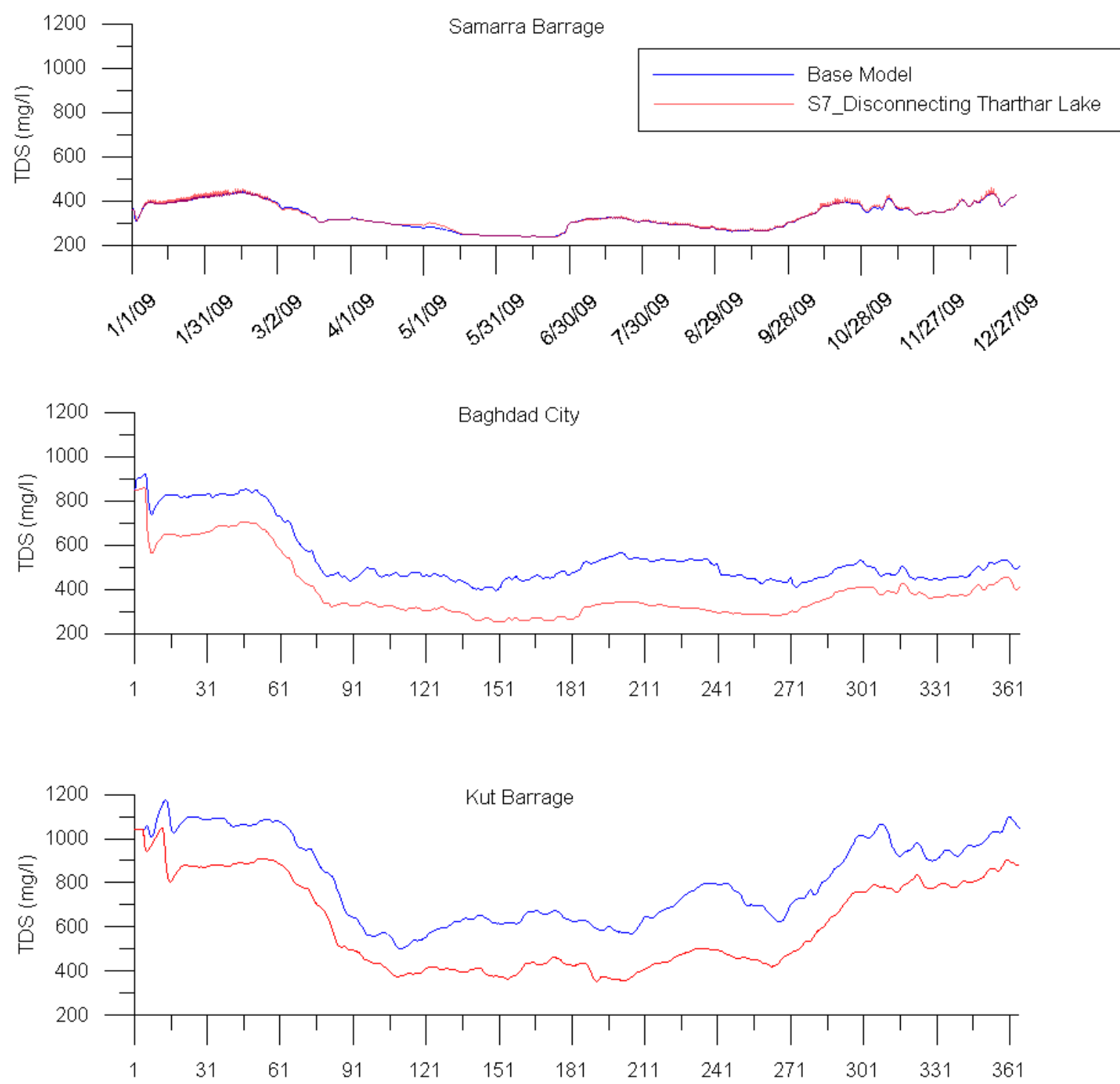

Figure 125 Model total dissolved solids (TDS) predictions for base model and management scenario 7 (disconnecting Tharthar Lake) at Samarra Barrage, Baghdad City, Kut Barrage. 

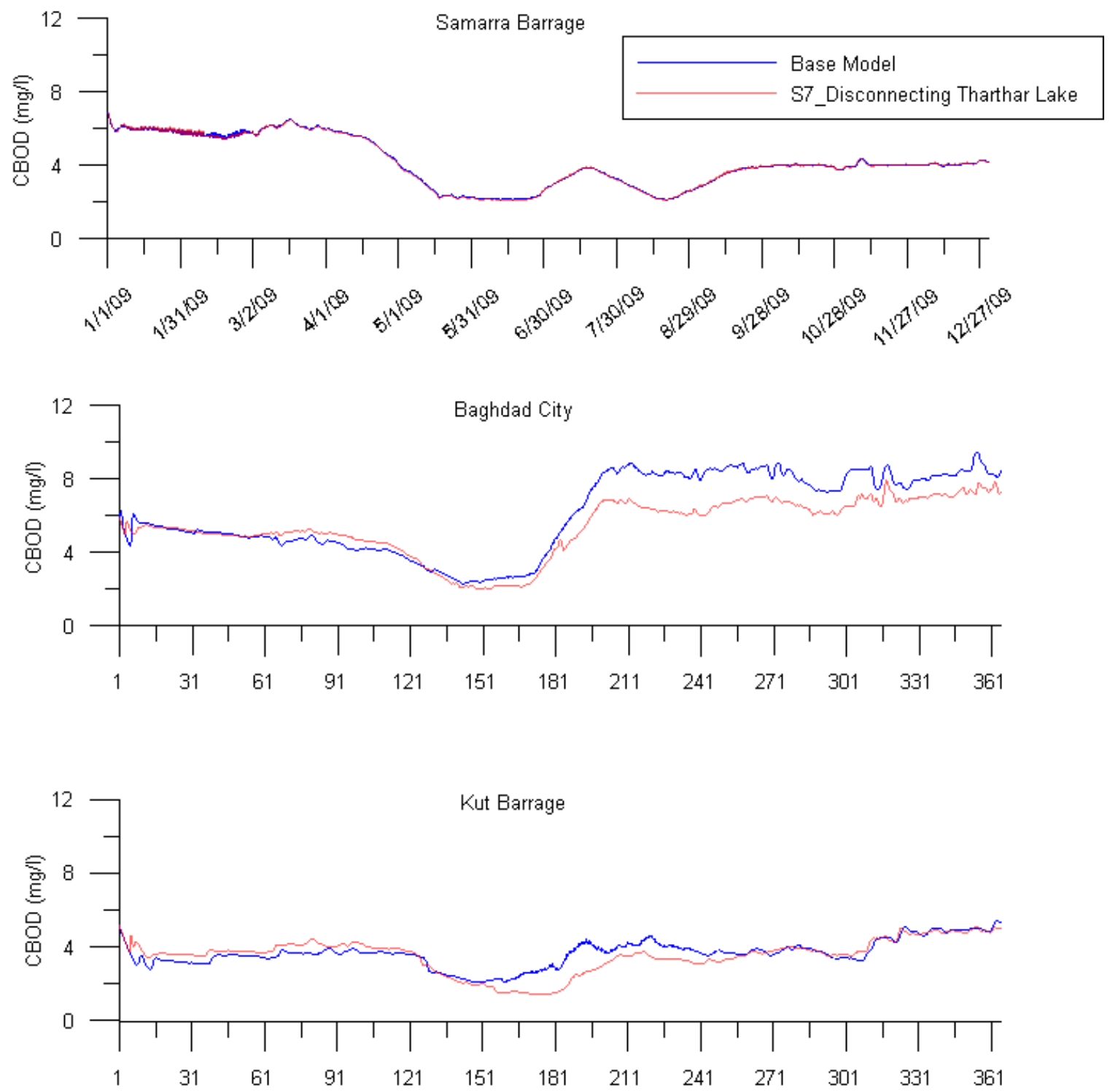

Figure 126: Model carbonaceous biological oxygen demand (CBOD) predictions for base model and management scenario 7 (disconnecting Tharthar Lake) at Samarra Barrage, Baghdad City, Kut Barrage. 

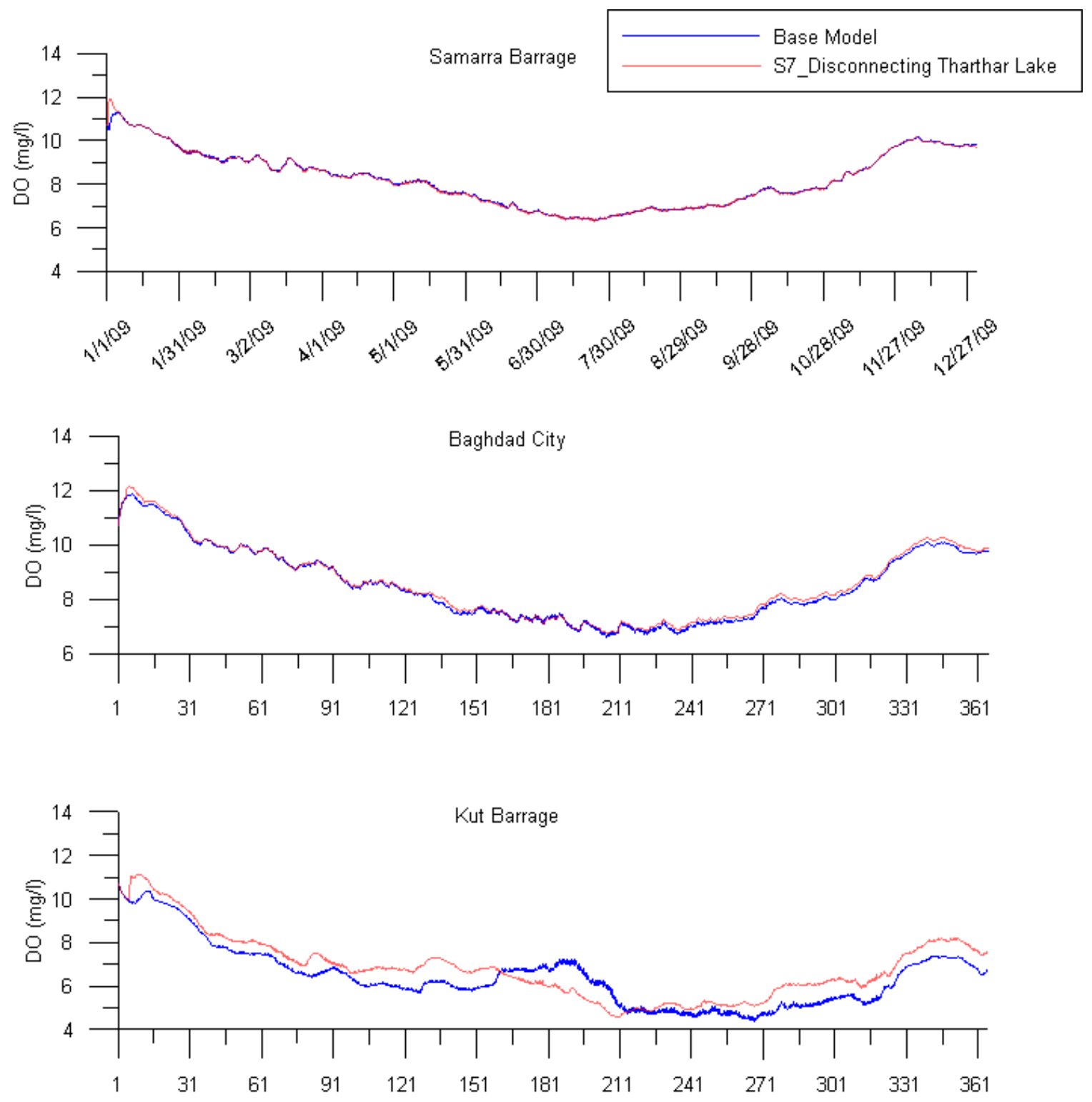

Figure 127: Model dissolved oxygen (DO) predictions for base model and management scenario 7 (disconnecting Tharthar Lake) at Samarra Barrage, Baghdad City, Kut Barrage. 

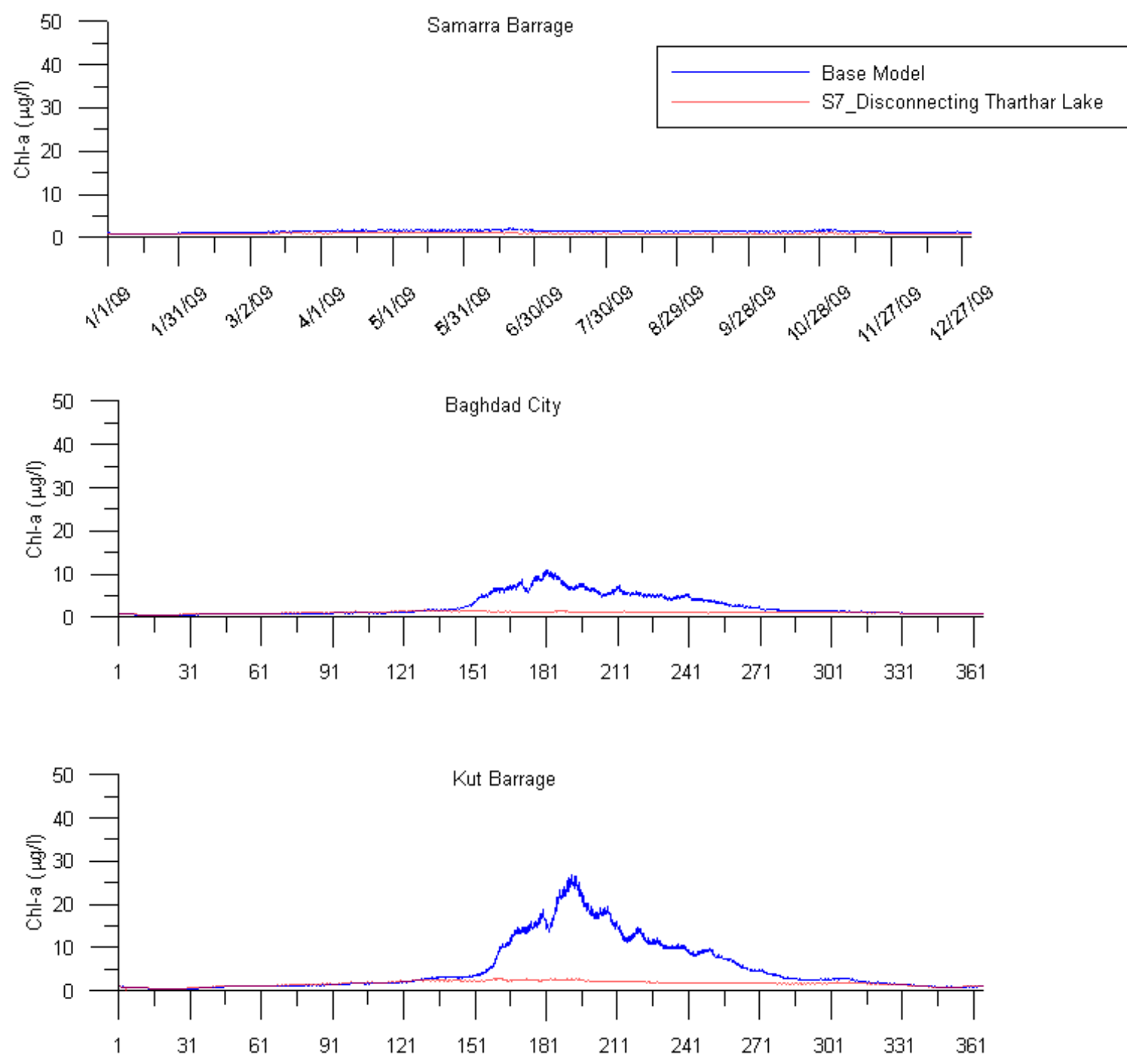

Figure 128: Model chlorophyll-a (Chl-a) predictions for base model and management scenario 7 (disconnecting Tharthar Lake) at Samarra Barrage, Baghdad City, Kut Barrage. 

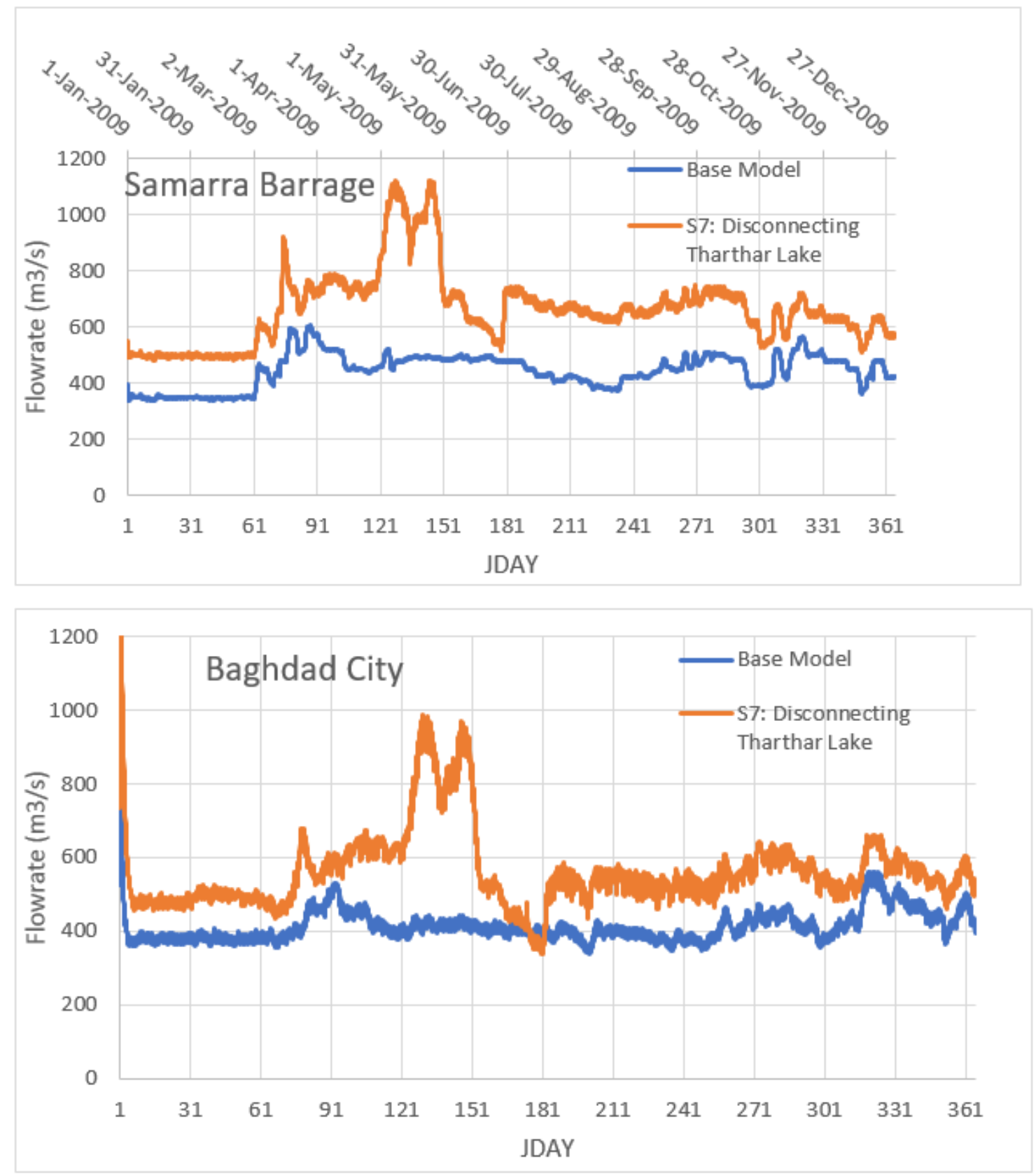

Figure 129: Model flowrate (Q) predictions for base model and management scenario 7 (disconnecting Tharthar Lake) at Samarra Barrage and Baghdad City. 


\section{Management Scenario 8: Long Term Model}

In this management scenario, a 6-year model simulation of the Tigris River system was performed to have an insight of how water quality constituents vary in Tharthar Lake.

Detention time in the lake was approximately 6 years with a volume of $28245 \mathrm{E} 6 \mathrm{~m}^{3}$ and average inflow and outflow of $150 \mathrm{~m}^{3} / \mathrm{s}$ and $200 \mathrm{~m}^{3} / \mathrm{s}$, respectively. Boundary conditions for the long-term model (2009-2014) were developed using the same boundary conditions of the Tigris River model for year 2009. Figure 130 through Figure 137 show model predictions of management scenario 8 for water age, temperature, total dissolved solids, phosphate, ammonium, nitrate, carbonaceous biological oxygen demand, dissolved oxygen, and chlorophyll-a, respectively, at the outlet of Tharthar Lake. The average temperature in the lake increased from $17.44^{\circ} \mathrm{C}$ to $17.56^{\circ} \mathrm{C}$, while no change in water temperatures was noticed in the mainstem. The average TDS concentration decreased by $16 \%$ from $1239 \mathrm{mg} / \mathrm{l}$ to $1041 \mathrm{mg} / \mathrm{l}$ in Tharthar Lake due to a continuous dilution by fresh waters diverted from Samarra Barrage. Fresh water enters the lake at a point located close to the lake's outlet and causes a high dilution in the water near the lake's outlet. PO4, NH4, and NO3 concentrations decreased by 2\%, 66\%, and 26\%, respectively. Average concentrations of CBOD and Chl-a were decreased from $0.71 \mathrm{mg} / \mathrm{l}$ and $2 \mu \mathrm{g} / \mathrm{l}$ to $0.63 \mathrm{mg} / \mathrm{l}$ and $1.61 \mu \mathrm{g} / \mathrm{l}$, respectively. 


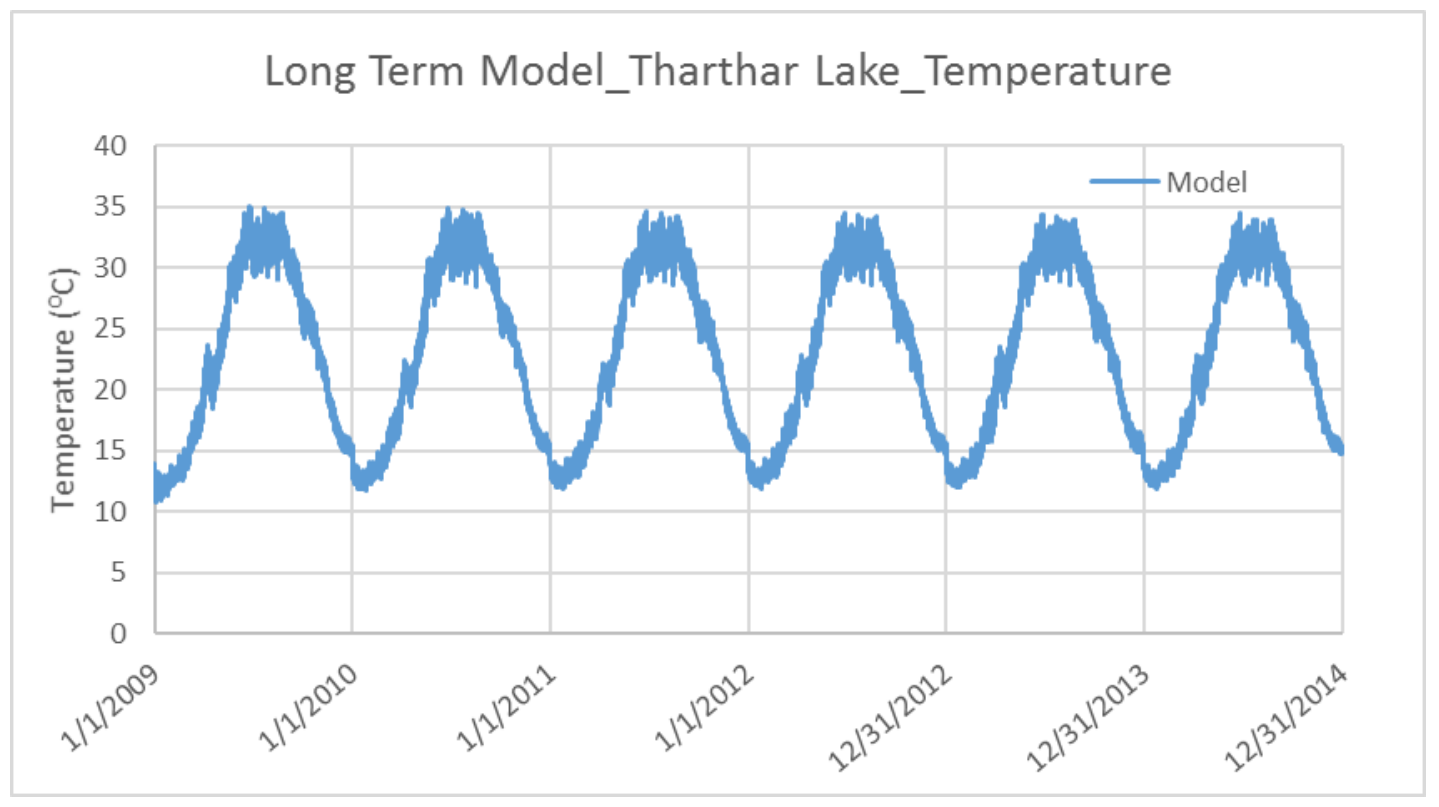

Figure 130: Model water temperature $\left(\mathrm{T}_{\mathrm{w}}\right)$ predictions for management scenario 8 (Long Term simulation) in Tharthar Lake.

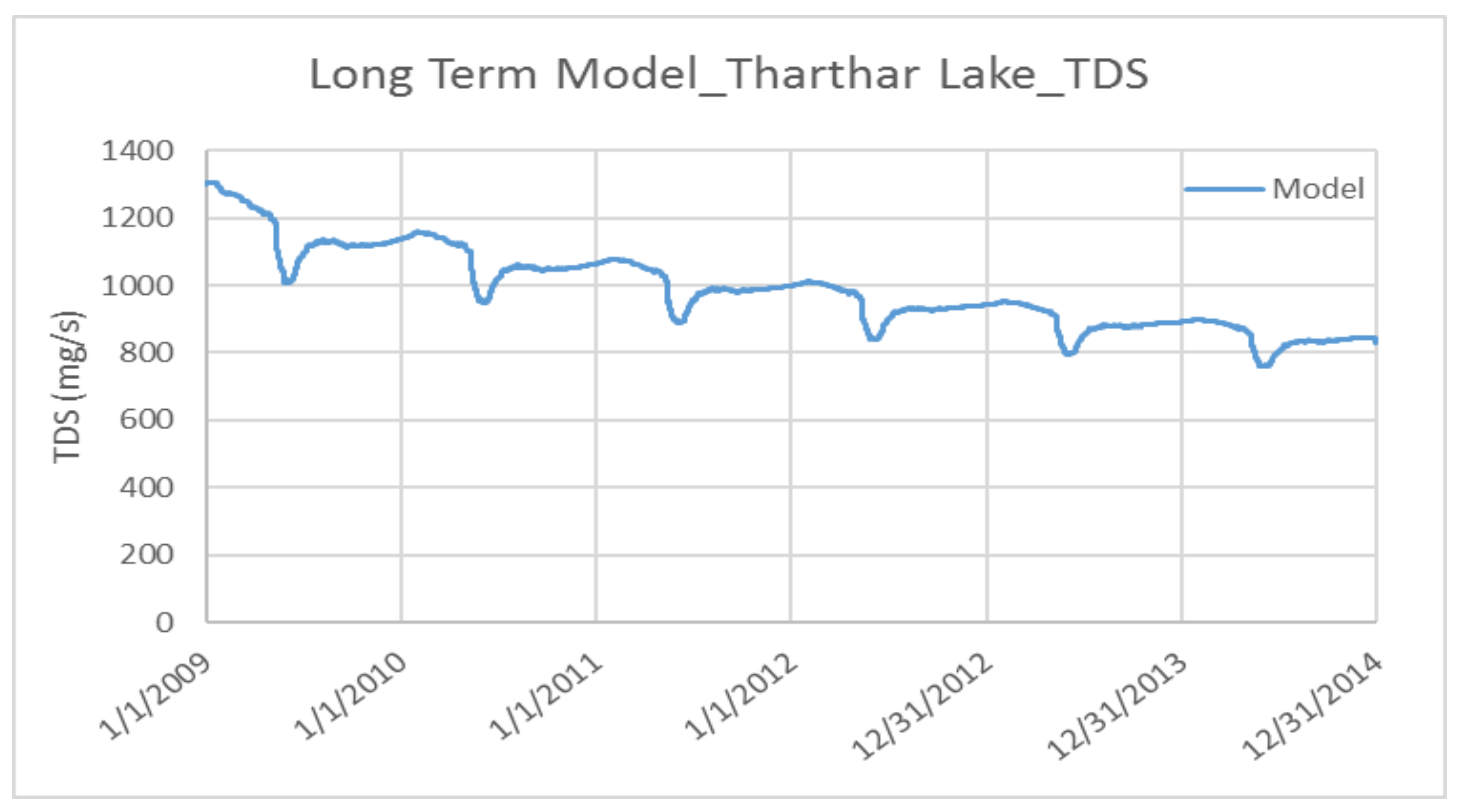

Figure 131: Model total dissolved solids (TDS) predictions for management scenario 8 (Long Term simulation) in Tharthar Lake. 


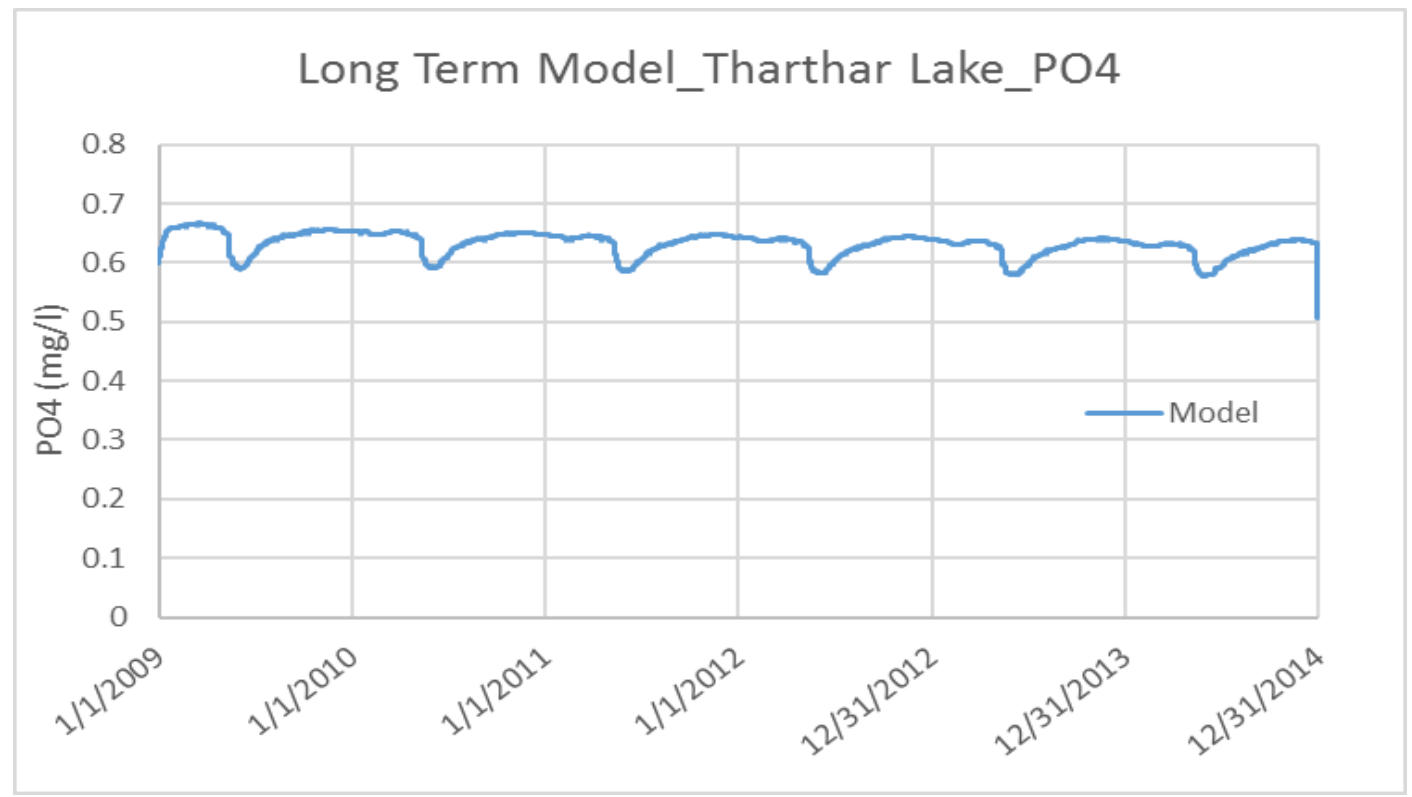

Figure 132: Model phosphate (PO4) predictions for management scenario 8 (Long Term simulation) in Tharthar Lake.

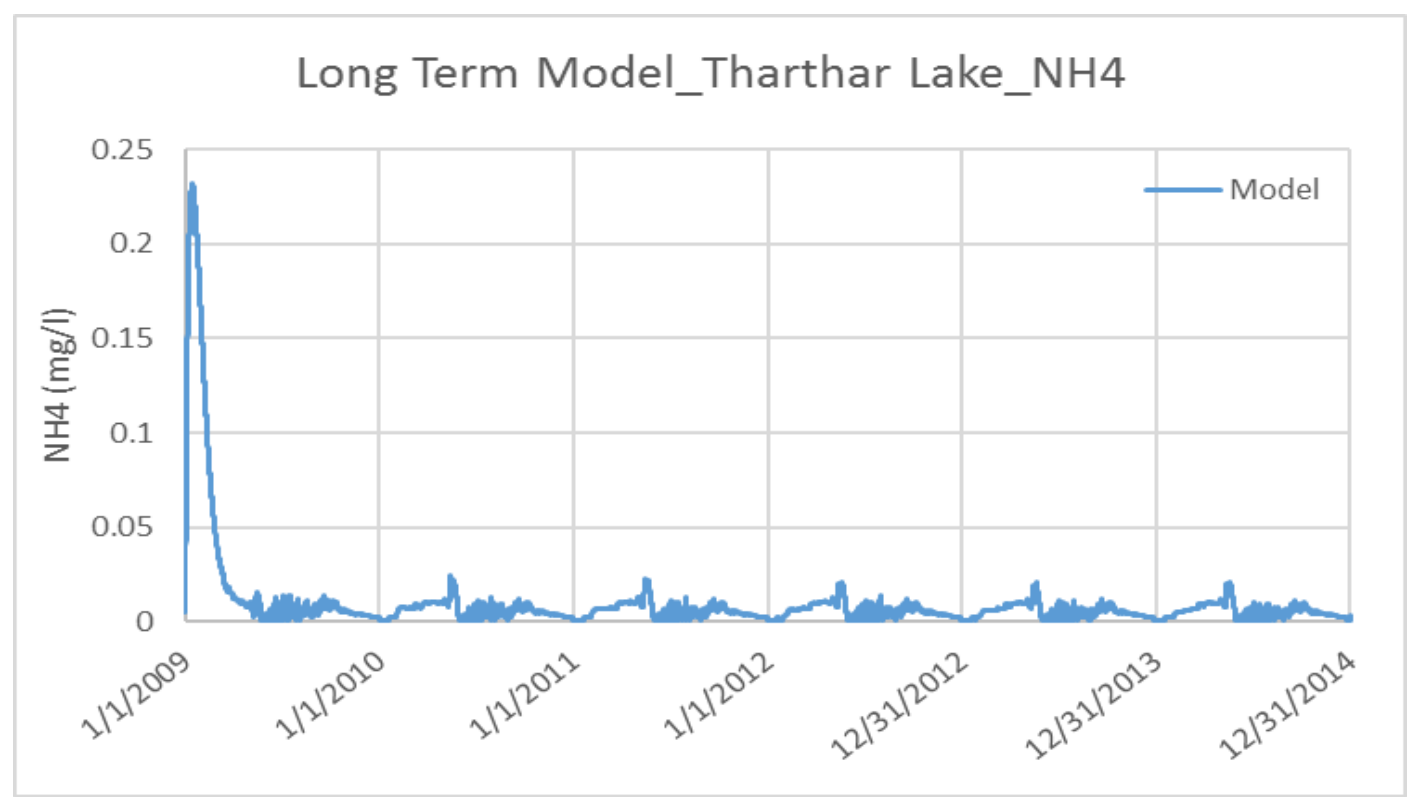

Figure 133: Model ammonia (NH4) predictions for management scenario 8 (Long Term simulation) in Tharthar Lake. 


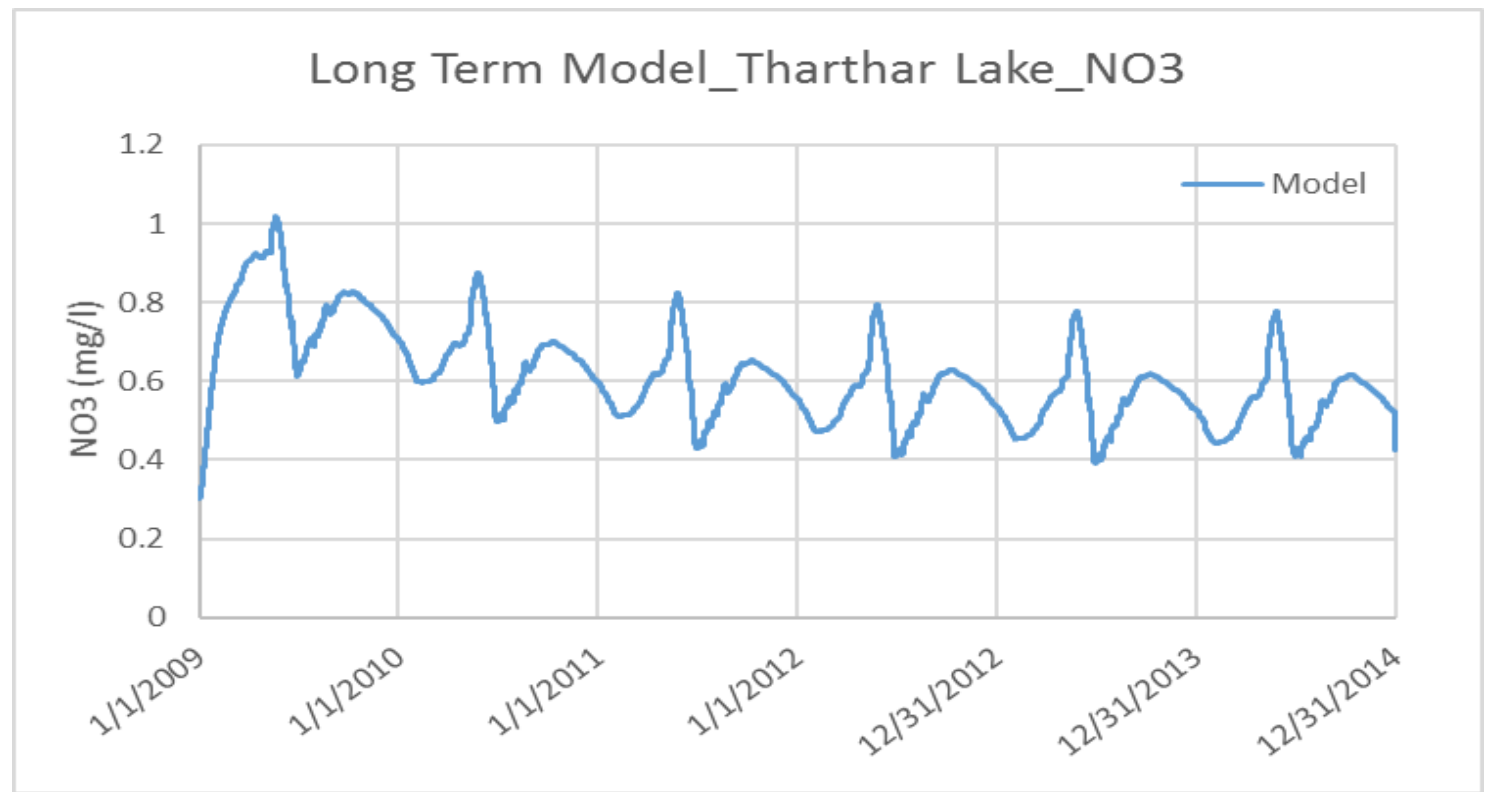

Figure 134: Model nitrate (NO3) predictions for management scenario 8 (Long Term simulation) in Tharthar Lake.

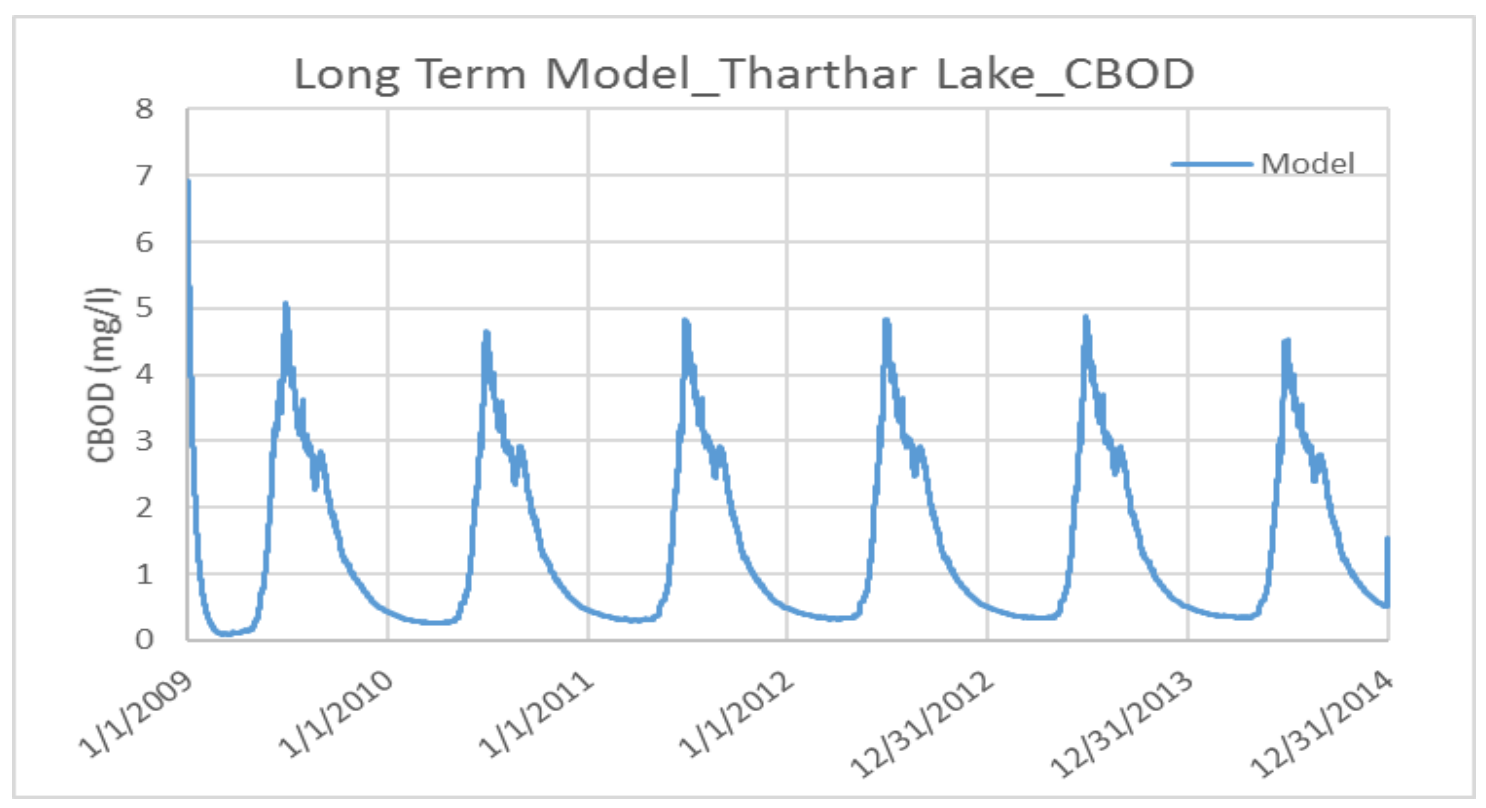

Figure 135: Model carbonaceous biological oxygen demand (CBOD) predictions for management scenario 8 (Long Term simulation) in Tharthar Lake. 


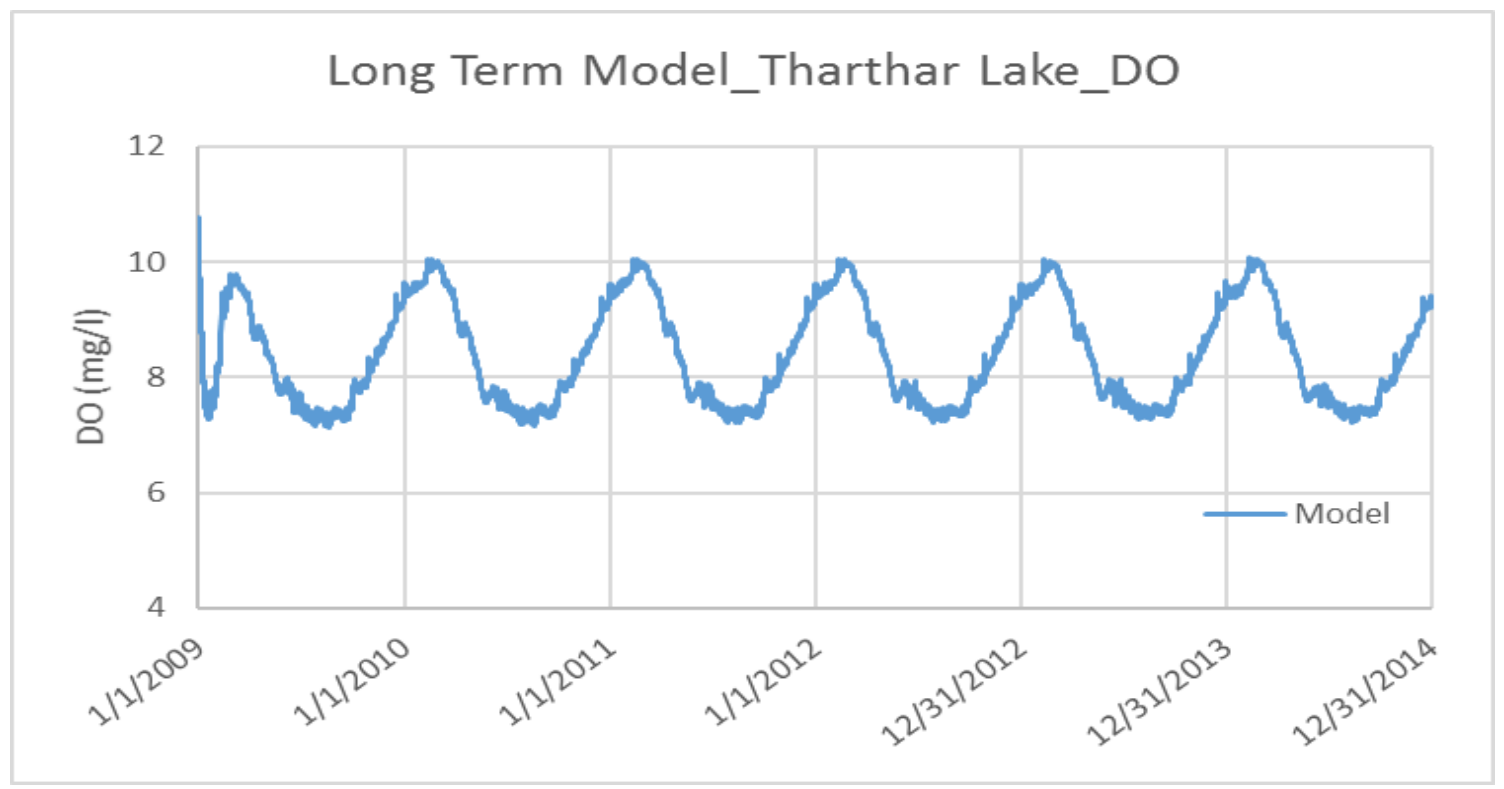

Figure 136: Model dissolved oxygen (DO) predictions for management scenario 8 (Long Term simulation) in Tharthar Lake.

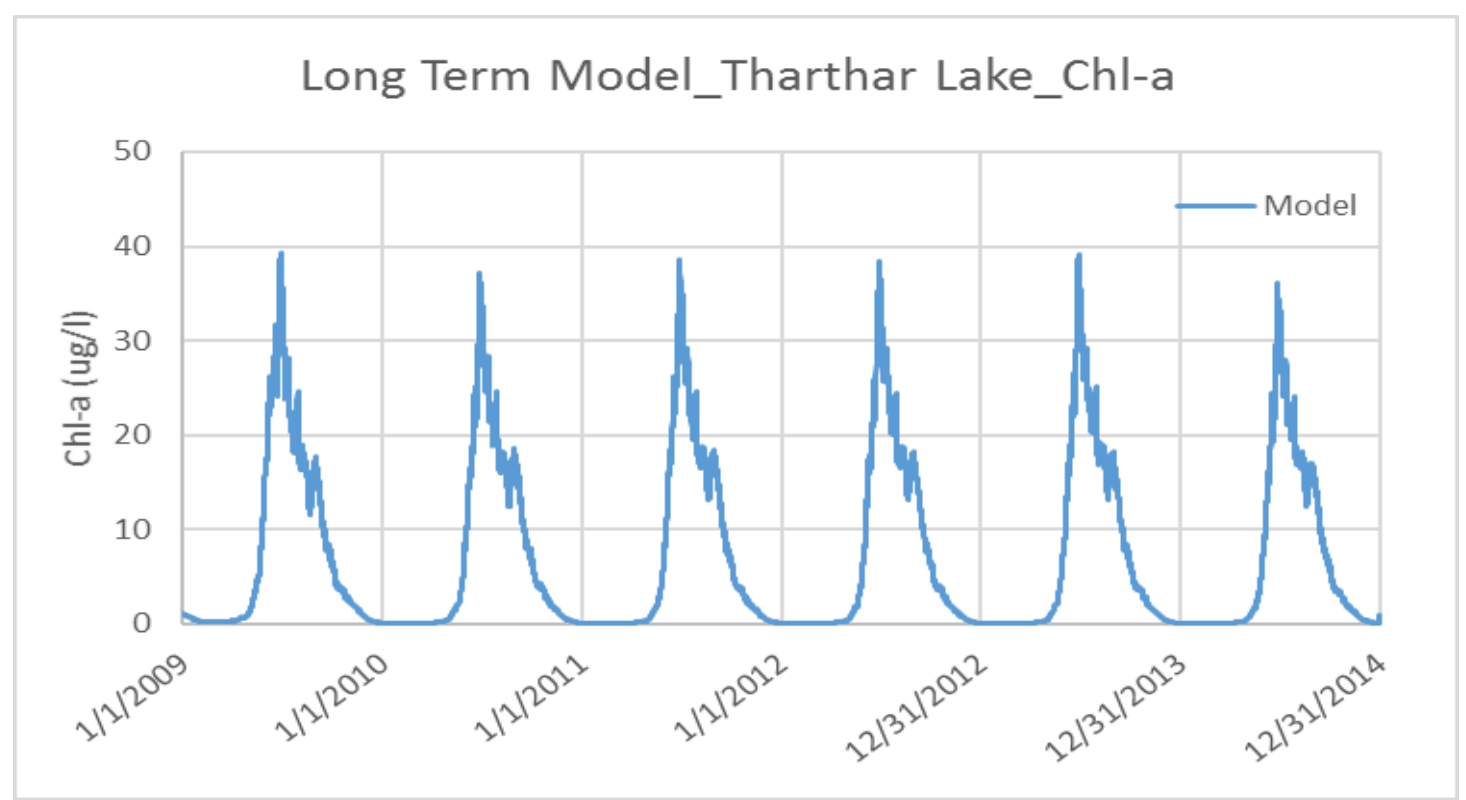

Figure 137: Model chlorophyll-a (Chl-a) predictions for management scenario 8 (Long Term simulation) in Tharthar Lake. 


\section{Management Scenario 9: Decreasing BOD in the Tigris River within Baghdad City}

In this management scenario, BOD concentrations in the Tigris River within Baghdad city were decreased by $50 \%$ to study its impact on DO and Chl-a concentrations in Baghdad city and downstream cites. Effluents with high BOD concentrations were directly discharged into the mainstem of the river causing significant increase in BOD concentrations in Baghdad city and downstream cities. Figure 138 through Figure 140 show model predictions of management scenario 9 for carbonaceous biological oxygen demand, dissolved oxygen, and chlorophyll-a, respectively, at Baghdad city and Kut Barrage. Predictions of management scenario 9 were compared with the base model of the Tigris River system. BOD concentrations in the mainstem decreased by $24 \%$, while DO concentrations increased by $2.8 \%$. There were no significant impacts on Chl-a concentrations in the mainstem of the river. 


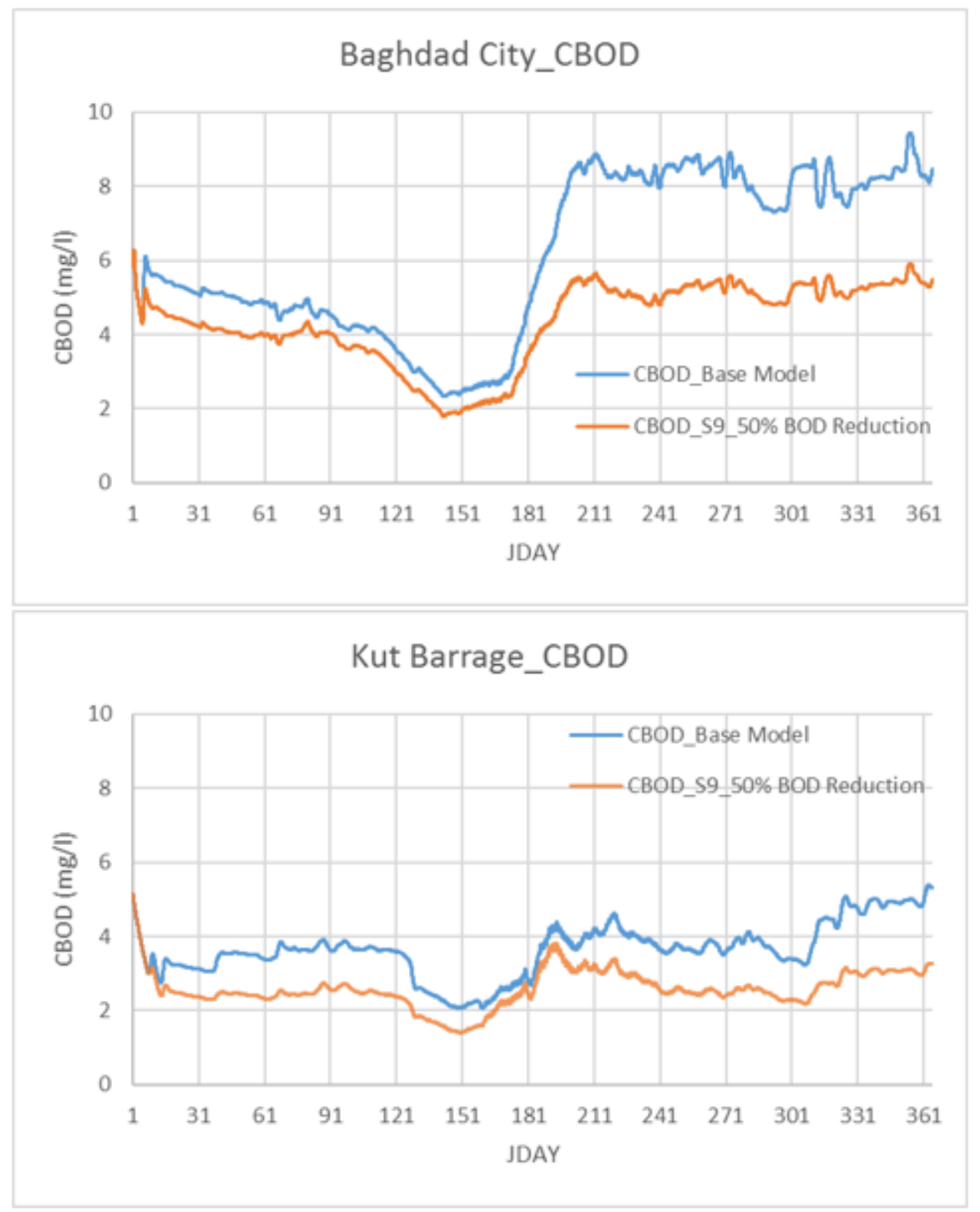

Figure 138: Model carbonaceous biological oxygen demand (CBOD) predictions for base model and management scenario 9 (50\% BOD Reduction) at Baghdad City and Kut Barragel. 


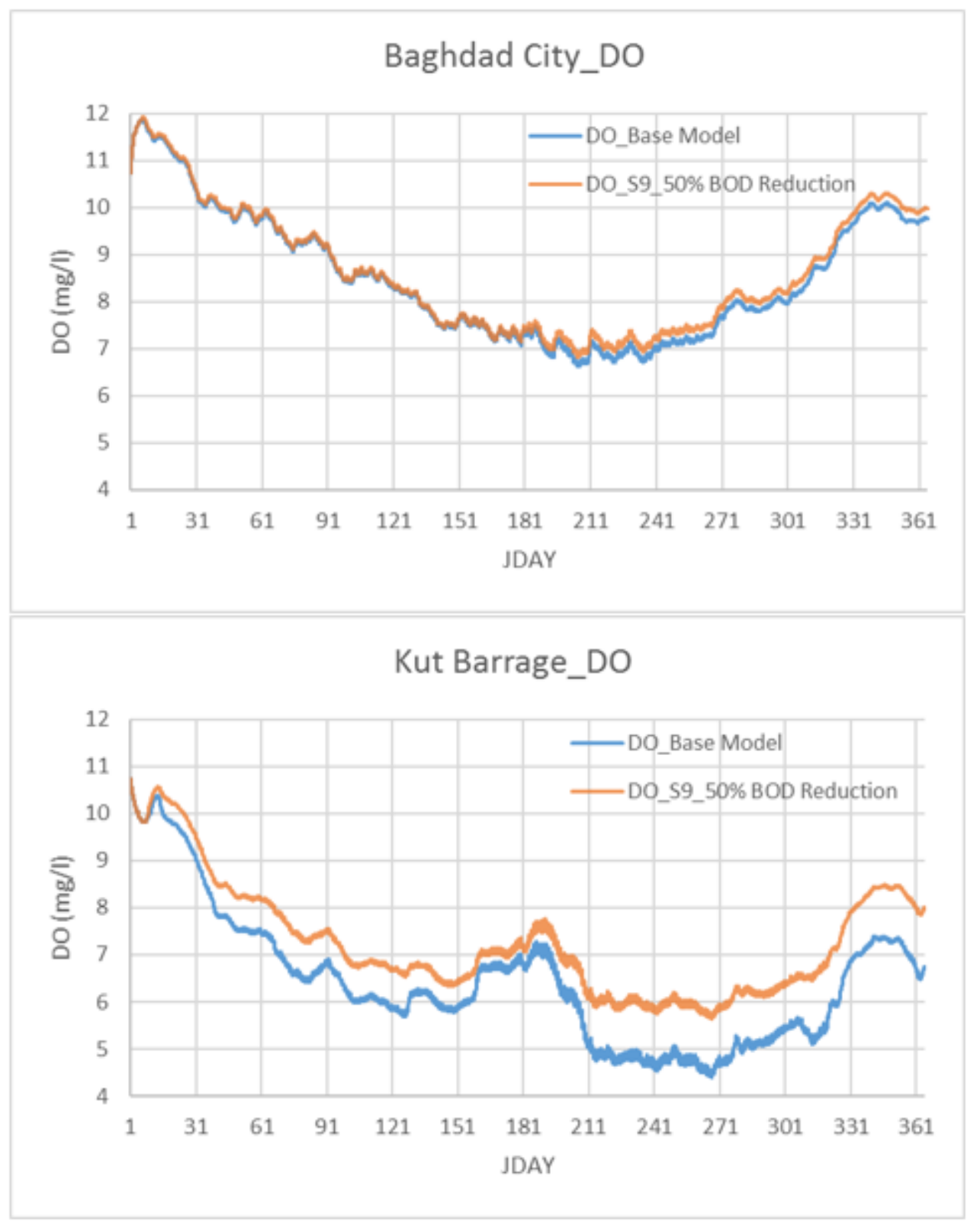

Figure 139: Model dissolved oxygen (DO) predictions for base model and management scenario 9 (50\% BOD Reduction) at Baghdad City and Kut Barrage. 


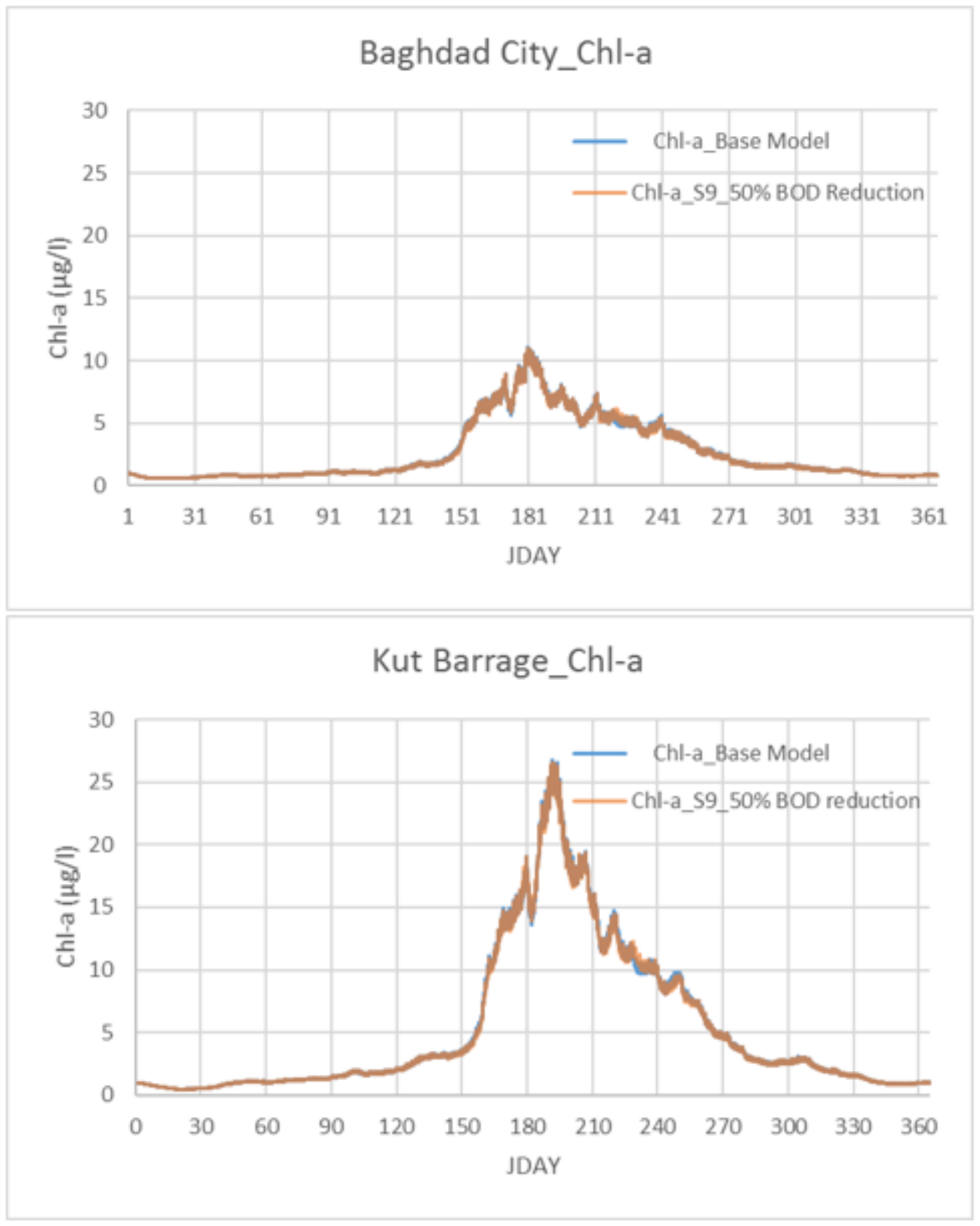

Figure 140: Model chlorophyll-a (Chl-a) predictions for base model and management scenario 9 (50\% BOD Reduction) at Baghdad City and Kut Barrage. 


\section{Management Scenario 10: Dissolved Oxygen Release from Mosul Dam}

Dissolve oxygen (DO) concentrations released upstream from Mosul Dam were set to 1.5 $\mathrm{mg} / \mathrm{l}$ from June $15^{\text {th }}$ to August $15^{\text {th }}$ to evaluate how long it takes for DO water from Mousul dam to reach saturation in the summer. Figure 141 shows model predictions of DO at model segments $2,4,6,7,8,9$, and 11 . DO reached an equilibrium concentration at model segment 11, $50 \mathrm{~km}$ downstream Mosul Dam after about a day of the release. Therefore, upstream boundary conditions affect model predictions of DO for approximately $50 \mathrm{~km}$ downstream the point of the release.

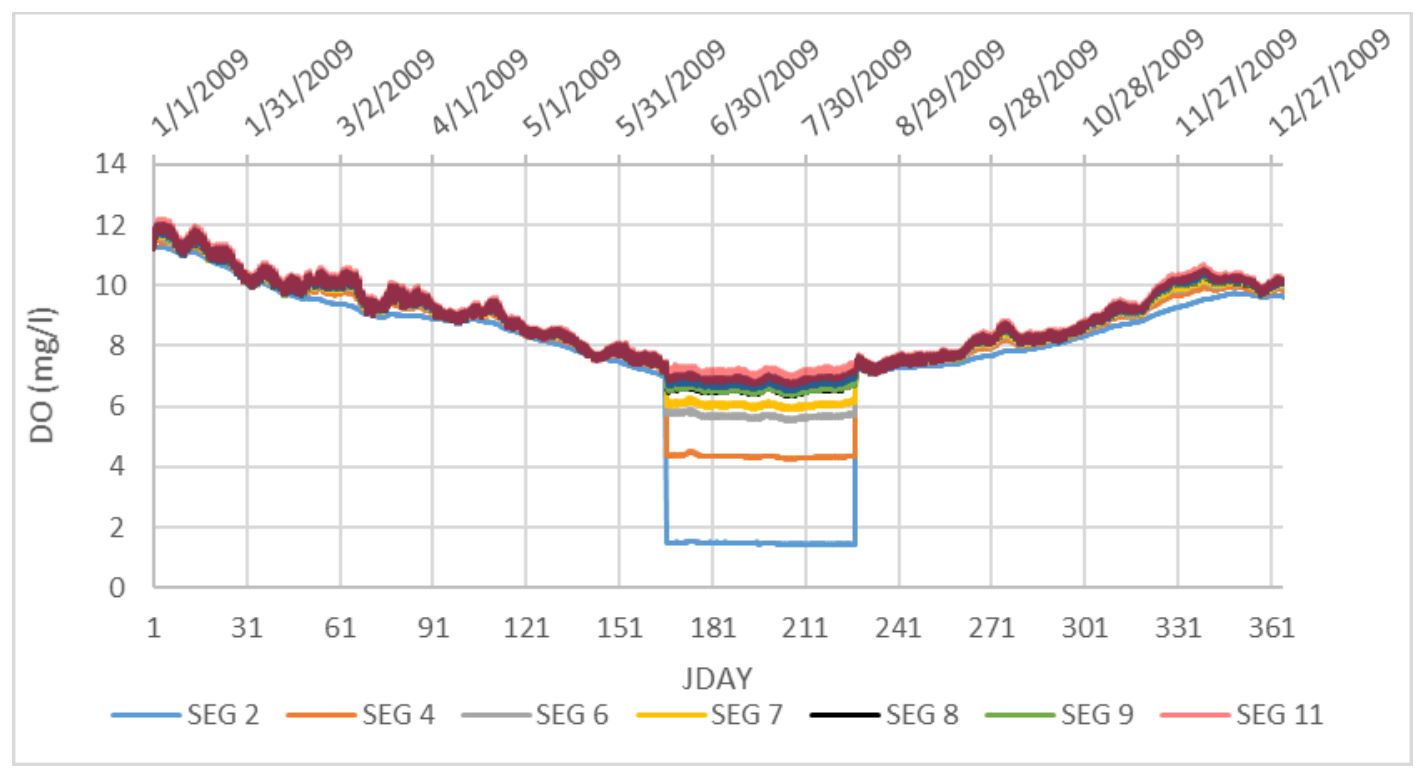

Figure 141: Model predictions of DO in the Mainstem of the Tigris River at model segments 2, 4, $6,7,8,9$, and 11 . 


\section{Summary of Management Scenarios}

Different management scenarios were implemented on the Tigris River system and compared with the base model to study the effect of each individual scenario on the mainstem of the Tigris River and Tharthar Lake. Increasing the upstream flow rates at Mosul Dam decreased TDS and nutrient concentrations, while increasing nutrient concentrations at Mosul Dam directly affected the entire system's water quality by increasing in the system's nutrient concentrations. Temperatures in the Middle East region are expected to increase due to the impact of climate change (AFED, 2009; IPCC, 2007; and WRI, 2002). A study conducted by Zakaria et al. (2013) showed an increase in temperatures due to the impact of climate change. In this study, climate change directly impacted the system's temperatures and decreased DO concentrations at Samarra Barrage, Baghdad city, Kut Barrage, and Tharthar Lake.

Most water quality constituents such as TDS, NH4, CBOD, and Chl-a concentrations tended to increase downstream of Samarra Barrage at both Baghdad city and Kut Barrage. The DO concentrations at Kut Barrage and Tharthar Lake were highly affected by algae production at these stations. On the other hand, disconnecting Tharthar Lake changed the entire hydrologic regime in the mainstem of the Tigris River downstream of Samarra Barrage by passing high volumes of water to Baghdad city and downstream areas. In addition, Chl-a concentrations in the mainstem were reduced after disconnecting Tharthar Lake from the Tigris River system, and DO concentrations decreased at Kut Barrage as a

result. Appendix B shows histograms for different scenario runs comparing water temperatures, total dissolved solids, phosphate, ammonium, nitrate, carbonaceous biological oxygen demand, dissolved oxygen, and chlorophyll-a in the mainstem of the 
Tigris River and Tharthar Lake. Table 25 and Table 26 list the average of water quality constituents in the mainstem of the Tigris River and Tharthar Lake for the base model and model simulations for the year 2009.

Table 25: Average of water quality constituents in the mainstem of the Tigris River for the base model and management scenarios.

\begin{tabular}{|c|c|c|c|c|c|c|c|c|c|c|}
\hline $\begin{array}{c}\text { Water } \\
\text { Quality } \\
\text { Parameter }\end{array}$ & $\begin{array}{c}\text { Base } \\
\text { Model } \\
\text { Run \# } \\
1\end{array}$ & $\begin{array}{c}\text { Increasing } \\
\text { Hydrology } \\
\text { Run\#2 }\end{array}$ & $\begin{array}{c}\text { Decre } \\
\text { asing } \\
\text { Hydro } \\
\text { logy } \\
\text { Run\#3 }\end{array}$ & $\begin{array}{c}\text { Decreasing } \\
\text { Hydrology } \\
\text { with } \\
\text { Increasing } \\
\text { Nutrients } \\
\text { Run\# } 4\end{array}$ & $\begin{array}{c}\text { Increasing } \\
\text { Tharthar } \\
\text { Lake's } \\
\text { Flow } \\
\text { Run\# } 5\end{array}$ & $\begin{array}{l}\text { Climate } \\
\text { Change } \\
\text { Run\# } 6\end{array}$ & $\begin{array}{c}\text { Climate } \\
\text { Change } \\
\text { with } \\
\text { Decreasing } \\
\text { Hydrology } \\
\text { Run\# } 7\end{array}$ & $\begin{array}{c}\text { Disconnecting } \\
\text { Tharthar Lake } \\
\text { Run\# } 8\end{array}$ & $\begin{array}{c}\text { Long } \\
\text { Term_6 } \\
\text { Years } \\
\text { 2009- } \\
2014 \\
\text { Run\# } 9\end{array}$ & \begin{tabular}{|c|}
$50 \%$ BOD \\
Reduction \\
Run\# 10
\end{tabular} \\
\hline Temp $\left({ }^{\circ} \mathrm{C}\right)$ & 20.71 & 20.80 & 20.59 & 20.60 & 20.73 & 21.68 & 21.56 & 20.91 & 20.83 & 20.73 \\
\hline TDS (mg/l) & 495 & 470 & 527 & 539 & 493 & 495 & 528 & 397 & 500 & 493 \\
\hline P04 (mg/l) & 0.357 & 0.357 & 0.358 & 0.374 & 0.357 & 0.358 & 0.359 & 0.354 & 0.367 & 0.349 \\
\hline $\mathrm{NH} 4(\mathrm{mg} / \mathrm{l})$ & 0.235 & 0.230 & 0.246 & 0.249 & 0.236 & 0.234 & 0.244 & 0.236 & 0.222 & 0.188 \\
\hline NO3 (mg/l) & 1.540 & 1.520 & 1.575 & 1.627 & 1.542 & 1.542 & 1.576 & 1.549 & 1.457 & 1.518 \\
\hline $\begin{array}{l}\text { CBOD } \\
(\mathrm{mg} / \mathrm{l})\end{array}$ & 5.912 & 5.744 & 6.181 & 6.183 & 5.913 & 5.875 & 6.140 & 5.229 & 5.727 & 4.511 \\
\hline DO $(\mathrm{mg} / \mathrm{l})$ & 8.147 & 8.191 & 8.086 & 8.086 & 8.149 & 7.989 & 7.926 & 8.283 & 8.199 & 8.371 \\
\hline Chl-a $(\mu \mathrm{g} / \mathrm{l})$ & 1.968 & 1.998 & 1.857 & 1.869 & 2.000 & 2.018 & 1.912 & 1.177 & 2.238 & 1.961 \\
\hline
\end{tabular}

Table 26: Average of water quality constituents in Tharthar Lake for the base model and management scenarios.

\begin{tabular}{|l|l|l|l|l|l|l|l|l|l|}
\hline $\begin{array}{l}\text { Water } \\
\text { Quality } \\
\text { Parameter }\end{array}$ & $\begin{array}{l}\text { Base } \\
\text { Model } \\
\text { Run\#1 }\end{array}$ & $\begin{array}{l}\text { Increasing } \\
\text { Hydrology } \\
\text { Run\# 2 }\end{array}$ & $\begin{array}{l}\text { Decreasing } \\
\text { Hydrology } \\
\text { Run\#3 }\end{array}$ & $\begin{array}{l}\text { Decreasing } \\
\text { Hydrology } \\
\text { with } \\
\text { Increasing } \\
\text { Nutrients } \\
\text { Run\#4 }\end{array}$ & $\begin{array}{l}\text { Increasing } \\
\text { Tharthar } \\
\text { Lake's Flow } \\
\text { Run\#5 }\end{array}$ & $\begin{array}{l}\text { Climate } \\
\text { Change } \\
\text { Run\#6 }\end{array}$ & $\begin{array}{l}\text { Climate } \\
\text { Change with } \\
\text { Decreasing } \\
\text { Hydrology } \\
\text { Run\#7 }\end{array}$ & $\begin{array}{l}\text { Long Term_6 } \\
\text { Years } \\
\text { 2009-2014 } \\
\text { Run\# 8 }\end{array}$ & $\begin{array}{l}\text { 50\%BOD } \\
\text { Reduction } \\
\text { Run\#9 }\end{array}$ \\
\hline Temp $\left({ }^{\circ} \mathbf{C}\right)$ & 17.44 & 17.42 & 17.46 & 17.46 & 17.44 & 18.35 & 18.37 & 17.56 & 17.49 \\
\hline TDS $(\mathbf{m g} / \mathbf{l})$ & 1239 & 1226 & 1253 & 1254 & 1231 & 1241 & 1255 & 1041 & 1239 \\
\hline PO4 $(\mathbf{m g} / \mathbf{l})$ & 0.405 & 0.405 & 0.405 & 0.406 & 0.405 & 0.405 & 0.405 & 0.397 & 0.405 \\
\hline NH4 $(\mathbf{m g} / \mathbf{l})$ & 0.042 & 0.042 & 0.042 & 0.042 & 0.042 & 0.041 & 0.040 & 0.014 & 0.042 \\
\hline NO3 $(\mathbf{m g} / \mathbf{l})$ & 1.245 & 1.248 & 1.242 & 1.245 & 1.244 & 1.196 & 1.190 & 0.920 & 1.246 \\
\hline $\begin{array}{l}\text { CBOD } \\
(\mathbf{m g} / \mathbf{l})\end{array}$ & 0.712 & 0.716 & 0.705 & 0.705 & 0.711 & 0.729 & 0.721 & 0.634 & 0.709 \\
\hline DO $(\mathbf{m g} / \mathbf{l})$ & 6.981 & 6.963 & 7.004 & 7.006 & 6.970 & 6.663 & 6.684 & 7.691 & 6.984 \\
\hline Chl-a $(\boldsymbol{\mu g} / \mathbf{l})$ & 2.017 & 2.036 & 1.990 & 1.991 & 2.014 & 2.082 & 2.045 & 1.609 & 2.005 \\
\hline
\end{tabular}




\section{Chapter Eight: Conclusions and Recommendations}

The Tigris River system (the mainstem of the Tigris River and Tharthar Lake with its canals) in Iraq was modeled using the 2-D hydrodynamics and water quality model CEQUAL-W2 Version 4.0 from Mosul Dam (river km 0) upstream Mosul City to Kut Barrage (river km 880) in Kut City. The model was run from January $1^{\text {st }}, 2009$ to December $31^{\text {st }}$, 2009. The model state variables included longitudinal and vertical velocity, water level, water temperature, total dissolved solids, phosphate, ammonia, nitrate, carbonaceous oxygen demand, dissolve oxygen, and algae. Chlorophyll-a was also included in the Tigris River model as a derived water quality constituent. Scenarios were performed with the base model of the Tigris River to give more insight into how the river responds to changes in hydrology, an upstream increase in nutrients at Mosul Dam, and possible climate change of increasing air temperatures. The Tigris River system was classified into 9 waterbodies with 9 branches, 343 longitudinal segments, and 84 vertical layers for each segment with $1 \mathrm{~m}$ height for each layer.

Field data such as flow, water level, bathymetry and some water quality constituents (total dissolved solids and nitrate) were provided from the Water Resources Ministry in Iraq (MOWR, 2014) and were used to develop the model's input files and to calibrate the model by comparing model predictions to field data. Meteorological data for the Tigris River model were obtained from the Iraqi Ministry of Transportation, the General Organization for Meteorology and Seismic Monitoring (MOT-IMOAS 2014). 
Field data for water temperature were extremely scarce in Iraq and therefore water temperatures for upstream boundary conditions at Mosul Dam and model calibration at Baeji and Baghdad cities were estimated from Landsat using remote sensing and image processing technique.

Model predictions of flow and water level were compared to field data at three stations along the mainstem of the Tigris River located at Baeji city, downstream Samarra Barrage and Baghdad city with flow absolute mean error varying from 12.57 to $3.38 \mathrm{~m}^{3} / \mathrm{s}$ and water level absolute mean error varying from 0.036 to $0.018 \mathrm{~m}$. The average percentage errors of flowrate at Baeji city, downstream Samarra Barrage and Baghdad city were 1.93\%, 0.83\%, and $0.81 \%$ respectively. Adding a distributed tributary to the Tigris River model allowed for flow calibration by accounting for ungaged flow such as ground water, runoff, and irrigation return flow. Model predictions of flow could be improved by having more field data at different gaging stations along the mainstem of the Tigris River and Tharthar Lake.

Model predictions of temperatures were compared to remotely sensed temperature data at both Baeji and Baghdad cities. Model predictions of temperatures significantly agreed with the estimated data since model predictions were within $95 \%$ confidence interval with a noticeable bias in winter months due to uncertainty in Landsat estimations at both Baeji and Baghdad cities. The absolute mean error of temperature predictions varied from 0.91 to $1.04^{\circ} \mathrm{C}$. Model predictions of temperatures could significantly be improved by providing temperature field data at multiple gaging stations both longitudinally and vertically to compare with the model vertical profile. 
Model predictions of total dissolved solids and nitrate were compared to monthly averaged field data. Model predictions of TDS were compared to field data at Samarra Barrage, Baghdad city, and Kut Barrage. TDS concentrations in the Tigris River started to significantly increase from Mosul dam to Kut Barrage with a peak in winter months due to storm water runoff. Unregulated effluents from three waste water treatment plants (WWTPs) within Baghdad city cause a significant increase in TDS concentrations in addition to irrigation back flow in Baghdad city and downstream areas since this region contains agricultural lands. Model predictions of NO3 were compared to field data at both Samarra Barrage and Baghdad city. There was no significant increase in NO3 concentrations between Samarra Barrage and Baghdad city.

Model predictions of other water quality state variables such as phosphate, ammonium, biochemical oxygen demand, algae and chlorophyll-a and dissolved oxygen were estimated based on field data collected from the literature. BOD concentrations within Baghdad city were extremely high due to direct discharge of industrial wastewater into the mainstem of the Tigris River from numerous factories located along the river banks. There were no considerable changes in both $\mathrm{PO} 4$ and NH4 concentrations in Baghdad and downstream cites. A sensitivity study was conducted to check if satellite images show high Chl-a concentrations using a Chl-a correlation provided from previous literature studies. The study showed that the best algal growth rate was $0.98 \mathrm{~d}^{-1}$ that subsequently used for all management scenarios of the Tigris River system. Evaporation rate in Tharthar Lake was $2.2 \mathrm{~m}$ for the simulated year 2009 which compared well with measured evaporation of $2.27 \mathrm{~m}$ for a nearby lake (CSO, 2010). 
Multiple scenarios were implemented using the base 2009 model of the Tigris River by altering hydrology, increasing upstream nutrients, increasing air temperature, disconnecting Tharthar Lake from the Tigris River system, and simulating a long-term model of the Tigris River system. Increasing upstream flowrates at Mosul Dam by 15\% decreased TDS concentrations from $495 \mathrm{mg} / \mathrm{l}$ to $470 \mathrm{mg} / \mathrm{l}$ in the mainstem. CBOD concentrations in the mainstem were also decreased by $3 \%$.

On the other hand, decreasing upstream flow showed a significant impact on water quality in the Tigris River causing a significant increase in concentrations of TDS by 6.55\%, PO4 by $3 \%, \mathrm{NH} 4$ by $4.5 \%, \mathrm{NO} 3$ by $2.3 \%$, and CBOD by $5 \%$, while $\mathrm{DO}$ concentration decreased by $0.33 \%$. Increasing nutrient concentrations by $10 \%$ at Mosul Dam increased PO4, NH4, and NO3concentrations in the mainstem by $4.6 \%, 5.65 \%$, and $5.65 \%$, respectively. Assuming an increase in air temperatures of $2{ }^{\circ} \mathrm{C}$ and a corresponding increase in dew point temperatures increased water temperatures in the mainstem of the Tigris River from 20.7 ${ }^{\circ} \mathrm{C}$ to $21.7^{\circ} \mathrm{C}$ causing a subsequent decrease in DO levels from $8.15 \mathrm{mg} / \mathrm{l}$ to $7.98 \mathrm{mg} / \mathrm{l}$. Average TDS concentrations in the mainstem and Tharthar Lake increased from $494.5 \mathrm{mg} / \mathrm{l}$ and $1239 \mathrm{mg} / \mathrm{l}$ to $495 \mathrm{mg} / \mathrm{l}$ and $1241 \mathrm{mg} / \mathrm{l}$, respectively. NO3 concentration in the lake decreased from $1.24 \mathrm{mg} / \mathrm{l}$ to $1.196 \mathrm{mg} / \mathrm{l}$, while there were no changes in PO4 and $\mathrm{NH} 4$ concentrations compared with the base model. There were no significant impacts on CBOD concentration in the mainstem. Chl-a concentrations were slightly increased in the mainstem due to climate change effect with an average concentration changed from 1.97 $\mu \mathrm{g} /$ to $2 \mu \mathrm{g} / \mathrm{l}$. 
Disconnecting Tharthar Lake from the Tigris River system significantly affected the hydrologic regime downstream of Samarra Barrage by passing 36\% more water from Samarra Barrage to Baghdad city causing a substantial decrease in TDS concentration by $25 \%$. In addition, Chl-a concentrations were decreased dramatically from $1.97 \mu \mathrm{g} / \mathrm{l}$ to 1.18 $\mu \mathrm{g} / \mathrm{l}$ in the mainstem of the Tigris River.

A long-term 6-year simulation was performed on the Tigris River system. The average temperature in Tharthar Lake increased from $17.44^{\circ} \mathrm{C}$ to $17.5^{\circ} \mathrm{C}$, while no change in water temperatures was noticed in the mainstem. The average TDS concentration decreased from $1239 \mathrm{mg} / \mathrm{l}$ to $1041 \mathrm{mg} / \mathrm{l}$ in Tharthar Lake, while the average TDS concentration was increased from $495 \mathrm{mg} / \mathrm{l}$ to $500 \mathrm{mg} / \mathrm{l}$ in the mainstem. There were no major changes in the average concentrations of $\mathrm{PO} 4, \mathrm{NH} 4$, and $\mathrm{NO} 3$ in the mainstem. PO4, $\mathrm{NH} 4$, and $\mathrm{NO} 3$ concentrations decreased by $2 \%, 62 \%$, and $95.4 \%$, respectively. Average concentrations of CBOD and Chl-a decreased from $0.71 \mathrm{mg} / \mathrm{l}$ and $2 \mu \mathrm{g} / \mathrm{l}$ to $0.63 \mathrm{mg} / \mathrm{l}$ and $1.6 \mu \mathrm{g} / \mathrm{l}$, respectively.

After decreasing BOD concentrations of the Tigris River by 50\%, BOD concentrations in the mainstem decreased by $24 \%$, while DO concentrations increased by $2.8 \%$. There were no significant impacts on Chl-a concentrations in the mainstem of the river.

Finally, it was found that approximately $50 \mathrm{~km}$ below Mosul Dam was affected by extremely low dissolved oxygen release from Mosul Dam before DO concentrations reached an equilibrium concentration. 
The following conclusions can be made:

- Due to extremely low flow rates, there was no significant effect of highly saline water discharged through Audiam tributary to the mainstem of the Tigris River.

- Ungaged flow in the Tigris River system was significantly important in the model flow calibration and can be accounted for using distributed tributaries.

- Water Treatment plants in Baghdad city withdrew about $6 \%$ of the average flow in the Tigris River.

- Saline water diverted from Tharthar Lake, irrigation return flow, wastewater effluents, and urban runoff caused high TDS concentration in the Tigris River from Baghdad city to Kut Barrage.

- The mainstem of the Tigris River within Mosul city was not affected by treated wastewater as it discharged to natural Wadies. Also, the Tigris River from Tikrit city to Samarra Barrage was not affected by discharging $25 \%$ of the treated wastewater due to extremely low flow rates.

- Landsat images proved a good resource to estimate water temperatures in the Tigris River for upstream boundary conditions at Mosul Dam and for in-river calibration.

- Chlorophyll-a concentrations in Tharthar Lake could be retrieved from Landsat images.

- Air temperature is a significant predictor of surface water temperature of the Tigris River.

- Temperature calibration in the Tigris River system was highly sensitive to meteorological input data. 
- There was no noticeable stratification found in both Samarra Barrage and Kut Barrage.

- Surface water temperature in Tharthar Lake varied longitudinally along the NorthSouth axis with warmer temperatures in the lower part compared with the upper part of the lake.

- High Manning's friction in the Tigris River within Baghdad city was observed due to the effect of channel irregularity and obstruction (such as debris deposits and bridge piers), the degree of meandering, and imperfections in the given crosssectional geometry.

- Diverted water from Tharthar Lake to the Tigris River caused a significant increase in the water age of the river within Baghdad and downstream cites.

- A parcel of water released from Mosul Dam reaches to Baeji, Samarra Barrage, Baghdad, and Kut Barrage after approximately 3 days, 5 days, 10 days, and 19 days, respectively.

- Increasing upstream flow by $15 \%$ at Mosul Dam significantly improved TDS concentrations in the mainstem and in Tharthar Lake, while decreasing upstream flow negatively impacted TDS concentrations in the Tigris River system.

- A $10 \%$ increase in the annual average flow diverted from Samarra Barrage to Tharthar Lake should be allocated to constantly reduce salinity in the lake.

- $50 \mathrm{~km}$ long in the mainstem of the Tigris River below Mosul Dam was affected by extremely low DO release from Mosul Dam before DO concentrations reached steady state. 
The following recommendations can be made:

- The head water quantity and quality of the Tigris River as it inters Iraq through the Turkey-Iraqi border should be monitored based on previously signed agreements between the two countries because this is an important boundary condition for predicting downstream water quality

- Since the model started at the base on Mosul dam, the reservoir itself should be monitored and modeled to assess water quality transformations within the reservoir

- The average annual flow of the Tigris River in Baghdad city should not be less than the existing annual average flow of $420 \mathrm{~m}^{3} / \mathrm{s}$ to keep the average TDS concentration in the mainstem less than $500 \mathrm{mg} / \mathrm{l}$. A decrease in the river flow will negatively impact its quality by increasing TDS, nutrients, BOD, and Chl-a concentrations.

- Since the Upper Zab tributary is the biggest contributor, after the upper Tigris basin, to the Tigris River with $33 \%$ of its annual volume, its flow should be managed through constructing a new dam that controls its discharge to the mainstem of the river.

- Wastewater in Baghdad city should efficiently be treated.

- Man-made canals used for irrigation should strictly be monitored to understand the impact of irrigation return flow on the mainstem of the Tigris River.

- Unregulated water withdrawn from the main stream of the Tigris River for irrigation should be controlled and new polices should be strictly implemented. 
- More strategies on restoring the Tigris River should be planned a head as the future climate change will significantly impact the river's thermal regime.

\section{The Tigris River Model Improvements and Recommendations}

The mainstem of the Tigris River and Tharthar Lake was modeled for the year of 2009. The current model can be improved by the following suggestions organized by data type.

\section{Flow Data}

Having flow rate data, the Tigris River system model uncertainty can be reduced. Flowrate data in Tharthar Lake and its canals are extremely important for model comparisons and currently no such data were available for this study. Flowrate data are also needed for the mainstem of the Tigris River in the area between Baghdad city and Kut Barrage where numerous unmonitored withdrawals, runoff, and irrigation return flow occurred. These data give more understanding and more insight of how water is entering and leaving the system. It is also very important to have flow data for both the Upper Zab and Lower Zab tributaries since they are significant contributors to the Tigris water. Currently, the Upper Zab tributary was completely unmonitored for flow. Finally, flow data from Samarra Barrage to Erwaeiya canal are needed as well.

\section{Temperature Data}

In-situ water temperature data of the Tigris River system would be important for improving model calibration. The current model was evaluated utilizing surface water temperatures estimated from Landsat which add a level of uncertainty in model predictions and ultimately affect the temperature calibration. The mainstem of the Tigris River and Tharthar Lake lack temperature monitoring stations. Moreover, vertical temperature 
profiles in Tharthar Lake would be very important to verify the model's predicted thermal dynamics in the water column. In addition, all tributaries of the Tigris River had no available temperature data, and therefore it is crucial to monitor flow temperature of at least both the Upper Zab and Lower Zab which are the main tributaries of the Tigris River. Availability of field temperature data gives the opportunity to validate satellite temperate and to reduce the level of uncertainty in the satellite estimates.

\section{Water Quality Data}

The mainstem of the Tigris River and Tharthar Lake lack most of water quality constituents used in the model study. Most of the available data of the Tigris River were monthly average TDS and nitrates during the simulated year 2009, while there were no data available for phosphate, dissolved oxygen, ammonia, organic matter, alkalinity, inorganic carbon, and algae. Although some monthly average data were available, it was difficult to distinguish specific seasonal and diurnal trends. Upstream of the Tigris River model at Mosul Dam, there were no water quality data available except for monthly average data of TDS. Knowing that the Mosul Dam can affect water quality significantly, knowing the discharge water quality coming from Mosul Dam is an important aspect of understanding how this inflow affects the Tigris River. Tharthar Lake also had no water quality data available during the simulated year. In addition, more water quality monitoring stations should be available along the main tributaries of the Tigris River such as Upper Zab and Lower Zab. Also, no water quality data were available from the WWTPs that discharge effluents into Diyala River, a tributary of the Tigris River, and eventually discharge into the mainstem of the Tigris River. Therefore, water quality data from WWTPs would be important for assessing water quality impacts on the Tigris River. 


\section{Model Grid and Bathymetry Data}

Having $500 \mathrm{~m}$ or $1 \mathrm{~km}$ cross sections of the Tigris River would allow for more accurate calibration of flow and depths, temperature, and water quality constituents. The current cross section data of the mainstem of the Tigris River were provided with $5 \mathrm{~km}$ increments with some areas with missing data filled by interpolation. Moreover, more accurate bathymetric data of Tharthar Lake could significantly improve model calibration of the lake. A new cross section survey of the mainstem of the Tigris River would be important to provide bathymetric data of the system as a result of sediments were introduced into the water system after numerous wars in Iraq.

\section{Meteorological Data}

Improved meteorological data would be useful for temperature and water quality calibration. Solar radiation data would be a valuable and would significantly affect the water temperature calibration. Moreover, metrological data were only available from a meteorological station near Baghdad airport in Baghdad city and therefore more metrological data in the western parts of Iraq where Tharthar Lake is located would be important to understand thermal dynamics and summer stratification in Tharthar Lake. 


\section{References}

Abdul Jabar, R. A., Al-Lami, A. A-Z., Abdul Khader, R. S., Radhi, A. G., (2008). "Effects of some physical and chemical factors of Lower Zab water on Tigris River." Tikrit J. of Pure Sci. 13, 132-142.

Abdul Razzak, I. A., Sulaymon, A. H., and Al-Zoubaidy, A. R. (2009). "Modeling the distribution of BOD and TDS in part of Tigris River within Baghdad.” J. Engineering, 15, 3673-3691.

Abdul Razzak, I., (2006) "Studying and modeling the effects of pollution sources in Tigris river between Al-A'imma Bridge and al-Jumhuriya Bridge in Baghdad.” Master's thesis, University of Baghdad, Iraq.

Adams, E. E. and Wells, S. A. (1984) "Field Measurements on Side Arms of Lake Anna, Virginia," Journal of Hydraulic Engineering, ASCE, Vol. 110, No. 6, 773-793.

Aenab, A. M., and Singh, S. K., (2012). "Evaluation of drinking water pollution and health effects in Baghdad, Iraq." J. Environ. Protection, 3, 533-537.

AFED (Arab Forum for Environment and Development) (2009). "Impact of Climate Change on Arab Countries."

http://www.afedonline.org/en/ (October/19/2017)

Alena, A. M., and Singh, S. K., (2012). "Evaluation of drinking water pollution and health effects in Baghdad, Iraq." J. Environ. Protection, 3, 533-537.

Ali, A. A., Al-Ansari, N. A., and Knutsson, S., (2012). "Morphology of Tigris River within Baghdad city.” J. Hydrol. Earth Syst. Sci., 16, 3783-3790.

Alobaidy, A. H., Maulood, B. K., and Kadhem, A. J. (2010). "Evaluating raw and treated water quality of Tigris River within Baghdad by index analysis." J. Water Res. and prot., 2, 629-635.

Ansari, F., Awasthi, A. K., and Srivastava, B. P. (2012). "Physico-chemical Characterization of Distillery Effluent and its Dilution Effect at Different Levels." Scholars Research Library Archives of Applied Science Research, 4(4), 1705-1715.

Al-Anbari, R. A., Mahmood, T. A., and Yousif, W. F., (2006). "Hydraulic geometry of the Tigris River from Mosul to Bejee related to water temperature modeling.” J. Env. Hydrol., $14,1-11$.

Al-Ansari, N., Ali, A. A., Al-Suhail, Q., \& Knutsson, S. (2015). Flow of River Tigris and its Effect on the Bed Sediment within Baghdad, Iraq. Open Engineering, 5(1), 465-477. https://doi.org/10.1515/eng-2015-0054 
Al-Ansari, N. and Knutsson, S., (2011). "Toward prudent management of water resources in Iraq." J. Advanced Science and Eng. Res., 1, 53-67.

Al-Badry, M., and Artin, Y., (1972). "Study of salinity of Tigris and Euphrates Rivers and Tharthar Lake with reference to sweetening period of Tharthar lake "unpublished report", Ministry of Irrigation, D.G of Dams and Reservoirs.

Al-Dabbas, M., and Hassan, H. A., (1987). "On condition Tharthar salinity problem model." J. Agriculture and Water Resources Research, AWRRC, Council for Scientific research, Iraq.

Al-Dabbas, M. and Al-Juburi, H., (1985). "Hydrochemical analysis and sediment distribution of Tharthar reservoir." Unpublished report, Water Resources Dept., AWRRC., Council for Scientific Research, Iraq.

Al-Jebouri, M. M., and Edham, M. H., (2012). "An Assessment of biological pollution in certain sector of lower Al-Zab and river Tigris waters using bacterial indicators and related factors in Iraq." J. Water Resources and Pollution, 4, 32-38

Al-Jubori, M.A.M. (1998). "Watercourse flow pattern of the River Tigris between the two Zabs.” Ph.D. thesis, Mosul Univ., Iraq.

Al-Layla, M. A, and Al-Rizzo, H. M., (1989). "A water quality model for the Tigris River downstream of Sadam Dam, Iraq.” J. Hydro. Sci., 34:6, 687-704.

Al-Layla, M. A, Kharrufa, S. N., Akrawi, S. M., (1990). "Effect of Saddam Dam on Tigris River water quality.” J. Environ. Sci. Health, A25(1), 47-66.

Al-Marsoumi, A. H., Al-Bayati, K. M., and Al-Mallah, E. A., (2006). "Hydrogeochemical aspects of Tigris and Euphrates Rivers within Iraq: A comparative study.” J. RAF. Sci., 17, 2, 34-49.

Al-Murib, M. (2014) "Application of CE-QUAL-W2 on Tigris River in Iraq." Civil and environmental Engineering Master's Project Report.

http://pdxscholar.library.pdx.edu/cengin_gradprojects/9

Al-Obaidy, F. M. Sh. (1996). "Hydrological study of the stage and other characteristics of Tigris River." M.S. thesis, Mosul Univ., Iraq.

Al-Rawi, S. M., (2005). "Contribution of Man - Made Activities to the Pollution of the Tigris within Mosul Area/IRAQ." International J. Environ. Research \& Public Health, 2, 245-250.

Al-Samak, M.A.S., Al-Saati, B.A, Al-Janabi, F.H., Al-Timimi, A.A. and Ghalib, S.A. (1985). "Iraq-Regional Study.” Vol.1, Dar Al-Kutib, Mosul Univ., P304 (in Arabic). 
Al-Shahrabaly, Q. M. (2008). "River discharges for Tigris and Euphrates gauging stations." Ministry of water Resources, Baghdad.

APHA (American Public Health Association) (1992). Standard methods for the examination of water and wastewater, 18ed., Washington, DC.

Aziz, A. M., Aws, A. (2012). "Wastewater production treatment and use in Iraq country report.” Ministry of water Resources, Iraq.

Baban, I. J., (1977). "General survey of hardness in natural waters of Iraq and effects of drainage schemes on it.” M.S. thesis, Baghdad Univ., Iraq.

Boer, T. (2014). "Assessing the Accuracy of Water Temperature Determination and Monitoring of Inland Surface Waters Using Landsat 7 ETM + Thermal Infrared Images A Case Study on the Rhine River, North Sea Canal, and Hollands Diep." M.S. thesis, Delft University of Technology, Delft, The Netherlands.

Burnham, G., Lafta, R., Doocy, S., and Roberts, L., (2006). "Mortality after the 2003 Invasion of Iraq: A cross-sectional cluster sample survey.” Lancet, 368, 9545, 1421-1428.

Camberato, J., (2001). "Irrigation water quality." Clemson University, http://www.scnla.com/Irrigation_Water_Quality.pdf $($ Apr.19, 2017)

Charbeneau, R. J., and Holley, E. R., (2001). "Backwater effects of bridge piers in subcritical flow." Research report conducted for the Texas Dept. of Transportation. http://ctr.utexas.edu/wp-content/uploads/pubs/1805_1.pdf

CSO (2010). "Central Statistical Organization in Iraq_Environmental Statistics Report in Iraq for the year 2009.” In Arabic. Accessed on April-21-2017. http://www.cosit.gov.iq/ar/env-stat/envi-stat

Chander, G., \& Markham, B. (2003). Revised Landsat-5 TM radiometric calibration procedures and post calibration dynamic ranges. IEEE Transactions on Geoscience and Remote Sensing, 41, 2674-2677.

Chow, V.T., (1959). “Open-channel hydraulics”: New York, McGraw-Hill, 680 p.

Chipman, J. W., Lillesand, T. M., Schmaltz, J. E., Leale, J. E., \& Nordheim, M. J. (2004). Mapping lake water clarity with Landsat images in Wisconsin, USA. Canada Journal of Remote Sensing, 30, 1-7.

Cole, T. M., Wells, S. A. (2017). “CE-QUA1-W2: a two-dimensional, laterally averaged, hydrodynamic and water quality model." version 3.71. Instruction Report EL-2000. US Army Engineering and Research Development Center, Vicksburg. 
Coll, C., Galve, J. M., Sánchez, J.M., and Caselles, V. (2010), "Validation of Landsat7/ETM+ Thermal-Band Calibration and Atmospheric Correction with Ground-Based Measurements", IEEE Trans. Geosci. Remote Sens., vol. 48, no. 1, pp. 547-555.

Di Baldassarre, G., \& Montanari, A. (2009). Uncertainty in river discharge observations: a quantitative analysis. Hydrology and Earth System Sciences, 13(6), 913-921. https://doi.org/10.5194/hess-13-913-2009

Edinger, J.E., and Buchak, E.M. 1975. "A Hydrodynamic, Two-Dimensional Reservoir Model: The Computational Basis", prepared for US Army Engineer Division, Ohio River, Cincinnati, Ohio.

Fan, D., Huang, Y., Song, L., Liu, D., \& Zhang, G. (2014). "Prediction of chlorophyll a concentration using HJ-1 satellite imagery for Xiangxi Bay in Three Gorges Reservoir." Water Science and Engineering, 7(1), 70-80.

FAO (2008) "Irrigation in the Middle East region in figures - AQUASTAT Survey" http://www.fao.org/nr/water/aquastat/basins/euphrates-tigris/Euphrates.tigrisCP_eng.pdf. (Sep. 12, 2017).

Fuller, R. M., Groom, G. B., \& Jones, A. R. (1994). "The land cover map of Great Britain: An automated classification of Landsat Thematic Mapper data", Photogrammetric Engineering and Remote Sensing, 60, 553-562.

Giardino, C., Pepe, M., Brivio, P. A., Ghezzi, P., and Zilioli, E., (2001). "Detecting chlorophyll. Secchi disk depth and surface temperature in a sub-alpine lake using Landsat Imagery." J. Sci. Total Environ. 268, 19-29.

Hanson, B., Schwankl, L., and Fulton, A., (2004). "Introduction to irrigation scheduling." Scheduling irrigations: When and how much water to apply, Water Management Handbook Series, UC ANR publication 3396.

Hikmat, M. (2005). "Two-dimensional numerical model for the distribution of pollutants in Tigris River downstream of Tharthar-Tigris channe1." M.S. thesis, University of Baghdad, Baghdad, Iraq.

Husain, A. (2009). "Monthly changes of some physiochemical parameters for Tigris RiverBaghdad between 2002-2003. J. Engineering and Technology, 27, 64-70.

IPCC (Intergovernmental Panel on Climate Change) (2007) Climate Change 2007: Climate Change Impacts, Adaptation and Vulnerability. Cambridge University Press, Geneva.

Ismail, A. H., and Abed, G. A., (2013). "BOD and DO modeling for Tigris River at Baghdad city portion using QUAL2K model.” J. Kerbala University. 11, 257-273.

Issa, I. E., Al-Ansari, N. A., Sherwany, G, and Knutsson, S., (2014). "Expected future of water resources within Tigris-Euphrates Rivers, Iraq." J. water Resources and Protection, $6,421-432$. 
Jasim, H. A. J. (1988). "Some effects of Tharthar-Tigris canal on water quality of the Tigris River." M.S. thesis, Baghdad Univ., Iraq.

Jehad, A. A., (1983). "Effect of Tharthar canal salty water on the quality of Euphrates water." M.S. thesis, Technology Univ., Iraq.

Jimeneze-Munoz, J. C., Sobrino, J. A. (2003) "A generalized single-channel method for retrieving land surface temperature from remote sensing data." J. Geophysical Research, 108, (D22).

Kabbara, N., Benkhelil, J. Awad, M., and Barale, V., (2008) "Monitoring water quality in the coastal area of Tripoli (Lebanon) using high-resolution satellite data." J. Photogrammetry \&Remote sensing, 63, 488-495.

Kadhem, A. J., (2013). "Assessment of water quality in Tigris River-Iraq by using GIS mapping." J. Natural Resources, 4, 441-448.

Khattab, M. F. O., and Merkel, B. J., (2014) "Application of Landsat 5 and Landsat 7 images data for water quality mapping in Mosul Dam Lake, northern Iraq." Arab J. Geosci. 7, 3557-3573.

Lamaro, A. A., Marinelarena, A., Torrusio, S. E., and Sala, S. E., (2013) "Water surface temperature estimation from Landsat $7 \mathrm{ETM}+$ thermal infrared data using the generalized single-channel method: Case study of Embalse del Rio tercero (Corodoba, Argentina)." J. Advances in Space Research, 51, 492-500.

Leopold, L. B., and Maddock, T.J., (1953) "hydraulic geometry of stream channels and some physiographic implication.” USGS professional paper 252, 55p.

Liu X, Wang L, Sherman DJ, Wu Q, Su H (2011) Algorithmic foundation and software tools for extracting shoreline features from remote sensing imagery and LiDAR data. J Geogr Inf Syst 3(2):99-119.

Lu, D., Mausel, P., Brondizio, E. and Moran, E., (2002), Assessment of atmospheric correction methods for Landsat TM data applicable to Amazon basin LBA research. International Journal of Remote Sensing, 23, pp. 1671-2651.

Ministry of Environment, "System Maintenance of River and Public Water Pollution in Iraq," 1998. http://www.moen.gov.iq

Ministry of Water Resources-Iraq (MWR) (2005), Schematic diagram of main control structures in Iraq, General directorate of water resources management, hydrological studies center.

Mix Max (2009). "Iraq the Lasting Love" http://iraqthelastinglove.blogspot.com/2009/09/more-from-iraqs-old-days.html.

(September 21, 2017) 
MOT-IMOAS (2014) "Ministry of Transportation-Iraqi Meterological Organization and Seismology" http://www.meteoseism.gov.iq/index.php (Oct. 18, 2017).

MOWR (2014) "Ministry of Water Resources in Iraq" https://www.mowr.gov.iq/en (Oct. 16, 2017).

Mutlak, S. M., Salih, B. M., and Tawfiq, S. J., (1980). "Quality of Tigris River passing through Baghdad for irrigation.” J. Water, Air, and Soil Pollut. 13, 9-16.

Nas, B., Ekercin, S., and Karabork, H., (2010). "An application of Landsat-5TM image data for water quality mapping in Lake Beysehir, Turkey.” J. Water Air Soil Pollut. 212, 183-197.

NASA (2014). "Land Remote-Sensing Satellite System 7"

https://www.nasa.gov/directorates/heo/scan/services/missions/earth/Landsat7.html

(Nov. 25, 2017).

Odemis, B., Sangun, M. K., and Evrendilek, F. (2010). "Quantifying long-term changes in water quality and quantity of Euphrates and Tigris rivers, Turkey." J. Environ. Monit. Assess, 170, 475-490.

Olmanson, L. G., Bauer, M. E.,\&Brezonik, P. L. (2008). “A 20-year Landsat water clarity census of Minnesota's 10, 000 Lakes". Remote Sensing of Environment, 122(11), 40864097.

Othman, K. I., and Deguan, W. (2004). "Characteristics of Tigris River bed at Mosul City, Iraq.” Journal of Lake Sciences, 16, 61-71.

Rabee A-M., Abdul-Kareem., B. M., Al-Dhamin, A. S., (2011). "Seasonal variations of some ecological parameters in Tigris River water at Baghdad region, Iraq." J. Water Resources and Protection, 3, 262-267.

Rahi, K. A., and Halihan, T. (2010). "Changes in the salinity of the Euphrates River system in Iraq.” Regional Environmental Change, 10(1), 27-35.

Reddy, M. A. (1997). A detailed statistical study on selection of optimum IRS LISS pixel configuration for development of water quality models. International Journal of Remote Sensing, 18, 2559-2570.

Ritchie, R., Cooper CM., Schiebe, FB., (1990) "The relationship of MMS and TM digital data with suspended sediments, chlorophyll and temperature in Moon Lake, Mississippi." J. Remote Sensing of Environment, 33, 137-148.

Ryu, JH, Won JS, Min, KD (2002). "Waterline exreaction from Landsat TM data in a tidal flat: a case study in Gomso Bay, Korea.” J. Remote Sens Environ, 83(3), 442-456

Sauer, V. B., \& Meyer, R. W. (1992). “Determination of error in individual discharge measurements.” United States Geological Survey Open - File Report.

Simon, R. N., Tormos, T., and Danis, P. A., (2014) "Retrieving water surface temperature from archive Landsat thermal infrared data: Application of the mono-channel atmospheric 
correction algorithm over two freshwater reservoirs." International J. Applied Earth Observation and Geoinformation, 30, 247-250.

Sissakian, V. K., (2011). "Genesis and age estimation of the Tharthar depression, central west Iraq.” J. Iraqi Bulletin of Geology and Mining, 7, 47-62.

Swiss Consultants. (1979). "Tigris River water resources study." "unpublished report", Ministry of Irrigation.

The World Bank. (2006). "Iraq - Country water resource assistance strategy: addressing major threats to people's livelihoods." 1-97. https://doi.org/36297-IQ

UN-ESCWA and BGR, (2013), Inventory of Shared Water Resources in Western Asia, United Nations Economic and Social Commission for Western Asia and Bundesanstalt für Geowissenschaften und Rohstoffe, Beirut.

United Nation (UN) factsheet (2013) "Water in Iraq Factsheet" http://www.iraqicivilsociety.org/wp-content/uploads/2014/02/Water-Factsheet.pdf (Aug. 28, 2017).

U.S. Army Corps of Engineers, (2010). "HEC-RAS" manual. http://www.hec.usace.army.mil// (Aug. 31, 2017).

United States Geological Survey (USGS) http://glovis.usgs.gov/ (Aug. 31, 2017).

United States Geological Survey (USGS)

http://www.earthexplorer.usgs.gov/ (Aug. 31, 2017).

USAID (2003) "Providing Sanitation to Iraq"

http://pdf.usaid.gov/pdf_docs/Pdack151.pdf (Aug. 31, 2017).

USAID (2007) "Iraq Private Sector Growth and Employment Generation." http://www.iajd.org/files/3_1.pdf. (Aug. 31, 2017).

Wanielista M, Kersten R, Eaglin R. (1997) "Hydrology: Water Quantity and Quality Control,” 2nd edition. John Wiley \& Sons, Inc. pp. 68-72.

Wang, F., Han, L., Kung, H., and Ardale, R. (2006) “Application of Landsat5 TM imagery in assessing and mapping water quality in Reelfoot Lake, Tennessee" International J. Remote sensing, 27, 5269-5283.

Water Research Foundation (2015). "EPA Secondary Maximum Contaminant Levels: A Strategy for Drinking Water Quality and Consumer Acceptability.” Web report\#4537. http://www.waterrf.org/Pages/Projects.aspx?PID=4537 (April/19/2017).

Worldometers. "World Population." http://www.worldometers.info/world-population/iraq-population/ (December/23/2017). 
Wulder, M. A.,White, J. C., Goward, S. N., Masek, J. G., Irons, J. R., Herold, M., Cohen,W. B., Loveland, T. R., \&Woodcock, C. E. (2008). "Landsat continuity: Issues and opportunities for land cover monitoring”, Remote Sensing of Environment, 112, 955-969.

WRI (World Resources Institute) (2002) Drylands, People, and Ecosystem Goods and Services: A Web-Based Geo-Spatial Analysis. http://www.wri.org

Zakaria, S., Al-ansari, N., \& Knutsson, S. (2013). "Historical and Future Climatic Change Scenarios for Temperature and Rainfall for Iraq," 7(12), 1574-1594. 


\section{Appendix A: Management Scenarios of the Tigris River Model}

\section{Management Scenario 1: Increasing Upstream Flow}
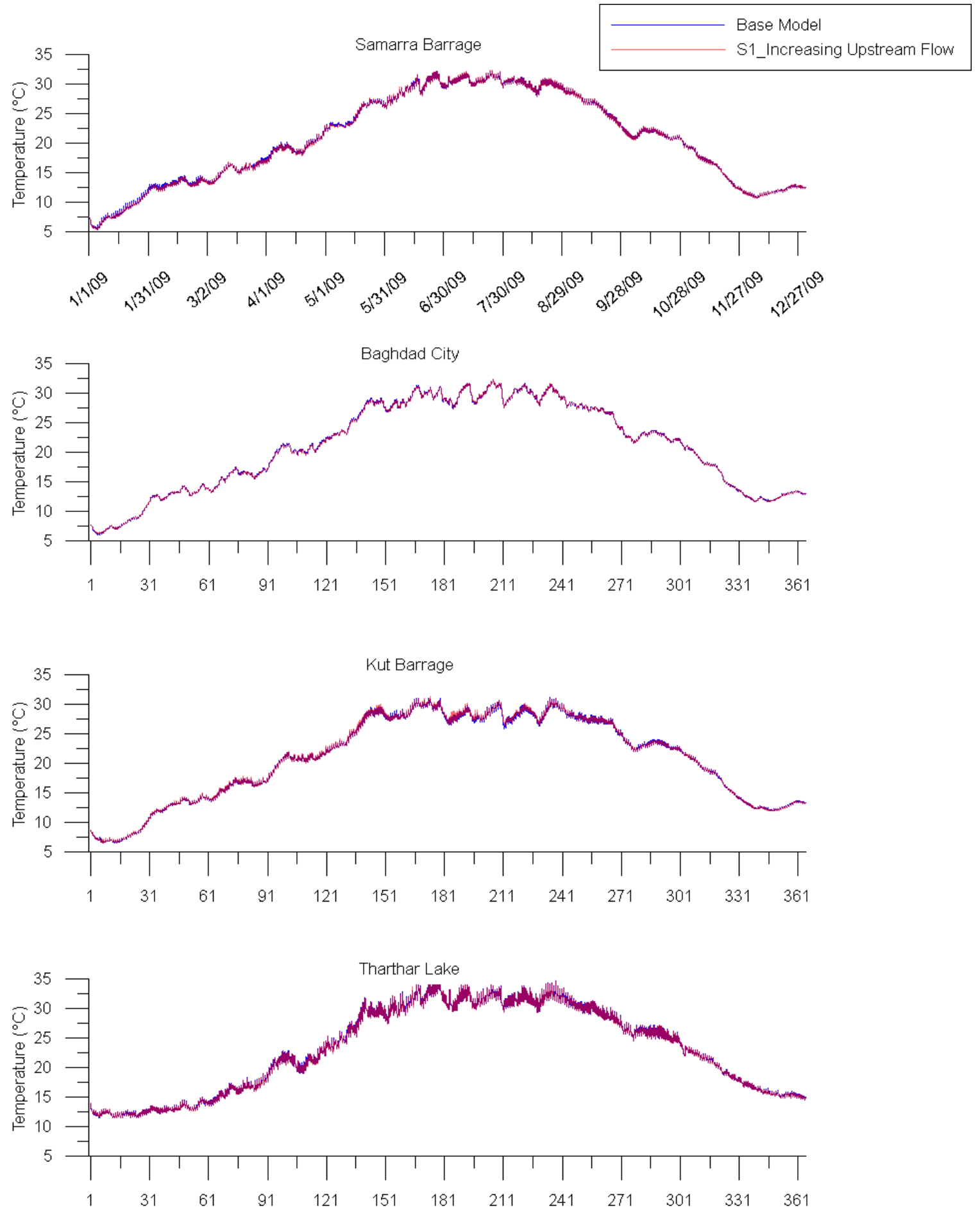

Figure 142: Model temperature $\left(\mathrm{T}_{\mathrm{w}}\right)$ predictions for base model and management scenario 1 (increasing upstream flow) at Samarra Barrage, Baghdad City, Kut Barrage, and Tharthar Lake. 

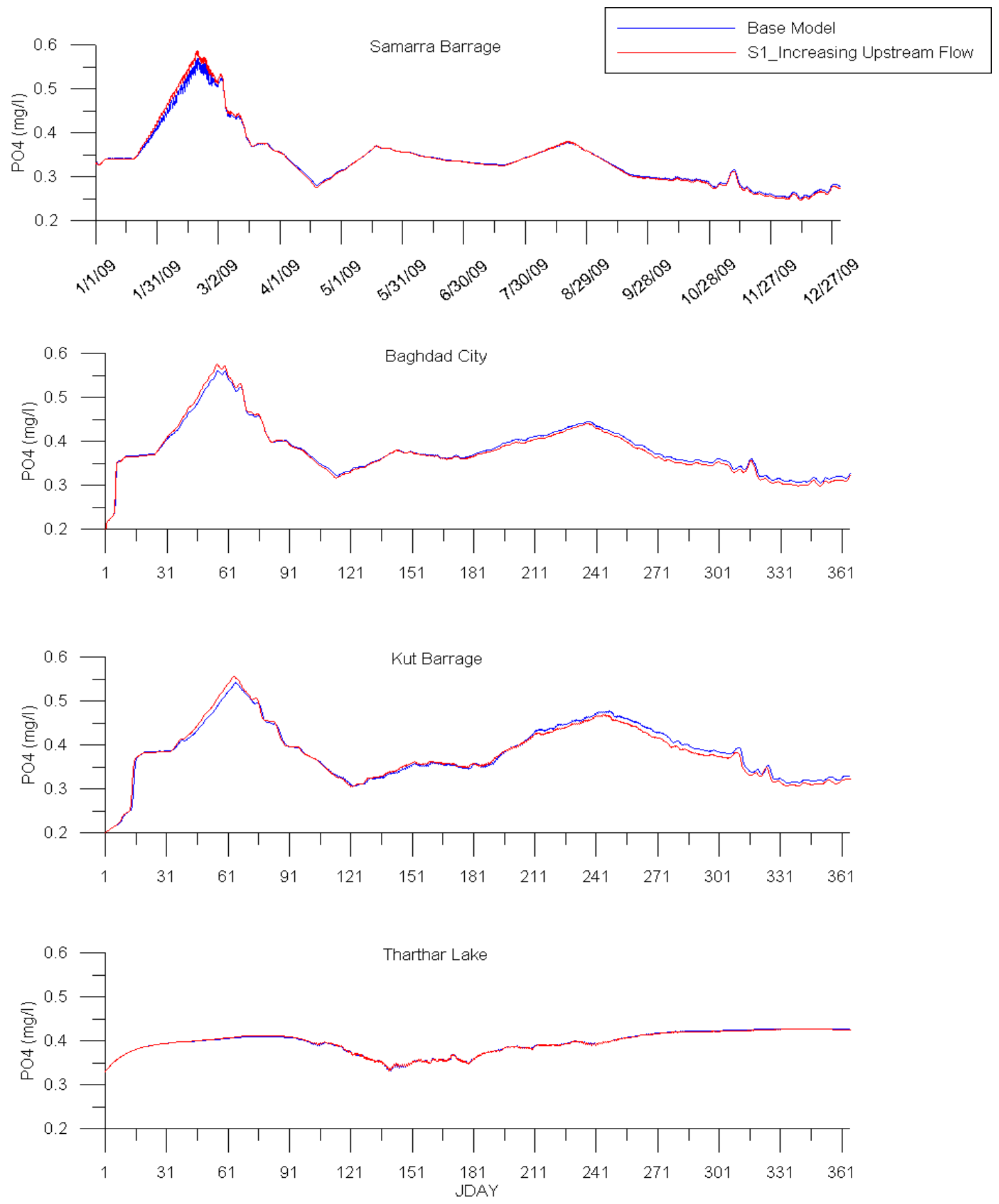

Figure 143: Model phosphate (PO4) predictions for base model and management scenario 1 (increasing upstream flow) at Samarra Barrage, Baghdad City, Kut Barrage, and Tharthar Lake. 

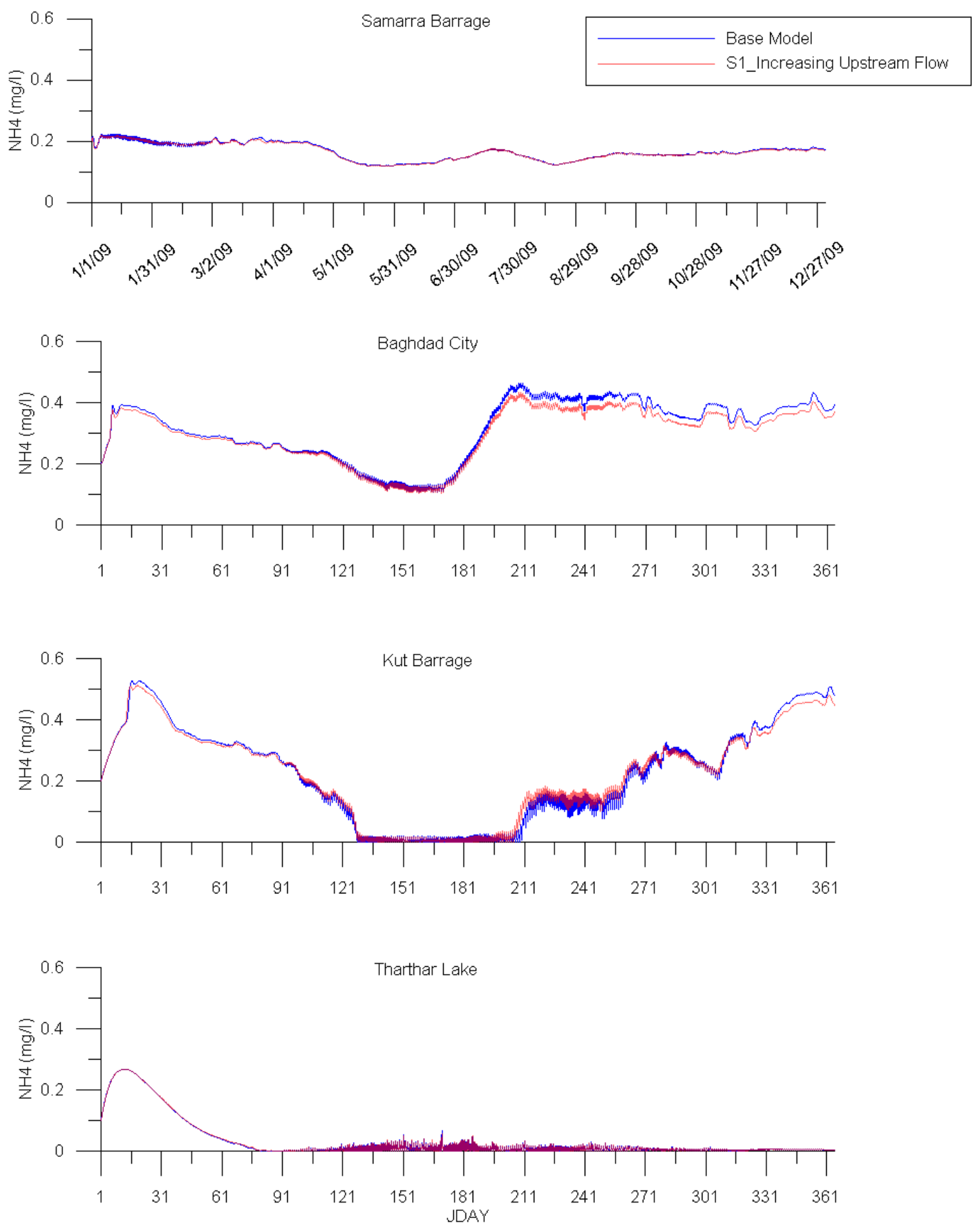

Figure 144: Model ammonia (NH4) predictions for base model and management scenario 1 (increasing upstream flow) at Samarra Barrage, Baghdad City, Kut Barrage, and Tharthar Lake. 

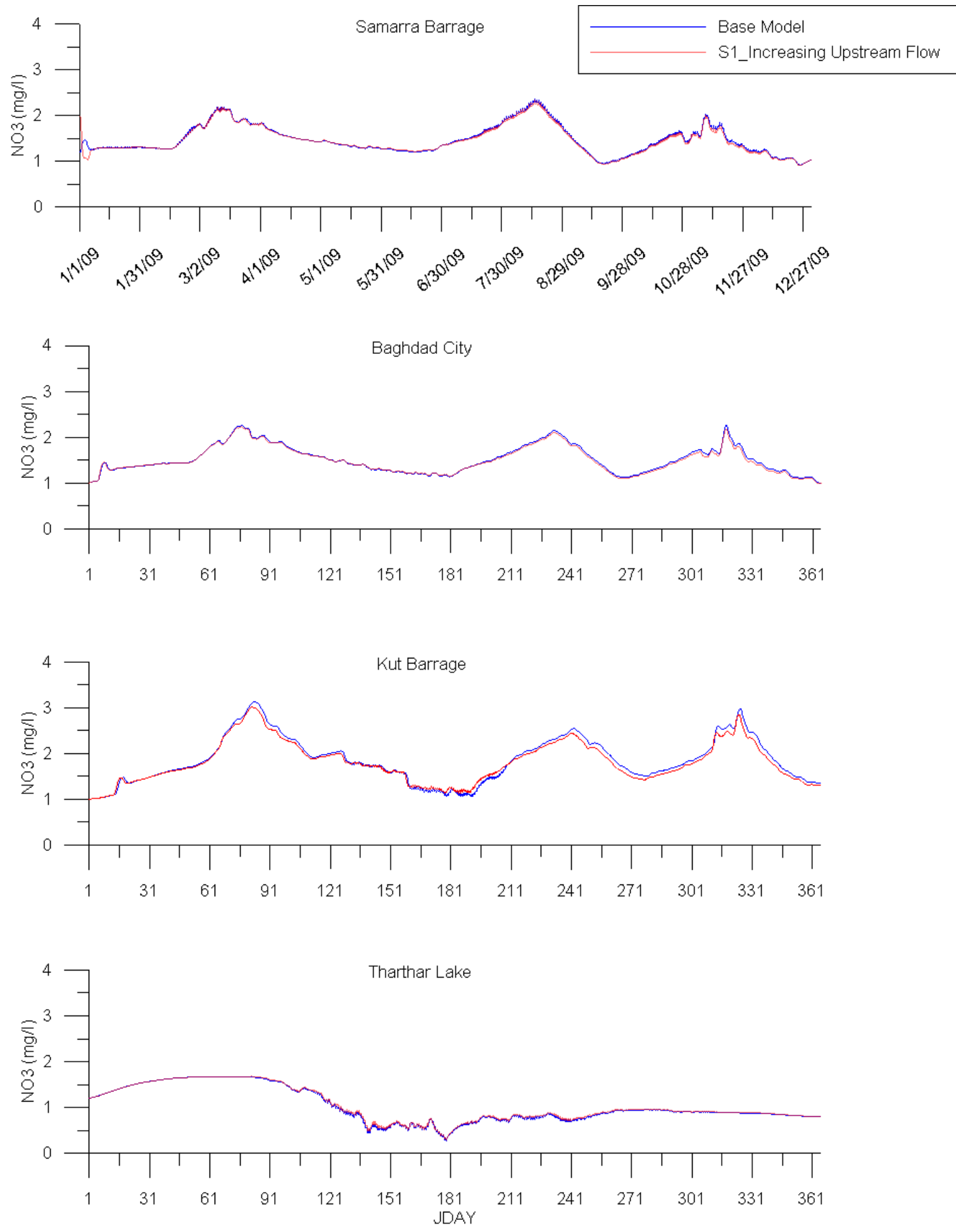

Figure 145: Model nitrate (NO3) predictions for base model and management scenario 1 (increasing upstream flow) at Samarra Barrage, Baghdad City, Kut Barrage and Tharthar Lake. 

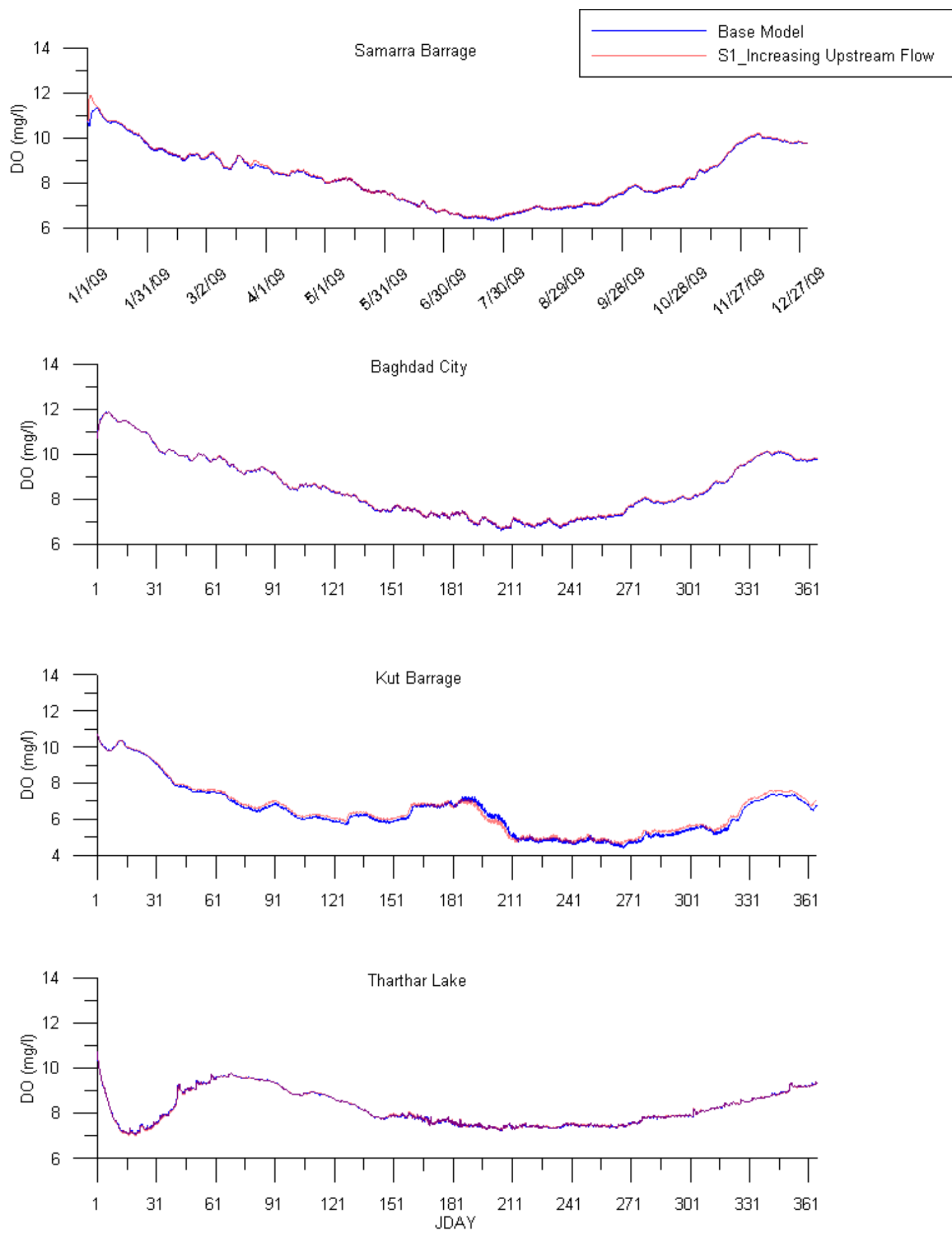

Figure 146: Model dissolved oxygen (DO) predictions for base model and management scenario 1 (increasing upstream flow) at Samarra Barrage, Baghdad City, Kut Barrage, and Tharthar Lake. 

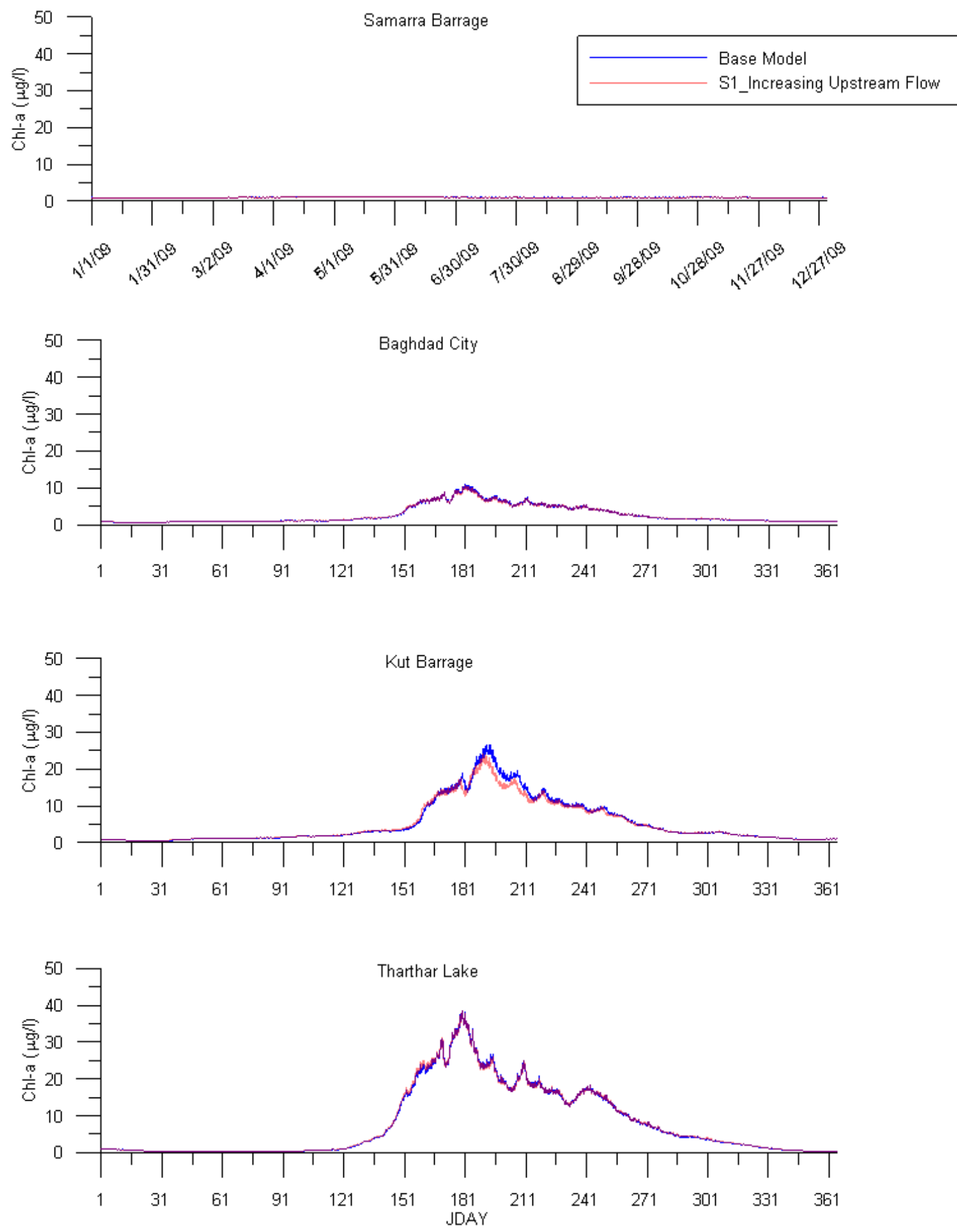

Figure 147: Model chlorophyll-a (Chl-a) predictions for base model and management scenario 1 (increasing upstream flow) at Samarra Barrage, Baghdad City, Kut Barrage, and Tharthar Lake. 


\section{Management Scenario 2: Decreasing Upstream Flow}
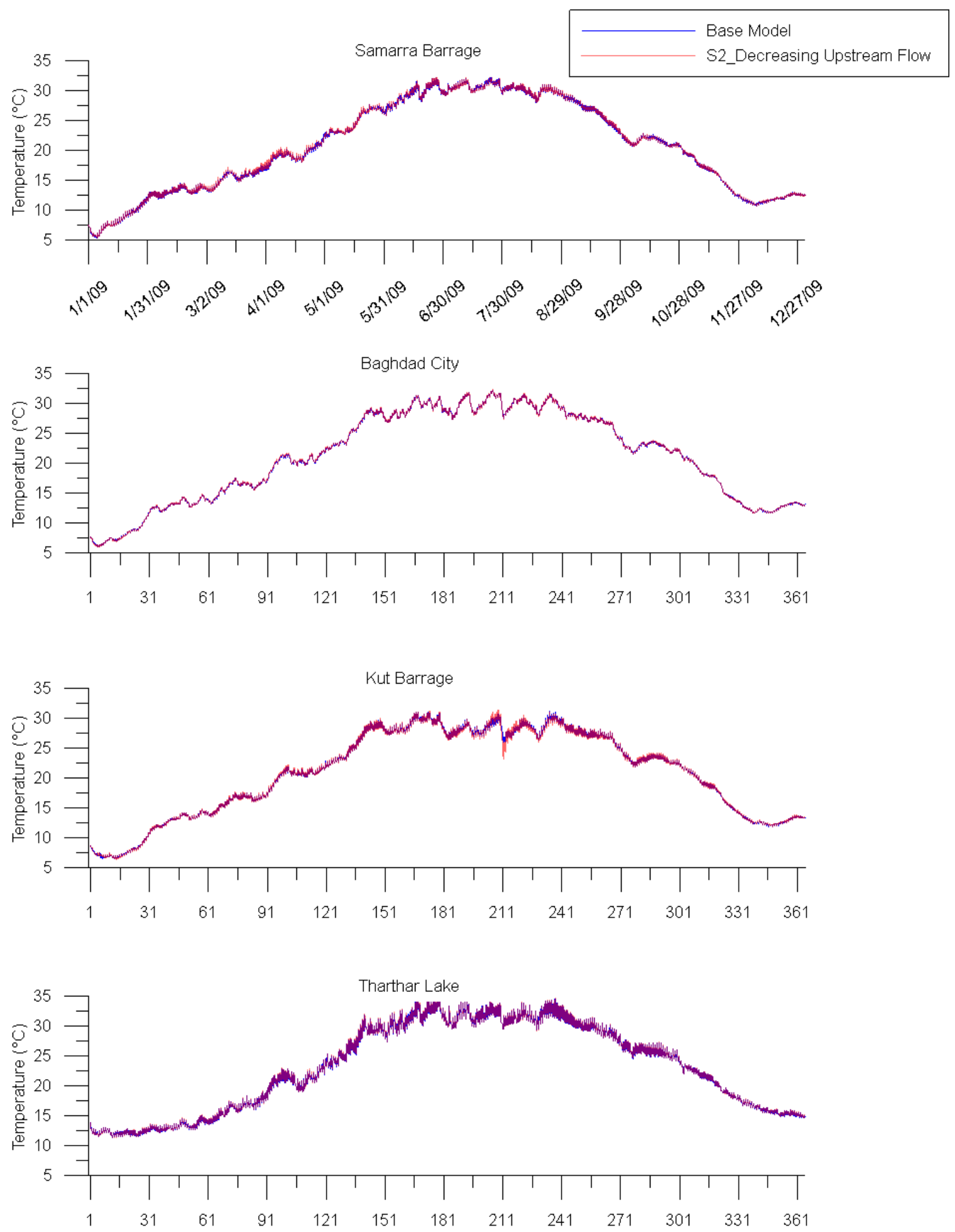

Figure 148: Model temperature $\left(\mathrm{T}_{\mathrm{w}}\right)$ predictions for base model and management scenario 2 (decreasing upstream flow) at Samarra Barrage, Baghdad City, Kut Barrage, and Tharthar Lake. 

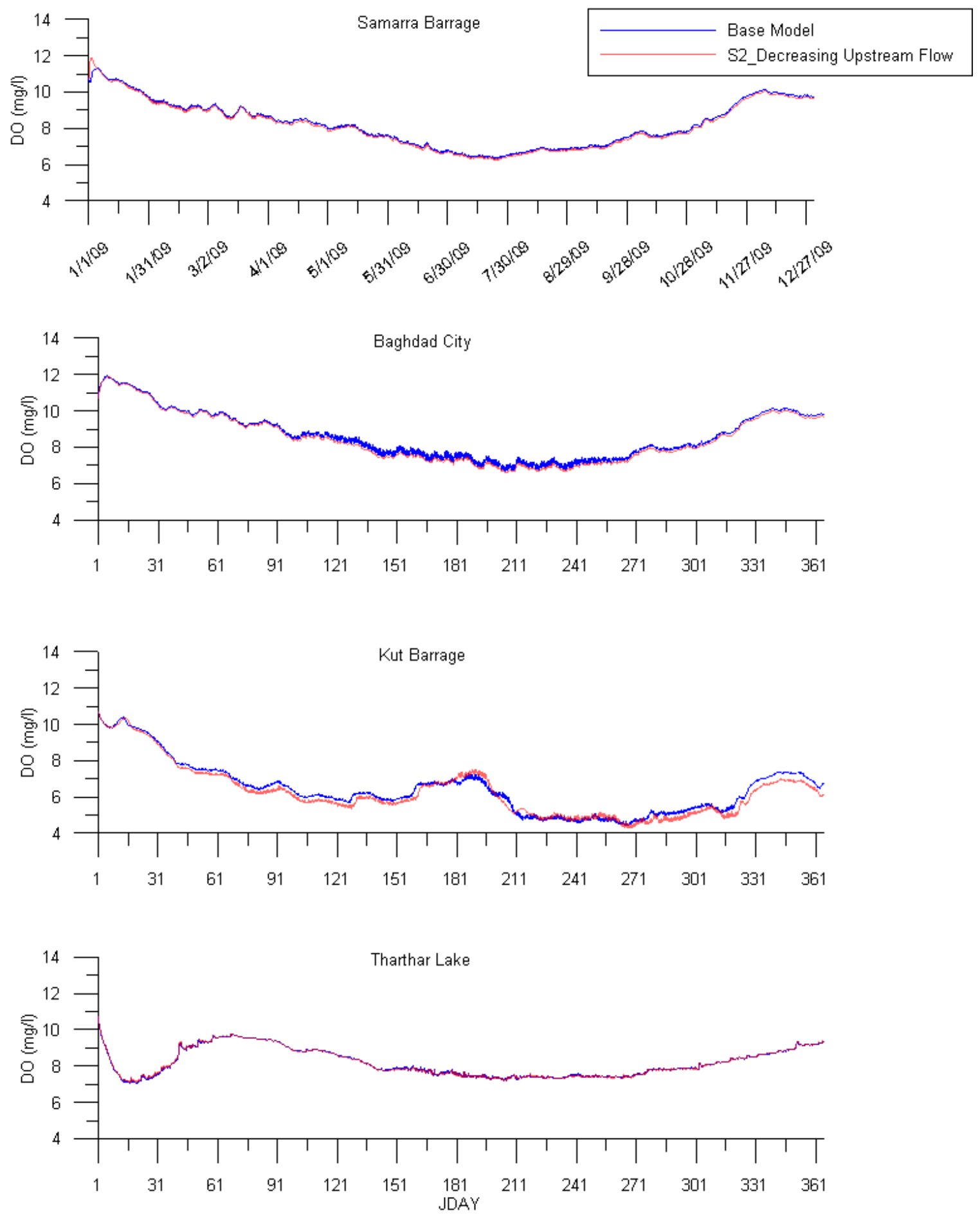

Figure 149: Model dissolved oxygen (DO) predictions for base model and management scenario 2 (decreasing upstream flow) at Samarra Barrage, Baghdad City, Kut Barrage and Tharthar Lake. 

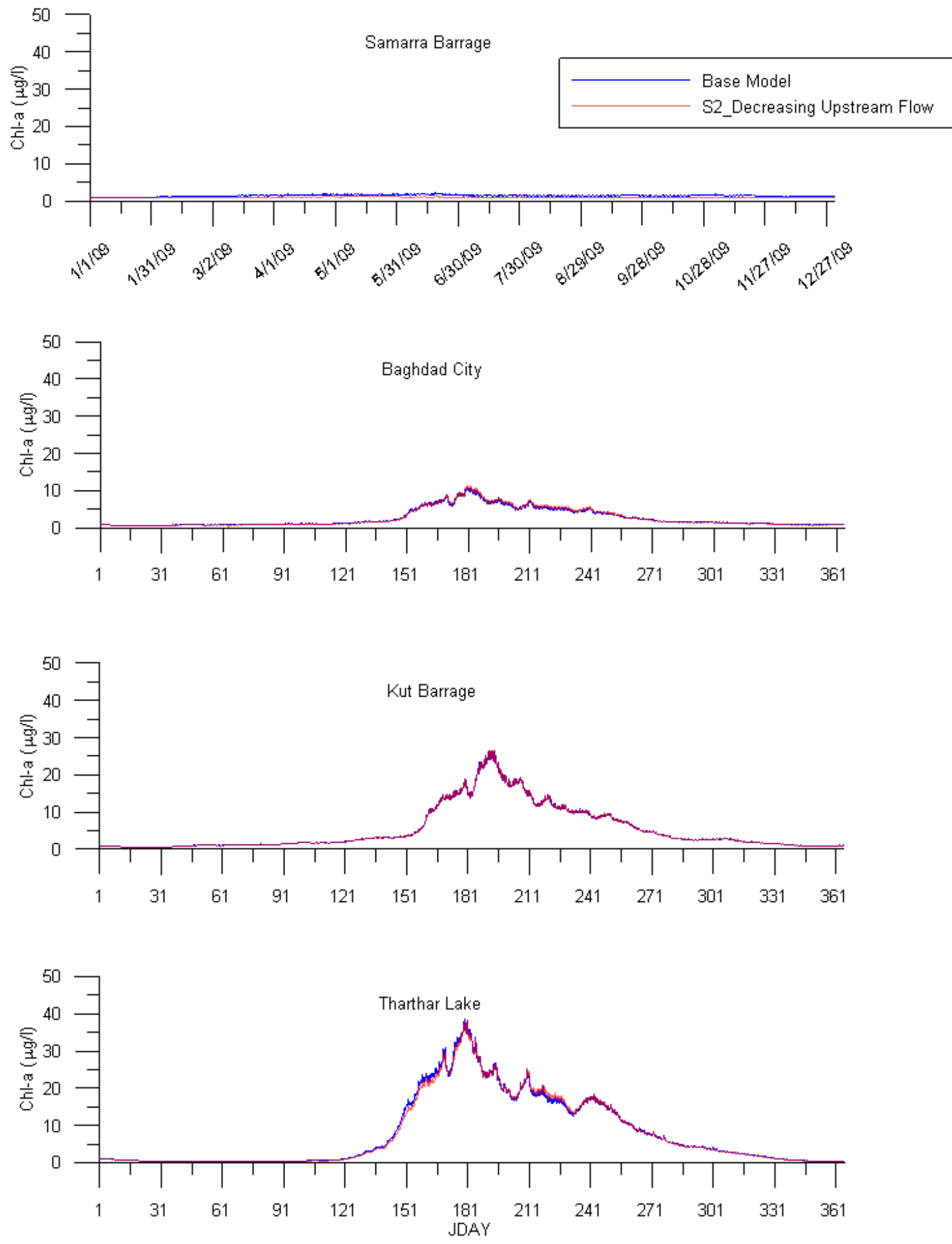

Figure 150: Model chlorophyll-a (Chl-a) predictions for base model and management scenario 2 (decreasing upstream flow) at Samarra Barrage, Baghdad City, Kut Barrage, and Tharthar Lake. 


\section{Management Scenario 3: Decreasing Upstream Flow and Increasing Nutrients}
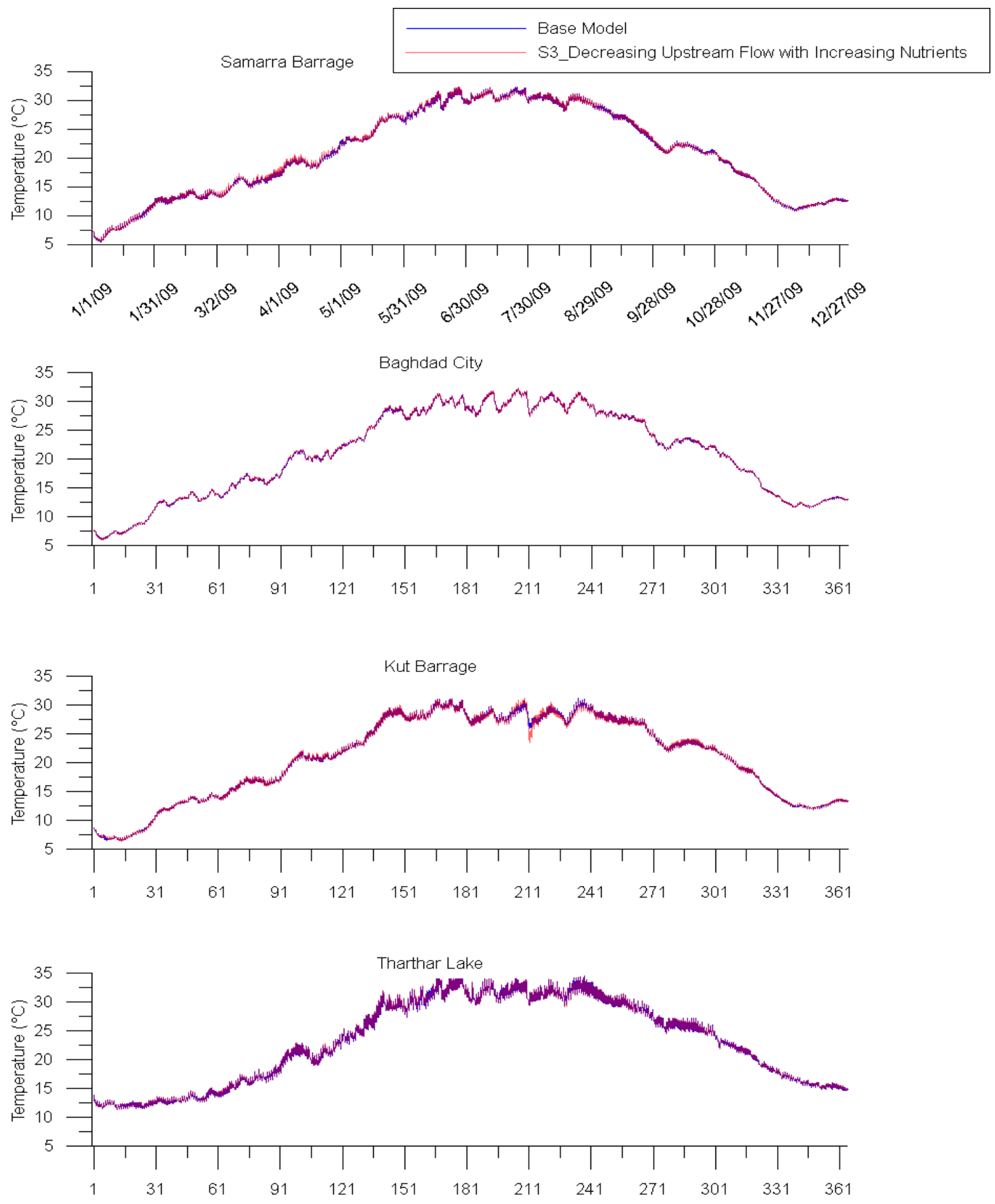

Figure 151: Model temperature $\left(\mathrm{T}_{\mathrm{w}}\right)$ predictions for base model and management scenario 3 (decreasing upstream flow with increasing nutrients) at Samarra Barrage, Baghdad City, Kut Barrage, and Tharthar Lake. 

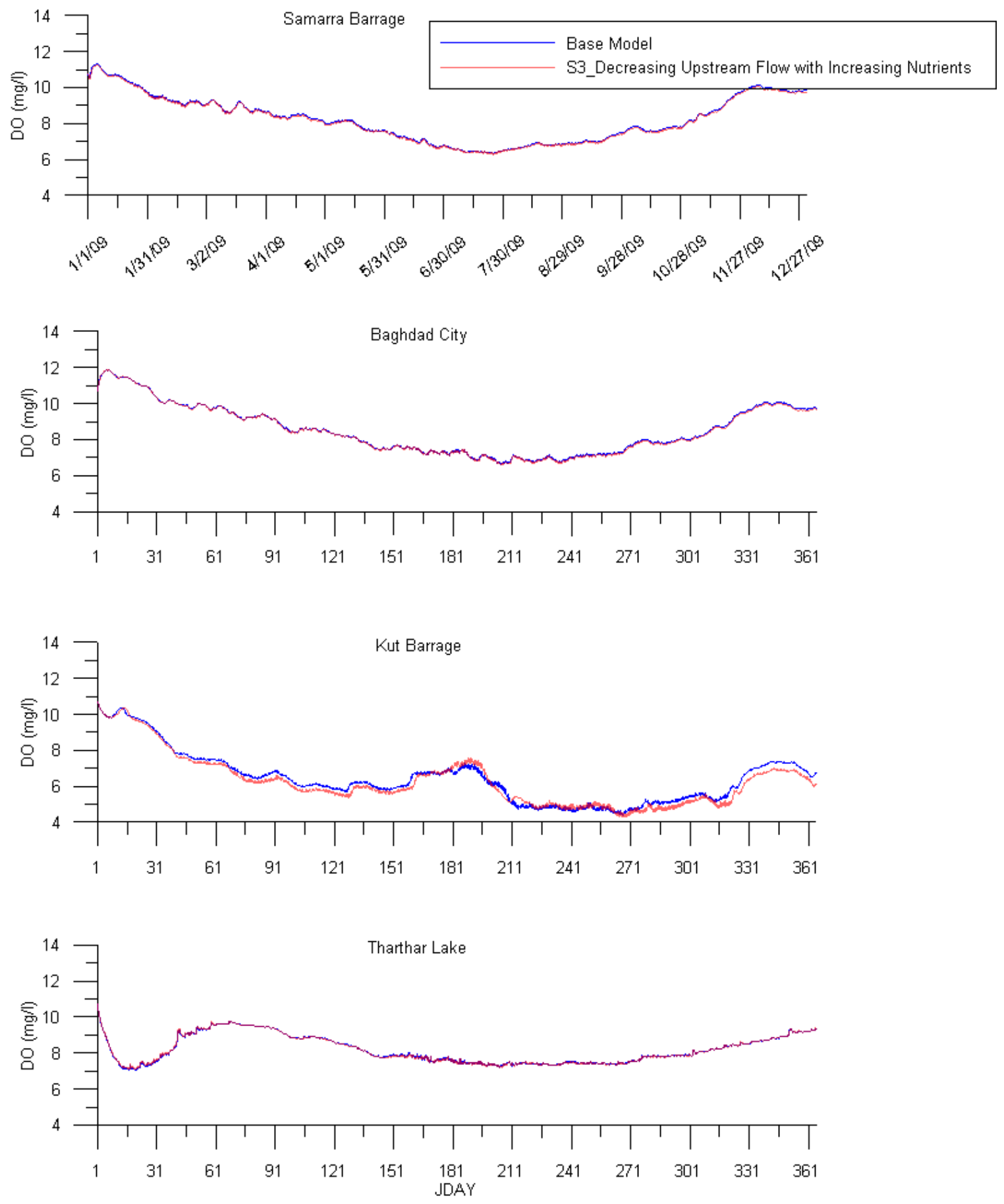

Figure 152: Model dissolved oxygen (DO) predictions for base model and management scenario 3 (decreasing upstream flow with increasing nutrients) at Samarra Barrage, Baghdad City, Kut Barrage, and Tharthar Lake. 

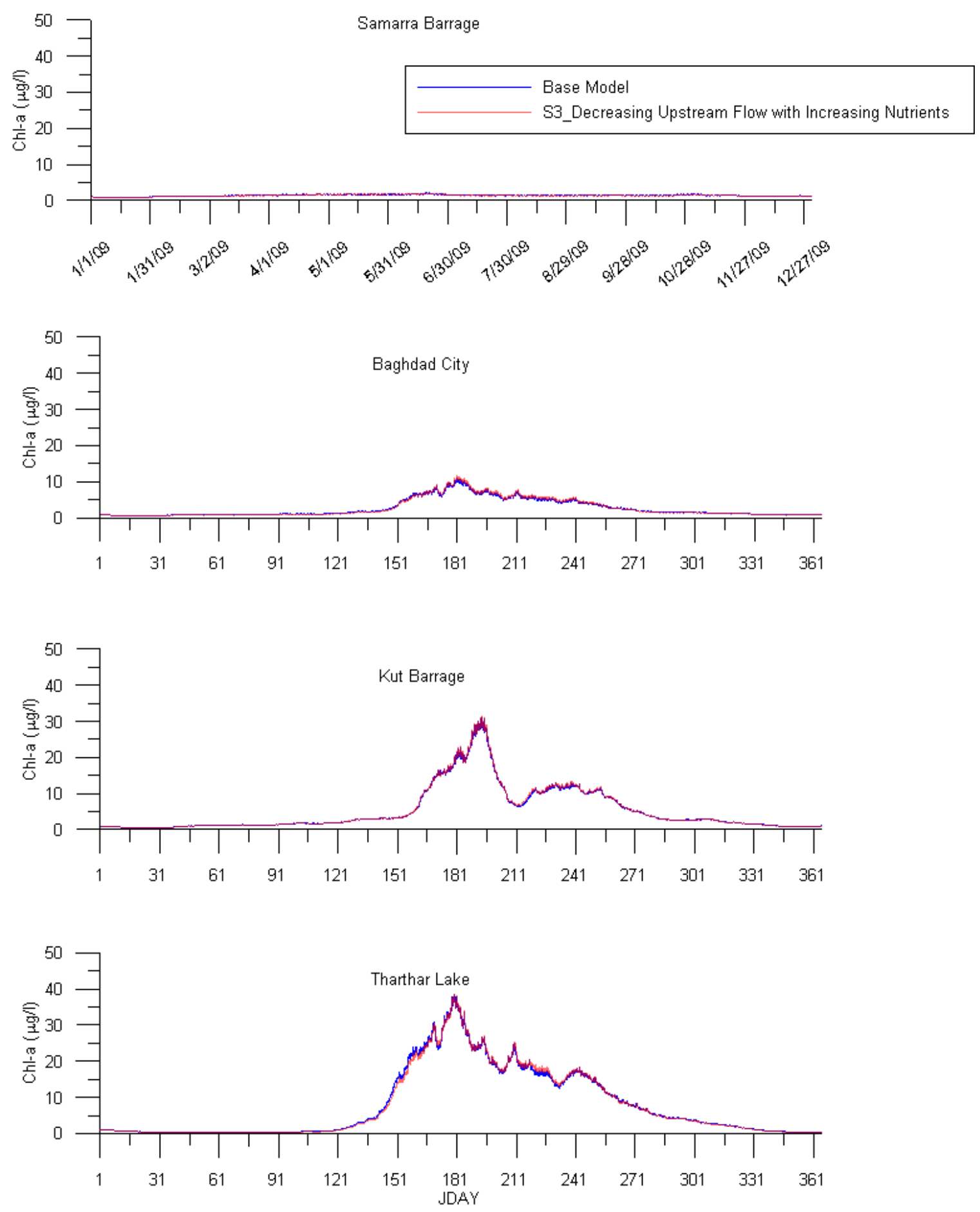

Figure 153: Model chlorophyll-a (Chl-a) predictions for base model and management scenario 3 (decreasing upstream flow with increasing nutrients) at Samarra Barrage, Baghdad City, Kut Barrage, and Tharthar Lake. 


\section{Management Scenario 4: Increasing Tharthar Lake's Flow}
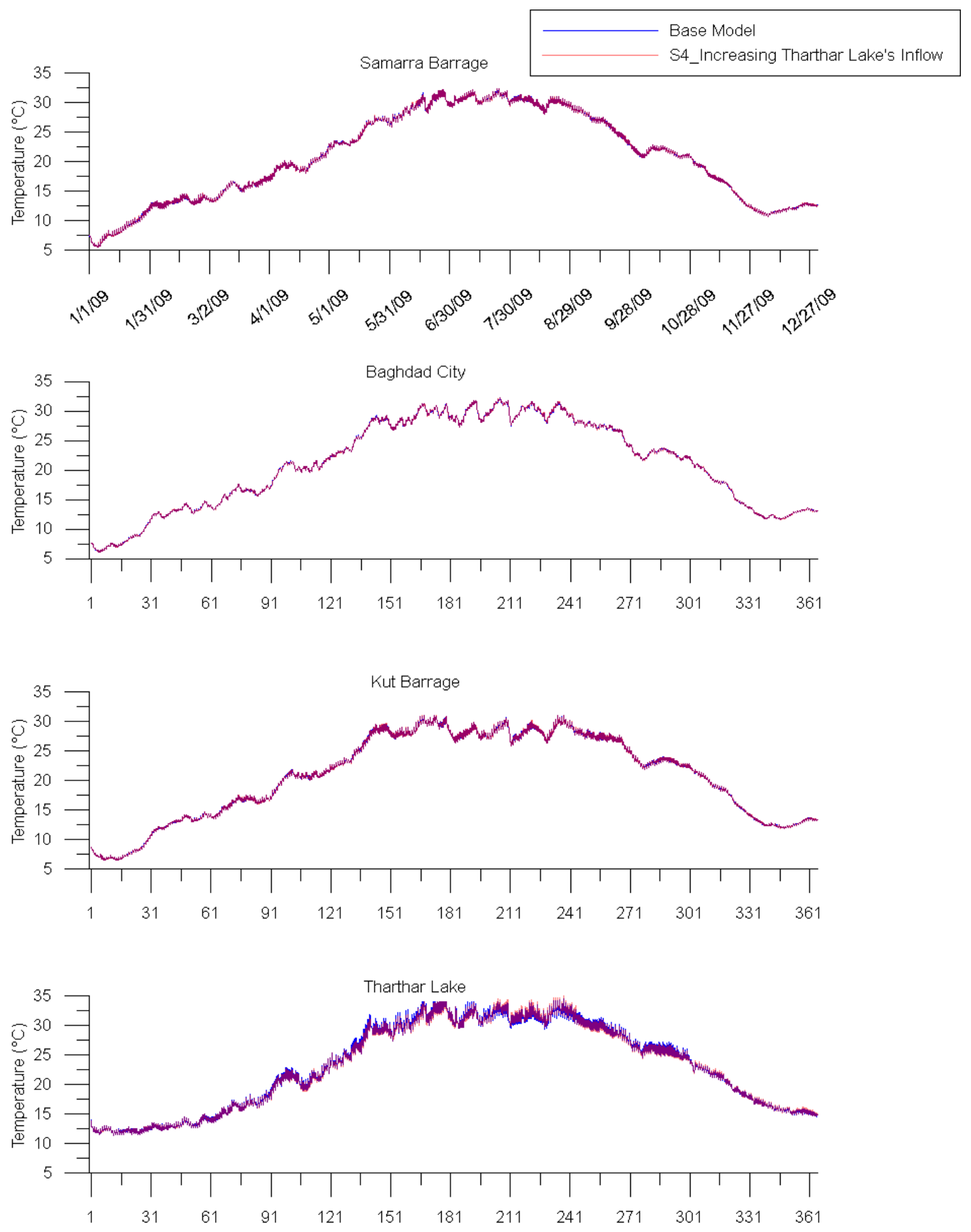

Figure 154: Model temperature $\left(\mathrm{T}_{\mathrm{w}}\right)$ predictions for base model and management scenario 4 (increasing Tharthar Lake's inflow) at Samarra Barrage, Baghdad City, Kut Barrage, and Tharthar Lake. 

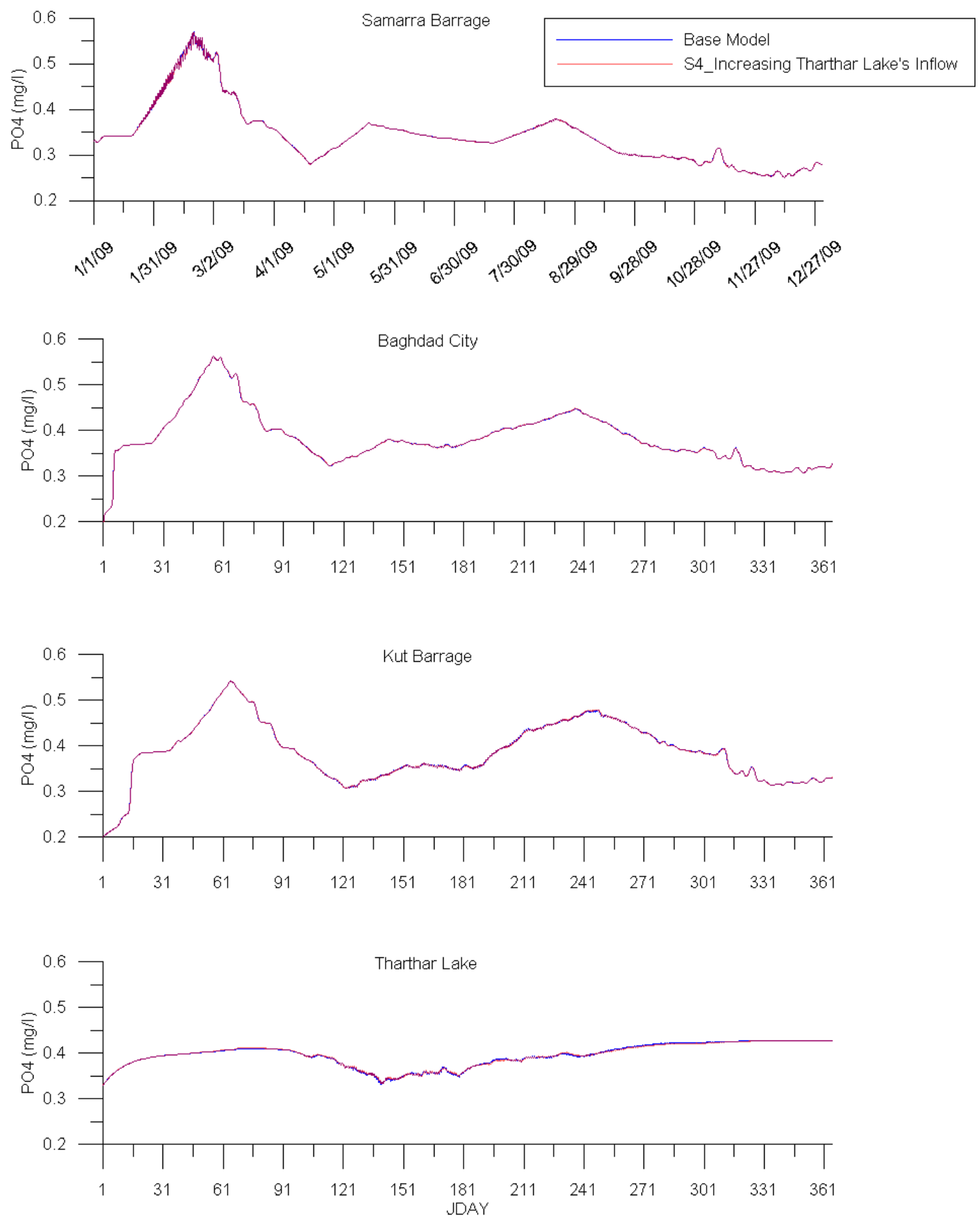

Figure 155: Model phosphate (PO4) predictions for base model and management scenario 4 (increasing Tharthar Lake's inflow) at Samarra Barrage, Baghdad City, Kut Barrage, and Tharthar Lake. 

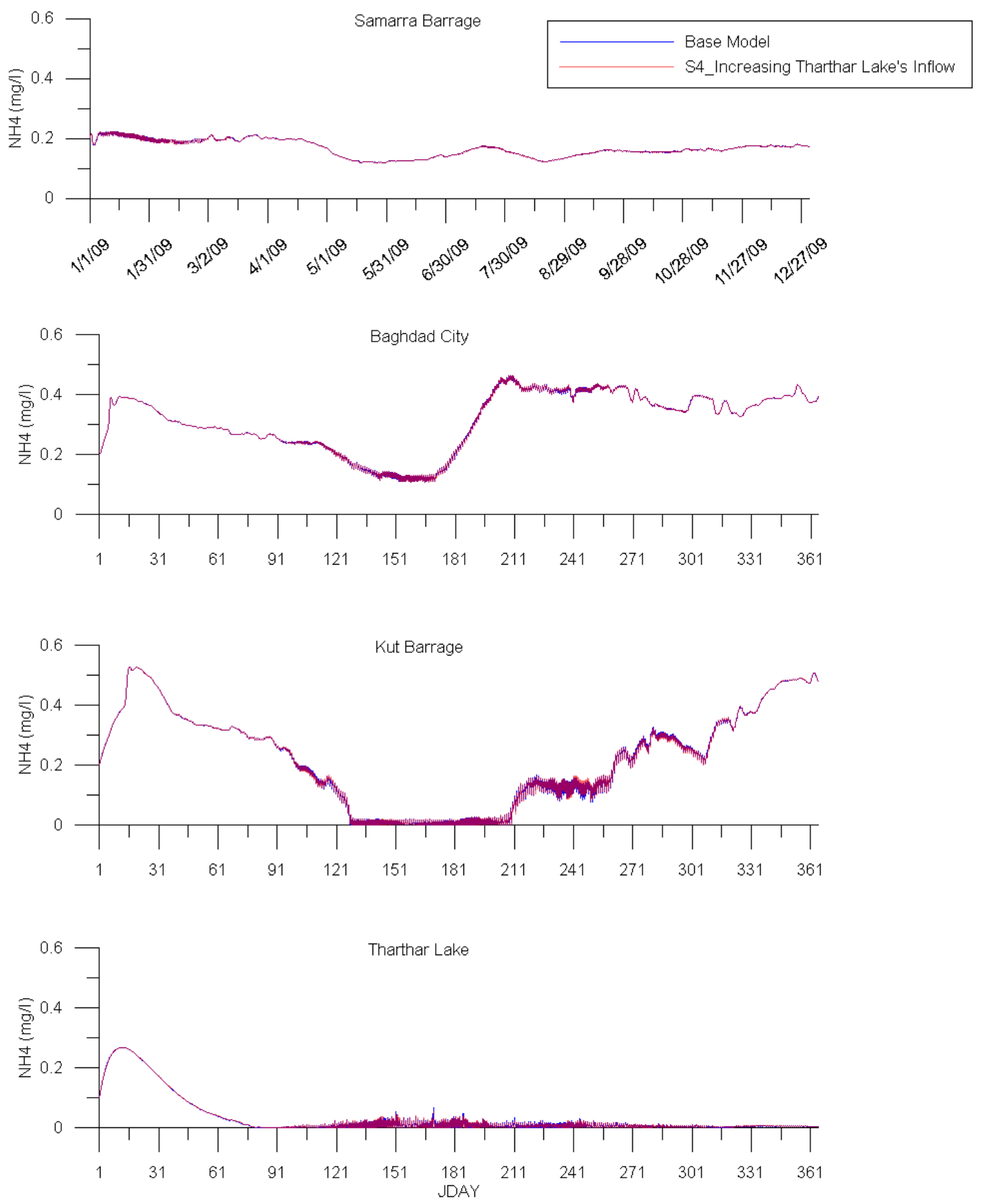

Figure 156: Model ammonia (NH4) predictions for base model and management scenario 4 (increasing Tharthar Lake's inflow) at Samarra Barrage, Baghdad City, Kut Barrage, and Tharthar Lake. 

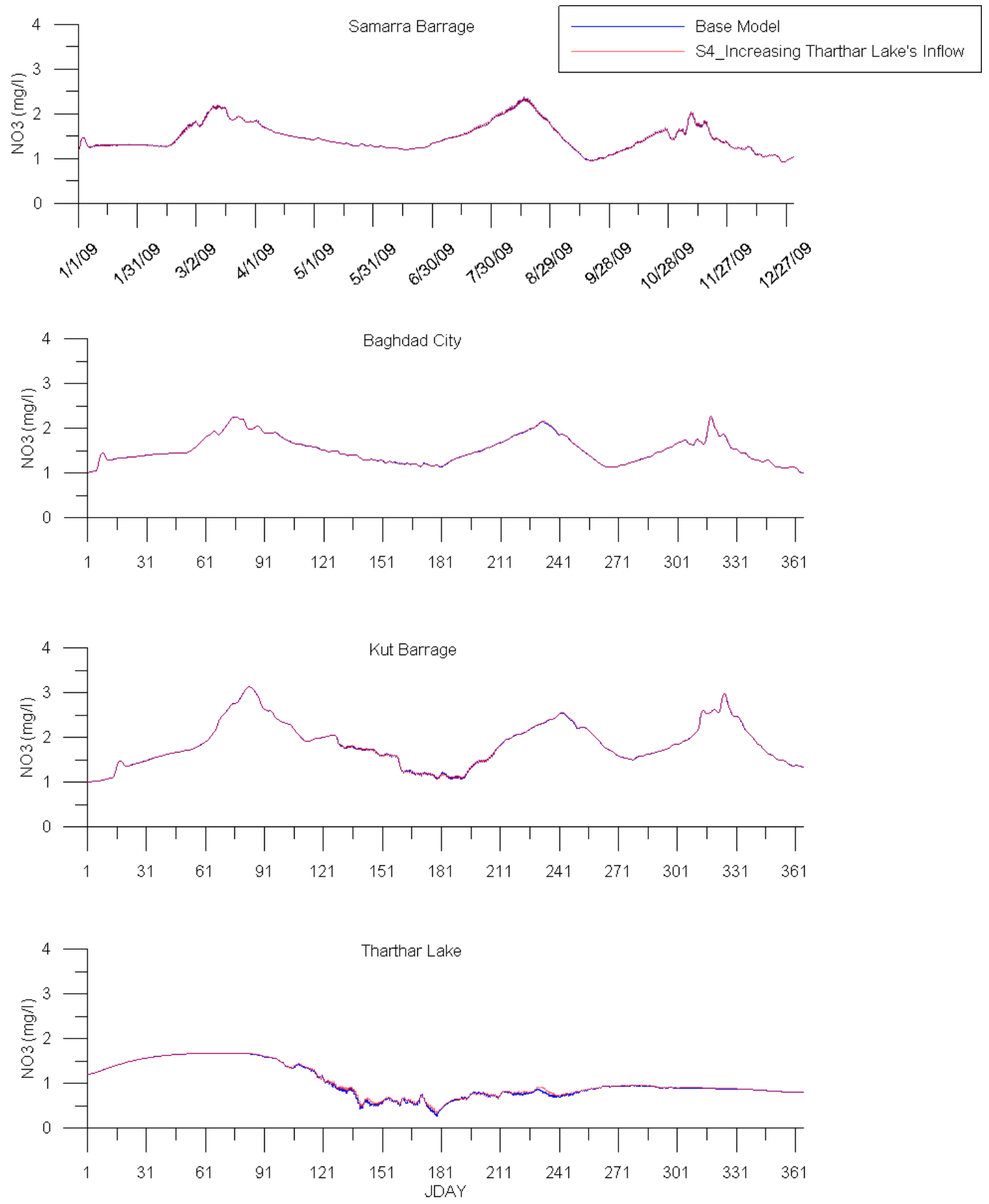

Figure 157: Model nitrate (NO3) predictions for base model and management scenario 4 (increasing Tharthar Lake's inflow) at Samarra Barrage, Baghdad City, Kut Barrage, and Tharthar Lake. 

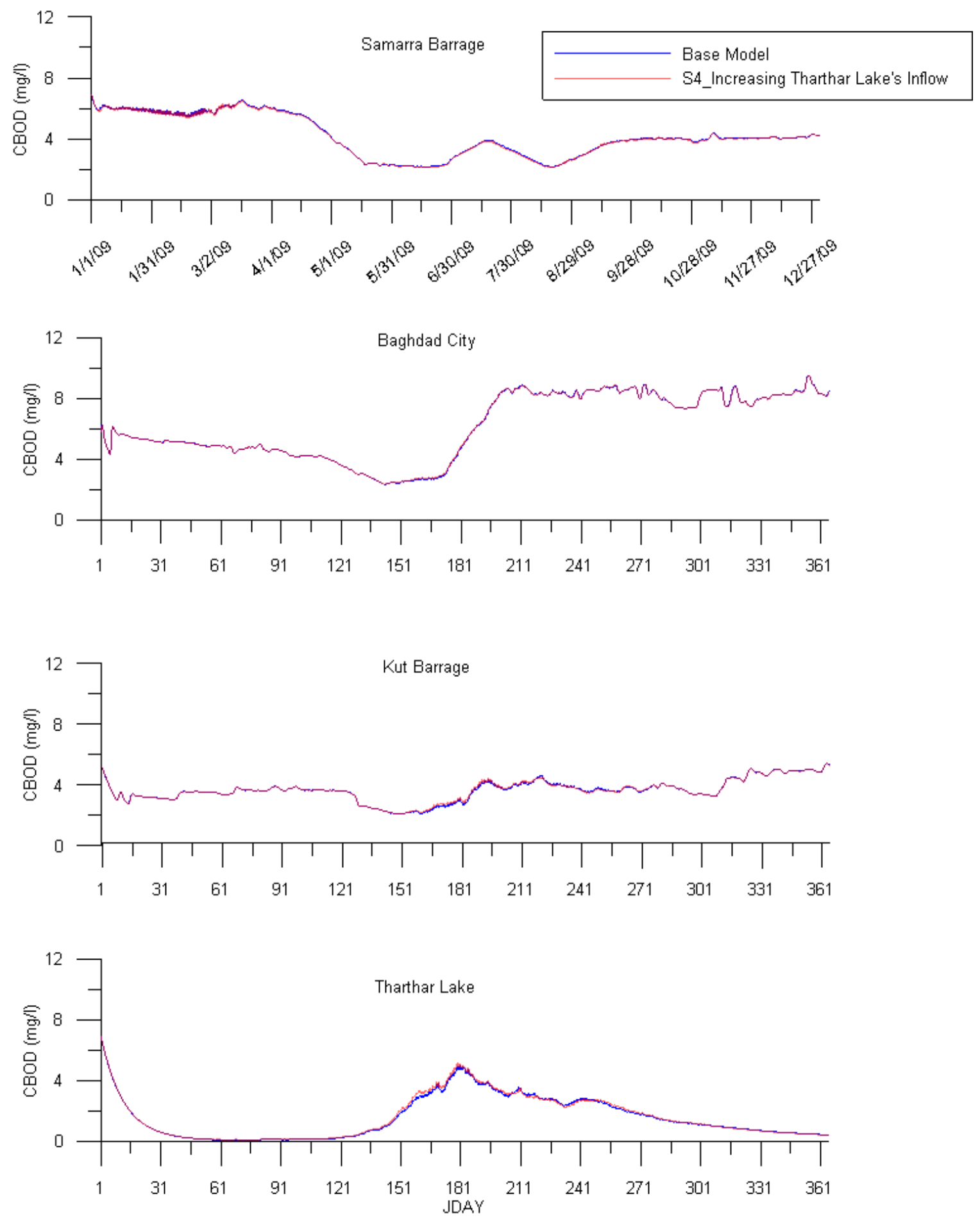

Figure 158: Model carbonaceous biological oxygen demand (CBOD) predictions for base model and management scenario 4 (increasing Tharthar Lake's inflow) at Samarra Barrage, Baghdad City, Kut Barrage, and Tharthar Lake. 

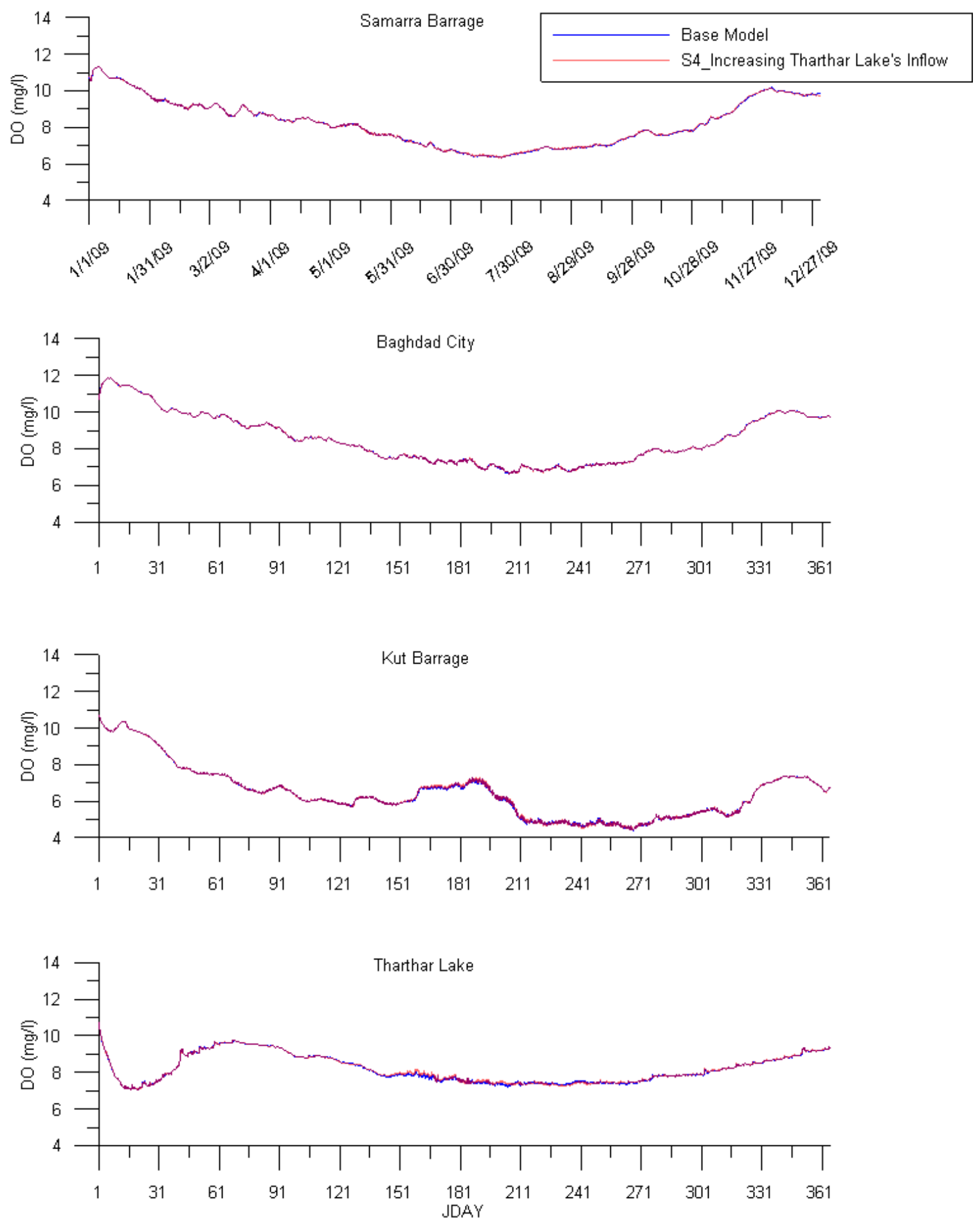

Figure 159: Model dissolved oxygen (DO) predictions for base model and management scenario 4 (increasing Tharthar Lake's inflow) at Samarra Barrage, Baghdad City, Kut Barrage, and Tharthar Lake. 

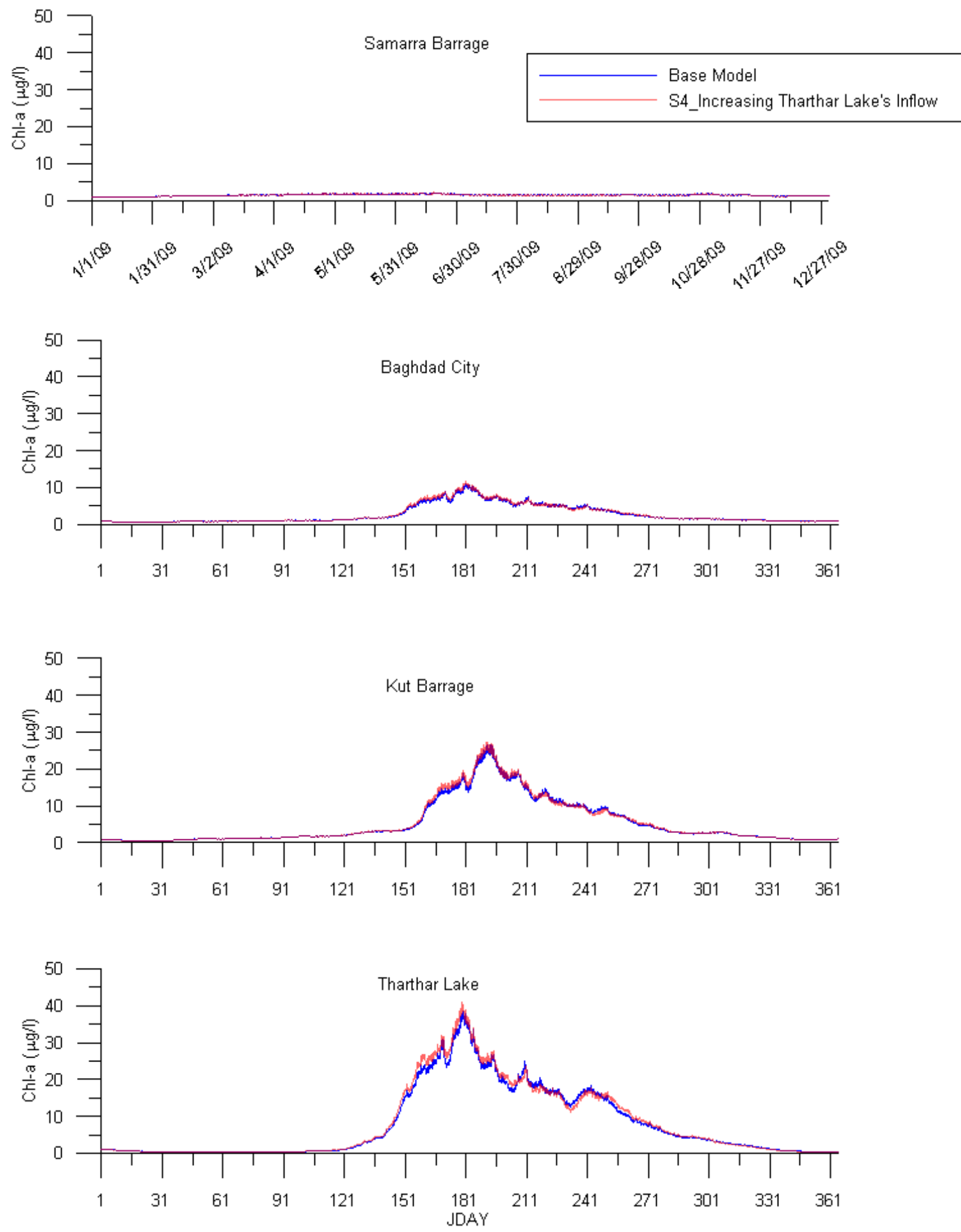

Figure 160: Model chlorophyll-a (Chl-a) predictions for base model and management scenario 4 (increasing Tharthar Lake's inflow) at Samarra Barrage, Baghdad City, Kut Barrage, and Tharthar Lake. 


\section{Management Scenario 5: The Effect of Climate Change}
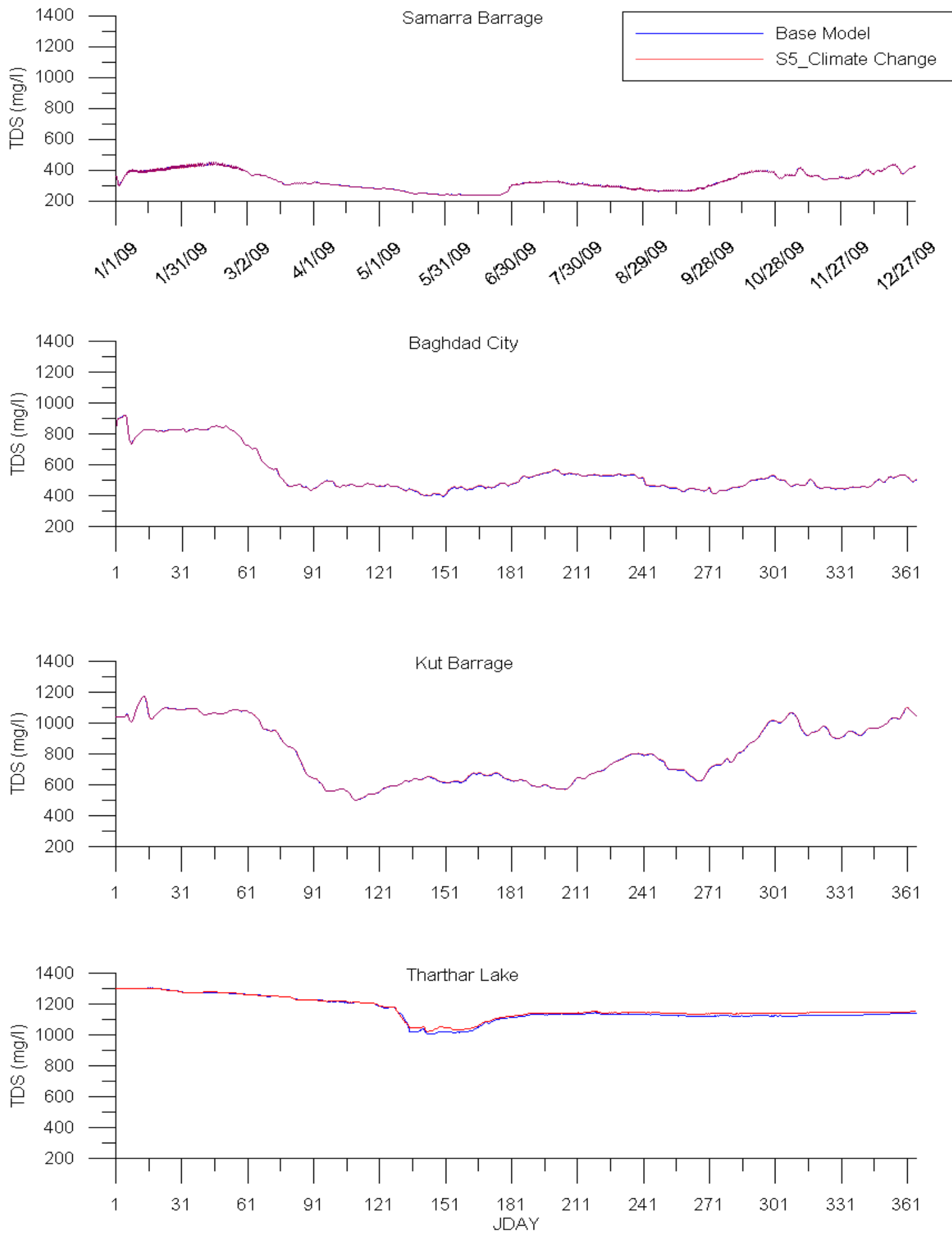

Figure 161: Model total dissolved solids (TDS) predictions for base model and management scenario 5 (climate change) at Samarra Barrage, Baghdad City, Kut Barrage, and Tharthar Lake. 

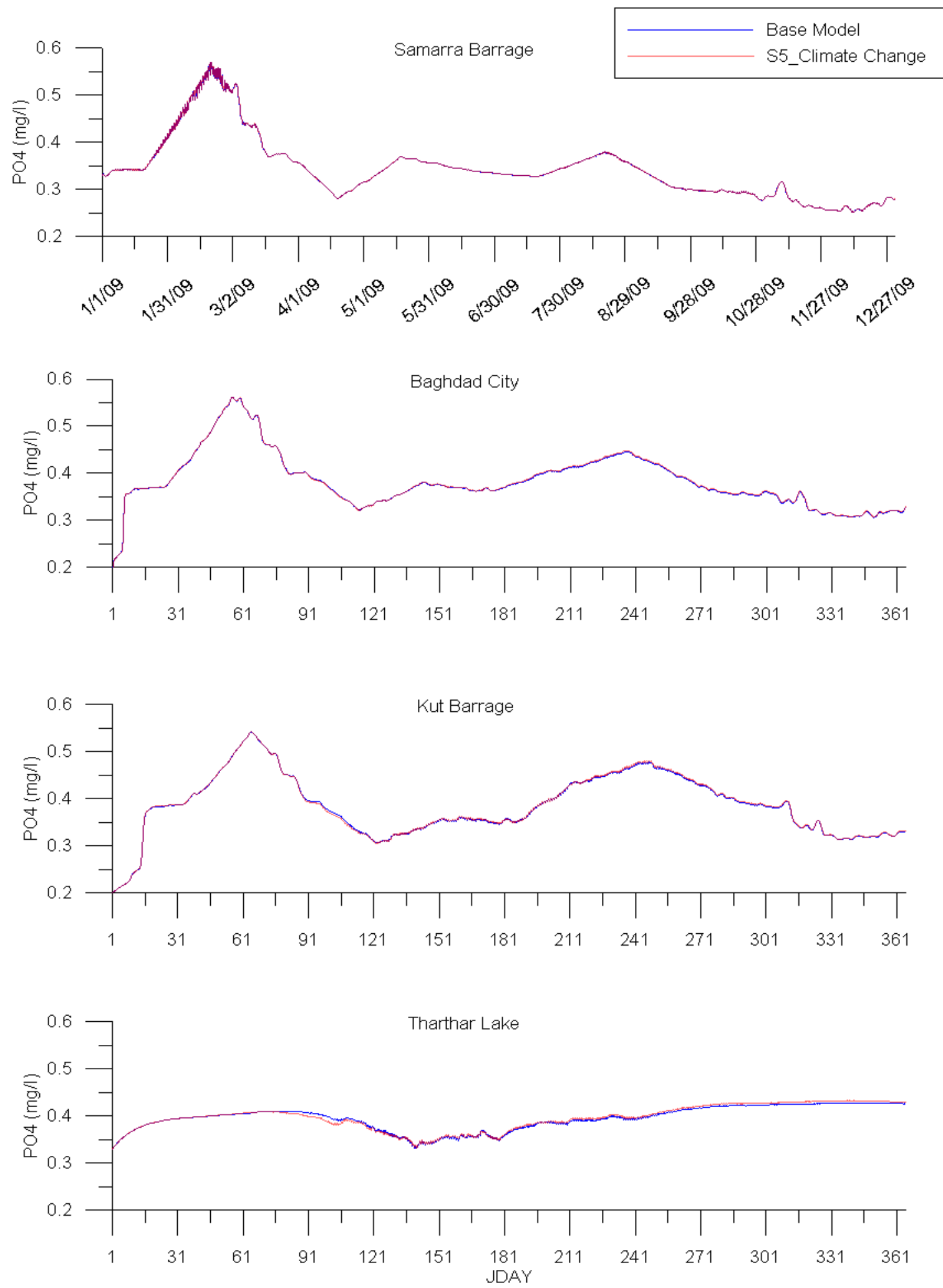

Figure 162: Model phosphate (PO4) predictions for base model and management scenario 5 (climate change) at Samarra Barrage, Baghdad City, Kut Barrage, and Tharthar Lake. 

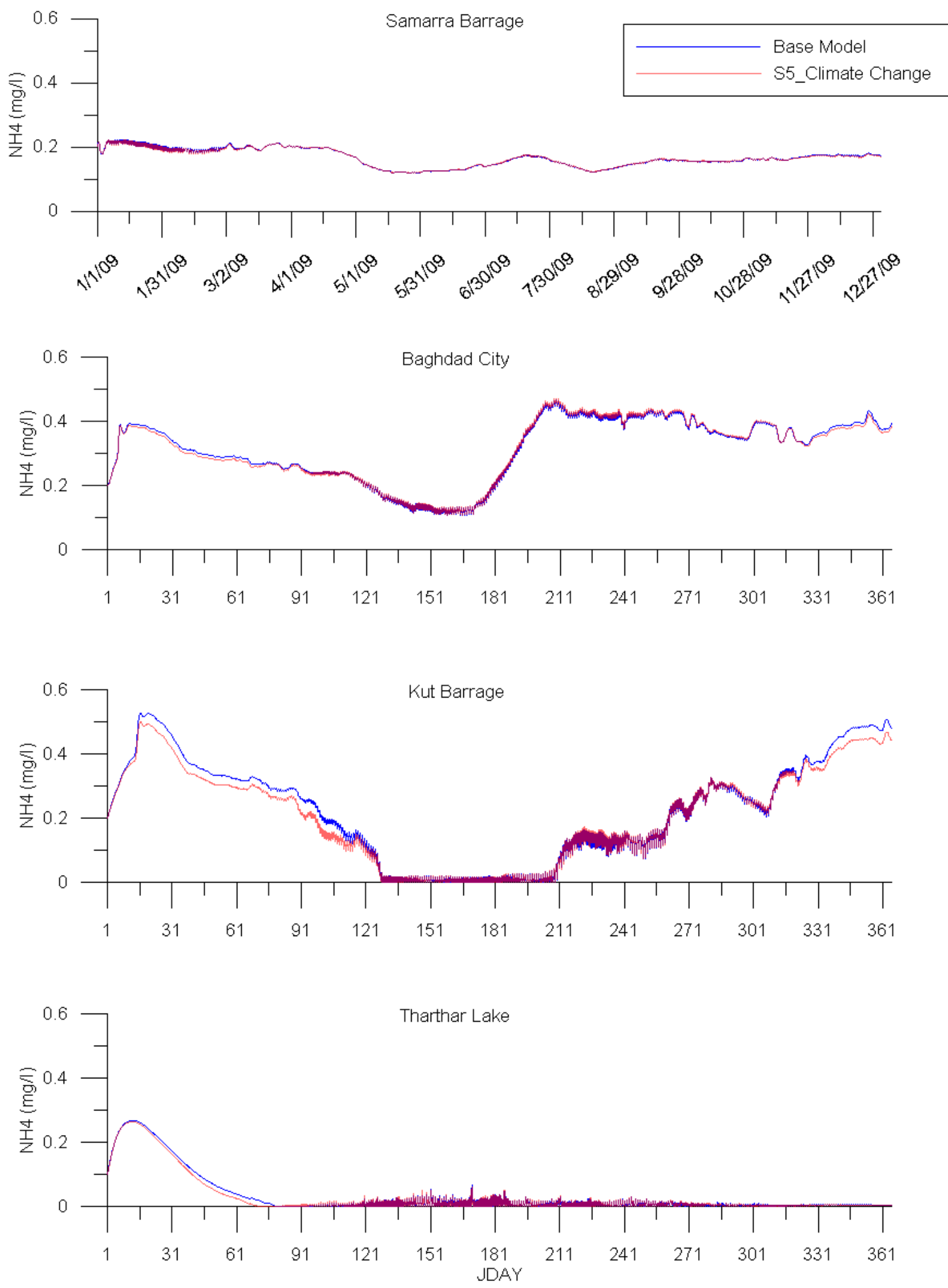

Figure 163: Model ammonia (NH4) predictions for base model and management scenario 5 (climate change) at Samarra Barrage, Baghdad City, Kut Barrage, and Tharthar Lake. 

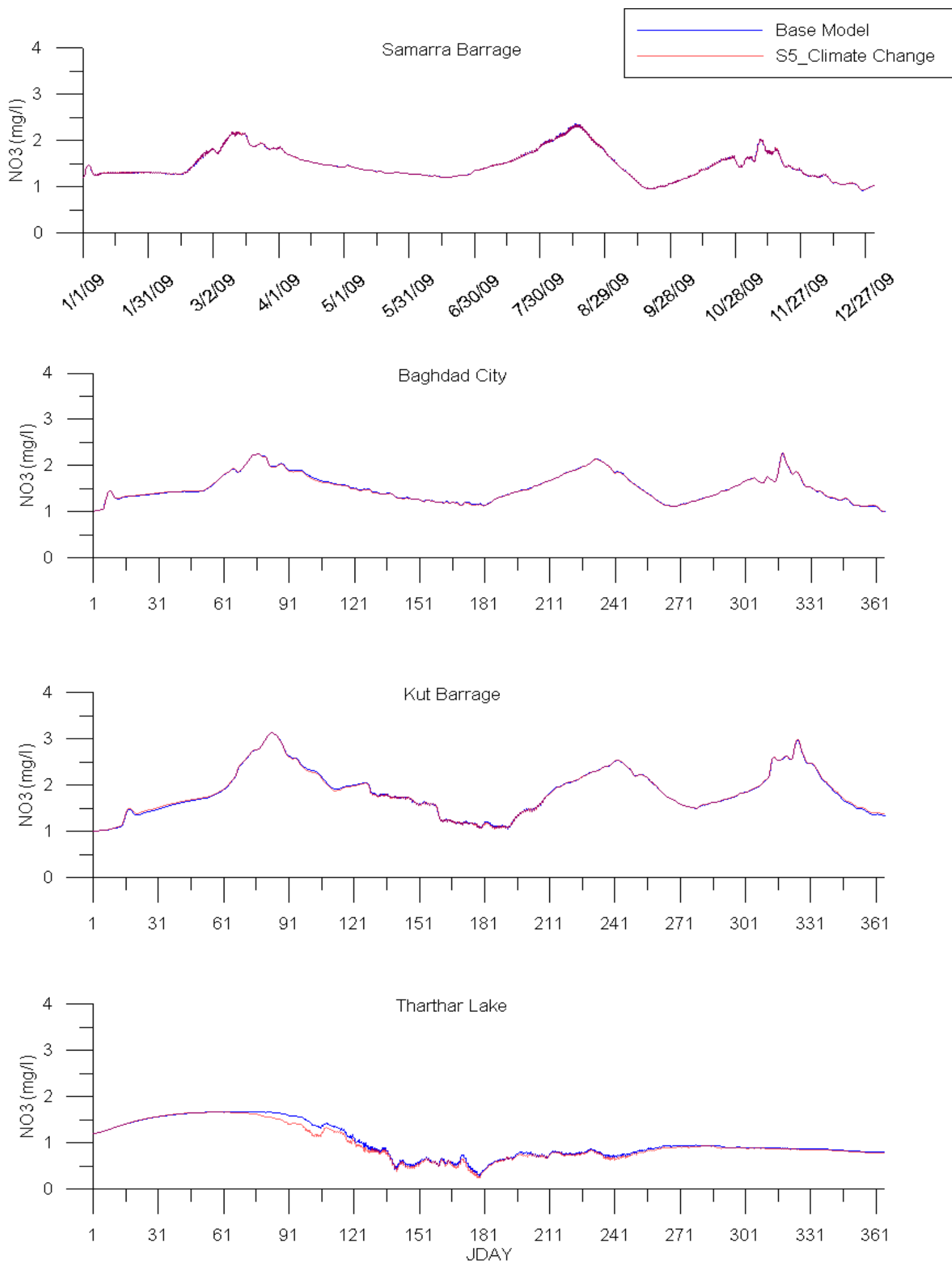

Figure 164: Model nitrate (NO3) predictions for base model and management scenario 5 (climate change) at Samarra Barrage, Baghdad City, Kut Barrage, and Tharthar Lake. 

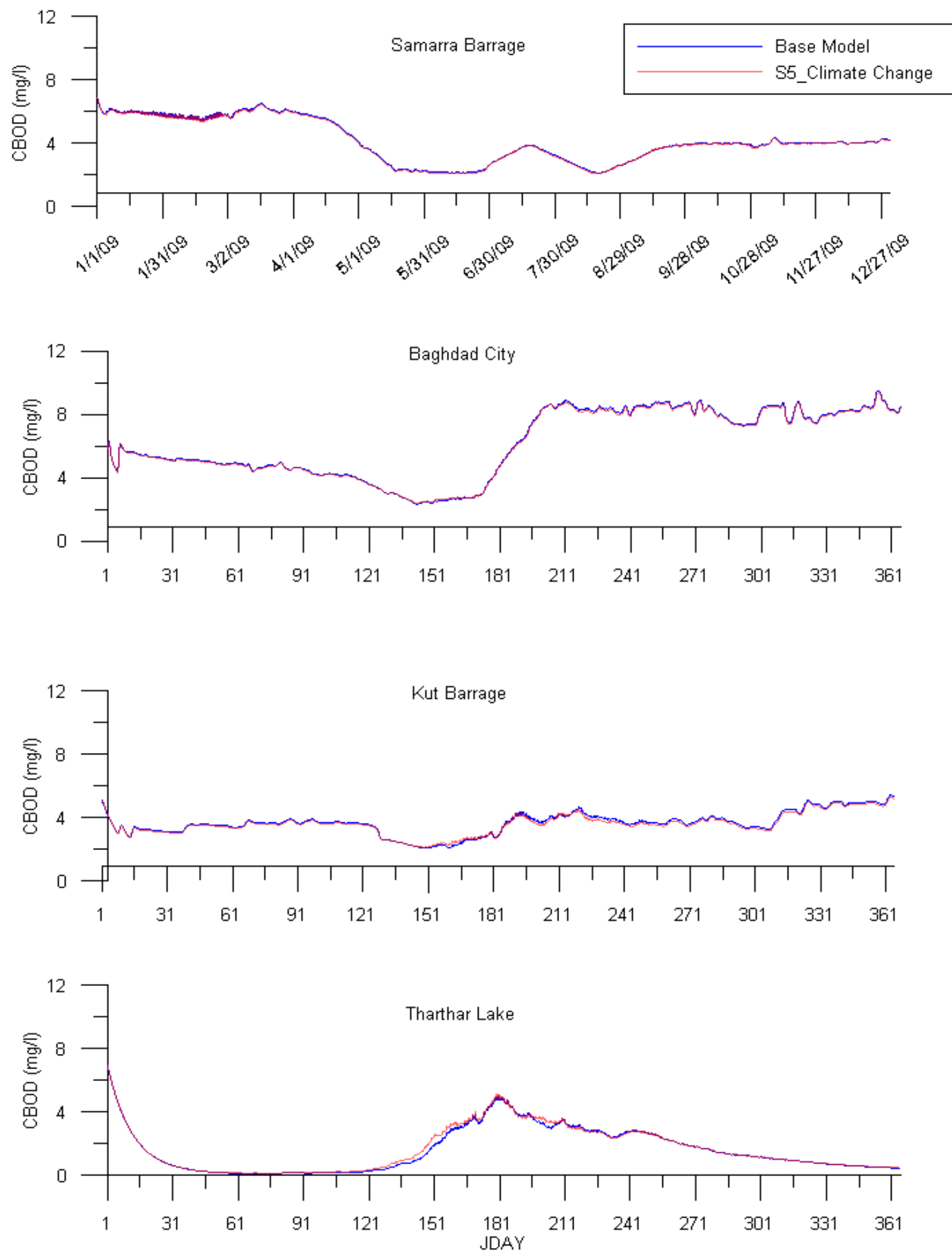

Figure 165: Model carbonaceous biological oxygen demand (CBOD) predictions for base model and management scenario 5 (climate change) at Samarra Barrage, Baghdad City, Kut Barrage, and Tharthar Lake. 


\section{Management Scenario 6: The Effect of Climate Change with Decreasing Upstream}

\section{Flow}
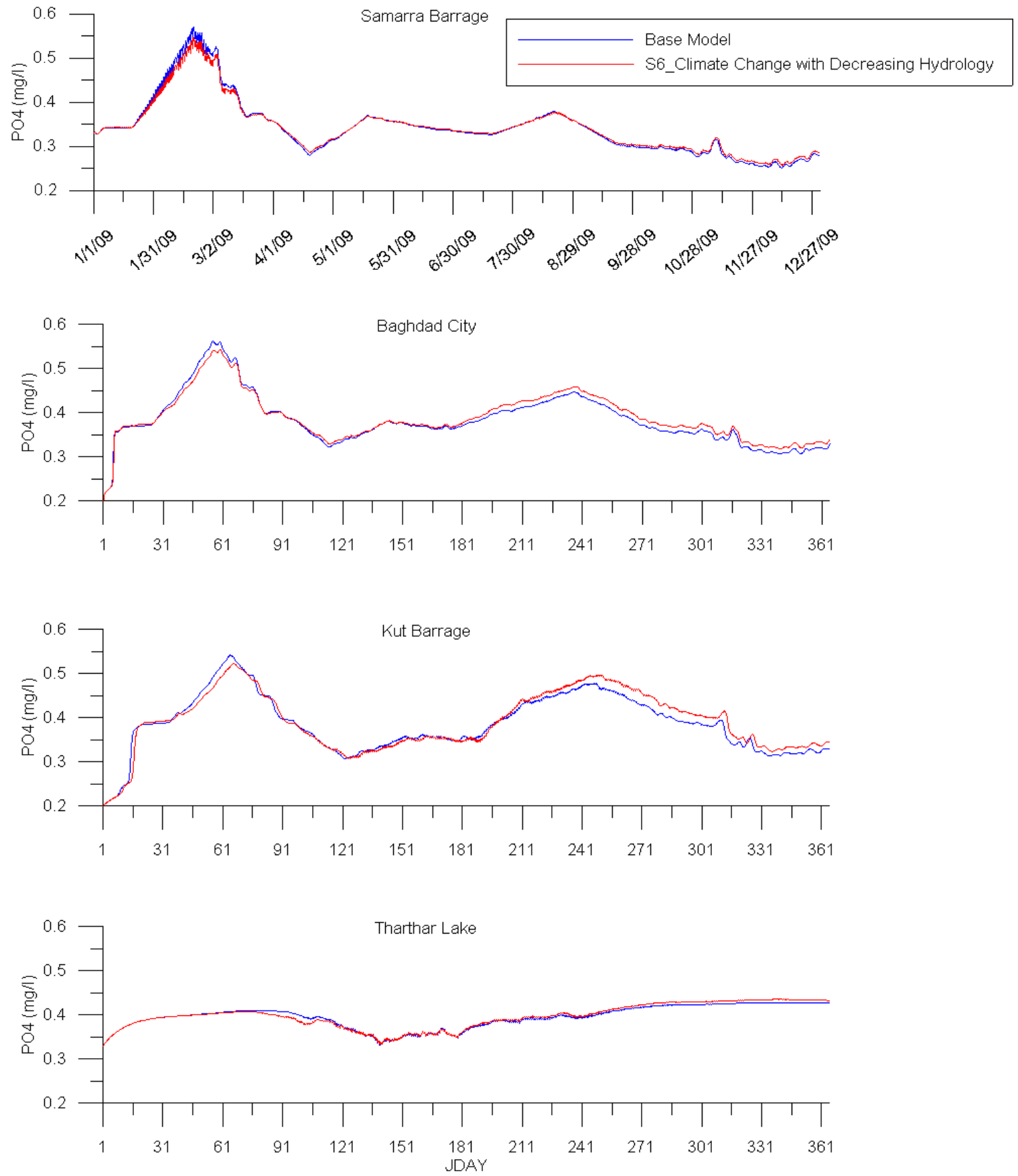

Figure 166: Model phosphate (PO4) predictions for base model and management scenario 6 (climate change with decreasing hydrology) at Samarra Barrage, Baghdad City, Kut Barrage and Tharthar Lake. 

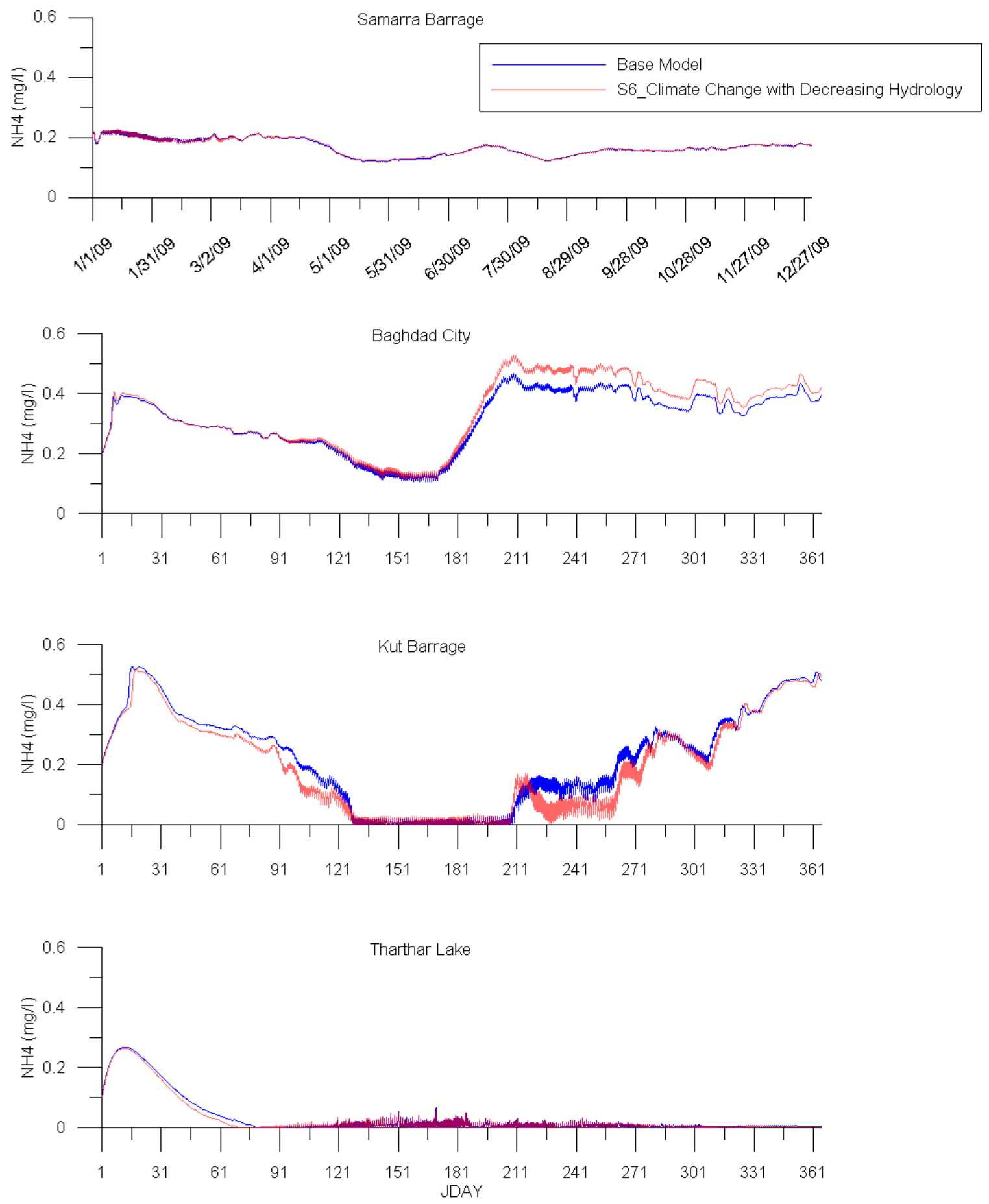

Figure 167: Model ammonia (NH4) predictions for base model and management scenario 6 (climate change with decreasing hydrology) at Samarra Barrage, Baghdad City, Kut Barrage and Tharthar Lake. 

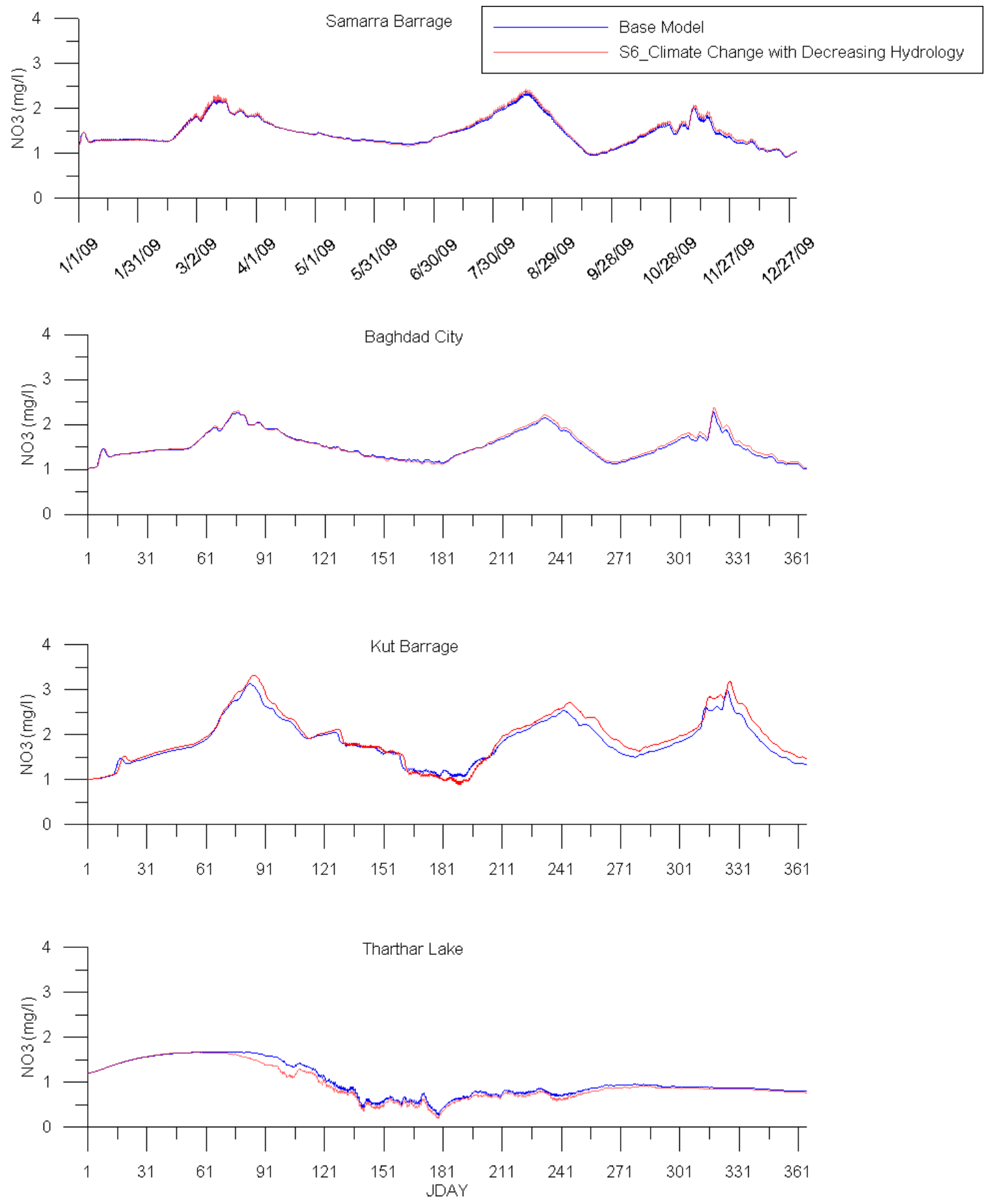

Figure 168: Model nitrate (NO3) predictions for base model and management scenario 6 (climate change with decreasing hydrology) at Samarra Barrage, Baghdad City, Kut Barrage and Tharthar Lake. 


\section{Management Scenario 7: Disconnecting Tharthar Lake}
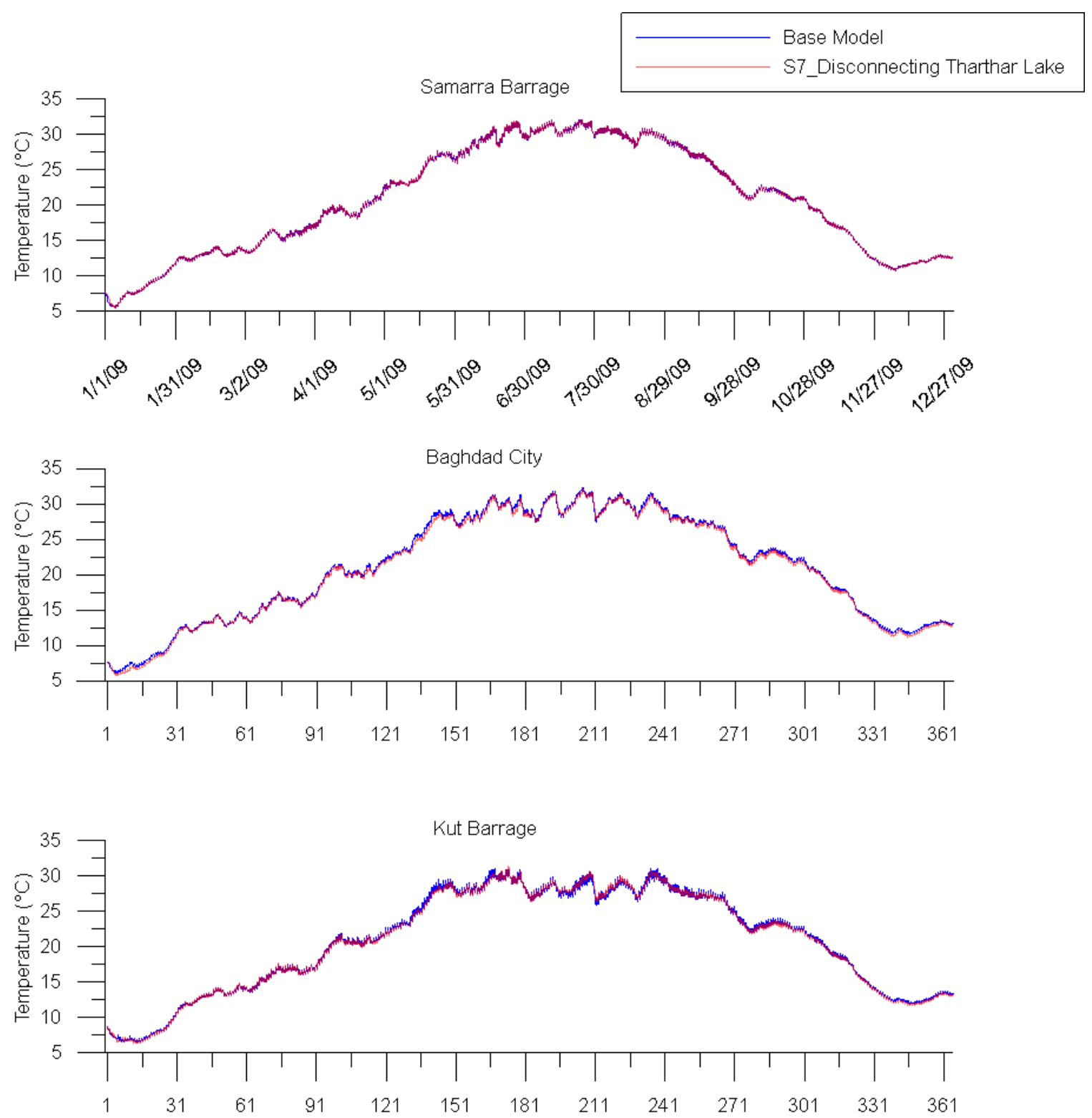

Figure 169: Model water temperature $\left(\mathrm{T}_{\mathrm{w}}\right)$ predictions for base model and management scenario 7 (disconnecting Tharthar Lake) at Samarra Barrage, Baghdad City, and Kut Barrage. 

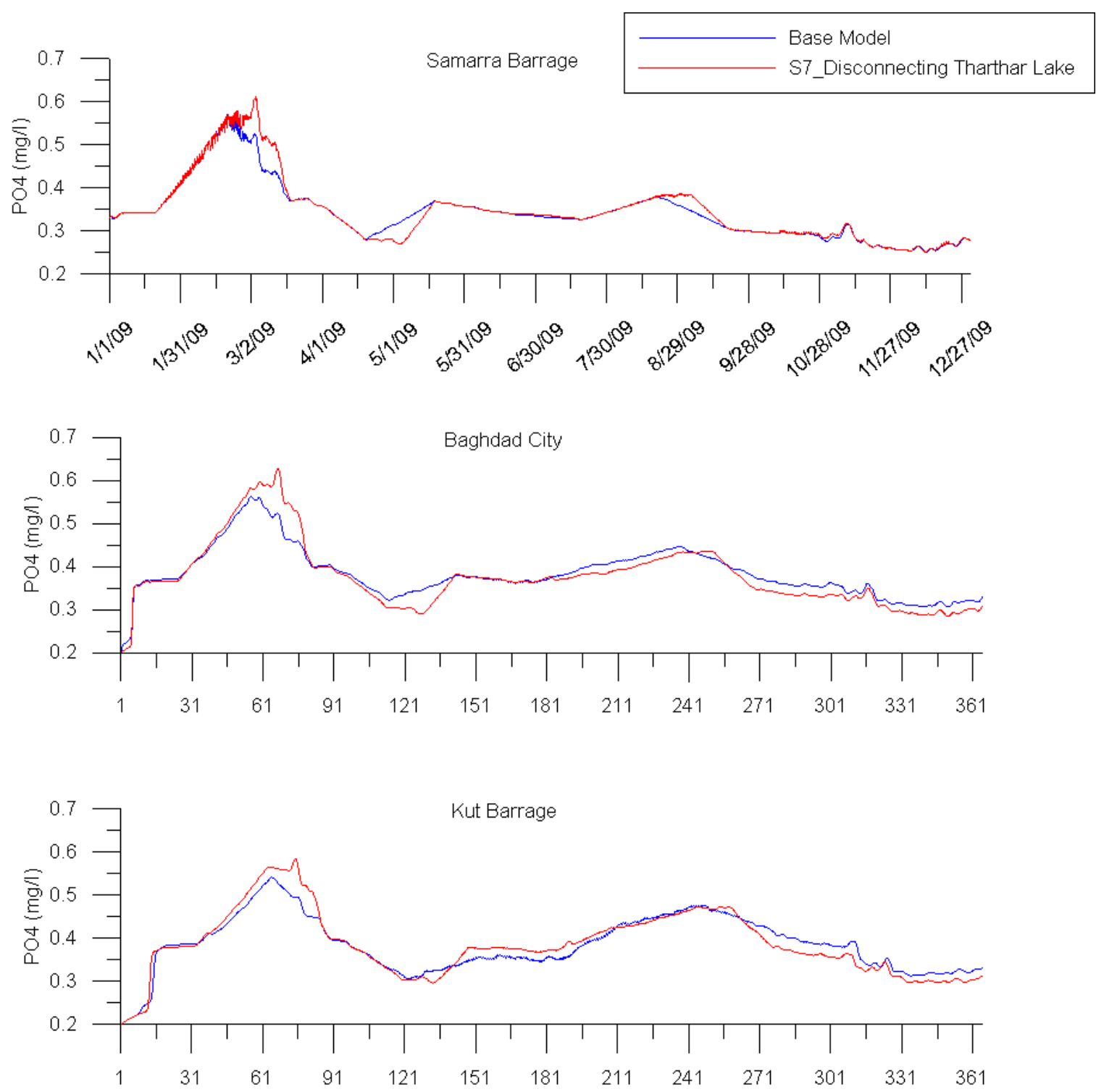

Figure 170: Model phosphate (PO4) predictions for base model and management scenario 7 (disconnecting Tharthar Lake) at Samarra Barrage, Baghdad City, Kut Barrage. 

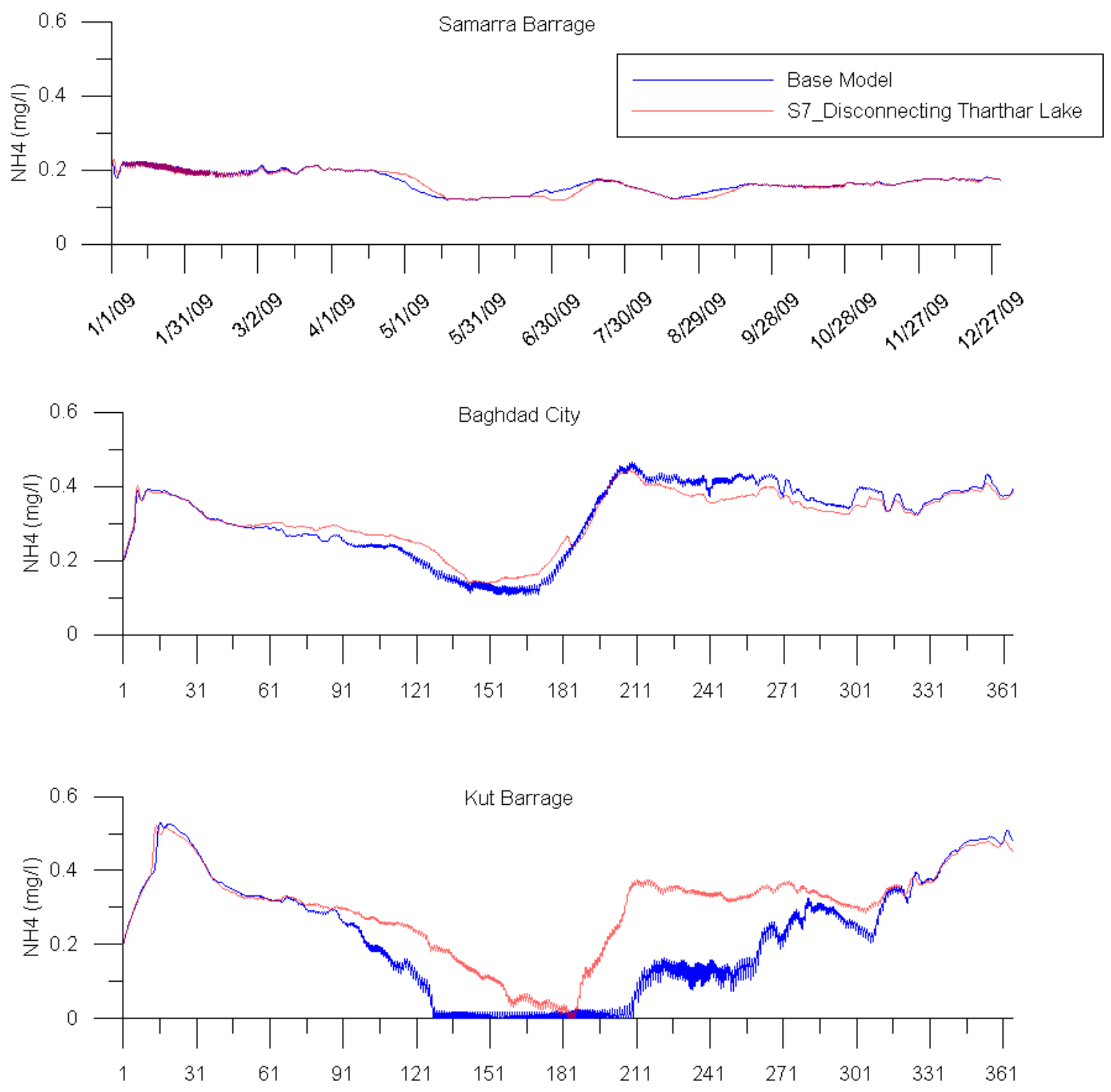

Figure 171: Model ammonia (NH4) predictions for base model and management scenario 7 (disconnecting Tharthar Lake) at Samarra Barrage, Baghdad City, Kut Barrage. 

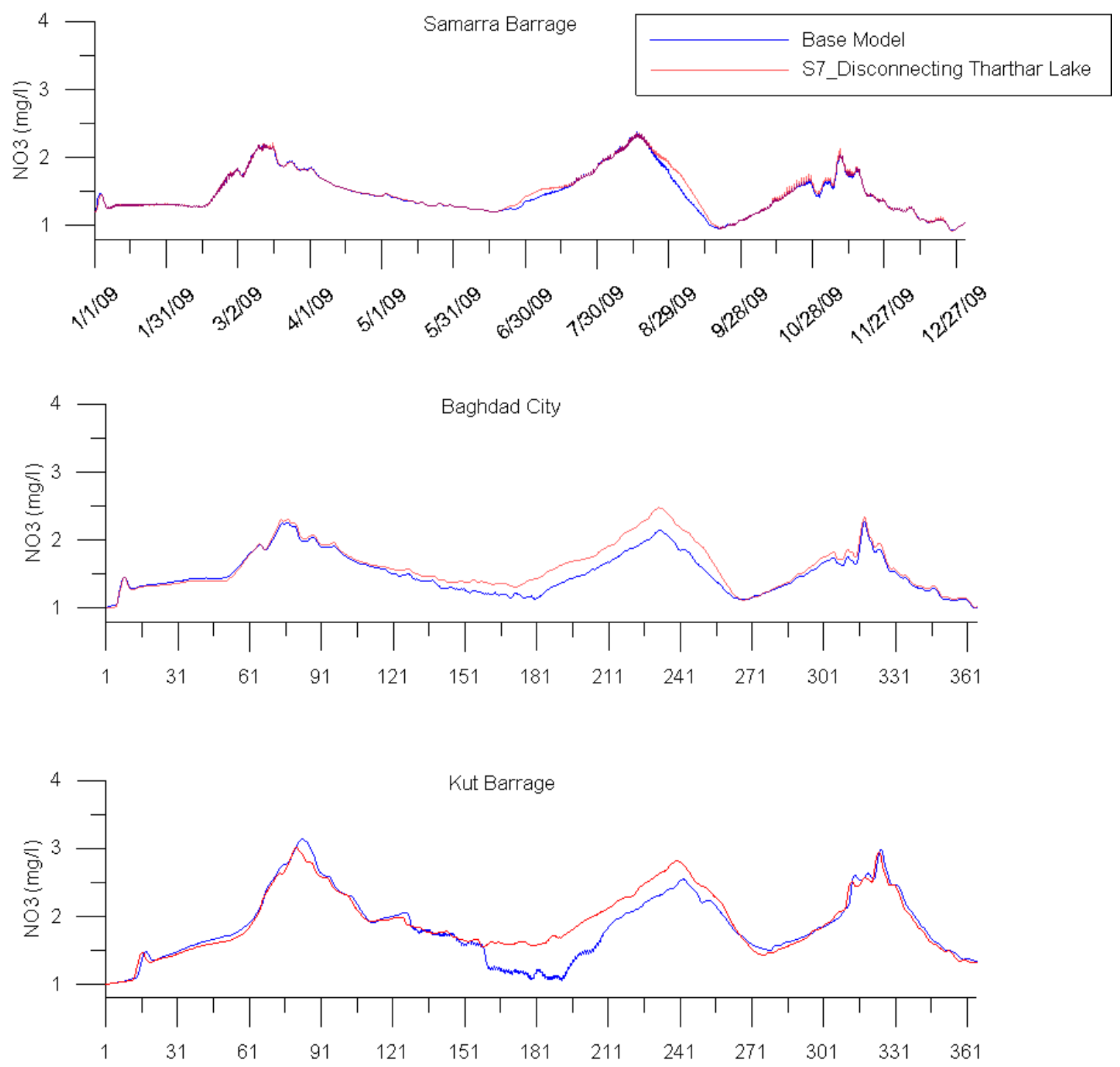

Figure 172: Model nitrate (NO3) predictions for base model and management scenario 7 (disconnecting Tharthar Lake) at Samarra Barrage, Baghdad City, Kut Barrage. 


\section{Appendix B: Histograms of Water Quality Constituents in the Tigris River System}

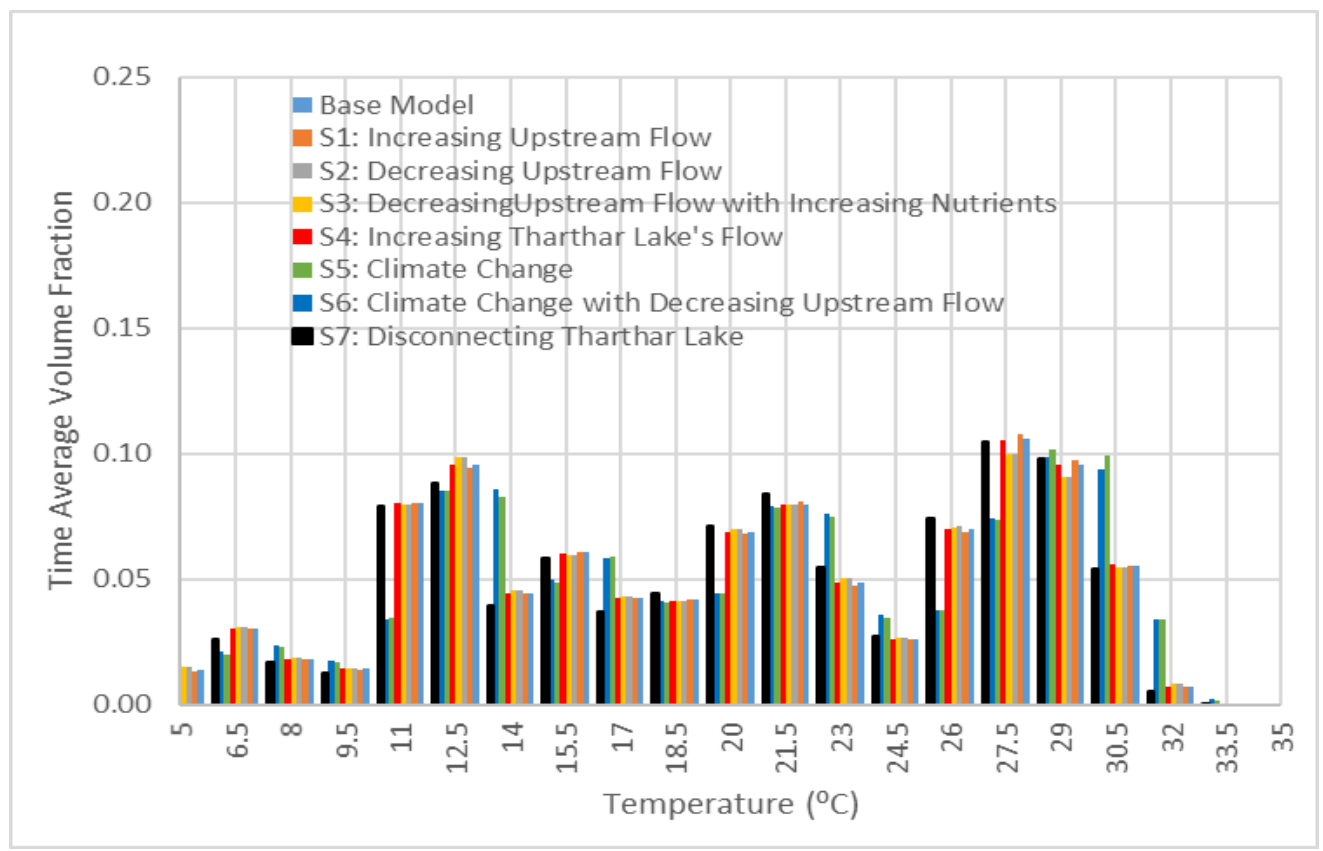

Figure 173: Environmental performance for 7 different scenario runs comparing water temperatures in the mainstem of the Tigris River.

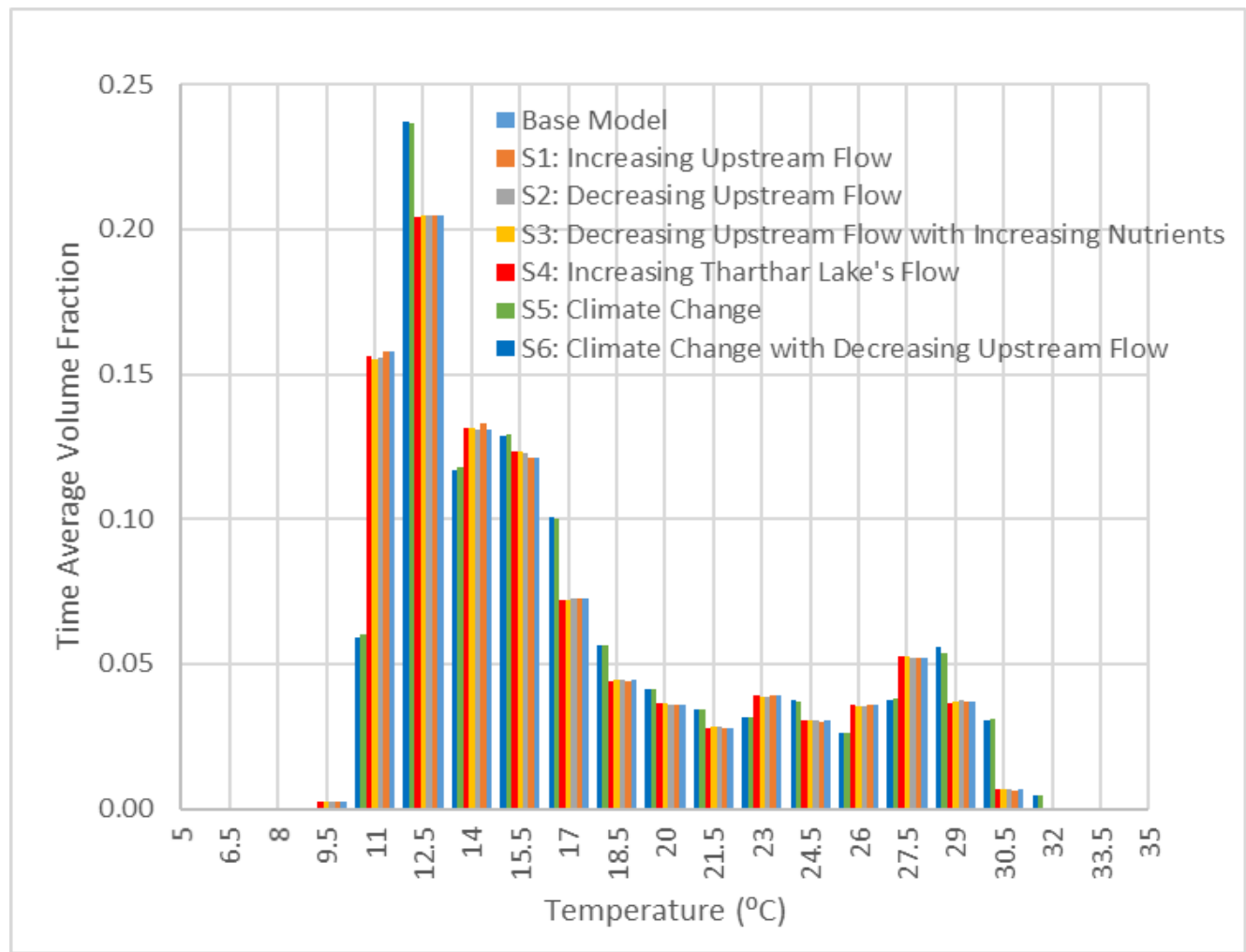

Figure 174: Environmental performance for 6 different scenario runs comparing water temperatures in Tharthar Lake. 


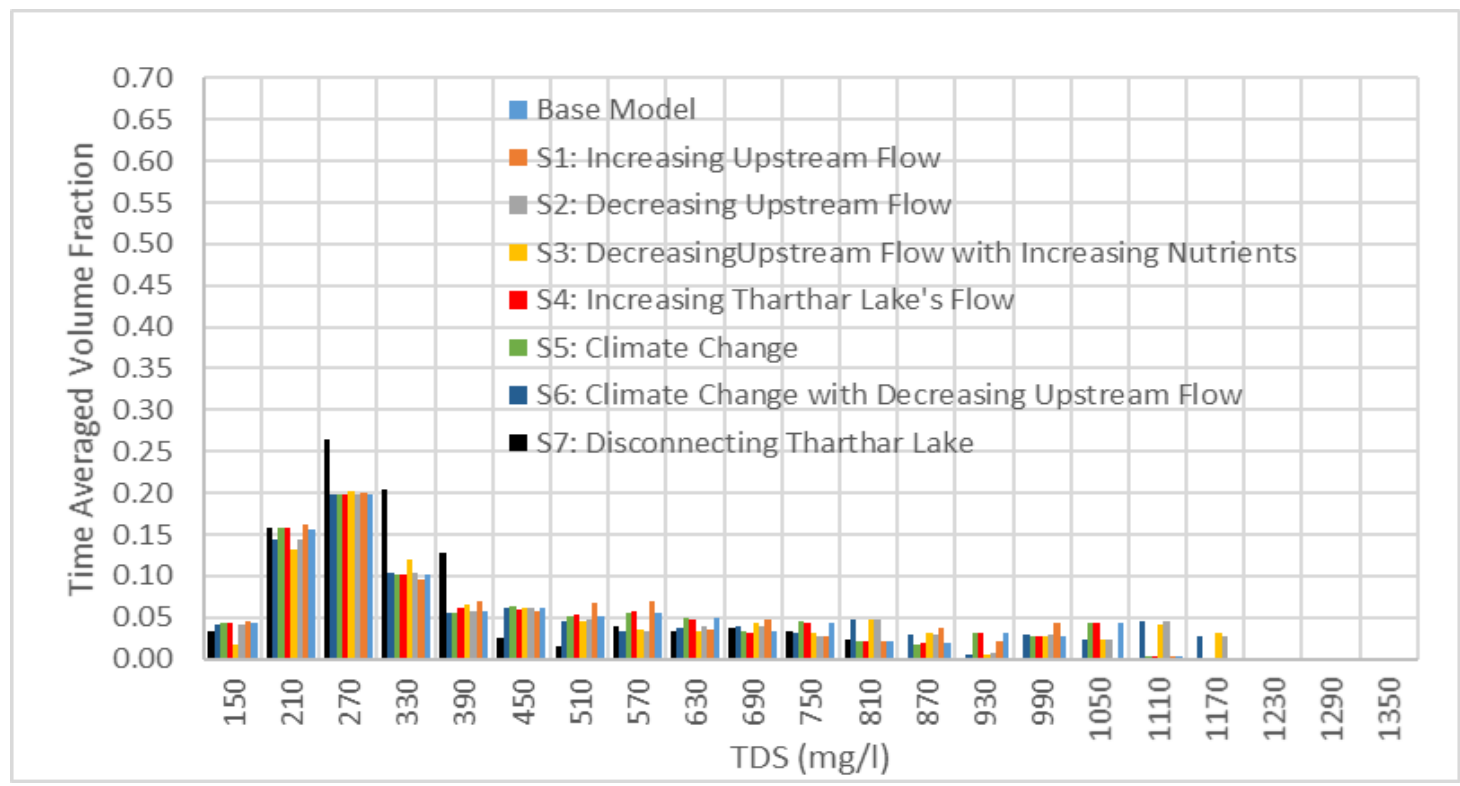

Figure 175: Environmental performance for 7 different scenario runs comparing total dissolved solids in the mainstem of the Tigris River.

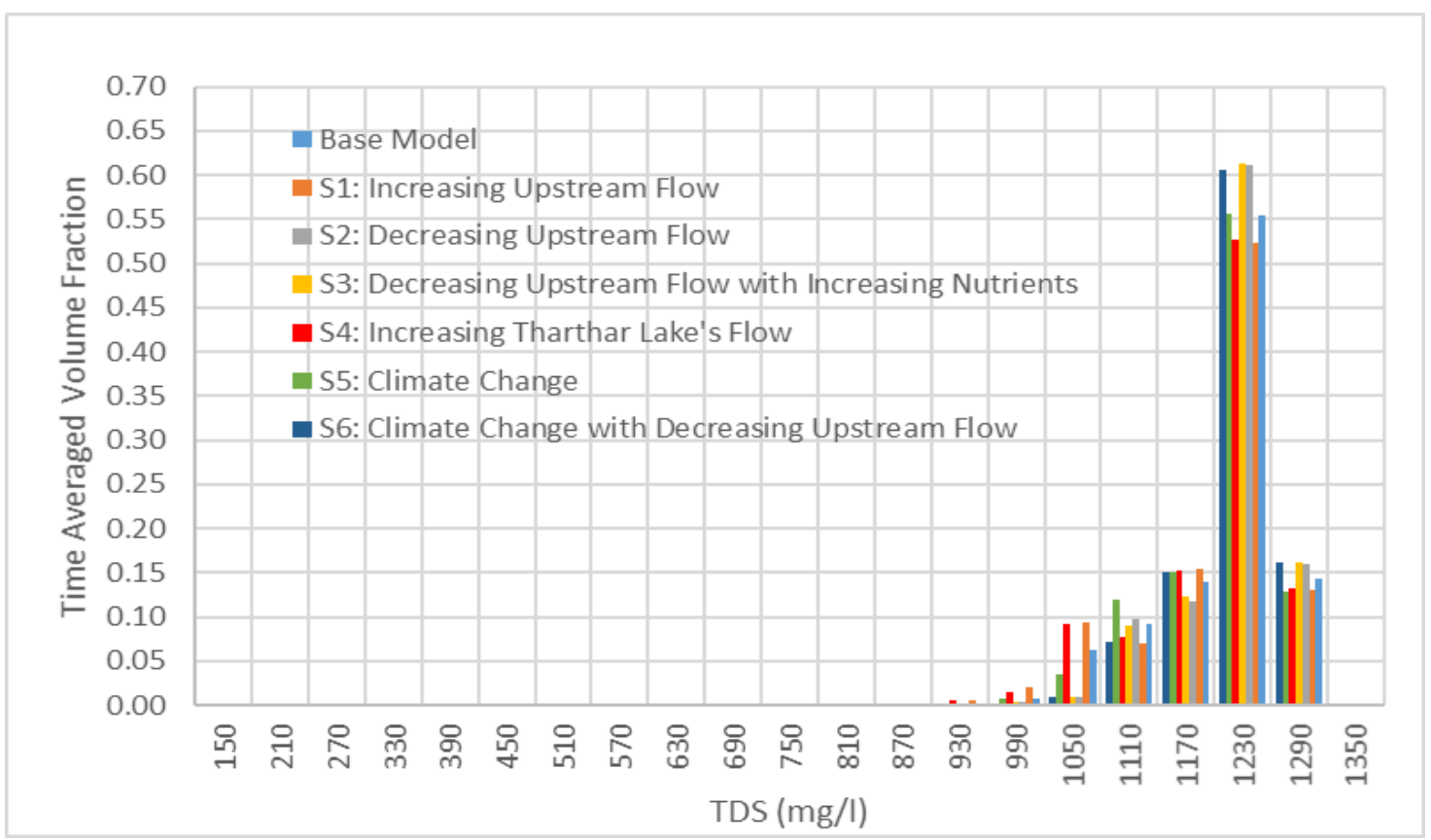

Figure 176: Environmental performance for 6 different scenario runs comparing total dissolved solids in Tharthar Lake. 


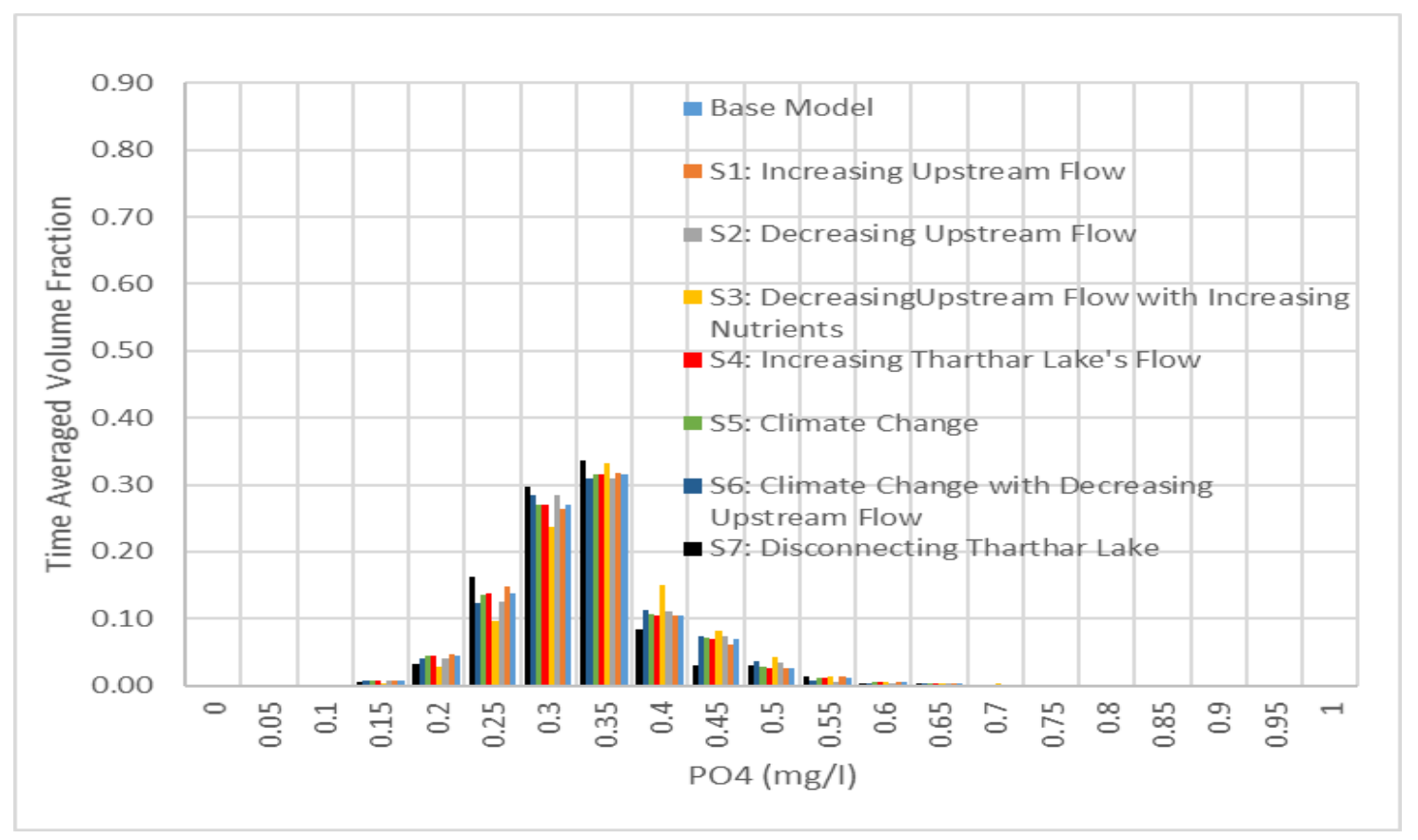

Figure 177: Environmental performance for 7 different scenario runs comparing phosphate in the mainstem of the Tigris River.

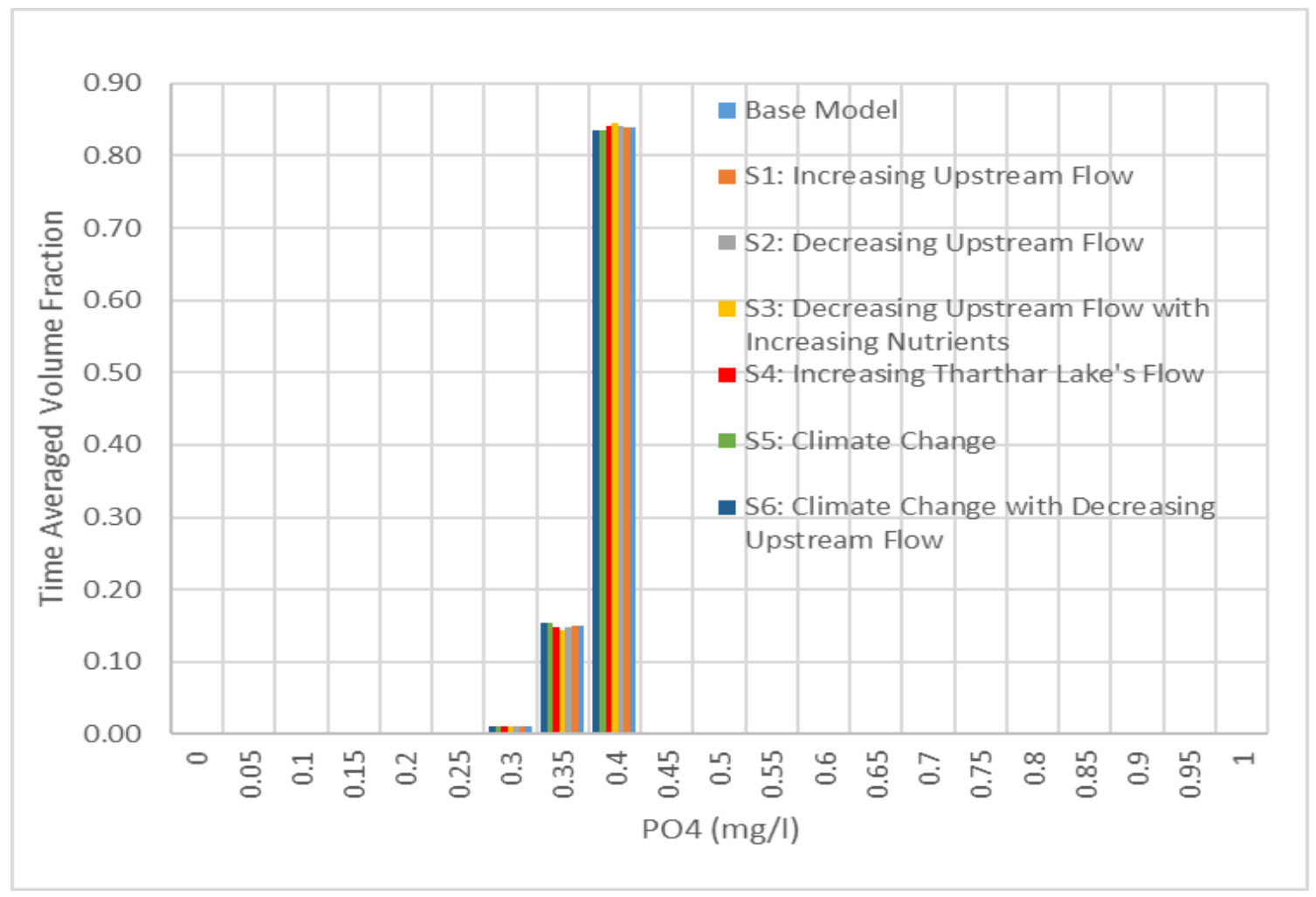

Figure 178: Environmental performance for 6 different scenario runs comparing phosphate in Tharthar Lake. 


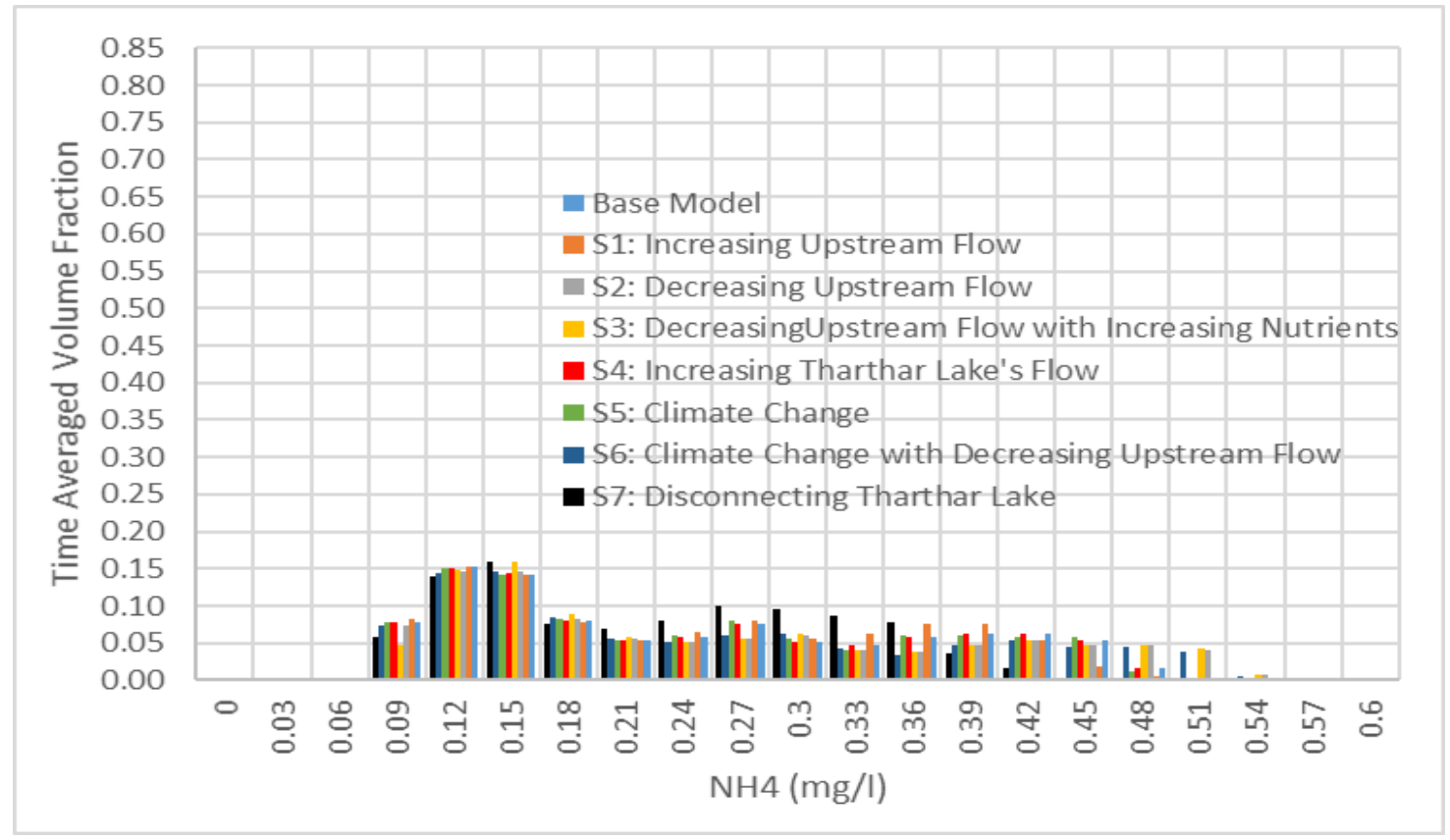

Figure 179: Environmental performance for 7 different scenario runs comparing ammonium in the mainstem of the Tigris River.

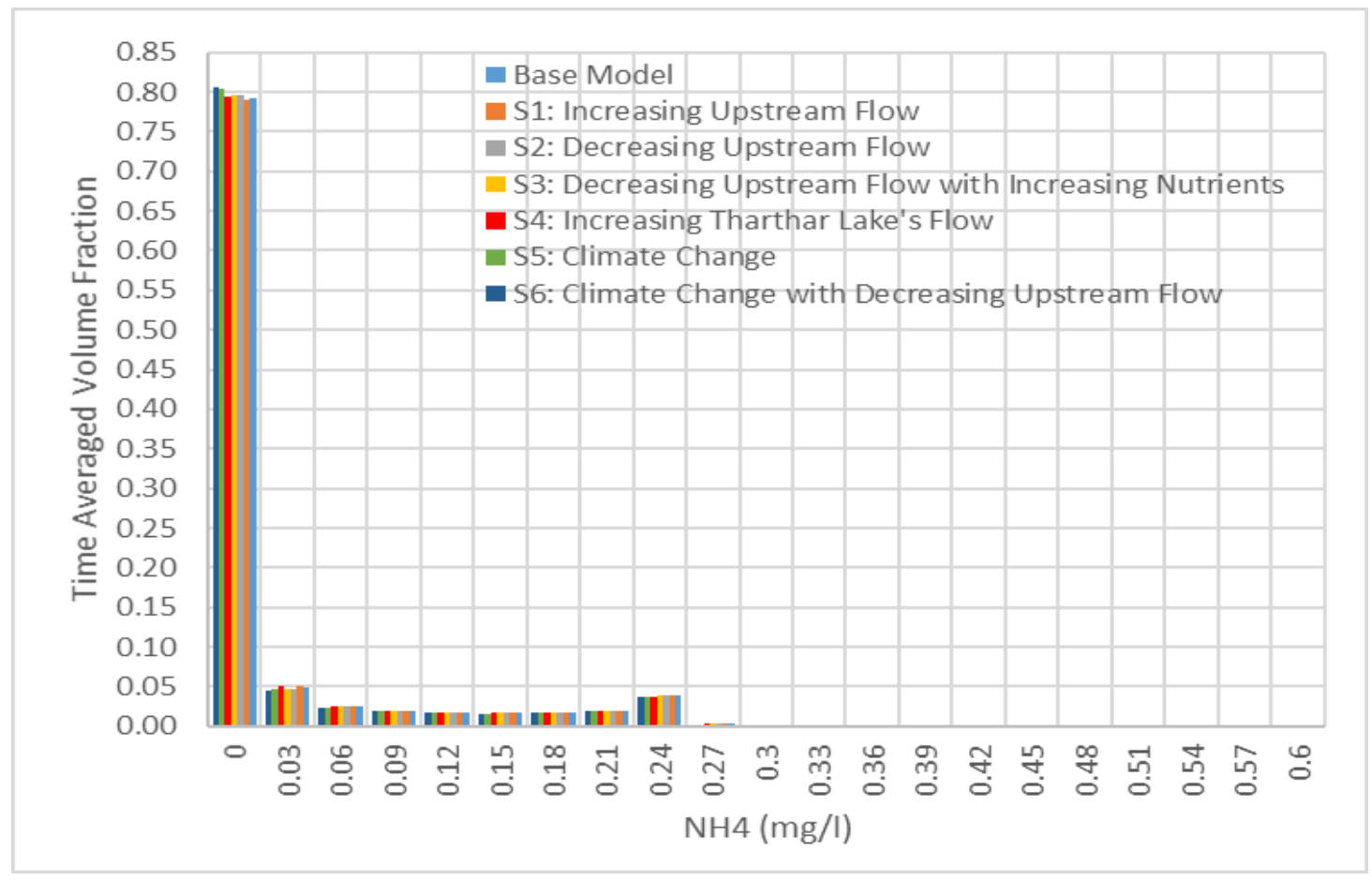

Figure 180: Environmental performance for 6 different scenario runs comparing ammonium in Tharthar Lake. 


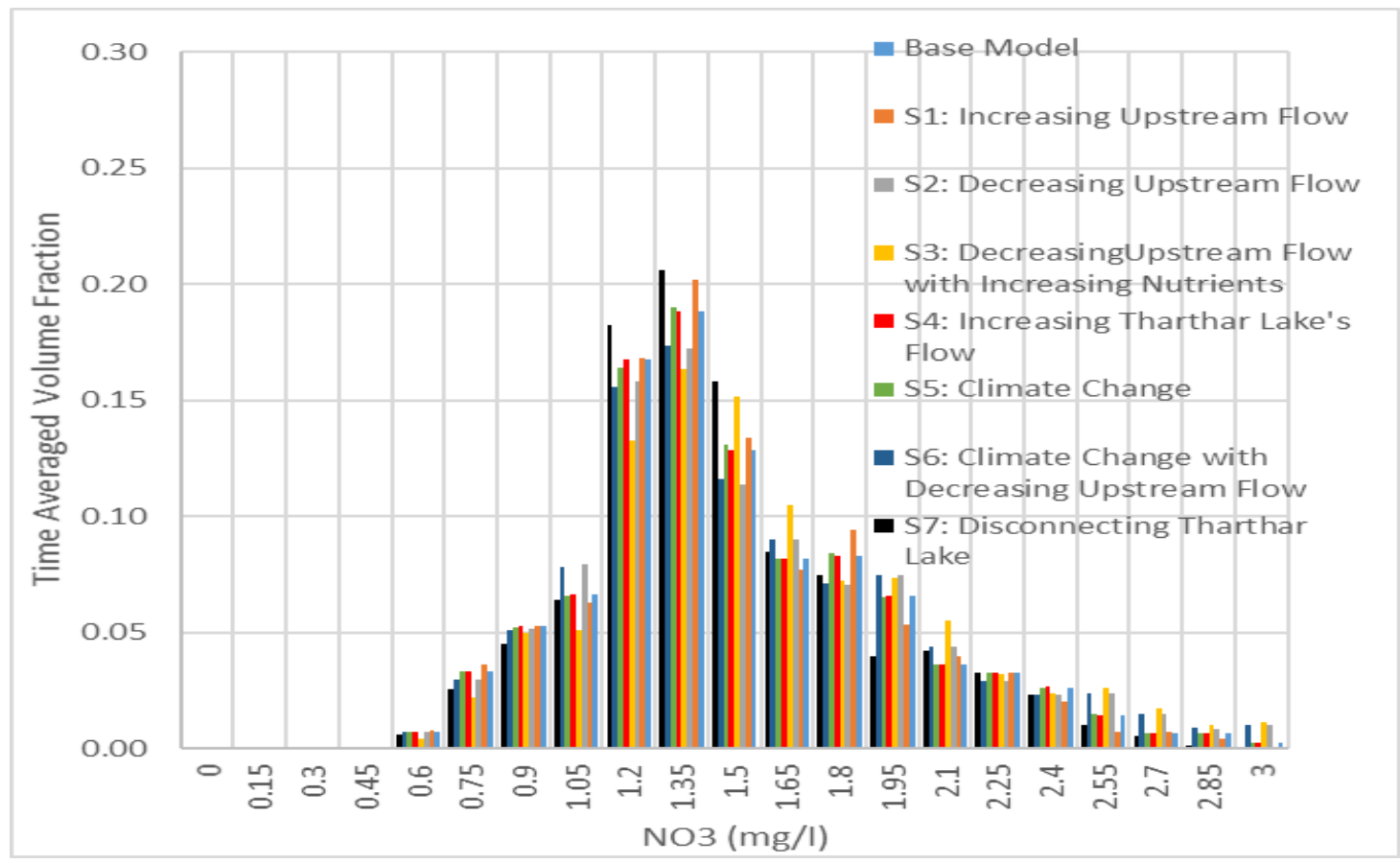

Figure 181: Environmental performance for 7 different scenario runs comparing nitrate in the mainstem of the Tigris River.

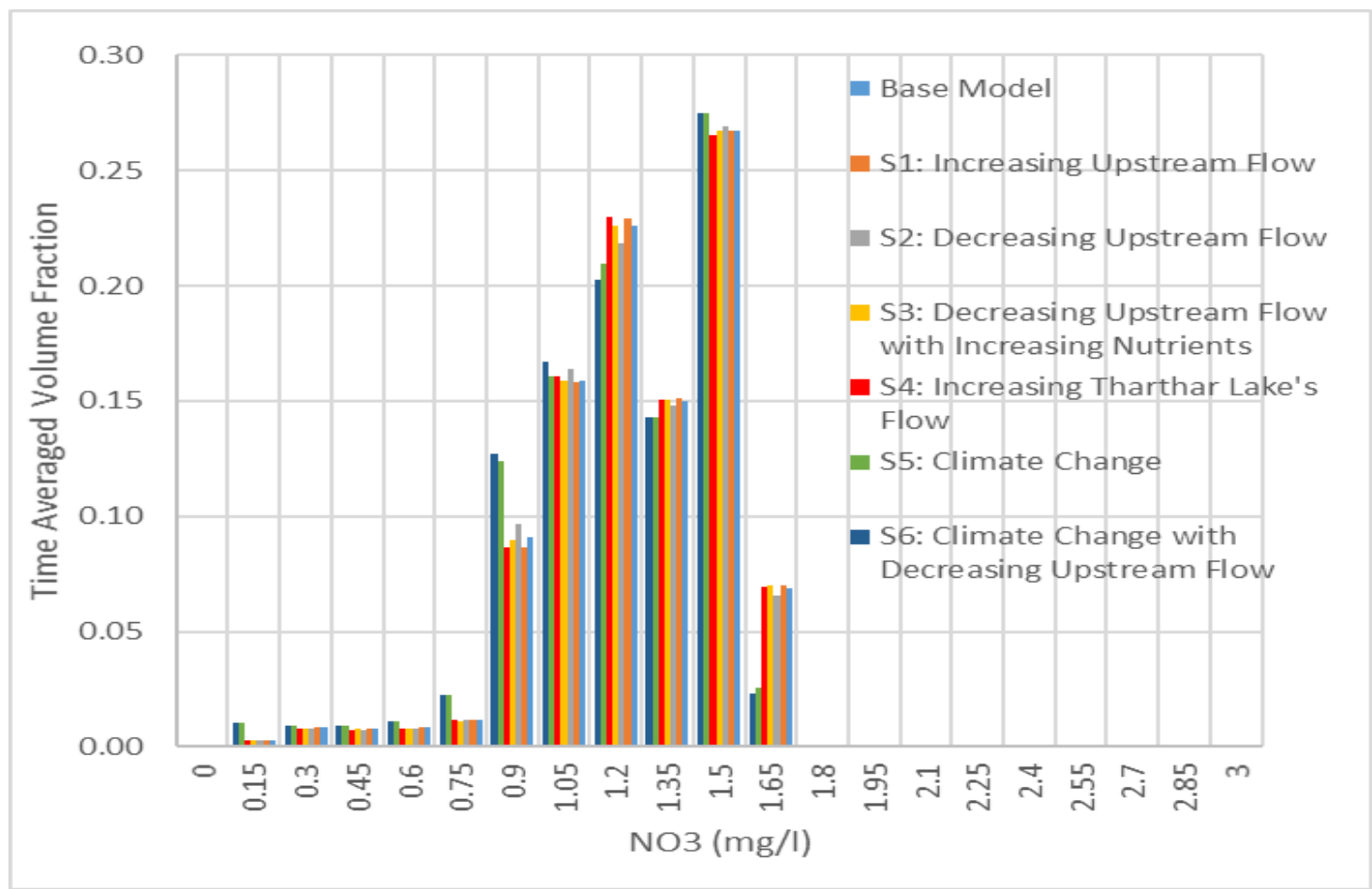

Figure 182: Environmental performance for 6 different scenario runs comparing nitrate in Tharthar Lake. 


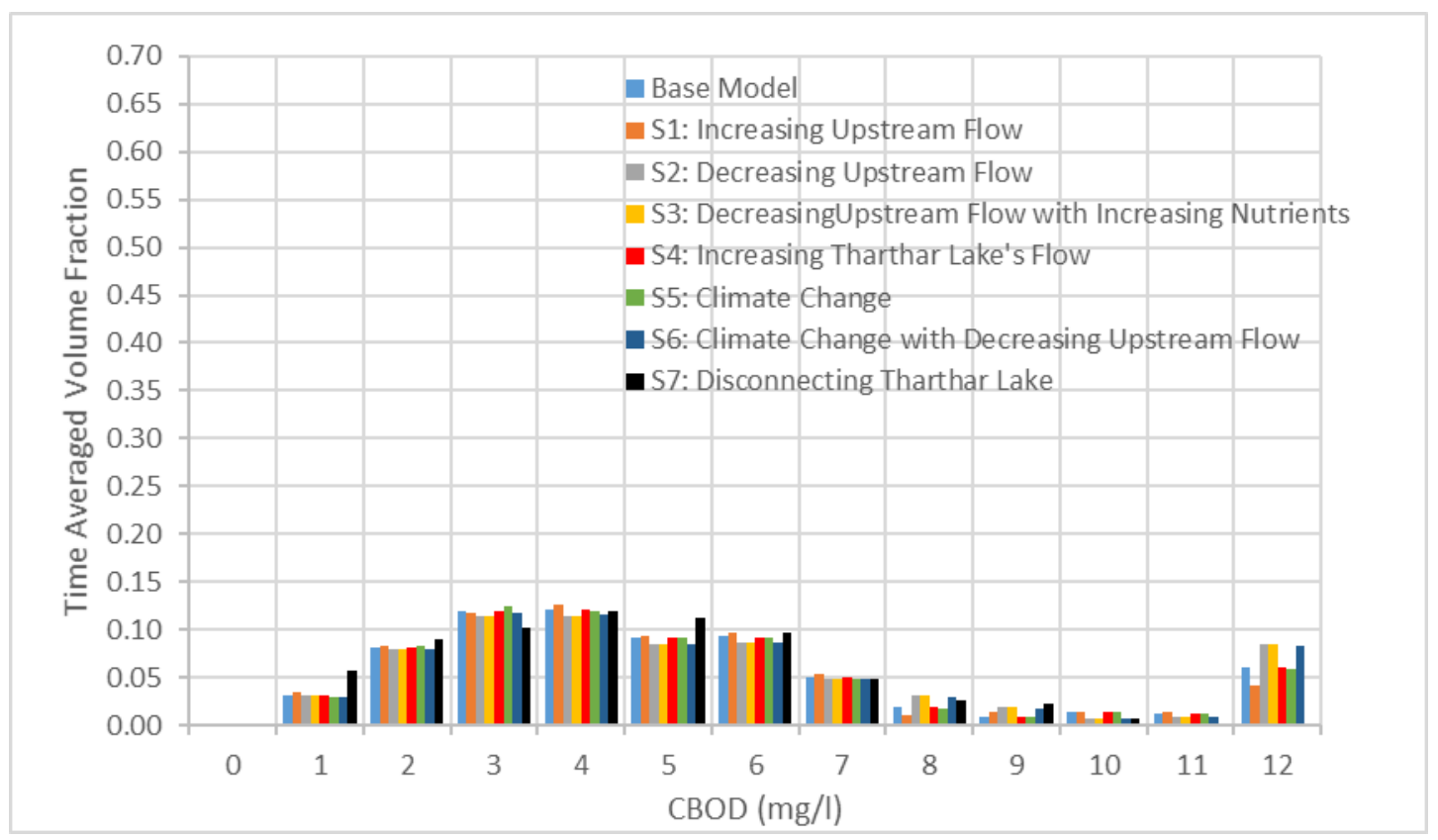

Figure 183: Environmental performance for 7 different scenario runs comparing carbonaceous biological oxygen demand in the mainstem of the Tigris River.

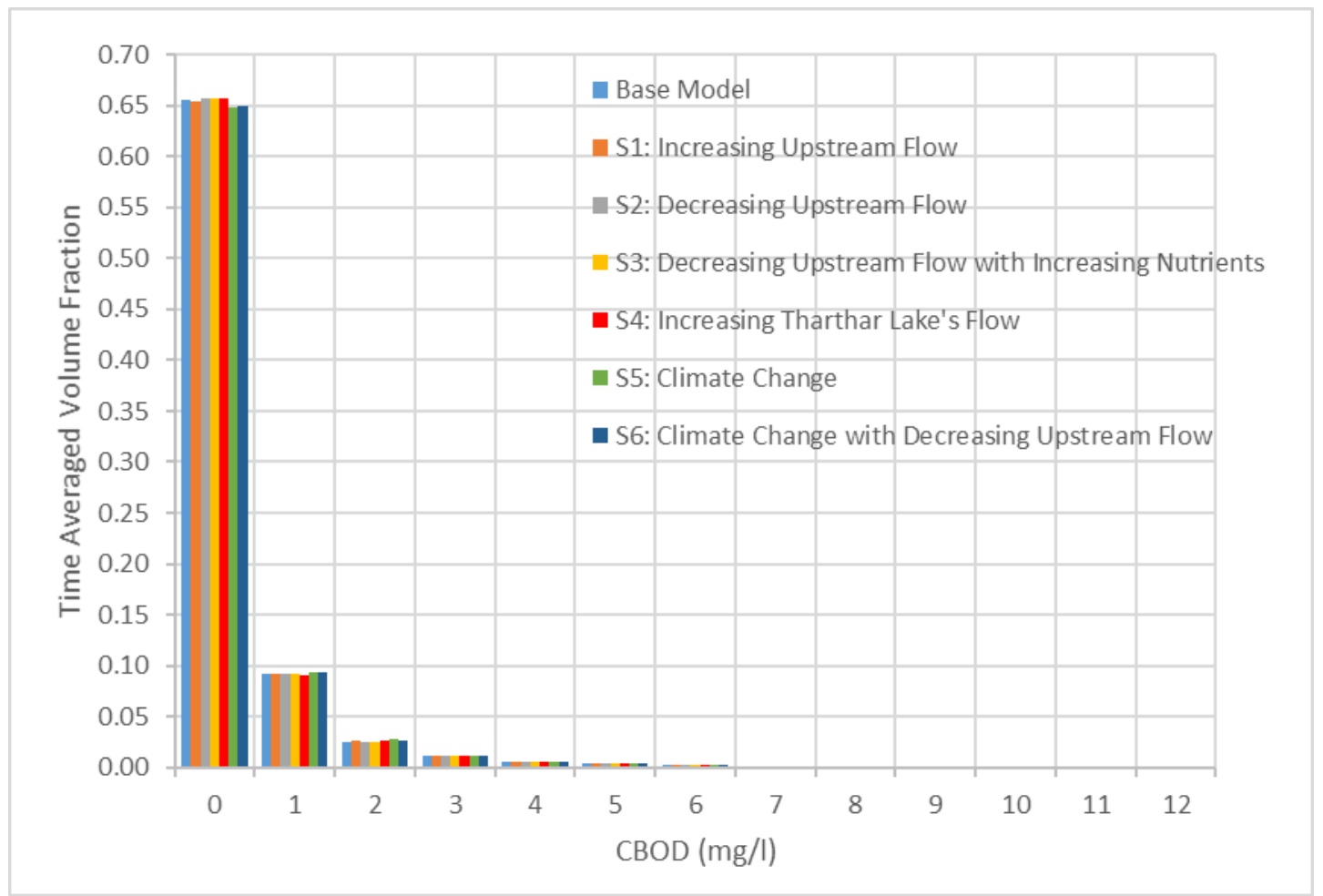

Figure 184: Environmental performance for 6 different scenario runs comparing carbonaceous biological oxygen demand in Tharthar Lake. 


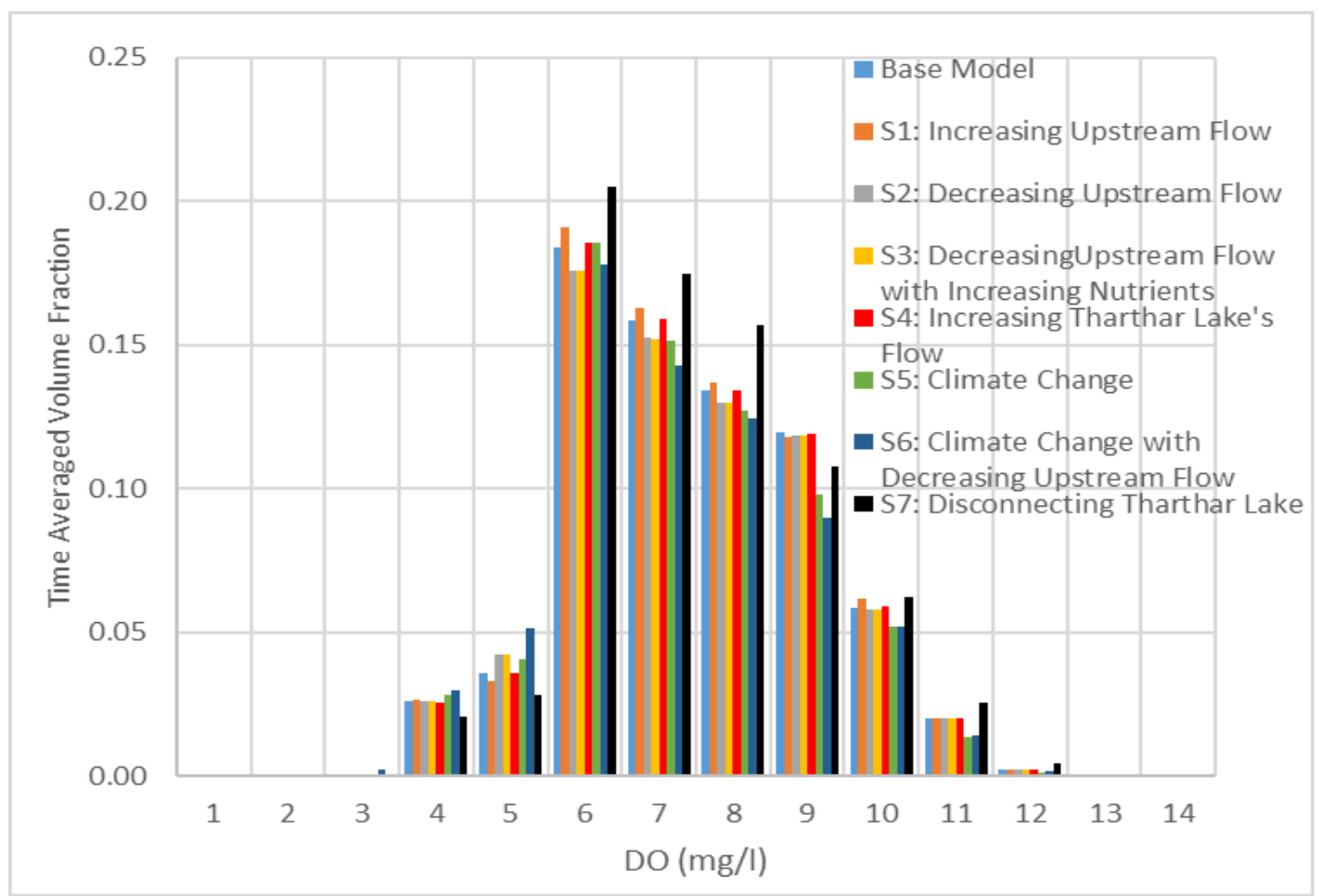

Figure 185: Environmental performance for 7 different scenario runs comparing dissolved oxygen in the mainstem of the Tigris River.

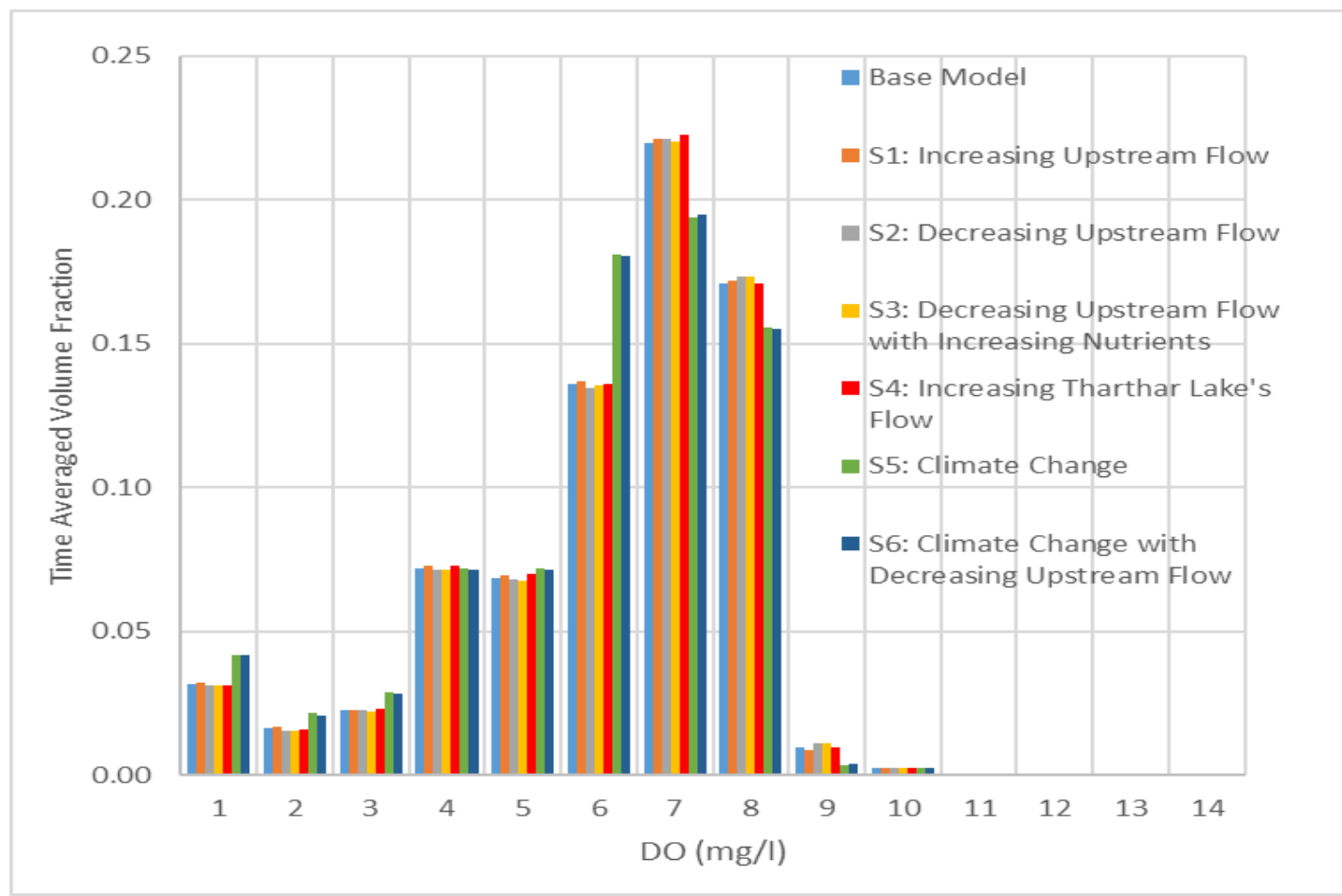

Figure 186: Environmental performance for 6 different scenario runs comparing dissolved oxygen in Tharthar Lake. 


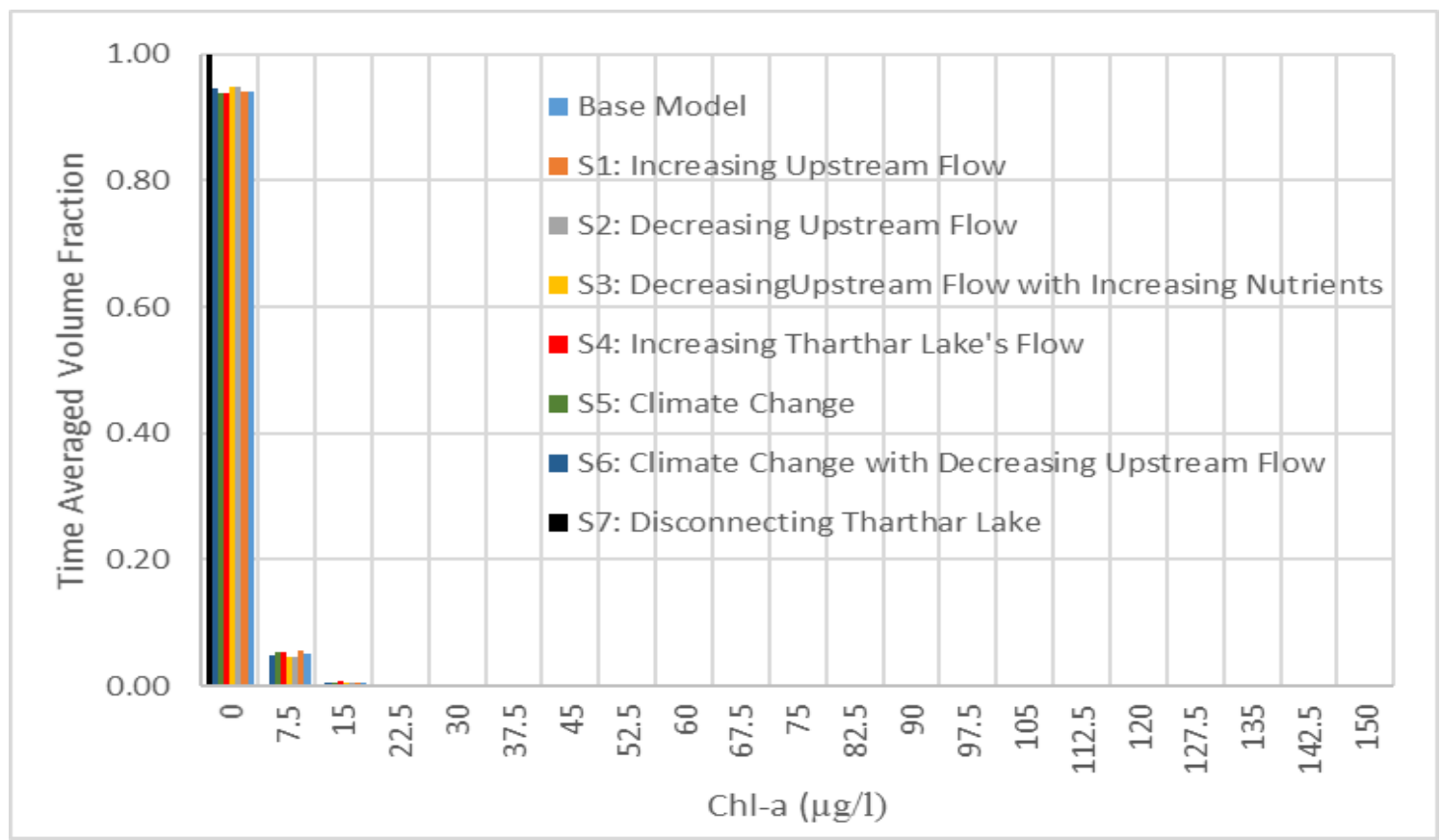

Figure 187: Environmental performance for 7 different scenario runs comparing chlorophyll-a in the mainstem of the Tigris River.

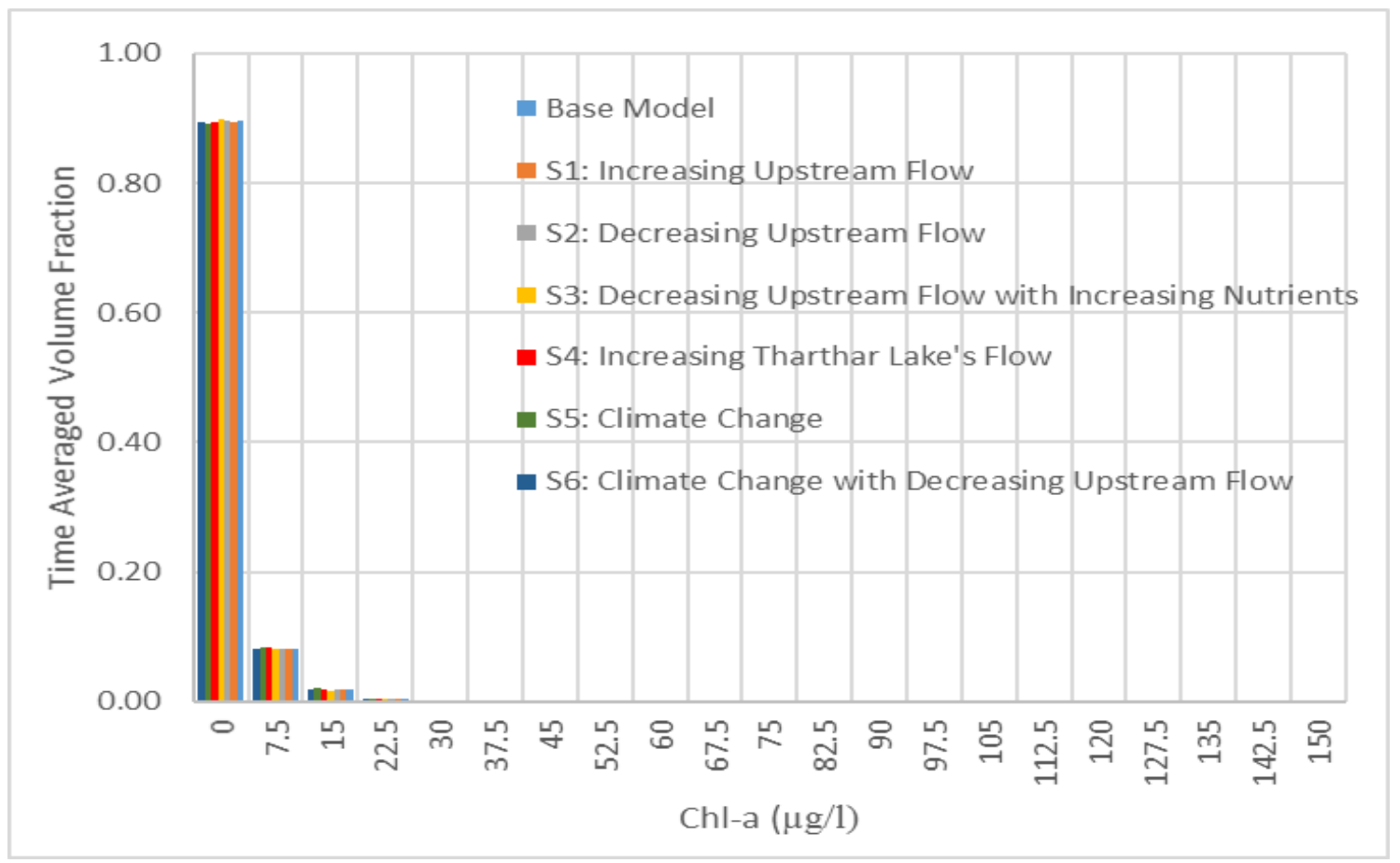

Figure 188: Environmental performance for 6 different scenario runs comparing chlorophyll-a in Tharthar Lake. 


\section{Appendix C: The Tigris River Model Control File}

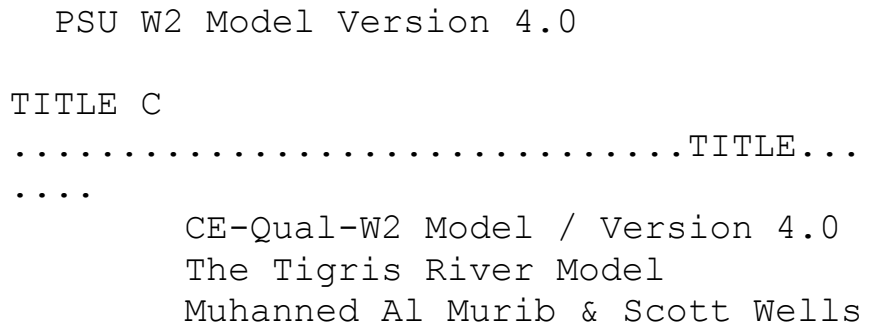

GRID

$\begin{array}{rrrrrr}\text { NWB } & \text { NBR } & \text { IMX } & \text { KMX } & \text { NPROC } & \text { CLOSEC } \\ 9 & 9 & 343 & 84 & 1 & \text { OFF }\end{array}$

IN/OUTFL NPU

$\begin{array}{lllllll}\text { NTR } & \text { NST } & \text { NIW } & \text { NWD } & \text { NGT } & \text { NSP } & \text { NPI }\end{array}$

0

$\begin{array}{lrrrrrrr}\text { CONSTITU } & \text { NGC } & \text { NSS } & \text { NAL } & \text { NEP } & \text { NBOD } & \text { NMC } & \text { NZP } \\ & 2 & 1 & 1 & 0 & 1 & 0 & 0\end{array}$

MISCELL NDAY SELECTC HABTATC ENVIRPC AERATEC INITUWL $100 \quad$ OFF $O F F \quad$ ON $\quad$ OFF $\quad$ OFF

TIME CON TMSTRT TMEND YEAR

$1.000365 .000 \quad 2009$

DLT CON NDT DLTMIN DLTINTR

$20.100 \quad \mathrm{ON}$

DLT DATE DLTD DLTD DLTD DLTD DLTD DLTD DLTD

DLTD DLTD

$1.00000 \quad 2.000$

DLT MAX DLtMAX DLtMAX DLtMAX DLtMAX DLtMAX DLTMAX DLTMAX DLTMAX DLTMAX $25.0000 \quad 50.000$

DLT FRN DLTF DLTF DLTF DLTF DLTF DLTF DLTF

$\begin{array}{ll}\text { DLTF } & \text { DLTF } \\ & 0.90000 \quad 0.9000\end{array}$

DLT LIMI VISC CELC

$\begin{array}{lll}\text { WB } 1 & \mathrm{ON} & \mathrm{ON}\end{array}$ 


\begin{tabular}{|c|c|c|c|c|c|c|c|}
\hline WB 2 & ON & ON & & & & & \\
\hline WB 3 & ON & ON & & & & & \\
\hline WB 4 & ON & ON & & & & & \\
\hline WB 5 & ON & ON & & & & & \\
\hline WB 6 & ON & ON & & & & & \\
\hline WB 7 & ON & ON & & & & & \\
\hline WB 8 & ON & ON & & & & & \\
\hline WB 9 & ON & ON & & & & & \\
\hline & US & DS & UHS & DHS & $\mathrm{UQB}$ & $\mathrm{DQB}$ & NLMIN \\
\hline $\begin{array}{l}\text { BR1 } \\
0.00054\end{array}$ & 2 & 70 & 0 & 73 & 0 & 0 & 1 \\
\hline $\begin{array}{l}\text { BR2 } \\
10.00000\end{array}$ & $\begin{array}{r}73 \\
10.000001\end{array}$ & 80 & 70 & 0 & 0 & 0 & \\
\hline $\begin{array}{l}\text { BR3 } \\
10.00015\end{array}$ & $\begin{array}{c}83 \\
540.000154\end{array}$ & 137 & -80 & 140 & 0 & 0 & \\
\hline $\begin{array}{l}\text { BR4 } \\
10.00000\end{array}$ & $\begin{array}{c}140 \\
10.000001\end{array}$ & 189 & 137 & 0 & 0 & 0 & \\
\hline $\begin{array}{l}\text { BR5 } \\
0.00012\end{array}$ & $\begin{array}{r}192 \\
0.00012\end{array}$ & 206 & 0 & 0 & 0 & 0 & 1 \\
\hline $\begin{array}{l}\text { BR6 } \\
0.00000\end{array}$ & $\begin{array}{r}209 \\
0.00000\end{array}$ & 297 & 0 & 0 & 0 & 0 & 1 \\
\hline $\begin{array}{l}\text { BR7 } \\
0.00011\end{array}$ & $\begin{array}{r}300 \\
0.00011\end{array}$ & 305 & -297 & 0 & 0 & 0 & 1 \\
\hline $\begin{array}{l}\text { BR8 } \\
0.00020\end{array}$ & $\begin{array}{r}308 \\
0.00020\end{array}$ & 320 & 0 & 0 & 0 & 0 & 1 \\
\hline $\begin{array}{l}\text { BR9 } \\
10.00000\end{array}$ & $\begin{array}{c}323 \\
010.000001\end{array}$ & 342 & 0 & 0 & 0 & 0 & \\
\hline LOCATION & LAT & LONG & EBOT & BS & $\mathrm{BE}$ & JBDN & \\
\hline WB 1 & 36.3566 & -43.164 & 61.0000 & 1 & 1 & 1 & \\
\hline WB 2 & 34.1600 & -43.900 & 60.0000 & 2 & 2 & 2 & \\
\hline WB 3 & 33.3128 & -44.361 & 11.0000 & 3 & 3 & 3 & \\
\hline WB 4 & 32.5168 & -45.847 & 11.0000 & 4 & 4 & 4 & \\
\hline WB 5 & 34.1600 & -43.900 & 45.0000 & 5 & 5 & 5 & \\
\hline WB 6 & 33.9847 & -43.252 & -3.0000 & 6 & 6 & 6 & \\
\hline WB 7 & 33.9847 & -43.252 & 38.0000 & 7 & 7 & 7 & \\
\hline WB 8 & 33.9847 & -43.252 & 30.0000 & 8 & 8 & 8 & \\
\hline WB 9 & 34.1600 & -43.900 & 45.0000 & 9 & 9 & 9 & \\
\hline INIT CND & $\mathrm{T} 2 \mathrm{I}$ & ICEI & WTYPEC & GRIDC & & & \\
\hline WB 1 & 6.11000 & 0.00000 & FRESH & $\mathrm{RECT}$ & & & \\
\hline WB 2 & 7.60000 & 0.00000 & FRESH & $\mathrm{RECT}$ & & & \\
\hline WB 3 & 7.70000 & 0.00000 & FRESH & $\mathrm{RECT}$ & & & \\
\hline WB 4 & 8.70000 & 0.00000 & FRESH & $\mathrm{RECT}$ & & & \\
\hline WB 5 & 6.11000 & 0.00000 & FRESH & $\mathrm{RECT}$ & & & \\
\hline WB 6 & 14.0000 & 0.00000 & FRESH & $\mathrm{RECT}$ & & & \\
\hline WB 7 & 8.00000 & 0.00000 & FRESH & $\mathrm{RECT}$ & & & \\
\hline WB 8 & 8.00000 & 0.00000 & FRESH & $\mathrm{RECT}$ & & & \\
\hline WB 9 & 6.11000 & 0.00000 & FRESH & $\mathrm{RECT}$ & & & \\
\hline CALCULA & VBC & $\mathrm{EBC}$ & $\mathrm{MBC}$ & $\mathrm{PQC}$ & EVC & $\mathrm{PRC}$ & \\
\hline
\end{tabular}




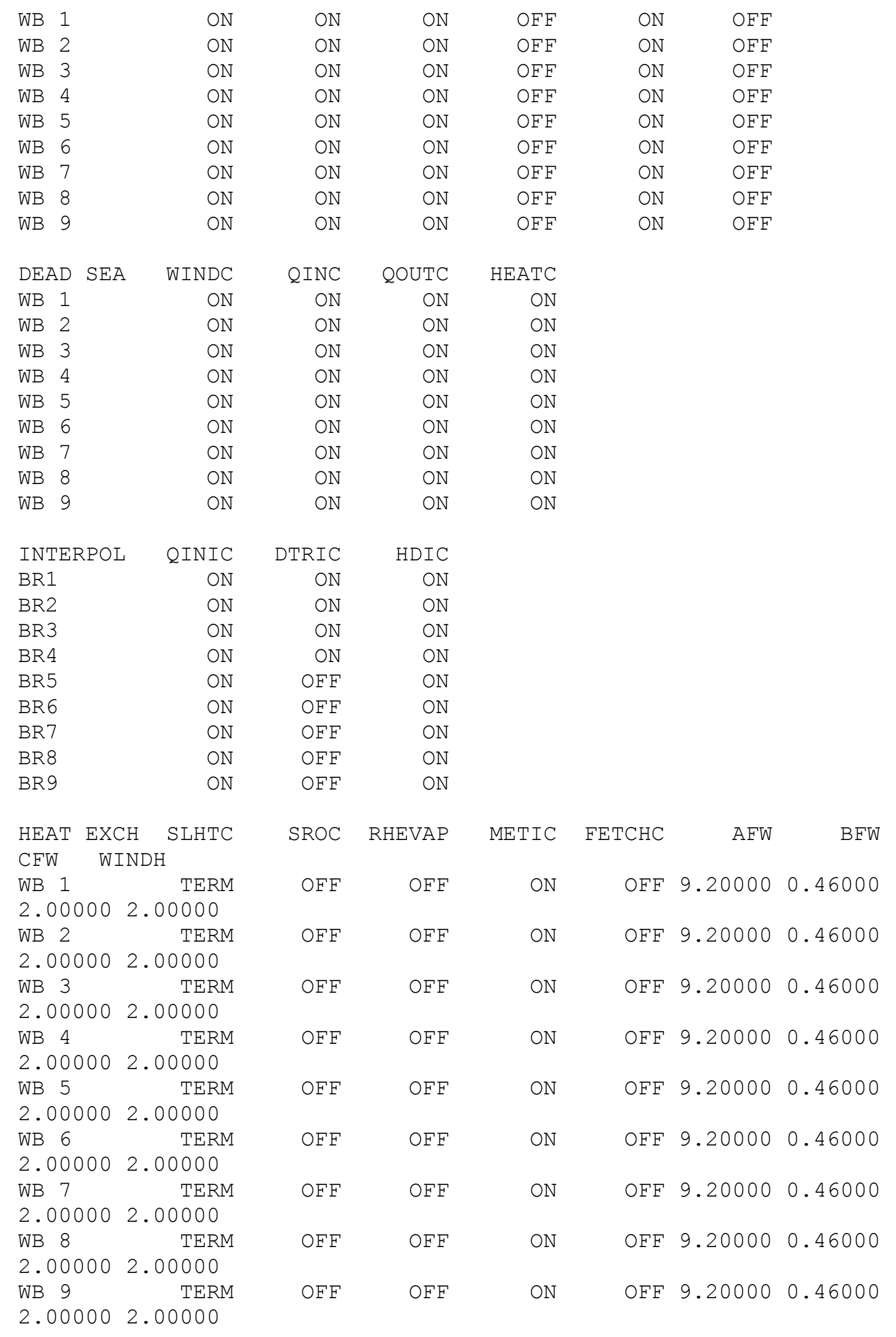




\begin{tabular}{|c|c|c|c|c|c|c|c|}
\hline $\begin{array}{l}\text { ICE COVE } \\
\text { ICET2 }\end{array}$ & ICEC & SLICEC & ALBEDO & HWICE & $\mathrm{BICE}$ & GICE & ICEMIN \\
\hline $\begin{array}{l}\text { WB } 1 \\
0.00000\end{array}$ & $\mathrm{OFF}$ & DETAIL & 0.00000 & 0.00000 & 0.00000 & 0.00000 & 0.00000 \\
\hline $\begin{array}{l}\text { B } 2 \\
.00000\end{array}$ & $\mathrm{OFF}$ & DETAIL & 0.00000 & 0.00000 & 0.00000 & 0.00000 & 0.00000 \\
\hline $\begin{array}{l}\text { B } 3 \\
.00000\end{array}$ & $\mathrm{OFF}$ & DETAIL & 0.00000 & 0.00000 & 0.00000 & 0.00000 & 0.00000 \\
\hline $\begin{array}{l}\text { B } 4 \\
.00000\end{array}$ & $\mathrm{OFF}$ & DETAIL & 0.00000 & 0.00000 & 0.00000 & 0.00000 & 0.00000 \\
\hline $\begin{array}{l}\text { B } 5 \\
.00000\end{array}$ & $\mathrm{OFF}$ & DETAIL & 0.00000 & 0.00000 & 0.00000 & 0.00000 & 0.00000 \\
\hline $\begin{array}{l}\text { NB } 6 \\
0.00000\end{array}$ & $\mathrm{OFF}$ & DETAIL & 0.00000 & 0.00000 & 0.00000 & 0.00000 & 0.00000 \\
\hline $\begin{array}{l}\text { NB } 7 \\
0.00000\end{array}$ & $\mathrm{OFF}$ & DETAIL & 0.00000 & 0.00000 & 0.00000 & 0.00000 & 0.00000 \\
\hline $\begin{array}{l}\text { WB } 8 \\
0.00000\end{array}$ & $\mathrm{OFF}$ & DETAIL & 0.00000 & 0.00000 & 0.00000 & 0.00000 & 0.00000 \\
\hline $\begin{array}{l}\text { B } 9 \\
.00000\end{array}$ & $\mathrm{OFF}$ & DETAIL & 0.00000 & 0.00000 & 0.00000 & 0.00000 & 0.00000 \\
\hline RANSPOR & SLTRC & THETA & & & & & \\
\hline WB 1 & ULTIMATE & 0.55000 & & & & & \\
\hline WB 2 & ULTIMATE & 0.55000 & & & & & \\
\hline WB 3 & ULTIMATE & 0.55000 & & & & & \\
\hline WB 4 & ULTIMATE & 0.55000 & & & & & \\
\hline WB 5 & ULTIMATE & 0.55000 & & & & & \\
\hline NB 6 & ULTIMATE & 0.55000 & & & & & \\
\hline WB 7 & ULTIMATE & 0.55000 & & & & & \\
\hline WB 8 & ULTIMATE & 0.55000 & & & & & \\
\hline WB 9 & ULTIMATE & 0.55000 & & & & & \\
\hline $\begin{array}{l}\text { HYD COEF } \\
\text { ZO }\end{array}$ & $A X$ & DX & $\mathrm{CBHE}$ & TSED & FI & TSEDF & FRICC \\
\hline $\begin{array}{l}\text { WB } 1 \\
0.00100\end{array}$ & 1.0000 & 1.00000 & 0.30000 & 20.0000 & 0.01000 & 1.00000 & MANN \\
\hline $\begin{array}{l}\text { WB } 2 \\
0.00100\end{array}$ & 1.0000 & 1.00000 & 0.30000 & 20.0000 & 0.01000 & 1.00000 & MANN \\
\hline $\begin{array}{l}\text { WB } 3 \\
0.00100\end{array}$ & 1.0000 & 1.00000 & 0.30000 & 12.0000 & 0.01000 & 1.00000 & MANN \\
\hline $\begin{array}{l}\text { WB } 4 \\
0.00100\end{array}$ & 1.0000 & 1.00000 & 0.30000 & 12.0000 & 0.01000 & 1.00000 & MANN \\
\hline $\begin{array}{l}\text { WB } 5 \\
0.00100\end{array}$ & 1.0000 & 1.00000 & 0.30000 & 12.0000 & 0.01000 & 1.00000 & MANN \\
\hline $\begin{array}{l}\text { WB } 6 \\
0.00100\end{array}$ & 1.0000 & 1.00000 & 0.30000 & 12.0000 & 0.01000 & 1.00000 & MANN \\
\hline $\begin{array}{l}\text { WB } 7 \\
0.00100\end{array}$ & 1.0000 & 1.00000 & 0.30000 & 12.0000 & 0.01000 & 1.00000 & MANN \\
\hline $\begin{array}{l}\text { WB } 8 \\
0.00100\end{array}$ & 1.0000 & 1.00000 & 0.30000 & 12.0000 & 0.01000 & 1.00000 & MANN \\
\hline $\begin{array}{l}\text { WB } 9 \\
0.00100\end{array}$ & 1.0000 & 1.00000 & 0.30000 & 12.0000 & 0.01000 & 1.00000 & MANN \\
\hline
\end{tabular}




\begin{tabular}{|c|c|c|c|c|c|c|c|}
\hline EDDY VIS & $\mathrm{AZC}$ & AZSLC & AZMAX & $\mathrm{FBC}$ & $\mathrm{E}$ & ARODI & STRCKLR \\
\hline BOUNDFR & TKECAL & & & & & & \\
\hline WB 1 & TKE & IMP & 1.00000 & 3 & 9.53500 & 0.43000 & 24.0000 \\
\hline 10.0000 & IMP & & & & & & \\
\hline WB 2 & TKE & IMP & 1.00000 & 3 & 9.53500 & 0.43100 & 0.00000 \\
\hline 0.00000 & IMP & & & & & & \\
\hline WB 3 & TKE & IMP & 1.00000 & 3 & 9.53500 & 0.43100 & 0.00000 \\
\hline 0.00000 & IMP & & & & & & \\
\hline WB 4 & TKE & IMP & 1.00000 & 3 & 9.53500 & 0.43100 & 0.00000 \\
\hline 0.00000 & IMP & & & & & & \\
\hline WB 5 & TKE & IMP & 1.00000 & 3 & 9.53500 & 0.43100 & 0.00000 \\
\hline 0.00000 & IMP & & & & & & \\
\hline WB 6 & TKE & IMP & 1.00000 & 3 & 9.53500 & 0.43100 & 0.00000 \\
\hline 0.00000 & IMP & & & & & & \\
\hline WB 7 & TKE & IMP & 1.00000 & 3 & 9.53500 & 0.43100 & 0.00000 \\
\hline 0.00000 & IMP & & & & & & \\
\hline WB 8 & TKE & IMP & 1.00000 & 3 & 9.53500 & 0.43100 & 0.00000 \\
\hline 0.00000 & IMP & & & & & & \\
\hline WB 9 & TKE & IMP & 1.00000 & 3 & 9.53500 & 0.43100 & 0.00000 \\
\hline 0.00000 & IMP & & & & & & \\
\hline N STRUC & NSTR & DYNELEV & & & & & \\
\hline BR1 & 0 & $\mathrm{OFF}$ & & & & & \\
\hline BR2 & 1 & $\mathrm{OFF}$ & & & & & \\
\hline BR3 & 0 & $\mathrm{OFF}$ & & & & & \\
\hline BR4 & 0 & OFF & & & & & \\
\hline BR5 & 0 & $O F F$ & & & & & \\
\hline BR 6 & 1 & $\mathrm{OFF}$ & & & & & \\
\hline BR7 & 0 & $O F F$ & & & & & \\
\hline BR8 & 0 & $\mathrm{OFF}$ & & & & & \\
\hline BR9 & 0 & $\mathrm{OFF}$ & & & & & \\
\hline STR INT & STRIC & STRIC & STRIC & STRIC & STRIC & STRIC & STRIC \\
\hline STRIC & STRIC & & & & & & \\
\hline BR 1 & & & & & & & \\
\hline BR 2 & $\mathrm{ON}$ & & & & & & \\
\hline BR 3 & & & & & & & \\
\hline BR 4 & $\mathrm{ON}$ & & & & & & \\
\hline BR 5 & & & & & & & \\
\hline BR 6 & ON & & & & & & \\
\hline BR 7 & $\mathrm{ON}$ & & & & & & \\
\hline BR 8 & & & & & & & \\
\hline BR 9 & & & & & & & \\
\hline STR TOP & KTSTR & KTSTR & KTSTR & KTSTR & KTSTR & KTSTR & KTSTR \\
\hline KTSTR & KTSTR & & & & & & \\
\hline BR1 & & & & & & & \\
\hline BR2 & 2 & & & & & & \\
\hline BR3 & & & & & & & \\
\hline BR4 & 2 & & & & & & \\
\hline BR5 & & & & & & & \\
\hline BR 6 & 2 & & & & & & \\
\hline BR7 & 2 & & & & & & \\
\hline
\end{tabular}




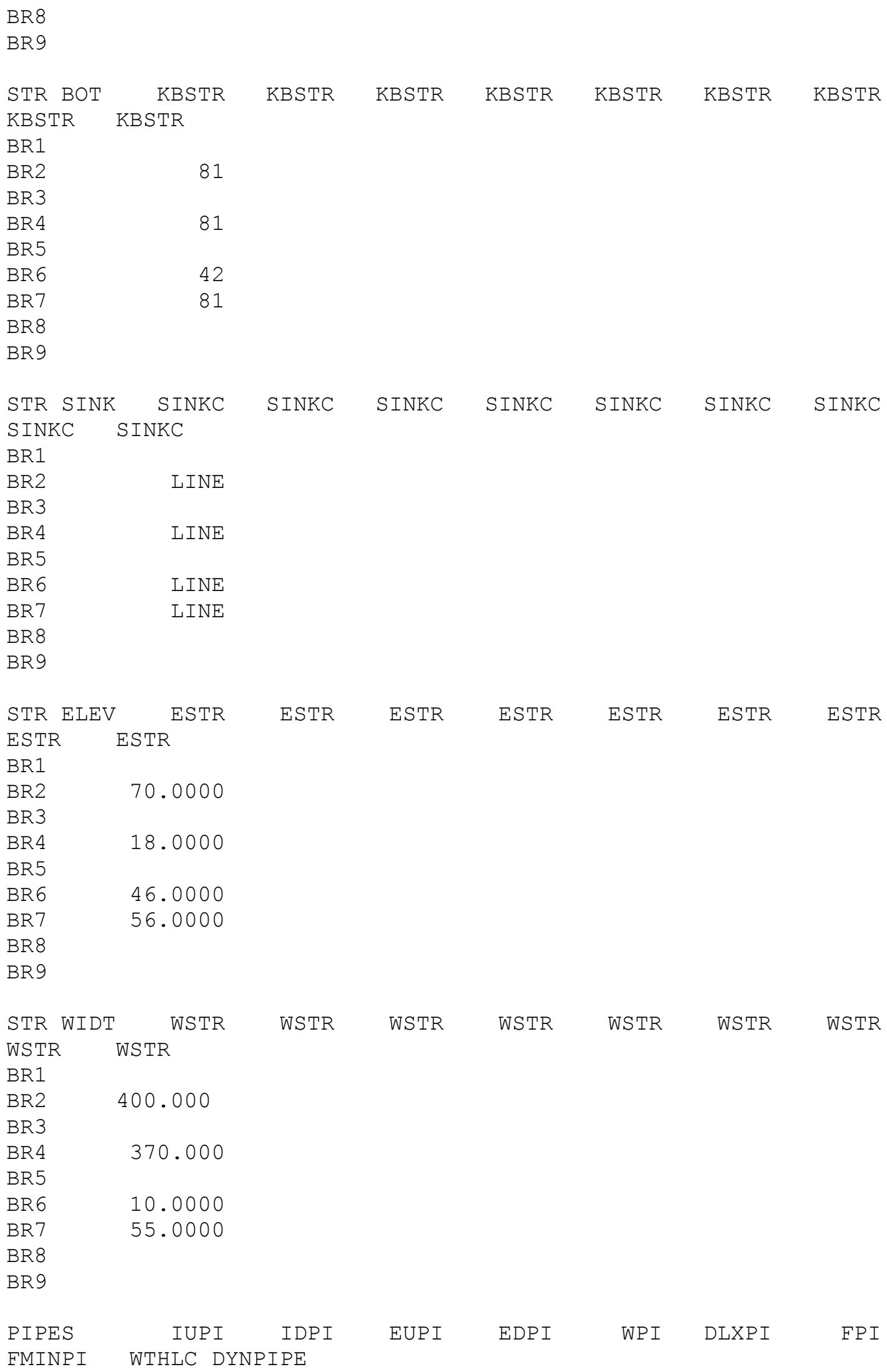




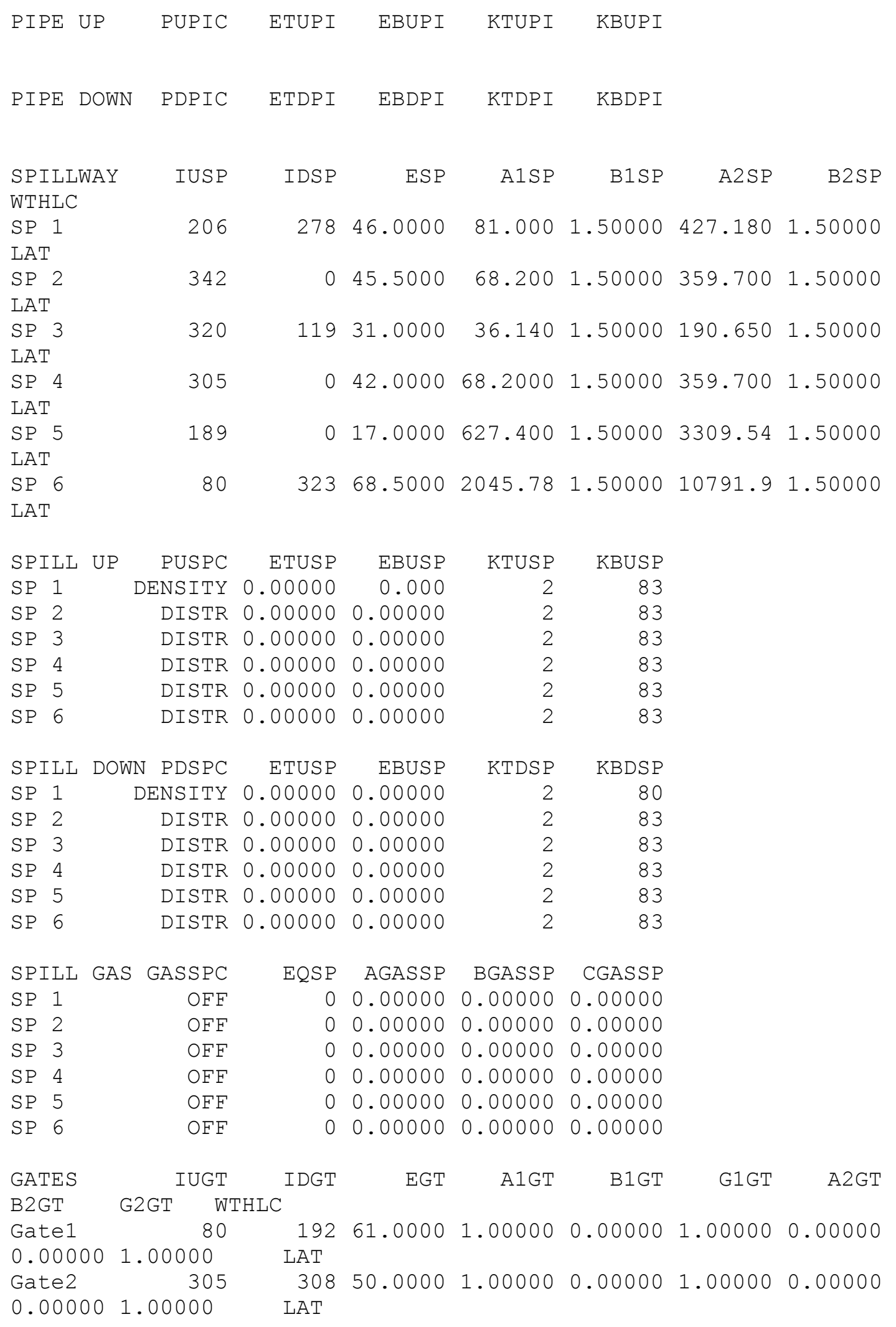




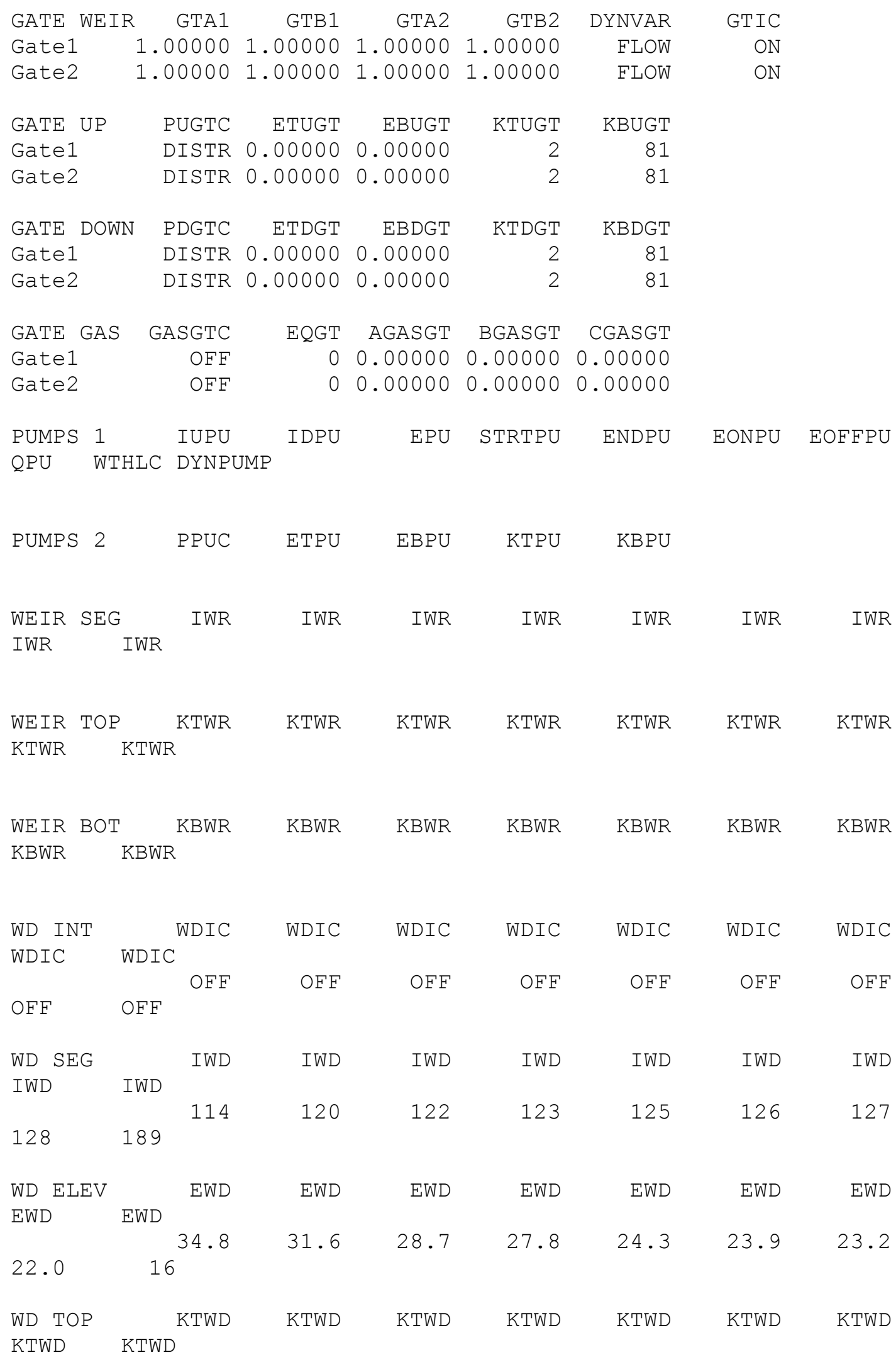




\begin{tabular}{|c|c|c|c|c|c|c|c|}
\hline 2 & 2 & 2 & 2 & 2 & 2 & 2 & 2 \\
\hline \multirow{3}{*}{$\begin{array}{l}\text { WD BOT } \\
\text { KBWD }\end{array}$} & KBWD & KBWD & KBWD & KBWD & KBWD & KBWD & KBWD \\
\hline & KBWD & & & & & & \\
\hline & 83 & 83 & 83 & 83 & 83 & 83 & 83 \\
\hline 83 & 83 & & & & & & \\
\hline \multirow{3}{*}{$\begin{array}{l}\text { TRIB PLA } \\
\text { PTRC }\end{array}$} & PTRC & PTRC & PTRC & PTRC & PTRC & PTRC & PTRC \\
\hline & PTRC & & & & & & \\
\hline & DISTR & DISTR & DISTR & DISTR & DISTR & DISTR & DISTR \\
\hline \multirow{2}{*}{$\begin{array}{l}\text { TRIB INT } \\
\text { TRIC }\end{array}$} & TRIC & TRIC & TRIC & TRIC & TRIC & TRIC & TRIC \\
\hline & ON & $\mathrm{ON}$ & $\mathrm{ON}$ & ON & $\mathrm{ON}$ & ON & $\mathrm{ON}$ \\
\hline \multirow{2}{*}{$\begin{array}{l}\text { TRIB SEG } \\
\text { ITR }\end{array}$} & ITR & ITR & ITR & ITR & ITR & ITR & ITR \\
\hline & ITR & 50 & 97 & 130 & 84 & 140 & 66 \\
\hline \multirow{3}{*}{$\begin{array}{l}\text { TRIB TOP } \\
\text { ELTRT }\end{array}$} & ELTRT & ELTRT & ELTRT & ELTRT & ELTRT & ELTRT & ELTRT \\
\hline & ELTRT & & & & & & \\
\hline & 0.00000 & 0.00000 & 0.00000 & 0.00000 & 0.00000 & 0.00000 & 0.00000 \\
\hline \multirow{3}{*}{$\begin{array}{l}\text { TRIB BOT } \\
\text { ELTRB }\end{array}$} & ELTRB & ELTRB & ELTRB & ELTRB & ELTRB & ELTRB & ELTRB \\
\hline & ELTRB & & & & & & \\
\hline & 0.00000 & 0.00000 & 0.00000 & 0.00000 & 0.00000 & 0.00000 & 0.00000 \\
\hline DST TRIB & DTRC & DTRC & DTRC & DTRC & DTRC & DTRC & DTRC \\
\hline \multicolumn{2}{|c|}{ DTRC DTRC } & & & & & & \\
\hline BR 1 & ON & & & & & & \\
\hline BR 2 & ON & & & & & & \\
\hline BR 3 & ON & & & & & & \\
\hline BR 4 & ON & & & & & & \\
\hline BR 5 & $\mathrm{OFF}$ & & & & & & \\
\hline BR 6 & $\mathrm{OFF}$ & & & & & & \\
\hline BR 7 & $\mathrm{OFF}$ & & & & & & \\
\hline BR 8 & $\mathrm{OFF}$ & & & & & & \\
\hline BR 9 & $\mathrm{OFF}$ & & & & & & \\
\hline \multirow{2}{*}{$\begin{array}{l}\text { HYD PRIN } \\
\text { HPRWBC }\end{array}$} & J HPRWBC & HPRWBC & HPRWBC & HPRWBC & HPRWBC & HPRWBC & HPRWBC \\
\hline & HPRWBC & & & & & & \\
\hline \multirow{2}{*}{$O F F$} & $\mathrm{OFF}$ & $\mathrm{OFF}$ & $\mathrm{OFF}$ & $\mathrm{OFF}$ & $\mathrm{OFF}$ & $\mathrm{OFF}$ & $\mathrm{OFF}$ \\
\hline & $\mathrm{OFF}$ & & & & & & \\
\hline $\mathrm{U}$ & ON & ON & ON & ON & ON & ON & ON \\
\hline \multirow{2}{*}{$\begin{array}{l}\text { ON } \\
W\end{array}$} & $\mathrm{ON}$ & & & & & & \\
\hline & ON & ON & ON & ON & ON & ON & $\mathrm{ON}$ \\
\hline \multirow{2}{*}{$\begin{array}{l}\mathrm{ON} \\
\mathrm{T}\end{array}$} & $\mathrm{ON}$ & & & & & & \\
\hline & ON & ON & ON & ON & $\mathrm{ON}$ & ON & $\mathrm{ON}$ \\
\hline \multirow{2}{*}{$\begin{array}{l}\text { ON } \\
\text { RHO }\end{array}$} & ON & & & & & & \\
\hline & $\mathrm{OFF}$ & $\mathrm{OFF}$ & $\mathrm{OFF}$ & $\mathrm{OFF}$ & $\mathrm{OFF}$ & $\mathrm{OFF}$ & $\mathrm{OFF}$ \\
\hline $\mathrm{OFF}$ & $\mathrm{OFF}$ & & & & & & \\
\hline
\end{tabular}




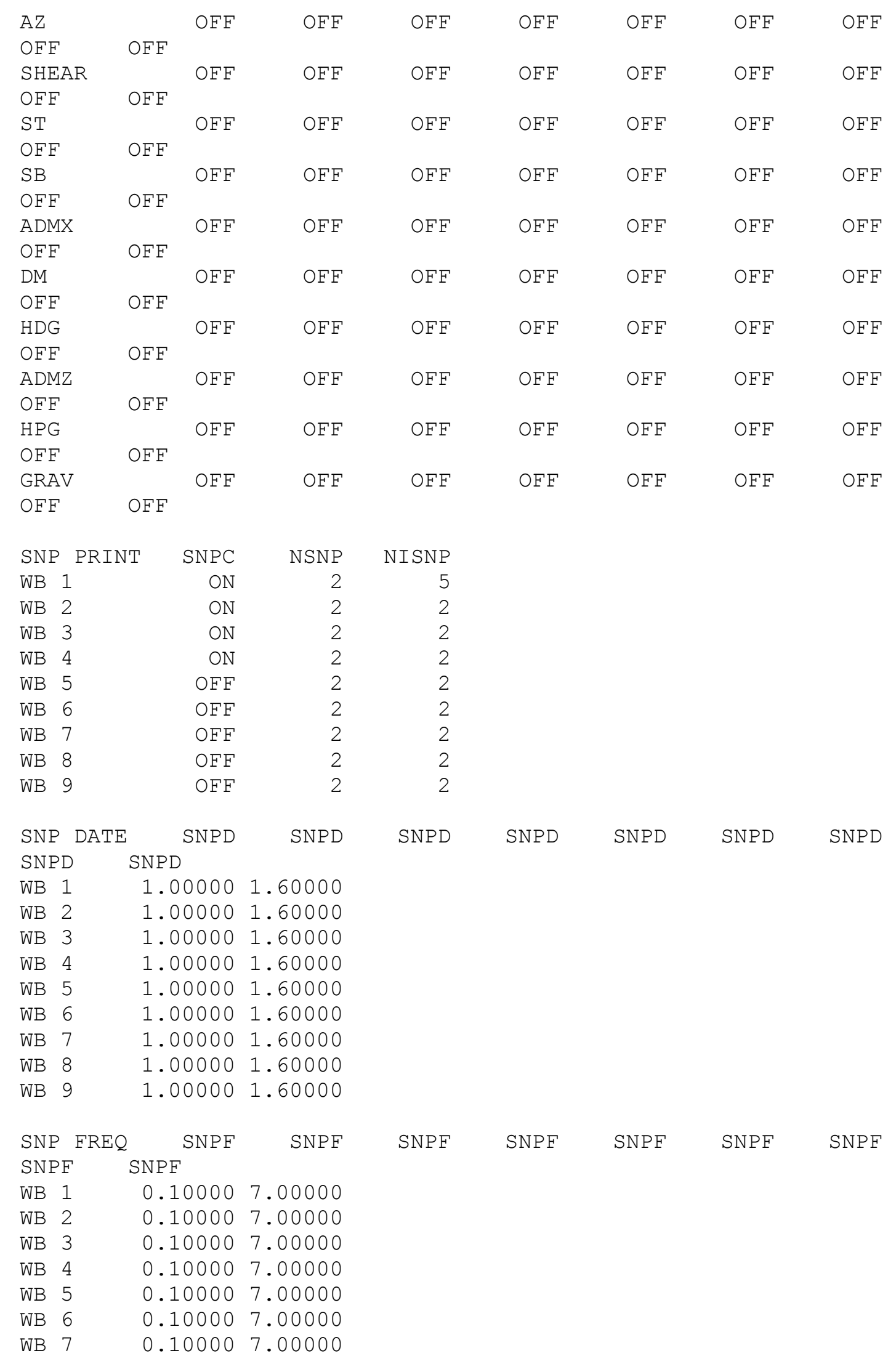




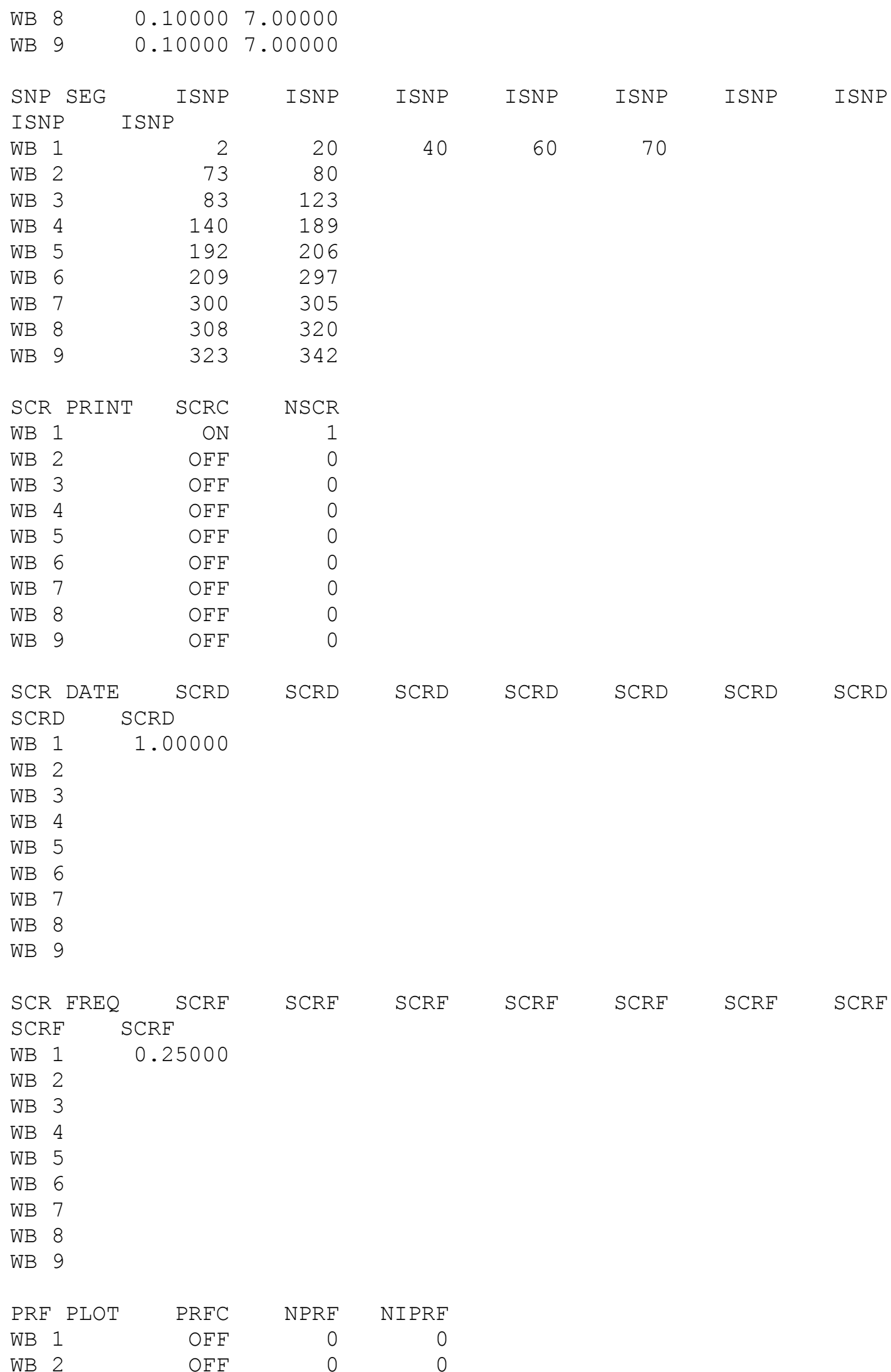




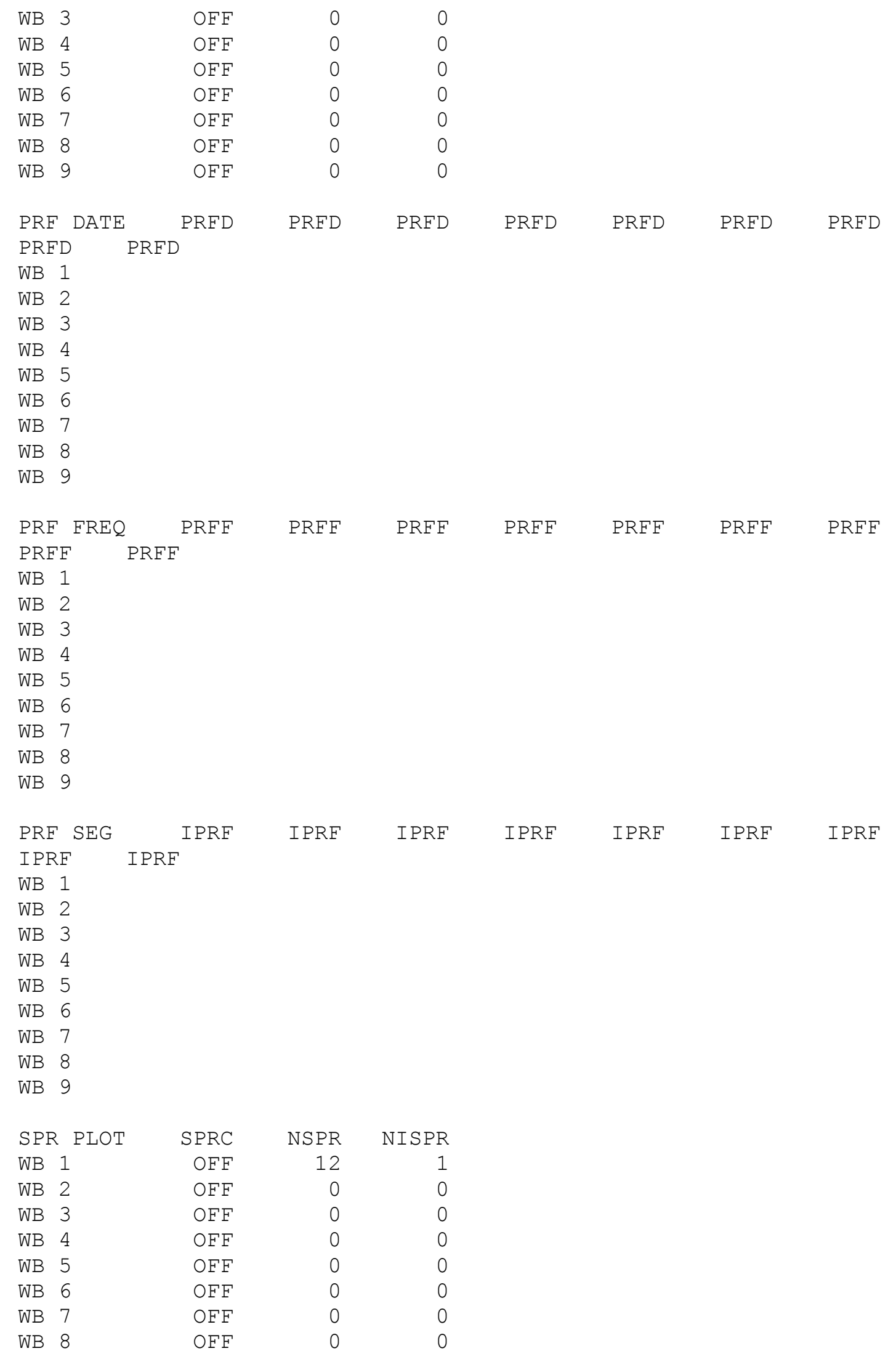




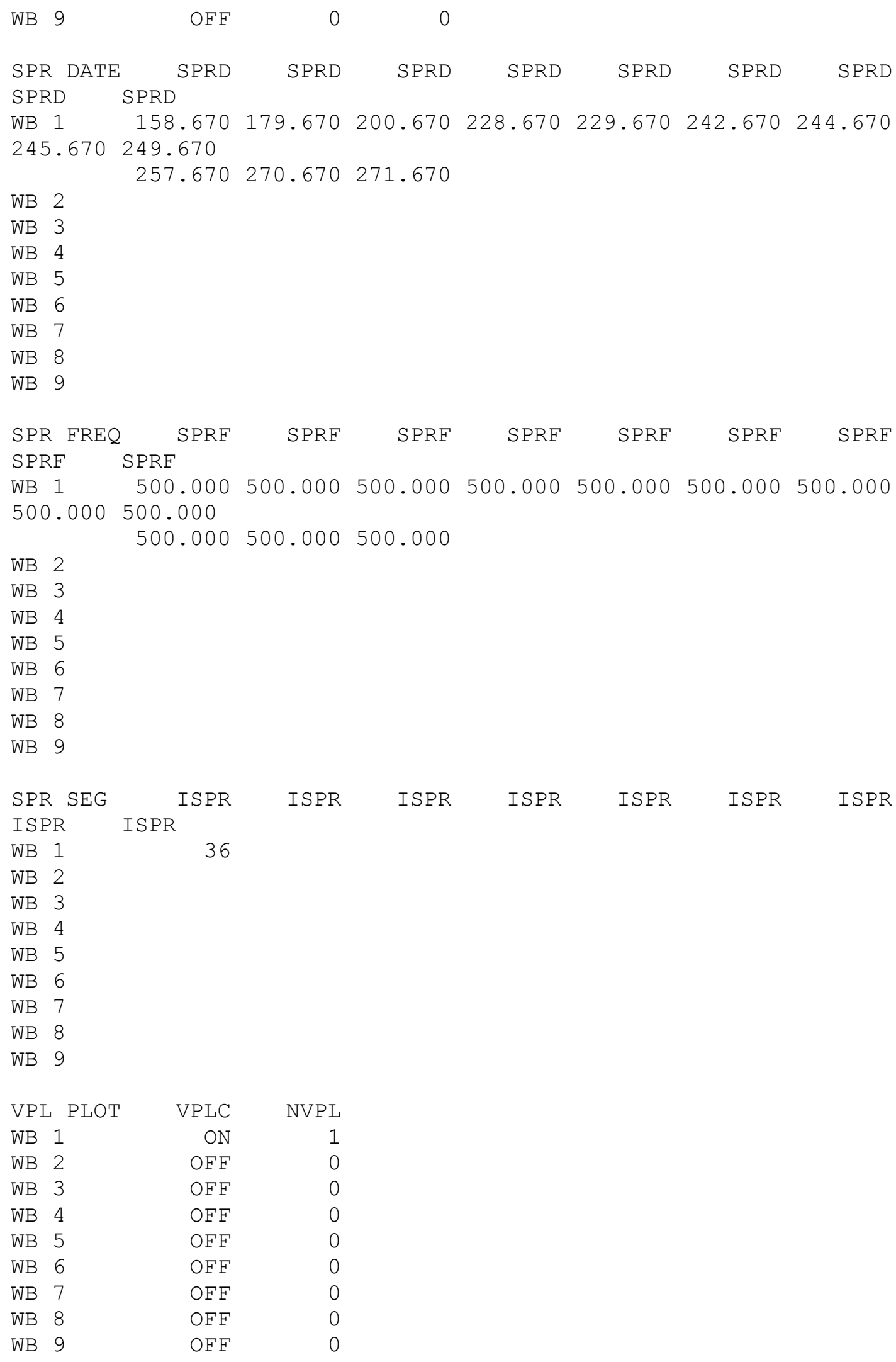

$\begin{array}{rr}\text { ON } & 1 \\ \text { OFF } & 0 \\ O F F & 0 \\ \text { OFF } & 0 \\ \text { OFF } & 0 \\ O F F & 0 \\ O F F & 0 \\ O F F & 0 \\ O F F & 0\end{array}$




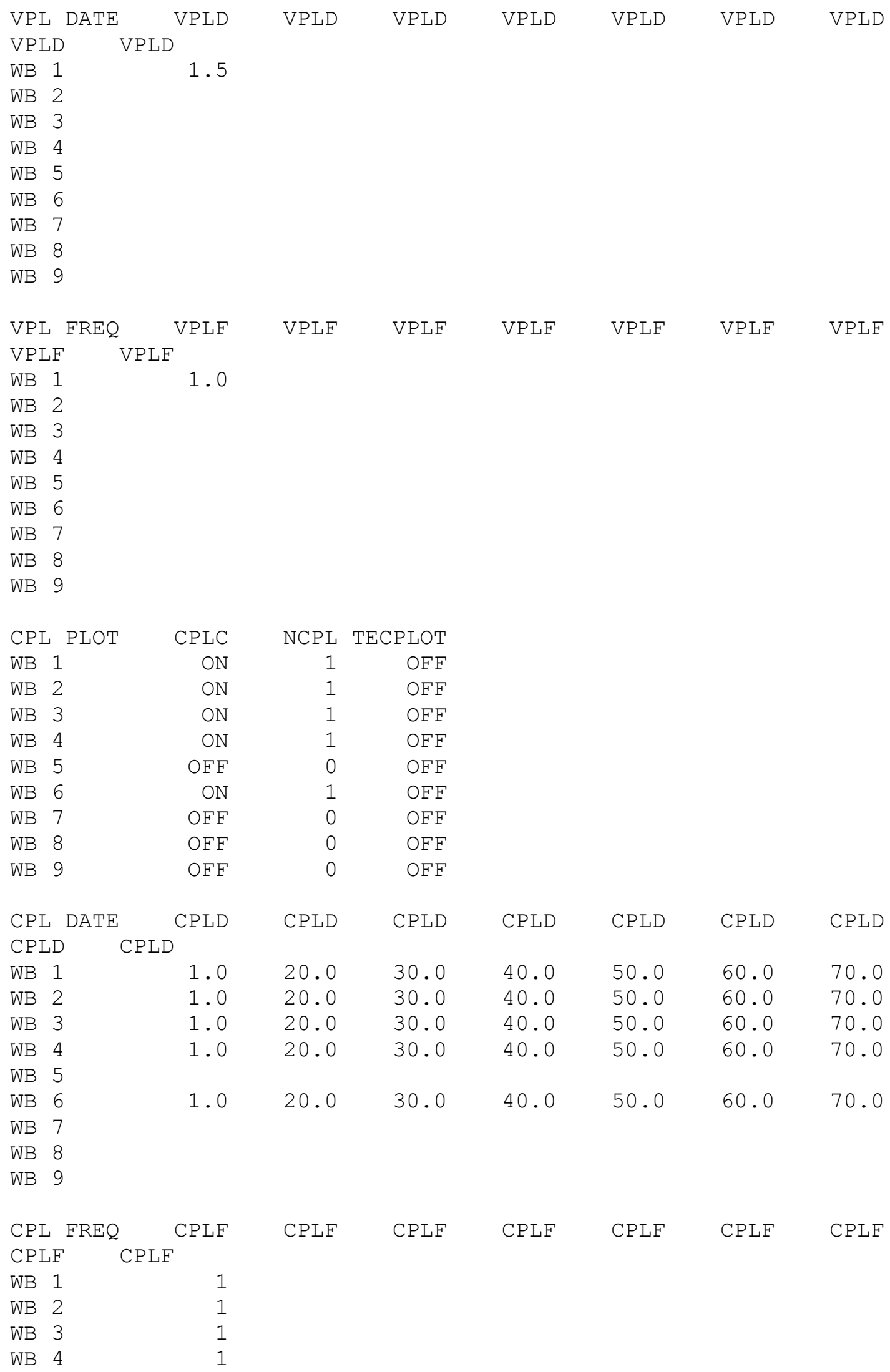




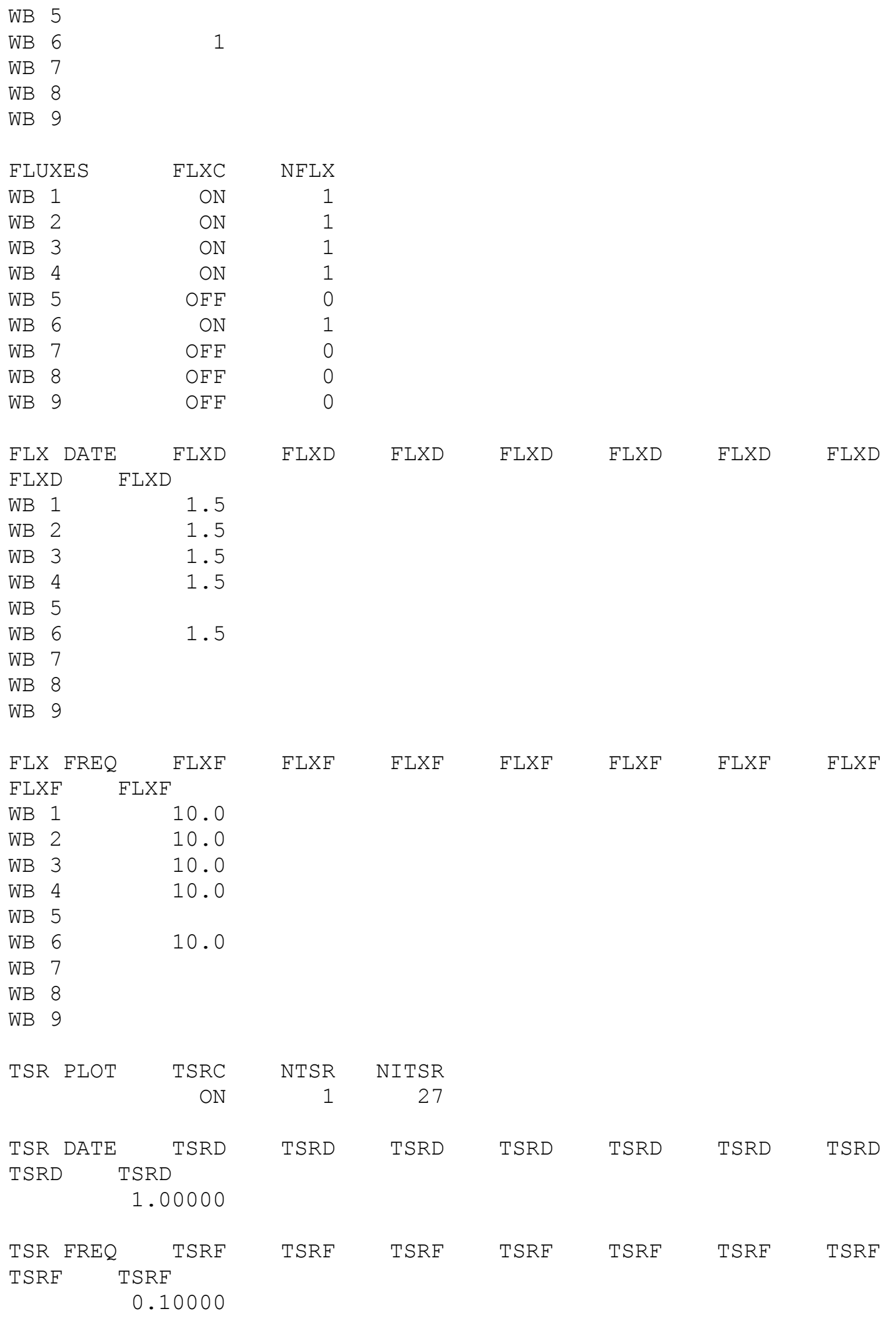




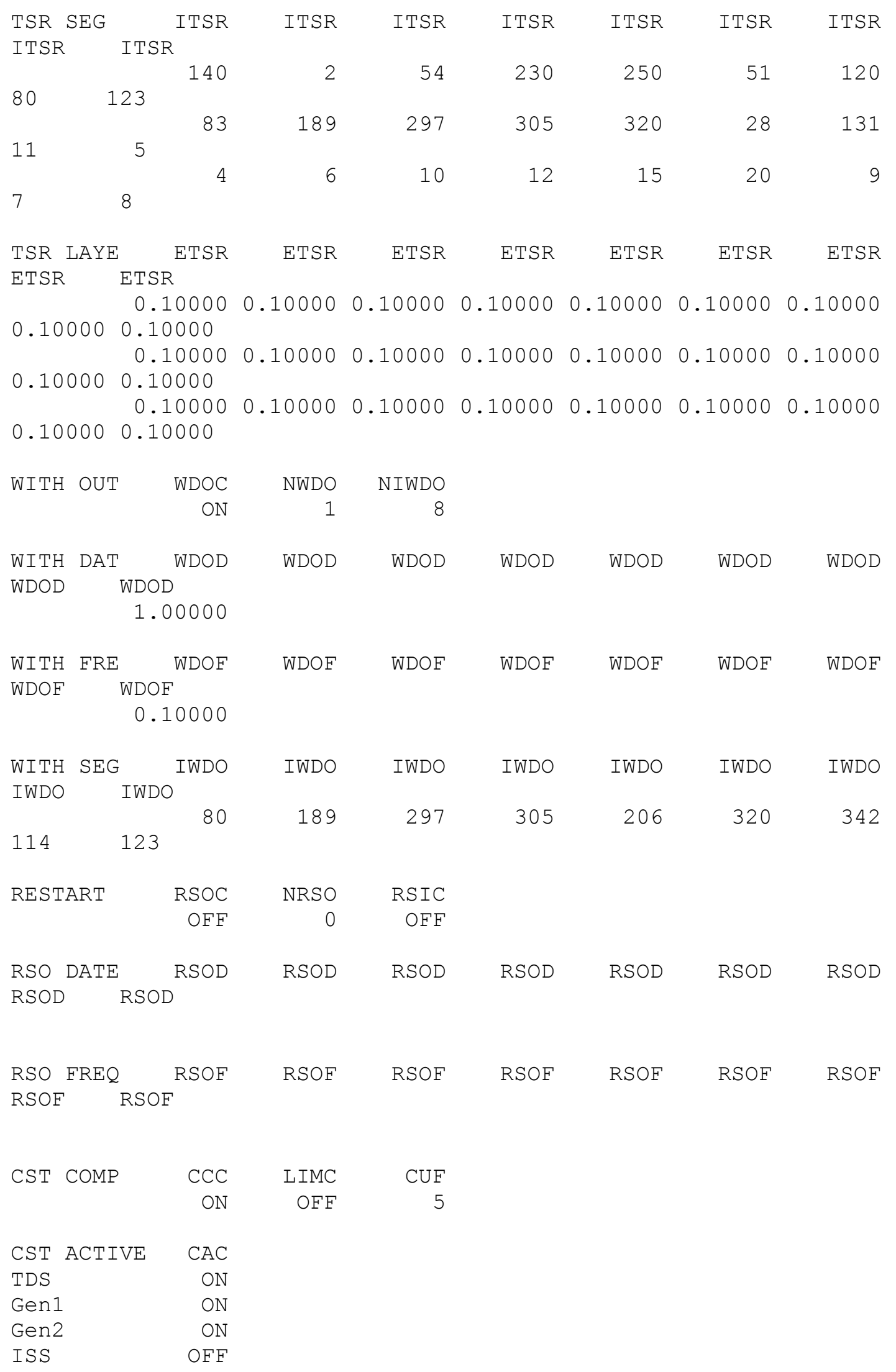




\begin{tabular}{|c|c|c|c|c|c|c|c|c|}
\hline $\mathrm{PO} 4$ & & ON & & & & & & \\
\hline NH 4 & & ON & & & & & & \\
\hline NO3 & & ON & & & & & & \\
\hline DSI & & $\mathrm{OFF}$ & & & & & & \\
\hline PSI & & $\mathrm{OFF}$ & & & & & & \\
\hline $\mathrm{FE}$ & & $\mathrm{OFF}$ & & & & & & \\
\hline LDOM & & ON & & & & & & \\
\hline RDOM & & ON & & & & & & \\
\hline $\mathrm{LPOM}$ & & ON & & & & & & \\
\hline RPOM & & ON & & & & & & \\
\hline BOD1 & & $\mathrm{ON}$ & & & & & & \\
\hline BOD1-P & & $\mathrm{ON}$ & & & & & & \\
\hline $\mathrm{BOD} 1-\mathrm{N}$ & & $\mathrm{ON}$ & & & & & & \\
\hline ALG1 & & ON & & & & & & \\
\hline DO & & ON & & & & & & \\
\hline TIC & & $\mathrm{OFF}$ & & & & & & \\
\hline ALK & & $\mathrm{OFF}$ & & & & & & \\
\hline LDOM-P & & $\mathrm{OFF}$ & & & & & & \\
\hline RDOM-P & & $\mathrm{OFF}$ & & & & & & \\
\hline LPOM-P & & $\mathrm{OFF}$ & & & & & & \\
\hline $\mathrm{RPOM}-\mathrm{P}$ & & $\mathrm{OFF}$ & & & & & & \\
\hline LDOM-N & & $\mathrm{OFF}$ & & & & & & \\
\hline $\mathrm{RDOM}-\mathrm{N}$ & & $\mathrm{OFF}$ & & & & & & \\
\hline LPOM-N & & $\mathrm{OFF}$ & & & & & & \\
\hline $\mathrm{RPOM}-\mathrm{N}$ & & $\mathrm{OFF}$ & & & & & & \\
\hline CST DERI & & DWBC & CDWBC & CDWBC & CDWBC & CDWBC & CDWBC & CDWBC \\
\hline CDWBC & CDWB & & & & & & & \\
\hline $\mathrm{DOC}$ & & $\mathrm{OFF}$ & $\mathrm{OFF}$ & $\mathrm{OFF}$ & $\mathrm{OFF}$ & $\mathrm{OFF}$ & $\mathrm{OFF}$ & $\mathrm{OFF}$ \\
\hline $\mathrm{OFF}$ & $\mathrm{OFF}$ & & & & & & & \\
\hline POC & & $\mathrm{OFF}$ & $\mathrm{OFF}$ & $\mathrm{OFF}$ & $\mathrm{OFF}$ & $\mathrm{OFF}$ & $\mathrm{OFF}$ & $\mathrm{OFF}$ \\
\hline $\mathrm{OFF}$ & $\mathrm{OFF}$ & & & & & & & \\
\hline TOC & & $\mathrm{OFF}$ & $\mathrm{OFF}$ & $\mathrm{OFF}$ & $\mathrm{OFF}$ & $\mathrm{OFF}$ & $\mathrm{OFF}$ & $\mathrm{OFF}$ \\
\hline $\mathrm{OFF}$ & $\mathrm{OFF}$ & & & & & & & \\
\hline DON & & $\mathrm{OFF}$ & $\mathrm{OFF}$ & $\mathrm{OFF}$ & $\mathrm{OFF}$ & $\mathrm{OFF}$ & $\mathrm{OFF}$ & $\mathrm{OFF}$ \\
\hline $\mathrm{OFF}$ & $\mathrm{OFF}$ & & & & & & & \\
\hline PON & & $\mathrm{OFF}$ & $\mathrm{OFF}$ & $\mathrm{OFF}$ & $\mathrm{OFF}$ & $\mathrm{OFF}$ & $\mathrm{OFF}$ & $\mathrm{OFF}$ \\
\hline $\mathrm{OEF}$ & $\mathrm{OFF}$ & & & & & & & \\
\hline TON & & $\mathrm{OFF}$ & $\mathrm{OFF}$ & $\mathrm{OFF}$ & $\mathrm{OFF}$ & $\mathrm{OFF}$ & $\mathrm{OFF}$ & $\mathrm{OFF}$ \\
\hline $\mathrm{OFF}$ & $\mathrm{OFF}$ & & & & & & & \\
\hline TKN & & $\mathrm{OFF}$ & OFF & $\mathrm{OFF}$ & $\mathrm{OFF}$ & $\mathrm{OFF}$ & $\mathrm{OFF}$ & $\mathrm{OFF}$ \\
\hline $\mathrm{OFF}$ & $\mathrm{OFF}$ & & & & & & & \\
\hline TN & & ON & ON & ON & ON & ON & ON & ON \\
\hline $\mathrm{ON}$ & ON & & & & & & & \\
\hline $\mathrm{DOP}$ & & $\mathrm{OFF}$ & $\mathrm{OFF}$ & $\mathrm{OFF}$ & $\mathrm{OFF}$ & $\mathrm{OFF}$ & $\mathrm{OFF}$ & $\mathrm{OFF}$ \\
\hline $\mathrm{OFF}$ & $\mathrm{OFF}$ & & & & & & & \\
\hline $\mathrm{POP}$ & & $\mathrm{OFF}$ & $\mathrm{OFF}$ & $\mathrm{OFF}$ & $\mathrm{OFF}$ & $\mathrm{OFF}$ & $\mathrm{OFF}$ & $\mathrm{OFF}$ \\
\hline $\mathrm{OFF}$ & $\mathrm{OFF}$ & & & & & & & \\
\hline TOP & & $\mathrm{OFF}$ & $\mathrm{OFF}$ & $\mathrm{OFF}$ & $\mathrm{OFF}$ & $\mathrm{OFF}$ & $\mathrm{OFF}$ & $\mathrm{OFF}$ \\
\hline $\mathrm{OFF}$ & $\mathrm{OFF}$ & & & & & & & \\
\hline $\mathrm{TP}$ & & ON & ON & ON & ON & ON & ON & ON \\
\hline ON & ON & & & & & & & \\
\hline
\end{tabular}




\begin{tabular}{|c|c|c|c|c|c|c|c|c|}
\hline $\begin{array}{l}\text { APR } \\
\text { OFF }\end{array}$ & OFF & $\mathrm{OFF}$ & $\mathrm{OFF}$ & $\mathrm{OFF}$ & $\mathrm{OFF}$ & $\mathrm{OFF}$ & $\mathrm{OFF}$ & $\mathrm{OFF}$ \\
\hline CHLA & & $\mathrm{ON}$ & ON & ON & ON & ON & ON & ON \\
\hline ON & ON & & & & & & & \\
\hline АTOT & & OFF & $\mathrm{OFF}$ & $O F F$ & OFF & $\mathrm{OFF}$ & $O F F$ & OFF \\
\hline $\mathrm{OFF}$ & $\mathrm{OFF}$ & & & & & & & \\
\hline$\because \mathrm{DO}$ & & OFF & $\mathrm{OFF}$ & $\mathrm{OFF}$ & $\mathrm{OFF}$ & $\mathrm{OFF}$ & $O F F$ & $\mathrm{OFF}$ \\
\hline OFF & $\mathrm{OFF}$ & & & & & & & \\
\hline TSS & & $\mathrm{OFF}$ & $\mathrm{OFF}$ & $\mathrm{OFF}$ & $\mathrm{OFF}$ & $\mathrm{OFF}$ & $\mathrm{OFF}$ & $\mathrm{OFF}$ \\
\hline $\mathrm{OFF}$ & $O F F$ & & & & & & & \\
\hline TISS & & $\mathrm{OFF}$ & $\mathrm{OFF}$ & $\mathrm{OFF}$ & $\mathrm{OFF}$ & $\mathrm{OFF}$ & $\mathrm{OFF}$ & OFF \\
\hline $\mathrm{OFF}$ & OFF & & & & & & & \\
\hline CBOD & & ON & ON & ON & ON & ON & ON & ON \\
\hline ON & ON & & & & & & & \\
\hline $\mathrm{pH}$ & & $\mathrm{OFF}$ & $\mathrm{OFF}$ & $\mathrm{OFF}$ & $\mathrm{OFF}$ & $\mathrm{OFF}$ & $\mathrm{OFF}$ & $\mathrm{OFF}$ \\
\hline $\mathrm{OFF}$ & OFF & & & & & & & \\
\hline $\mathrm{CO} 2$ & & $\mathrm{OFF}$ & $\mathrm{OFF}$ & $\mathrm{OFF}$ & $\mathrm{OFF}$ & $\mathrm{OFF}$ & $O F F$ & $\mathrm{OFF}$ \\
\hline $\mathrm{OFF}$ & $\mathrm{OFF}$ & & & & & & & \\
\hline $\mathrm{HCO} 3$ & & $\mathrm{OFF}$ & $\mathrm{OFF}$ & $\mathrm{OFF}$ & $\mathrm{OFF}$ & $\mathrm{OFF}$ & $\mathrm{OFF}$ & $\mathrm{OFF}$ \\
\hline $\mathrm{OFF}$ & $\mathrm{OFF}$ & & & & & & & \\
\hline $\mathrm{CO} 3$ & & OFF & $\mathrm{OFF}$ & OFF & OFF & OFF & $O F F$ & $\mathrm{OFF}$ \\
\hline $\mathrm{OFF}$ & $\mathrm{OFF}$ & & & & & & & \\
\hline CST FLUX & I C & WBC & CFWBC & CFWBC & CFWBC & CFWBC & CFWBC & CFWBC \\
\hline CFWBC & CFWB & & & & & & & \\
\hline TISSIN & & $\mathrm{OFF}$ & $\mathrm{OFF}$ & $\mathrm{OFF}$ & $\mathrm{OFF}$ & $\mathrm{OFF}$ & $\mathrm{OFF}$ & $\mathrm{OFF}$ \\
\hline $\mathrm{OFF}$ & $\mathrm{OFF}$ & & & & & & & \\
\hline TISSOUT & & $\mathrm{OFF}$ & $\mathrm{OFF}$ & $\mathrm{OFF}$ & $\mathrm{OFF}$ & $\mathrm{OFF}$ & $\mathrm{OFF}$ & $\mathrm{OFF}$ \\
\hline $\mathrm{OFF}$ & OFF & & & & & & & \\
\hline $\mathrm{PO} 4 \mathrm{AR}$ & & ON & ON & $\mathrm{ON}$ & $\mathrm{ON}$ & ON & ON & $\mathrm{ON}$ \\
\hline ON & ON & & & & & & & \\
\hline $\mathrm{PO} 4 \mathrm{AG}$ & & ON & ON & $\mathrm{ON}$ & $\mathrm{ON}$ & ON & $\mathrm{ON}$ & $\mathrm{ON}$ \\
\hline ON & ON & & & & & & & \\
\hline $\mathrm{PO} 4 \mathrm{AP}$ & & ON & ON & $\mathrm{ON}$ & ON & ON & ON & $\mathrm{ON}$ \\
\hline ON & ON & & & & & & & \\
\hline $\mathrm{PO} 4 \mathrm{ER}$ & & ON & ON & ON & ON & ON & ON & $\mathrm{N}$ \\
\hline ON & ON & & & & & & & \\
\hline $\mathrm{PO} 4 \mathrm{EG}$ & & ON & ON & ON & ON & ON & ON & ON \\
\hline ON & ON & & & & & & & \\
\hline $\mathrm{PO} 4 \mathrm{EP}$ & & ON & $\mathrm{ON}$ & $\mathrm{ON}$ & $\mathrm{ON}$ & ON & ON & $\mathrm{N}$ \\
\hline ON & ON & & & & & & & \\
\hline $\mathrm{PO} 4 \mathrm{POM}$ & & $\mathrm{OFF}$ & $\mathrm{OFF}$ & $\mathrm{OFF}$ & $\mathrm{OFF}$ & $\mathrm{OFF}$ & $\mathrm{OFF}$ & $\mathrm{OFF}$ \\
\hline $\mathrm{OFF}$ & OFF & & & & & & & \\
\hline PO4DOM & & $\mathrm{OFF}$ & $\mathrm{OFF}$ & $\mathrm{OFF}$ & $\mathrm{OFF}$ & $\mathrm{OFF}$ & $\mathrm{OFF}$ & $\mathrm{OFF}$ \\
\hline $\mathrm{OFF}$ & OFF & & & & & & & \\
\hline $\mathrm{PO} 4 \mathrm{OM}$ & & ON & ON & $\mathrm{ON}$ & $\mathrm{ON}$ & ON & ON & 0 \\
\hline ON & ON & & & & & & & \\
\hline PO4SED & & ON & ON & ON & ON & ON & ON & $\mathrm{ON}$ \\
\hline ON & ON & & & & & & & \\
\hline $\mathrm{PO} 4 \mathrm{SOD}$ & & ON & $\mathrm{ON}$ & ON & ON & ON & ON & ON \\
\hline $\mathrm{ON}$ & ON & & & & & & & \\
\hline PO4SET & & $\mathrm{ON}$ & ON & ON & ON & ON & ON & $\mathrm{N}$ \\
\hline ON & ON & & & & & & & \\
\hline
\end{tabular}




\begin{tabular}{|c|c|c|c|c|c|c|c|c|}
\hline NH4NITR & & ON & ON & ON & ON & ON & ON & ON \\
\hline ON & ON & & & & & & & \\
\hline $\mathrm{NH} 4 \mathrm{AR}$ & & ON & ON & ON & ON & ON & ON & ON \\
\hline ON & ON & & & & & & & \\
\hline $\mathrm{NH} 4 \mathrm{AG}$ & & $\mathrm{ON}$ & ON & ON & ON & ON & ON & ON \\
\hline $\mathrm{ON}$ & ON & & & & & & & \\
\hline $\mathrm{NH} 4 \mathrm{AP}$ & & $\mathrm{ON}$ & ON & ON & ON & ON & ON & ON \\
\hline $\mathrm{ON}$ & ON & & & & & & & \\
\hline $\mathrm{NH} 4 \mathrm{ER}$ & & $\mathrm{ON}$ & ON & ON & ON & $\mathrm{ON}$ & ON & $\mathrm{ON}$ \\
\hline $\mathrm{ON}$ & ON & & & & & & & \\
\hline $\mathrm{NH} 4 \mathrm{EG}$ & & $\mathrm{ON}$ & ON & ON & ON & $\mathrm{ON}$ & ON & $\mathrm{ON}$ \\
\hline ON & ON & & & & & & & \\
\hline $\mathrm{NH} 4 \mathrm{EP}$ & & ON & ON & ON & ON & ON & ON & ON \\
\hline $\mathrm{ON}$ & ON & & & & & & & \\
\hline $\mathrm{NH} 4 \mathrm{POM}$ & & OFF & $\mathrm{OFF}$ & OFF & $\mathrm{OFF}$ & $\mathrm{OFF}$ & $\mathrm{OFF}$ & $\mathrm{OFF}$ \\
\hline OFF & OFF & & & & & & & \\
\hline $\mathrm{NH} 4 \mathrm{DOM}$ & & OFF & $O F F$ & $\mathrm{OFF}$ & $\mathrm{OFF}$ & $\mathrm{OFF}$ & $\mathrm{OFF}$ & $O F F$ \\
\hline $\mathrm{OFF}$ & $\mathrm{OFF}$ & & & & & & & \\
\hline $\mathrm{NH} 4 \mathrm{OM}$ & & $\mathrm{ON}$ & ON & ON & ON & ON & ON & ON \\
\hline ON & ON & & & & & & & \\
\hline NH 4SED & & ON & ON & ON & ON & ON & ON & ON \\
\hline ON & ON & & & & & & & \\
\hline $\mathrm{NH} 4 \mathrm{SOD}$ & & ON & ON & ON & ON & ON & ON & $\mathrm{ON}$ \\
\hline ON & ON & & & & & & & \\
\hline NO3DEN & & $\mathrm{ON}$ & ON & ON & ON & $\mathrm{ON}$ & ON & $\mathrm{ON}$ \\
\hline $\mathrm{ON}$ & ON & & & & & & & \\
\hline NO3AG & & ON & ON & ON & ON & $\mathrm{ON}$ & ON & $\mathrm{ON}$ \\
\hline $\mathrm{ON}$ & ON & & & & & & & \\
\hline NO3EG & & ON & ON & ON & ON & ON & ON & $\mathrm{ON}$ \\
\hline $\mathrm{ON}$ & ON & & & & & & & \\
\hline NO3SED & & ON & ON & ON & ON & ON & ON & ON \\
\hline $\mathrm{ON}$ & ON & & & & & & & \\
\hline DSIAG & & $\mathrm{OFF}$ & $\mathrm{OFF}$ & $\mathrm{OFF}$ & $\mathrm{OFF}$ & $\mathrm{OFF}$ & $\mathrm{OFF}$ & $\mathrm{OFF}$ \\
\hline $\mathrm{OFF}$ & $\mathrm{OFF}$ & & & & & & & \\
\hline DSIEG & & OFF & $\mathrm{OFF}$ & $\mathrm{OFF}$ & OFF & $\mathrm{OFF}$ & $\mathrm{OFF}$ & $O F F$ \\
\hline $\mathrm{OFF}$ & $\mathrm{OFF}$ & & & & & & & \\
\hline DSIPIS & & $\mathrm{OFF}$ & $\mathrm{OFF}$ & $\mathrm{OFF}$ & $\mathrm{OFF}$ & $\mathrm{OFF}$ & $\mathrm{OFF}$ & $\mathrm{OFF}$ \\
\hline $\mathrm{OFF}$ & OFF & & & & & & & \\
\hline DSISED & & OFF & $\mathrm{OFF}$ & $\mathrm{OFF}$ & $\mathrm{OFF}$ & $\mathrm{OFF}$ & $\mathrm{OFF}$ & $\mathrm{OFF}$ \\
\hline $\mathrm{OFF}$ & $\mathrm{OFF}$ & & & & & & & \\
\hline DSISOD & & OFF & $\mathrm{OFF}$ & $\mathrm{OFF}$ & $\mathrm{OFF}$ & $\mathrm{OFF}$ & $\mathrm{OFF}$ & $\mathrm{OFF}$ \\
\hline $\mathrm{OFF}$ & $\mathrm{OFF}$ & & & & & & & \\
\hline DSISET & & $\mathrm{OFF}$ & $\mathrm{OFF}$ & $\mathrm{OFF}$ & $\mathrm{OFF}$ & $\mathrm{OFF}$ & $\mathrm{OFF}$ & $\mathrm{OFF}$ \\
\hline $\mathrm{OFF}$ & $\mathrm{OFF}$ & & & & & & & \\
\hline PS IAM & & OFF & $\mathrm{OFF}$ & $\mathrm{OFF}$ & $\mathrm{OFF}$ & $\mathrm{OFF}$ & $\mathrm{OFF}$ & $\mathrm{OFF}$ \\
\hline $\mathrm{OFF}$ & $\mathrm{OFF}$ & & & & & & & \\
\hline PSINET & & OFF & $\mathrm{OFF}$ & $\mathrm{OFF}$ & $\mathrm{OFF}$ & $\mathrm{OFF}$ & $\mathrm{OFF}$ & $\mathrm{OFF}$ \\
\hline $\mathrm{OFF}$ & $\mathrm{OFF}$ & & & & & & & \\
\hline PSIDK & & $\mathrm{OFF}$ & $\mathrm{OFF}$ & $\mathrm{OFF}$ & $\mathrm{OFF}$ & $\mathrm{OFF}$ & $\mathrm{OFF}$ & $\mathrm{OFF}$ \\
\hline $\mathrm{OFF}$ & $\mathrm{OFF}$ & & & & & & & \\
\hline FESET & & OFF & $\mathrm{OFF}$ & $\mathrm{OFF}$ & $\mathrm{OFF}$ & $\mathrm{OFF}$ & $\mathrm{OFF}$ & $\mathrm{OFF}$ \\
\hline $\mathrm{OFF}$ & OFF & & & & & & & \\
\hline
\end{tabular}




\begin{tabular}{|c|c|c|c|c|c|c|c|c|}
\hline FESED & & OFF & $\mathrm{OFF}$ & $\mathrm{OFF}$ & $\mathrm{OFF}$ & $\mathrm{OFF}$ & $\mathrm{OFF}$ & $\mathrm{OFF}$ \\
\hline $\mathrm{OFF}$ & $\mathrm{OFF}$ & & & & & & & \\
\hline LDOMDK & & OFF & $\mathrm{OFF}$ & OFF & OFF & $\mathrm{OFF}$ & OFF & $O F F$ \\
\hline$O F F$ & OFF & & & & & & & \\
\hline LRDOM & & $\mathrm{OFF}$ & $\mathrm{OFF}$ & OFF & $\mathrm{OFF}$ & OFF & $\mathrm{OFF}$ & $O F F$ \\
\hline$O F F$ & OFF & & & & & & & \\
\hline RDOMDK & & $\mathrm{OFF}$ & $\mathrm{OFF}$ & OFF & OFF & OFF & $\mathrm{OFF}$ & $\mathrm{OFF}$ \\
\hline $\mathrm{OFF}$ & $\mathrm{OFF}$ & & & & & & & \\
\hline LDOMAP & & $\mathrm{OFF}$ & $\mathrm{OFF}$ & $\mathrm{OFF}$ & $\mathrm{OFF}$ & $\mathrm{OFF}$ & $\mathrm{OFF}$ & $\mathrm{OFF}$ \\
\hline $\mathrm{OFF}$ & $\mathrm{OFF}$ & & & & & & & \\
\hline LDOMEP & & $\mathrm{OFF}$ & $\mathrm{OFF}$ & $\mathrm{OFF}$ & $\mathrm{OFF}$ & $\mathrm{OFF}$ & $\mathrm{OFF}$ & $\mathrm{OFF}$ \\
\hline $\mathrm{OFF}$ & $\mathrm{OFF}$ & & & & & & & \\
\hline LPOMDK & & $\mathrm{OFF}$ & $\mathrm{OFF}$ & $\mathrm{OFF}$ & OFF & $\mathrm{OFF}$ & $\mathrm{OFF}$ & $\mathrm{OFF}$ \\
\hline $\mathrm{OFF}$ & OFF & & & & & & & \\
\hline LRPOM & & $\mathrm{OFF}$ & OFF & $\mathrm{OFF}$ & $\mathrm{OFF}$ & $\mathrm{OFF}$ & $\mathrm{OFF}$ & $O F F$ \\
\hline $\mathrm{OFF}$ & $\mathrm{OFF}$ & & & & & & & \\
\hline RPOMDK & & OFF & OFF & $\mathrm{OFF}$ & $\mathrm{OFF}$ & $\mathrm{OFF}$ & $\mathrm{OFF}$ & $\mathrm{OFF}$ \\
\hline $\mathrm{OFF}$ & OFF & & & & & & & \\
\hline LPOMAP & & OFF & $\mathrm{OFF}$ & OFF & $\mathrm{OFF}$ & $\mathrm{OFF}$ & $\mathrm{OFF}$ & $O F F$ \\
\hline$O F F$ & $\mathrm{OFF}$ & & & & & & & \\
\hline LPOMEP & & $\mathrm{OFF}$ & $\mathrm{OFF}$ & OFF & OFF & OFF & $\mathrm{OFF}$ & OFF \\
\hline $\mathrm{OFF}$ & $\mathrm{OFF}$ & & & & & & & \\
\hline LPOMSET & & $\mathrm{OFF}$ & $\mathrm{OFF}$ & OFF & $\mathrm{OFF}$ & $\mathrm{OFF}$ & $\mathrm{OFF}$ & $O F F$ \\
\hline $\mathrm{OFF}$ & $\mathrm{OFF}$ & & & & & & & \\
\hline RPOMSET & & $\mathrm{OFF}$ & $\mathrm{OFF}$ & $\mathrm{OFF}$ & $\mathrm{OFF}$ & $\mathrm{OFF}$ & $\mathrm{OFF}$ & $\mathrm{OFF}$ \\
\hline $\mathrm{OFF}$ & OFF & & & & & & & \\
\hline CBODDK & & OFF & $\mathrm{OFF}$ & $\mathrm{OFF}$ & OFF & $\mathrm{OFF}$ & $\mathrm{OFF}$ & $O F F$ \\
\hline $\mathrm{OFF}$ & OFF & & & & & & & \\
\hline DOAP & & $\mathrm{OON}$ & ON & ON & ON & ON & ON & ON \\
\hline ON & $\mathrm{ON}$ & & & & & & & \\
\hline DOAR & & $\mathrm{OON}$ & ON & ON & ON & $\mathrm{ON}$ & ON & $\mathrm{ON}$ \\
\hline $\mathrm{ON}$ & $\mathrm{ON}$ & & & & & & & \\
\hline DOEP & & $\mathrm{OFF}$ & $\mathrm{OFF}$ & $\mathrm{OFF}$ & $\mathrm{OFF}$ & $\mathrm{OFF}$ & $\mathrm{OFF}$ & $\mathrm{OFF}$ \\
\hline $\mathrm{OFF}$ & $\mathrm{OFF}$ & & & & & & & \\
\hline DOER & & OFF & $\mathrm{OFF}$ & $\mathrm{OFF}$ & $\mathrm{OFF}$ & OFF & $\mathrm{OFF}$ & $\mathrm{OFF}$ \\
\hline $\mathrm{OFF}$ & OFF & & & & & & & \\
\hline DOPOM & & $\mathrm{OFF}$ & $\mathrm{OFF}$ & $\mathrm{OFF}$ & $\mathrm{OFF}$ & $\mathrm{OFF}$ & $\mathrm{OFF}$ & $\mathrm{OFF}$ \\
\hline $\mathrm{OFF}$ & $\mathrm{OFF}$ & & & & & & & \\
\hline DODOM & & $\mathrm{OFF}$ & $\mathrm{OFF}$ & $\mathrm{OFF}$ & $\mathrm{OFF}$ & $\mathrm{OFF}$ & OFF & $\mathrm{OFF}$ \\
\hline $\mathrm{OFF}$ & $\mathrm{OFF}$ & & & & & & & \\
\hline DOOM & & $\mathrm{ON}$ & ON & $\mathrm{ON}$ & ON & ON & ON & $\mathrm{ON}$ \\
\hline $\mathrm{ON}$ & ON & & & & & & & \\
\hline DONITR & & ON & ON & ON & ON & ON & ON & ON \\
\hline ON & ON & & & & & & & \\
\hline DOCBOD & & $\mathrm{OFF}$ & $\mathrm{OFF}$ & OFF & OFF & $\mathrm{OFF}$ & $\mathrm{OFF}$ & OFF \\
\hline $\mathrm{OFF}$ & $\mathrm{OFF}$ & & & & & & & \\
\hline DOREAR & & ON & ON & $\mathrm{ON}$ & ON & ON & ON & ON \\
\hline $\mathrm{ON}$ & ON & & & & & & & \\
\hline DOSED & & $\mathrm{ON}$ & ON & ON & ON & ON & ON & $\mathrm{ON}$ \\
\hline $\mathrm{ON}$ & ON & & & & & & & \\
\hline DOSOD & & ON & ON & ON & ON & ON & ON & ON \\
\hline ON & ON & & & & & & & \\
\hline
\end{tabular}




\begin{tabular}{|c|c|c|c|c|c|c|c|}
\hline ICAG & $\mathrm{OFF}$ & OFF & $\mathrm{OFF}$ & $\mathrm{OFF}$ & $\mathrm{OFF}$ & $\mathrm{OFF}$ & $\mathrm{OFF}$ \\
\hline $\mathrm{FF}$ & $\mathrm{OFF}$ & & & & & & \\
\hline ICEG & $\mathrm{OFF}$ & OFF & $\mathrm{OFF}$ & $\mathrm{OFF}$ & $\mathrm{OFF}$ & OFF & $\mathrm{OFF}$ \\
\hline $\mathrm{FF}$ & $\mathrm{OFF}$ & & & & & & \\
\hline DDK & $\mathrm{OFF}$ & $\mathrm{OFF}$ & $\mathrm{OFF}$ & $\mathrm{OFF}$ & OFF & $\mathrm{OFF}$ & $\mathrm{OFF}$ \\
\hline $\mathrm{F}$ & $\mathrm{OFF}$ & & & & & & \\
\hline DAS & $\mathrm{OFF}$ & $\mathrm{OFF}$ & $\mathrm{OFF}$ & $\mathrm{OFF}$ & $\mathrm{OFF}$ & $\mathrm{OFF}$ & $\mathrm{OFF}$ \\
\hline$F$ & $\mathrm{OFF}$ & & & & & & \\
\hline EDLPOM & $\mathrm{OFF}$ & $\mathrm{OFF}$ & $\mathrm{OFF}$ & $\mathrm{OFF}$ & $\mathrm{OFF}$ & OFF & $\mathrm{OFF}$ \\
\hline$F$ & OFF & & & & & & \\
\hline EDSET & $\mathrm{OFF}$ & OFF & $\mathrm{OFF}$ & $\mathrm{OFF}$ & $\mathrm{OFF}$ & OFF & $\mathrm{OFF}$ \\
\hline & $\mathrm{OFF}$ & & & & & & \\
\hline DDK & $\mathrm{OFF}$ & $\mathrm{OFF}$ & $\mathrm{OFF}$ & $\mathrm{OFF}$ & $\mathrm{OFF}$ & $\mathrm{OFF}$ & $\mathrm{OFF}$ \\
\hline & OFF & & & & & & \\
\hline $\mathrm{T}$ ICON & C2 IWB & C2IWB & C2 IWB & C2IWB & C2IWB & C2IWB & $2 \mathrm{IWB}$ \\
\hline IWB & C2IWB & & & & & & \\
\hline $\begin{array}{l}\mathrm{DS} \\
300.00\end{array}$ & $\begin{array}{r}249.000 \\
400.000\end{array}$ & 360.000 & 850.00 & 1040.00 & 400.00 & 1300.00 & 1300.00 \\
\hline $\begin{array}{l}\text { en1 } \\
.00000\end{array}$ & $\begin{array}{l}0.00000 \\
0.00000\end{array}$ & 000 & 0.00000 & 0.00000 & 0.00000 & 0.00000 & 0.00000 \\
\hline $\begin{array}{l}\text { en2 } \\
.00000\end{array}$ & $\begin{array}{l}0.00000 \\
0.00000\end{array}$ & 0000 & 0.00000 & 0.00000 & 0.00000 & 0.00000 & 0.00000 \\
\hline $\begin{array}{l}S S \\
.00000\end{array}$ & $\begin{array}{l}0.00000 \\
0.00000\end{array}$ & 0.00000 & 0.00000 & 0.00000 & 0.00000 & 0.00000 & 0.00000 \\
\hline $\begin{array}{l}04 \\
.33000\end{array}$ & $\begin{array}{l}0.31500 \\
0.33000\end{array}$ & 0.33000 & 0.20000 & 0.20000 & 0.33000 & 0.33000 & 0.33000 \\
\hline 140000 & $\begin{array}{l}0.10000 \\
0.10000\end{array}$ & 0.20000 & 0.20000 & 0.20000 & 0.10000 & 0.10000 & 0.10000 \\
\hline $\begin{array}{l}.3 \\
.20000\end{array}$ & $\begin{array}{l}1.50000 \\
1.20000\end{array}$ & 1.20000 & 1.00000 & 1.00000 & 1.20000 & 1.20000 & 1.20000 \\
\hline $\begin{array}{l}I \\
00000\end{array}$ & $\begin{array}{l}0.0 \\
0.00\end{array}$ & 0.00000 & 0.00000 & 0.00000 & 0.00000 & 0.00000 & 0.00000 \\
\hline $\begin{array}{l}\text { SI } \\
.00000\end{array}$ & $\begin{array}{r}0.0 \\
0.00\end{array}$ & 0.00000 & 0.00000 & 0.00000 & 0.00000 & 0.00000 & 0.00000 \\
\hline 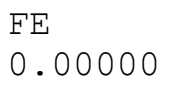 & $\begin{array}{r}0.0 \\
0.00\end{array}$ & 000 & 0.00000 & 0.00000 & 0.00000 & 0.00000 & 0.00000 \\
\hline $\begin{array}{l}\text { OOM } \\
.00000\end{array}$ & $\begin{array}{r}0.0 \\
0.00\end{array}$ & 0.00000 & 0.00000 & 0.00000 & 0.00000 & 0.00000 & 0.00000 \\
\hline $\mathrm{M}$ & $\begin{array}{r}0.0 \\
0.00\end{array}$ & 0.00000 & 0.00000 & 0.00000 & 0.00000 & 0.00000 & 0.00000 \\
\hline $\mathrm{POM}$ & $\begin{array}{r}0.0 \\
0.00\end{array}$ & 0000 & 0.00000 & 0.00000 & 0.00000 & 0.00000 & 0.00000 \\
\hline $\begin{array}{l}\mathrm{POM} \\
.00000\end{array}$ & $\begin{array}{l}0.00000 \\
0.00000\end{array}$ & 0.00000 & 00000 & 0.00000 & 0.00000 & 0.00000 & 0.00000 \\
\hline $\begin{array}{l}\text { 3OD1 } \\
.85000\end{array}$ & $\begin{array}{l}6.86000 \\
6.85000\end{array}$ & 5000 & 80000 & 8000 & 85000 & 5000 & 35000 \\
\hline $\begin{array}{l}\text { 30D1-P } \\
0.06800\end{array}$ & $\begin{array}{l}0.06900 \\
0.06800\end{array}$ & 6800 & 000 & 5000 & 6800 & 6800 & 300 \\
\hline $\begin{array}{l}30 \mathrm{OD} 1-\mathrm{N} \\
.54800\end{array}$ & $\begin{array}{l}0.55000 \\
0.54800\end{array}$ & 4800 & 0600 & 0.40600 & 0.54800 & 0.54800 & 0.54800 \\
\hline GG1 & $\begin{array}{l}0.05000 \\
0.05000\end{array}$ & 5000 & 5000 & 0.05000 & 0.05000 & 0.05000 & 0.0 \\
\hline
\end{tabular}




\begin{tabular}{|c|c|c|c|c|c|c|c|}
\hline DO & 11.20000 & 10.7600 & 10.7300 & 10.7300 & 10.7600 & 10.7600 & 10.76 \\
\hline 0.7600 & 10.7600 & & & & & & \\
\hline $\begin{array}{l}\text { IC } \\
.00000\end{array}$ & $\begin{array}{l}0.00000 \\
0.00000\end{array}$ & 0.00000 & 0.00000 & 0.00000 & 0.00000 & 0.00000 & 0.00000 \\
\hline $\mathrm{LK}$ & 0.00000 & 0.00000 & 0.00000 & 0.00000 & 0.00000 & 0.00000 & 0.00000 \\
\hline .00000 & 0.00000 & & & & & & \\
\hline $\mathrm{DOM}-\mathrm{P}$ & 0.00000 & 0.00000 & 0.00000 & 0.00000 & 0.00000 & 0.00000 & 0.00000 \\
\hline DOM-P & 0.00000 & 0.00000 & 0.00000 & 0.00000 & 0.00000 & 0.00000 & 0.00000 \\
\hline .00000 & 0.00000 & & & . & & & \\
\hline $\mathrm{POM}-\mathrm{P}$ & 0.00000 & 0.00000 & 0.00000 & 0.00000 & 0.00000 & 0.00000 & 0.00000 \\
\hline .00000 & 0.00000 & & & & & & \\
\hline $\mathrm{POM}-\mathrm{P}$ & 0.00000 & 0.00000 & 0.00000 & 0.00000 & 0.00000 & 0.00000 & 0.00000 \\
\hline .00000 & 0.00000 & & & & & & \\
\hline $\mathrm{DOM}-\mathrm{N}$ & 0.00000 & 0.00000 & 0.00000 & 0.00000 & 0.00000 & 0.00000 & 0.00000 \\
\hline .00000 & 0.00000 & & & & & & \\
\hline $\mathrm{DOM}-\mathrm{N}$ & 0.00000 & 0.00000 & 0.00000 & 0.00000 & 0.00000 & 0.00000 & 0.00000 \\
\hline .00000 & 0.00000 & & & & & & \\
\hline $\mathrm{POM}-\mathrm{N}$ & 0.00000 & 0.00000 & 0.00000 & 0.00000 & 0.00000 & 0.00000 & 0.00000 \\
\hline .00000 & 0.00000 & & & & & & \\
\hline $\mathrm{POM}-\mathrm{N}$ & 0.00000 & 0.00000 & 0.00000 & 0.00000 & 0.00000 & 0.00000 & 0.00000 \\
\hline .00000 & 0.00000 & & & & & & \\
\hline ST PRIN & J CPRWBC & CPRWBC & CPRWBC & CPRWBC & CPRWBC & CPRWBC & CPRWBC \\
\hline PRWBC & CPRWBC & & & & & & \\
\hline DS & ON & ON & ON & ON & ON & ON & ON \\
\hline $\mathrm{N}$ & ON & & & & & & \\
\hline en1 & $\mathrm{ON}$ & ON & $\mathrm{ON}$ & ON & ON & ON & ON \\
\hline $\mathrm{N}$ & ON & & & & & & \\
\hline en2 & $\mathrm{ON}$ & ON & ON & ON & ON & ON & ON \\
\hline $\mathrm{N}$ & ON & & & & & & \\
\hline SS & OFF & OFF & $\mathrm{OFF}$ & $\mathrm{OFF}$ & $\mathrm{OFF}$ & $\mathrm{OFF}$ & $\mathrm{OFF}$ \\
\hline $\mathrm{FF}$ & OFF & & & & & & \\
\hline 04 & $\mathrm{ON}$ & ON & $\mathrm{ON}$ & ON & ON & ON & ON \\
\hline $\mathrm{N}$ & ON & & & & & & \\
\hline 4 & ON & ON & ON & ON & ON & ON & ON \\
\hline $\mathrm{N}$ & ON & & & & & & \\
\hline 03 & $\mathrm{ON}$ & ON & ON & ON & ON & ON & ON \\
\hline $\mathrm{DN}$ & ON & & & & & & \\
\hline DSI & $\mathrm{OFF}$ & OFF & $\mathrm{OFF}$ & $\mathrm{OFF}$ & $\mathrm{OFF}$ & $\mathrm{OFF}$ & $\mathrm{OFF}$ \\
\hline $\mathrm{OFF}$ & $\mathrm{OFF}$ & & & & & & \\
\hline PSI & $\mathrm{OFF}$ & $\mathrm{OFF}$ & $\mathrm{OFF}$ & $\mathrm{OFF}$ & $\mathrm{OFF}$ & $\mathrm{OFF}$ & $\mathrm{OFF}$ \\
\hline $\mathrm{OFF}$ & OFF & & & & & & \\
\hline $\mathrm{FE}$ & $\mathrm{OFF}$ & $\mathrm{OFF}$ & $\mathrm{OFF}$ & $\mathrm{OFF}$ & $\mathrm{OFF}$ & $\mathrm{OFF}$ & $\mathrm{OFF}$ \\
\hline $\mathrm{OFF}$ & $\mathrm{OFF}$ & & & & & & \\
\hline LDOM & ON & ON & ON & ON & $\mathrm{ON}$ & ON & $\mathrm{ON}$ \\
\hline ON & ON & & & & & & \\
\hline RDOM & $\mathrm{ON}$ & ON & ON & ON & ON & ON & $\mathrm{ON}$ \\
\hline ON & ON & & & & & & \\
\hline LPOM & ON & ON & ON & ON & ON & ON & ON \\
\hline ON & ON & & & & & & \\
\hline RPOM & ON & ON & ON & ON & ON & ON & ON \\
\hline & Ol & & & & & & \\
\hline
\end{tabular}




\begin{tabular}{|c|c|c|c|c|c|c|c|c|}
\hline $\begin{array}{l}\text { BOD1 } \\
\text { ON }\end{array}$ & ON & ON & $\mathrm{ON}$ & ON & ON & $\mathrm{ON}$ & ON & $\mathrm{ON}$ \\
\hline BOD1 - P & & $\mathrm{ON}$ & $\mathrm{ON}$ & ON & ON & ON & ON & ON \\
\hline ON & $\mathrm{ON}$ & & & & & & & \\
\hline BOD1-N & & $\mathrm{ON}$ & $\mathrm{ON}$ & ON & ON & ON & ON & ON \\
\hline ON & ON & & & & & & & \\
\hline ALG1 & & ON & $\mathrm{ON}$ & ON & ON & ON & ON & 01 \\
\hline ON & ON & & & & & & & \\
\hline DO & & $\mathrm{ON}$ & $\mathrm{ON}$ & ON & ON & $\mathrm{ON}$ & $\mathrm{ON}$ & 0 \\
\hline ON & ON & & & & & & & \\
\hline TIC & & $\mathrm{OFF}$ & $\mathrm{OFF}$ & $\mathrm{OFF}$ & $\mathrm{OFF}$ & $\mathrm{OFF}$ & $\mathrm{OFF}$ & $\mathrm{OFF}$ \\
\hline $\mathrm{OFF}$ & $\mathrm{OFF}$ & & & & & & & \\
\hline ALK & & $\mathrm{OFF}$ & $\mathrm{OFF}$ & $\mathrm{OFF}$ & $\mathrm{OFF}$ & $\mathrm{OFF}$ & $\mathrm{OFF}$ & $\mathrm{OFF}$ \\
\hline $\mathrm{OFF}$ & $\mathrm{OFF}$ & & & & & & & \\
\hline LDOM-P & & $\mathrm{OFF}$ & $\mathrm{OFF}$ & $\mathrm{OFF}$ & $\mathrm{OFF}$ & $\mathrm{OFF}$ & $\mathrm{OFF}$ & $\mathrm{OFF}$ \\
\hline $\mathrm{OFF}$ & $\mathrm{OFF}$ & & & & & & & \\
\hline RDOM-P & & $\mathrm{OFF}$ & $\mathrm{OFF}$ & $\mathrm{OFF}$ & $\mathrm{OFF}$ & $\mathrm{OFF}$ & $\mathrm{OFF}$ & $\mathrm{OFF}$ \\
\hline $\mathrm{OFF}$ & $\mathrm{OFF}$ & & & & & & & \\
\hline LPOM-P & & $\mathrm{OFF}$ & $\mathrm{OFF}$ & $\mathrm{OFF}$ & $\mathrm{OFF}$ & $\mathrm{OFF}$ & $\mathrm{OFF}$ & $\mathrm{OFF}$ \\
\hline $\mathrm{OFF}$ & $\mathrm{OFF}$ & & & & & & & \\
\hline $\mathrm{RPOM}-\mathrm{P}$ & & $\mathrm{OFF}$ & $\mathrm{OFF}$ & $\mathrm{OFF}$ & $\mathrm{OFF}$ & $\mathrm{OFF}$ & $\mathrm{OFF}$ & $\mathrm{OFF}$ \\
\hline $\mathrm{OFF}$ & $\mathrm{OFF}$ & & & & & & & \\
\hline LDOM-N & & $\mathrm{OFF}$ & $\mathrm{OFF}$ & $\mathrm{OFF}$ & $\mathrm{OFF}$ & $\mathrm{OFF}$ & $\mathrm{OFF}$ & $\mathrm{OFF}$ \\
\hline $\mathrm{OFF}$ & $\mathrm{OFF}$ & & & & & & & \\
\hline $\mathrm{RDOM}-\mathrm{N}$ & & $\mathrm{OFF}$ & $\mathrm{OFF}$ & $\mathrm{OFF}$ & $\mathrm{OFF}$ & $\mathrm{OFF}$ & $\mathrm{OFF}$ & $\mathrm{OFF}$ \\
\hline $\mathrm{OFF}$ & OFF & & & & & & & \\
\hline LPOM-N & & $\mathrm{OFF}$ & $\mathrm{OFF}$ & $\mathrm{OFF}$ & $\mathrm{OFF}$ & $\mathrm{OFF}$ & $\mathrm{OFF}$ & $\mathrm{OFF}$ \\
\hline $\mathrm{OFF}$ & $\mathrm{OFF}$ & & & & & & & \\
\hline $\mathrm{RPOM}-\mathrm{N}$ & & $\mathrm{OFF}$ & $\mathrm{OFF}$ & $\mathrm{OFF}$ & $\mathrm{OFF}$ & $\mathrm{OFF}$ & $\mathrm{OFF}$ & $\mathrm{OFF}$ \\
\hline $\mathrm{OFF}$ & $O F F$ & & & & & & & \\
\hline CIN CON & $C I$ & NBRC & CINBRC & CINBRC & CINBRC & CINBRC & CINBRC & CINBRC \\
\hline CINBRC & CINB. & & & & & & & \\
\hline TDS & & ON & $\mathrm{ON}$ & ON & ON & ON & ON & 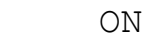 \\
\hline ON & ON & & & & & & & \\
\hline Gen1 & & $\mathrm{ON}$ & ON & $\mathrm{ON}$ & ON & ON & ON & 0 \\
\hline ON & $\mathrm{ON}$ & & & & & & & \\
\hline Gen2 & & $\mathrm{OFF}$ & $\mathrm{OFF}$ & $\mathrm{OFF}$ & $\mathrm{OFF}$ & $\mathrm{OFF}$ & $\mathrm{OFF}$ & $\mathrm{OFF}$ \\
\hline $\mathrm{OFF}$ & OFF & & & & & & & \\
\hline ISS & & $\mathrm{OFF}$ & $\mathrm{OFF}$ & $\mathrm{OFF}$ & $\mathrm{OFF}$ & $\mathrm{OFF}$ & $\mathrm{OFF}$ & $\mathrm{OFF}$ \\
\hline $\mathrm{OFF}$ & OFF & & & & & & & \\
\hline $\mathrm{PO} 4$ & & ON & $\mathrm{ON}$ & ON & ON & ON & ON & $\mathrm{ON}$ \\
\hline ON & $\mathrm{ON}$ & & & & & & & \\
\hline NH 4 & & ON & ON & ON & $\mathrm{ON}$ & ON & ON & Ol \\
\hline ON & ON & & & & & & & \\
\hline NO3 & & ON & ON & ON & $\mathrm{ON}$ & ON & ON & OI \\
\hline ON & ON & & & & & & & \\
\hline DSI & & $\mathrm{OFF}$ & $\mathrm{OFF}$ & $\mathrm{OFF}$ & $\mathrm{OFF}$ & $\mathrm{OFF}$ & $\mathrm{OFF}$ & $\mathrm{OFF}$ \\
\hline $\mathrm{OFF}$ & $\mathrm{OFF}$ & & & & & & & \\
\hline PSI & & $\mathrm{OFF}$ & $\mathrm{OFF}$ & $\mathrm{OFF}$ & $\mathrm{OFF}$ & $\mathrm{OFF}$ & $\mathrm{OFF}$ & $\mathrm{OFF}$ \\
\hline $\mathrm{OFF}$ & $\mathrm{OFF}$ & & & & & & & \\
\hline $\mathrm{FE}$ & & $\mathrm{OFF}$ & OFF & $\mathrm{OFF}$ & $\mathrm{OFF}$ & $\mathrm{OFF}$ & $\mathrm{OFF}$ & $\mathrm{OFF}$ \\
\hline $\mathrm{OFF}$ & $\mathrm{OFF}$ & & & & & & & \\
\hline
\end{tabular}




\begin{tabular}{|c|c|c|c|c|c|c|c|c|}
\hline $\begin{array}{l}\text { LDOM } \\
\text { ON }\end{array}$ & ON & ON & ON & $\mathrm{ON}$ & ON & ON & ON & ON \\
\hline RDOM & & ON & ON & ON & ON & ON & ON & ON \\
\hline ON & $\mathrm{ON}$ & & & & & & & \\
\hline LPOM & & ON & ON & $\mathrm{ON}$ & ON & ON & ON & ON \\
\hline ON & $\mathrm{ON}$ & & & & & & & \\
\hline $\mathrm{RPOM}$ & & ON & ON & $\mathrm{ON}$ & ON & ON & ON & ON \\
\hline ON & $\mathrm{ON}$ & & & & & & & \\
\hline BOD1 & & ON & ON & $\mathrm{ON}$ & ON & ON & ON & ON \\
\hline ON & $\mathrm{ON}$ & & & & & & & \\
\hline BOD1-P & & ON & ON & $\mathrm{ON}$ & ON & ON & ON & ON \\
\hline ON & ON & & & & & & & \\
\hline $\mathrm{BOD} 1-\mathrm{N}$ & & ON & ON & $\mathrm{ON}$ & ON & ON & ON & ON \\
\hline ON & ON & & & & & & & \\
\hline ALG1 & & ON & $\mathrm{ON}$ & $\mathrm{ON}$ & ON & ON & ON & ON \\
\hline ON & ON & & & & & & & \\
\hline DO & & ON & ON & ON & ON & ON & ON & ON \\
\hline ON & ON & & & & & & & \\
\hline TIC & & $\mathrm{OFF}$ & $\mathrm{OFF}$ & OFF & $\mathrm{OFF}$ & $O F F$ & $\mathrm{OFF}$ & $\mathrm{OFF}$ \\
\hline $\mathrm{OFF}$ & $\mathrm{OFF}$ & & & & & & & \\
\hline ALK & & $\mathrm{OFF}$ & $\mathrm{OFF}$ & $\mathrm{OFF}$ & OFF & OFF & OFF & $\mathrm{OFF}$ \\
\hline $\mathrm{OFF}$ & $\mathrm{OFF}$ & & & & & & & \\
\hline LDOM-P & & $\mathrm{OFF}$ & $\mathrm{OFF}$ & $\mathrm{OFF}$ & $\mathrm{OFF}$ & OFF & $\mathrm{OFF}$ & $\mathrm{OFE}$ \\
\hline $\mathrm{OFF}$ & $\mathrm{OFF}$ & & & & & & & \\
\hline $\mathrm{RDOM}-\mathrm{P}$ & & $\mathrm{OFF}$ & $\mathrm{OFF}$ & $\mathrm{OFF}$ & $\mathrm{OFF}$ & $\mathrm{OFF}$ & $\mathrm{OFF}$ & $\mathrm{OFE}$ \\
\hline $\mathrm{OFF}$ & $\mathrm{OFF}$ & & & & & & & \\
\hline $\mathrm{LPOM}-\mathrm{P}$ & & $\mathrm{OFF}$ & $\mathrm{OFF}$ & $\mathrm{OFF}$ & $\mathrm{OFF}$ & $\mathrm{OFF}$ & $\mathrm{OFF}$ & $\mathrm{OFF}$ \\
\hline $\mathrm{OFF}$ & $\mathrm{OFF}$ & & & & & & & \\
\hline $\mathrm{RPOM}-\mathrm{P}$ & & $\mathrm{OFF}$ & $\mathrm{OFF}$ & $\mathrm{OFF}$ & $\mathrm{OFF}$ & $\mathrm{OFF}$ & $\mathrm{OFF}$ & $\mathrm{OFE}$ \\
\hline $\mathrm{OFF}$ & $\mathrm{OFF}$ & & & & & & & \\
\hline LDOM-N & & $\mathrm{OFF}$ & $\mathrm{OFF}$ & $\mathrm{OFF}$ & $\mathrm{OFF}$ & $\mathrm{OFF}$ & $\mathrm{OFF}$ & $\mathrm{OFE}$ \\
\hline $\mathrm{OFF}$ & $\mathrm{OFF}$ & & & & & & & \\
\hline $\mathrm{RDOM}-\mathrm{N}$ & & $\mathrm{OFF}$ & $\mathrm{OFF}$ & $\mathrm{OFF}$ & $\mathrm{OFF}$ & $\mathrm{OFF}$ & $\mathrm{OFF}$ & $\mathrm{OFE}$ \\
\hline $\mathrm{OFF}$ & $\mathrm{OFF}$ & & & & & & & \\
\hline LPOM-N & & $\mathrm{OFF}$ & $\mathrm{OFF}$ & $\mathrm{OFF}$ & $\mathrm{OFF}$ & $\mathrm{OFF}$ & $\mathrm{OFF}$ & $\mathrm{OFE}$ \\
\hline $\mathrm{OFF}$ & $\mathrm{OFF}$ & & & & & & & \\
\hline $\mathrm{RPOM}-\mathrm{N}$ & & $\mathrm{OFF}$ & $\mathrm{OFF}$ & $\mathrm{OFF}$ & $\mathrm{OFF}$ & OFF & OFF & $\mathrm{OFE}$ \\
\hline $\mathrm{OFF}$ & $\mathrm{OFF}$ & & & & & & & \\
\hline CTR CON & $\mathrm{CT}$ & $\mathrm{RTRC}$ & CTRTRC & CTRTRC & CTRTRC & CTRTRC & CTRTRC & CTRTRC \\
\hline CTRTRC & CTRT & & & & & & & \\
\hline TDS & & ON & ON & ON & ON & ON & ON & ON \\
\hline $\mathrm{OFF}$ & $\mathrm{OFF}$ & & & & & & & \\
\hline Gen1 & & ON & $\mathrm{ON}$ & ON & ON & ON & ON & $\mathrm{ON}$ \\
\hline $\mathrm{OFF}$ & $\mathrm{OFF}$ & & & & & & & \\
\hline Gen2 & & $\mathrm{OFF}$ & $\mathrm{OFF}$ & $\mathrm{OFF}$ & $\mathrm{OFF}$ & OFF & OFF & $\mathrm{OFE}$ \\
\hline $\mathrm{OFF}$ & $\mathrm{OFF}$ & & & & & & & \\
\hline ISS & & $\mathrm{OFF}$ & $\mathrm{OFF}$ & $\mathrm{OFF}$ & $\mathrm{OFF}$ & $\mathrm{OFF}$ & $\mathrm{OFF}$ & $\mathrm{OFE}$ \\
\hline $\mathrm{OFF}$ & $\mathrm{OFF}$ & & & & & & & \\
\hline $\mathrm{PO} 4$ & & ON & ON & ON & ON & ON & ON & ON \\
\hline $\mathrm{OFF}$ & $\mathrm{OFF}$ & & & & & & & \\
\hline NH 4 & & ON & ON & ON & $\mathrm{ON}$ & ON & ON & U \\
\hline $\mathrm{OFF}$ & $\mathrm{OFF}$ & & & & & & & \\
\hline
\end{tabular}




\begin{tabular}{|c|c|c|c|c|c|c|c|c|}
\hline $\mathrm{NO} 3$ & & ON & ON & ON & ON & ON & ON & $\mathrm{ON}$ \\
\hline OFF & $\mathrm{OFF}$ & & & & & & & \\
\hline DSI & & OFF & OFF & $\mathrm{OFF}$ & $\mathrm{OFF}$ & $\mathrm{OFF}$ & $\mathrm{OFF}$ & $\mathrm{OFF}$ \\
\hline $\mathrm{OFF}$ & OFF & & & & & & & \\
\hline PSI & & OFF & $\mathrm{OFF}$ & $\mathrm{OFF}$ & $\mathrm{OFF}$ & $\mathrm{OFF}$ & $\mathrm{OFF}$ & $\mathrm{OFF}$ \\
\hline $\mathrm{OFF}$ & $\mathrm{OFF}$ & & & & & & & \\
\hline $\mathrm{FE}$ & & $\mathrm{OFF}$ & $\mathrm{OFF}$ & $\mathrm{OFF}$ & $\mathrm{OFF}$ & $\mathrm{OFF}$ & $\mathrm{OFF}$ & $\mathrm{OFF}$ \\
\hline $\mathrm{OFF}$ & $\mathrm{OFF}$ & & & & & & & \\
\hline LDOM & & ON & ON & ON & ON & ON & ON & ON \\
\hline OFF & $\mathrm{OFF}$ & & & & & & & \\
\hline $\mathrm{RDOM}$ & & $\mathrm{ON}$ & ON & ON & ON & ON & ON & ON \\
\hline OFF & $\mathrm{OFF}$ & & & & & & & \\
\hline LPOM & & $\mathrm{ON}$ & ON & ON & ON & ON & ON & ON \\
\hline OFF & $\mathrm{OFF}$ & & & & & & & \\
\hline $\mathrm{RPOM}$ & & ON & ON & ON & ON & ON & ON & $\mathrm{ON}$ \\
\hline $\mathrm{OFF}$ & OFF & & & & & & & \\
\hline BOD1 & & ON & ON & ON & ON & ON & ON & ON \\
\hline $\mathrm{OFF}$ & $\mathrm{OFF}$ & & & & & & & \\
\hline $\mathrm{BOD} 1-\mathrm{P}$ & & ON & ON & ON & ON & ON & ON & ON \\
\hline $\mathrm{OFF}$ & $\mathrm{OFF}$ & & & & & & & \\
\hline $\mathrm{BOD} 1-\mathrm{N}$ & & ON & ON & ON & ON & ON & ON & ON \\
\hline OFF & $\mathrm{OFF}$ & & & & & & & \\
\hline ALG1 & & $\mathrm{ON}$ & ON & ON & ON & ON & ON & ON \\
\hline OFF & $\mathrm{OFF}$ & & & & & & & \\
\hline DO & & $\mathrm{ON}$ & ON & ON & ON & ON & ON & ON \\
\hline $\mathrm{OFF}$ & OFF & & & & & & & \\
\hline TIC & & OFF & $\mathrm{OFF}$ & $\mathrm{OFF}$ & $\mathrm{OFF}$ & $\mathrm{OFF}$ & $\mathrm{OFF}$ & $\mathrm{OFF}$ \\
\hline $\mathrm{OFF}$ & $\mathrm{OFF}$ & & & & & & & \\
\hline ALK & & $\mathrm{OFF}$ & $\mathrm{OFF}$ & $\mathrm{OFF}$ & $\mathrm{OFF}$ & $\mathrm{OFF}$ & $\mathrm{OFF}$ & $\mathrm{OFF}$ \\
\hline $\mathrm{OFF}$ & OFF & & & & & & & \\
\hline $\mathrm{LDOM}-\mathrm{P}$ & & $\mathrm{OFF}$ & $\mathrm{OFF}$ & $\mathrm{OFF}$ & $\mathrm{OFF}$ & $\mathrm{OFF}$ & $\mathrm{OFF}$ & $\mathrm{OFF}$ \\
\hline $\mathrm{OFF}$ & $\mathrm{OFF}$ & & & & & & & \\
\hline $\mathrm{RDOM}-\mathrm{P}$ & & $\mathrm{OFF}$ & $\mathrm{OFF}$ & $\mathrm{OFF}$ & $\mathrm{OFF}$ & $\mathrm{OFF}$ & $\mathrm{OFF}$ & $\mathrm{OFF}$ \\
\hline $\mathrm{OFF}$ & $\mathrm{OFF}$ & & & & & & & \\
\hline LPOM-P & & $\mathrm{OFF}$ & $\mathrm{OFF}$ & $\mathrm{OFF}$ & $\mathrm{OFF}$ & $\mathrm{OFF}$ & $\mathrm{OFF}$ & $\mathrm{OFF}$ \\
\hline $\mathrm{OFF}$ & OFF & & & & & & & \\
\hline $\mathrm{RPOM}-\mathrm{P}$ & & $\mathrm{OFF}$ & $\mathrm{OFF}$ & $\mathrm{OFF}$ & $\mathrm{OFF}$ & $\mathrm{OFF}$ & $\mathrm{OFF}$ & $\mathrm{OFF}$ \\
\hline $\mathrm{OFF}$ & $\mathrm{OFF}$ & & & & & & & \\
\hline $\mathrm{LDOM}-\mathrm{N}$ & & $\mathrm{OFF}$ & OFF & OFF & $\mathrm{OFF}$ & $\mathrm{OFF}$ & $\mathrm{OFF}$ & $\mathrm{OFF}$ \\
\hline $\mathrm{OFF}$ & $\mathrm{OFF}$ & & & & & & & \\
\hline $\mathrm{RDOM}-\mathrm{N}$ & & OFF & $\mathrm{OFF}$ & OFF & OFF & $\mathrm{OFF}$ & $\mathrm{OFF}$ & $\mathrm{OFF}$ \\
\hline $\mathrm{OFF}$ & $\mathrm{OFF}$ & & & & & & & \\
\hline $\mathrm{LPOM}-\mathrm{N}$ & & OFF & $\mathrm{OFF}$ & $\mathrm{OFF}$ & $\mathrm{OFF}$ & $\mathrm{OFF}$ & $\mathrm{OFF}$ & $\mathrm{OFF}$ \\
\hline $\mathrm{OFF}$ & $\mathrm{OFF}$ & & & & & & & \\
\hline $\mathrm{RPOM}-\mathrm{N}$ & & OFF & OFF & OFF & OFF & $\mathrm{OFF}$ & $\mathrm{OFF}$ & $\mathrm{OFF}$ \\
\hline $\mathrm{OFF}$ & $\mathrm{OFF}$ & & & & & & & \\
\hline $\mathrm{CDT} \quad \mathrm{CON}$ & $C D^{\prime}$ & TBRC & CDTBRC & CDTBRC & CDTBRC & CDTBRC & CDTBRC & CDTBRC \\
\hline CDTBRC & CDTB & & & & & & & \\
\hline TDS & & ON & $\mathrm{ON}$ & ON & ON & $\mathrm{OFF}$ & $\mathrm{OFF}$ & $\mathrm{OFF}$ \\
\hline $\mathrm{OFF}$ & $\mathrm{OFF}$ & & & & & & & \\
\hline Gen1 & & ON & ON & ON & ON & $\mathrm{OFF}$ & $\mathrm{OFF}$ & $\mathrm{OFF}$ \\
\hline $\mathrm{OFF}$ & $\mathrm{OFF}$ & & & & & & & \\
\hline
\end{tabular}




\begin{tabular}{|c|c|c|c|c|c|c|c|c|}
\hline $\begin{array}{l}\text { Gen2 } \\
\text { OFF }\end{array}$ & OFF & $\mathrm{OFF}$ & $\mathrm{OFF}$ & $\mathrm{OFF}$ & $\mathrm{OFF}$ & $\mathrm{OFF}$ & $\mathrm{OFF}$ & $\mathrm{OFF}$ \\
\hline ISS & & $\mathrm{OFF}$ & $\mathrm{OFF}$ & $\mathrm{OFF}$ & OFF & $\mathrm{OFF}$ & $\mathrm{OFF}$ & $\mathrm{OFF}$ \\
\hline OFF & $\mathrm{OFF}$ & & & & & & & \\
\hline $\mathrm{PO} 4$ & & ON & ON & ON & ON & $\mathrm{OFF}$ & $\mathrm{OFF}$ & $\mathrm{OFF}$ \\
\hline OFF & $\mathrm{OFF}$ & & & & & & & \\
\hline NH 4 & & ON & ON & ON & ON & $\mathrm{OFF}$ & $\mathrm{OFF}$ & $\mathrm{OFF}$ \\
\hline $\mathrm{OFF}$ & OFF & & & & & & & \\
\hline NO3 & & ON & ON & ON & ON & $\mathrm{OFF}$ & $\mathrm{OFF}$ & $\mathrm{OFF}$ \\
\hline $\mathrm{OFF}$ & $\mathrm{OFF}$ & & & & & & & \\
\hline DSI & & $\mathrm{OFF}$ & $\mathrm{OFF}$ & $\mathrm{OFF}$ & $\mathrm{OFF}$ & $\mathrm{OFF}$ & $\mathrm{OFF}$ & $\mathrm{OFF}$ \\
\hline OFF & $\mathrm{OFF}$ & & & & & & & \\
\hline PSI & & $\mathrm{OFF}$ & $\mathrm{OFF}$ & $\mathrm{OFF}$ & $\mathrm{OFF}$ & $\mathrm{OFF}$ & $\mathrm{OFF}$ & $\mathrm{OFF}$ \\
\hline OFF & $\mathrm{OFF}$ & & & & & & & \\
\hline $\mathrm{FE}$ & & $\mathrm{OFF}$ & $\mathrm{OFF}$ & OFF & OFF & $\mathrm{OFF}$ & $\mathrm{OFF}$ & $\mathrm{OFF}$ \\
\hline OFF & OFF & & & & & & & \\
\hline LDOM & & ON & ON & ON & ON & $\mathrm{OFF}$ & $\mathrm{OFF}$ & $O F F$ \\
\hline $\mathrm{OFF}$ & $\mathrm{OFF}$ & & & & & & & \\
\hline RDOM & & ON & ON & ON & ON & $\mathrm{OFF}$ & $\mathrm{OFF}$ & $\mathrm{OFF}$ \\
\hline $\mathrm{OFF}$ & $\mathrm{OFF}$ & & & & & & & \\
\hline LPOM & & ON & ON & ON & ON & $\mathrm{OFF}$ & $\mathrm{OFF}$ & $\mathrm{OFF}$ \\
\hline $\mathrm{OFF}$ & OFF & & & & & & & \\
\hline RPOM & & ON & ON & ON & ON & $\mathrm{OFF}$ & $\mathrm{OFF}$ & $\mathrm{OFF}$ \\
\hline OFF & OFF & & & & & & & \\
\hline BOD1 & & ON & ON & ON & ON & $\mathrm{OFF}$ & $\mathrm{OFF}$ & $\mathrm{OFF}$ \\
\hline $\mathrm{OFF}$ & $\mathrm{OFF}$ & & & & & & & \\
\hline BOD1-P & & ON & ON & ON & ON & $\mathrm{OFF}$ & $\mathrm{OFF}$ & $\mathrm{OFF}$ \\
\hline $\mathrm{OFF}$ & $\mathrm{OFF}$ & & & & & & & \\
\hline $\mathrm{BOD} 1-\mathrm{N}$ & & ON & ON & ON & ON & $\mathrm{OFF}$ & $\mathrm{OFF}$ & $\mathrm{OFF}$ \\
\hline $\mathrm{OFF}$ & $\mathrm{OFF}$ & & & & & & & \\
\hline ALG1 & & ON & ON & ON & ON & $\mathrm{OFF}$ & $\mathrm{OFF}$ & $\mathrm{OFF}$ \\
\hline $\mathrm{OFF}$ & $\mathrm{OFF}$ & & & & & & & \\
\hline DO & & ON & ON & ON & ON & $\mathrm{OFF}$ & $\mathrm{OFF}$ & $\mathrm{OFF}$ \\
\hline $\mathrm{OFF}$ & $\mathrm{OFF}$ & & & & & & & \\
\hline TIC & & $\mathrm{OFF}$ & $\mathrm{OFF}$ & $\mathrm{OFF}$ & $\mathrm{OFF}$ & $\mathrm{OFF}$ & $\mathrm{OFF}$ & $\mathrm{OFF}$ \\
\hline $\mathrm{OFF}$ & $\mathrm{OFF}$ & & & & & & & \\
\hline ALK & & $\mathrm{OFF}$ & $\mathrm{OFF}$ & $\mathrm{OFF}$ & $\mathrm{OFF}$ & $\mathrm{OFF}$ & $\mathrm{OFF}$ & $\mathrm{OFF}$ \\
\hline $\mathrm{OFF}$ & $\mathrm{OFF}$ & & & & & & & \\
\hline LDOM-P & & $\mathrm{OFF}$ & $\mathrm{OFF}$ & $\mathrm{OFF}$ & $\mathrm{OFF}$ & $\mathrm{OFF}$ & $\mathrm{OFF}$ & $\mathrm{OFF}$ \\
\hline $\mathrm{OFF}$ & $\mathrm{OFF}$ & & & & & & & \\
\hline $\mathrm{RDOM}-\mathrm{P}$ & & $\mathrm{OFF}$ & $\mathrm{OFF}$ & $\mathrm{OFF}$ & $\mathrm{OFF}$ & $\mathrm{OFF}$ & $\mathrm{OFF}$ & $\mathrm{OFF}$ \\
\hline $\mathrm{OFF}$ & $\mathrm{OFF}$ & & & & & & & \\
\hline LPOM-P & & $\mathrm{OFF}$ & $\mathrm{OFF}$ & $\mathrm{OFF}$ & $\mathrm{OFF}$ & $\mathrm{OFF}$ & $\mathrm{OFF}$ & $\mathrm{OFF}$ \\
\hline $\mathrm{OFF}$ & $\mathrm{OFF}$ & & & & & & & \\
\hline RPOM-P & & $\mathrm{OFF}$ & $\mathrm{OFF}$ & $\mathrm{OFF}$ & OFF & $\mathrm{OFF}$ & $\mathrm{OFF}$ & $\mathrm{OFF}$ \\
\hline $\mathrm{OFF}$ & $\mathrm{OFF}$ & & & & & & & \\
\hline $\mathrm{LDOM}-\mathrm{N}$ & & $\mathrm{OFF}$ & $\mathrm{OFF}$ & $\mathrm{OFF}$ & OFF & $\mathrm{OFF}$ & $\mathrm{OFF}$ & $\mathrm{OFF}$ \\
\hline $\mathrm{OFF}$ & $\mathrm{OFF}$ & & & & & & & \\
\hline $\mathrm{RDOM}-\mathrm{N}$ & & $\mathrm{OFF}$ & $\mathrm{OFF}$ & $\mathrm{OFF}$ & OFF & $\mathrm{OFF}$ & $\mathrm{OFF}$ & $\mathrm{OFF}$ \\
\hline $\mathrm{OFF}$ & $\mathrm{OFF}$ & & & & & & & \\
\hline $\mathrm{LPOM}-\mathrm{N}$ & & $\mathrm{OFF}$ & $\mathrm{OFF}$ & $\mathrm{OFF}$ & OFF & $\mathrm{OFF}$ & $\mathrm{OFF}$ & $\mathrm{OFF}$ \\
\hline $\mathrm{OFF}$ & OFF & & & & & & & \\
\hline
\end{tabular}




\begin{tabular}{|c|c|c|c|c|c|c|c|c|}
\hline $\begin{array}{l}\text { RPOM-N } \\
\text { OFF }\end{array}$ & $\mathrm{OFF}$ & $\mathrm{OFF}$ & $\mathrm{OFF}$ & $\mathrm{OFF}$ & $\mathrm{OFF}$ & $\mathrm{OFF}$ & $\mathrm{OFF}$ & $\mathrm{OFF}$ \\
\hline $\begin{array}{l}\text { CPR CON } \\
\text { CPRBRC }\end{array}$ & $\begin{array}{r}\mathrm{CPI} \\
\mathrm{CPRB}\end{array}$ & $\begin{array}{l}\mathrm{RBRC} \\
\mathrm{RC}\end{array}$ & CPRBRC & CPRBRC & CPRBRC & CPRBRC & $\mathrm{CPRBRC}$ & CPRBRC \\
\hline TDS & & $\mathrm{OFF}$ & $\mathrm{OFF}$ & $\mathrm{OFF}$ & $\mathrm{OFF}$ & OFF & OFF & $\mathrm{OFF}$ \\
\hline OFF & $\mathrm{OFF}$ & & & & & & & \\
\hline Gen1 & & $\mathrm{OFF}$ & $\mathrm{OFF}$ & $\mathrm{OFF}$ & $\mathrm{OFF}$ & $\mathrm{OFF}$ & $\mathrm{OFF}$ & $\mathrm{OFF}$ \\
\hline $\mathrm{OFF}$ & $\mathrm{OFF}$ & & & & & & & \\
\hline Gen2 & & $\mathrm{OFF}$ & $\mathrm{OFF}$ & $\mathrm{OFF}$ & $\mathrm{OFF}$ & $\mathrm{OFF}$ & OFF & $\mathrm{OFF}$ \\
\hline $\mathrm{OFF}$ & $\mathrm{OFF}$ & & & & & & & \\
\hline ISS & & $\mathrm{OFF}$ & $\mathrm{OFF}$ & $\mathrm{OFF}$ & $\mathrm{OFF}$ & $\mathrm{OFF}$ & $\mathrm{OFF}$ & $\mathrm{OFF}$ \\
\hline OFF & OFF & & & & & & & \\
\hline $\mathrm{PO} 4$ & & $\mathrm{OFF}$ & OFF & OFF & $\mathrm{OFF}$ & $\mathrm{OFF}$ & OFF & $\mathrm{OFF}$ \\
\hline $\mathrm{OFF}$ & OFF & & & & & & & \\
\hline $\mathrm{NH} 4$ & & $\mathrm{OFF}$ & $\mathrm{OFF}$ & $\mathrm{OFF}$ & $\mathrm{OFF}$ & OFF & OFF & $\mathrm{OFF}$ \\
\hline $\mathrm{OFF}$ & $\mathrm{OFF}$ & & & & & & & \\
\hline NO3 & & $\mathrm{OFF}$ & $\mathrm{OFF}$ & $\mathrm{OFF}$ & $\mathrm{OFF}$ & $\mathrm{OFF}$ & $\mathrm{OFF}$ & $\mathrm{OFF}$ \\
\hline $\mathrm{OFF}$ & $\mathrm{OFF}$ & & & & & & & \\
\hline DSI & & $\mathrm{OFF}$ & $\mathrm{OFF}$ & $\mathrm{OFF}$ & $\mathrm{OFF}$ & $\mathrm{OFF}$ & $\mathrm{OFF}$ & $\mathrm{OFF}$ \\
\hline OFF & $\mathrm{OFF}$ & & & & & & & \\
\hline PSI & & $\mathrm{OFF}$ & $\mathrm{OFF}$ & $\mathrm{OFF}$ & $\mathrm{OFF}$ & $\mathrm{OFF}$ & OFF & $\mathrm{OFF}$ \\
\hline $\mathrm{OFF}$ & OFF & & & & & & & \\
\hline $\mathrm{FE}$ & & $\mathrm{OFF}$ & OFF & $\mathrm{OFF}$ & $\mathrm{OFF}$ & OFF & OFF & $\mathrm{OFF}$ \\
\hline $\mathrm{OFF}$ & $\mathrm{OFF}$ & & & & & & & \\
\hline LDOM & & $\mathrm{OFF}$ & $\mathrm{OFF}$ & $\mathrm{OFF}$ & $\mathrm{OFF}$ & $\mathrm{OFF}$ & OFF & $\mathrm{OFF}$ \\
\hline $\mathrm{OFF}$ & $\mathrm{OFF}$ & & & & & & & \\
\hline $\mathrm{RDOM}$ & & $\mathrm{OFF}$ & OFF & $\mathrm{OFF}$ & $\mathrm{OFF}$ & $\mathrm{OFF}$ & OFF & $\mathrm{OFF}$ \\
\hline $\mathrm{OFF}$ & $\mathrm{OFF}$ & & & & & & & \\
\hline LPOM & & $\mathrm{OFF}$ & $\mathrm{OFF}$ & $\mathrm{OFF}$ & $\mathrm{OFF}$ & $\mathrm{OFF}$ & $\mathrm{OFF}$ & $\mathrm{OFF}$ \\
\hline $\mathrm{OFF}$ & $\mathrm{OFF}$ & & & & & & & \\
\hline $\mathrm{RPOM}$ & & $\mathrm{OFF}$ & OFF & $\mathrm{OFF}$ & $\mathrm{OFF}$ & $\mathrm{OFF}$ & OFF & $\mathrm{OFF}$ \\
\hline $\mathrm{OFF}$ & $\mathrm{OFF}$ & & & & & & & \\
\hline BOD1 & & $\mathrm{OFF}$ & $\mathrm{OFF}$ & $\mathrm{OFF}$ & $\mathrm{OFF}$ & $\mathrm{OFF}$ & $\mathrm{OFF}$ & $\mathrm{OFF}$ \\
\hline $\mathrm{OFF}$ & $\mathrm{OFF}$ & & & & & & & \\
\hline BOD1-P & & $\mathrm{OFF}$ & $\mathrm{OFF}$ & $\mathrm{OFF}$ & $\mathrm{OFF}$ & $\mathrm{OFF}$ & $\mathrm{OFF}$ & $\mathrm{OFF}$ \\
\hline $\mathrm{OFF}$ & $\mathrm{OFF}$ & & & & & & & \\
\hline $\mathrm{BOD} 1-\mathrm{N}$ & & $\mathrm{OFF}$ & $\mathrm{OFF}$ & $\mathrm{OFF}$ & $\mathrm{OFF}$ & $\mathrm{OFF}$ & $\mathrm{OFF}$ & $\mathrm{OFF}$ \\
\hline $\mathrm{OFF}$ & $\mathrm{OFF}$ & & & & & & & \\
\hline ALG1 & & $\mathrm{OFF}$ & $\mathrm{OFF}$ & $\mathrm{OFF}$ & $\mathrm{OFF}$ & $\mathrm{OFF}$ & $\mathrm{OFF}$ & $\mathrm{OFF}$ \\
\hline $\mathrm{OFF}$ & $\mathrm{OFF}$ & & & & & & & \\
\hline DO & & $\mathrm{OFF}$ & OFF & $\mathrm{OFF}$ & $\mathrm{OFF}$ & $\mathrm{OFF}$ & OFF & $\mathrm{OFF}$ \\
\hline $\mathrm{OFF}$ & $\mathrm{OFF}$ & & & & & & & \\
\hline TIC & & $\mathrm{OFF}$ & $\mathrm{OFF}$ & $\mathrm{OFF}$ & $\mathrm{OFF}$ & $\mathrm{OFF}$ & $\mathrm{OFF}$ & $\mathrm{OFF}$ \\
\hline $\mathrm{OFF}$ & $\mathrm{OFF}$ & & & & & & & \\
\hline ALK & & $\mathrm{OFF}$ & $\mathrm{OFF}$ & $\mathrm{OFF}$ & $\mathrm{OFF}$ & $\mathrm{OFF}$ & $\mathrm{OFF}$ & $\mathrm{OFF}$ \\
\hline $\mathrm{OFF}$ & $\mathrm{OFF}$ & & & & & & & \\
\hline $\mathrm{LDOM}-\mathrm{P}$ & & $\mathrm{OFF}$ & $\mathrm{OFF}$ & $\mathrm{OFF}$ & $\mathrm{OFF}$ & OFF & $\mathrm{OFF}$ & $\mathrm{OFF}$ \\
\hline $\mathrm{OFF}$ & $\mathrm{OFF}$ & & & & & & & \\
\hline $\mathrm{RDOM}-\mathrm{P}$ & & $\mathrm{OFF}$ & $\mathrm{OFF}$ & $\mathrm{OFF}$ & $\mathrm{OFF}$ & $\mathrm{OFF}$ & $\mathrm{OFF}$ & $\mathrm{OFF}$ \\
\hline $\mathrm{OFF}$ & $\mathrm{OFF}$ & & & & & & & \\
\hline $\mathrm{LPOM}-\mathrm{P}$ & & $\mathrm{OFF}$ & $\mathrm{OFF}$ & OFF & $\mathrm{OFF}$ & $\mathrm{OFF}$ & $\mathrm{OFF}$ & $\mathrm{OFF}$ \\
\hline $\mathrm{OFF}$ & $\mathrm{OFF}$ & & & & & & & \\
\hline
\end{tabular}




\begin{tabular}{|c|c|c|c|c|c|c|c|}
\hline RPOM-P & $\mathrm{OFF}$ & $\mathrm{OFF}$ & OFF & $\mathrm{OFF}$ & $\mathrm{OFF}$ & OFF & $\mathrm{OFF}$ \\
\hline $\mathrm{OFF}$ & $\mathrm{OFF}$ & & & & & & \\
\hline LDOM-N & OFF & $\mathrm{OFF}$ & OFF & $\mathrm{OFF}$ & $\mathrm{OFF}$ & $\mathrm{OFF}$ & OFF \\
\hline $\mathrm{OFF}$ & $\mathrm{OFF}$ & & & & & & \\
\hline $\mathrm{RDOM}-\mathrm{N}$ & OFF & $\mathrm{OFF}$ & OFF & $\mathrm{OFF}$ & OFF & OFF & $\mathrm{OFF}$ \\
\hline $\mathrm{OFF}$ & $\mathrm{OFF}$ & & & & & & \\
\hline LPOM-N & OFF & $\mathrm{OFF}$ & $\mathrm{OFF}$ & $\mathrm{OFF}$ & OFF & OFF & $\mathrm{OFF}$ \\
\hline $\mathrm{OFF}$ & OFF & & & & & & \\
\hline $\mathrm{RPOM}-\mathrm{N}$ & $\mathrm{OFF}$ & $\mathrm{OFF}$ & $\mathrm{OFF}$ & $\mathrm{OFF}$ & $\mathrm{OFF}$ & $\mathrm{OFF}$ & $\mathrm{OFF}$ \\
\hline $\mathrm{OFF}$ & $\mathrm{OFF}$ & & & & & & \\
\hline$E X \quad C O E F$ & EXH2O & EXSS & EXOM & BETA & $\mathrm{EXC}$ & EXIC & \\
\hline WB 1 & 0.45000 & 0.01000 & 0.40000 & 0.45000 & OFF & OFF & \\
\hline WB 2 & 0.45000 & 0.01000 & 0.40000 & 0.45000 & OFF & OFF & \\
\hline WB 3 & 0.45000 & 0.01000 & 0.40000 & 0.45000 & $\mathrm{OFF}$ & OFF & \\
\hline WB 4 & 0.45000 & 0.01000 & 0.40000 & 0.45000 & OFF & $\mathrm{OFF}$ & \\
\hline WB 5 & 0.45000 & 0.01000 & 0.40000 & 0.45000 & OFF & $\mathrm{OFF}$ & \\
\hline WB 6 & 0.45000 & 0.01000 & 0.40000 & 0.45000 & $\mathrm{OFF}$ & $\mathrm{OFF}$ & \\
\hline WB 7 & 0.45000 & 0.01000 & 0.40000 & 0.45000 & OFF & $\mathrm{OFF}$ & \\
\hline WB 8 & 0.45000 & 0.01000 & 0.40000 & 0.45000 & $\mathrm{OFF}$ & OFF & \\
\hline WB 9 & 0.45000 & 0.01000 & 0.40000 & 0.45000 & $\mathrm{OFF}$ & $\mathrm{OFF}$ & \\
\hline ALG EX & $\begin{array}{r}\text { EXA } \\
0.20000\end{array}$ & EXA & EXA & EXA & EXA & EXA & \\
\hline $\mathrm{ZOO} \mathrm{EX}$ & $\begin{array}{r}\text { EXZ } \\
0.20000\end{array}$ & EXZ & EXZ & EXZ & EXZ & EXZ & \\
\hline MACRO EX & $\begin{array}{r}\text { EXM } \\
0.01000\end{array}$ & EXM & EXM & EXM & EXM & EXM & \\
\hline GENERIC & CGQ10 & CGODK & CGIDK & CGS & & & \\
\hline CG 1 & 0.00000 & -1.0000 & 0.00000 & 0.00000 & & & \\
\hline CG 2 & 0.00000 & 0.0000 & 0.00000 & 0.00000 & & & \\
\hline S SOLIDS & SSS & SEDRC & TAUCR & & & & \\
\hline SS\# 1 & 1.50000 & $\mathrm{OFF}$ & 0.00000 & & & & \\
\hline ALGAL RAT & AG & AR & $A E$ & AM & AS & AHSP & AHSN \\
\hline AHSSI & ASAT & & & & & & \\
\hline $\begin{array}{l}\text { ALG1 } \\
0.000004\end{array}$ & $\begin{array}{r}0.98000 \\
40.0000\end{array}$ & 0.04000 & 0.04000 & 0.10000 & 0.20000 & 0.00300 & 0.01400 \\
\hline $\begin{array}{l}\text { ALGAL TEM } \\
\text { AK4 }\end{array}$ & AT1 & AT2 & AT3 & AT 4 & AK1 & AK2 & AK3 \\
\hline $\begin{array}{l}\text { ALG1 } \\
0.10000\end{array}$ & 5.00000 & 25.0000 & 35.0000 & 40.0000 & 0.10000 & 0.99000 & 0.99000 \\
\hline $\begin{array}{l}\text { ALG STOI } \\
\text { ANPR }\end{array}$ & ALGP & ALGN & ALGC & ALGSI & ACHLA & ALPOM & ANEQN \\
\hline $\begin{array}{l}\text { ALG1 } \\
0.00100\end{array}$ & 0.00500 & 0.08000 & 0.45000 & 0.18000 & 0.05000 & 0.80000 & 2 \\
\hline
\end{tabular}




\begin{tabular}{|c|c|c|c|c|c|c|c|}
\hline EPIPHYTE & EPIC & EPIC & EPIC & EPIC & EPIC & EPIC & EPIC \\
\hline EPIC & EPIC & & & & & & \\
\hline EPI1 & $\mathrm{OFF}$ & $\mathrm{OFF}$ & $\mathrm{OFF}$ & $\mathrm{OFF}$ & $\mathrm{OFF}$ & $\mathrm{OFF}$ & $\mathrm{OFF}$ \\
\hline $\mathrm{OFF}$ & $\mathrm{OFF}$ & & & & & & \\
\hline EPI PRIN & EPRC & EPRC & EPRC & EPRC & $\mathrm{EPRC}$ & EPRC & $\mathrm{EPRC}$ \\
\hline EPRC & EPRC & & & & & & \\
\hline EPI1 & $\mathrm{OFF}$ & $\mathrm{OFF}$ & $\mathrm{OFF}$ & $\mathrm{OFF}$ & $\mathrm{OFF}$ & $\mathrm{OFF}$ & $\mathrm{OFF}$ \\
\hline $\mathrm{OFF}$ & $\mathrm{OFF}$ & & & & & & \\
\hline EPI INIT & EPICI & EPICI & EPICI & EPICI & EPICI & EPICI & EPICI \\
\hline EPICI & EPICI & & & & & & \\
\hline $\begin{array}{l}\text { EPI1 } \\
0.00000\end{array}$ & $\begin{array}{r}0.00000 \\
0.00000\end{array}$ & 0.00000 & 0.00000 & 0.00000 & 0.00000 & 0.00000 & 0.00000 \\
\hline $\begin{array}{l}\text { EPI RATE } \\
\text { EHSSI }\end{array}$ & $\mathrm{EG}$ & $E R$ & $\mathrm{EE}$ & EM & $\mathrm{EB}$ & EHSP & $\mathrm{EHSN}$ \\
\hline $\begin{array}{l}\text { EPI1 } \\
0.00000\end{array}$ & 1.20000 & 0.04000 & 0.04000 & 0.10000 & 0.00100 & 0.00300 & 0.01400 \\
\hline EPI HALF & ESAT & EHS & ENEQN & ENPR & & & \\
\hline EPII & 150.000 & 25.0000 & 2 & 0.00500 & & & \\
\hline EPI TEMP & ET1 & ET2 & ET3 & ET4 & EK1 & EK2 & EK3 \\
\hline $\begin{array}{l}\text { EPI1 } \\
0.10000\end{array}$ & 1.00000 & 3.00000 & 20.0000 & 30.0000 & 0.30000 & 0.99000 & 0.99000 \\
\hline EPI STOI & $\mathrm{EP}$ & EN & $\mathrm{EC}$ & ESI & ECHLA & EPOM & \\
\hline EPI1 & 0.00500 & 0.08000 & 0.45000 & 0.00000 & 0.65000 & 0.80000 & \\
\hline ZOOP RATE & & $\mathrm{ZR}$ & $\mathrm{ZM}$ & ZEFF & PREFP & ZOOMIN & ZS2P \\
\hline Zoo1 & 1.50000 & 0.10000 & 0.01000 & 0.50000 & 0.50000 & 0.01000 & 0.30000 \\
\hline $\begin{array}{l}\text { ZOOP ALGE } \\
\text { PRFFA }\end{array}$ & $\begin{array}{l}P \quad \text { PREFA } \\
\text { PRFFA }\end{array}$ & PREFA & PREFA & PREFA & PREFA & PREFA & PREFA \\
\hline Zoo1 & 0.00000 & & & & & & \\
\hline ZOOP ZOOE & P PREFZ & PREFZ & PREFZ & PREFZ & PREFZ & PREFZ & PREFZ \\
\hline PREFZ & PREFZ & & & & & & \\
\hline Z००1 & 0.00000 & & & & & & \\
\hline $\begin{array}{l}\text { ZOOP TEME } \\
\text { ZK4 }\end{array}$ & $\mathrm{ZT1}$ & $\mathrm{ZT} 2$ & ZT3 & $\mathrm{ZT} 4$ & ZK1 & ZK2 & ZK3 \\
\hline $\begin{array}{l}Z \circ 01 \\
0.10000\end{array}$ & 0.00000 & 15.0000 & 20.0000 & 36.0000 & 0.10000 & 0.90000 & 0.98000 \\
\hline ZOOP STOI & & $\mathrm{ZN}$ & $\mathrm{ZC}$ & & & & \\
\hline Z००1 & 0.01500 & 0.08000 & 0.45000 & & & & \\
\hline MACROPHY & MACWBC & MACWBC & MACWBC & MACWBC & MACWBC & MACWBC & MACWBC \\
\hline MACWBC & MACWBC & & & & & & \\
\hline Mac1 & $\mathrm{OFF}$ & $\mathrm{OFF}$ & $\mathrm{OFF}$ & $\mathrm{OFF}$ & $\mathrm{OFF}$ & $\mathrm{OFF}$ & $\mathrm{OFF}$ \\
\hline
\end{tabular}




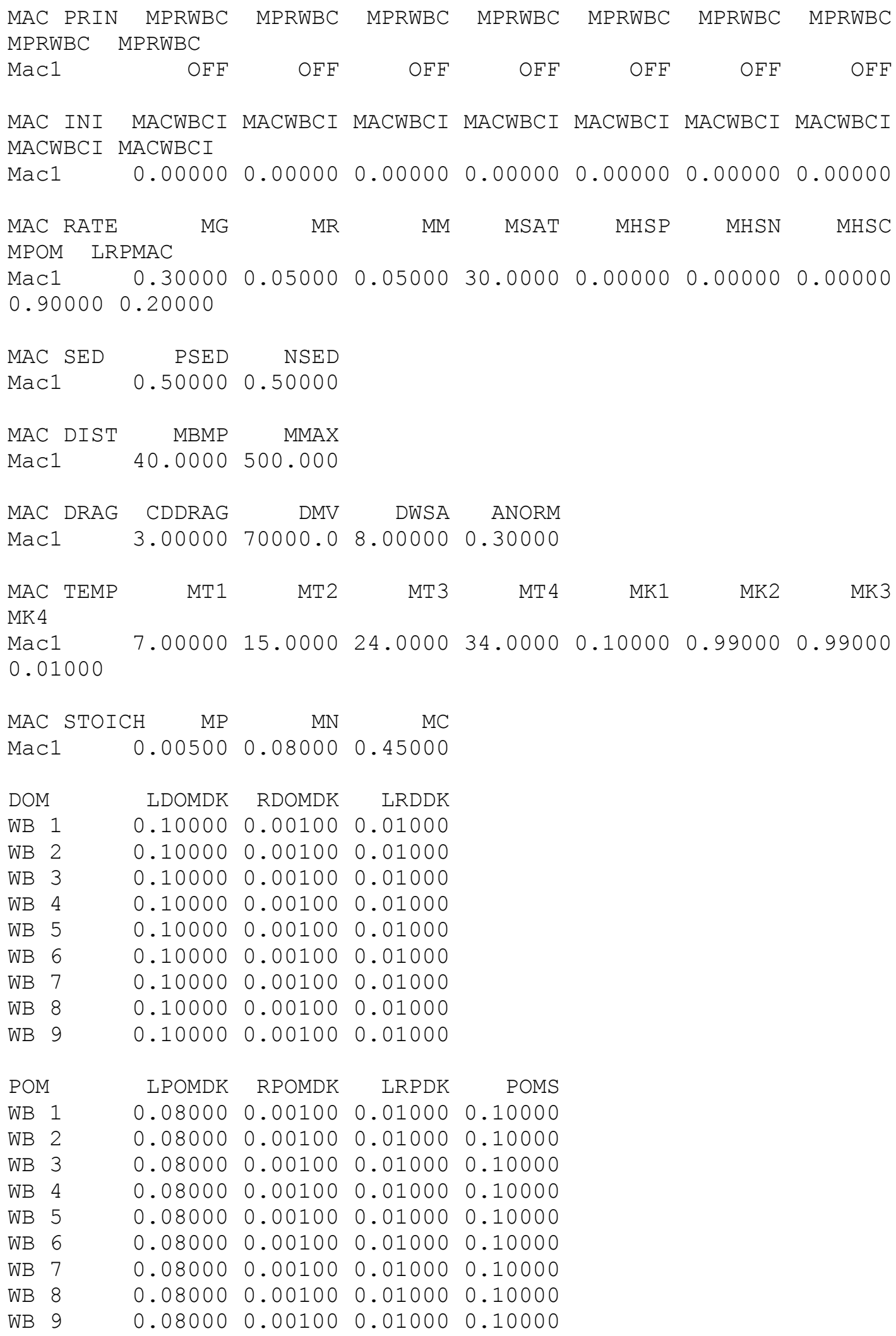




\begin{tabular}{|c|c|c|c|c|}
\hline OM STOIC & ORGP & ORGN & ORGC & ORGSI \\
\hline WB 1 & 0.00500 & 0.08000 & 0.45000 & 0.18000 \\
\hline WB 2 & 0.00500 & 0.08000 & 0.45000 & 0.08000 \\
\hline WB 3 & 0.00500 & 0.08000 & 0.45000 & 0.08000 \\
\hline WB 4 & 0.00500 & 0.08000 & 0.45000 & 0.08000 \\
\hline WB 5 & 0.00500 & 0.08000 & 0.45000 & 0.08000 \\
\hline WB 6 & 0.00500 & 0.08000 & 0.45000 & 0.08000 \\
\hline WB 7 & 0.00500 & 0.08000 & 0.45000 & 0.08000 \\
\hline WB 8 & 0.00500 & 0.08000 & 0.45000 & 0.08000 \\
\hline WB 9 & 0.00500 & 0.08000 & 0.45000 & 0.08000 \\
\hline OM RATE & OMT1 & $\mathrm{OMT} 2$ & OMK1 & OMK2 \\
\hline WB 1 & 4.00000 & 25.0000 & 0.10000 & 0.99000 \\
\hline WB 2 & 4.00000 & 25.0000 & 0.10000 & 0.99000 \\
\hline WB 3 & 4.00000 & 25.0000 & 0.10000 & 0.99000 \\
\hline WB 4 & 4.00000 & 25.0000 & 0.10000 & 0.99000 \\
\hline WB 5 & 4.00000 & 25.0000 & 0.10000 & 0.99000 \\
\hline WB 6 & 4.00000 & 25.0000 & 0.10000 & 0.99000 \\
\hline WB 7 & 4.00000 & 25.0000 & 0.10000 & 0.99000 \\
\hline WB 8 & 4.00000 & 25.0000 & 0.10000 & 0.99000 \\
\hline WB 9 & 4.00000 & 25.0000 & 0.10000 & 0.99000 \\
\hline $\mathrm{CBOD}$ & $\mathrm{KBOD}$ & TBOD & $\mathrm{RBOD}$ & CBODS \\
\hline $\mathrm{BOD} 1$ & 0.10000 & 1.02000 & 1.00000 & 0.00000 \\
\hline CBOD ST & IC BODP & BODN & BODC & \\
\hline BOD 1 & 0.01000 & 0.08000 & 0.32000 & \\
\hline PHOSPHOR & $\mathrm{PO} 4 \mathrm{R}$ & PARTP & & \\
\hline WB 1 & 0.00100 & 0.00000 & & \\
\hline WB 2 & 0.00100 & 0.00000 & & \\
\hline WB 3 & 0.00100 & 0.00000 & & \\
\hline WB 4 & 0.00100 & 0.00000 & & \\
\hline WB 5 & 0.00100 & 0.00000 & & \\
\hline WB 6 & 0.00100 & 0.00000 & & \\
\hline WB 7 & 0.00100 & 0.00000 & & \\
\hline WB 8 & 0.00100 & 0.00000 & & \\
\hline WB 9 & 0.00100 & 0.00000 & & \\
\hline AMMONIUM & $\mathrm{NH} 4 \mathrm{R}$ & $\mathrm{NH} 4 \mathrm{DK}$ & & \\
\hline WB 1 & 0.00100 & 0.12000 & & \\
\hline WB 2 & 0.00100 & 0.12000 & & \\
\hline WB 3 & 0.00100 & 0.12000 & & \\
\hline WB 4 & 0.00100 & 0.12000 & & \\
\hline WB 5 & 0.00100 & 0.12000 & & \\
\hline WB 6 & 0.00100 & 0.12000 & & \\
\hline WB 7 & 0.00100 & 0.12000 & & \\
\hline WB 8 & 0.00100 & 0.12000 & & \\
\hline WB 9 & 0.00100 & 0.12000 & & \\
\hline $4 \mathrm{RATE}$ & $\mathrm{NH} 4 \mathrm{~T} 1$ & NH4T2 & $\mathrm{NH} 4 \mathrm{~K} 1$ & $\mathrm{NH} 4 \mathrm{~K} 2$ \\
\hline VB 1 & 5.00000 & 25.0000 & 0.10000 & 0.99000 \\
\hline B 2 & 5.00000 & 25.0000 & 0.10000 & 0.99000 \\
\hline
\end{tabular}




\begin{tabular}{|c|c|c|c|c|}
\hline WB 3 & 5.00000 & 25.0000 & 0.10000 & 0.99000 \\
\hline WB 4 & 5.00000 & 25.0000 & 0.10000 & 0.99000 \\
\hline WB 5 & 5.00000 & 25.0000 & 0.10000 & 0.99000 \\
\hline WB 6 & 5.00000 & 25.0000 & 0.10000 & 0.99000 \\
\hline WB 7 & 5.00000 & 25.0000 & 0.10000 & 0.99000 \\
\hline WB 8 & 5.00000 & 25.0000 & 0.10000 & 0.99000 \\
\hline WB 9 & 5.00000 & 25.0000 & 0.10000 & 0.99000 \\
\hline NITRATE & NO3DK & NO3S & FNO3SED & \\
\hline WB 1 & 0.03000 & 0.00100 & 0.00000 & \\
\hline WB 2 & 0.03000 & 0.00100 & 0.00000 & \\
\hline WB 3 & 0.03000 & 0.00100 & 0.00000 & \\
\hline WB 4 & 0.03000 & 0.00100 & 0.00000 & \\
\hline WB 5 & 0.03000 & 0.00100 & 0.00000 & \\
\hline WB 6 & 0.03000 & 0.00100 & 0.00000 & \\
\hline WB 7 & 0.03000 & 0.00100 & 0.00000 & \\
\hline WB 8 & 0.03000 & 0.00100 & 0.00000 & \\
\hline WB 9 & 0.03000 & 0.00100 & 0.00000 & \\
\hline NO3 RATE & NO3T1 & NO3T2 & NO3K1 & NO3K2 \\
\hline WB 1 & 5.00000 & 25.0000 & 0.10000 & 0.99000 \\
\hline WB 2 & 5.00000 & 25.0000 & 0.10000 & 0.99000 \\
\hline WB 3 & 5.00000 & 25.0000 & 0.10000 & 0.99000 \\
\hline WB 4 & 5.00000 & 25.0000 & 0.10000 & 0.99000 \\
\hline WB 5 & 5.00000 & 25.0000 & 0.10000 & 0.99000 \\
\hline WB 6 & 5.00000 & 25.0000 & 0.10000 & 0.99000 \\
\hline WB 7 & 5.00000 & 25.0000 & 0.10000 & 0.99000 \\
\hline WB 8 & 5.00000 & 25.0000 & 0.10000 & 0.99000 \\
\hline WB 9 & 5.00000 & 25.0000 & 0.10000 & 0.99000 \\
\hline SILICA & DSIR & PSIS & PSIDK & PARTSI \\
\hline WB 1 & 0.10000 & 0.00000 & 0.30000 & 0.20000 \\
\hline WB 2 & 0.00000 & 0.00000 & 0.00000 & 0.00000 \\
\hline WB 3 & 0.00000 & 0.00000 & 0.00000 & 0.00000 \\
\hline WB 4 & 0.00000 & 0.00000 & 0.00000 & 0.00000 \\
\hline WB 5 & 0.00000 & 0.00000 & 0.00000 & 0.00000 \\
\hline WB 6 & 0.00000 & 0.00000 & 0.00000 & 0.00000 \\
\hline WB 7 & 0.00000 & 0.00000 & 0.00000 & 0.00000 \\
\hline WB 8 & 0.00000 & 0.00000 & 0.00000 & 0.00000 \\
\hline WB 9 & 0.00000 & 0.00000 & 0.00000 & 0.00000 \\
\hline IRON & FER & FES & & \\
\hline WB 1 & 0.10000 & 0.00000 & & \\
\hline WB 2 & 0.00000 & 0.00000 & & \\
\hline WB 3 & 0.00000 & 0.00000 & & \\
\hline WB 4 & 0.00000 & 0.00000 & & \\
\hline WB 5 & 0.00000 & 0.00000 & & \\
\hline WB 6 & 0.00000 & 0.00000 & & \\
\hline WB 7 & 0.00000 & 0.00000 & & \\
\hline WB 8 & 0.00000 & 0.00000 & & \\
\hline WB 9 & 0.00000 & 0.00000 & & \\
\hline & & & & \\
\hline
\end{tabular}




\begin{tabular}{|c|c|c|c|c|c|c|c|c|}
\hline WB & 1 & 0.10000 & & & & & & \\
\hline WB & 2 & 0.10000 & & & & & & \\
\hline WB & 3 & 0.10000 & & & & & & \\
\hline WB & 4 & 0.10000 & & & & & & \\
\hline WB & 5 & 0.10000 & & & & & & \\
\hline WB & 6 & 0.10000 & & & & & & \\
\hline WB & 7 & 0.10000 & & & & & & \\
\hline WB & 8 & 0.10000 & & & & & & \\
\hline WB & 9 & 0.10000 & & & & & & \\
\hline $\mathrm{STO}$ & $\mathrm{OICH} 1$ & O2NH4 & $\mathrm{O} 2 \mathrm{OM}$ & & & & & \\
\hline & 1 & 4.57000 & 1.40000 & & & & & \\
\hline WB & 2 & 4.57000 & 1.40000 & & & & & \\
\hline WB & 3 & 4.57000 & 1.40000 & & & & & \\
\hline WB & 4 & 4.57000 & 1.40000 & & & & & \\
\hline WB & 5 & 4.57000 & 1.40000 & & & & & \\
\hline WB & 6 & 4.57000 & 1.40000 & & & & & \\
\hline & 7 & 4.57000 & 1.40000 & & & & & \\
\hline & 8 & 4.57000 & 1.40000 & & & & & \\
\hline WB & 9 & 4.57000 & 1.40000 & & & & & \\
\hline $\mathrm{STO}$ & $\mathrm{OICH} 2$ & $\mathrm{O} 2 \mathrm{AR}$ & $\mathrm{O} 2 \mathrm{AG}$ & & & & & \\
\hline ALG & & 1.10000 & 1.40000 & & & & & \\
\hline $\mathrm{STO}$ & $\mathrm{OICH} 3$ & O2ER & $\mathrm{O} 2 \mathrm{EG}$ & & & & & \\
\hline EPI & & 1.10000 & 1.80000 & & & & & \\
\hline $\mathrm{STO}$ & $\mathrm{OICH} 4$ & O2ZR & & & & & & \\
\hline Zoo & op1 & 1.10000 & & & & & & \\
\hline $\mathrm{STO}$ & $\mathrm{OICH} 5$ & $\mathrm{O} 2 \mathrm{MR}$ & $\mathrm{O} 2 \mathrm{MG}$ & & & & & \\
\hline Mac & & 1.10000 & 1.40000 & & & & & \\
\hline & LIMIT & $\begin{array}{r}\text { O2LIM } \\
0.70000\end{array}$ & & & & & & \\
\hline SED & DIMENT & SEDC & SEDPRC & SEDCI & SEDK & SEDS & FSOD & FSED \\
\hline \multicolumn{9}{|c|}{ SEDBR DYNSEDK } \\
\hline WB & 1 & $\mathrm{OFF}$ & $O F F$ & 0.00000 & 0.08000 & 0.10000 & 1.00000 & 1.00000 \\
\hline 0.0 & 00000 & $\mathrm{OFF}$ & & & & & & \\
\hline WB & 2 & $\mathrm{OFF}$ & $\mathrm{OFF}$ & 0.00000 & 0.00000 & 0.00000 & 1.00000 & 1.00000 \\
\hline 0.0 & 00000 & $\mathrm{OFF}$ & & & & & & \\
\hline WB & 3 & OFF & $\mathrm{OFF}$ & 0.00000 & 0.00000 & 0.00000 & 1.00000 & 1.00000 \\
\hline 0.0 & 00000 & $\mathrm{OFF}$ & & & & & & \\
\hline WB & 4 & OFF & OFF & 0.00000 & 0.00000 & 0.00000 & 1.00000 & 1.00000 \\
\hline 0.0 & 00000 & $\mathrm{OFF}$ & & & & & & \\
\hline WB & 5 & OFF & OFF & 0.00000 & 0.00000 & 0.00000 & 1.00000 & 1.00000 \\
\hline 0.0 & 00000 & $\mathrm{OFF}$ & & & & & & \\
\hline WB & 6 & ON & $\mathrm{ON}$ & 0.00000 & 0.08000 & 0.10000 & 1.00000 & 1.00000 \\
\hline 0.0 & 00800 & OFF & & & & & & \\
\hline WB & 7 & $\mathrm{OFF}$ & $\mathrm{OFF}$ & 0.00000 & 0.00000 & 0.00000 & 1.00000 & 1.00000 \\
\hline 0.0 & 00000 & $\mathrm{OFF}$ & & & & & & \\
\hline
\end{tabular}




\begin{tabular}{|c|c|c|c|c|c|c|c|}
\hline \multirow{4}{*}{$\begin{array}{l}\text { WB } 8 \\
0.00000 \\
W B 9 \\
0.00000\end{array}$} & \multicolumn{2}{|r|}{$\mathrm{OFF}$} & \multirow[t]{2}{*}{0.00000} & \multirow[t]{2}{*}{0.00000} & \multirow[t]{2}{*}{0.00000} & \multirow[t]{2}{*}{1.00000} & \multirow[t]{2}{*}{1.00000} \\
\hline & OFF & & & & & & \\
\hline & $\mathrm{OFF}$ & $\mathrm{OFF}$ & 0.00000 & 0.00000 & 0.00000 & 1.00000 & 1.00000 \\
\hline & $\mathrm{OFF}$ & & & & & & \\
\hline SOD RATE & SODT1 & SODT2 & SODK1 & SODK2 & & & \\
\hline WB 1 & 4.00000 & 30.0000 & 0.10000 & 0.99000 & & & \\
\hline WB 2 & 4.00000 & 30.0000 & 0.10000 & 0.99000 & & & \\
\hline WB 3 & 4.00000 & 30.0000 & 0.10000 & 0.99000 & & & \\
\hline WB 4 & 4.00000 & 30.0000 & 0.10000 & 0.99000 & & & \\
\hline WB 5 & 4.00000 & 30.0000 & 0.10000 & 0.99000 & & & \\
\hline WB 6 & 4.00000 & 30.0000 & 0.10000 & 0.99000 & & & \\
\hline WB 7 & 4.00000 & 30.0000 & 0.10000 & 0.99000 & & & \\
\hline WB 8 & 4.00000 & 30.0000 & 0.10000 & 0.99000 & & & \\
\hline WB 9 & 4.00000 & 30.0000 & 0.10000 & 0.99000 & & & \\
\hline$S$ DEMAND & SOD & $\mathrm{SOD}$ & SOD & SOD & SOD & SOD & $\mathrm{SOD}$ \\
\hline SOD & SOD & & & & & & \\
\hline & 0.60000 & 0.60000 & 0.60000 & 0.60000 & 0.60000 & 0.60000 & 0.60000 \\
\hline 0.60000 & 0.60000 & & & & & & \\
\hline & 0.60000 & 0.60000 & 0.60000 & 0.60000 & 0.60000 & 0.60000 & 0.60000 \\
\hline 0.60000 & 0.60000 & & & & & & \\
\hline & 0.60000 & 0.60000 & 0.60000 & 0.60000 & 0.60000 & 0.60000 & 0.60000 \\
\hline 0.60000 & 0.60000 & & & & & & \\
\hline & 0.60000 & 0.60000 & 0.60000 & 0.60000 & 0.60000 & 0.60000 & 0.60000 \\
\hline 0.60000 & 0.60000 & & & & & & \\
\hline & 0.60000 & 0.60000 & 0.60000 & 0.60000 & 0.60000 & 0.60000 & 0.60000 \\
\hline 0.60000 & 0.60000 & & & & & & \\
\hline & 0.60000 & 0.60000 & 0.60000 & 0.60000 & 0.60000 & 0.60000 & 0.60000 \\
\hline & 0.60000 & 0.60000 & 0.60000 & 0.60000 & 0.60000 & 0.60000 & 0.60000 \\
\hline 0.60000 & 0.60000 & & & & & & \\
\hline 0.60000 & $\begin{array}{l}0.60000 \\
0.60000\end{array}$ & 0.60000 & 0.60000 & 0.60000 & 0.60000 & 0.60000 & 0.60000 \\
\hline & 0.60000 & 0.60000 & 0.60000 & 0.60000 & 0.60000 & 0.60000 & 0.60000 \\
\hline 0.60000 & 0.60000 & & & & & & \\
\hline 60000 & $\begin{array}{l}0.60000 \\
0.60000\end{array}$ & 0.60000 & 0.60000 & 0.60000 & 0.60000 & 0.60000 & 0.60000 \\
\hline & 0.60000 & 0.60000 & 0.60000 & 0.60000 & 0.60000 & 0.60000 & 0.60000 \\
\hline 0.60000 & 0.60000 & & & & & & \\
\hline 0.60000 & $\begin{array}{l}0.60000 \\
0.60000\end{array}$ & 0.60000 & 0.60000 & 0.60000 & 0.60000 & 0.60000 & 0.60000 \\
\hline & 0.60000 & 0.60000 & 0.60000 & 0.60000 & 0.60000 & 0.60000 & 0.60000 \\
\hline 0.60000 & 0.60000 & & & & & & \\
\hline 0.60000 & $\begin{array}{l}0.60000 \\
0.60000\end{array}$ & 0.60000 & 0.60000 & 0.60000 & 0.60000 & 0.60000 & 0.60000 \\
\hline & 0.60000 & 0.60000 & 0.60000 & 0.60000 & 0.60000 & 0.60000 & 0.60000 \\
\hline 0.60000 & 0.60000 & & & & & & \\
\hline & 0.60000 & 0.60000 & 0.60000 & 0.60000 & 0.60000 & 0.60000 & 0.60000 \\
\hline 0.60000 & 0.60000 & & & & & & \\
\hline e & $\begin{array}{r}0.60000 \\
0.60000\end{array}$ & 0.60000 & 0.60000 & 0.60000 & 0.60000 & 0.60000 & 0.60000 \\
\hline
\end{tabular}




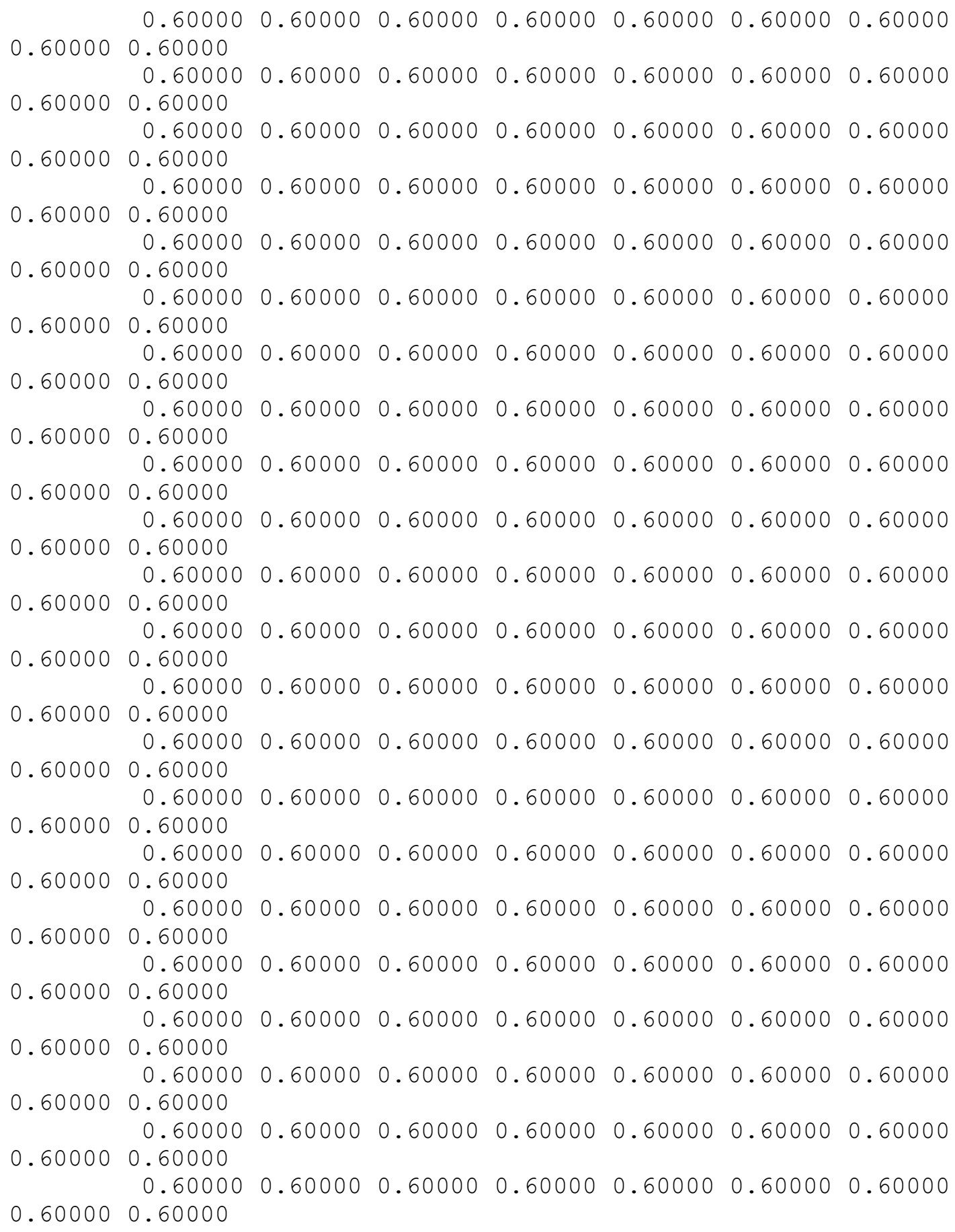




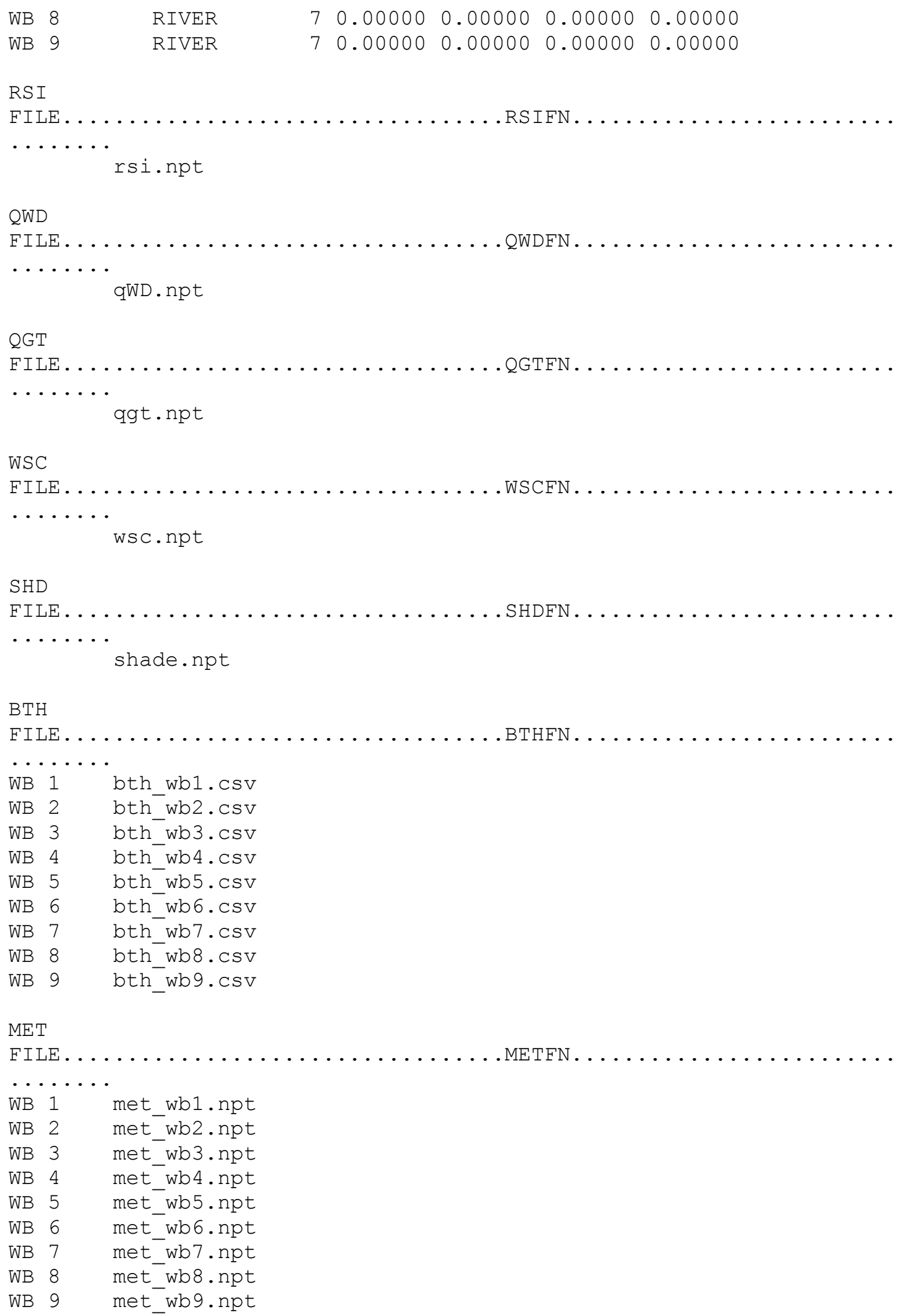




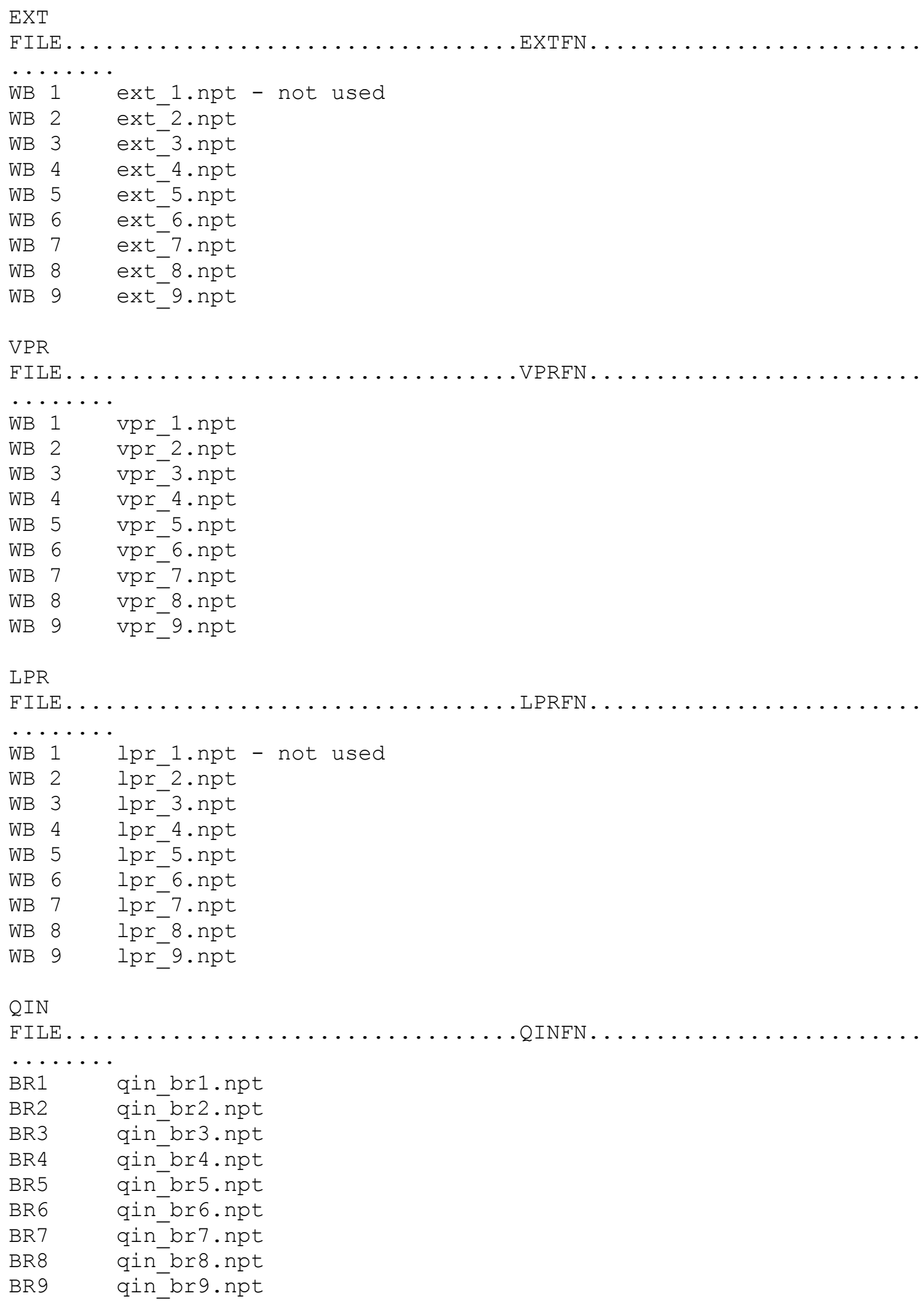




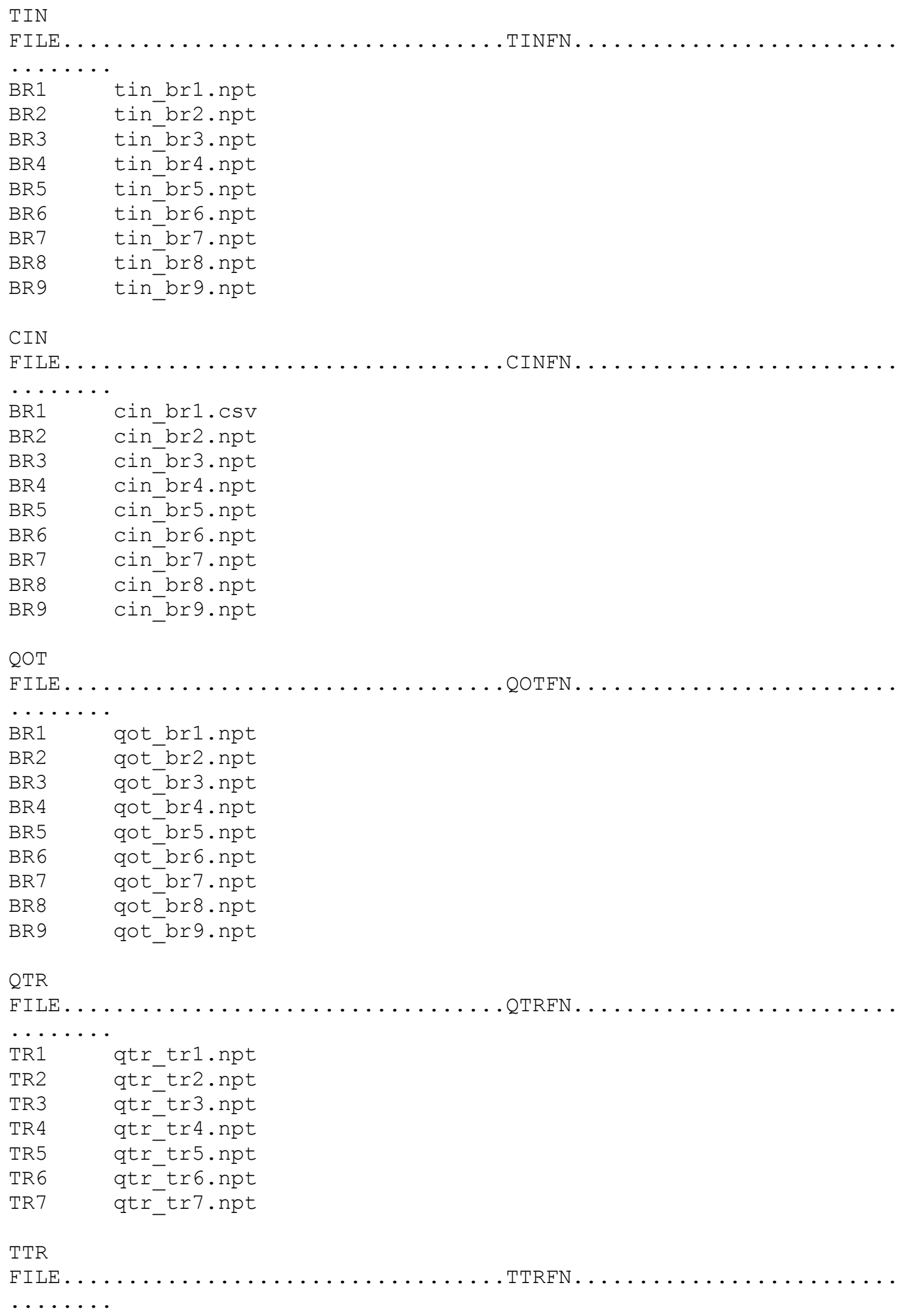




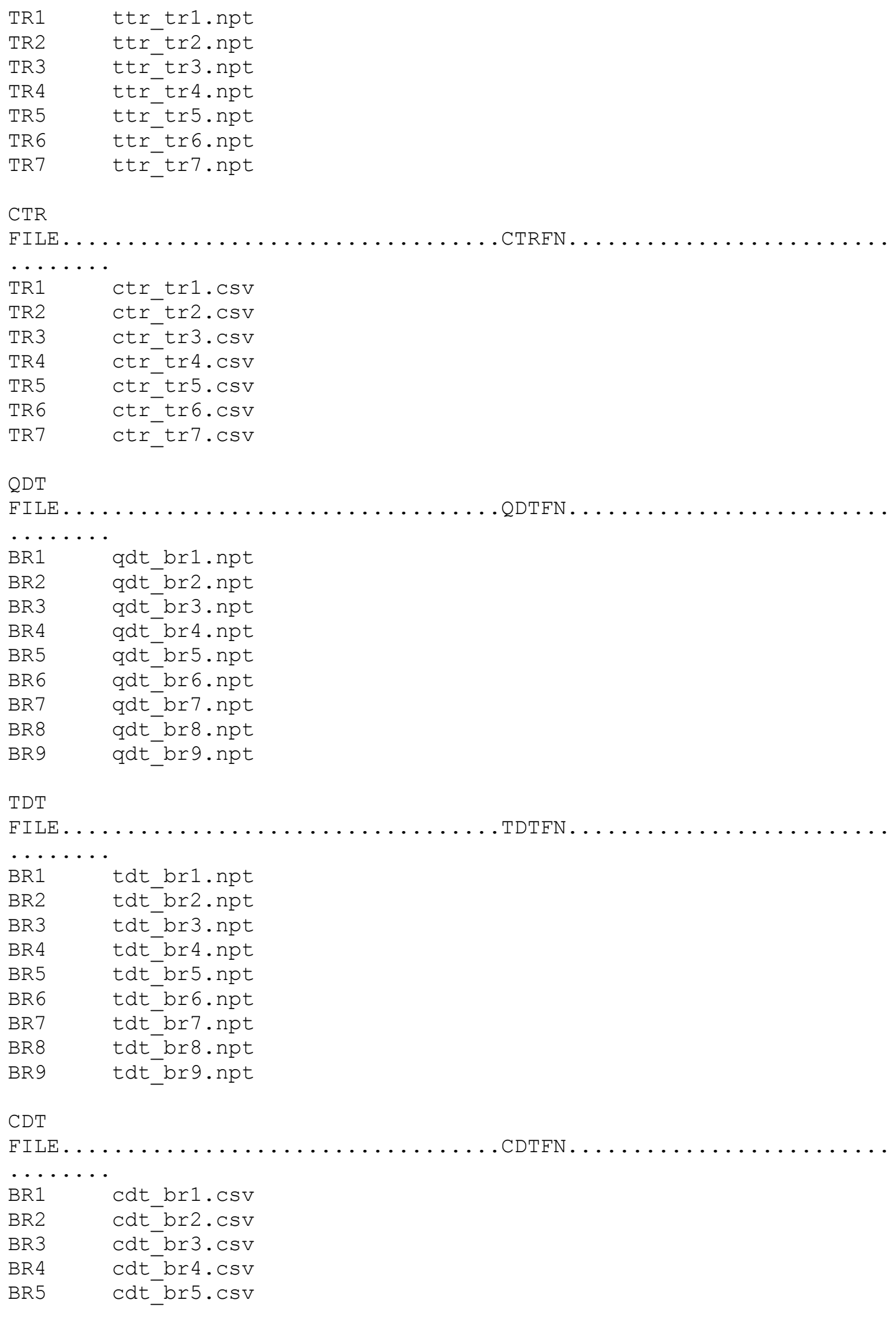




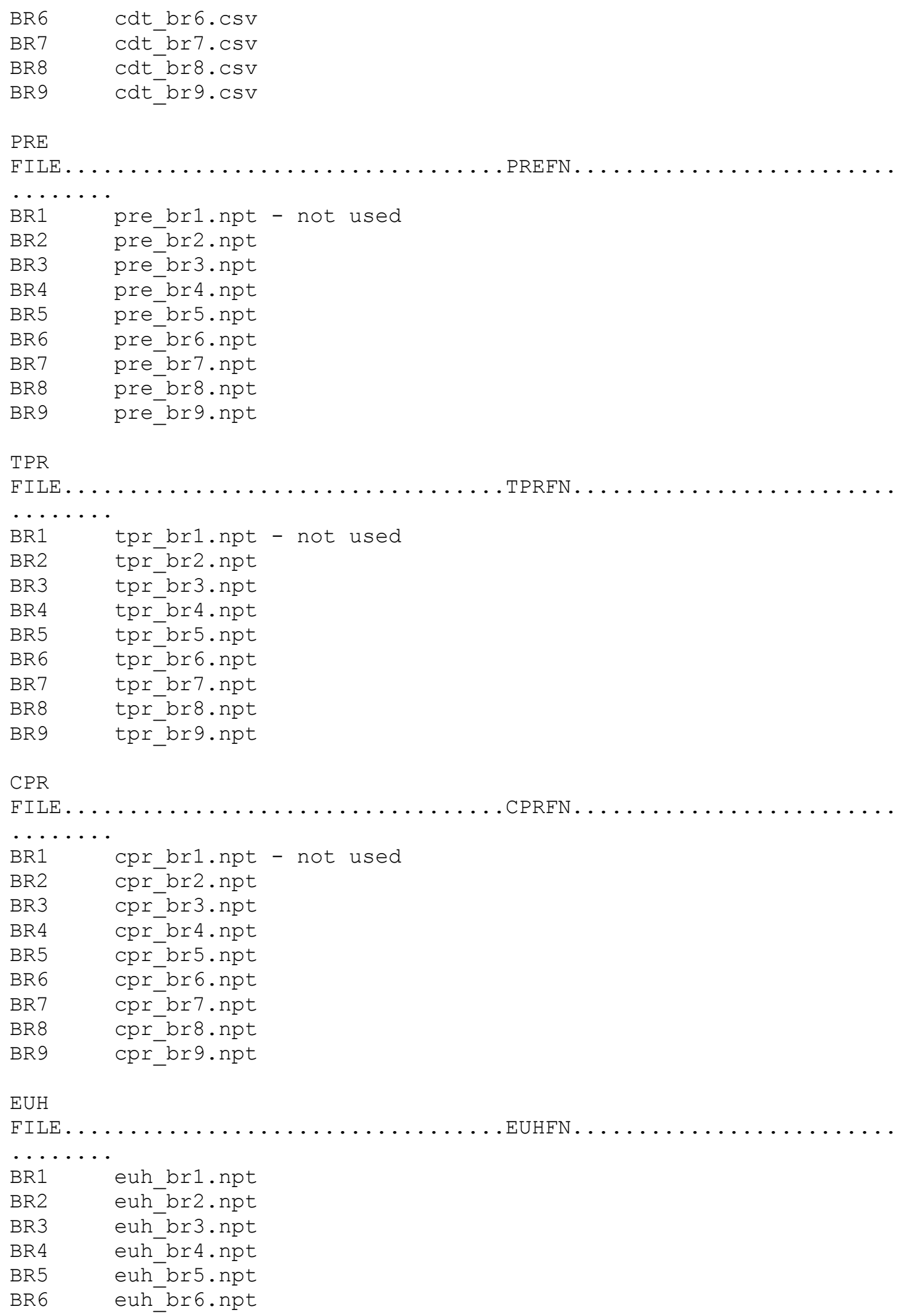




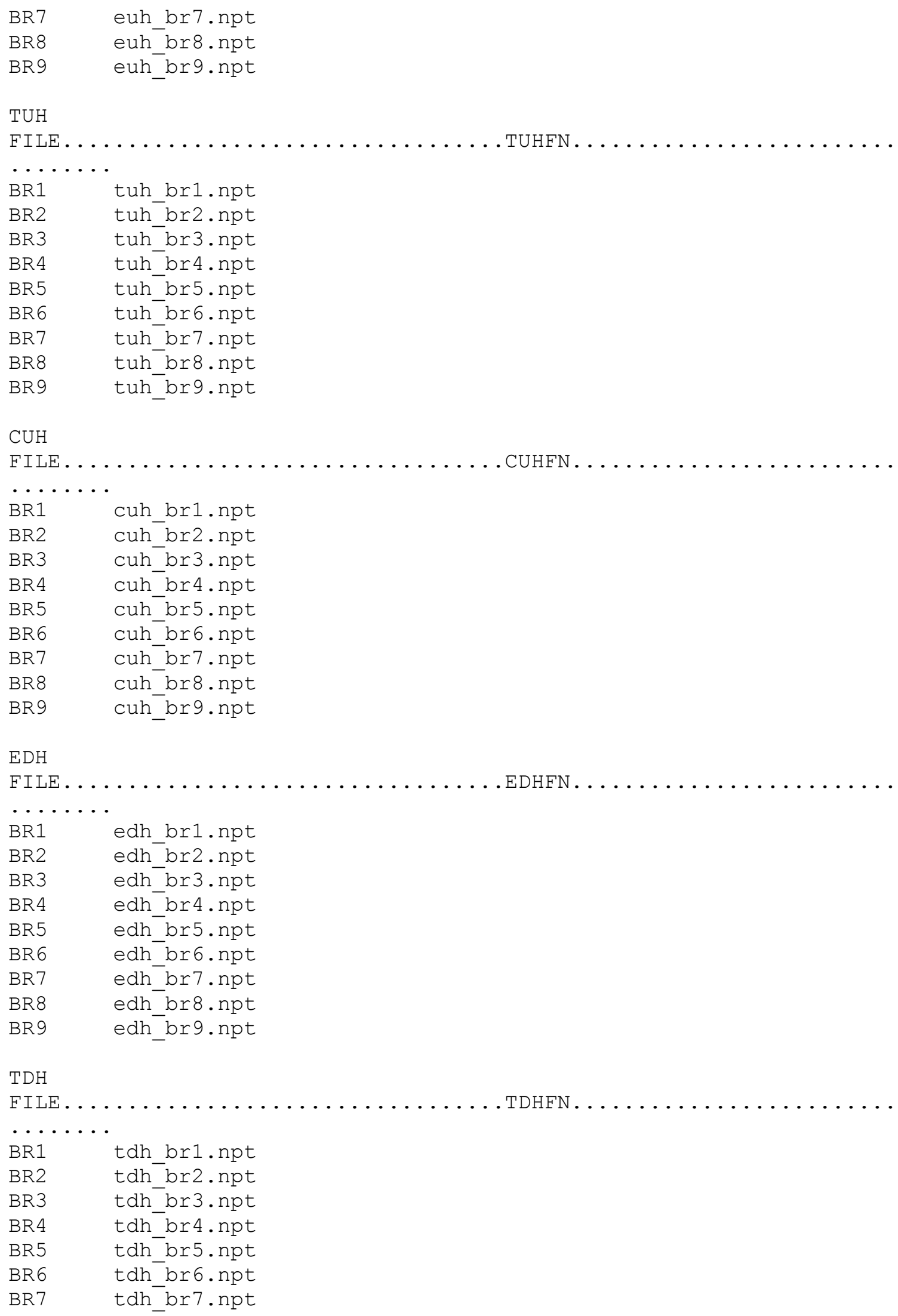




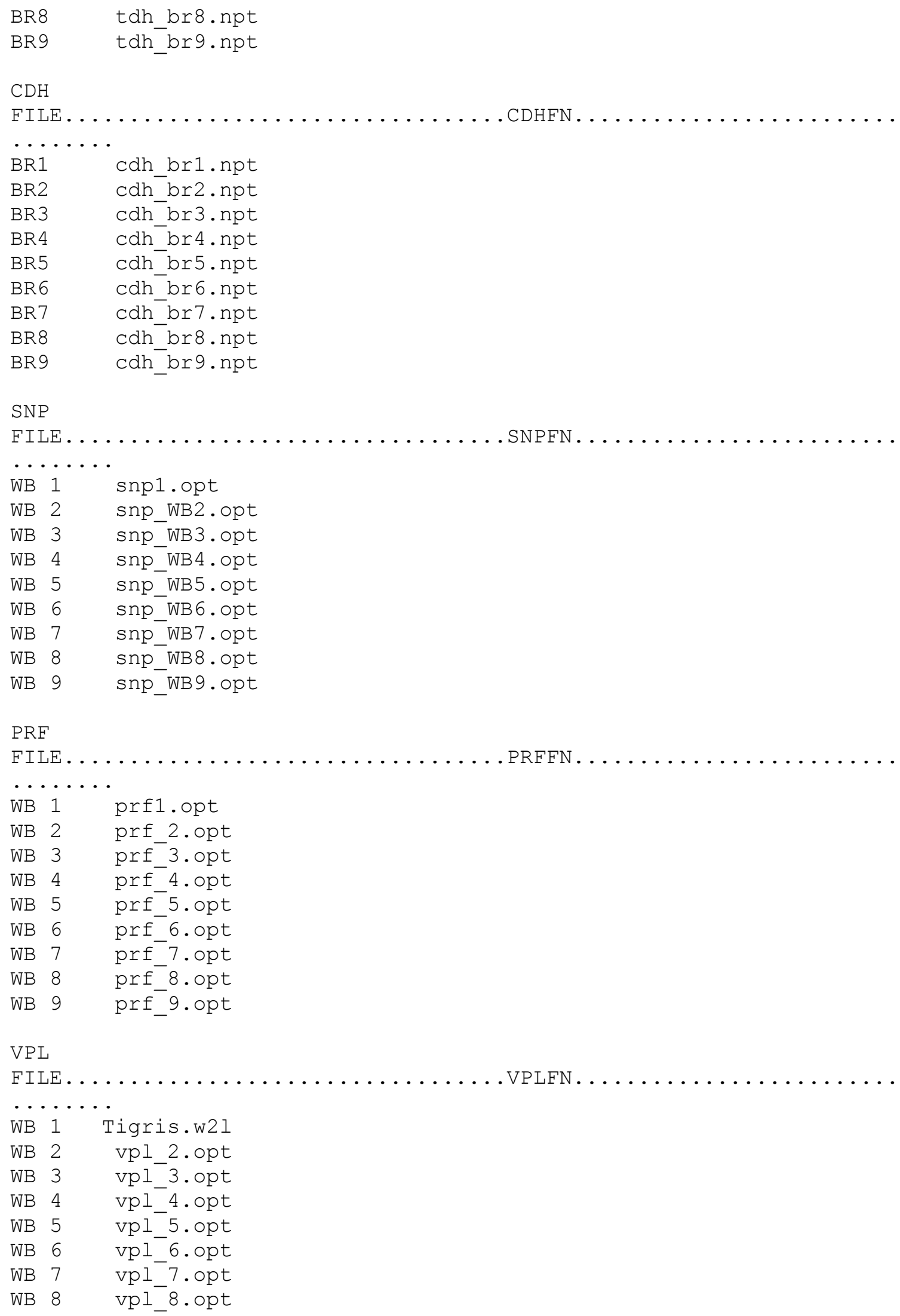




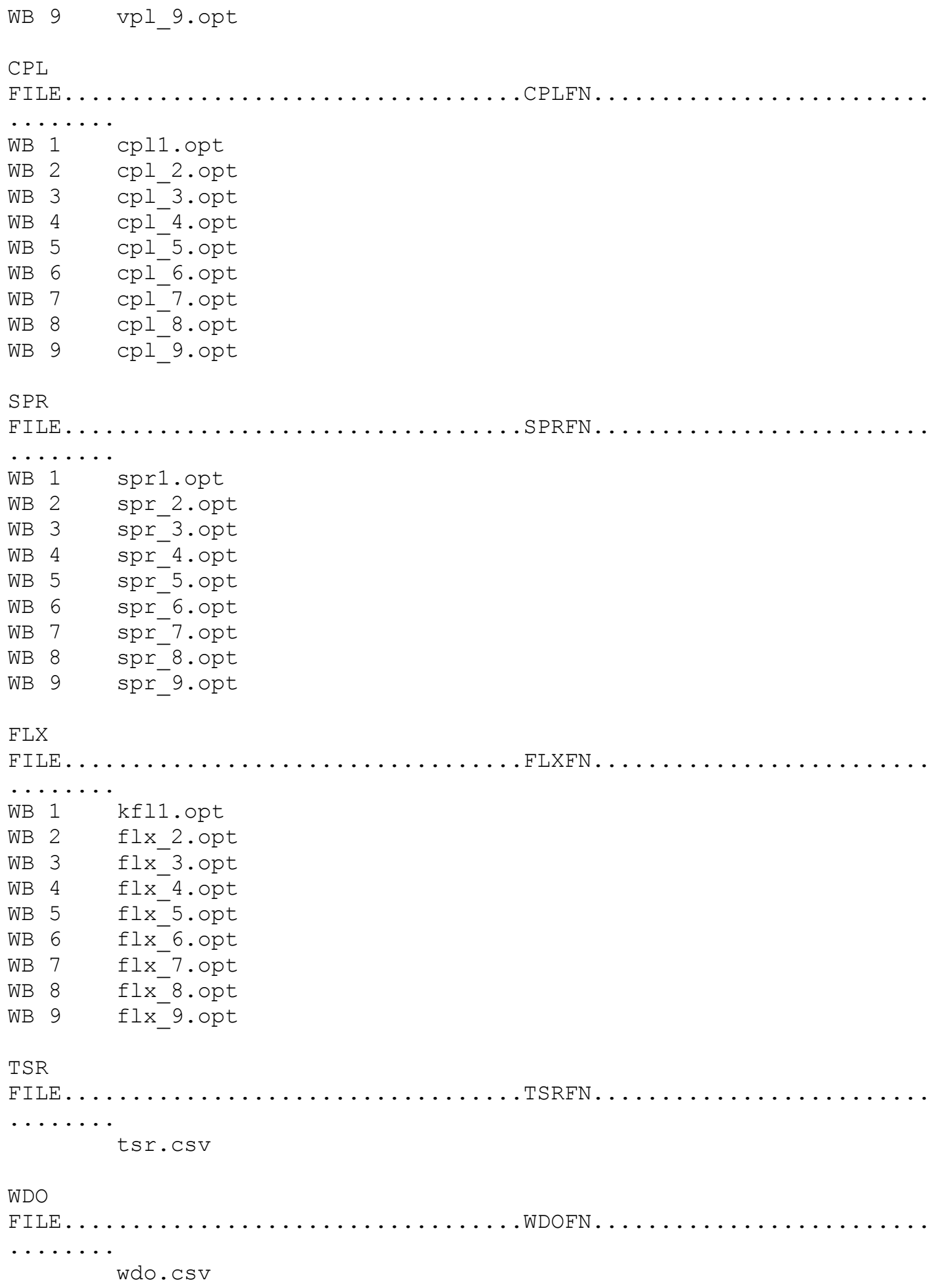

